UNIVERSIDADE DE SÃO PAULO - USP

INSTITUTO DE GEOCIÊNCIAS - IGC

\title{
TELEVISIONAMENTO ÓPTICO DE SONDAGENS - PROPOSTA METODOLÓGICA PARA EXECUÇÃO E SUAS APLICAÇÕES EM OBRAS SUBTERRÂNEAS
}

Daniela Garroux Gonçalves de Oliveira

Orientador: Prof. Dr. Fabio Taioli

DISSERTAÇÃO DE MESTRADO

Programa de Pós-Graduação em Recursos Minerais e Hidrogeologia

São Paulo

2015 
Autorizo a reprodução e divulgação total ou parcial deste trabalho, por qualquer meio convencional ou eletrônico, para fins de estudo e pesquisa, desde que citada a fonte.

Ficha catalográfica preparada pelo Serviço de Biblioteca e Documentação do Instituto de Geociências da Universidade de São Paulo

Oliveira, Daniela Garroux Gonçalves de

Televisionamento óptico de sondagens - proposta metodológica para execução e suas aplicações em obras subterrâneas / Daniela Garroux Gonçalves de Oliveira. - São Paulo, 2015

187 p.: il

Dissertação (Mestrado): IGc/USP

Orient.: Taioli, Fábio

1. Escavação subterrânea 2. Metrô (São Paulo) 3. Caracterização geológico-geotécnica 4 . Televisionamento óptico de sondagens 5. Túneis: análise cinemática I. Título 
DANIELA GARROUX GONÇALVES DE OLIVEIRA

TELEVISIONAMENTO ÓPTICO DE SONDAGENS - PROPOSTA METODOLÓGICA PARA EXECUÇÃO E SUAS APLICAÇÕES EM OBRAS SUBTERRÂNEAS

Dissertação de Mestrado apresentada ao Programa de Pós-Graduação em Recursos Minerais e Hidrogeologia do Instituto de Geociências da Universidade de São Paulo.

Orientador: Prof. Dr. Fabio Taioli

São Paulo 
Ao meu pai Prof. José Manoel Gonçalves de Oliveira (in memoriam). 


\section{AGRADECIMENTOS}

Gostaria de expressar meus sinceros agradecimentos às pessoas que ajudaram direta ou indiretamente na concepção desta dissertação.

À Companhia do Metropolitano de São Paulo pelo fornecimento dos dados e por toda a oportunidade oferecida de aprendizado e crescimento profissional. E um reconhecido agradecimento a toda equipe técnica e colegas metroviários que contribuíram imensamente para que este trabalho se concretizasse, em especial Hugo Cássio Rocha, Guilherme Braidato Robbe, Marcelo Denser Monteiro, Fabrícia Massoni Cicotti, Manuel Xavier Lemos Filho, Bárbara Passos da Cunha, Francisco Carlos Pelegate Dias, Fernando Pessoto Hirata, Anderson de Melo Martins, Karina Gonçalves de Oliveira, Paula Maia Ribeiro Avesani e toda a equipe do CDB/GCI.

À Empresa Alphageos Tecnologia Aplicada S.A. pela oportunidade do primeiro contato com a técnica do televisionamento óptico, em especial Ruy Thales Baillot, Edemir Augusto do Couto e Marcelo Santos, assim como os geólogos que aí contribuíram na aplicação desta metodologia.

À Empresa Progeo Engenharia Ltda, na figura do Geólogo Daniel Diniz França, pela quantidade significativa de sondagens televisionadas e pela paciência em analisar tantas imagens em conjunto, discutindo a aplicabilidade da metodologia proposta.

Ao Geólogo Sérgio Tokudo, da Matra Engenharia e Consultoria, pelo primeiro incentivo de publicação dos primeiros insights sobre o televisionamento. Ao Geólogo Luiz Ferreira Vaz, da Themag Engenharia Ltda, pelas discussões sobre a aplicação desta ferramenta em projetos de engenharia. E ao Geólogo Hélio Shimada, do Instituto Geológico, pela ajuda com a revisão final deste trabalho.

Ao IPT por todos os anos de ensinamento através do estágio na área de geologia de engenharia, nos meus primeiros contatos com testemunhos de sondagens e túneis, certamente daí surgindo minha paixão por escavações subterrâneas, e em especial agradecimento ao Geólogo Adalberto Aurélio Azevedo, pelas discussões sobre a metodologia e aplicação do televisionamento.

Ao Prof. Dr. Fabio Taioli pela orientação, discussões e sugestões que colaboraram para o desenvolvimento deste estudo. Assim como também ao Prof. Dr. Ginaldo Ademar da Cruz Campanha pela orientação na primeira tentativa de encalço de mestrado neste tema.

A todos os colegas da EBEI - Empresa Brasileira de Engenharia de Infraestrutura que contribuíram tanto no meu crescimento profissional como em sugestões para a elaboração deste 
presente estudo, em especial a Lilian de Moura Gonçalves, Vanessa Pereira Silva e Vinícius Oliveira Carvalho na elaboração de desenhos e ajuda com a formatação de texto. Aos colegas Bianca Tamy Takahashi e Gustavo Fracola da Silva pela paciência e apoio diário nos projetos. Agradeço também João Manoel Fernandes, Maria Beatriz Hopf Fernandes e Fabio Luiz Ramos de Abreu pelo apoio, confiança e inspiração profissional.

À Infra7 Engenharia, principalmente aos Engenheiros Flavio Massayuki Kuwajima e Julio Cesar Galrão Nakano, pela oportunidade com os projetos metroviários, onde foi possível experimentar com as possíveis aplicações dos dados obtidos no televisionamento.

A todos os colegas do meio técnico que contribuíram imensamente em diversos aspectos deste trabalho, em especial Alessandro Lugli Nascimento, Claudio Cabral Dias, Tiago Antonelli, Luiz Fernando dos Santos, Gabriel Guimarães Facuri, Claudia Pimenta, Magali Dubas Gurgueira e Ivo Teixeira. Agradeço, também, Claudia Lopes, da CPRM - Serviço Geológico do Brasil, pela ajuda com as referências bibliográficas.

Aos professores Tarcísio Barreto Celestino e Alberto Pio Fiori pela contribuição no conhecimento da Teoria dos Blocos Chaves, assim como valiosas sugestões para este trabalho.

A toda equipe de apoio do Instituto de Geociências, em especial a Magali Poli Fernandes Rizzo e Leonardo José Cappucci pela paciência e apoio.

A toda minha família e amigos pela ajuda e compreensão nos momentos de ausência durante este período, em especial ao meu pai, que foi meu maior incentivador e influência na minha paixão pela pesquisa. 
"O espaço subterrâneo não é mais um espaço opcional, mas antes um espaço necessário."

(HANAMURA, T.)

"O risco deveria ser um dos fundamentos básicos de um verdadeiro ser humano. No momento em que você vê que as coisas estão ficando estáveis, mova-as." 


\section{RESUMO}

OLIVEIRA, D. G. G. de. Televisionamento óptico de sondagens - proposta metodológica para execução e suas aplicações em obras subterrâneas. 2015. 187 f. Dissertação (Mestrado) - Instituto de Geociências, Universidade de São Paulo, São Paulo, 2015.

A caracterização de um maciço rochoso constitui um passo essencial na geologia de engenharia, proporcionando a possibilidade de previsão do comportamento deste maciço frente às inúmeras solicitações de qualquer obra a ser realizada. No caso de obras subterrâneas urbanas, como linhas metroviárias, por exemplo, a caracterização geológico-geotécnica de maciços rochosos é fundamental para a identificação de condicionantes geológicos associados à sua estabilidade, sendo eficaz na determinação de parâmetros geotécnicos que influenciarão no projeto de escavação desse maciço, seja este através do método convencional (NATM) ou mecanizado, com o uso de tuneladoras (TBM).

Feições estruturais como planos de foliação, dobras, falhas e sistemas de fraturas merecem atenção especial por estarem associadas a zonas de fraqueza, além de todas as características geomecânicas do maciço. Em zonas urbanizadas como a Região Metropolitana de São Paulo (RMSP) as condições geológicas, geomorfológicas e de ocupação dificultam a exposição e a identificação destas feições em superfície. Neste contexto foram desenvolvidas novas técnicas para facilitar o acesso às feições supracitadas. Dentre estas se encontra o televisionamento óptico (OPTV, OTV, Optical Televiewer), que consiste na obtenção de imagens $360^{\circ}$ das paredes dos furos de sondagem, fornecendo o que pode ser considerado um testemunho virtual de sondagem.

O televisionamento óptico é uma tecnologia introduzida no Brasil desde 2001, entretanto apenas recentemente tendo sido introduzido no manual de sondagens da ABGE (2013), contudo não havendo especificações sobre metodologia de aquisição, de interpretação e possibilidades de aplicação. Este trabalho apresenta sugestões para a aquisição destas imagens, sua interpretação e sugestões de aplicações em obras de engenharia, tendo como exemplo a aplicação em projetos de obras subterrâneas do Metrô de São Paulo.

No caso específico de escavações subterrâneas urbanas, o conhecimento do subsolo é essencial, já que sua construção é uma atividade a ser desenvolvida dentro do contexto urbano, podendo provocar interferências significativas com a comunidade, implicando em um alto risco à população lindeira. Somado a isto há o fato de que um maciço pouco conhecido poderá implicar em contenções superdimensionadas, aumentando o custo da obra ou subdimensionadas, aumentando o seu risco.

Conforme citado em ISRM (1978), à medida que as descrições de maciços rochosos e suas descontinuidades se tornem mais completas e unificadas, será viável projetar estruturas de engenharia em rocha reduzindo os gastos e aumentando a confiabilidade da interpretação e extrapolação dos resultados.

Palavras-chave: Televisionamento óptico, investigação geológico-geotécnica, caracterização de maciços rochosos, escavações subterrâneas urbanas. 


\begin{abstract}
OLIVEIRA, D. G. G. de. Optical televiewer in boreholes - methodological proposal for implementation and application in underground work. 2015. 187 f. Dissertação (Mestrado) Instituto de Geociências, Universidade de São Paulo, São Paulo, 2015.
\end{abstract}

The rock mass characterization is an essential step in engineering geology, providing the possibility of performance prediction of this massive due to numerous requests of any work to be done. In the case of urban underground works, such as subway lines, for example, geological and geotechnical characterization of rock masses is critical for identifying geological conditions linked to its stability, being effective in determining the geotechnical parameters that influence the design of massive excavation, whether by the conventional method (NATM), or mechanized, using tunneling boring machines (TBM).

Structural features such as foliation planes, folds, faults and fracture systems deserve special attention as they are associated with weakness zones in addition to all the geomechanical characteristics of the massif. In urbanized areas, such as São Paulo Metropolitan Region (RMSP), geological, geomorphological and occupation hinders exposure and identification of these features on the surface. In this context, new techniques have been developed to facilitate access to the above features. Among these new techniques is the optical televiewer (OPTV, OTV), which is to obtain $360^{\circ}$ images of the borehole walls, providing what might be considered a virtual core of a borehole.

The optical televiewer has been a technology introduced in Brazil since 2001, but only recently has been published in $\mathrm{ABGE}^{1}$ Borehole Manual (2013), however, there are no specifications on the acquisition methodology, interpretation and application possibilities. This paper presents suggestions for the acquisition of these images, their interpretation and suggestions of applications in engineering works, taking as an example the design in projects of underground works of the São Paulo Metro.

In the specific case of urban underground excavations ground knowledge is essential, since its construction is an activity to be developed within the urban context, which could cause significant interference with the community, resulting in a high risk to neighboring population. Added to this is the fact that a little-known mass can result in oversized contention, increasing the cost of the work or undersized, increasing its risk.

As mentioned in ISRM (1978), as the descriptions of rock masses and discontinuities become more complete and unified, it will be feasible to design engineering structures in rock reducing the costs and increasing the reliability of the interpretation and extrapolation of the results.

Keywords: Optical televiewer, geological-geotechnical investigation, rock massif characterization, urban underground excavations.

\footnotetext{
${ }^{1} \mathrm{ABGE}$ - Engineering and Environmental Geology Brazilian Association
} 


\section{LISTA DE FIGURAS}

Figura 1 - Mapa da região metropolitana de São Paulo e linhas do Metrô de São Paulo onde foram realizados televisionamento de sondagens para o presente estudo (Modificado de Metrô-SP).........................................28

Figura 2 - Os sistemas orogênicos da Mantiqueira e do Tocantins (Hasui, 2010).

Figura 3 - Mapa geológico da Região Metropolitana de São Paulo, com destaque para o embasamento (Monteiro et al., 2012).

Figura 4 - Contexto geológico regional do Rifte Continental do Sudeste do Brasil (RCSB) (Riccomini et al., 2004).

Figura 5 - Mapa geológico da Bacia de São Paulo e porção sudoeste da Bacia de Taubaté (Riccomini et al., 2004).

Figura 6 - Seções geológicas na Bacia de São Paulo construídas a partir de dados de sondagens para água subterrânea e observações de superfície (Riccomini et al., 2004).

Figura 7 - Quadro litoestratigráfico e evolução tectono-sedimentar do segmento central do RCSB (Riccomini et al., 2004).

Figura 8 - Estereograma de juntas identificando as sete famílias de juntas (Hasui, 1993).

Figura 9 - Modelo de estruturas cisalhantes de Riedel para cisalhamentos dextrais (Modificado em Hasui, 1993).

Figura 10 - Imagem (a) equipamento de televisionamento e (b) esquema do sistema de captação de imagens (Malone et al., 2013)...

Figura 11- Desenho esquemático do sistema completo de aquisição (Baillot et al., 2004).

Figura 12 - Imagens do televisionamento óptico em furos de sondagem de $150 \mathrm{~mm}$ de diâmetro realizados em arenito (Williams \& Johnson, 2004).

Figura 13 - Ilustração representando o esquema de transformação das imagens inicialmente "enroladas", fechadas, para imagens "desenroladas", ou abertas (modificado de Glover \& Bormann, 2007)......................50

Figura 14 - Ilustração dos distintos casos de abertura para descontinuidade (ISRM, 1978). .58

Figura 15 - Proposta de ISRM (1978) para determinação de ondulações e irregularidades em planos de descontinuidades.

Figura 16 - Perfis de rugosidade propostos por Barton (1987).

Figura 17 - Condições para o desprendimento de blocos no teto de escavações (Fiori \& Carmignani, 2009). .64 Figura 18 - A área sombreada representa uma figura de intersecção de dois sistemas de juntas em projeção ciclográfica e o plano inclinado da escavação (Fiori \& Carmignani, 2009).

Figura 19 - Condições para o escorregamento de cunhas no teto de escavações (Fiori \& Carmignani, 2009). .65

Figura 20 - Cunha de rocha em condições estáveis (Fiori \& Carmignani, 2009).

Figura 21 - Planos de juntas que se intersectam e definem uma cunha de rocha na base de um túnel (Fiori \& Carmignani, 2009).

Figura 22 - Procedimento para rotação de $90^{\circ}$ dos pontos ab, ac e bc de intersecção das juntas (Fiori \& Carmignani, 2009).

Figura 23 - Construção da seção verdadeira de uma cunha na parede de um túnel (Hoek \& Brown, 1980, traduzido em Fiori \& Carmignani, 2009).

Figura 24 - Tipos de blocos. Goodman (1989) e modificado por Fiori \& Carmignani (2009). 
Figura 25 - Diagrama de Schmidt-Lambert modificado para definição dos blocos-chave, Fiori \& Carmignani (2009).

Figura 26 - Exemplo de construção de grandes círculos e PJs para um sistema de juntas, modificado de Goodman (1989).

Figura 27- Representação das pirâmides de juntas para três famílias de descontinuidades e um túnel de direção NE-SW, Fiori \& Carmignani (2009).

Figura 28 - Pirâmide de Junta (PJ ou JP) que aparecerá como bloco-chave para o teto de um túnel (Goodman, 1985).

Figura 29 - Traços dos planos da PJ101 considerando plano horizontal com visada de cima para baixo, indicando semiespaços inferiores e superiores (Goodman, 1989)...............................................................73

Figura 30 - Forma do bloco-chave PJ101 com visada de cima para baixo.......................................................73

Figura 31 - Forma do bloco-chave PJ101 com visada de cima para baixo......................................................73

Figura 32 - PJ que se encontra totalmente dentro da PS, parede sul do túnel (Goodman, 1989).....................74

Figura 33 - Determinação dos mergulhos aparentes das descontinuidades consideradas para a PJ100, na

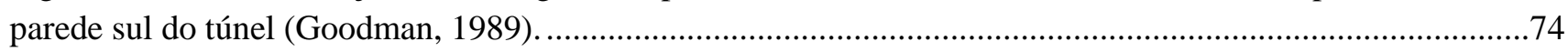

Figura 34 - Traços dos planos da PJ100 considerando plano horizontal com visada norte, indicando

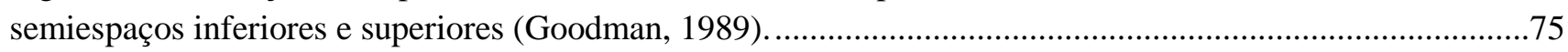

Figura 35 - Formato do bloco-chave da PJ100 na parede sul, com visada para norte (Goodman, 1989)..........75

Figura 36 - Formato do bloco-chave da PJ100 na parede sul, com visada para sul (Goodman, 1989). .............75

Figura 37 - Mapa de traços de descontinuidades presentes na parede sul de um túnel (Goodman, 1989). ........76

Figura 38 - Resultado dos blocos removíveis encontrados na parede sul (Goodman, 1989)............................76

Figura 39 - Exemplo de fratura delimitada digitalmente, com uma linha vermelha, após análise utilizando Software de televisionamento RGLDIP da câmera OPTV, da Robertson Geolloging. E exemplo de descontinuidade rugosa, citado no item RUGOSIDADE. Fonte: Metrô-SP....................................................82

Figura 40 - Perfis de rugosidade de Barton et al. (1987) à esquerda, e adaptação dos perfis de rugosidade para aplicação em imagens de televisionamento.

Figura 41 - Cálculo da amplitude de perfis de rugosidade em superfície rochosa, considerando a amplitude da rugosidade (a) e o tamanho dos grãos (Barton, 2013).

Figura 42 - Comparação de fratura aberta em imagem de televisionamento, apresentando preenchimento de fragmentos de rocha, à direita e imagem de testemunho de sondagem (Baillot et al., 2004).

Figura 43- Exemplo de polos de fraturas de medidas no televisionamento plotados em estereograma SchmidtLambert, hemisfério inferior (Oliveira et al., 2013).

Figura 44- Exemplo de Diagrama Schmidt-Lambert estatístico de concentração de polos, hemisfério inferior (Oliveira et al., 2013).

Figura 45 - Exemplo de diagrama estatístico de roseta, hemisfério inferior (Oliveira et al., 2013). .96

Figura 46 - Localização da área onde foi realizado o televisionamento dos furos de sondagem para projeto básico de extensão da Linha 2 - Verde, Metrô-SP (imagem do Google Earth).

Figura 47 - Furos de sondagem analisados no trecho não adotado da extensão da Linha 2 Verde, Metrô-SP (imagem do Google Earth).

Figura 48 - Exemplo do procedimento realizado para cada um dos furos considerados para tratamento estatístico.

Figura 49 - Variação do parâmetro alteração das paredes das descontinuidades ao longo do trecho - Linha 2 Verde Extensão Vila Prudente - Guarulhos. 
Figura 50 - Variação do parâmetro abertura das descontinuidades ao longo do trecho- Linha 2 Verde Extensão Vila Prudente - Guarulhos.

Figura 51 - Variação do parâmetro rugosidade das descontinuidades ao longo do trecho- Linha 2 Verde Extensão Vila Prudente - Guarulhos.

Figura 52 - Variação do parâmetro grau de fraturamento das descontinuidades ao longo do trecho- Linha 2 Verde Extensão Vila Prudente - Guarulhos.

Figura 53 - Diagrama de concentração de polos para furos selecionados da Linha 2 Verde, Software Dips (Rocscience, 1999).

Figura 54 - Planos das principais famílias definidas para furos selecionados da Linha 2 Verde, e eixo do túnel de via para alternativa não adotada, Software Dips (Rocscience, 1999).

Figura 55 - Análise bidimensional da interação dos planos de fraturas principais e eixo do túnel, utilizando Software Unwedge (Rocscience, 2004).

Figura 56 - Análise tridimensional da interação dos planos de fraturas principais e eixo do túnel, apresentando blocos formados, utilizando Software Unwedge (Rocscience, 2004).

Figura 57 - Análise tridimensional apresentando cada bloco formado, indicando fator de segurança, volume e peso de cada bloco, elaborado com Software Unwedge (Rocscience, 2004).

Figura 58 - Traçado esquemático da Linha 4 Amarela Fase 3, indicando as principais unidades construtivas (Google Earth). 106

Figura 59 - Furos de sondagens televisionados ao longo da Linha 4 Amarela - Fase 3 (Google Earth)..... 107

Figura 60 - Seção longitudinal geológico-geotécnica 1 de 4, simplificada, da Linha 4 Amarela - Fase 3 extensão Taboão da Serra. Fonte: Metrô-SP.

Figura 61 - Seção longitudinal geológico-geotécnica 2 de 4, simplificada, da Linha 4 Amarela - Fase 3 extensão Taboão da Serra. Fonte: Metrô-SP.

Figura 62 - Seção longitudinal geológico-geotécnica 3 de 4, simplificada, da Linha 4 Amarela - Fase 3 extensão Taboão da Serra. Fonte: Metrô-SP.

Figura 63 - Seção longitudinal geológico-geotécnica 4 de 4, simplificada, da Linha 4 Amarela - Fase 3 extensão Taboão da Serra. Fonte: Metrô-SP.

Figura 64 - Legenda das unidades e materiais geológicos referentes às seções das figuras anteriores (modificado de Kutner \& Bjornberg, 1997).

Figura 65 - Quantificação das unidades que ocorrem no trecho, tendo como base as informações das sondagens ao longo da seção geológico-geotécnica.

Figura 66 - Quantidade da classe geomecânica do maciço rochoso ao longo do trecho em questão, a partir da classificação de Bieniawski (1989).

Figura 67 - Variação do parâmetro alteração das paredes das descontinuidades ao longo do trecho. ..............116

Figura 68 - Variação do parâmetro abertura das descontinuidades ao longo do trecho.

Figura 69 - Variação do parâmetro rugosidade das descontinuidades ao longo do trecho.

Figura 70 - Variação do parâmetro grau de fraturamento ao longo do trecho.

Figura 71 - Estereograma de concentração de polos das fraturas para a sondagem televisada 4503.

Figura 72 - Estereograma de concentração de polos das fraturas para a sondagem televisada 4505.

Figura 73 - Estereograma de concentração de polos das fraturas para a sondagem televisada 4515.

Figura 74 - Estereograma de concentração de polos das fraturas para a sondagem televisada 4532.

Figura 75 - Estereograma de concentração de polos das fraturas para a sondagem televisada 4536. 
Figura 76 - Estereograma de concentração de polos das fraturas para a sondagem televisada 4539 (inclinada).

Figura 77 - Estereograma de concentração de polos das fraturas para a sondagem televisada $4540 \ldots \ldots \ldots \ldots \ldots . . . .123$

Figura 78 - Estereograma de concentração de polos das fraturas para a sondagem televisada 4544.

Figura 79 - Estereograma de concentração de polos das fraturas para a sondagem televisada 4545.

Figura 80 - Estereograma de concentração de polos das fraturas para a sondagem televisada 4548.

Figura 81 - Estereograma de concentração de polos das fraturas para a sondagem televisada 4559

Figura 82 - Estereograma de concentração de polos das fraturas para a sondagem televisada 4564.

Figura 83 - Estereograma de concentração de polos das fraturas para a sondagem televisada 4572 ..............125

Figura 84- Estereograma de concentração de polos das fraturas para a sondagem televisada 4580

Figura 85 - Estereograma de concentração de polos das fraturas para a sondagem televisada 4596.

Figura 86 - Estereograma de concentração de polos das fraturas para a sondagem televisada 4597 (inclinada).

Figura 87 - Estereograma de concentração de polos das fraturas para a sondagem televisada 4603 (inclinada).

Figura 88 - Estereograma de concentração de polos das fraturas de todos os furos, considerando-se apenas as fraturas abertas e semi-abertas.

Figura 89 - Localização e direção das cinco linhas estruturais delimitadas ao longo do trecho referente à Linha 4 - Fase 3 (Google Earth).

Figura 90 - Estereograma para sondagens pertencentes à Linha Estrutural 1 e respectivas famílias de descontinuidades.

Figura 91 - Estereograma para sondagens pertencentes à Linha Estrutural 2 e respectivas famílias de descontinuidades, tendo sido consideradas apenas as fraturas abertas e semi-abertas da sondagem 4572 .......129 Figura 92 - Estereograma para sondagens pertencentes à Linha Estrutural 3 e respectivas famílias de descontinuidades.

Figura 93 - Estereograma para sondagens pertencentes à Linha Estrutural 4 e respectivas famílias de descontinuidades.

Figura 94 - Estereograma para sondagens pertencentes à Linha Estrutural 5 e respectivas famílias de descontinuidades.

Figura 95 - Análise cinemática bidimensional de cunhas, para Linha Estrutural 1, combinação 1 de 4 famílias de descontinuidades $(\mathrm{F} 1+\mathrm{F} 2+\mathrm{F} 3)$ (Software Unwedge).

Figura 96 - Seção do túnel ao longo da Linha Estrutural 1 com respectivas cunhas geradas pela combinação 1 de 4 de famílias de descontinuidades $(\mathrm{F} 1+\mathrm{F} 2+\mathrm{F} 3)$ (Software Unwedge).

Figura 97 - Seções do túnel ao longo da Linha Estrutural 1 com respectivas cunhas geradas pela combinação 1 de 4 de famílias de descontinuidades $(\mathrm{F} 1+\mathrm{F} 2+\mathrm{F} 3)$, indicando o fator de segurança (FS), volume e peso de cada bloco (Software Unwedge).

Figura 98 - Análise cinemática bidimensional de cunhas, para Linha Estrutural 1, combinação 2 de 4 famílias de descontinuidades (F1+F2+F4) (Software Unwedge).

Figura 99 - Seção do túnel ao longo da Linha Estrutural 1 com respectivas cunhas geradas pela combinação2 de 4 famílias de descontinuidades $(\mathrm{F} 1+\mathrm{F} 2+\mathrm{F} 4)$ (Software Unwedge).

Figura 100 - Seções do túnel ao longo da Linha Estrutural 1 com respectivas cunhas geradas pela combinação 2 de 4 de famílias de descontinuidades $(\mathrm{F} 1+\mathrm{F} 2+\mathrm{F} 4)$, indicando o fator de segurança $(\mathrm{FS})$, volume e peso de cada bloco (Software Unwedge). 
Figura 101 - Análise cinemática bidimensional de cunhas, para Linha Estrutural 1, combinação 3 de 4 famílias de descontinuidades $(\mathrm{F} 1+\mathrm{F} 3+\mathrm{F} 4)$ (Software Unwedge)...

Figura 102 - Seção do túnel ao longo da Linha Estrutural 1 com respectivas cunhas geradas pela combinação 3 de 4 de famílias de descontinuidades $(\mathrm{F} 1+\mathrm{F} 3+\mathrm{F} 4)$ (Software Unwedge).

Figura 103 - Seções do túnel ao longo da Linha Estrutural 1 com respectivas cunhas geradas pela combinação 3 de 4 de famílias de descontinuidades $(\mathrm{F} 1+\mathrm{F} 3+\mathrm{F} 4)$, indicando o fator de segurança (FS), volume e peso de cada bloco (Software Unwedge).

Figura 104 - Análise cinemática bidimensional de cunhas, para Linha Estrutural 1, combinação 4 de 4 famílias de descontinuidades (F2+F3+F4) (Software Unwedge).

Figura 105 - Seção do túnel ao longo da Linha Estrutural 1 com respectivas cunhas geradas pela combinação 4 de 4 famílias de descontinuidades ( $\mathrm{F} 2+\mathrm{F} 3+\mathrm{F} 4)$ (Software Unwedge)...

Figura 106 - Seções do túnel ao longo da Linha Estrutural 1 com respectivas cunhas geradas pela combinação 4 de 4 de famílias de descontinuidades $(\mathrm{F} 2+\mathrm{F} 3+\mathrm{F} 4)$, indicando o fator de segurança $(\mathrm{FS})$, volume e peso de cada bloco (Software Unwedge).

Figura 107 - Análise cinemática bidimensional de cunhas, para Linha Estrutural 2, combinação 1 de 3 famílias de descontinuidades $(\mathrm{F} 1+\mathrm{F} 2+\mathrm{F} 3)$ (Software Unwedge).

Figura 108- Seção do túnel ao longo da Linha Estrutural 2 com respectivas cunhas geradas pela combinação 1 de 3 famílias de descontinuidades $(\mathrm{F} 1+\mathrm{F} 2+\mathrm{F} 3)$ (Software Unwedge)...

Figura 109- Seções do túnel ao longo da Linha Estrutural 2 com respectivas cunhas geradas pela combinação 1 de 3 de famílias de descontinuidades $(\mathrm{F} 1+\mathrm{F} 2+\mathrm{F} 3)$, indicando o fator de segurança (FS), volume e peso de cada bloco (Software Unwedge).

Figura 110- Análise cinemática bidimensional de cunhas, para Linha Estrutural 3, combinação 1 de 5 famílias de descontinuidades (F2+F3+F5) (Software Unwedge).

Figura 111- Seção do túnel ao longo da Linha Estrutural 3 com respectivas cunhas geradas pela combinação 1 de 5 famílias de descontinuidades (F2+F3+F5) (Software Unwedge).

Figura 112 - Seções do túnel ao longo da Linha Estrutural 3 com respectivas cunhas geradas pela combinação 1 de 5 de famílias de descontinuidades (F2+F3+F5), indicando o fator de segurança (FS), volume e peso de cada bloco (Software Unwedge).

Figura 113- Análise cinemática bidimensional de cunhas, para Linha Estrutural 3, combinação 2 de 5 famílias de descontinuidades (F2+F3+F6) (Software Unwedge).

Figura 114 - Seção do túnel ao longo da Linha Estrutural 3 com respectivas cunhas geradas pela combinação2 de 5 famílias de descontinuidades (F2+F3+F6) (Software Unwedge).

Figura 115 - Seções do túnel ao longo da Linha Estrutural 3 com respectivas cunhas geradas pela combinação 2 de 5 de famílias de descontinuidades $(\mathrm{F} 2+\mathrm{F} 3+\mathrm{F} 6)$, indicando o fator de segurança (FS), volume e peso de cada bloco (Software Unwedge).

Figura 116 - Análise cinemática bidimensional de cunhas, para Linha Estrutural 3, combinação 3 de 5 famílias de descontinuidades (F2+F3+F7) (Software Unwedge).

Figura 117 - Seção do túnel ao longo da Linha Estrutural 3 com respectivas cunhas geradas pela combinação 3 de 5 famílias de descontinuidades (F2+F3+F7) (Software Unwedge).

Figura 118 - Seções do túnel ao longo da Linha Estrutural 3 com respectivas cunhas geradas pela combinação 3 de 5 de famílias de descontinuidades (F2+F3+F7), indicando o fator de segurança (FS), volume e peso de cada bloco (Software Unwedge).

Figura 119 - Análise cinemática bidimensional de cunhas, para Linha Estrutural 3, combinação 4 de 5 famílias de descontinuidades (F2+F5+F6) (Software Unwedge). 
Figura 120 - Seção do túnel ao longo da Linha Estrutural 3 com respectivas cunhas geradas pela combinação 4 de 5 famílias de descontinuidades ( $\mathrm{F} 2+\mathrm{F} 5+\mathrm{F} 6)$ (Software Unwedge).

Figura 121- Seções do túnel ao longo da Linha Estrutural 3 com respectivas cunhas geradas pela combinação 4 de 5 de famílias de descontinuidades (F2+F5+F6), indicando o fator de segurança (FS), volume e peso de cada bloco (Software Unwedge).

Figura 122 - Análise cinemática bidimensional de cunhas, para Linha Estrutural 3, combinação 5 de 5 famílias de descontinuidades (F2+F5+F7) (Software Unwedge).

Figura 123 - Seção do túnel ao longo da Linha Estrutural 3 com respectivas cunhas geradas pela combinação 5 de 5 famílias de descontinuidades (F2+F5+F7) (Software Unwedge).

Figura 124 - Seções do túnel ao longo da Linha Estrutural 3 com respectivas cunhas geradas pela combinação 5 de 5 de famílias de descontinuidades (F2+F5+F7), indicando o fator de segurança (FS), volume e peso de cada bloco (Software Unwedge). 148

Figura 125 - Análise cinemática bidimensional de cunhas, para Linha Estrutural 3, combinação 6 de 5 famílias de descontinuidades (F2+F6+F7) (Software Unwedge). .148

Figura 126 - Seção do túnel ao longo da Linha Estrutural 3 com respectivas cunhas geradas pela combinação 6 de 5 famílias de descontinuidades (F2+F6+F7) (Software Unwedge). .148

Figura 127 - Seções do túnel ao longo da Linha Estrutural 3 com respectivas cunhas geradas pela combinação 6 de 5 de famílias de descontinuidades (F2+F6+F7), indicando o fator de segurança (FS), volume e peso de cada bloco (Software Unwedge).

Figura 128 - Análise cinemática bidimensional de cunhas, para Linha Estrutural 3, combinação 7 de 5 famílias de descontinuidades (F3+F5+F6) (Software Unwedge).

Figura 129 - Seção do túnel ao longo da Linha Estrutural 3 com respectivas cunhas geradas pela combinação 7 de 5 famílias de descontinuidades (F3+F5+F6) (Software Unwedge)..

Figura 130 - Seções do túnel ao longo da Linha Estrutural 3 com respectivas cunhas geradas pela combinação 7 de 5 de famílias de descontinuidades (F3+F5+F6), indicando o fator de segurança (FS), volume e peso de cada bloco (Software Unwedge).

Figura 131 - Análise cinemática bidimensional de cunhas, para Linha Estrutural 3, combinação 8 de 5 famílias de descontinuidades (F3+F5+F7) (Software Unwedge).

Figura 132 - Seção do túnel ao longo da Linha Estrutural 3 com respectivas cunhas geradas pela combinação 8 de 5 famílias de descontinuidades (F3+F5+F7) (Software Unwedge).

Figura 133 - Seções do túnel ao longo da Linha Estrutural 3 com respectivas cunhas geradas pela combinação 8 de 5 de famílias de descontinuidades (F3+F5+F7), indicando o fator de segurança (FS), volume e peso de cada bloco (Software Unwedge).

Figura 134 - Análise cinemática bidimensional de cunhas, para Linha Estrutural 3, combinação 9 de 5 famílias de descontinuidades (F3+F6+F7) (Software Unwedge).

Figura 135 - Seção do túnel ao longo da Linha Estrutural 3 com respectivas cunhas geradas pela combinação 9 de 5 famílias de descontinuidades (F3+F6+F7) (Software Unwedge).

Figura 136 - Seções do túnel ao longo da Linha Estrutural 3 com respectivas cunhas geradas pela combinação 9 de 5 de famílias de descontinuidades (F3+F6+F7), indicando o fator de segurança (FS), volume e peso de cada bloco (Software Unwedge).

Figura 137 - Análise cinemática bidimensional de cunhas, para Linha Estrutural 3, combinação 10 de 5 famílias de descontinuidades (F5+F6+F7) (Software Unwedge).

Figura 138 - Seção do túnel ao longo da Linha Estrutural 3 com respectivas cunhas geradas pela combinação de 10 de 5 famílias de descontinuidades (F5+F6+F7) (Software Unwedge). 
Figura 139 - Seções do túnel ao longo da Linha Estrutural 3 com respectivas cunhas geradas pela combinação 10 de 5 de famílias de descontinuidades (F5+F6+F7), indicando o fator de segurança (FS), volume e peso de cada bloco (Software Unwedge).

Figura 140 - Análise cinemática bidimensional de cunhas, para Linha Estrutural 4, combinação 1 de 4 famílias de descontinuidades $(\mathrm{F} 1+\mathrm{F} 2+\mathrm{F} 3)$ (Software Unwedge).

Figura 141 - Seção do túnel ao longo da Linha Estrutural 4 com respectivas cunhas geradas pela combinação 1 de 4 famílias de descontinuidades $(\mathrm{F} 1+\mathrm{F} 2+\mathrm{F} 3)$ (Software Unwedge).

Figura 142-Seções do túnel ao longo da Linha Estrutural 4 com respectivas cunhas geradas pela combinação 1 de 4 de famílias de descontinuidades $(\mathrm{F} 1+\mathrm{F} 2+\mathrm{F} 3)$, indicando o fator de segurança (FS), volume e peso de cada bloco (Software Unwedge).

Figura 143 - Análise cinemática bidimensional de cunhas, para Linha Estrutural 4, combinação 2 de 4 famílias de descontinuidades (F1+F2+F5) (Software Unwedge). 155

Figura 144 - Seção do túnel ao longo da Linha Estrutural 4 com respectivas cunhas geradas pela combinação 2 de 4 famílias de descontinuidades (F1+F2+F5) (Software Unwedge). .155

Figura 145 - Seções do túnel ao longo da Linha Estrutural 4 com respectivas cunhas geradas pela combinação 2 de 4 de famílias de descontinuidades $(\mathrm{F} 1+\mathrm{F} 2+\mathrm{F} 5)$, indicando o fator de segurança (FS), volume e peso de cada bloco (Software Unwedge). .155

Figura 146 - Análise cinemática bidimensional de cunhas, para Linha Estrutural 4, combinação 3 de 4 famílias de descontinuidades $(\mathrm{F} 1+\mathrm{F} 3+\mathrm{F} 5)$ (Software Unwedge). 156

Figura 147 - Seção do túnel ao longo da Linha Estrutural 4 com respectivas cunhas geradas pela combinação 3 de 4 famílias de descontinuidades (F1+F3+F5) (Software Unwedge).

Figura 148 - Seções do túnel ao longo da Linha Estrutural 4 com respectivas cunhas geradas pela combinação 3 de 4 de famílias de descontinuidades $(\mathrm{F} 1+\mathrm{F} 3+\mathrm{F} 5)$, indicando o fator de segurança (FS), volume e peso de cada bloco (Software Unwedge).

Figura 149 - Análise cinemática bidimensional de cunhas, para Linha Estrutural 4, combinação 4 de 4 famílias de descontinuidades (F2+F3+F5) (Software Unwedge).

Figura 150 - Seção do túnel ao longo da Linha Estrutural 4 com respectivas cunhas geradas pela combinação 4 de 4 famílias de descontinuidades (F2+F3+F5) (Software Unwedge).

Figura 151 - Seções do túnel ao longo da Linha Estrutural 4 com respectivas cunhas geradas pela combinação 4 de 4 de famílias de descontinuidades (F2+F3+F5), indicando o fator de segurança (FS), volume e peso de cada bloco (Software Unwedge).

Figura 152 - Análise cinemática bidimensional de cunhas, para Linha Estrutural 5, combinação 1 de 4 famílias de descontinuidades $(\mathrm{F} 1+\mathrm{F} 2+\mathrm{F} 3)$ (Software Unwedge).

Figura 153 - Seção do túnel ao longo da Linha Estrutural 5 com respectivas cunhas geradas pela combinação 1 de 4 famílias de descontinuidades (F1+F2+F3) (Software Unwedge)

Figura 154 - Seções do túnel ao longo da Linha Estrutural 5 com respectivas cunhas geradas pela combinação 1 de 4 de famílias de descontinuidades $(\mathrm{F} 1+\mathrm{F} 2+\mathrm{F} 3)$, indicando o fator de segurança $(\mathrm{FS})$, volume e peso de cada bloco (Software Unwedge).

Figura 155 - Análise cinemática bidimensional de cunhas, para Linha Estrutural 5, combinação 2 de 4 famílias de descontinuidades $(\mathrm{F} 1+\mathrm{F} 2+\mathrm{F} 5)$ (Software Unwedge).

Figura 156 - Seção do túnel ao longo da Linha Estrutural 5 com respectivas cunhas geradas pela combinação 2 de 4 famílias de descontinuidades (F1+F2+F5) (Software Unwedge). 
Figura 157 - Seções do túnel ao longo da Linha Estrutural 5 com respectivas cunhas geradas pela combinação 2 de 4 de famílias de descontinuidades $(\mathrm{F} 1+\mathrm{F} 2+\mathrm{F} 5)$, indicando o fator de segurança (FS), volume e peso de cada bloco (Software Unwedge).

Figura 158 - Análise cinemática bidimensional de cunhas, para Linha Estrutural 5, combinação 3 de 4 famílias de descontinuidades (F1+F3+F5) (Software Unwedge).

Figura 159 - Seção do túnel ao longo da Linha Estrutural 5 com respectivas cunhas geradas pela combinação 3 de 4 famílias de descontinuidades $(\mathrm{F} 1+\mathrm{F} 3+\mathrm{F} 5)$ (Software Unwedge).

Figura 160 - Seções do túnel ao longo da Linha Estrutural 5 com respectivas cunhas geradas pela combinação 3 de 4 de famílias de descontinuidades $(\mathrm{F} 1+\mathrm{F} 3+\mathrm{F} 5)$, indicando o fator de segurança (FS), volume e peso de cada bloco (Software Unwedge).

Figura 161 - Análise cinemática bidimensional de cunhas, para Linha Estrutural 5, combinação 4 de 4 famílias de descontinuidades (F2+F4+F5) (Software Unwedge).

Figura 162 - Seção do túnel ao longo da Linha Estrutural 5 com respectivas cunhas geradas pela combinação 4 de 4famílias de descontinuidades (F2+F4+F5) (Software Unwedge).

Figura 163 - Seções do túnel ao longo da Linha Estrutural 5 com respectivas cunhas geradas pela combinação 4 de 4 de famílias de descontinuidades (F2+F4+F5), indicando o fator de segurança (FS), volume e peso de cada bloco (Software Unwedge). .162

Figura 164 - Exemplo de análise cinemática tridimensional para escavação de um poço (Software Unwedge).

Figura 165 - Exemplo de análise cinemática tridimensional para túnel de acesso de um dos poços (Software Unwedge).

Figura 166 - Paredes consideradas para as análises na Estação do Largo do Taboão (P1, P2, P3 e P4) (Metrô$\mathrm{SP})$

Figura 167 - Fraturas filmadas no televisionamento do furo de sondagem 4532, na região do Largo do Taboão.

Figura 168 - Perfil individual da sondagem 4532, com trecho de baixa recuperação em rocha indicado com círculo.

Figura 169 - Diagrama de contagem de polos com os dados obtidos do televisionamento das sondagens da região da Estação Largo do Taboão (Software Dips).

Figura 170 - Resumo das famílias definidas como essenciais para a análise estrutural das paredes da vala da estação (Software Dips).

Figura 171 - Resumo das possibilidades de escorregamento e ruptura em maciços rochosos, traduzido de Hoek \& Bray (1981). .168

Figura 172 - Análise bidimensional da Parede 1 considerando principais famílias e principais possibilidades de escorregamento.

Figura 173 - Análise bidimensional da Parede 2 considerando principais famílias e principais possibilidades de escorregamento.

Figura 174 - Análise bidimensional da Parede 3 considerando principais famílias e principais possibilidades de escorregamento.

Figura 175 - Análise bidimensional da Parede 4 considerando principais famílias e principais possibilidades de escorregamento.

Figura 176 - Blocos removíveis (em amarelo) para parede P1, sendo PE a parede de escavação (a rocha) e PS o espaço escavado. 
Figura 177 - Blocos removíveis (em amarelo) para parede P2, sendo PE a parede de escavação (a rocha) e PS

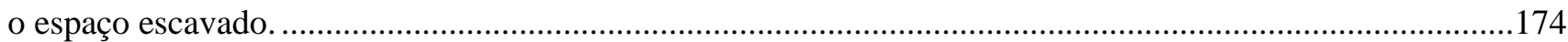

Figura 178 - Blocos removíveis (em amarelo) para parede P3, sendo PE a parede de escavação (a rocha) e PS

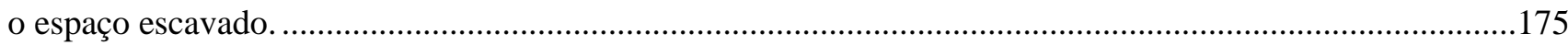

Figura 179 - Blocos removíveis (em amarelo) para parede P4, sendo PE a parede de escavação (a rocha) e PS o espaço escavado 176

Figura 180 - Ilustração da possível situação a ser encontrada após o uso extensivo do televisionamento óptico e suas inúmeras aplicações. 


\section{LISTA DE TABELAS}

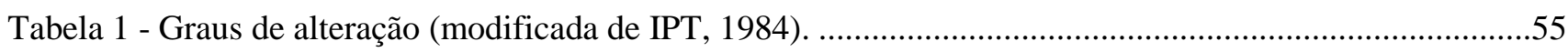

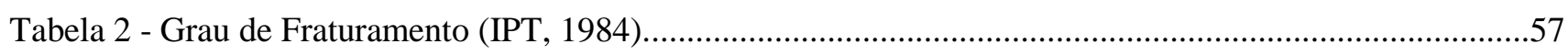

Tabela 3 - Caracterização das aberturas de descontinuidades, traduzido de ISRM (1978). .............................58

Tabela 4 - Tipos de superfície e preenchimento de descontinuidades (IPT, 1984)..........................................59

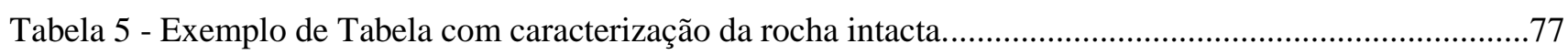

Tabela 6 - Estruturas penetrativas delimitadas em imagem de televisionamento.............................................78

Tabela 7 - Graus de alteração do maciço rochoso (adaptado de ISRM, 1978 e Serra Junior \& Ojima, 1998). .80

Tabela 8 - Exemplo de tabela com parâmetros descritos para descontinuidades delimitadas em imagens de

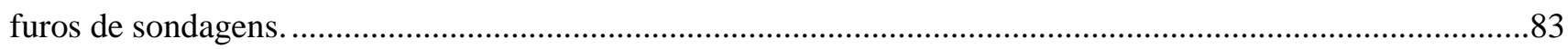

Tabela 9 - Caracterização do preenchimento, modificado de IPT (1984) .......................................................90

Tabela 10 - Linhas estruturais e respectivas famílias consideradas em cada uma destas. ...............................131

Tabela 11 - Parâmetros utilizados para análise no Software Unwedge considerando maciço não drenado......134

Tabela 12 - Principais famílias definidas para análise das paredes da vala da Estação Largo do Taboão. .......167

Tabela 13 - Resumo da análise cinemática bidimensional das paredes da vala da Estação Largo do Taboão.171

Tabela 14 - Resumo dos blocos chaves (removíveis) nas 4 paredes da Estação largo do Taboão. ..................177

Tabela 15 - Valores obtidos de permeabilidade para trecho fraturado na sondagem 4545 (Metrô-SP)...........179 


\section{LISTA DE QUADROS}

Quadro 1 - Intervalos encontrados para resistência à compressão uniaxial para os litotipos mais comuns (dados de Hansen, 1988 e Hoek \& Brown, 1980) (compilado por Palmstrom, 1995). 


\section{LISTA DE FOTOS}

Foto 1- Foto do equipamento da Robertson Geologging, detalhe do sistema de captação e cone de proteção (Baillot et al., 2004)......

Foto 2- Equipamento montado para iniciar filmagem, obra do Metrô do Rio de Janeiro, região da Gávea, RJ (arquivo pessoal).

Foto 3 - Equipamento sendo montado em furo inclinado, obra do Metrô de São Paulo, Largo do Taboão da Serra, SP (arquivo pessoal).

Foto 4 - Exemplo de interferência na imagem devido ao revestimento metálico no furo de sondagem. Fonte: Metrô de São Paulo.

Foto 5 - Exemplo de interferência na imagem devido ao revestimento metálico no furo de sondagem. Fonte: Metrô de São Paulo.

Foto 6 - Exemplo de interferência na imagem devido ao revestimento metálico no furo de sondagem. Fonte: Metrô de São Paulo.

Foto 7 - Mudança brusca na textura, os dois trechos devem ser descritos separadamente. Fonte: Metrô-SP. .78

Foto 8 - Foliação da rocha indicada pela linha pontilhada laranja, famílias de fraturas cortando a foliação. Fonte: Metrô-SP. .78

Foto 9 - Foliação da rocha indicada pela linha pontilhada laranja, com fratura paralela à foliação. Fonte: Metrô-SP.

Foto 10 - Dobras intrafoliais centimétricas em rocha gnáissica do embasamento da Bacia de São Paulo. Fonte: Metrô-SP.

Foto 11 - Dobra de arrasto com trecho cisalhado e cominuído. Fonte: Metrô-SP.

Foto 12 - Veios centimétricos de material esverdeado, provavelmente quartzo + epídoto. Fonte: Metrô-SP.

Foto 13- Imagem ortogonal ao eixo de uma dobra centimétrica, notar foliação mudando de direção de mergulho, acima e abaixo na foto. Fonte: Metrô-SP.

Foto 14 - Pequena dobra intrafolial, notar efeito na direção de mergulho da foliação. Fonte: MetrôSP.

Foto 15 - Diferenças no aspecto de trechos menos e mais alterados (acima e abaixo do veio). Fonte: Metrô-SP.

Foto 16 - Diferenças no aspecto de trechos menos e mais alterados (abaixo e acima do veio). Fonte: Metrô-SP.

Foto 17 - Veio com fraturas no seu topo e base, ilustrando presença de uma estrutura penetrativa e de descontinuidades, na mesma feição. Fonte: Metrô-SP.

Foto 18 - Falha com componente normal e rejeito aparente aproximado de $12 \mathrm{~cm}$. Fonte: Metrô-SP.

Foto 19 - Foto do testemunho de sondagem referente à falha da Foto 18, onde não foi possível observar a presença da estrutura, devido à quebra do testemunho rochoso. Fonte: Metrô-SP.

Foto 20 - Fratura aberta e subvertical, paredes colapsadas, não sendo possível determinar o plano exato desta fratura aberta. Fonte: Metrô-SP...

Foto 21 - Plano de fratura aberta bem definido e fraturas semi-abertas, da mesma família, logo abaixo. Fonte: Metrô-SP. 
Foto 22 - Fratura vertical aberta no testemunho de sondagem, à esquerda, e sua respectiva imagem à direita (arquivo pessoal).

Foto 23 - Fratura horizontal aberta no testemunho de sondagem, à esquerda e imagem no televisionamento de sondagem, à direita (arquivo pessoal).

Foto 24 - Fraturas abertas com preenchimento ausente, ocorrendo apenas película de alteração, classificada segundo Tabela 9 como D4. Fonte: Metrô-SP.

Foto 25 - Fratura aberta, com preenchimento de fragmentos de rocha (D5). Provavelmente restante do preenchimento arenoso foi lavado (D5/D6). Fonte: Metrô-SP.

Foto 26 - Fenda (fratura aberta), com preenchimento de fragmentos de rocha (D5), também com preenchimento areno-argiloso tendo sido lavado (D5/D6). Fonte: Metrô-SP.

Foto 27 - Fratura com preenchimento argiloso de coloração esverdeada, tipicamente encontrado em algumas descontinuidades do embasamento da BSSP, na região norte da RMSP (extensão da Linha 2

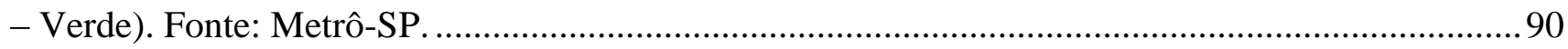

Foto 28 - Fratura com preenchimento de material pétreo rijo (quartzo - D2). Fonte: Metrô-SP........ 91 Foto 29 - Fratura apresentando evidências claras de percolação d'água. Fonte: Metrô-SP................91 Foto 30 - Exemplo de ocorrência de set de fraturas verticais, com relação à direção do furo

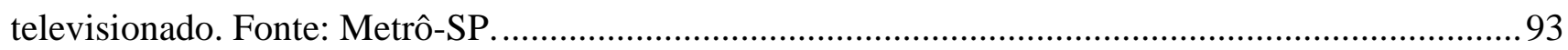

Foto 31 - Fraturas abertas subverticais que foram filmadas em furo inclinado, após observação destas fraturas em furo vertical. Fonte: Metrô-SP.

Foto 32 - Sistema de fraturas paralelas, pouco espaçadas, aumentando o grau de fraturamento no trecho de um maciço pouco fraturado. Fonte: Metrô-SP. ............................................................... 94

Foto 33 - Televisionamento da sondagem 4503 (Metrô-SP). ......................................................... 112

Foto 34 - Televisionamento da sondagem 4540 (Metrô-SP). .............................................................. 112

Foto 35 - Televisionamento da sondagem 4515 (Metrô-SP). .........................................................112

Foto 36 - Televisionamento da sondagem 4559 (presença de veios dobrados) (Metrô-SP). .............112

Foto 37 - Televisionamento da sondagem 4515 (Metrô-SP). ........................................................113

Foto 38 - Televisionamento da sondagem 4548 (aspecto da estrutura milonítica) (Metrô-SP)........113

Foto 39 - Testemunho das sondagem 4534 indicando rocha com feições cataclasadas 4515 (Metrô$\mathrm{SP})$.

Foto 40 - Testemunho da sondagem inclinada 4539, indicando rocha com feições cataclasadas 4515 (Metrô-SP).

Foto 41- Fratura aberta na sondagem 4559 (Metrô-SP) .............................................................. 118

Foto 42- Fraturas abertas na sondagem 4539 (inclinada) (Metrô-SP)............................................ 118

Foto 43 - Fraturas abertas na sondagem 4544 (Metrô-SP).......................................................... 118

Foto 44 - Conjunto de fraturas abertas, formando fenda, ao longo da sondagem inclinada 4597 (Metrô-SP).

Foto 45 - Trecho fraturado a 29,6 metros na sondagem 4505, onde a permeabilidade foi superior aos demais intervalos (Metrô-SP).

Foto 46 - Trecho fraturado a 35,16 metros na sondagem 4505, onde a permeabilidade foi superior aos demais intervalos (Metrô-SP).

Foto 47 - Fraturas abertas no furo 4545, trecho onde foi realizado ensaio de perda d'água com grau de condutividade H5 (muito alto). 


\section{LISTA DE ABREVIATURAS E SIGLAS}

ABGE Associação Brasileira de Geologia de Engenharia e Ambiental

A.T.O. Acompanhamento Técnico de Obra

BSSP Bacia Sedimentar de São Paulo

CMSP Companhia do Metropolitano de São Paulo

EBEI Empresa Brasileira de Engenharia de Infraestrutura

IPT Instituto de Pesquisas Tecnológicas

ISRM International Society of Rock Mechanics - Sociedade Internacional de Mecânica de Rochas

NATM New Austrian Tunnelling Method - Novo Método Austríaco de Túneis

OPTV Televisionamento Óptico

OTV Televisionamento Óptico

RCSB Rifte Continental do Sudeste do Brasil

RMSP Região Metropolitana de São Paulo

TBM Tunnelling Boring Machine - Método Mecanizado de Túneis

VSE Poço de Ventilação e Saída de Emergência 


\section{SUMÁRIO}

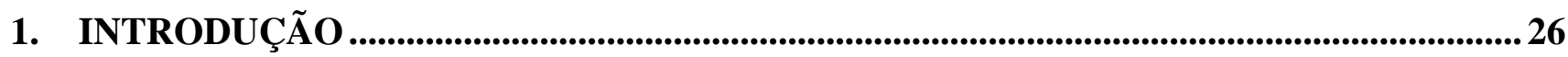

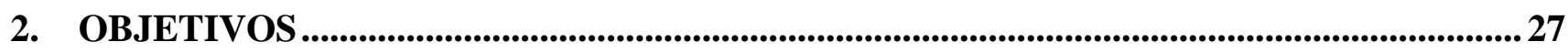

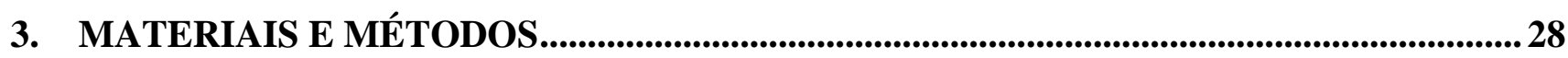

4. REVISÃO BILIOGRÁFICA .........................................................................................

4.1 Geologia Regional ................................................................................................................... 30

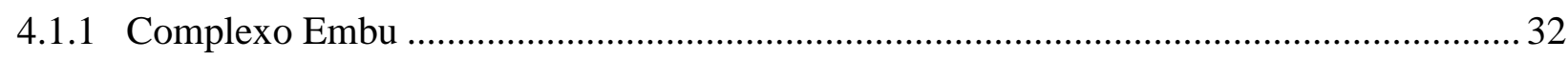

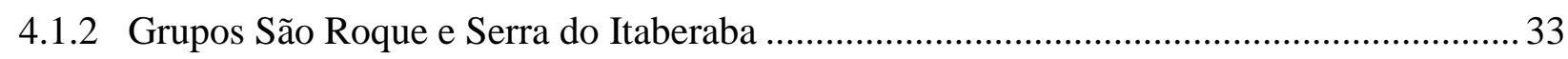

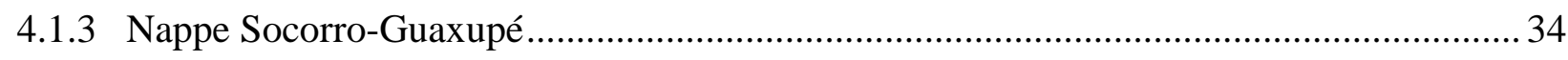

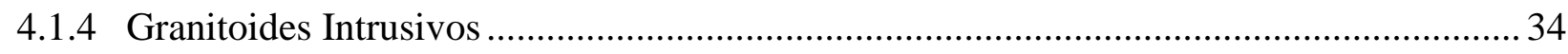

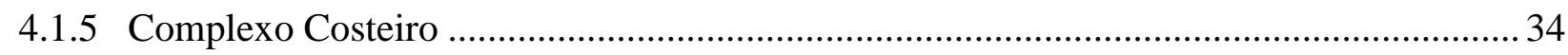

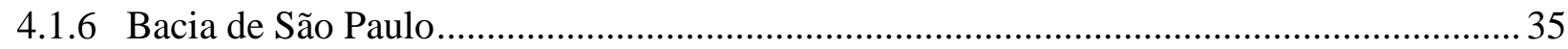

4.1.7 Geologia estrutural ........................................................................................... 41

4.2 Televisionamento Óptico de Furos de Sondagem ...................................................................44

4.3 Caracterização Geológico-Geotécnica de Maciços Rochosos ...............................................5 52

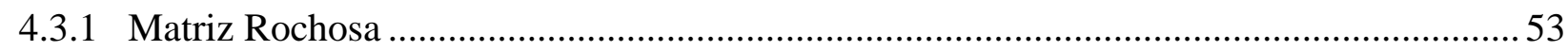

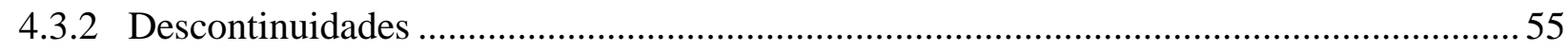

4.4 Análise Cinemática de Túneis em Maciços Rochosos .............................................................63

5. CARACTERIZAÇÃO DO TESTEMUNHO VIRTUAL - METODOLOGIA PROPOSTA76

5.1 Rocha Intacta ...................................................................................................................................... 76

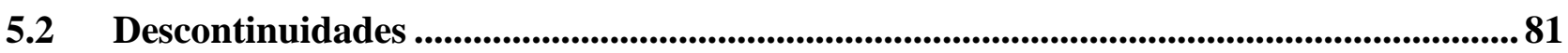

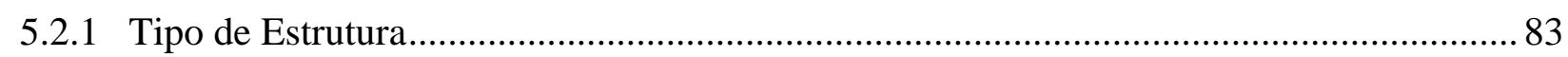

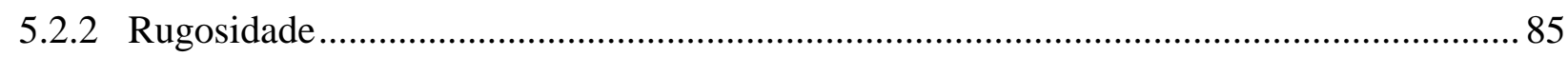

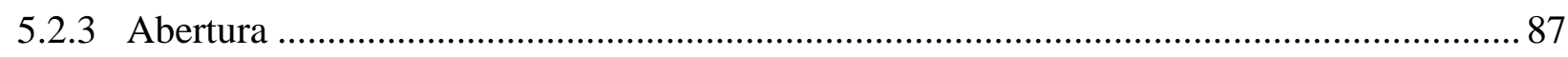

5.2.4 Preenchimento, Percolação D’Água e Condições de Alterações das Paredes ..................... 89

5.2.5 Grau de Fraturamento e Espaçamento .......................................................................... 91

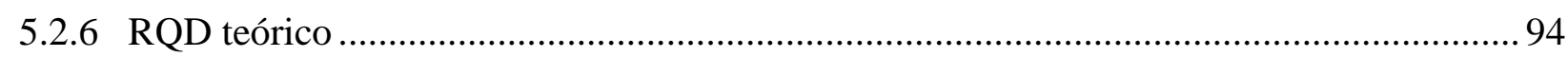

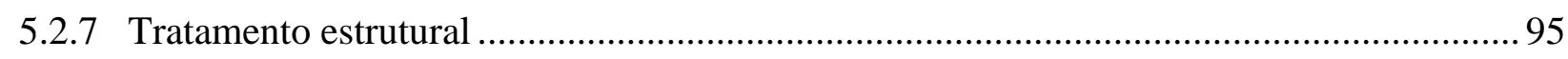

6. APLICAÇÃO DO TELEVISIONAMENTO ÓPTICO - ESTUDO DE CASO......................97

6.1 Estudo de caso 1: Linha 2 Verde - Extensão Vila Prudente - Guarulhos .......................97

6.2 Estudo de caso 2: Linha 4 Amarela - Extensão Vila Sônia - Taboão da Serra.............105

6.2.1 Caracterização geológico-geotécnica do maciço rochoso ................................................. 107 
6.2.2 Aspectos geológico-geotécnicos das descontinuidades ................................................ 115

6.2.3 Análise estrutural e de estabilidade cinemática ............................................................ 120

6.2.4 Aplicação dos dados para análise estrutural e de estabilidade dos poços ....................... 162

6.2.5 Aplicação dos dados para análise estrutural e de estabilidade das paredes da Estação

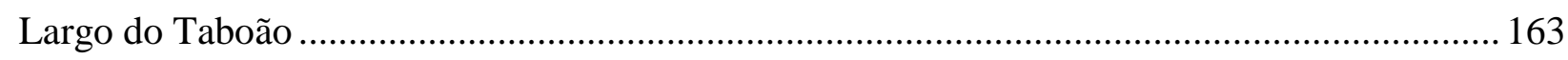

6.2.6 Correlação dos dados do televisionamento com ensaios de perda d'água sob pressão ... 178

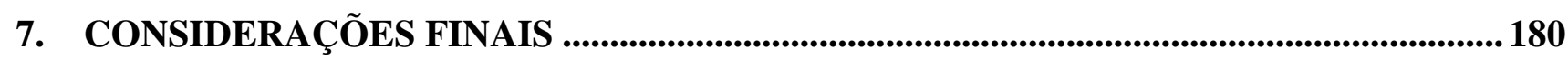

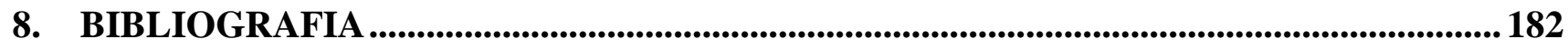




\section{INTRODUÇÃO}

O televisionamento é um método relativamente novo, tendo sido introduzido no Brasil no ano de 2001 (Baillot et al., 2004). Apesar de todas as vantagens que esta tecnologia oferece, apenas recentemente foram inclusas considerações sobre este método no Manual de Sondagens da ABGE (2013), não havendo especificações detalhadas de uma sistemática na obtenção e interpretação dos dados obtidos neste serviço.

O televisionamento de furos de sondagem requer uma atenção especial para que seja aproveitado ao máximo, obtendo-se todas as informações possíveis para melhor caracterizar e classificar um maciço rochoso, contribuindo com a caracterização feita em testemunhos de sondagens.

Este trabalho apresenta sugestões para a aquisição de imagens, sua respectiva interpretação e possibilidades de aplicações em obras de engenharia, tendo como exemplo a aplicação em projetos de obras subterrâneas do Metrô de São Paulo. A proposta foi inicialmente apresentada em Oliveira et al. (2012) e atualizada em Oliveira et al. (2013). Dentre os produtos gerados está a elaboração de uma especificação técnica com o objetivo de estabelecer os requisitos para a execução dos serviços de televisionamento realizados em sondagens, indicando uma metodologia para a descrição das feições geológico-geotécnicas observadas nestas imagens, para as obras de túneis do Metrô de São Paulo, tendo principalmente como base o manual de descrição quantitativa de descontinuidades da ISRM (1978), além da experiência prática obtida em conjunto com as executoras deste serviço em diversos projetos da Companhia do Metropolitano de São Paulo (Oliveira et al., 2013).

Foi possível a verificação de diversas aplicações como a caracterização geológico-geotécnica, a classificação de maciços e a análise cinemática da estabilidade de um túnel, tendo como fonte de dados os furos de sondagem televisionados em rochas do embasamento da Bacia de São Paulo, ao longo do projeto básico de extensão da Linha 4 Amarela, Fase 3 (extensão para o município de Taboão da Serra). Os dados obtidos foram aplicados na análise estrutural e nas soluções de estabilidades em diversas unidades construtivas deste trecho de projeto metroviário, mais especificamente ao longo do túnel de via, dois VSE's (poços de ventilação e saída de emergência), quatro poços de acesso, além das paredes da vala a serem implantadas para a futura Estação Largo do Taboão.

Propõe-se também a aplicação do parâmetro RQD - Rock Quality Designation, já tradicionalmente obtido em furos de sondagem e adaptado para linhas de medida, scanlines, sendo denominado RQD teórico, sugerido por Priest \& Hudson (1976), detalhado em Oliveira (2000). 
Considerou-se aqui que um testemunho virtual é diretamente análogo a uma scanline, sendo sugerida esta aplicação de RQD teórico para testemunhos virtuais e comparação com os valores de RQD medidos nos testemunhos destas mesmas sondagens.

\section{OBJETIVOS}

Este trabalho tem como objetivo principal apresentar um grau de padronização satisfatório na caracterização e classificação de descontinuidades e sua respectiva rocha intacta, a partir de imagens das paredes de furos de sondagem obtidas pelo método do televisionamento óptico, adicionalmente oferecendo sugestões de aplicações destes dados em obras subterrâneas, mais especificamente, as urbanas.

O propósito deste estudo é verificar as possibilidades de adaptação da metodologia utilizada na descrição de testemunhos de sondagens para a descrição de testemunhos virtuais, obtidos a partir das imagens de televisionamento óptico, propondo-se uma sistemática a ser aplicada tanto na aquisição dos dados, assim como em sua interpretação. Ademais, serão averiguadas várias alternativas de aplicação desta técnica, como a análise cinemática da estabilidade de blocos rochosos em escavações subterrâneas.

Para tal, foram utilizadas imagens obtidas do televisionamento realizado nos estudos de investigação das linhas do Metrô de São Paulo, além de seus respectivos testemunhos de sondagem, para efeito de comparação. A Figura 1 esboça a localização dos projetos de linhas do Metrô de São Paulo onde esta técnica foi aplicada e os dados foram obtidos para este presente trabalho. As linhas metroviárias onde os dados de televisionamento foram considerados para este estudo são: Linha 6 Laranja, Linha 4 Amarela, Linha 2 Verde e Linha 5 Lilás. 


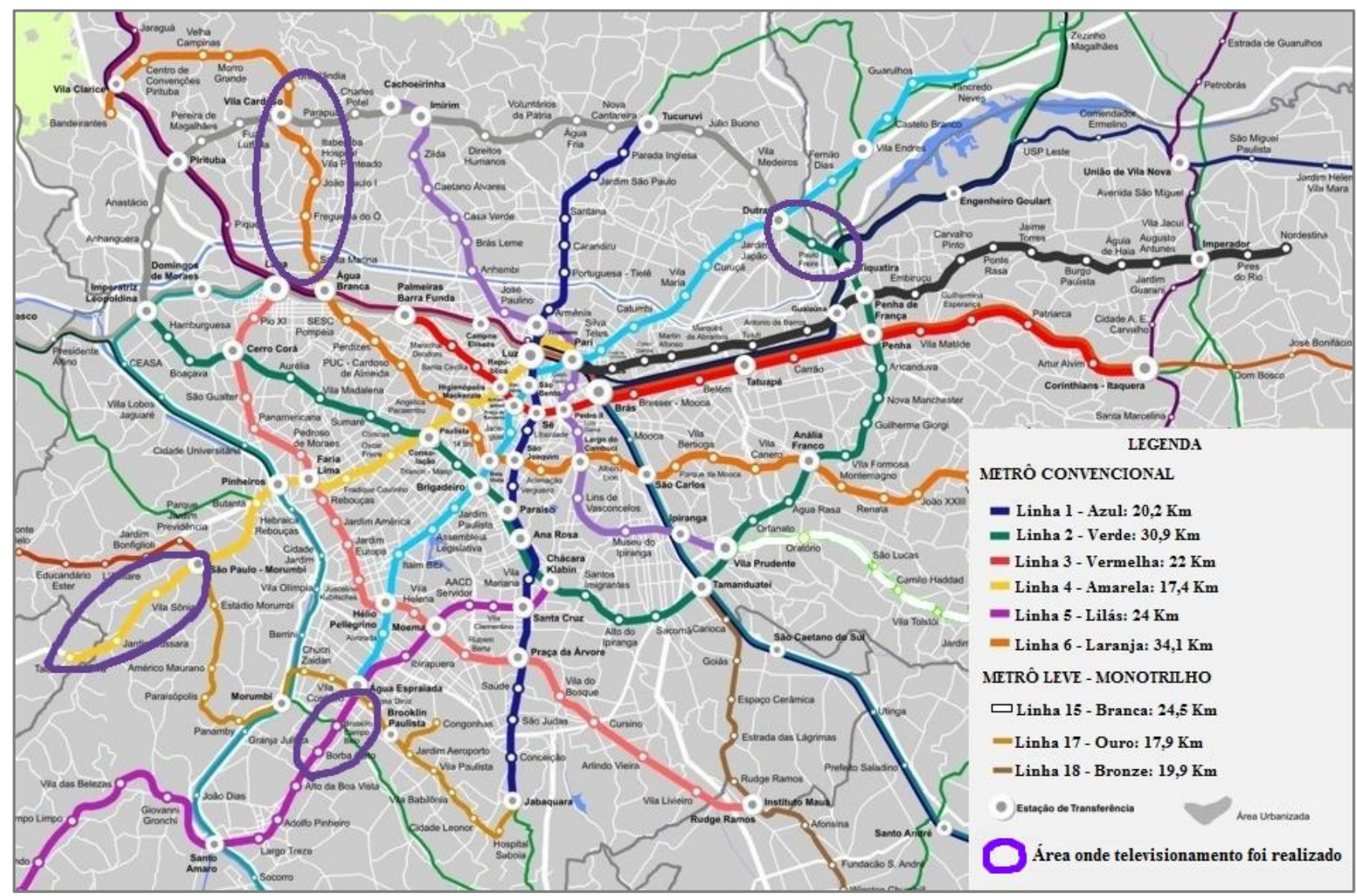

Figura 1 - Mapa da região metropolitana de São Paulo e linhas do Metrô de São Paulo onde foram realizados televisionamento de sondagens para o presente estudo (Modificado de Metrô-SP).

\section{MATERIAIS E MÉTODOS}

O desenvolvimento do trabalho teve início com a aplicação do equipamento de televisionamento em diversos projetos no ano de 2011 juntamente com a empresa executora de sondagens Alphageos Tecnologia Aplicada S.A.. Constatou-se, em seguida, a necessidade de se buscar um padrão para a descrição destas imagens, optando-se em ter como base a metodologia sugerida para descrição de descontinuidades da Sociedade Internacional de Mecânica de Rochas ISRM (1978).

Iniciou-se uma pesquisa bibliográfica para levantamento dos conhecimentos prévios sobre o assunto. Concomitantemente foram publicados, em conjunto com a equipe técnica da Companhia do Metropolitano de São Paulo e a empresa executora de sondagens Progeo Engenharia Ltda., dois artigos propondo sugestões para a caracterização dos testemunhos virtuais originados no televisionamento de sondagens. Verificou-se a necessidade de adaptações, assim como a definição de aplicações concretas na utilização deste produto em projetos de obras subterrâneas urbanas. 
Foram realizadas diversas sondagens ao longo da Linha 2 Verde, extensão para Guarulhos, com o intuito de se investigar o subsolo para o projeto desta linha metroviária, tendo sido televisionado o total de 32 sondagens, sendo que 874 metros de rocha foram filmados. Igualmente, com o mesmo propósito, foram executadas inúmeras sondagens para o projeto de extensão da Linha 4 Amarela - Fase 3, tendo sido televisionadas 17 sondagens, com um total de 503 metros de rocha filmada. Alguns outros televisionamentos foram realizados em outras linhas do Metrô de São Paulo, contando com um total de 51 sondagens e 2.201 metros de rocha filmada. Além destas, adicionam-se algumas sondagens televisionadas em outros projetos, como o Metrô do Rio de Janeiro, por exemplo, que serviram como experiência adquirida na elaboração desta metodologia proposta.

Estas imagens foram analisadas, descritas e caracterizadas seguindo a metodologia da ISRM e adaptada para o televisionamento, conforme o sugerido em Oliveira et al. (2012) e Oliveira et al. (2013). Alguns dos testemunhos de sondagens foram descritos e feições encontradas foram comparadas com os testemunhos virtuais. Os dados foram tratados, organizados em planilhas e comparados os resultados obtidos entre os testemunhos reais e virtuais. Uma metodologia foi proposta, assim como consideradas todas as necessidades de adaptação para a caracterização e classificação de um maciço rochoso observado a partir de imagens de televisionamento.

Foram elaborados diagramas estatísticos, ilustrando a variação de alguns parâmetros ao longo dos trechos analisados nas extensões da Linha 2 e da Linha 4. No caso da extensão da Linha 4, o trabalho teve continuidade através da projetista EBEI - Empresa Brasileira de Engenharia de Infraestrutura. Os dados obtidos do televisionamento ao longo deste trecho de 2,4 Km de extensão da Linha 4 Amarela foram utilizados para caracterizar e classificar o maciço rochoso, assim como servir de subsídio para as soluções de engenharia adotadas para o túnel de via, para os poços e paredes da Estação Largo do Taboão.

Os dados foram tratados com o Software Dips (Rocscience, 1999) e posteriormente uma análise estrutural e de estabilidade foi realizada utilizando o Software Unwedge (Rocscience, 2004). Os dados estruturais obtidos foram comparados com aqueles disponíveis na literatura técnica e apresentados em tabelas. A análise estrutural foi realizada tanto bidimensionalmente, segundo o proposto por Hoek \& Bray (1981), como tridimensionalmente, aplicando para isso a Teoria dos Blocos Chaves, de Goodman \& Shi (1985). Foram feitas sugestões a respeito da escavação do túnel de via, assim como demais unidades construtivas desta linha.

Adicionalmente os dados do televisionamento foram utilizados para definir os intervalos em rocha a serem realizados ensaios de perda d'água sob pressão (EPA), sendo feitas correlações diretas com as imagens obtidas no OPTV, testemunhos de sondagens e valores de permeabilidade. 
Finalmente foram apresentadas sugestões de continuidade para pesquisa nesse assunto, considerando que as possibilidades de aplicações são extensas e já prevendo a necessidade de verificação da aplicabilidade desta metodologia proposta em outros contextos geológicos, assim como sua aplicação em distintas obras de infraestrutura.

\section{REVISÃo BILIOGRÁFICA}

\subsection{Geologia Regional}

A Região Metropolitana de São Paulo (RMSP) está inserida no contexto geológico regional Pré-Cambriano que compõe a Província Mantiqueira (Almeida et al., 1977). Esta província ocupa uma área da ordem de $450.000 \mathrm{~km}^{2}$, confrontando-se de um lado com as bacias costeiras e a margem continental e de outro, com as Províncias São Francisco, Tocantins e Paraná. É representada por três grandes compartimentos sendo, em ordem estratigráfica, o embasamento Pré-Cambriano, os sedimentos Paleógenos a Neógenos da Bacia de São Paulo (anteriormente denominados de Terciários) e as coberturas Quaternárias (Pleistocênicas a Holocênicas). Segundo Hasui (2010) a Província Mantiqueira é dividida nos cinturões Araçuaí, Ribeira e Tijucas (Figura 2).

O embasamento da RMSP está inserido em um complexo sistema influenciado por várias entidades geotectônicas. Hasui (2010) menciona que, embora a história geológica regional remonte ao Arqueano (4000 a $2500 \mathrm{Ma}$ ) e envolva processos Paleoproterozoicos (2500 a $1600 \mathrm{Ma})$ e Mesoproterozoicos (1600 a 1000 Ma), relacionados com a evolução dos supercontinentes Colúmbia e Rodínia, foram no Neoproterozoico (1000 a 542 Ma) que se incidiram os movimentos de fragmentação e colisão a que se deve a estruturação regional aqui encontrada.

Esses processos colisionais remontam ao grande intervalo existente entre 900 e 500 Ma, período onde as grandes massas continentais, após a fragmentação de Rodínia, iniciaram um processo de aglutinação por meio de progressivas convergências levando à formação do megacontinente Gondwana. Este processo de aglutinação culminou no fechamento de paleoceanos que existiam entre as massas continentais da América do Sul e da África. O fechamento destes paleoceanos ocorreu por meio de um grande evento colisional, com a formação dos sistemas orogênicos Mantiqueira e Tocantins. Enquanto se formava o Gondwana os outros continentes se espalharam e todos eles voltaram a se agregar por volta de $230 \mathrm{Ma}$ para formar o Pangea. A quebra deste, por fim, deu origem aos atuais continentes (Hasui, 2010). 


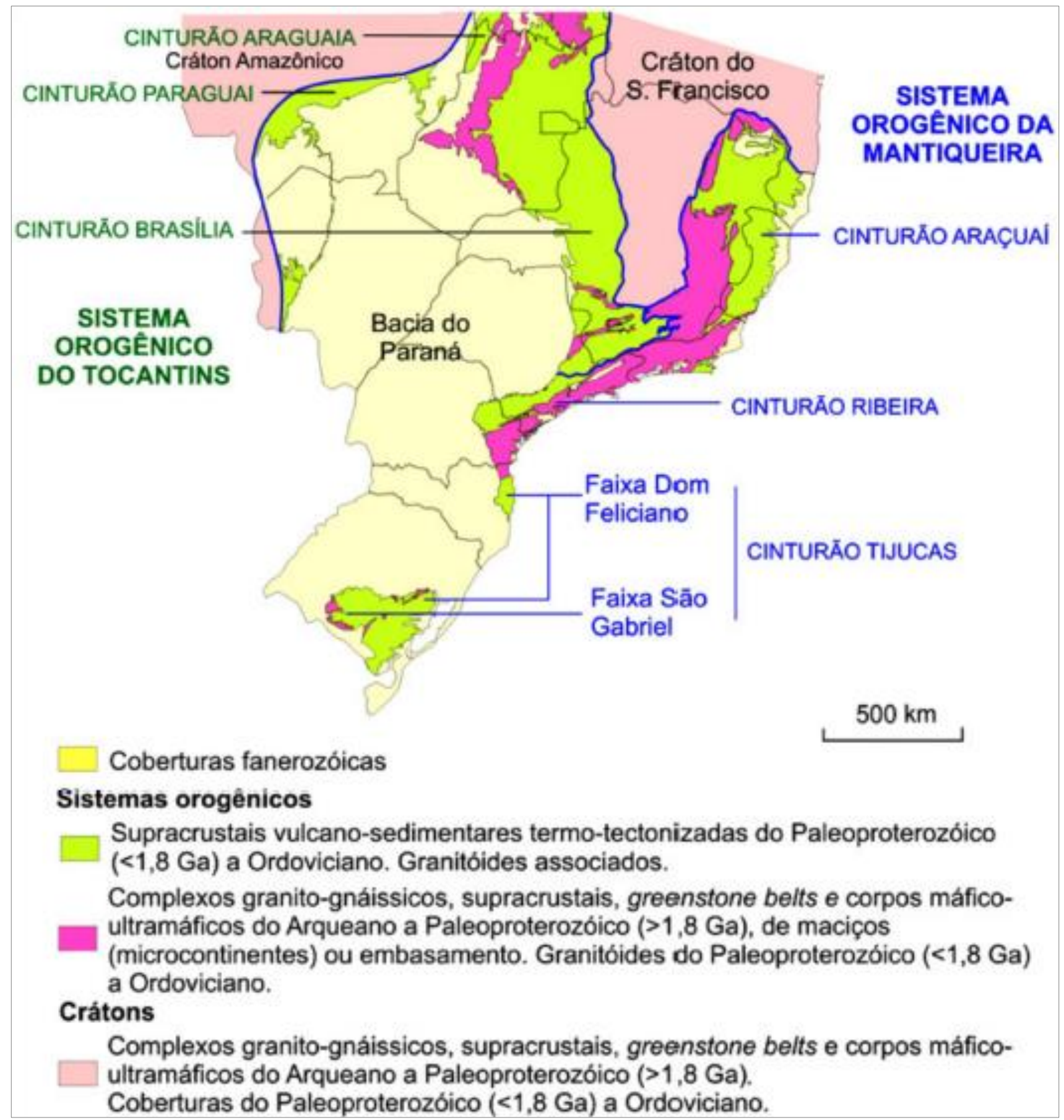

Figura 2 - Os sistemas orogênicos da Mantiqueira e do Tocantins (Hasui, 2010 ).

A região de interesse encontra-se dentro do Orógeno Ribeira. Hasui et al. (1975) denomina este segmento do Orógeno Ribeira como parte do Segmento Meridional, com trend estrutural de direção NNE, condicionada por um sistema de falhas transcorrentes. As lineações de estiramento do Orógeno Ribeira possuem direções em torno de NE-SW, coerentes com o sistema transcorrente Paraíba do Sul, e indicam a direção do transporte de massa e sentido de movimento, que coincide com a polaridade metamórfica, sentido para o qual o metamorfismo regional decresce (Hasui, 2010). 
Quanto aos litotipos, o arcabouço geológico da RMSP é basicamente constituído por rochas metamórficas e ígneas, associadas ao Complexo Embu e aos Grupos São Roque e Serra do Itaberaba, além de corpos de rochas granitoides intrusivas. Com menor expressão ocorrem as rochas do Complexo Costeiro, Complexo Pico do Papagaio, da Nappe Socorro-Guaxupé e do Grupo Votuverava (Monteiro et al., 2012).

\subsubsection{Complexo Embu}

O Complexo Embu, unidade de maior ocorrência no embasamento da RMSP, ocorre na porção centro-sul da Grande São Paulo, ocupando faixas de afloramentos com direção NE-SW, formado por xistos, filitos, migmatitos, gnaisses migmatizados e corpos lenticulares de quartzitos, anfibolitos e rochas calciossilicatadas. É limitado ao norte pelo sistema de falhas de Taxaquara e do Rio Jaguari e ao sul pela falha de Cubatão, separando-o dos grupos São Roque e Serra do Itaberaba, e do Complexo Costeiro, respectivamente (Monteiro et al., 2012).

Segundo Juliani (1992), o Complexo Embu é composto por três conjuntos de litotipos:

- Rochas ortognáissicas polimigmatizadas e polideformadas que constituem o Complexo Granito-Gnáissico-Migmatítico. Estes constituem o embasamento das supracrustais, com idades preliminares Arqueanas a Paleoproterozoicas. Segundo Hasui (1993) este conjunto se caracteriza por gnaisses de tipos diversos na RMSP (porfiroides e homogêneos predominantes, bandados, subordinados, ocasionalmente laminados), que se mostram mais ou menos migmatizados (estruturas principalmente bandadas ou estromatíticas) e possuem enclaves esparsos e restritos de rochas metassedimentares e anfibolitos;

- Rochas metassedimentares em grau metamórfico elevado, incluindo gnaisses com extensas faixas de xistos de fácies anfibolito médio a superior, correspondentes ao Complexo Embu. $\mathrm{Na}$ RMSP, Hasui (1993) assinala a ocorrência de metassedimentos de fácies anfibolito, representados essencialmente por micaxistos, quartzitos e rochas calciossilicáticas, com alguns anfibolitos associados. Estas rochas mostram-se mais ou menos migmatizadas (estruturas principalmente bandadas ou estromatíticas);

- Sericita xistos e filitos de baixo grau metamórfico, que podem corresponder a porções das rochas metassedimentares supracitadas, que sofreram metamorfismo em condições de temperaturas mais baixas. 
Na Figura 3 é possível visualizar o Complexo Embu, representado pela cor verde, que se encontra em contato por granitoides intrusivos, representados pela cor vermelha no mapa. Ainda ocorrem ao norte do Complexo Embu os grupos São Roque, Serra do Itaberaba e Amparo e ao sul o Complexo Costeiro, brevemente citados a seguir.

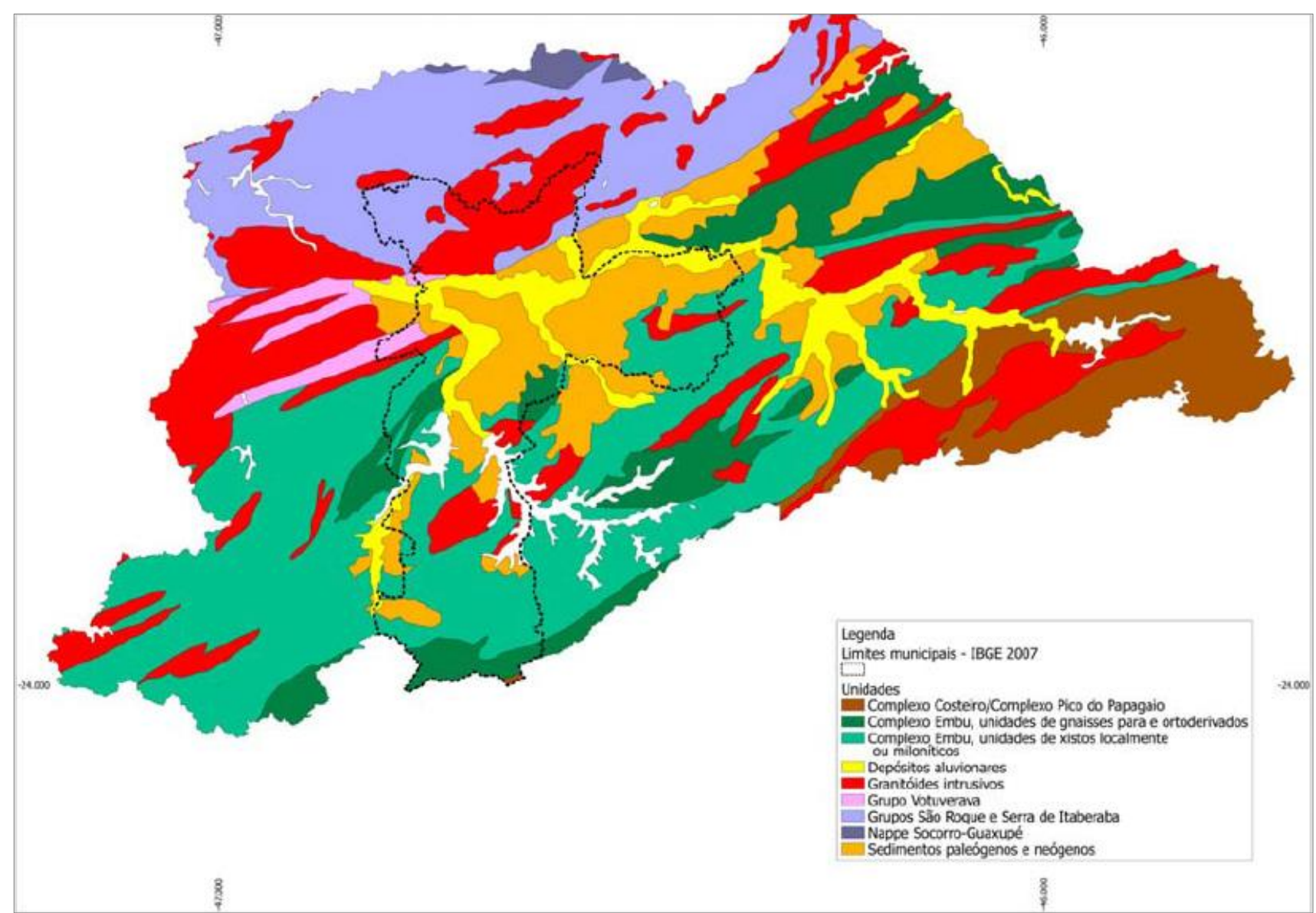

Figura 3 - Mapa geológico da Região Metropolitana de São Paulo, com destaque para o embasamento (Monteiro et al., 2012).

\subsubsection{Grupos São Roque e Serra do Itaberaba}

Os grupos São Roque e Serra do Itaberaba são constituídos por rochas metassedimentares e metavulcânicas representadas principalmente por filitos, metarenitos e quartzitos, tendo secundariamente a ocorrência de anfibolitos, metacalcários, dolomitos, xistos porfiroblásticos e rochas calciossilicatadas (Rodriguez, 1998). Juliani \& Beljavskis (1995) considera a sequência metavulcano-sedimentar do Grupo Serra do Itaberaba como basal, sobre a qual se depositou o Grupo São Roque.

Segundo Juliani (1993) a análise litológica, estratigráfica e do quimismo dos variados litotipos indica que a sequência vulcano-sedimentar do Grupo Serra do Itaberaba pode ter tido o início de sua evolução com a deposição de sedimentos e de rochas ígneas em um ambiente de rifte 
ensiálico que posteriormente evoluiu para bacia oceânica. A continuidade da sedimentação deu-se em bacia de retro-arco, com intrusão de rochas intermediárias. O Grupo São Roque constitui-se em sequência de metassedimentos cuja deposição pode ser associada a corrente de turbidez, mas, em ambiente marinho provavelmente plataformal, instalado, pelo menos em parte, sobre a sequência metavulcano-sedimentar erodida do Grupo Serra do Itaberaba.

\subsubsection{Nappe Socorro-Guaxupé}

Os terrenos a norte da falha de Jundiuvira correspondem à Nappe Socorro-Guaxupé. Rodriguez (1998), em referência à antiga denominação da unidade aflorante nesta área (Grupo Amparo), menciona que estas rochas são constituídas por metassedimentos e rochas gnáissicas e migmatíticas.

IPT (1981) reconhece três fases principais de deformação atribuídas, respectivamente, aos ciclos Transamazônico, Uruaçuano e Brasiliano. A primeira formam dobras recumbentes com eixos NNE e transposição associada; a segunda, planos axiais subverticais com eixos NNW e a última mostram dobras suaves, com planos axiais empinados e eixos NE. Admite idade Transamazônica para este grupo, com rejuvenescimentos nos ciclos Brasiliano e Uruaçuano.

\subsubsection{Granitoides Intrusivos}

Grande quantidade de batólitos a pequenos stocks de granitoides afloram nas proximidades da RMSP, alguns parcialmente recobertos pelos sedimentos da Bacia de São Paulo. Segundo Hasui et al.(1978) os maciços granitoides identificados ao longo da Faixa de Dobramentos São Roque são principalmente do fácies Cantareira, caracterizados predominantemente por granito-gnaisses, de granulação fina a média, foliação marcante e sem grandes variações composicionais ou texturais macroscopicamente discerníveis, sendo estes sin-tectônicos aos terrenos metamórficos adjacentes.

Conforme Hasui \& Carneiro (1980) as rochas granitoides que ocorrem na RMSP constituem batólitos que sustentam relevos de topografia elevada, tais como as serras da Cantareira, Itaqui, Itapeti e Caucaia, onde ocorrem os mais extensos corpos granitoides.

\subsubsection{Complexo Costeiro}

O Complexo Costeiro é constituído por rochas predominantemente migmatíticas policíclicas de paleossoma gnáissico. Sua ocorrência restringe-se a uma estreita faixa no extremo sudeste ao sul 
da falha de Cubatão. Ocorrem nesta área migmatitos e gnaisses graníticos porfiroblásticos frequentemente milonitizados, biotita-gnaisses e gnaisses peraluminosos. Ao norte, esta unidade entra em contato com o Complexo Embu através da falha de Cubatão e a leste limita-se com um corpo granítico (Rodriguez, 1998).

De acordo com IPT (1981) este complexo se caracteriza por ser bastante heterogêneo, onde as rochas sofreram metamorfismo de fácies granulito e anfibolito, bem como migmatização e granitização em graus variáveis. A superposição de diferentes eventos de metamorfismo, deformação, migmatização, granitogênese e blastomilonitização sugere um quadro de rochas Arqueanas retrabalhadas em eventos termotectônicos policíclicos.

\subsubsection{Bacia de São Paulo}

A cobertura sedimentar Fanerozoica na região corresponde aos depósitos Terciários da Bacia de São Paulo do segmento central do Rifte Continental do Sudeste do Brasil (RCSB), além de depósitos Quaternários, caracterizados por aluviões, colúvios e elúvios, intimamente relacionados a feições geomorfológicas. Segundo Riccomini (1989) o preenchimento vulcano-sedimentar do rifte, caracterizado pelo Grupo Taubaté, compreende um sistema de leques aluviais associados à planície fluvial de rios entrelaçados (Formação Resende), basal e lateral na bacia, um sistema lacustre (Formação Tremembé), e um sistema meandrante (Formação São Paulo), este já numa fase de colmatação da depressão. As condições climáticas teriam sido semiáridas durante a sedimentação das Formações Resende e Tremembé, passando para úmidas durante a deposição da Formação São Paulo.

O RCSB, de idade Paleógena, é uma depressão alongada e deprimida com pouco mais de 900 km de comprimento, tendo sido instalado no domínio da Faixa Ribeira, de idade Neoproterozoica, que inclui núcleos mais antigos. Zonas de cisalhamento de direção $\mathrm{NE}$ a E-W, reativadas como falhas normais no Paleógeno e transcorrentes no Neógeno, ensejaram a instalação e deformação das bacias que compõe o RCSB. Morfologicamente o RCSB apresenta-se como uma faixa estreita e deprimida, alongada segundo a direção ENE, seguindo a linha de costa atual, da qual dista em média cerca de 70 km, alcançando o Oceano Atlântico em suas terminações sudoeste e nordeste (Figura 4). 


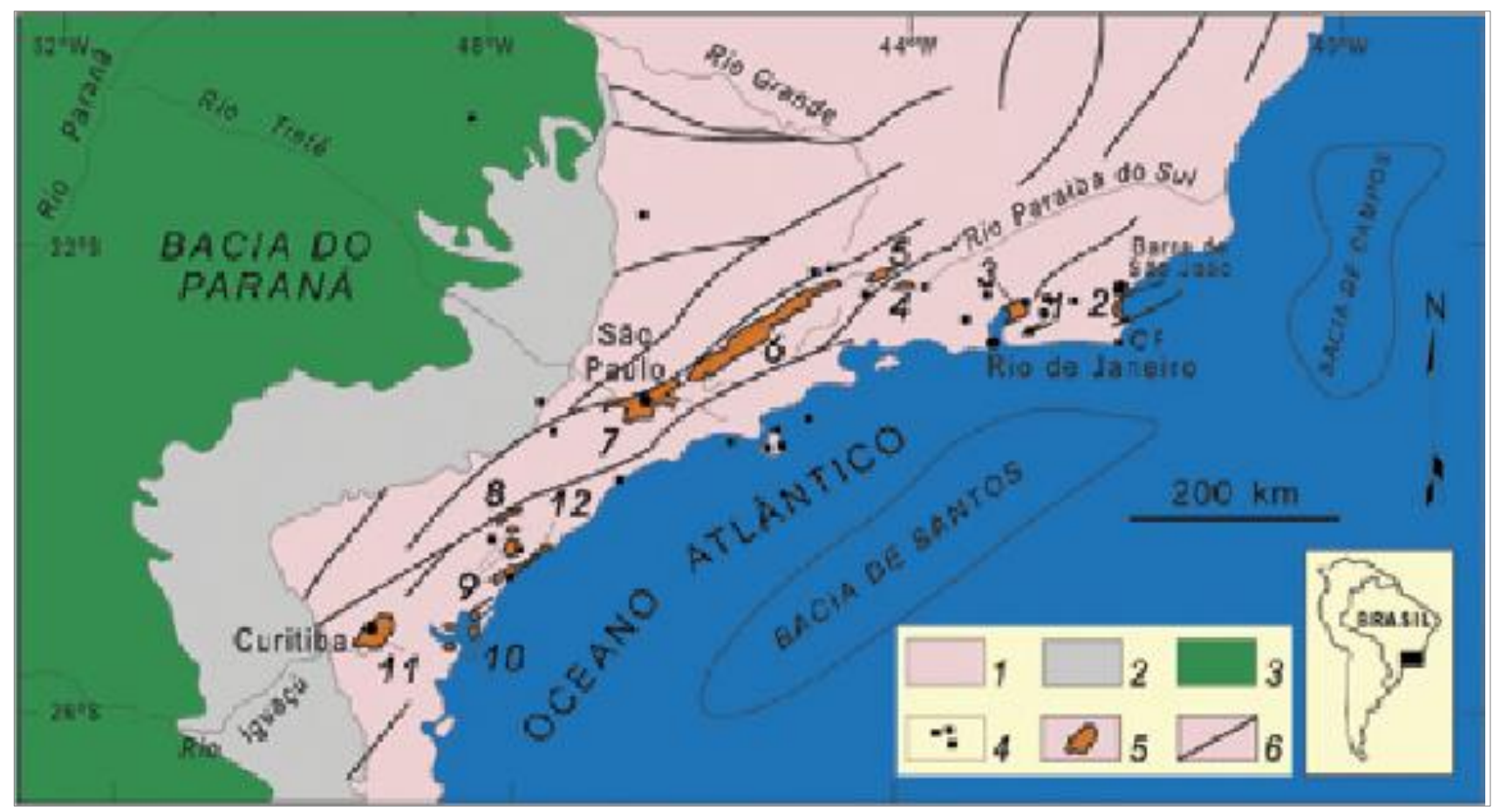

Figura 4 - Contexto geológico regional do Rifte Continental do Sudeste do Brasil (RCSB): 1) embasamento Pré-Cambriano; 2) rochas sedimentares Paleozoicas da Bacia do Paraná; 3) rochas vulcânicas toleíticas Eocretáceas da Formação Serra Geral; 4) rochas relacionadas ao magmatismo alcalino Mesozoico-Cenozoico; 5) bacias Cenozoicas do rifte (1- Bacia de Itaboraí, 2- Gráben de Barra de São João, 3- Bacia do Macacu, 4- Bacia de Volta Redonda, 5- Bacia de Resende, 6- Bacia de Taubaté, 7- Bacia de São Paulo, 8- Gráben de Sete Barras, 9- Formação Pariquera-Açu, 10- Formação Alexandra e Gráben de Guaraqueçaba, 11- Bacia de Curitiba, 12- Gráben de Cananéia); 6) zonas de cisalhamento Pré-Cambrianas, em parte reativadas durante o Mesozoico e Cenozoico (Riccomini et al., 2004).

Segundo Hasui \& Carneiro (1980) a bacia tem forma irregular com forma elíptica de 60 X 30 km, sendo que a esta configuração se ajusta a rede de drenagem atual de São Paulo e adjacências. A bacia possui embasamento com relevo tão ou mais acentuado que o existente nos terrenos PréCambrianos circunjacentes. Esse paleorelevo influiu não só nas variações de espessura do pacote sedimentar, mas também na configuração areal da bacia.

A Bacia de São Paulo foi retalhada por falhas pós-sedimentares que causaram soerguimentos e abatimentos locais de seu substrato. A julgar pelo seu formato e distribuição de fácies sedimentares, pode-se considerar que a bacia era originalmente um hemigráben (Figuras 5 e 6), controlado por falhas normais reativadas ao longo das zonas de cisalhamento Proterozoicas de Taxaquara e Jaguari, dispostas ao longo de sua borda norte (Riccomini \& Coimbra, 1992). O preenchimento sedimentar da BSSP corresponde à deposição Paleógena do Grupo Taubaté (Formação Resende, Formação Tremembé e Formação São Paulo) e Neógena da Formação Itaquaquecetuba (Figura 7). 
A Formação Resende, unidade basal e lateral do Grupo Taubaté, encerra os depósitos de leques aluviais associados a planícies aluviais de rios entrelaçados da bacia. É formada por orto e paraconglomerados nas áreas proximais e lamitos nas porções medianas e distais dos leques aluviais, além de arenitos fluviais em rios entrelaçados axiais à bacia (Riccomini, 1989).

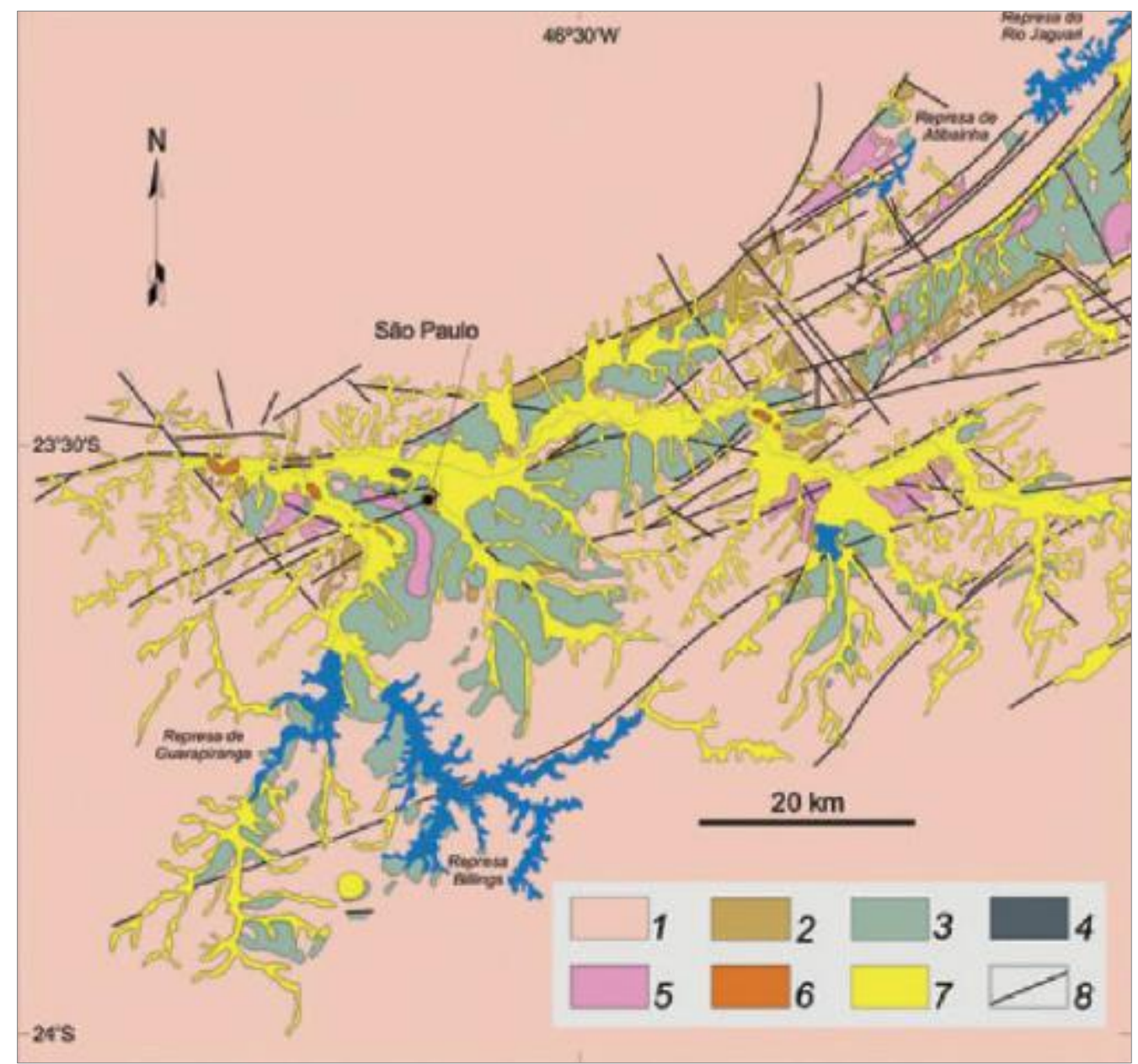

Figura 5 - Mapa geológico da Bacia de São Paulo e porção sudoeste da Bacia de Taubaté: 1) embasamento Pré-Cambriano; 2) Formação Resende (sistema de leques aluviais proximais); 3) Formação Resende (sistema de leques aluviais medianos a distais associados à planície aluvial de rios entrelaçados); 4) Formação Tremembé; 5) Formação São Paulo; 6) Formação Itaquaquecetuba; 7) sedimentos Quaternários; 8) falhas Cenozóicas, em parte reativadas do embasamento Pré-Cambriano (Riccomini et al., 2004).

O sistema de leques aluviais da Formação Resende grada lateral e verticalmente para o sistema lacustre do tipo playa-lake da Formação Tremembé, presente na porção centro-norte da Bacia de São Paulo (Riccomini \& Coimbra, 1992). É composta por: argilitos verdes maciços; dolomitos tabulares; ritmitos formados pela alternância de folhelhos e margas; arenitos com estratificação cruzada sigmoidal e granodecrescência de areia média até silte; e arenitos grossos, arcoseanos (Riccomini, 1989). Esta formação foi reconhecida em escavações para a construção da 
Estação Barra Funda da Companhia do Metropolitano de São Paulo, onde camadas tabulares de argilitos maciços verdes encontram-se intercaladas com argilitos cinza-escuro a preto, ricos em matéria orgânica (Riccomini \& Coimbra, 1992).

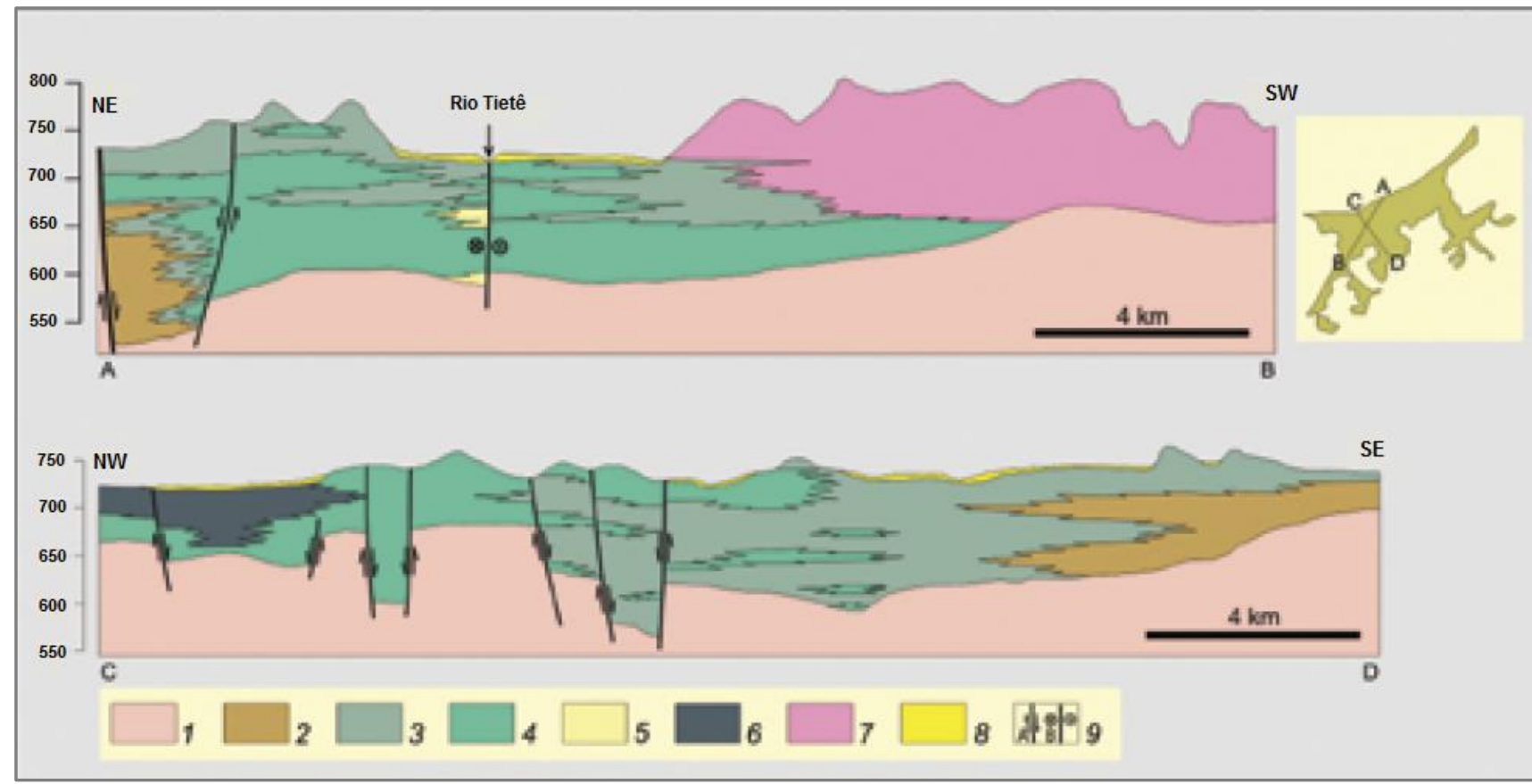

Figura 6 - Seções geológicas na Bacia de São Paulo construídas a partir de dados de sondagens para água subterrânea e observações de superfície: 1) embasamento Pré-Cambriano; 2) orto e paraconglomerados de leques aluviais proximais da Formação Resende; 3) lamitos de leques aluviais medianos a distais da Formação Resende; 4) lamitos de leques aluviais distais e, principalmente, areias e conglomerados de sistema fluvial entrelaçado da Formação Resende; 5) predominância de areias grossas e conglomerados de sistema fluvial entrelaçado da Formação Resende; 6) sistema lacustre da Formação Tremembé; 7) sistema fluvial meandrante da Formação São Paulo; 8) aluviões Quaternários; 9) falha normal (A) e falha transcorrente dextral (B) (Riccomini et al., 2004).

A Formação São Paulo recobre concordantemente a Formação Resende e assinala a fase de maior quiescência tectônica e terminal do estágio sin-rifte da sedimentação no RCSB, quando ainda estavam interligadas as bacias de São Paulo, Taubaté, Resende e Volta Redonda (Riccomini, 1989). Compreende um sistema fluvial meandrante, sendo as principais litofácies compostas por arenitos grossos, conglomeráticos, com estratificações cruzadas, base erosiva e presença de clastos argilosos, representantes de depósitos de canais meandrantes; siltitos e argilitos laminados, às vezes fossilíferos (linhitos), depositados em meandros abandonados; e arenitos médios a grossos como sedimentos de rompimento de diques marginais, gradando para sedimentos mais finos, rítmicos e laminados de planície de inundação (Riccomini et al., 2004). 


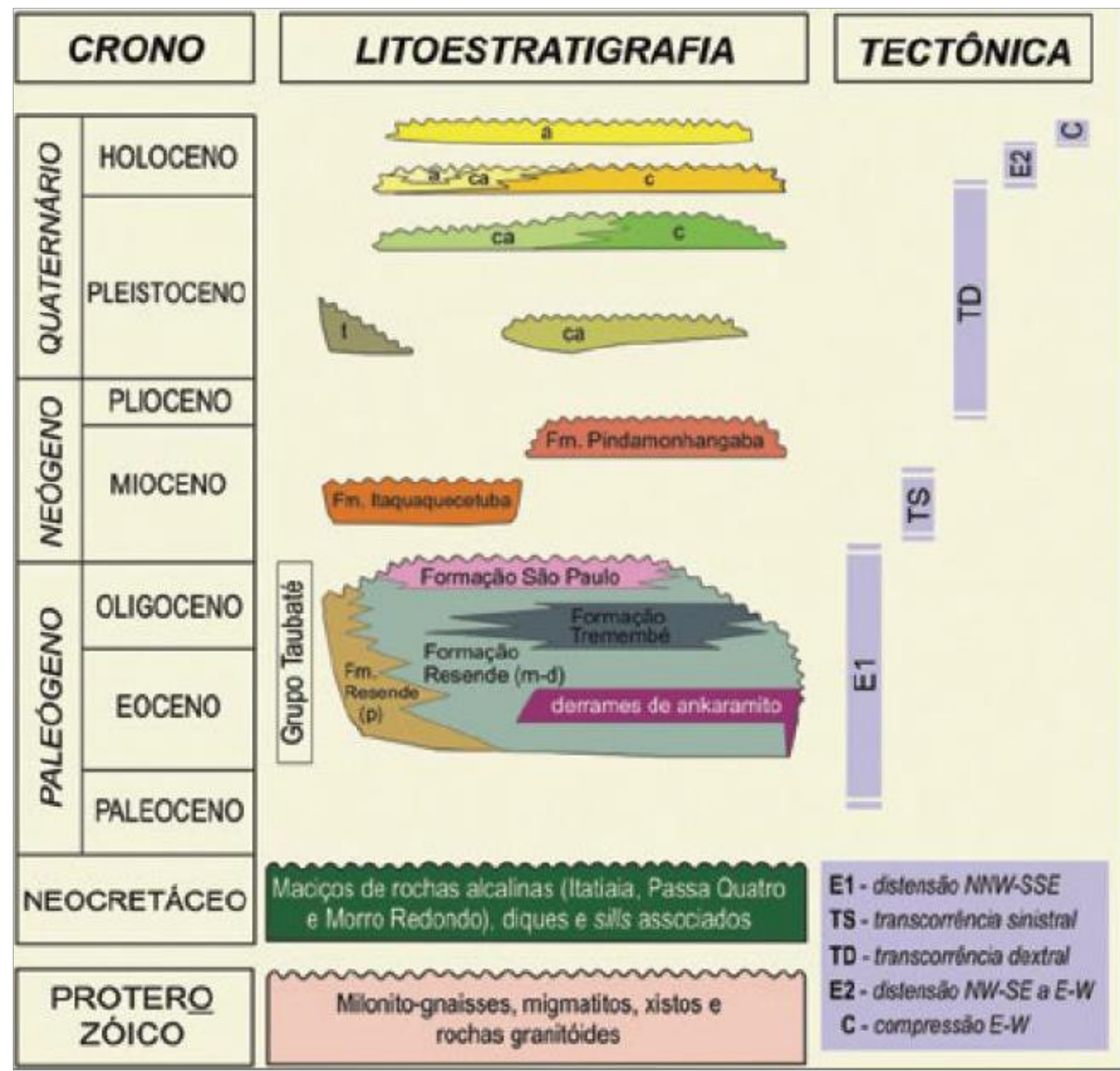

Figura 7 - Quadro litoestratigráfico e evolução tectono-sedimentar do segmento central do RCSB Letras: p-leques aluviais proximais; $\mathrm{m}$-d-leques aluviais medianos a distais associados à planície aluvial de rios entrelaçados; t-depósitos de tálus; c-depósitos coluviais; ca-depósitos colúvio-aluviais; adepósitos aluviais (Riccomini et al., 2004).

A Formação Itaquaquecetuba representa um sistema fluvial entrelaçado, restrito à BSSP, que ocorre assentado diretamente sobre rochas do embasamento Pré-Cambriano, sem que tenha sido verificada a sua relação com as unidades sedimentares Paleógenas. A deposição da unidade foi controlada por falhas de direção ENE e NNW, em cujas vizinhanças formaram-se cunhas clásticas, contendo brechas polimíticas com blocos decimétricos a métricos angulosos de rochas do embasamento e megaclastos de siltitos arenosos a folhelhos cinza e marrom-escuro ricos em restos vegetais (Riccomini et al., 2004). 
Sobrepostos aos depósitos Terciários ocorrem os depósitos aluvionares de idade Quaternária, de idade Pleistocênica a Holocênica (atual), relacionados a canais e planícies de inundação das bacias hidrográficas de mesma idade. Estes depósitos, em geral, são recobertos por camadas de aterro (Gurgueira, 2013).

Estes depósitos são texturalmente imaturos, reunidos sob a designação informal de "sedimentos Neocenozoicos". Admite-se que os mais antigos destes depósitos possam ser até Pliocênicos, sendo representados principalmente por ocorrências pouco extensas, que aparecem em situações topográficas diversas (topos de morros, encostas, fundos de vales). Os depósitos mais recentes são representados por aluviões delgados e relativamente extensos, dispostos ao longo das várzeas atuais, e também pela camada superficial de coluviões atuais, de distribuição generalizada. Delgados horizontes de turfa aparecem comumente sobre os aluviões das várzeas atuais (Melo et al., 1987).

De acordo com Monteiro et al. (2012) os depósitos Pleistocênicos compreendem predominantemente coluviões argilo-arenosos, com lentes argilosas a conglomeráticas, ocasionalmente contendo madeira fóssil, e aluviões subordinados constituídos por conglomerados basais sobrepostos por areias grossas a conglomeráticas com estratificações cruzadas, gradando para areias médias a finas, com porções argilosas. E os depósitos Holocênicos são representados por coluviões e aluviões, com espessura geralmente inferior a dez metros. Os coluviões são descontínuos embora com distribuição generalizada, podendo conter cascalheiras (stone lines) na base. Os depósitos aluviais estão depositados em várzeas e baixos terraços, constituídos por camadas arenosas e argilosas ricas em matéria orgânica, geralmente exibindo cascalheiras na base.

Conforme observado por Massad (2012) os aluviões Quaternários na Bacia de São Paulo situam-se principalmente entre as cotas 723 e 720 metros, ao longo dos rios Tietê, Pinheiros e Tamanduateí. Sua formação deu-se em regime fluvial, através de dois processos fisicamente próximos, mas que dão origem a solos bem diferentes, quais sejam: a meandragem e a inundação. Nas áreas de inundação, caracterizadas por topografia mais suave, menores energia para o transporte dos sedimentos e condições mais estáveis de sedimentação, encontram-se solos mais finos e de granulometria mais uniforme. É justamente o contrário do observado nas áreas de antiga meandragem e áreas próximas ao pé de regiões de topografia mais acidentada, aonde ocorrem solos granulometricamente bem distintos, de argilas pouco arenosas até areias pouco argilosas. 


\subsubsection{Geologia estrutural}

Segundo Campanha et al. (1985) certamente a característica estrutural mais marcante do embasamento cristalino da Bacia de São Paulo são suas inúmeras zonas de cisalhamento e falhas transcorrentes, sendo que em escala regional possuem direção ENE-WSW. Este complexo sistema de falhamentos e zonas de cisalhamento controla a distribuição das diversas unidades que compõem o embasamento, estando associadas a diversas falhas menores, normais e de empurrão, resultando em um sistema de falhas complexo e difícil de ser representado em mapa.

Característica notável do Cinturão Ribeira, onde se encontra instalada a Bacia de São Paulo, é o seu recorte por densa trama de zonas de cisalhamento dúcteis, orientadas, segundo ENE a E-W (Sadowski \& Motidome, 1987), ativas até o final do Ciclo Brasiliano, no Cambro-Ordoviciano. São zonas de cisalhamento dextrais subverticais e profundas, que registram importante componente transpressional durante a evolução do cinturão (Trouw et al., 2000).

Tendo sido responsáveis, em parte, pela subsidência que gerou o rifte do sudeste brasileiro no qual a Bacia de São Paulo se desenvolveu, os falhamentos normais associados às grandes zonas de cisalhamento foram desenvolvidos durante o clímax deformacional destas rochas, no Neoproterozoico, e reativados em diversas ocasiões no Cenozoico. As importantes zonas de cisalhamento foram geradas em sistemas deformacionais dúcteis-rúpteis, gerando faixas de deformação paralelas ao traçado principal das falhas, que chegam a atingir a espessura de $5 \mathrm{~km}$ e mais de $1 \mathrm{~km}$ de milonitização das unidades. Os litotipos variam de milonitos a ultra e protomilonitos, ocorrendo também cataclasitos em zonas continuamente deformadas, nas quais houve uma atenuação das condições de temperatura e pressão (Campanha et al., 1985).

Hasui et al. (1993) apontam quatro eventos deformacionais distintos para as unidades do embasamento da Bacia de São Paulo. Estes teriam se iniciado em caráter colisional, com um cavalgamento de leste para oeste (oblíquo às zonas de cisalhamento regionais) responsável pelo desenvolvimento da foliação regional, associado ao bandamento e à gnaissificação nas unidades gnaisse-migmatíticas e pela xistosidade dos metassedimentos, e por desmembrar e justapor as unidades em lentes tectônicas, por meio de estiramentos. A progressão desta deformação, após a conclusão do cavalgamento, resultou nas transcorrências geradoras das grandes zonas de cisalhamento regionais. Posteriormente, estas unidades foram dobradas em escalas que variam de centimétricas a quilométricas. Por fim, a última das fases de deformação consistiu na geração de juntas rúpteis subverticais, dispostas em quatro famílias ENE-WSW (juntas de distensão), NNW-SSE (juntas de tração), NW-SE e NNE-SSW (juntas de cisalhamento). 
Também no mesmo ano de 1993, em estudo para subsidiar o projeto da Linha 4 Amarela da Companhia do Metropolitano de São Paulo, Hasui (1993) identificou, por meio de medições de campo, sete famílias de juntas, identificadas no estereograma da Figura 8. Destas, as quatro principais são subverticais e apresentam disposições que estão de acordo com o modelo de estruturas cisalhantes de Riedel, apresentado na Figura 9, formadas durante o evento deformacional, um cisalhamento dextral. A família mais numerosa de juntas (1), de orientação ENE-WSW, corresponde a juntas paralelas à foliação principal (juntas de relaxamento). A segunda família mais numerosa (2), de direção NNW-SSE corresponde às juntas de tração (juntas T), perpendiculares à direção de menor esforço durante o cisalhamento. As famílias de juntas subverticais oblíquas (3 e 4), de direção NWSE e NNE-SSW, correspondem às direções de falhas conjugadas sintéticas e antitéticas ( $\mathrm{R}$ e R'), respectivamente. Do restante das famílias de juntas, menos numerosas, duas são inclinadas, com uma (5) tendo uma direção aproximadamente NE-SW e mergulho de cerca de $50^{\circ}$ para SE e outra (6) com direção NNW-SSE e mergulho de cerca de $40^{\circ}$ para NE. A última (7) constitui uma família subhorizontal.

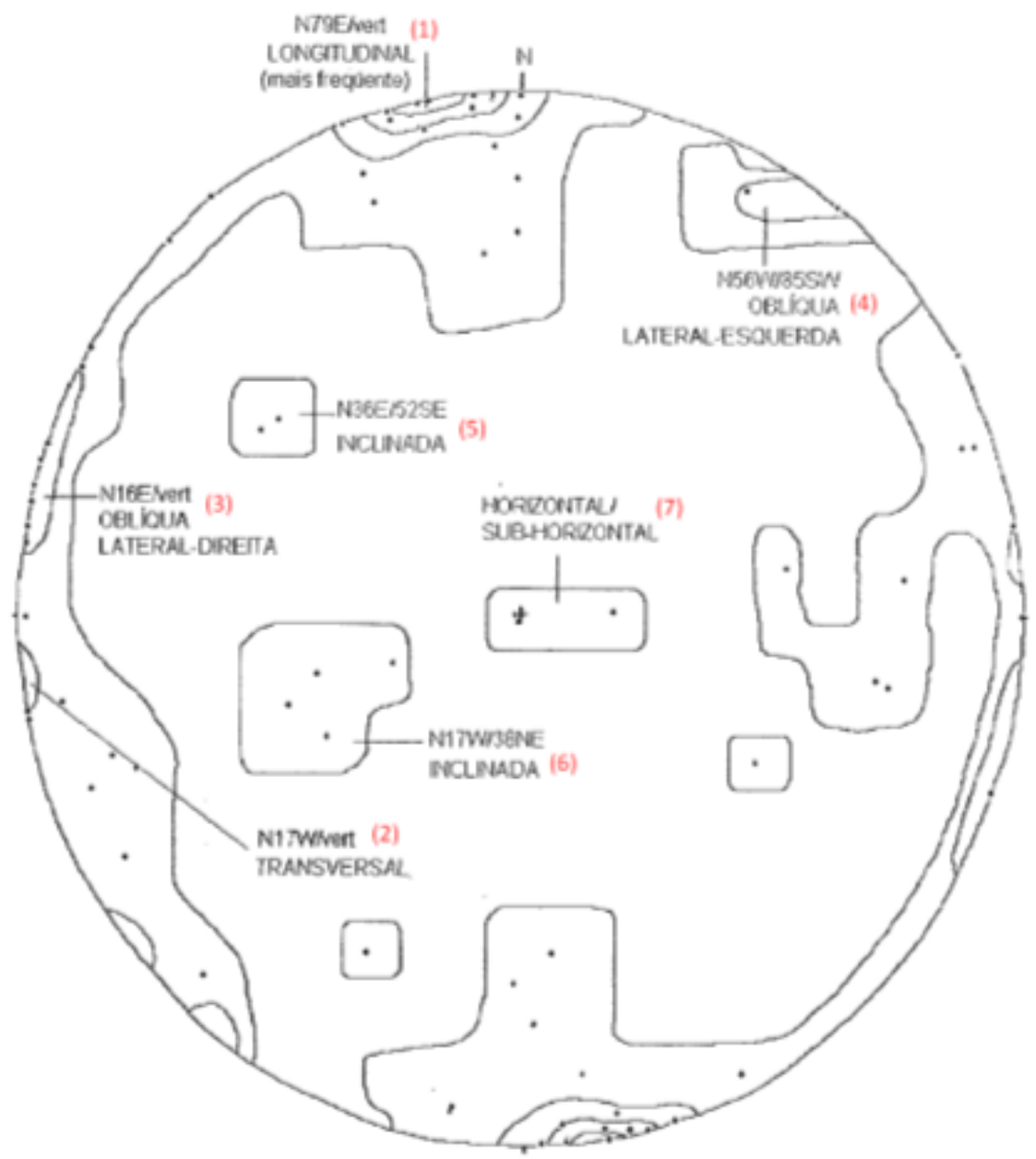

Figura 8 - Estereograma de juntas identificando as sete famílias de juntas (Hasui, 1993). 


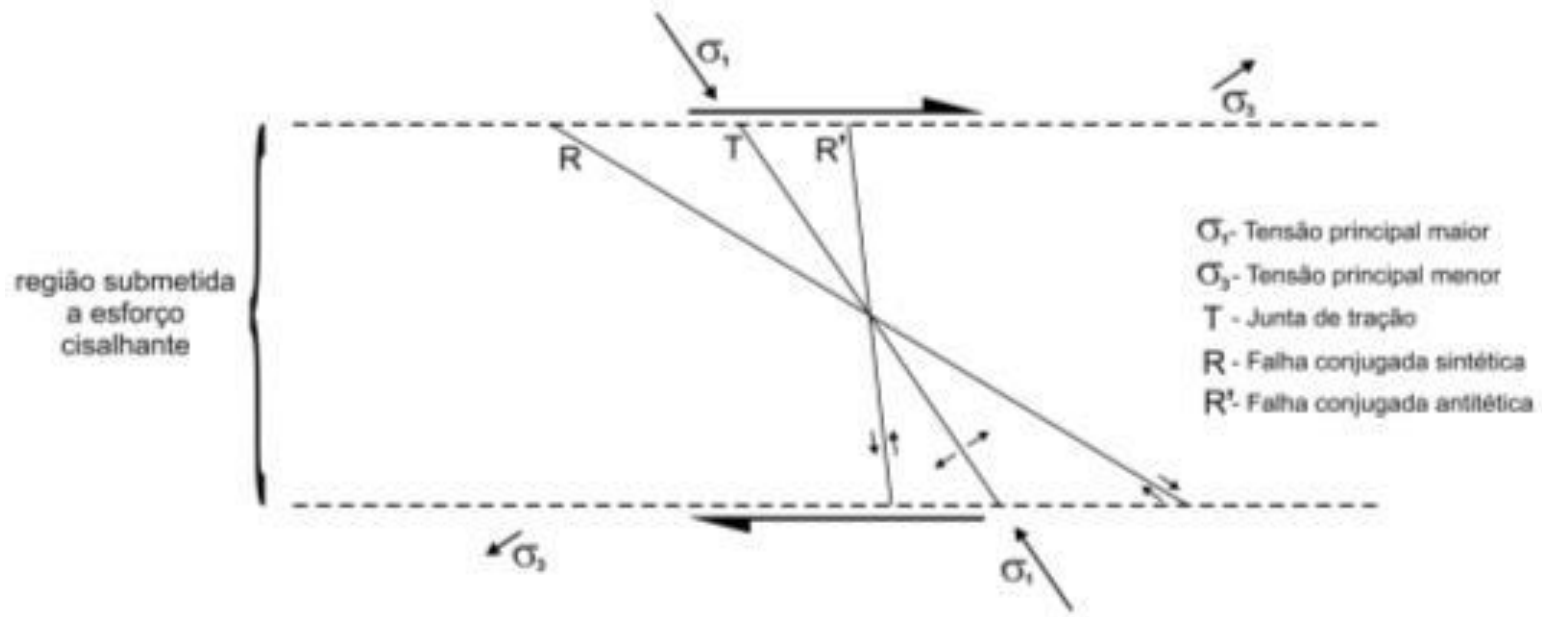

Figura 9 - Modelo de estruturas cisalhantes de Riedel para cisalhamentos dextrais (Modificado em Hasui, 1993).

Com relação à evolução estrutural do Complexo Embu, Fernandes (1991) relata que este foi afetado por 5 fases de deformação, sendo 4 fases de deformação de direção NE e uma quinta de direção NW. O metamorfismo principal, possivelmente do Proterozoico Superior, relaciona-se às duas primeiras fases e situa-se no final do grau médio e início do grau forte. A segunda fase de deformação gerou a foliação principal, em posição plano-axial a dobras recumbentes, e é frequentemente acompanhada por uma textura blastomilonítica com achatamento e estiramento mineral de direção NE. As lineações de estiramento NE presentes na S2 sugerem uma direção de transporte, contemporâneo à F2, paralelo ao trend do cinturão de dobramentos. À terceira fase de deformação relacionam-se grandes dobras apertadas a fechadas e inversas e, à quarta, dobras normais, abertas e fechadas. A quinta fase é tardia e transversal ao trend regional NE. As zonas de cisalhamento que recortam a área do Complexo Embu fornecem-lhe um padrão de compartimentação em blocos amendoados e, provavelmente, foram ativas desde períodos penecontemporâneos à terceira fase de deformação até épocas posteriores à quarta fase. As rochas metamórficas, que ocupam as porções internas das zonas de cisalhamento, foram submetidas a um retrometamorfismo de baixo grau, e intrudidas por corpos alongados de granitóides blastomiloníticos.

De acordo com Riccomini et al. (2004), o segmento central do RCSB, durante o Neógeno, esteve sob ação de um regime transcorrente, com distensão NW-SE e compressão NE-SW localizada. Altos estruturais relacionados à transpressão causaram a segmentação da depressão original do rifte. Bacias de afastamento (pull-apart) relacionadas à transtração ou ao relaxamento final dos esforços compressivos instalaram-se no alto estrutural que separa as bacias de São Paulo e Taubaté, acompanhadas da deposição de arenitos com estratificação cruzada e conglomerados de sistema fluvial entrelaçado. Evidências de movimentações neotectônicas podem ser observadas em várias 
localidades ao longo do RCSB. Elas estão relacionadas a um evento compressivo de direção NW-SE, do Pleistoceno tardio a Holoceno, seguido, sucessivamente, por extensão de direção E-W a NW-SE e, finalmente, compressão E-W.

Riccomini \& Coimbra (1992) descrevem dois conjuntos principais de estruturas na região do RCSB e, consequentemente, na Bacia de São Paulo. O primeiro diz respeito às foliações metamórficas e de transposição nas rochas Paleozoicas e Pré-Cambrianas, bem como zonas de cisalhamento e juntas. $\mathrm{O}$ segundo conjunto engloba principalmente estruturas de reativação, que afetam tanto o embasamento quanto os sedimentos e condicionam o embaciamento e deformações nos sedimentos. Os mesmos autores ressaltam, que devido às estruturas sin e pós-sedimentares, há existências de heterogeneidades no preenchimento e continuidade lateral das camadas sedimentares da Bacia de São Paulo.

Uma análise da profundidade dos sedimentos da bacia indica como o abatimento de blocos foi importante para o processo de subsidência que gerou o espaço físico para seu preenchimento, por meio da reativação, com deslocamento normal, das falhas do embasamento da bacia, como foi apontado por um exame dos tensores de deformação destas falhas (Campanha et al., 1985). A reativação destas falhas foi um processo que se manteve após a sedimentação da bacia, gerando falhas também no pacote sedimentar.

Fernandes et al. (2005) tendo como objetivo principal avaliar o fator "fraturas", como caminhos preferenciais de circulação e armazenamento de água em aquíferos fraturados, elaborou um mapa de lineamentos para as rochas do Pré-Cambriano no Estado de São Paulo, obtendo os seguintes intervalos de direções preferenciais destas fraturas em ordem decrescente de importância: N5W/10E; N85E/75W; N30/65W; N60/75E e N25/35E.

\subsection{Televisionamento Óptico de Furos de Sondagem}

Segundo Williams \& Johnson (2004) o primeiro televisionamento óptico (OPTV, ou OTV, ou Optical Televiewer) foi desenvolvido como um sistema único em 1987. Assim como o televisionamento acústico, este sistema resulta em imagens $360^{\circ}$ contínuas e orientadas das paredes de furos de sondagens, onde as características, as relações e orientações de feições litológicas e estruturais podem ser definidas. No caso do óptico, ao contrário do acústico, essas feições podem ser diretamente visualizadas na imagem.

Hoek (1966) em seu livro sobre mecânica das rochas cita o uso de equipamentos de filmagem em furos de sondagem, para a avaliação de planos de descontinuidades em escavações subterrâneas. 
O sistema descrito é uma versão preliminar de um equipamento simples de perfilagem ótica, contendo um espelho simples inclinado, rodeado por aglomerado de luzes, sendo este sistema inserido no furo e as imagens observadas através de um telescópio. O autor afirma que este equipamento é um dos instrumentos mais efetivos para aprimorar o exame visual de superfícies rochosas. Ressalta, ainda, que a presença de descontinuidades geológicas implica em uma influência significativa no comportamento do maciço rochoso.

Baillot et al. (2004) relatam que uma primeira versão do equipamento de televisionamento foi desenvolvido primeiramente no Japão e apresentada durante o ISC 98 nos Estados Unidos (International Conference on Site Characterization, 1998), entretanto esta versão não teve sua produção continuada. A versão primeiramente utilizada no Brasil no ano de 2001, segundo os autores, foi desenvolvida na França por René Colas em 1998 e era comercializada com o nome de Colas Camera. Atualmente, o equipamento mais utilizado no Brasil é o Hi-OPTV da empresa Robertson Geologging Ltd. (UK). Outro equipamento também já disponível para aquisição no Brasil é o ONI40 da Advanced Logic Technology (Luxemburgo). Os seus Softwares de interpretação são o RgDip e o WellCad, respectivamente.

Há outras empresas fabricando este equipamento ou mesmo similares, até mesmo já se encontra em desenvolvimento um sistema similar para o imageamento de frentes de escavação por tuneladoras, apresentado recentemente no Congresso Internacional de Túneis por Chmelina et al. (2014). Certamente a tendência é que esta tecnologia se desenvolva cada vez mais ao longo dos próximos anos. Também vale citar que um sistema bastante similar de televisionamento de furos foi inicialmente desenvolvido no IPT em 1984, porém não havendo sido publicado (comunicação verbal).

Malone et al. (2013) relatando o seu uso em sondagens no gelo, cita o funcionamento do equipamento, sendo que este consiste de uma câmera que captura dados através de um espelho cônico, fornecendo uma visão anular de toda a parede do furo. Um anel de luzes, controlado desde a superfície, permite o usuário controlar a luminosidade e a exposição das paredes do furo de sondagem. O instrumento também grava a profundidade, orientação e o mergulho da câmera ao ser movimentada ao longo do furo, corrigindo concomitantemente a imagem e fornecendo um imageamento mais acurado e completo do que as ferramentas anteriores (Figura 10 e Foto 1). 


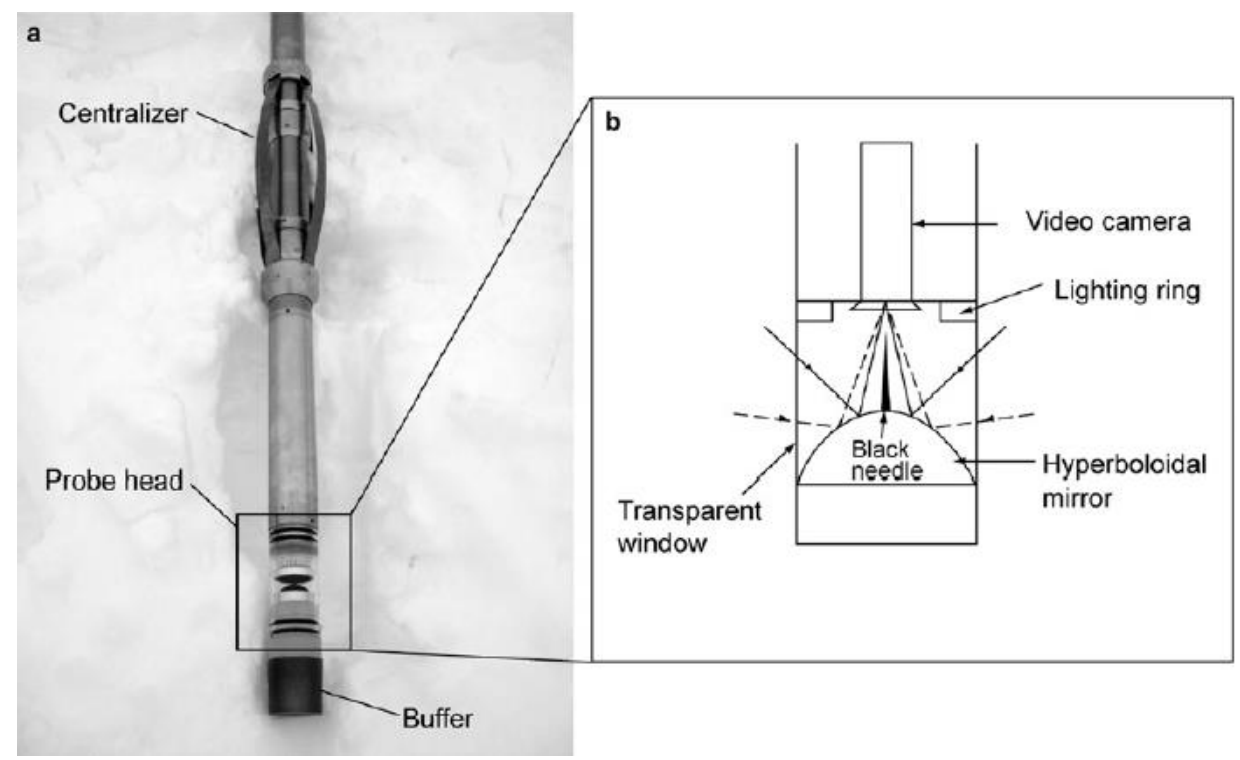

Figura 10 - Imagem (a) equipamento de televisionamento e (b) esquema do sistema de captação de imagens (Malone et al., 2013).

Segundo Oliveira et al. (2013) o equipamento de televisionamento consiste, simplificadamente, em uma sonda com corpo de aço, com uma câmera em sua parte interna, ligada a um cabo especial que, além de sustentar a sonda, envia os sinais adquiridos a uma central acoplada a um computador. Esta sonda é também equipada com um sistema de magnetômetros e acelerômetros tri-ortogonais, que possibilitam orientá-la espacialmente, além de um sistema de anotação de profundidade. O controle do sistema é efetuado por intermédio de um Software de aquisição ligado diretamente à câmera. As imagens e dados obtidos são, posteriormente, exportados para outro Software que permite o tratamento das informações obtidas. A Figura 11 ilustra uma simplificação do sistema de aquisição e as Fotos 2 e 3 retratam este sistema montado no campo.

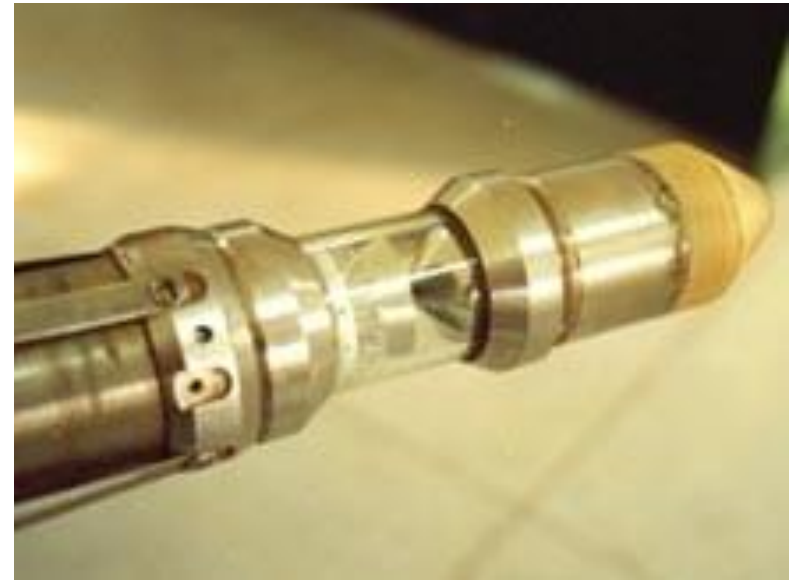

Foto 1- Foto do equipamento da Robertson Geologging, detalhe do sistema de captação e cone de proteção (Baillot et al., 2004).

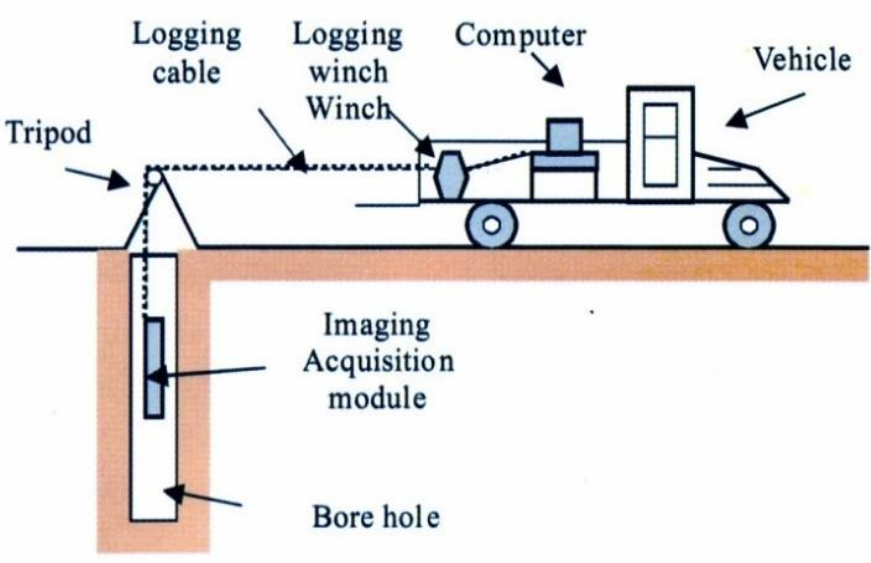

Figura 11- Desenho esquemático do sistema completo de aquisição (Baillot et al., 2004). 


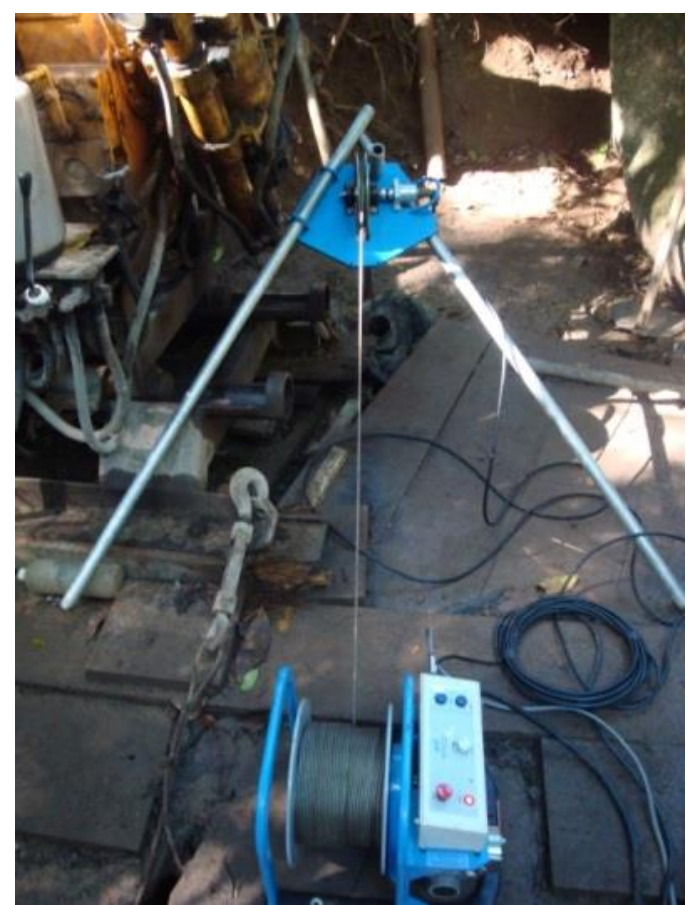

Foto 2- Equipamento montado para iniciar filmagem, obra do Metrô do Rio de Janeiro, região da Gávea, $\mathrm{RJ}$ (arquivo pessoal).

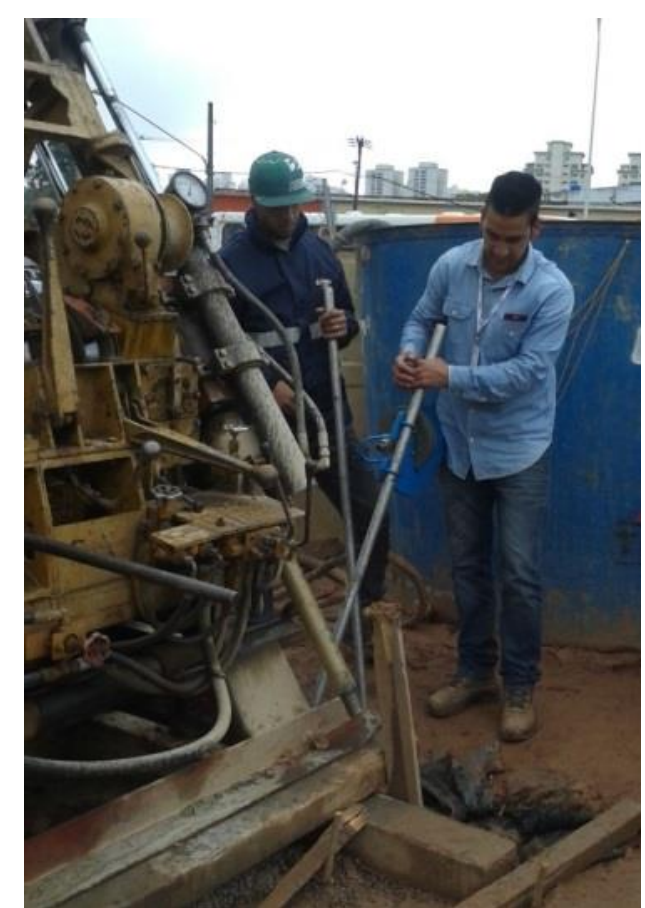

Foto 3 - Equipamento sendo montado em furo inclinado, obra do Metrô de São Paulo, Largo do Taboão da Serra, SP (arquivo pessoal).

Williams \& Johnson (2004) descrevem em detalhe o equipamento de televisionamento óptico. O sistema de imageamento usa um anel de luzes para iluminar o furo de sondagem, uma câmera CCD (charge-coupled device, dispositivo de carga acoplada, sensor para captação de imagens), e um refletor (espelho) cônico ou hiperbólico inserido em um cilindro transparente. Geralmente as ferramentas OPTV possuem comprimento entre 1,4 a 2,8 metros e diâmetro de 40 a $50 \mathrm{~mm}$. A câmera CCD mede a intensidade de cores nos espectros do vermelho, verde e azul. O espelho reflete nas lentes desta câmera uma fatia de $360^{\circ}$ da parede do furo de sondagem. A imagem óptica escaneada pode ser enviada para cima como um sinal analógico através do cabo de conexão e digitalizada ao subir a sonda (uphole) ou digitalizada na descida e enviada como um sinal digital (downhole). Na Figura 12, os autores comparam três casos de imageamento.

O diâmetro máximo que estas imagens podem ser coletadas é tipicamente de $300 \mathrm{~mm}$. A velocidade de imageamento é dependente da resolução selecionada tanto vertical como horizontal, além das configurações do sistema e o tipo de cabo. As velocidades médias giram em torno de 1 metro/minuto. As maiores velocidades de filmagens, segundo os autores, $3 \mathrm{~m} / \mathrm{min}$ em $1 \mathrm{~mm}$ e 720 pixels por linha foram alcançadas por um sistema que transmitia simultaneamente diversas fatias escaneadas com um sinal analógico em um cabo coaxial. 


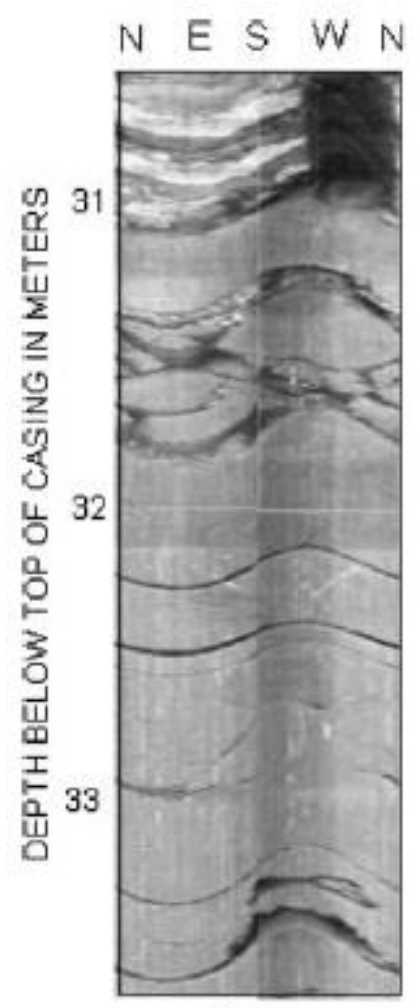

A

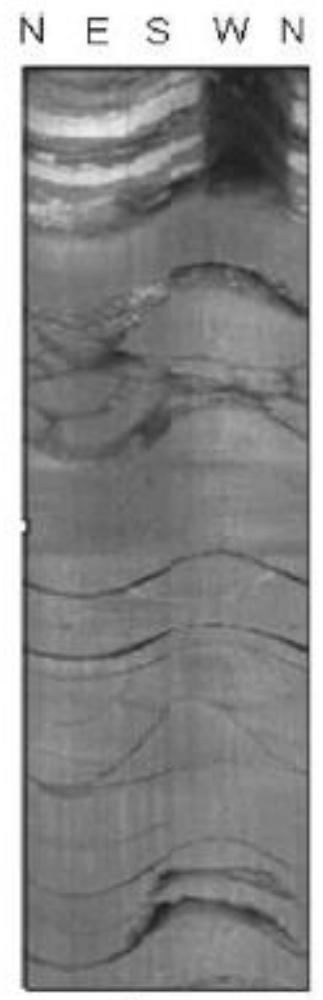

B

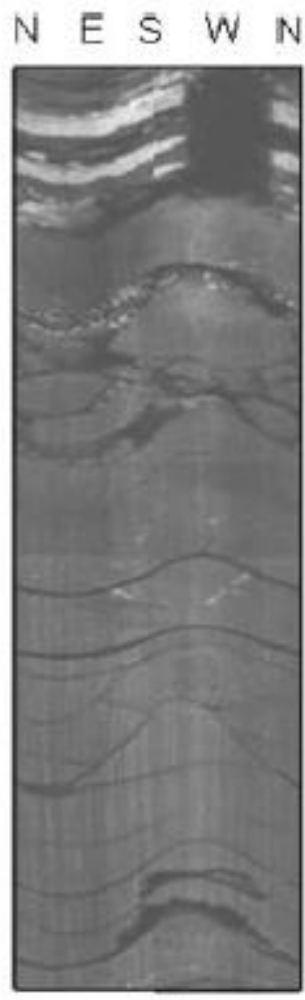

C

Figura 12 - Imagens do televisionamento óptico em furos de sondagem de $150 \mathrm{~mm}$ de diâmetro realizados em arenito: (A) com refletor cônico digital-furo acima (uphole); (B) com refletor cônico digital-furo abaixo (downhole); (C) com refletor hiperbólico digital-furo acima (uphole) (Williams \& Johnson, 2004).

As imagens podem ser feitas tanto em furos sem água ou com água limpa. A lama de perfuração, precipitações químicas, crescimento de bactérias e outras condições que afetem a claridade da água dentro do furo de sondagem podem afetar a qualidade das imagens do OPTV. As imagens de televisionamento devem ser declinadas com relação ao norte geográfico, sendo que este ajuste pode ser realizado durante a aquisição da imagem ou posteriormente.

Segundo o sugerido em Oliveira et al. (2013) para a aquisição das imagens é necessário que o furo esteja limpo, garantindo que informações não sejam ocultadas pela presença de água turva em seu interior. Cabe à empresa executora a decisão e a responsabilidade de qual método deverá ser utilizado para garantir uma boa filmagem, seja este usando a circulação de água para remover detritos do interior do furo ou o uso de produtos químicos para flocular o excesso de materiais em suspensão. Caso ocorra a opção pelo uso de produtos químicos, a empresa executora deverá se responsabilizar pela verificação da adequação destes produtos às normas ambientais vigentes. Para casos de televisionamento em furos inclinados, a aquisição de imagens deverá ser realizada logo após a abertura do furo, para garantir qualidade na imagem. A aquisição das imagens deverá ser realizada considerando-se o norte magnético, e apenas no processamento das imagens estas deverão ser 
declinadas com relação ao norte geográfico. E, por último, deve ser comparada a profundidade do revestimento do furo fornecido pela executora da sondagem com o encontrado no televisionamento, para calibração das demais profundidades.

As imagens realizadas em furos com revestimento metálico apresentarão uma zona de interferência, sendo que isto poderá ser solucionado, segundo Williams \& Johnson (2004), ao desligar o magnetômetro para filmar este trecho afetado, depois refeita a imagem com magnetômetro ligado, sendo realizado um encaixe das imagens posteriormente. Nas Fotos 4, 5 e 6 é possível notar esta interferência do revestimento metálico. Ainda citam a questão de centralização da ferramenta, que deve ser realizada corretamente, caso contrário, podendo sofrer deficiência na captação da imagem. No caso de furos que possuam diâmetro maior que $10 \mathrm{~cm}$ que o diâmetro da sonda de televisionamento, o sistema de centralização poderá ser realizado através de um espaçador metálico. O foco será regulado nos dados de entrada na câmera, sendo ajustado segundo diâmetro do furo.

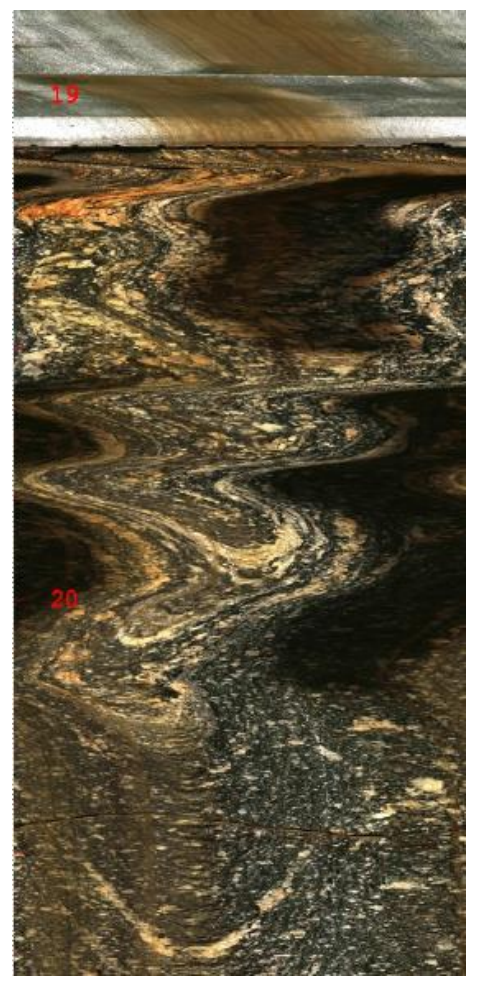

Foto 4 - Exemplo de interferência na imagem interferência na imagem devido devido ao revestimento ao revestimento metálico no furo metálico no furo de de sondagem. Fonte: Metrô de sondagem. Fonte: Metrô de São Paulo. São Paulo.
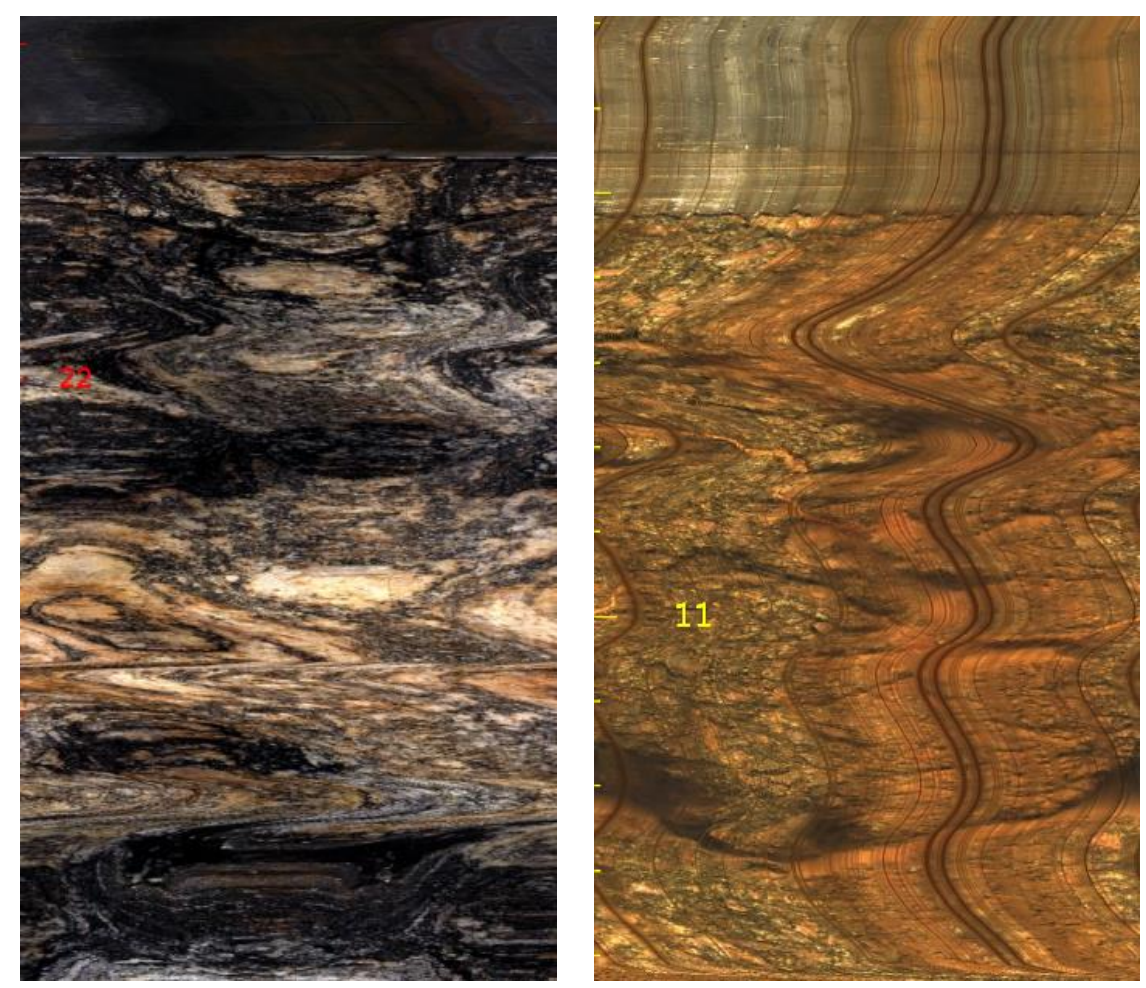

Foto 6 - Exemplo de interferência na imagem devido ao revestimento metálico no furo de sondagem. Fonte: Metrô de São Paulo.

As imagens obtidas e enviadas pela câmera são inicialmente anulares, ou "enroladas", exatamente como um testemunho virtual de sondagem (Baillot et al., 2004). Em uma segunda fase, 
essas imagens são processadas por um Software, especialmente desenvolvido para a restituição da forma cilíndrica das paredes do furo, transformando estas imagens "enroladas" em imagens "desenroladas", ou abertas, onde as estruturas inclinadas nesta imagem aparecem como perfis sinusoidais, conforme ilustrado na Figura 13. Para esse processamento de imagens, segundo Malone et al. (2013), é utilizado um filtro gaussiano, removendo assim ruídos espúrios e evitando qualquer interferência na imagem resultante.

\section{Planar Surface}

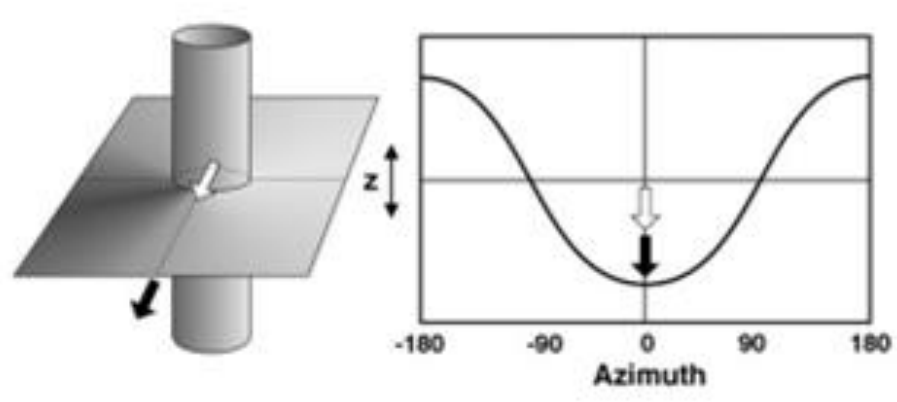

Non-planar Surface

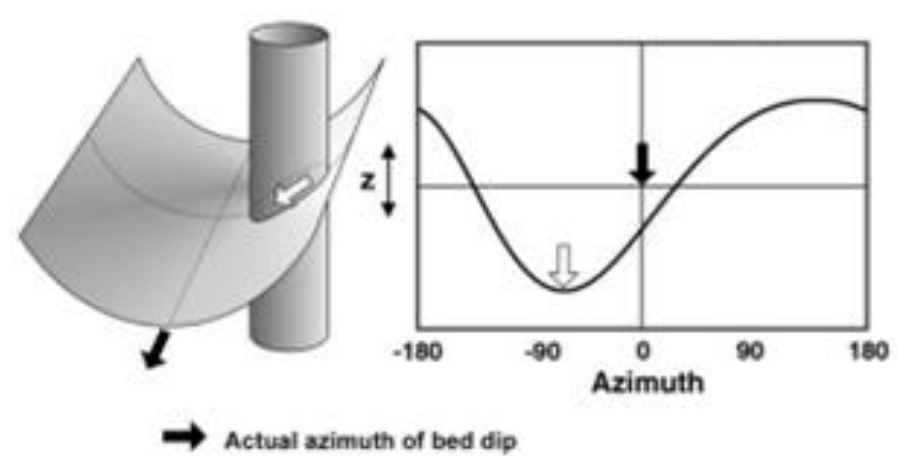

Figura 13 - Ilustração representando o esquema de transformação das imagens inicialmente "enroladas", fechadas, para imagens "desenroladas", ou abertas (modificado de Glover \& Bormann, 2007).

Oliveira et al. (2013) relatam que na fase de interpretação as descontinuidades são identificadas e caracterizadas, obtendo-se suas respectivas atitudes, além de outros parâmetros, sendo possível elaborar estereogramas dos polos e dos planos estruturais, bem como análises estatísticas.

As feições planares estruturais e litológicas são, portanto, classificadas e encaixadas interativamente com os traços sinusoidais, sendo que sua orientação real é calculada usando o Software de análise. As fraturas, assim como demais feições planares, e respectiva orientação são apresentadas em diagramas tipo tadpole e estereogramas (Williams \& Johnson, 2004). 
Segundo Baillot et al. (2004) uma das principais vantagens deste método é o aumento da produtividade no local investigado, resultando numa redução de tempo e custos, e fornecendo dados que estão mais próximos à realidade do maciço rochoso em questão. Isto se deve ao fato de que em testemunhos de sondagem geralmente a recuperação é menor, principalmente nas porções de pior qualidade do maciço amostrado. Sendo assim justamente as "piores" partes do maciço, que indicariam um valor Q, Índice de Qualidade de Maciço, muito baixo, são as com menor recuperação. Ao utilizar o método de televisionamento, esses níveis de menor qualidade de rocha não recuperada, ou de presença de solo, podem ser observados e devidamente caracterizados.

Em Willians \& Johnson (2004) é feita uma comparação entre o televisionamento óptico e o televisionamento acústico e conclui-se que fraturas são mais visíveis em uma gama maior de condições adversas no televisionamento acústico quando comparado ao óptico, incluindo-se rochas de coloração escura, furos com água turva e furos revestidos; entretanto o televisionamento óptico permite uma visualização direta das características e relações entre as feições como litologia, fraturas, foliações e acamamento.

Segundo os autores, a abordagem ideal seria uma investigação utilizando ambas as ferramentas, incluindo uma interpretação integrada, sendo possível obter uma combinação de informações qualitativas e quantitativas que podem ser utilizadas para caracterizar fraturas e litologias ao longo de furos de sondagem. Devido ao fato de que as imagens são contínuas e orientadas, estas são extremamente úteis para a análise de testemunhos de sondagens que normalmente não são orientados e implicam na falta de alguns intervalos, especialmente aqueles intervalos intensamente fraturados e que representam um interesse crítico à caracterização de um maciço.

Os mesmo autores também relatam que tanto no televisionamento óptico como no acústico poderá ocorrer uma influência da ferramenta de corte na perfuração da sondagem, onde o processo que envolve a perfuração do furo poderá afetar as características de planos de descontinuidades, podendo aumentá-los, aumentando o mergulho aparente do topo e base de fraturas abertas, ou removendo o preenchimento de fraturas, até mesmo resultando na aparência de uma fratura aberta, quando esta se encontrava anteriormente selada e com preenchimento.

O televisionamento como método de obtenção da orientação de planos de descontinuidades e características essenciais, como a abertura e preenchimento de tais planos de fraqueza no maciço rochoso, é citado também por Goodman (1989), ISRM (1978), além de outros, sem entrar no mérito da descrição da metodologia em si. 


\subsection{Caracterização Geológico-Geotécnica de Maciços Rochosos}

Um maciço do ponto de vista do seu aproveitamento em engenharia é um conjunto de blocos de rocha, justapostos e articulados. O material que forma os blocos constitui a matriz do maciço rochoso, também denominada rocha intacta, e as superfícies que o limita, as descontinuidades. Os maciços rochosos são essencialmente heterogêneos, anisótropos e descontínuos, e sua complexidade resulta da evolução geológica a que foram submetidos (Serra Junior \& Ojima, 1998).

Considerando-se que as características de um maciço rochoso são únicas para cada local, se faz necessário descrever os atributos do meio rochoso que, isolada ou conjuntamente, condicionam seu comportamento frente às solicitações impostas pela obra em questão. Tal procedimento denomina-se, segundo Serra Junior \& Ojima (1998), caracterização geológico-geotécnica do maciço rochoso. De modo geral, as características mais visadas no estudo do meio rochoso relacionam-se à deformabilidade, à resistência, à permeabilidade, e ao estado de tensões.

A caracterização geológico-geotécnica de um maciço rochoso se faz fundamental como base para a classificação geomecânica do maciço rochoso, passo essencial para qualquer projeto de uma obra subterrânea, qualquer que seja o tipo de classificação escolhida, seja o índice Q de Barton et al. (1974), o RMR de Bieniawski (1973; 1989) ou qualquer outra proposta de classificação geomecânica.

Segundo Serra Junior \& Ojima (1998) as características que traduzem a qualidade dos meios rochosos, do ponto de vista de seu aproveitamento em engenharia civil, associam-se, fundamentalmente, à litologia, ao estado de alteração, à coerência e às descontinuidades.

De acordo com Palmstrom (1995) devem fazer parte da caracterização de um maciço tanto a sua composição como a sua estrutura, incluindo como determinado maciço rochoso se inter-relaciona com demais litotipos dentro da geologia da área em questão. O autor sugere que, além da descrição da rocha e sua respectiva resistência (definido em laboratório ou em ensaios de campo, obtendo valores pré-estabelecidos para cada litotipo), devem ser incluídas as características de possíveis anisotropias (como foliações, acamamentos, etc.), alteração e durabilidade.

Para Priest (1993) esforços devem ser feitos para que as propriedades das descontinuidades sejam objetivamente analisadas buscando o intuito de caracterizar matematicamente o maciço rochoso, incluindo estes parâmetros quantitativamente nos cálculos dos projetos de engenharia. 
A seguir serão descritos sucintamente cada parâmetro utilizado para a caracterização geológico-geotécnica de um maciço rochoso, tanto com relação à sua matriz rochosa (ou rocha intacta) como em relação às suas descontinuidades.

\subsubsection{Matriz Rochosa}

O primeiro parâmetro a ser descrito é a litologia da massa rochosa. Segundo Franklin (1970) do ponto de vista da geologia de engenharia os diversos litotipos podem ser agrupados em aproximadamente 40 litologias principais, considerando sua resistência à compressão uniaxial e seu comportamento geomecânico. No Quadro 1 são apresentados os litotipos mais comuns e os valores correspondentes a sua resistência à compressão uniaxial, publicados por Hansen (1988) e Hoek \& Brown (1980).

Serra Junior \& Ojima (1998) sugerem que uma classificação litológica para aplicação em engenharia deve ser simplificada e objetiva, evitando-se nomenclaturas complexas, cujo emprego não proporcione resultados práticos. Já com relação ao parâmetro alteração da rocha intacta os autores explicam que, na caracterização do estado de alteração para fins de engenharia, o foco é dado às mudanças do material, que implicam na degradação de suas características mecânicas, sendo que para um mesmo litotipo, a rocha mostra-se menos resistente e mais deformável, quanto mais avançada a alteração.

A caracterização do estado de alteração do meio rochoso é feita tátil-visualmente, com base em variações do brilho e da cor dos minerais, além da friabilidade. A Tabela 1 apresenta os graus de alteração sugeridos por IPT (1984). São inúmeras as sugestões para a caracterização do grau de alteração da rocha intacta, optou-se, entretanto, apresentar a mais utilizada no país.

Também utilizada para caracterizar a rocha intacta, a coerência é definida com base em propriedades de tenacidade, dureza e friabilidade das rochas, sendo distinguida também tátilvisualmente, através da apreciação da resistência que a rocha oferece ao impacto do martelo e ao risco com a lâmina de aço. Inúmeras correlações foram feitas com outros parâmetros, como a resistência à compressão uniaxial, resistência à escavação e à perfuração (Serra Junior \& Ojima, 1998).

Com relação às estruturas de um maciço rochoso Magalhães \& Cella (1998) afirmam que a deficiência de sua caracterização em projetos de engenharia conduz, invariavelmente, a uma ampliação das investigações diretas e indiretas, que poderiam ser mais bem planejadas com a definição preliminar do modelo estrutural. Dividem as estruturas nas geradas em estado plástico 
(dobras, foliações, zonas de cisalhamento, lineações), também denominadas de estruturas penetrativas, e nas geradas em estado rúptil (descontinuidades em si, sendo estas as juntas ou fraturas e as falhas). Ainda alertam que as estruturas penetrativas, mesmo não sendo consideradas descontinuidades estruturais, podem representar elementos geotécnicos desfavoráveis, dependendo do nível e da orientação das tensões a que o maciço será submetido pela implantação da estrutura de engenharia. Também estas estruturas penetrativas podem servir como guia ou referência para determinar a orientação de outras estruturas planares.

Quadro 1 - Intervalos encontrados para resistência à compressão uniaxial para os litotipos mais comuns (dados de Hansen, 1988 e Hoek \& Brown, 1980) (compilado por Palmstrom, 1995).

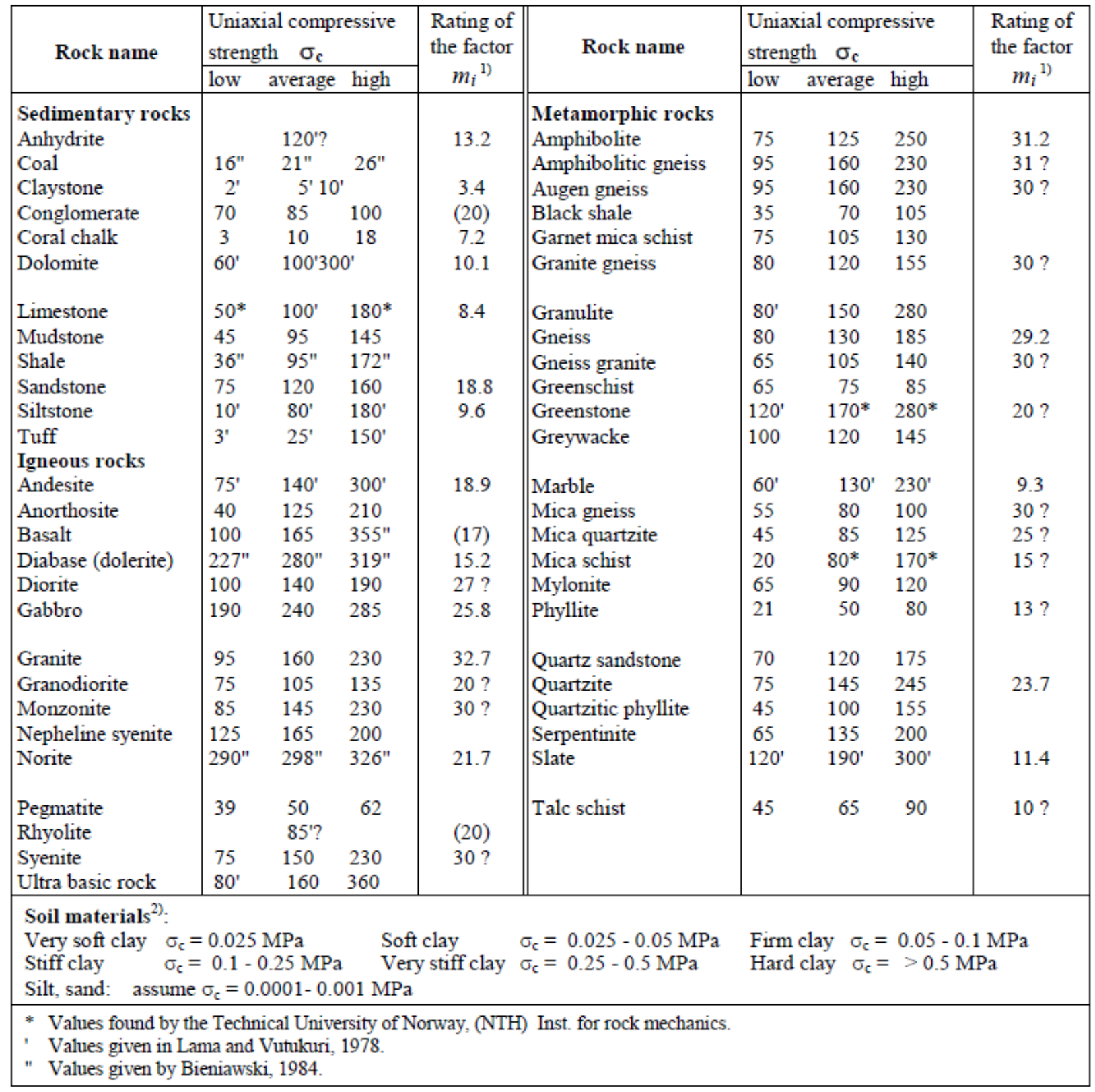


Tabela 1 - Graus de alteração (modificada de IPT, 1984).

\begin{tabular}{c|c|c}
\hline SIGLAS & DENOMINAÇÕES & CARACTERÍSTICAS DA ROCHA \\
\hline A1 & Rocha sã ou praticamente sã & $\begin{array}{c}\text { Apresenta minerais primários sem vestígios de } \\
\text { alterações ou com alterações físicas e químicas } \\
\text { incipientes. Neste caso a rocha é ligeiramente } \\
\text { descolorida. }\end{array}$ \\
\hline A2 & Rocha medianamente alterada & $\begin{array}{c}\text { Apresenta minerais medianamente alterados e a } \\
\text { rocha é bastante descolorida. }\end{array}$ \\
\hline A3 & Rocha muito alterada & $\begin{array}{c}\text { Apresenta minerais muito alterados, por vezes } \\
\text { pulverulentos e friáveis. }\end{array}$ \\
\hline A4 & Rocha extremamente alterada & $\begin{array}{c}\text { Apresenta minerais totalmente alterados e a rocha } \\
\text { intensamente descolorida, gradando para cores } \\
\text { de solo. }\end{array}$ \\
\hline
\end{tabular}

\subsubsection{Descontinuidades}

O termo descontinuidade, no âmbito da geotecnia, foi aplicado há mais de trinta anos por diversos autores no intuito de caracterizar qualquer quebra mecânica significativa, sem considerar origens, idades ou geometrias. Piteau (1970) listou as propriedades relevantes em descontinuidades que podem influenciar a qualidade de um maciço rochoso, como orientação, tamanho (equivalente à persistência), frequência (equivalente ao espaçamento), geometria da superfície (equivalente à rugosidade) e material de preenchimento.

A estes parâmetros a ISRM (1978) acrescentou resistência das paredes (equivalente ao estado de alteração das paredes), abertura, percolação d'água, número de famílias e tamanho de blocos, sendo os dois últimos relativos à distribuição das descontinuidades no maciço rochoso. Esta organização internacional de mecânica das rochas tinha como objetivo principal a padronização dos métodos descritivos destas feições, onde cada parâmetro seria descrito de forma menos subjetiva e mais quantitativa, sempre se adotando valores para cada característica atribuída a um determinado parâmetro.

Priest (1993), entretanto, afirma que estes métodos sugeridos são limitados pelo fato de não incorporarem as técnicas de processamento de dados, desenvolvida na década de 80 para a eliminação do enviesamento dos dados. 
A orientação de uma descontinuidade é sua posição ocupada no espaço, sendo definida pela direção do plano e seu respectivo mergulho. A orientação de diferentes conjuntos, ou sets, de descontinuidades irá determinar o formato dos blocos rochosos constituídos (ISRM, 1978).

Segundo Magalhães \& Cella (1998) a atitude das descontinuidades em relação a uma estrutura de engenharia pode condicionar sua estabilidade ou favorecer a ocorrência de deslizamentos. Portanto, é de suma importância registrar de forma apropriada toda a gama de orientações, obtendose a distribuição e a atitude média do conjunto de descontinuidades, de maneira a agrupá-las em famílias, ou sets. A orientação desses sets em relação à geometria da superfície de escavação pode indicar se os blocos são instáveis ou não, como será visto no próximo item de análise de estabilidade de túneis.

ISRM (1978) menciona a possibilidade de se utilizar câmeras de televisionamento em furos de sondagem para se estimar a orientação das descontinuidades. Também mencionando que a continuidade das descontinuidades principais poderia ser estimada em um conjunto de furos de sondagens que cruzem este plano de descontinuidade, o que poderia ser uma possibilidade para se estimar a persistência de uma descontinuidade com o equipamento de televisionamento em locais onde afloramentos rochosos não são existentes ou mesmo de difícil acesso, como zonas urbanizadas, por exemplo.

Um dos parâmetros definidos após este levantamento das atitudes das descontinuidades é o número de famílias presentes no maciço rochoso, delimitado a partir de estereograma SchmidtLambert e diagrama de concentração de polos, definindo então o número de famílias, assim como suas respectivas orientações. Priest (1993) sugere inúmeras ferramentas para correção do enviesamento dos dados em levantamentos desta natureza.

Mais uma das feições a serem descritas, a persistência de uma descontinuidade é sua extensão em área, ou seu tamanho em um plano, podendo ser quantificada observando seus traços na superfície de exposições rochosas. De acordo com a ISRM (1978) é certamente um dos parâmetros que apresenta maior dificuldade na sua determinação, apesar de ser considerada uma das mais importantes características. No caso de túneis, mais especificamente, não é necessário um plano possuir uma persistência tão grande para implicar na desestabilização das frentes e do teto da escavação.

Conforme afirmam Magalhães \& Cella (1998) o espaçamento é um dos aspectos mais relevantes para o comportamento geomecânico e geohidráulico dos maciços rochosos, sendo que em amplo sentido refere-se à quantidade de descontinuidades por unidade de medida, seja em 
comprimento linear, área ou volume. Por definição o espaçamento é considerado como a distância perpendicular entre dois planos consecutivos de descontinuidades pertencentes a uma mesma família. É obtido por meio de medidas efetuadas ao longo de uma direção determinada, que pode ser uma sondagem ou uma linha de levantamento sistemático de descontinuidades em afloramentos. Para este parâmetro a ISRM (1978) também sugere o uso de câmeras de televisionamento na sua definição.

A partir do espaçamento também é possível se obter um segundo parâmetro, a frequência de descontinuidades, comumente denominada de $\lambda$ por Priest (1993), que seria equivalente ao número de fraturas por metro linear de maciço, equivalente ao inverso da medida do espaçamento, incluindo todos os sistemas presentes. A partir da definição da frequência de espaçamento $(\lambda)$ é possível definir o grau de fraturamento, proposto pelo IPT (1984). Este grau de fraturamento visa caracterizar a distribuição das descontinuidades em testemunhos de sondagem. O fraturamento é expresso em graus de intensidade e explicita a quantidade de fraturas por metro, definido em trechos com fraturamento homogêneo (isofraturamento), conforme apresentado na Tabela 2.

A definição do grau de fraturamento irá influenciar no modelo de taxa de penetração de uma tuneladora, por exemplo, segundo Bruland (2000). Segundo este autor o fraturamento do maciço rochoso é composto pelo grau de fraturamento, ou seja, pela média de espaçamentos entre planos de fraqueza, e também pelo ângulo entre o eixo do túnel e a descontinuidade. Em maciços rochosos muito resistentes, o grau de fraturamento é o fator geológico que mais influencia a taxa de penetração, bem como nos custos de escavação. Este fator também tem certamente grande influência nas escavações por métodos convencionais (NATM).

Tabela 2 - Grau de Fraturamento (IPT, 1984).

\begin{tabular}{c|c|c}
\hline SIGLAS & FRATURAS/m & DENOMINAÇÕES DO MACIÇO \\
\hline F1 & $<1$ & Ocasionalmente fraturado \\
\hline F2 & 1 a 5 & Pouco Fraturado \\
\hline F3 & 6 a 10 & Medianamente Fraturado \\
\hline F4 & 11 a 20 & Muito fraturado \\
\hline F5 & $>20$ & Extremamente fraturado \\
\hline
\end{tabular}

Estudos mostram que os principais parâmetros que influenciam a taxa de penetração de uma tuneladora são a resistência e fragilidade do material, distância entre descontinuidades e orientação das mesmas (Zhao, 2007). Segundo Castro (2013) o conhecimento das propriedades das 
descontinuidades é de extrema importância, pois influencia não só a escolha do tipo de técnica de escavação, mas também o tipo de suporte a ser instalado, bem como a velocidade de escavação. Atenção especial deve ser dada ao risco de parada da tuneladora, que pode ser induzida pela quantidade de famílias de descontinuidades, que pode resultar em dúvidas na estabilidade do meio. A existência de material de preenchimento também pode causar eventuais instabilidades no maciço.

Portanto, demais parâmetros das descontinuidades devem ser considerados e devidamente caracterizados, como a abertura, preenchimento, rugosidade e condições de alteração das paredes das descontinuidades. Segundo ISRM (1978) a abertura é a distância perpendicular que separa paredes rochosas adjacentes, que pode estar vazia, sem preenchimento, ou com água. A abertura se distingue, então, de uma descontinuidade preenchida, com exceção daquelas que se encontravam preenchidas e tiveram seu preenchimento lavado, mesmo que parcialmente. Na Figura 14 é possível visualizar três possibilidades distinguidas pela ISRM, fratura fechada, aberta e não preenchida e com preenchimento, e na Tabela 3 se encontram as sugestões desta sociedade para quantificar e caracterizar a abertura das descontinuidades.
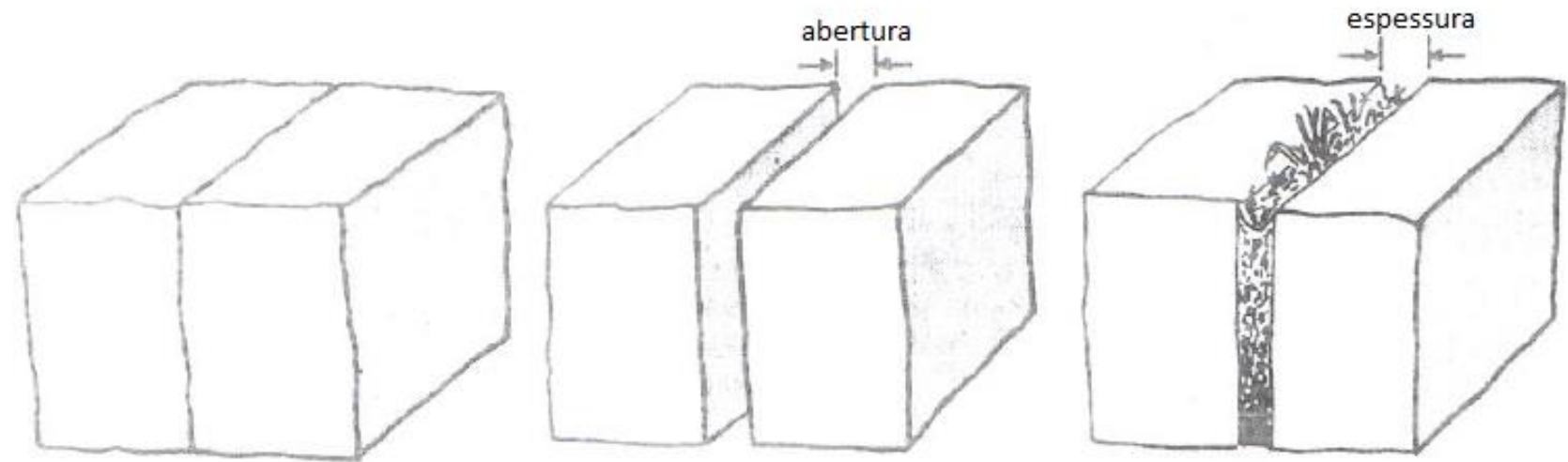

Figura 14 - Ilustração dos distintos casos de abertura para descontinuidade, no primeiro bloco observase uma fratura fechada, no segundo aberta e no terceiro com preenchimento (ISRM, 1978).

Tabela 3 - Caracterização das aberturas de descontinuidades, traduzido de ISRM (1978).

\begin{tabular}{c|c|c}
\hline ABERTURA & \multicolumn{2}{|c}{ DESCRIÇÃO } \\
\hline$<0.1 \mathrm{~mm}$ & Muito apertada & \multirow{2}{*}{ Feições fechadas } \\
\cline { 1 - 2 } $0.1-0.25 \mathrm{~mm}$ & Apertada & \multirow{3}{*}{ Feições semi-abertas } \\
\hline $0.25-0.5 \mathrm{~mm}$ & Parcialmente aberta & \\
\hline $0.5-2.5 \mathrm{~mm}$ & Aberta & \multirow{2}{*}{ Feições abertas } \\
\hline $2.5-10 \mathrm{~mm}$ & Moderadamente larga & \\
\hline$>10 \mathrm{~mm}$ & Larga & \\
\hline $1-10 \mathrm{~cm}$ & Muito larga &
\end{tabular}


O preenchimento, segundo a ISRM (1978), é o termo utilizado para o material que ocorre separando paredes adjacentes de uma mesma descontinuidade, por exemplo, calcita, clorita, argila, silte, material granular de falha, etc. A distância perpendicular entre as paredes é determinada de espessura, conforme visualizado na Figura 14. Devem ser sempre descritos os detalhes do tipo de material de preenchimento, granulação, mineralogia, textura, cor e sua respectiva espessura.

Segundo Serra Junior \& Ojima (1998) o tipo de preenchimento tem influência notável nos parâmetros geotécnicos de uma descontinuidade. É evidente a diferença de comportamento quanto à resistência ao cisalhamento e à deformabilidade entre uma descontinuidade preenchida por material argiloso mole e por material pétreo, por vezes, mais resistente e menos deformável que o próprio material que constitui o maciço rochoso. IPT (1984) sugere uma classificação para os tipos de preenchimentos mais ocorrentes no Brasil, apresentada na Tabela 4. Também juntamente com o tipo de preenchimento entra o parâmetro condições de alteração das paredes das descontinuidades, onde se caracteriza justamente esta feição já descrita para a rocha intacta nas paredes das descontinuidades.

Tabela 4 - Tipos de superfície e preenchimento de descontinuidades (IPT, 1984).

\begin{tabular}{c|c}
\hline SIGLA & SUPERFÍCIE DAS DESCONTINUIDADES \\
\hline D1 & Contato rocha-rocha, paredes sãs. \\
\hline D2 & Contato rocha-rocha, presença de material pétreo rijo: Ca - calcita $\quad \mathrm{Si}-$ sílica. \\
\hline D3 & Paredes com alteração incipiente, sinais de percolação d'água, preenchimento ausente. \\
\hline D4 & Paredes alteradas, preenchimento ausente. \\
\hline D5 & Paredes alteradas, com preenchimento: ag1- argiloso com espessura de 1mm; ag10, \\
$10 \mathrm{~mm}$. \\
\hline
\end{tabular}

A rugosidade de uma descontinuidade também entra como um parâmetro a ser descrito, sendo que é um importante componente do valor de resistência ao cisalhamento de um plano, principalmente no caso de fraturas não preenchidas. Esta importância decresce ao aumentar a existência e espessura de aberturas ou preenchimentos. De uma forma geral, a rugosidade das paredes de uma descontinuidade pode ser caracterizada em duas escalas, a ondulação (de proporções maiores) e as irregularidades (proporções menores). Na prática a ondulação afetará a direção inicial da movimentação de cisalhamento em um plano, enquanto que as irregularidades afetarão a resistência ao cisalhamento que normalmente seria medido em escala de laboratório (ISRM, 1978).

Segundo ISRM (op.cit.) a medição de irregularidades em apenas $2 \%$ do comprimento total de determinado plano é suficiente para estimar sua rugosidade média. As irregularidades podem ser 
medidas também diretamente em testemunhos de sondagens, além de afloramentos rochosos. Esta mesma sociedade, assim como diversos autores, propuseram distintas formas de se quantificar a rugosidade, tanto a ondulação como as irregularidades. São apresentadas aqui as propostas da ISRM, apresentada ilustradamente na Figura 15, e os perfis de rugosidade propostos por Barton (1987) com o intuito de determinar um dos parâmetros utilizados para o Sistema Q (Figura 16).

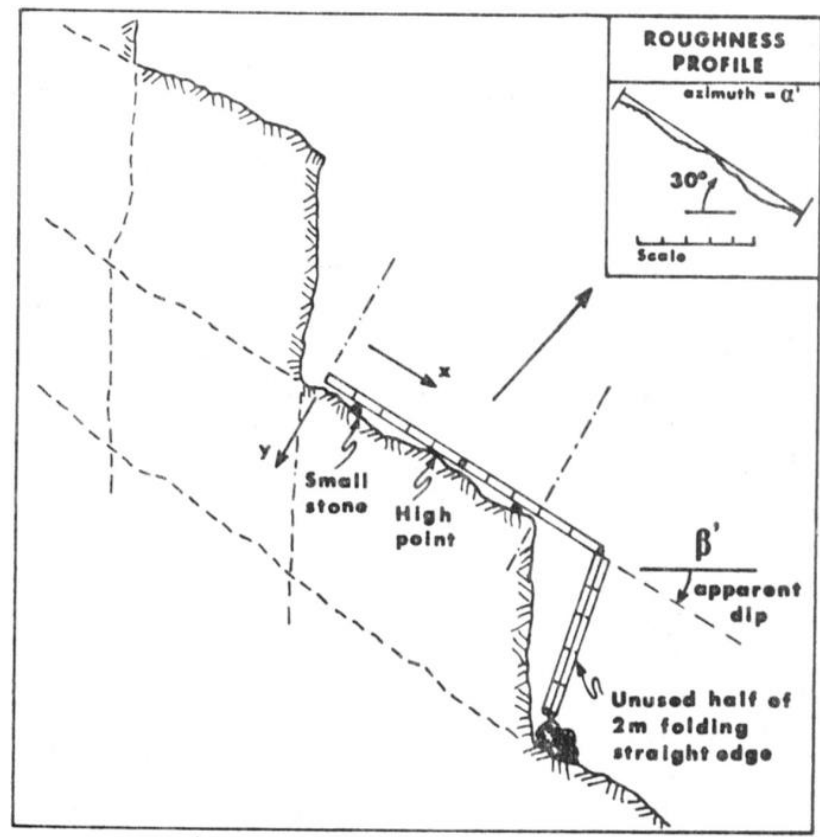

Figura 15 - Proposta de ISRM (1978) para determinação de ondulações e irregularidades em planos de descontinuidades. $O$ perfil da rugosidade é comparado utilizando-se uma linha de referência.

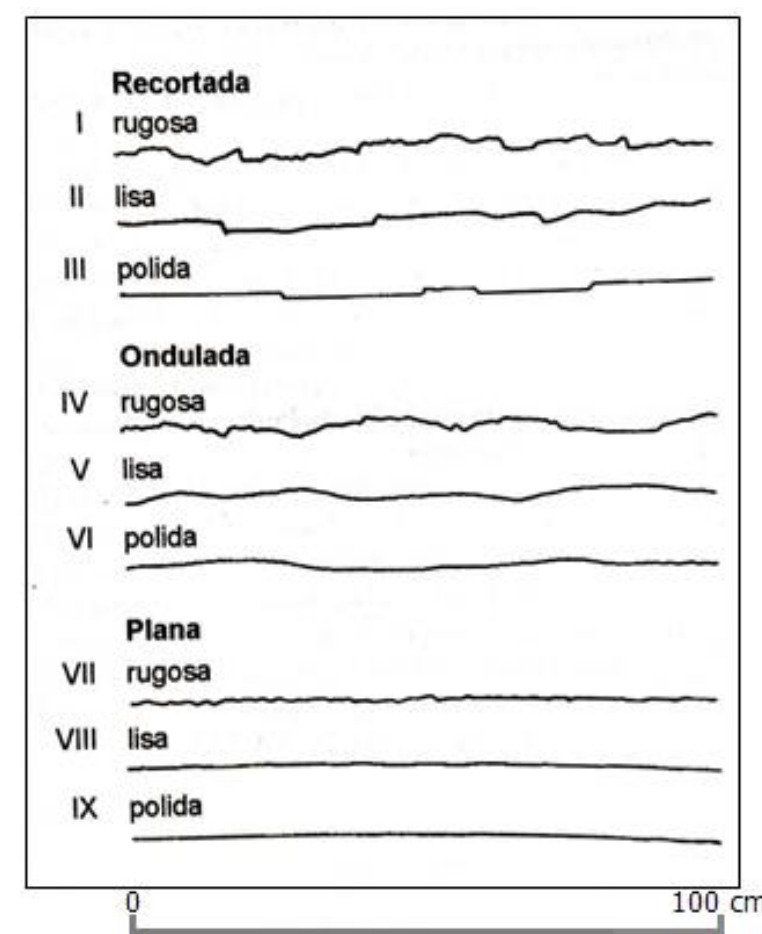

Figura 16 - Perfis de rugosidade propostos por Barton (1987). As linhas apresentadas nos perfis possuem aproximadamente $100 \mathrm{~cm}$ em comprimento, devendo ser considerada esta escala para comparação com superfície rochosa.

E como último dos parâmetros descritos pelos métodos da ISRM (1978) tem-se a percolação d'água, onde devem ser descritas a ocorrência de fluxo d'água ao longo dos planos de descontinuidades, assim como suas evidências, como paredes com película de oxidação. A influência do fluxo d'água é importante principalmente em projetos de túneis, sendo essencial sua caracterização não só em planos de descontinuidades, mas também através de ensaios específicos, como instalação de piezômetros e ensaios de perda d'água. A ISRM apresenta diversas tabelas para a descrição da percolação d'água, como em descontinuidades sem preenchimento, descontinuidades preenchidas e também ao longo das paredes e teto do túnel.

Em 1964, com o intuito de avaliar quantitativamente a qualidade de uma massa rochosa, Deere introduziu o parâmetro RQD (Rock Quality Designation), a partir de testemunhos de 
sondagens. O RQD é definido como o percentual da soma dos segmentos intactos do testemunho com comprimento superior a $10 \mathrm{~cm}$, em relação ao comprimento total da perfuração, ou trecho considerado.

Este parâmetro teve uma grande aceitação no meio técnico e posteriormente, juntamente em conjunto com outros índices, foi incluído como parâmetro essencial na classificação de maciços rochosos para escavações subterrâneas propostos por Bieniawski (1973, 1989), o RMR (Rock Mass Rating) e Barton et al. (1974), o Sistema Q.

Deere et al. (1967) sugeriu que uma scanline, linha de medida, pode ser diretamente análoga a um furo de sondagem, desde que o parâmetro RQD possa ser obtido em ambos os casos. A partir daí alguns autores buscaram encontrar uma correlação entre o RQD medido em furos de sondagem e o RQD, dito teórico, obtido em linhas de medidas.

Priest \& Hudson (1976) obtiveram um método para a determinação do RQD teórico (RQD*) a partir do valor médio do espaçamento ( $\lambda$ - número de descontinuidades por metro), utilizando uma função exponencial negativa (Equação 1).

$$
\mathrm{RQD}^{*}=100 \mathrm{e}^{-0.1 \lambda(0.1 \lambda+1)}
$$

Segundo os autores, utilizando-se dados experimentais, o RQD* foi comparado com o RQD medido, sendo obtido um erro máximo de $5 \%$ do valor e sugerem que este método deveria ser aplicado em uma variedade de tipos rochosos para determinar sua aplicabilidade.

Em 1982, Palmstrom sugeriu que o parâmetro RQD poderia ser estimado a partir do número de juntas por unidade de volume, onde o número de descontinuidades por metro segue a relação com o RQD expressa pela equação 2 .

$$
\mathrm{RQD}=115-3,3 \mathrm{Jv} \quad \text { (para JV } \geq 4,5) \quad \text { (Equação 2) }
$$

Onde:

Jv - índice volumétrico de juntas, que representa o número total de juntas em uma massa rochosa, derivada do espaçamento médio para cada família de descontinuidade.

Deere (1989) apresentou adaptações e atualizações para o parâmetro RQD, após mais de 20 anos de sua criação. Neste trabalho Deere aprofunda não só as questões que envolvem o RQD, mas também toda a caracterização dos parâmetros que descrevem uma descontinuidade. Deere afirma que inicialmente o RQD foi definido para ser utilizado em sondagens de tamanho NX (54,7 mm de diâmetro), porém podem ser utilizados outros diâmetros de testemunhos, sendo que deve mesmo assim ser considerado o mesmo comprimento de $10 \mathrm{~cm}$, não importando a espessura do testemunho. 
Entretanto, no caso de testemunhos menores, uma nota deve ser adicionada, pois um diâmetro menor poderia ser mais suscetível a quebras mecânicas. Também devem ser consideradas apenas as porções intactas, ou seja, caso estejam muito alteradas não devem ser somadas para se obter o RQD. E, ainda, intervalos menores que o comprimento total da manobra podem ser designados sempre que ocorrer zonas com RQD diferenciado do restante da manobra, também denominado de obtenção do RQD por isofraturamento.

Sen \& Eissa (1992) através de modelos conceituais e com base em medidas obtidas em scanlines, relacionam os parâmetros RQD e o índice volumétrico de juntas (Jv) com a média e desvio padrão, a partir de uma distribuição log-normal, ajustada pela frequência multiplicada pelos valores de espaçamento de descontinuidades, através da relação (Equação 3), que determina a esperança do RQD.

$$
\mathrm{E}(\mathrm{RQD})=100\left\{1-\mathrm{F}\left[\frac{\ln (0.1 \lambda)}{\sigma_{\ln \chi}}-\sigma_{\ln \chi}+1\right]\right\}
$$

Onde:

$\lambda$ - número médio de descontinuidades;

$\sigma \ln \chi$ - desvio padrão dos valores logaritmizados de espaçamento.

Nesta equação, o valor resultante dentro dos colchetes denota a área sobre a função de distribuição de probabilidade normal padronizada de $-\infty$ até o valor entre os colchetes.

Os autores, neste trabalho, ressaltam a importância do desvio padrão, modificando significativamente o valor do RQD e, dessa forma, caracterizando melhor a distribuição do espaçamento das descontinuidades. Por exemplo, para maciços pouco fraturados, um desvio padrão menor aumenta o valor médio do RQD, já em maciços muito fraturados um desvio padrão menor diminui o valor médio do RQD.

Um estudo mais detalhado sobre a aplicação desta técnica em pedreiras com distintos litotipos é apresentado em Oliveira (2000). Neste trabalho, concluiu-se que uma distribuição exponencial negativa seria a que melhor representaria o comportamento da variação de espaçamentos das descontinuidades, para maciços rochosos graníticos e gnáissicos. No caso de rochas basálticas, com disjunções colunares, e em rochas areníticas, com acamamento regular, os valores de espaçamento de descontinuidades se aproximariam de uma distribuição normal.

Devido ao fato de que ainda hoje em dia o parâmetro RQD é amplamente utilizado, as pesquisas e desenvolvimento nesta área seguem. Citam-se alguns trabalhos como Boadu \& Long 
(1994), Quigley \& McSwiney (1996), Schunnesson (1996), Harrison (1999), Sen (2000), Choi \& Park (2004), Palmstrom (2005), Kalenchuk et al. (2006), Murfitt et al. (2006), Li et al. (2009), Devkota et al. (2009), Mackiewicz \& Rippe (2010), Zhang (2010). Todos estes fizeram considerações importantes sobre o RQD e sua aplicação na classificação de maciços rochosos.

Choi \& Park (2004) comparam valores de RQD encontrados inicialmente nas sondagens verticais para um projeto de túnel, com os valores de RQD encontrados em scanlines horizontais ao longo da parede deste mesmo túnel, concluindo que foi encontrada uma diferença de até $24 \%$ nos valores para os dois casos. Palmstrom (2005) corrige sua relação inicial de Jv X RQD, apresentada na equação (2), concluindo que para valores de Jv maiores que 35, o RQD deveria ser considerado como sendo igual a zero e RQD igual a 100 para Jv menores que 4,5. Li et al. (2009) propõem uma nova correlação com o RQD que não só considera os trechos intactos, mas também aqueles trechos menores que $10 \mathrm{~cm}$ que não foram considerados na contagem do RQD tradicional.

\subsection{Análise Cinemática de Túneis em Maciços Rochosos}

A análise cinemática de blocos rochosos em túneis é necessária para se estimar a estabilidade de suas paredes e teto. Segundo Hoek (1966) em projetos realizados em estruturas rochosas, como escavações subterrâneas, a consideração mais importante é a estabilidade de toda a estrutura.

Os métodos analíticos baseiam-se em mecanismo de ruptura que se utilizam no cálculo de estabilidade de tais blocos rochosos. De acordo com Winiawer (2012) os dois métodos mais usualmente utilizados são: o desenvolvido por Warburton (1981), baseado num enfoque vetorial, e o de Goodman \& Shi (1985), fundamentado na teoria dos blocos chaves. Fiori \& Carmignani (2009) também apresentam o método baseado em Hoek \& Brown (1980) e Hoek \& Bray (1981), inicialmente propostos para paredes rochosas.

A cinemática refere-se à movimentação de corpos, sem fazer, entretanto, referência às forças que causam o movimento. Para que um bloco de rocha fique livre para cair do teto ou escorregar das paredes de uma escavação é necessário que seja separado do restante da massa rochosa por pelo menos três descontinuidades (Fiori \& Carmignani, op.cit.).

Segundo Goodman (1989) supondo-se que um bloco de rocha é isolado por uma intersecção de planos de descontinuidades e superfícies de escavação, não importa quantas faces ocorra neste bloco, pois este se movimentará em apenas algumas formas, seja caindo, deslizando sobre um dos planos, ou, sobre dois dos planos (ou uma combinação de deslizamento e rotação do bloco). 
Estes deslizamentos podem ser analisados por meio de projeções estereográficas. Um exemplo simples desta aplicação é apresentado nas Figuras de 17 a 20, de Fiori \& Carmignani, (2009). A Figura 17 mostra uma cunha de rocha com possibilidade de se desprender do teto em uma escavação, sendo esta delimitada por dois sistemas de juntas bem desenvolvidos e o plano horizontal do teto. A linha vertical, traçada a partir do ápice da cunha, deverá cair dentro da base da cunha para que ocorra a simples queda do bloco, sem deslizamento. Já na Figura 18 ilustra o aspecto de uma cunha delimitada por dois sistemas de juntas e um plano inclinado da escavação (teto do túnel). Resumindo, as condições para que ocorra o desprendimento de um bloco no teto de uma escavação, serão satisfeitas quando os grandes círculos representando os planos formarem uma figura fechada em torno do centro do diagrama.

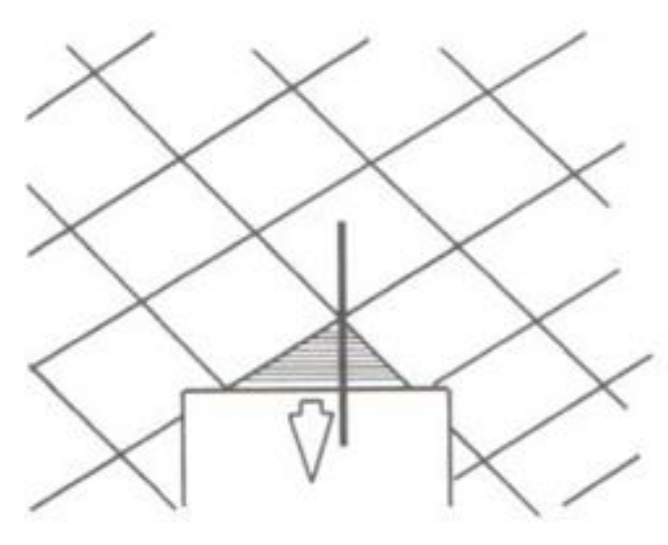

(a)

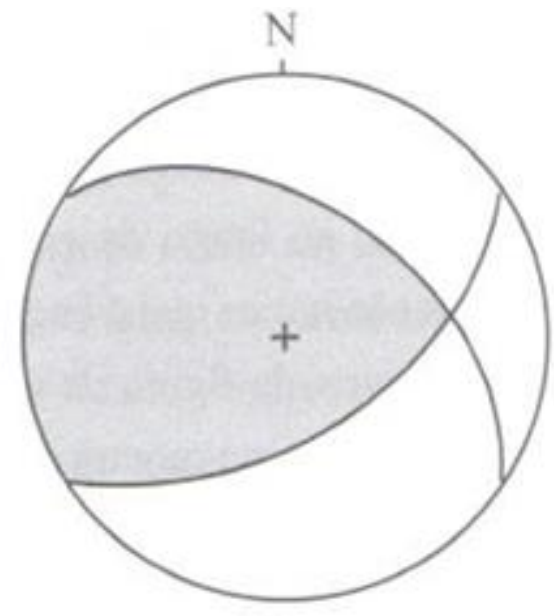

(b)

Figura 17 - Condições para o desprendimento de blocos no teto de escavações: (a) perfil do bloco no túnel (b) projeção estereográfica do bloco (Fiori \& Carmignani, 2009).

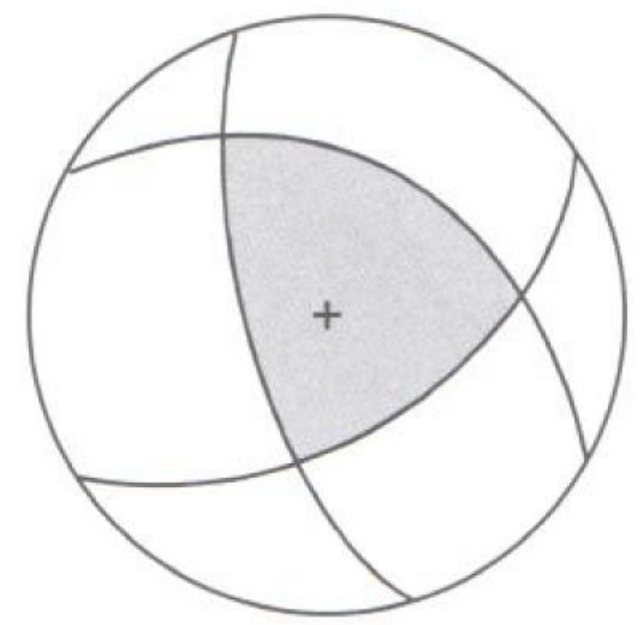

Figura 18 - A área sombreada representa uma figura de intersecção de dois sistemas de juntas em projeção ciclográfica e o plano inclinado da escavação. O centro do diagrama situa-se dentro da figura de intersecção, indicando a possibilidade de queda de bloco por ação da força da gravidade (Fiori \& Carmignani, 2009). 
Nas Figuras 19 e 20, a área de intersecção dos planos de descontinuidades não passa pelo centro do diagrama; portanto, o desprendimento do bloco ocorrerá pelo deslizamento ao longo de pelo menos um dos planos. Uma condição básica para que aconteça o deslizamento, conforme pode ser observado no exemplo da Figura 19, é que pelo menos um dos planos, assim como a área de intersecção entre estes, tenha mergulho maior que o ângulo de inclinação e maior que o ângulo de atrito $(\phi)$ definido para o maciço rochoso. No caso da Figura 20, por exemplo, a área de intersecção cai totalmente fora do cone de atrito, ou seja, o peso da cunha não será suficiente para superar a força de resistência do plano, ou dos planos nos quais se dará o deslizamento, sendo a cunha estável nesse caso.

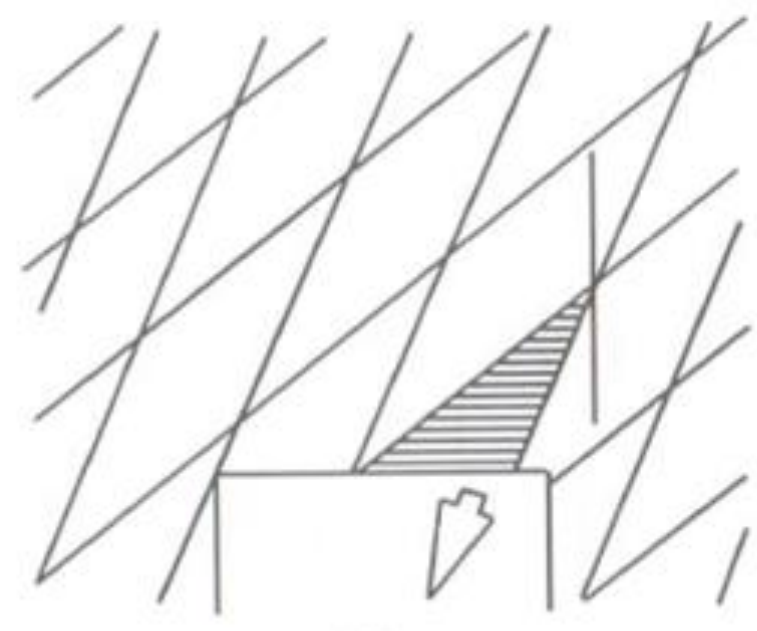

(a)

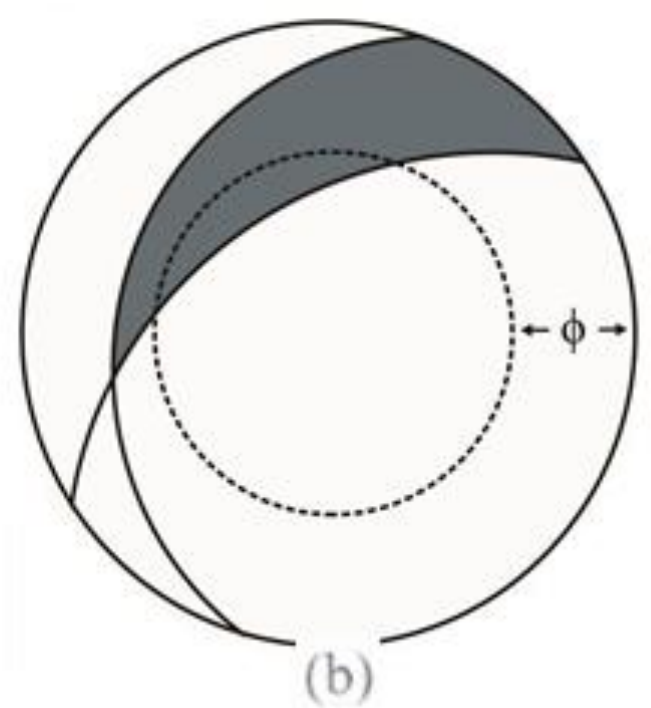

Figura 19 - Condições para o escorregamento de cunhas no teto de escavações, (a) perfil do bloco no túnel (b) projeção estereográfica do bloco (Fiori \& Carmignani, 2009).

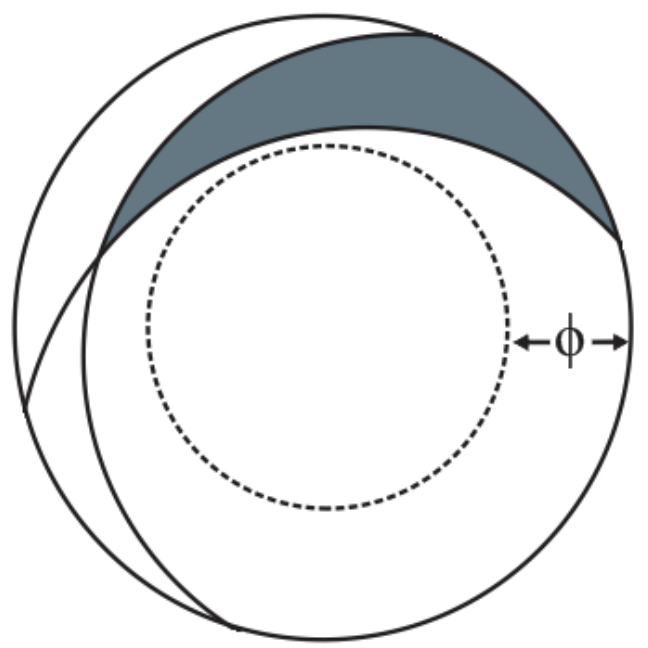

Figura 20 - Cunha de rocha em condições estáveis, a área de intersecção é menor que o ângulo de atrito, não havendo escorregamento do bloco (Fiori \& Carmignani, 2009). 
No caso da análise de estabilidade das paredes de uma escavação, Fiori e Carmignani (2009) relatam que, para se definir a forma da cunha nas paredes, é necessário inicialmente determinar a figura de intersecção, projetada em um plano vertical, utilizando estereogramas, conforme ilustrado na sequência das Figuras 21 a 23. Esta figura é obtida pela rotação dos grandes círculos em torno do eixo do túnel. Nesta análise, deverá ser analisada tanto a parede direita como a esquerda, conforme esquematizado nas figuras indicadas.

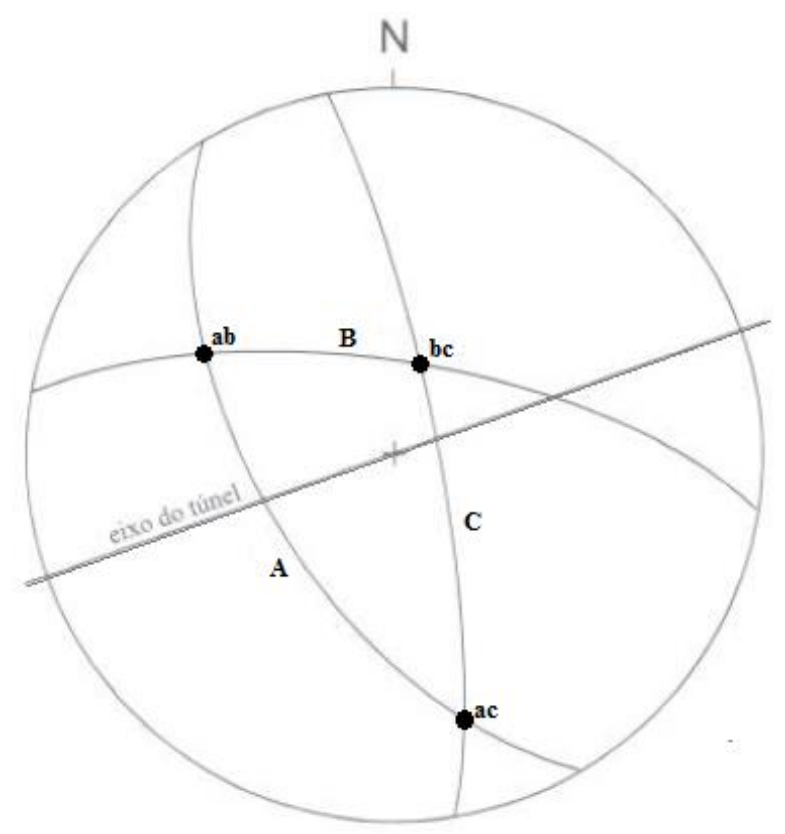

Figura 21 - Planos de juntas que se intersectam e definem uma cunha de rocha na base de um túnel (Fiori \& Carmignani, 2009).

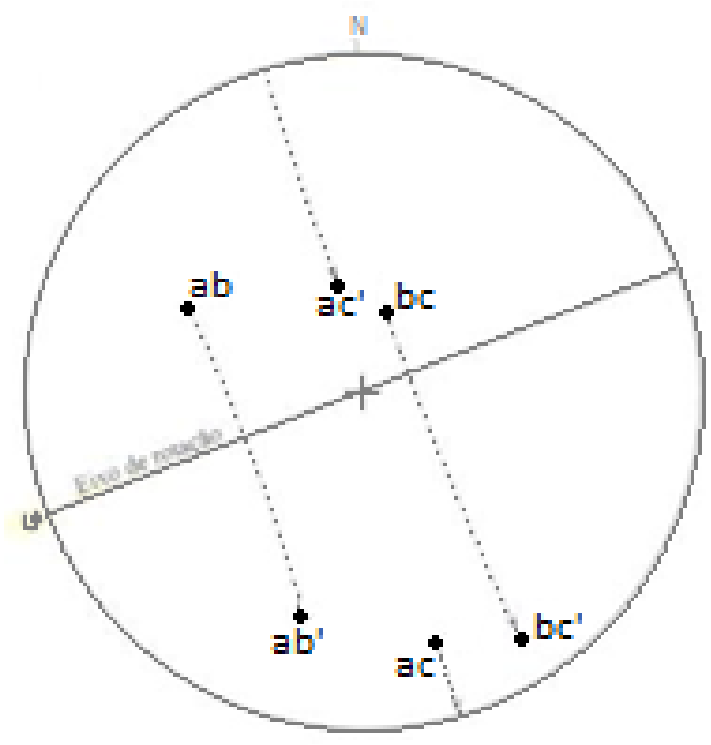

(a)

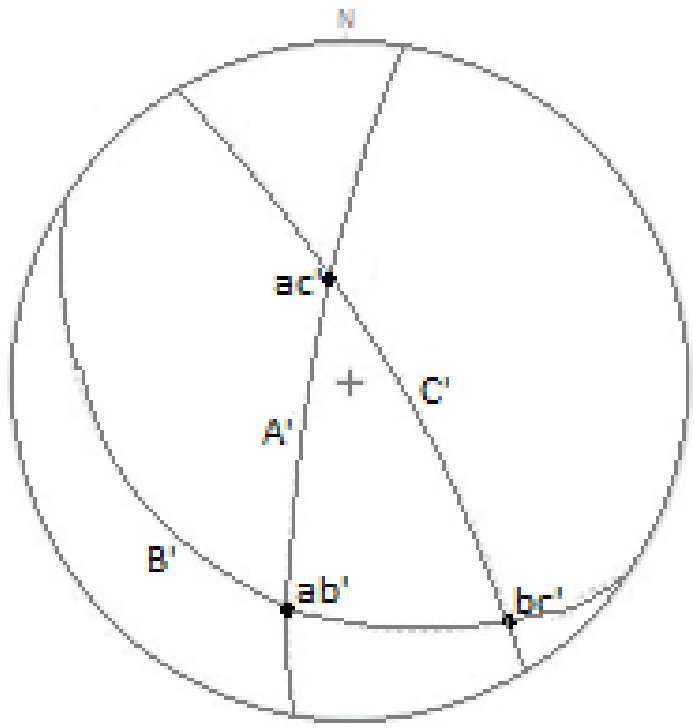

(b)

Figura 22 - Procedimento para rotação de $90^{\circ}$ dos pontos ab, ac e be de intersecção das juntas, projetando o bloco formado inicialmente na base do túnel para a parede deste (Fiori \& Carmignani, 2009). 

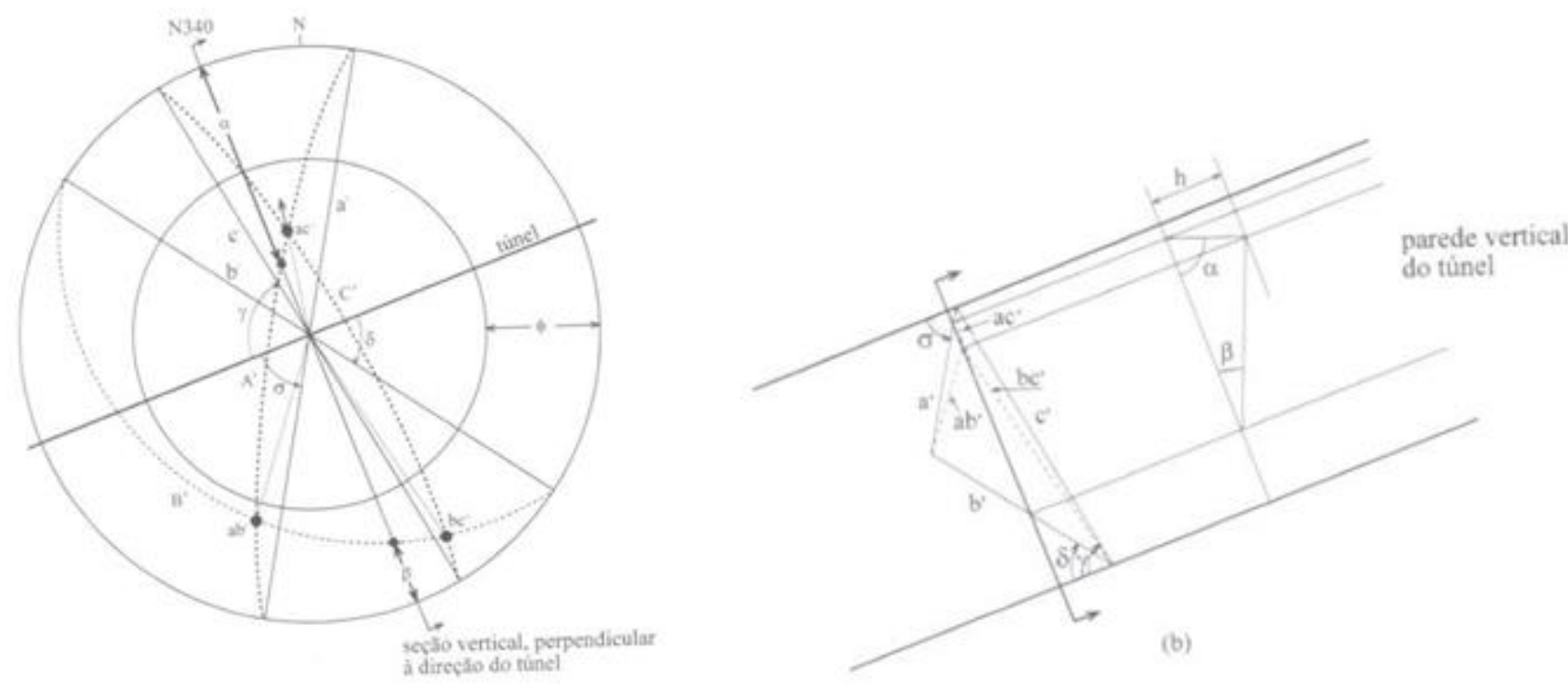

Figura 23 - Construção da seção verdadeira de uma cunha na parede de um túnel (Hoek \& Brown, 1980, traduzido em Fiori \& Carmignani, 2009).

Os mesmos autores ainda afirmam que planos relevantes, como um plano de falha ou uma zona de cisalhamento, devem ser indicados com símbolos distintos nos estereogramas e sempre considerados seus planos na análise de estabilidade, devido ao fato que estas feições requerem atenção especial. Para a obtenção dos principais planos de descontinuidades, deverá ser preparado um diagrama de contorno, onde poderão ser definidos os valores médios de orientação dos principais sets de descontinuidades que serão utilizados na análise cinemática. No caso de uma distribuição mais espalhada, haverá a necessidade de utilizar técnicas estatísticas para a definição das concentrações máximas.

Segundo Winiawer (2012) o método da análise vetorial de Warbunton (1981) se baseia na análise de estabilidade de blocos poliédricos arbitrários. Estes blocos são delimitados em parte pelas faces de contato entre blocos-juntas, e em parte pelas faces livres, em contato com uma escavação. As superfícies das faces são supostas como perfeitamente planas e os blocos perfeitamente rígidos e indeformáveis. Definem-se três tipos de movimento possíveis:

- A queda direta, onde o bloco se desprende de todas suas faces;

- Um deslizamento paralelo a uma face, deslizamento plano;

- Um deslizamento paralelo a duas faces ao longo de uma aresta comum as duas faces, deslizamento diédrico. 
O processo se desenvolve em várias etapas sucessivas para analisar uma a uma as faces do poliedro considerado. Este processo determina além da possibilidade de movimento de um bloco, o seu tipo de deslizamento.

Em 1985, Goodman \& Shi propuseram o método definido como a Teoria dos Blocos Chaves. Esta teoria se baseia no princípio da existência de determinados blocos definidos chaves, sendo que se a estabilidade de tais blocos é assegurada, então nenhum movimento deverá ocorrer. A teoria estabelece procedimentos para descrever, localizar estes blocos e definir o suporte ideal. Também é possível, através dessa teoria, projetar as estruturas escavadas com sua orientação e formato ideais, que minimizariam ou eliminariam completamente a necessidade de contenções artificiais.

Fiori \& Carmignani (2009) esclarecem que, quando uma escavação é feita, muitos blocos de rocha são formados justamente a partir da abertura desse novo plano (túnel). Muitos deles não podem se mover para o espaço livre da escavação, sejam por causa de suas formas, tamanhos, orientações, ou ainda, porque têm sua movimentação impedida pela presença de outros blocos adjacentes. Outros blocos, entretanto, estão em condições instáveis, ou aptos a se movimentar de imediato, tão logo seja feita a abertura da escavação ou a retirada de alguns blocos críticos, podendo ocasionar um efeito em cadeia, levando à instabilização de blocos adjacentes e, sucessivamente, ao desmoronamento de todo o talude ou parede de escavação. Por causa disso, os blocos mais perigosos são chamados de "blocoschave".

Segundo Winiawer (2012) nesta teoria se considera as superfícies das juntas como sendo perfeitamente planas, os blocos sendo rígidos e indeformáveis, a posição das famílias de fraturas é conhecida de maneira determinística e as descontinuidades se estendendo por todo o domínio de estudo.

Na Figura 24, podemos visualizar os seis distintos tipos de blocos. O bloco VI não apresenta nenhuma face livre aflorante no túnel, enquanto que o bloco do tipo $\mathrm{V}$ tem face livre, porém é de caráter infinito. Assim como os dois anteriores, o bloco IV também não poderá ser considerado bloco-chave, por não ser removível, já que sua forma afunilada não permitirá que este caia no espaço aberto sem arrastar consigo outros blocos.

Os demais blocos são finitos e removíveis, sendo que sua movimentação irá depender não somente da geometria, mas da direção da força resultante e das magnitudes dos ângulos de atrito atuantes nas faces. O bloco III é estável pela ação da gravidade, assim como os blocos do tipo II que são estáveis pela ação do atrito. Entretanto os blocos do tipo I são blocos instáveis, justamente os chamados de blocos-chave (Fiori \& Carmignani, 2009). 
Winiawer (2012) acrescenta que o objetivo deste método é identificar tais blocos-chave, que correspondem a blocos finitos, destacáveis, que se tornarão instáveis se forem intersectados por uma escavação. A queda de um bloco-chave não aumenta a possibilidade de instabilidade, mas sua prevenção assegura a estabilidade.

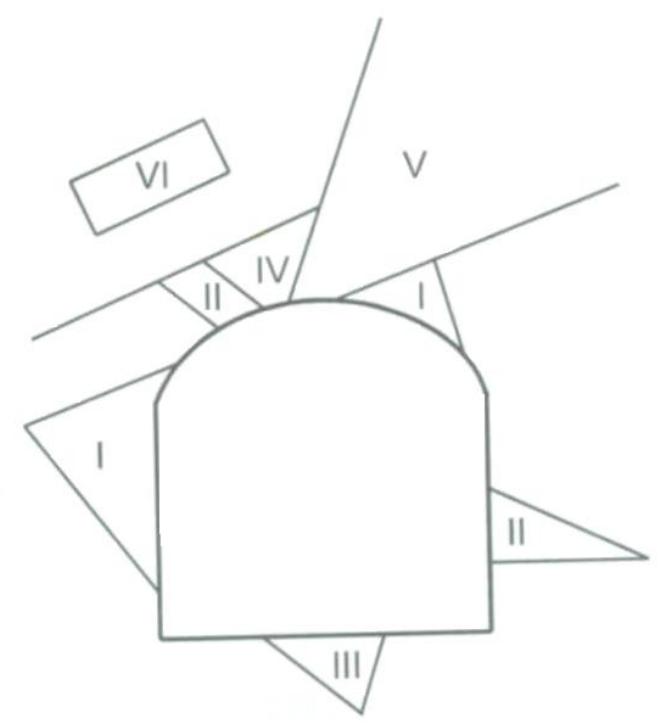

Figura 24 - Tipos de blocos. I: Blocos-chave, II: Bloco-Chave Potencial, III: Bloco Estável Removível, IV: Bloco Afunilado, V: Bloco Infinito, VI: Bloco de Junta. Goodman (1989) e modificado por Fiori \& Carmignani (2009).

Toda a análise é feita tridimensionalmente. Segundo Goodman (1989) as formas e a localização dos blocos são tridimensionais, ao contrário de outras análises cinemáticas que são realizadas bidimensionalmente. Para o autor, no caso de maciços rochosos fraturados, uma análise em duas dimensões será uma simplificação imprudente. Para efetuar esta análise, Goodman \& Shi (1985) propõem o uso de uma projeção estereográfica tridimensional, conforme ilustrado na Figura 25. Nas duas citações acima é possível acompanhar o cálculo em detalhe para a construção desta rede tridimensional. Basicamente, cada plano definido será projetado simultaneamente tanto no hemisfério inferior como no superior.

Inicialmente, deverão ser definidas as principais famílias de descontinuidades, sendo cada um destes planos plotado no estereograma apresentado na Figura 25. Serão definidas, então, o que Goodman \& Shi (1985) denominam de pirâmides de juntas (PJ, ou JP, Joint Pyramid). De acordo com Fiori \& Carmignani (2009), uma pirâmide de juntas PJ é a intersecção dos semiespaços de cada junta dentro de uma combinação particular de juntas, considerando-se que todas elas ocorram nas proximidades de um único ponto. As pirâmides de juntas são identificadas por um código, composto pelos dígitos 0 e 1 arranjados em correspondência à numeração original das juntas, conforme detalhado adiante. 
Vale ressaltar que Goodman \& Shi (1985) e Goodman (1989) consideram a parte interna do círculo de referência como hemisfério superior, enquanto que Fiori \& Carmignani (2009), como inferior, que é o padrão utilizado em geologia estrutural.

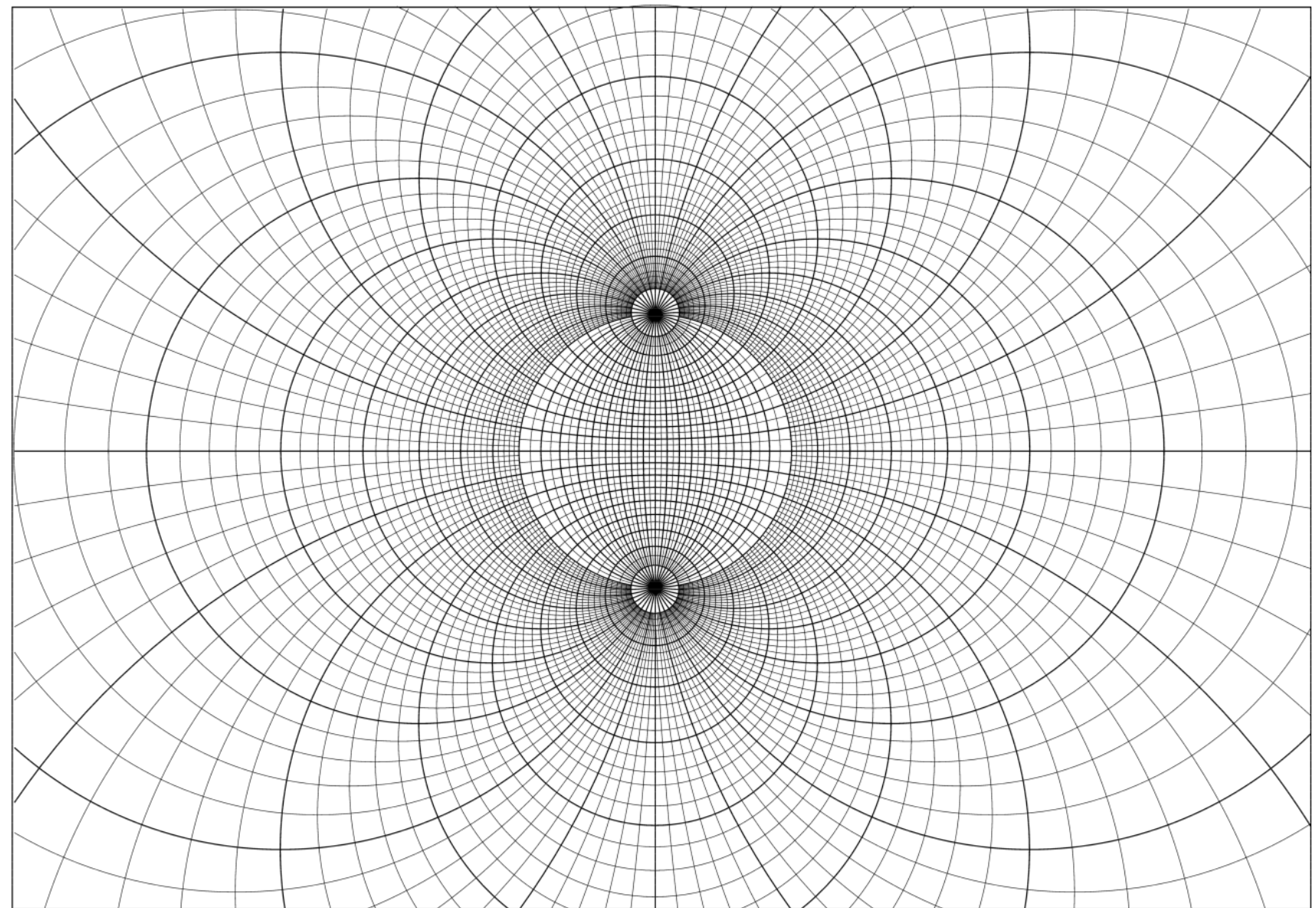

Figura 25 - Diagrama de Schmidt-Lambert modificado para definição dos blocos-chave, Fiori \& Carmignani (2009).

Portanto, segundo o apresentado em Goodman (1989) o dígito 0 identifica o semiespaço superior e o dígito 1 representa o semiespaço inferior de determinado plano de junta. Há a possibilidade de utilizar o dígito 2, que equivale à ausência de um determinado plano na formação de um bloco de rocha pertencente à combinação de juntas.

A Figura 26 ilustra um exemplo de como estas definições de PJs ocorrem. Nesta figura, modificada de Goodman (1989), ocorrem três planos de fraturas, sejam estes 1, 2 e 3. Todas as possíveis combinações de PJs estão indicadas. Tomando a PJ100, por exemplo, ela é formada pelo semiespaço inferior do plano 1, recebendo valor 1, e pelos semiespaços superiores tanto do plano 2 como o 3, recebendo valor 0. Já a PJ101 é formada pelos semiespaços inferiores dos planos 1 e 3, e superior do plano 2 . 


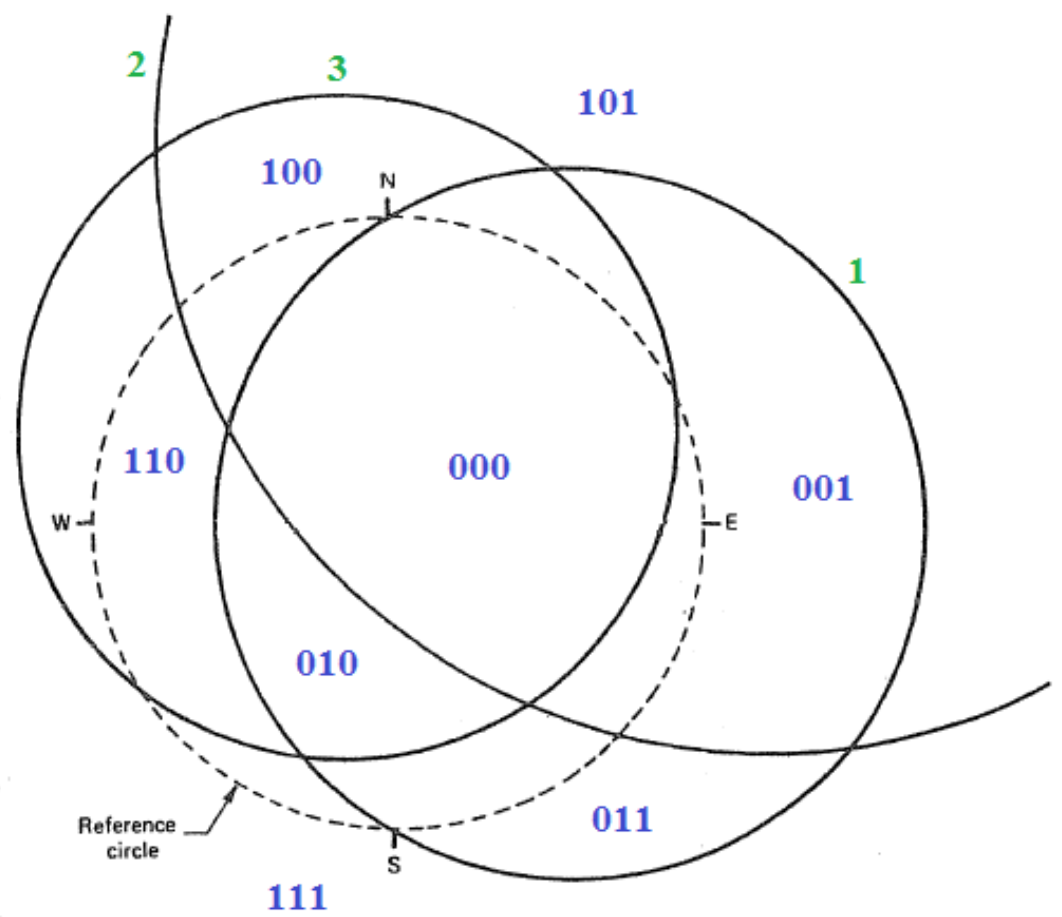

Figura 26 - Exemplo de construção de grandes círculos e PJs para um sistema de juntas. O ponto focal da projeção estereográfica situa-se na parte superior da esfera, modificado de Goodman (1989).

Também se utilizam os termos PE e PS. PE (pirâmide de escavação, ou EP, excavation pyramid) é o semiespaço que engloba a massa rochosa adjacente a uma face livre, enquanto PS (pirâmide de espaço, ou SP, space pyramid) é o semiespaço oposto, ou seja, o que engloba o espaço vazio da face livre. Simplificando, PE seria a rocha propriamente dita e PS o espaço já cavado, sem rocha. Segundo Fiori \& Carmignani (2009), o teorema de Shi mostra que um bloco é removível se a correspondente PJ cair inteiramente dentro da PS. Um exemplo pode ser visto na Figura 27, onde o túnel é representado pela linha reta. Se considerarmos a parede mais a nordeste deste túnel, a parede de escavação (PE) está a nordeste e a parede de espaço (PS) está a sudeste; portanto, a única PJ que cai inteiramente dentro da PS é a 110.

Goodman (1989) demonstra a aplicação desta teoria dos blocos no estudo de escavações subterrâneas. Utilizando como exemplo a mesma Figura 27, primeiramente é feito um estudo da estabilidade do teto do túnel, onde a pirâmide de escavação seria todo o semiespaço superior do círculo de referência ${ }^{2}$. Portanto a PE estaria dentro do círculo de referência e a PS fora dele, sendo que a única PJ que estaria totalmente dentro da PS é a 101, conforme pode ser visualizado na Figura 28. A PJ101 é formada pelos semiespaços inferiores dos planos 1 e 3 , e pelo semiespaço superior do plano 2.

\footnotetext{
${ }^{2}$ Neste caso foi considerada a parte interna do círculo de referência como sendo a projeção do hemisfério superior e não hemisfério inferior como geralmente utilizado em geologia estrutural.
} 


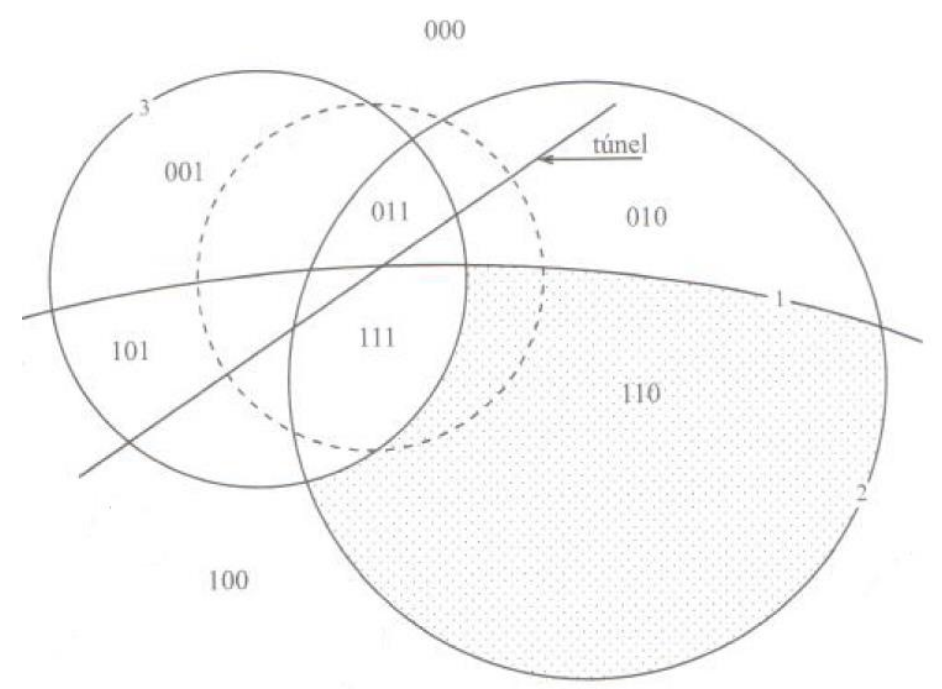

Figura 27- Representação das pirâmides de juntas para três famílias de descontinuidades e um túnel de direção NE-SW. Na parede NE, a PS está a SE, sendo que a PJ que cai totalmente na PS é a 110 (considerando a projeção do círculo de referência como sendo hemisfério inferior), Fiori \& Carmignani (2009).

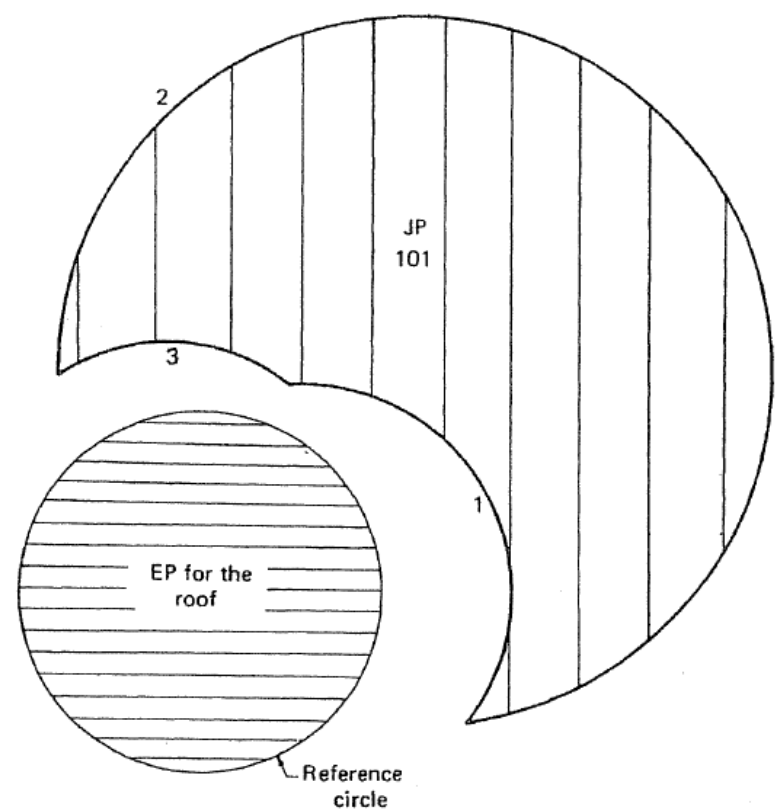

Figura 28 - Pirâmide de Junta (PJ ou JP) que aparecerá como bloco-chave para o teto de um túnel, sendo a única que não possui intersecção com a pirâmide de escavação (PE ou EP) para o teto de um túnel (Goodman, 1985).

O próximo passo descrito em Goodman (1989) seria então desenhar a forma do bloco removível considerando uma visada para o teto. Para isso, sugere que seja primeiramente considerado o bloco olhando para baixo. Na Figura 29, os planos são desenhados considerando suas direções, indicando seus respectivos mergulhos e semiespaço superior e inferior. O semiespaço superior de um plano inclinado está ao lado do vetor de mergulho, neste caso oposto ao considerado em geologia estrutural como o rumo do mergulho, já que estamos considerando o hemisfério superior. 


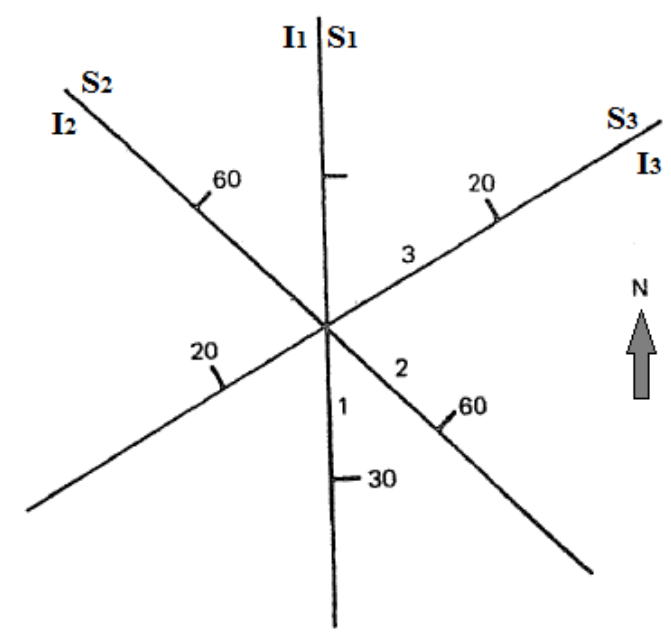

Figura 29 - Traços dos planos da PJ101 considerando plano horizontal com visada de cima para baixo, indicando semiespaços inferiores e superiores (Goodman, 1989).

Após considerar os semiespaços inferiores dos planos 1 e 3 , juntamente com o semiespaço superior do plano 2 é possível formar a forma correspondente ao bloco-chave do teto do túnel, conforme visualizado na Figura 30. Entretanto, esta Figura apresenta a forma representada considerando visada de cima para baixo. Como precisamos da mesma figura representada no teto do túnel, Goodman (1989) propõe uma rotação através do eixo EW, mudando o norte para baixo e sul para cima, obtendo dessa forma a Figura 31, com o formato do bloco-chave no teto do túnel.

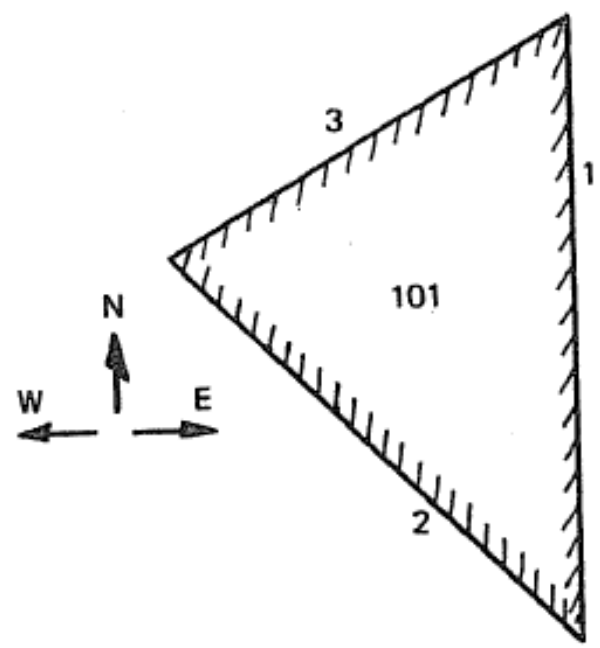

Figura 30 - Forma do bloco-chave PJ101 com visada de cima para baixo.

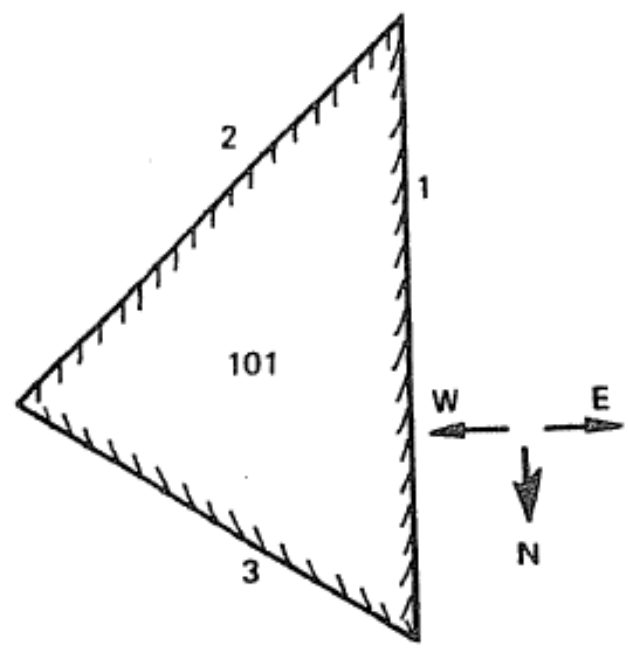

Figura 31 - Forma do bloco-chave PJ101 com visada de cima para baixo.

O mesmo procedimento pode ser realizado para as paredes do túnel. Utilizando ainda a mesma Figura 27 como exemplo, Goodman admite a existência de um túnel de direção EW e encontra a PJ que será considerada como bloco-chave se analisada a parede sul, obtendo a PJ100 
como bloco-chave (Figura 32). Contudo, para se desenhar a face livre deste bloco removível na parede sul, se faz necessário encontrar as inclinações aparentes destes planos, conforme ilustrado na Figura 33. Nesta figura os mergulhos são dados pelos pontos a, b e c, nos quais a linha EW intercepta os grandes círculos representativos destes planos, tendo sido obtidos, respectivamente, $30^{\circ}$ para $\mathrm{W}$, $53^{\circ}$ para $\mathrm{W}$ e $9^{\circ}$ para $\mathrm{E}$.

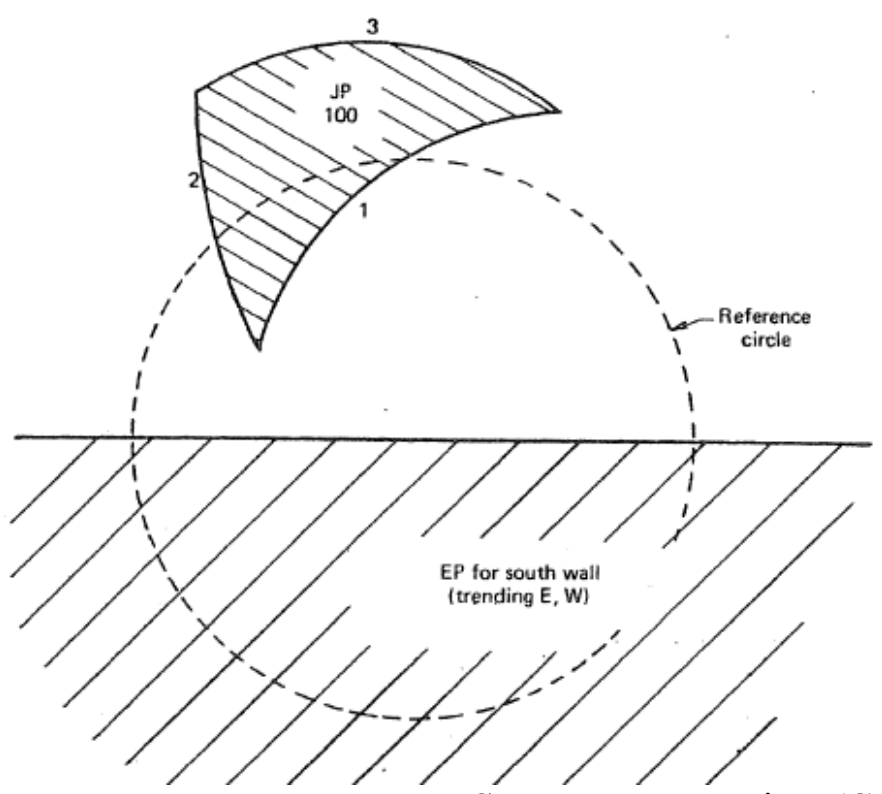

Figura 32 - PJ que se encontra totalmente dentro da PS, parede sul do túnel (Goodman, 1989).



Figura 33 - Determinação dos mergulhos aparentes das descontinuidades consideradas para a PJ100, na parede sul do túnel (Goodman, 1989).

Finalizando essa sequência de procedimentos, Goodman (1989) desenha em planta os planos encontrados para a PJ100, com visada para norte, marcando o semiespaço superior e inferior para cada set (Figura 34). Na Figura 35, representa-se a forma deste bloco, considerando visada para 
norte. Na Figura 36, este mesmo bloco foi rotacionado considerando uma linha vertical, trocando o leste com o oeste, dessa forma visualizando a parede sul. Ao chegar a uma forma concreta deste bloco-chave, o autor apresenta um mapa de traços de descontinuidades na parede sul de uma escavação subterrânea, como exemplo da aplicação desta teoria (Figura 37). Finalmente, após reconhecer o formato dos blocos neste mapa, poderá chegar a todos os blocos-chave neste trecho (Figura 38). Concluindo, então que, se esses blocos forem contidos com suportes, a parede estará estabilizada.

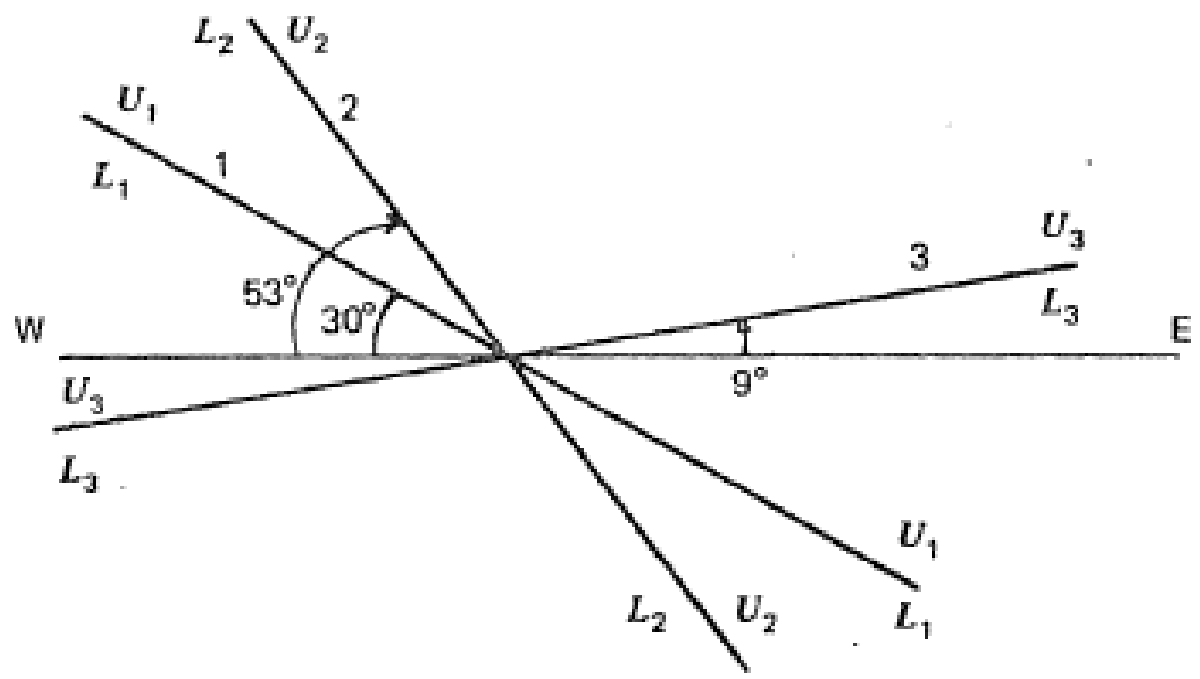

Figura 34 - Traços dos planos da PJ100 considerando plano horizontal com visada norte, indicando semiespaços inferiores e superiores (Goodman, 1989).

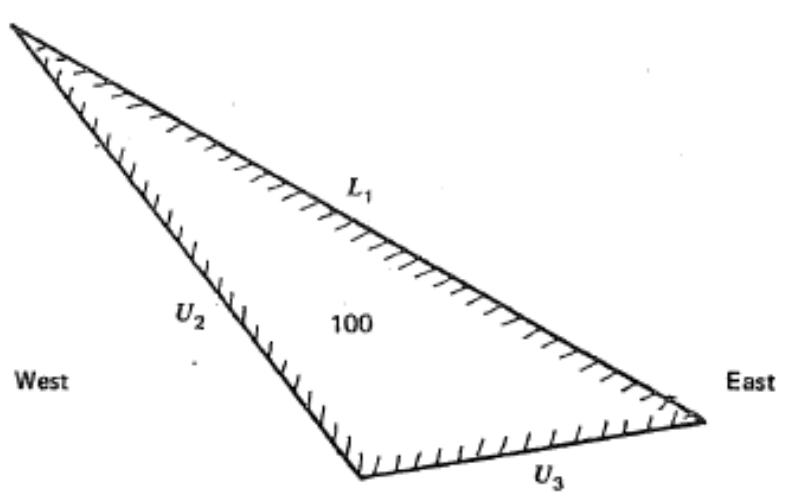

Figura 35 - Formato do bloco-chave da PJ100 na parede sul, com visada para norte (Goodman, 1989).

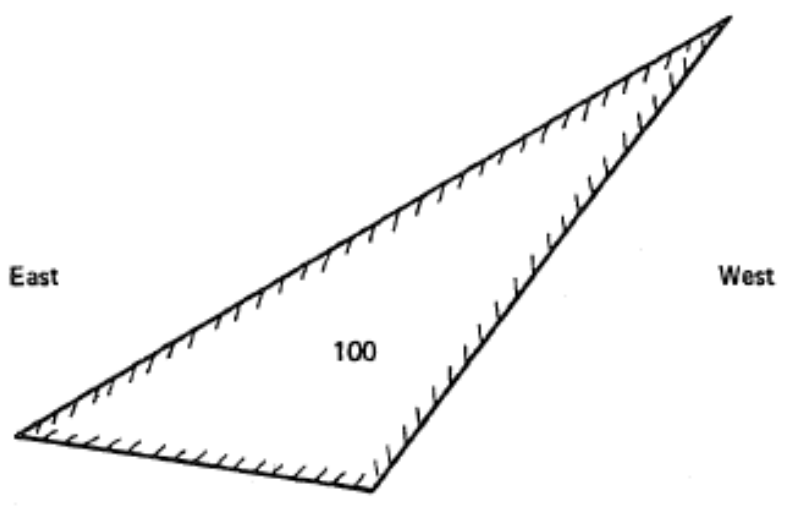

Figura 36 - Formato do bloco-chave da PJ100 na parede sul, com visada para sul (Goodman, 1989). 


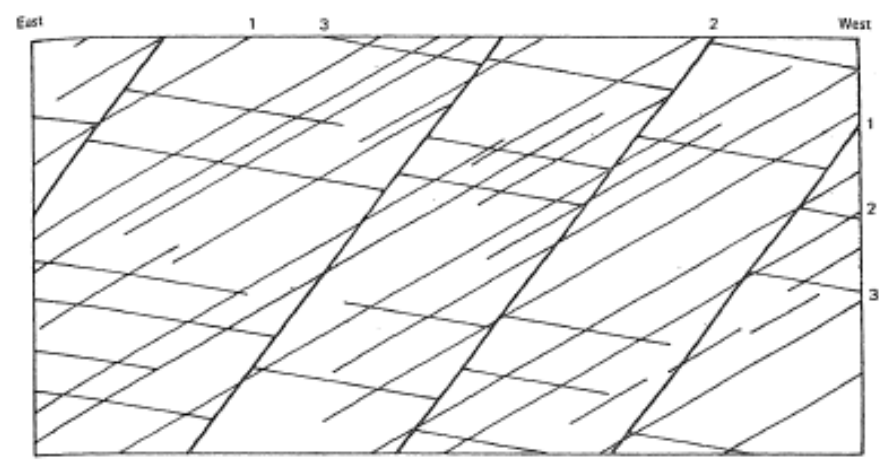

Figura 37 - Mapa de traços de descontinuidades presentes na parede sul de um túnel (Goodman, 1989).

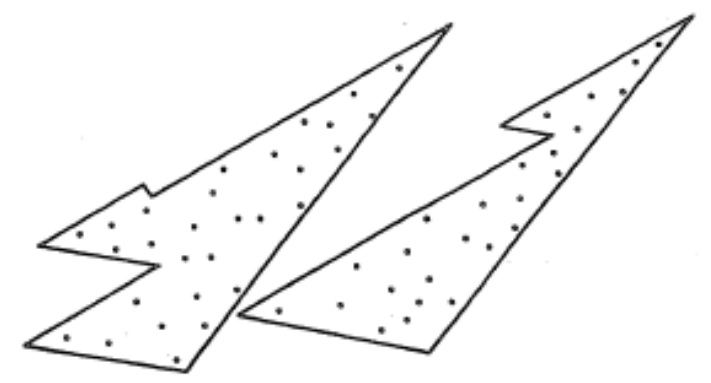

Figura 38 - Resultado dos blocos removíveis encontrados na parede sul (Goodman, 1989).

\section{CARACTERIZAÇÃO DO TESTEMUNHO VIRTUAL - METODOLOGIA PROPOSTA}

Neste capítulo apresenta-se a metodologia proposta para caracterização geológico-geotécnica de testemunhos virtuais obtidos através do televisionamento das paredes de sondagens. Esta proposta teve como base as informações apresentadas no item 4.3. Atualmente, esta metodologia vem sendo aplicada nos serviços executados para a Companhia do Metropolitano de São Paulo.

Considerando que um maciço rochoso, do ponto de vista da engenharia, é um conjunto de blocos de rocha delimitados por descontinuidades, é essencial que sejam descritas tanto a matriz rochosa como as descontinuidades que a delimitam, da mesma forma que se descrevem os testemunhos de sondagens. Sendo assim, sugere-se a divisão das descrições e interpretações em duas partes distintas, rocha intacta (matriz rochosa) e descontinuidades.

\subsection{Rocha Intacta}

Os parâmetros sugeridos para a descrição da matriz rochosa, possíveis de serem observados nas imagens de televisionamento e de interesse para projetos de engenharia, são: a descrição dos litotipos, estrutura, textura, composição mineralógica e seu grau de alteração.

Propõe-se a divisão do testemunho virtual em zonas sempre que houver mudanças em um destes parâmetros, principalmente definindo intervalos com graus de alteração distintos, delimitando domínios estruturais e litológicos diferentes. Sugere-se a elaboração de planilha indicando os diversos trechos definidos na matriz rochosa, conforme indicado na Tabela 5. A Foto 7 ilustra um caso de mudança na textura da rocha, além de incluir também uma descontinuidade, tendo certamente que ser dividido em trechos distintos na Tabela 5. 
Tabela 5 - Exemplo de Tabela com caracterização da rocha intacta.

\begin{tabular}{|c|c|c|c|c|c|c|c|}
\hline \multicolumn{3}{|c|}{ FURO 132} & \multicolumn{5}{|c|}{ TABELA - ROCHA INTACTA } \\
\hline $\begin{array}{l}\text { PROF. } \\
\text { (m) }\end{array}$ & $\begin{array}{l}\text { ESPESSURA } \\
\text { (m) }\end{array}$ & LITOLOGIA & UNIDADE & ESTRUTURA & TEXTURA & $\begin{array}{l}\text { COMPOSIÇÃO } \\
\text { MINERALÓGICA }\end{array}$ & $\begin{array}{c}\text { GRAU DE } \\
\text { ALTERAÇÃO }\end{array}$ \\
\hline 19,92 & 0,32 & \multirow{13}{*}{ Gnaisse } & \multirow{13}{*}{$\begin{array}{c}\text { Embasa- } \\
\text { mento da } \\
\text { Bacia de } \\
\text { São Paulo }\end{array}$} & \multirow{13}{*}{$\begin{array}{l}\text { Gnáissica, } \\
\text { minerais } \\
\text { orientados, } \\
\text { foliação } \\
\text { incipiente. } \\
\text { Presença de } \\
\text { veios de } \\
\text { quartzo- } \\
\text { feldspáticos } \\
\text { centimétricos }\end{array}$} & \multirow{13}{*}{$\begin{array}{l}\text { Inequi- } \\
\text { granular, } \\
\text { média/ } \\
\text { grossa, } \\
\text { cristais } \\
\text { tabulares de } \\
\text { feldspato. }\end{array}$} & \multirow{13}{*}{$\begin{array}{c}\text { Quartzo, } \\
\text { Feldspato, } \\
\text { minerais } \\
\text { máficos (biotita } \\
\text { e etc). }\end{array}$} & II \\
\hline 20,24 & 4,08 & & & & & & I \\
\hline 24,32 & 0,38 & & & & & & II \\
\hline 24,7 & 1,00 & & & & & & I \\
\hline 25,7 & 2,80 & & & & & & II \\
\hline 28,5 & 0,95 & & & & & & I \\
\hline 29,45 & 0,19 & & & & & & II \\
\hline 29,64 & 7,21 & & & & & & I \\
\hline 36,85 & 0,72 & & & & & & II \\
\hline 37,57 & 3,26 & & & & & & I \\
\hline 40,83 & 0,95 & & & & & & II \\
\hline 41,78 & 8,40 & & & & & & III \\
\hline 50,18 & Fim do furo & & & & & & \\
\hline
\end{tabular}

$\mathrm{Na}$ caracterização da rocha intacta, é essencial descrever os aspectos do corpo rochoso como um todo. Inclui-se aí as estruturas ditas penetrativas, que não interrompem, necessariamente, a continuidade física do meio rochoso, como a foliação, xistosidade, bandamento, acamamento, dobramentos, veios, etc. Estas estruturas devem ser devidamente caracterizadas, pois são de suma importância na definição do modelo geológico estrutural do maciço, diversas vezes indicando aspectos que influenciarão em seu comportamento geomecânico. Ademais, muitas destas estruturas estão frequentemente associadas a planos descontínuos, por exemplo, um sistema de fraturas com planos paralelos à foliação da rocha. Na Tabela 6, apresenta-se como exemplo a descrição destas estruturas penetrativas para uma imagem de televisionamento obtida em projetos do Metrô de São Paulo.

Por tantas vezes, esta distinção entre descontinuidades e feições penetrativas não é tão evidente, o que aumenta a importância da insistência em uma descrição detalhada de todas as feições observadas no maciço. Ressalta-se a importância de se demarcar a foliação ao longo de toda a imagem do furo de sondagem, verificando se há quaisquer mudanças relevantes na sua orientação, o que poderia fornecer indícios de alterações no padrão geológico-estrutural, indicando, por exemplo, a proximidade de uma zona de cisalhamento. Nas Fotos 8 e 9, é possível observar a foliação da rocha, sendo que na Foto 8 ocorre uma família de fraturas cortando a foliação, e na Foto 9 a foliação, 
subhorizontal, visualizada pela orientação preferencial dos minerais, ambas indicadas com a linha pontilhada de cor laranja. Nas duas fotos também podem ser observadas fraturas paralelas à foliação.

As Fotos 10 a 14 ilustram alguns aspectos estruturais penetrativos, observados em imagens da rocha gnáissica do embasamento cristalino da Bacia de São Paulo, obtidas em televisionamento de furos de sondagem ao longo de diversos projetos das linhas do Metrô.

Tabela 6 - Estruturas penetrativas delimitadas em imagem de televisionamento.

\begin{tabular}{c|c|c|c|c|l|c|c}
\hline \multicolumn{3}{c|}{ FURO SM-5902 } & \multicolumn{5}{c}{ TABELA - ESTRUTURAS PENETRATIVAS } \\
\hline NÚMERO & $\begin{array}{c}\text { PROF } \\
(\mathbf{m})\end{array}$ & $\begin{array}{c}\text { ESPESSURA } \\
(\mathbf{c m})\end{array}$ & $\begin{array}{c}\text { DIREÇÃO DE } \\
\text { MERGULHO }\end{array}$ & MERGULHO & LITOLOGIA & $\begin{array}{c}\text { TIPO DE } \\
\text { ESTRUTURA }\end{array}$ & $\begin{array}{c}\text { GRAU DE } \\
\text { ALTERAÇÃO }\end{array}$ \\
\hline 66 & 32,6 & & 242 & 28 & & FOLIAÇÃO & \\
\hline 74 & 33,29 & 10 & 356 & 30 & QUARTZO & VEIO & I \\
\hline 75 & 33,44 & & 244 & 35 & & FOLIAÇÃO & \\
\hline 90 & 33,58 & & 250 & 34 & & FOLIAÇÃO & \\
\hline 95 & 33,67 & 20 & 243 & 42 & MÁFICO & VEIO & II \\
\hline 105 & 34,45 & 8 & 312 & 32 & MÁFICO & VEIO & II \\
\hline 106 & 34,68 & & 236 & 55 & & FOLIAÇÃO & \\
\hline
\end{tabular}

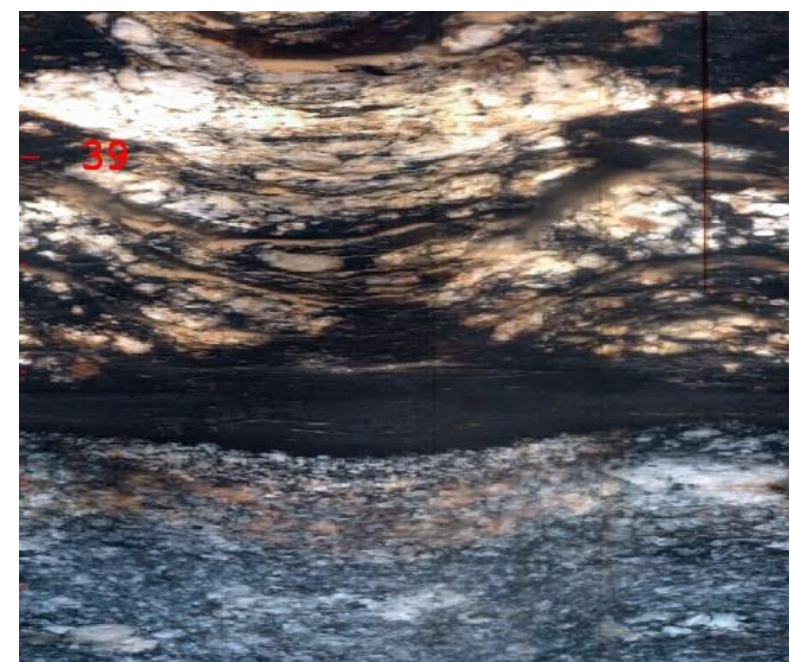

Foto 7 - Mudança brusca na textura, os dois trechos devem ser descritos separadamente. Fonte: Metrô-SP.

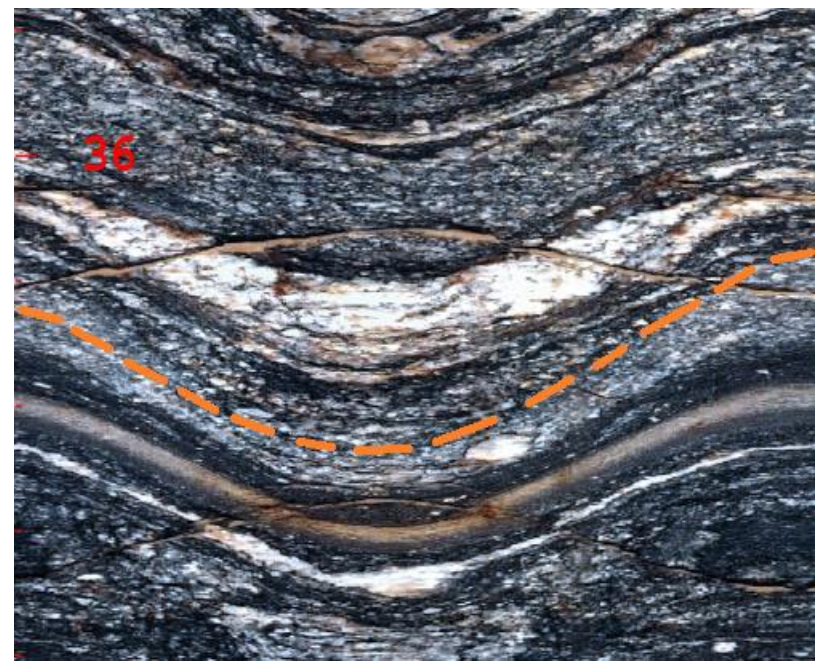

Foto 8 - Foliação da rocha indicada pela linha pontilhada laranja, famílias de fraturas cortando a foliação. Fonte: Metrô-SP. 


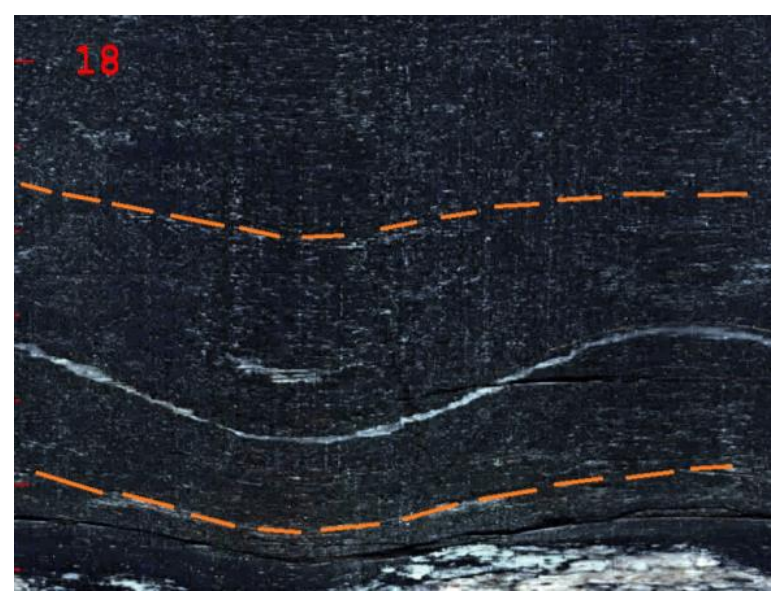

Foto 9 - Foliação da rocha indicada pela linha pontilhada laranja, com fratura paralela à foliação. Fonte: Metrô-SP.

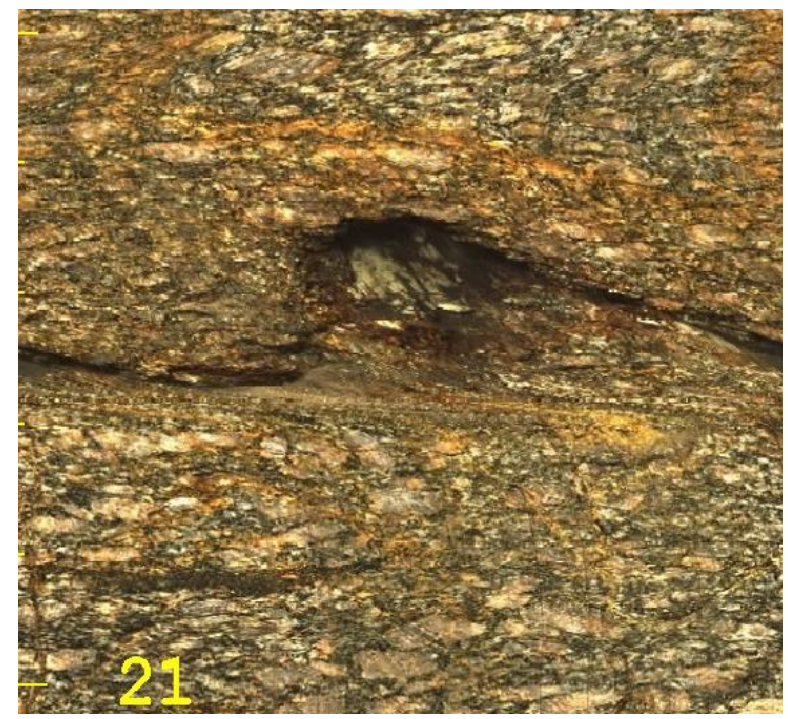

Foto 11 - Dobra de arrasto com trecho cisalhado e cominuído. Fonte: Metrô-SP.

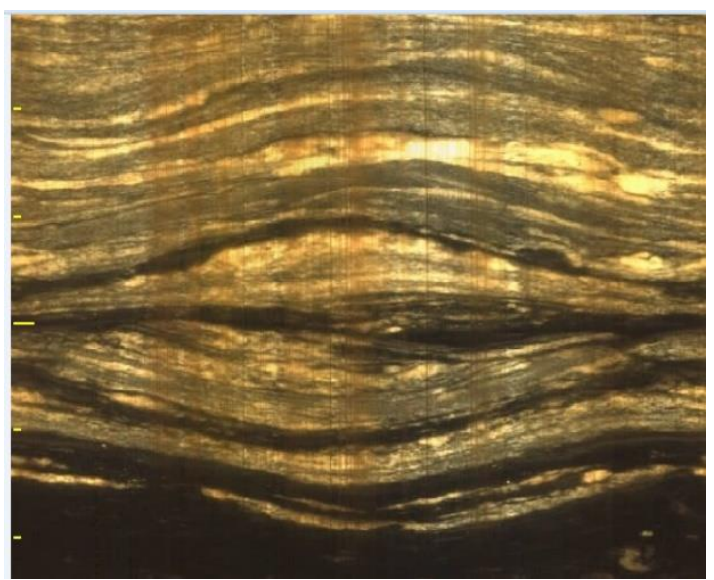

Foto 13- Imagem ortogonal ao eixo de uma dobra centimétrica, notar foliação mudando de direção de mergulho, acima e abaixo na foto. Fonte: Metrô-SP.

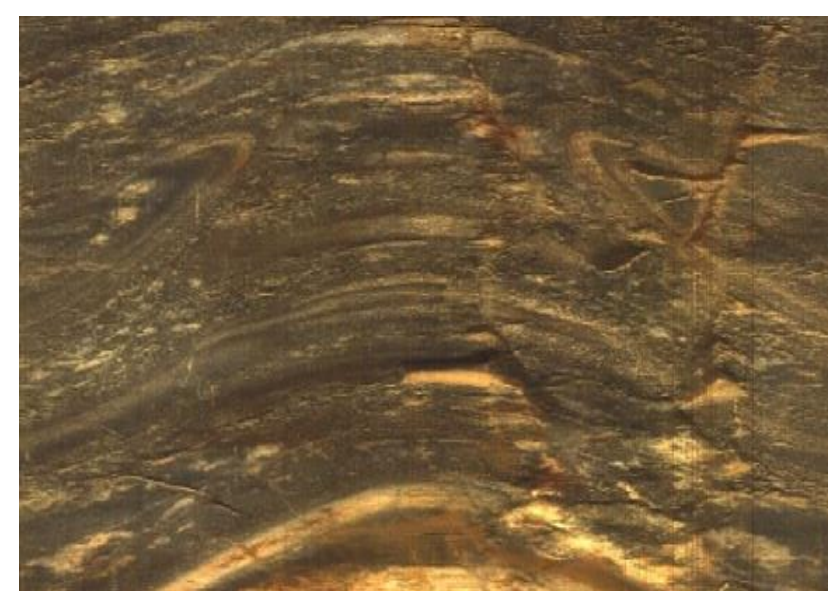

Foto 10 - Dobras intrafoliais centimétricas em rocha gnáissica do embasamento da Bacia de São Paulo. Fonte: Metrô-SP.

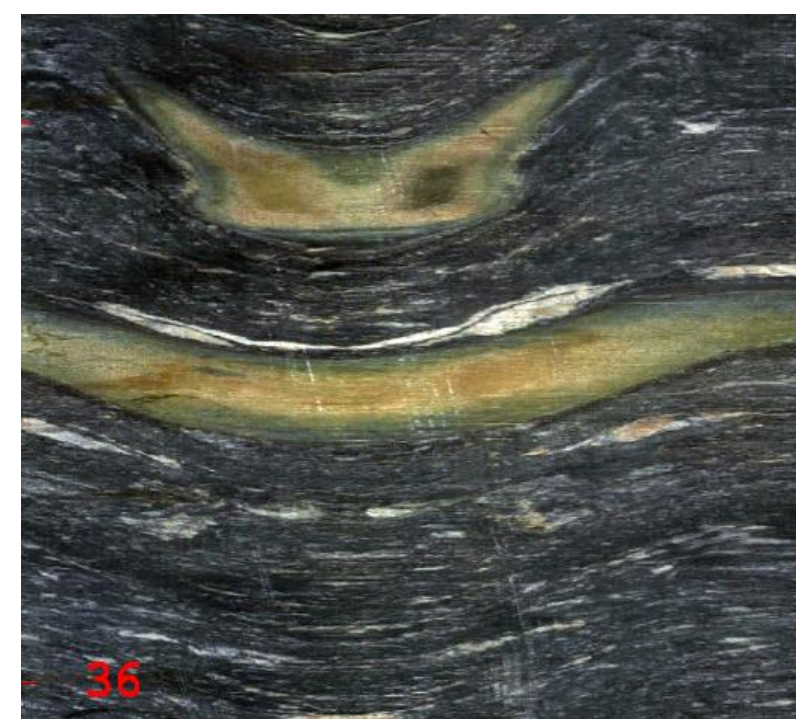

Foto 12 - Veios centimétricos de material esverdeado, provavelmente quartzo + epídoto. Fonte: Metrô-SP.

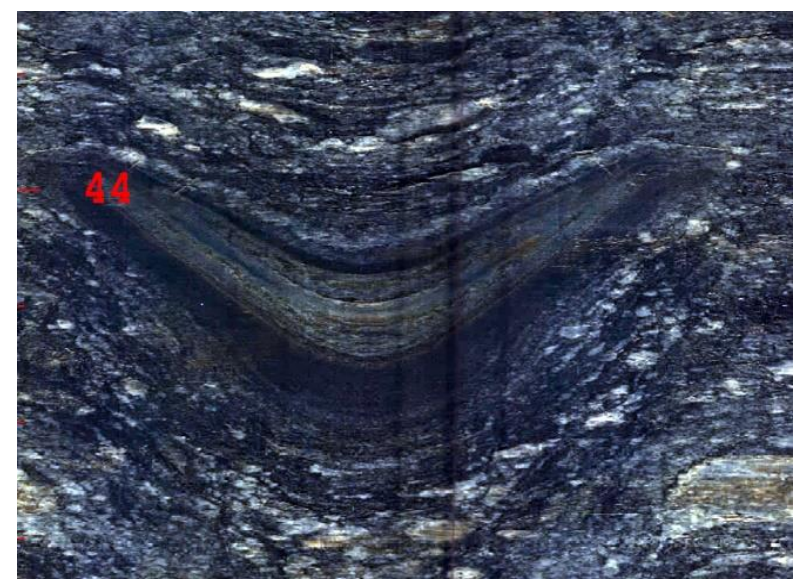

Foto 14 - Pequena dobra intrafolial, notar efeito na direção de mergulho da foliação. Fonte: MetrôSP. 
Com relação ao estado de alteração da rocha, apenas será possível uma caracterização limitada, feita visualmente. Na prática, poderão ser notadas variações no brilho e na coloração dos minerais, indicando uma maior alteração da rocha com relação aos trechos de rocha sã. Na descrição deste parâmetro em testemunhos de sondagens, além das variações nas características dos minerais que compõem a rocha, também é avaliada a sua resistência mecânica, como, quebra com dificuldade ao golpe do martelo, ou, quebra com facilidade sob pressão dos dedos.

Nas filmagens pode-se observar a "rugosidade" das paredes, que seria, indiretamente, a avaliação da resistência mecânica, considerando que a perfuração do furo pela sondagem mecanizada implicaria em um desgaste nestas paredes, sendo mais evidente este desgaste quanto mais alterada for a rocha, relação já citada anteriormente em Vaz et al.(2011). Exemplos disso podem ser observados nas Fotos 15 e 16, onde as paredes dos furos refletem o desgaste maior da rocha devido ao seu estado de alteração.

Para a caracterização de tais intervalos alterados sugere-se o uso da tabela adaptada de ISRM (1978) (Tabela 7).

Tabela 7 - Graus de alteração do maciço rochoso (adaptado de ISRM, 1978 e Serra Junior \& Ojima, 1998).

\begin{tabular}{|c|c|c|}
\hline SIGLAS & DENOMINAÇÕES & CARACTERÍSTICAS DA ROCHA \\
\hline I & $\begin{array}{l}\text { Rocha sã ou praticamente } \\
\text { sã }\end{array}$ & $\begin{array}{c}\text { Ausência de sinais de material rochoso alterado ou } \\
\text { minerais ligeiramente descoloridos. Minerais com } \\
\text { brilho. }\end{array}$ \\
\hline II & $\begin{array}{l}\text { Rocha medianamente } \\
\text { alterada }\end{array}$ & $\begin{array}{l}\text { Apresentam minerais com menor brilho e a rocha é } \\
\text { bastante descolorida. }\end{array}$ \\
\hline III & Rocha muito alterada & $\begin{array}{l}\text { Apresentam minerais sem brilho e a rocha é bastante } \\
\text { descolorida. Menos que a metade do material rochoso } \\
\text { está decomposto ou desintegrado. }\end{array}$ \\
\hline IV (IV a VI) & $\begin{array}{l}\text { Rocha extremamente } \\
\text { alterada }\end{array}$ & $\begin{array}{c}\text { Apresentam minerais totalmente sem brilho e a rocha } \\
\text { é intensamente descolorida. Mais do que a metade do } \\
\text { material está decomposto ou desintegrado, solo. }\end{array}$ \\
\hline
\end{tabular}




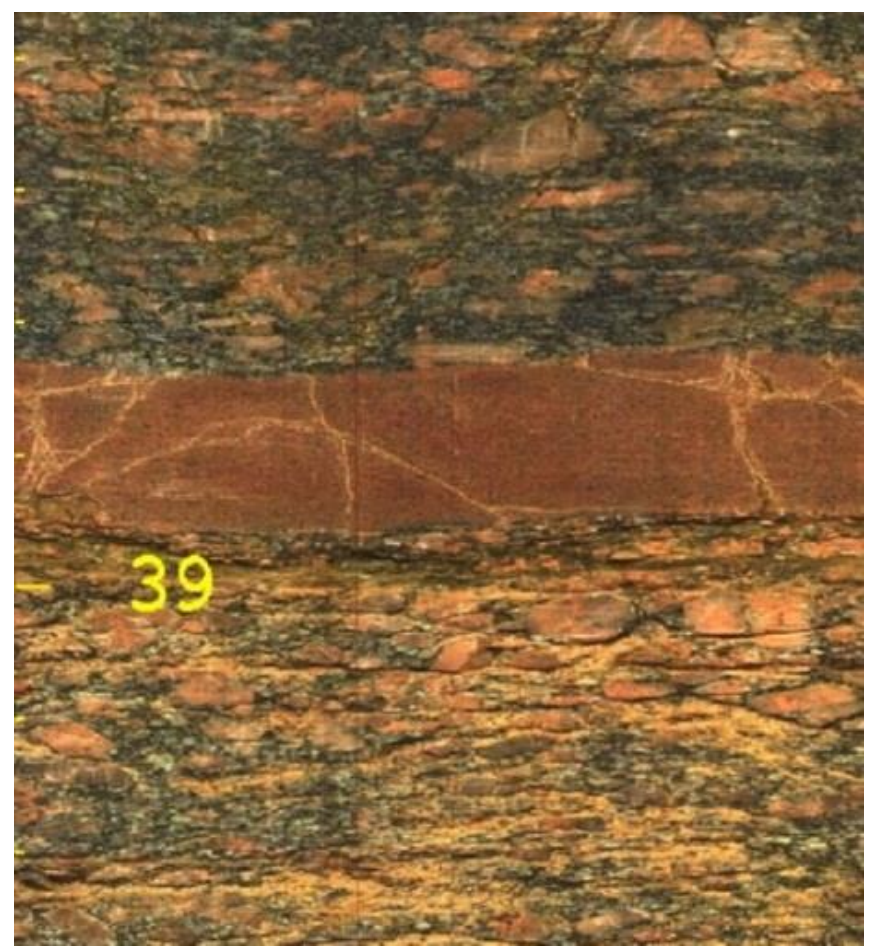

Foto 15 - Diferenças no aspecto de trechos menos e mais alterados (acima e abaixo do veio). Fonte: Metrô-SP.

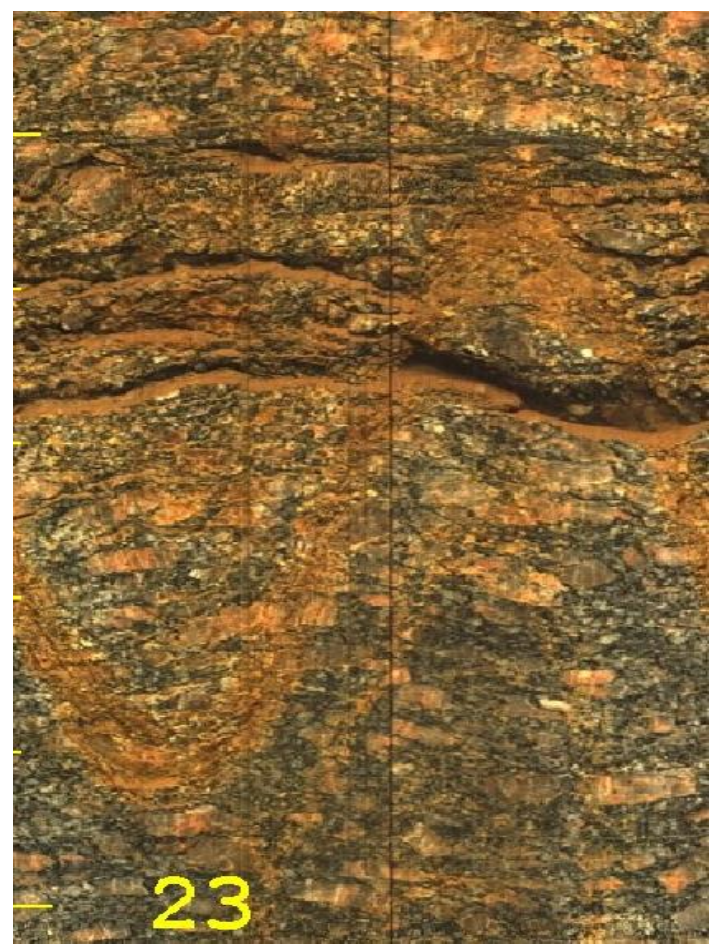

Foto 16 - Diferenças no aspecto de trechos menos e mais alterados (abaixo e acima do veio). Fonte: Metrô-SP.

\subsection{Descontinuidades}

O televisionamento fornece a imagem do testemunho virtual "enrolado" (imagem da superfície cilíndrica das paredes dos furos de sondagem e perfurações) e "desenrolado" (analogamente, imagem da superfície cilíndrica aberta das paredes dos furos de sondagem e perfurações). Nas imagens da superfície cilíndrica aberta das paredes dos furos, é possível definir as descontinuidades, pois estas, dependendo do mergulho da estrutura analisada, formam curvas senoidais, passíveis de serem definidas digitalmente a partir de três pontos demarcados sobre a imagem, definindo, automaticamente, uma linha, à qual corresponde a uma descontinuidade espacialmente posicionada, com sua respectiva atitude (Figura 39). 

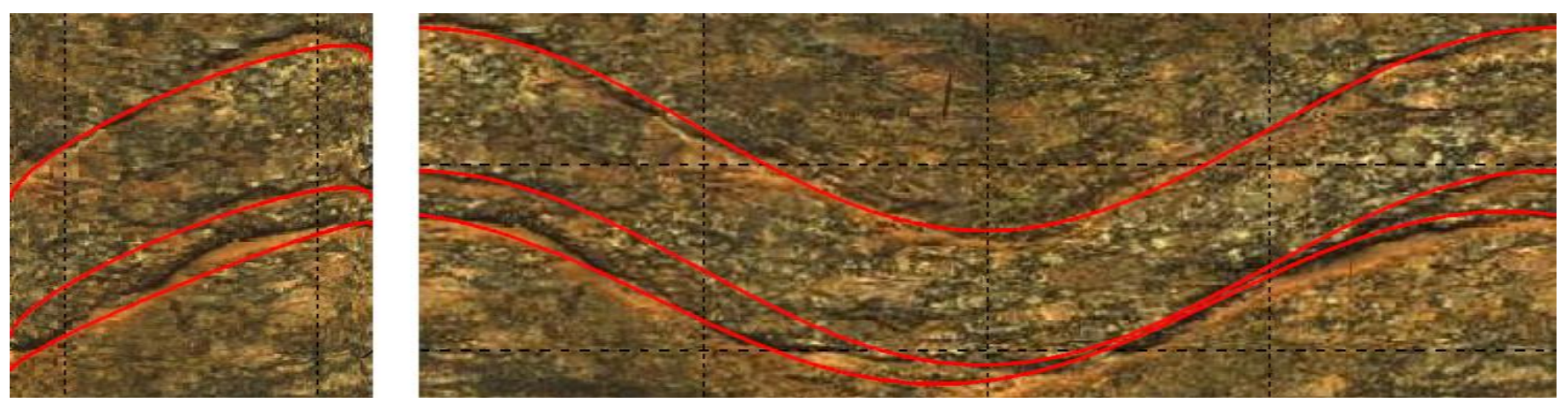

Figura 39 - Exemplo de fratura delimitada digitalmente, com uma linha vermelha (imagem "enrolada" à esquerda e "desenrolada" à direita), após análise utilizando Software de televisionamento RGLDIP da câmera OPTV, da Robertson Geolloging. E exemplo de descontinuidade rugosa, citado no item RUGOSIDADE. Fonte: Metrô-SP.

É certo que esta ferramenta, ao fornecer orientações destas descontinuidades e suas respectivas profundidades, já reflete uma grande vantagem no uso deste equipamento, sendo de grande utilidade na análise estrutural do maciço rochoso. Porém, a análise e interpretação destas feições podem prosseguir e fornecer mais informações relevantes do maciço rochoso.

Tendo como base os métodos sugeridos pela ISRM (1978), os demais parâmetros das descontinuidades devem ser descritos, como o tipo de estrutura, espaçamento, rugosidade, abertura, presença e material de preenchimento, alteração das paredes e percolação d'água, observados de forma indireta, já que, de modo geral, muitos destes aspectos estão nas superfícies das paredes das descontinuidades. Outras informações de caracterização e até mesmo classificação das descontinuidades no maciço rochoso podem ser determinados, como o grau de fraturamento e o RQD teórico, através de diversas correlações estabelecidas por distintos autores.

Todos os parâmetros devem ser descritos e apresentados em uma tabela de dados, como sugerido na Tabela 8. Cada descontinuidade deverá ser enumerada na fase de processamento de dados, incluindo-se como uma das informações presentes na imagem gerada no perfil de sondagem e apresentada na tabela. É essencial incluir em todas as tabelas de caracterização as informações sobre o furo de sondagem, como número, localização, profundidade atingida, profundidade do revestimento, inclinação do furo e quaisquer problemas de execução que possa haver ocorrido.

A seguir, apresenta-se detalhadamente a obtenção de cada parâmetro a ser levantado na tabela de caracterização das descontinuidades (Tabela 8). Nesta tabela poderá ser adicionado o cálculo do RQD teórico, como visto adiante. Também se sugere a inclusão de um campo “observações” nesta tabela, para informações adicionais que possam vir a surgir. 
Tabela 8 - Exemplo de tabela com parâmetros descritos para descontinuidades delimitadas em imagens de furos de sondagens.

\begin{tabular}{|c|c|c|c|c|c|c|c|c|c|c|c|c|}
\hline \multicolumn{5}{|c|}{ FURO SM-5902 } & \multicolumn{8}{|c|}{ TABELA - DESCONTINUIDADES } \\
\hline Núm & $\begin{array}{c}\text { Prof } \\
(\mathbf{m})\end{array}$ & $\begin{array}{c}\text { Espaça- } \\
\text { mento } \\
(\mathrm{m})\end{array}$ & $\begin{array}{c}\text { Tipo de } \\
\text { estrutura }\end{array}$ & $\begin{array}{c}\text { Direção de } \\
\text { mergulho }\end{array}$ & Mergulho & Rugosidade & Abertura & $\begin{array}{l}\text { Preenchi- } \\
\text { mento }\end{array}$ & $\begin{array}{l}\text { Espessura } \\
(\mathrm{cm})\end{array}$ & $\begin{array}{c}\text { Alteração } \\
\text { das paredes }\end{array}$ & $\begin{array}{c}\text { Percolação } \\
\text { d'água }\end{array}$ & $\begin{array}{c}\text { Grau de } \\
\text { fratura- } \\
\text { mento }\end{array}$ \\
\hline 1 & 52,86 & 0 & Fratura & 290 & 37 & Lisa & Fechada & Ausente & 0 & D1 & Ausente & \multirow{3}{*}{$\mathrm{F} 2$} \\
\hline 2 & 53,00 & 0,14 & Fratura & 310 & 39 & Lisa & Fechada & Máfico & 1 & D2 & Ausente & \\
\hline 3 & 53,18 & 0,18 & Fratura & 338 & 25 & Rugosa & $\begin{array}{l}\text { Semi- } \\
\text { aberta }\end{array}$ & $\begin{array}{l}\text { Película } \\
\text { argilosa }\end{array}$ & 0,5 & D3 & Ausente & \\
\hline 4 & 53,20 & 0,02 & Falha & 335 & 27 & Polida & Aberta & $\begin{array}{l}\text { Película } \\
\text { argilosa }\end{array}$ & 0,8 & D4 & Ausente & \multirow{2}{*}{$\mathrm{F} 1$} \\
\hline 5 & 53,25 & 0,05 & Fratura & 306 & 35 & Rugosa & Aberta & Ausente & 2 & D4 & $\begin{array}{l}\text { Sinais de } \\
\text { oxidação }\end{array}$ & \\
\hline 6 & 53,41 & 0,16 & Fratura & 116 & 74 & Rugosa & Fechada & Quartzo & 1 & D2 & Ausente & \multirow[b]{2}{*}{ F3 } \\
\hline 7 & 53,49 & 0,08 & Fratura & 111 & 68 & Lisa & $\begin{array}{l}\text { Semi- } \\
\text { aberta }\end{array}$ & $\begin{array}{l}\text { Película } \\
\text { argilosa }\end{array}$ & 0 & D4 & Ausente & \\
\hline
\end{tabular}

\subsubsection{Tipo de Estrutura}

É de suma importância classificar os tipos de estruturas observados, principalmente buscando separar fraturas das demais estruturas como foliação, bandamento, falha, zona de cisalhamento, veios, dobras, acamamento e contato litológico, conforme já mencionado anteriormente, diferenciando as estruturas penetrativas das descontinuidades propriamente ditas. Conforme apresentado anteriormente, as estruturas penetrativas e as descontinuidades são apresentadas em tabelas distintas (Tabelas 6 e 8, respectivamente).

Algumas vezes, mais de um tipo de estrutura ocorre em um mesmo trecho e isto deverá ser mencionado, como, por exemplo, o caso de fraturas delimitando um veio (Foto 17). Toda a ocorrência de planos de falha e cisalhamento deve ser detalhadamente caracterizada, devido à sua importância na estabilidade do maciço rochoso e sua influência nos projetos de obras de engenharia, especialmente obras subterrâneas, barragens e taludes (Foto 18).

No caso da Foto 18, por exemplo, fica clara a importância das imagens do televisionamento, quando comparado ao testemunho de sondagem na Foto 19. Exatamente a profundidade onde foi possível observar esta falha geológica na imagem do televisionamento, o testemunho de sondagem se fragmentou, impossibilitando o reconhecimento desta feição estrutural. Caso esta mesma sondagem não tivesse sido televisada, muito provavelmente a estrutura não teria sido observada. Vale mencionar que foram encontrados casos onde o executor da sondagem indicou quebra mecânica do testemunho de sondagem; entretanto, ao se cruzar as informações com as imagens de 
televisionamento, foi possível verificar que se tratava de uma fratura aberta e não uma quebra mecânica, conforme informado.

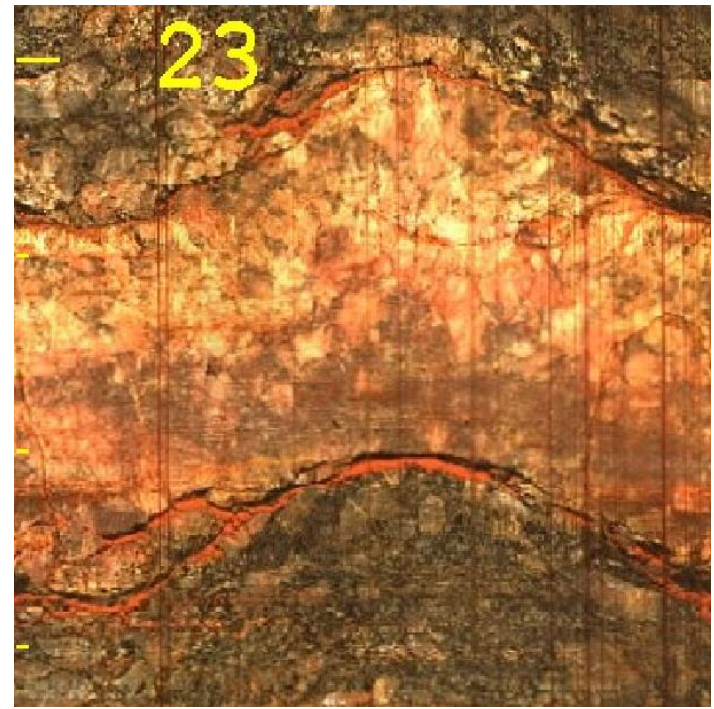

Foto 17 - Veio com fraturas no seu topo e base, ilustrando presença de uma estrutura penetrativa e de descontinuidades, na mesma feição. Fonte: Metrô-SP.

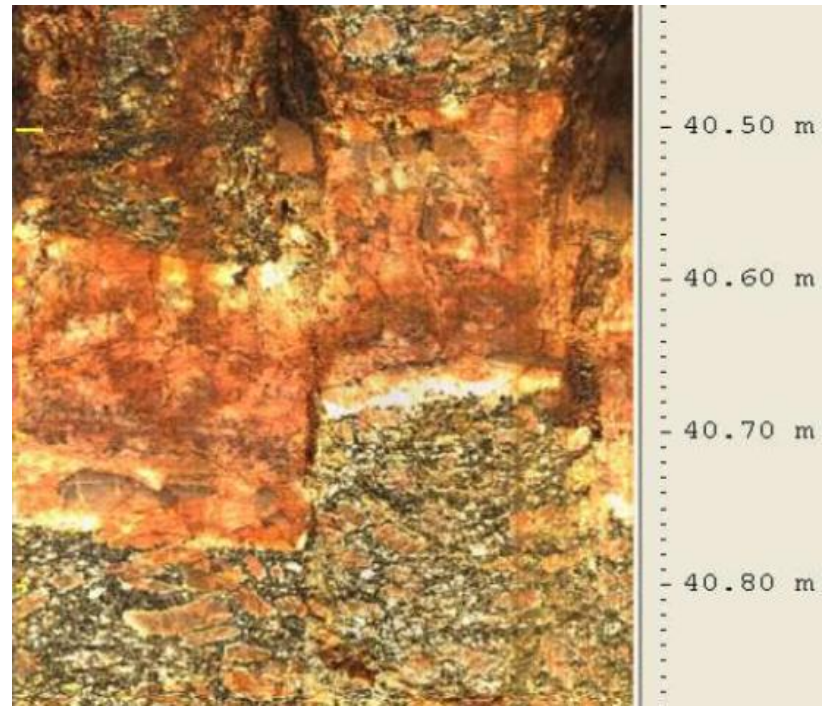

Foto 18 - Falha com componente normal e rejeito aparente aproximado de $12 \mathrm{~cm}$. Fonte: Metrô-SP.

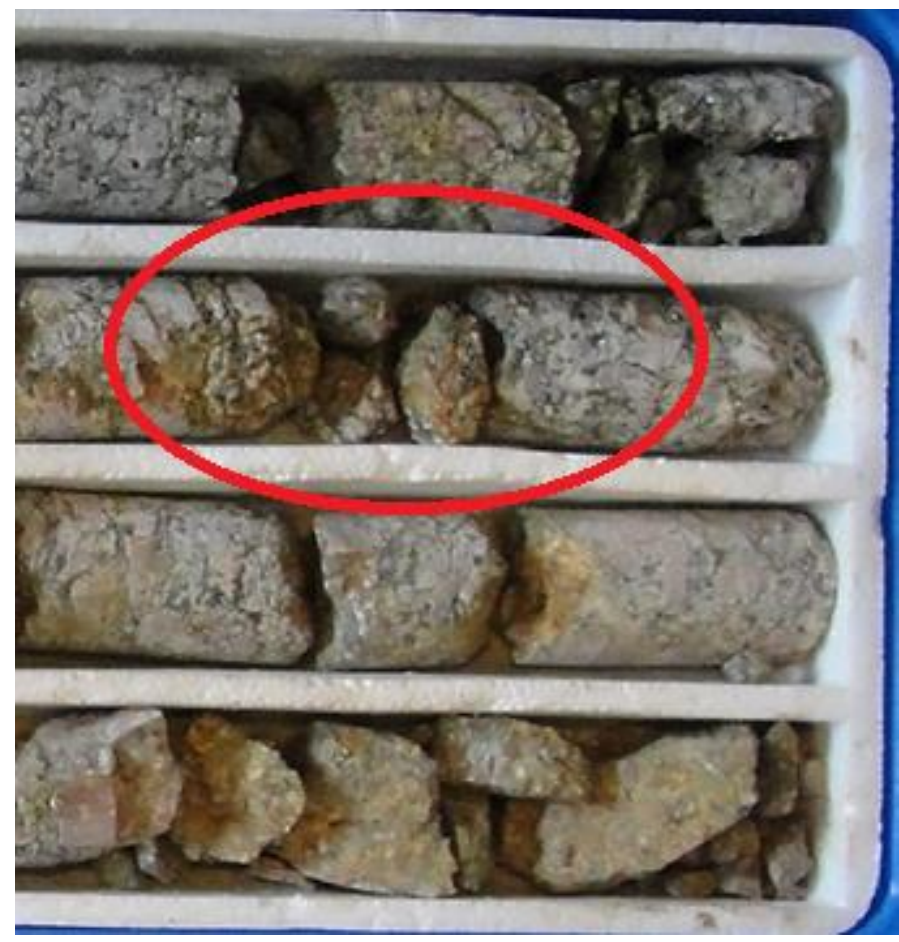

Foto 19 - Foto do testemunho de sondagem referente à falha da Foto 18, onde não foi possível observar a presença da estrutura, devido à quebra do testemunho rochoso. Fonte: Metrô-SP. 


\subsubsection{Rugosidade}

A rugosidade de descontinuidades é um importante componente na resistência ao cisalhamento, especialmente no caso onde há contato parede-parede. De forma geral, a rugosidade é caracterizada em termos de irregularidades (também definida como a rugosidade em si) e ondulações. Na prática, a ondulação afetará a direção inicial de deslizamento sobre um plano, enquanto que as rugosidades afetarão a resistência ao cisalhamento. A diferença principal está na escala de amostragem, conforme pode ser compreendido com maiores detalhes em ISRM (1978).

Um dos métodos de se avaliar a rugosidade em um plano, conforme sugerido por ISRM (1978) é a comparação do perfil de rugosidade usando uma linha reta como referência, como já comentado no item 4.3.2. No caso do televisionamento, considera-se como referência a linha traçada automaticamente quando selecionados os três pontos que definem o plano da descontinuidade no espaço. Na prática, ao serem marcados os traços de descontinuidades no testemunho virtual, quanto mais esta linha fica contida no traço da descontinuidade na imagem, menos rugosa esta seria e viceversa (Exemplo: Figura 39).

De qualquer forma, este procedimento não deixa de ser qualitativo, dependendo da experiência do analista, pois há casos de fraturas que não são facilmente definidas como lisas ou rugosas, outras, entretanto, são bastante evidentes. Há que se considerar que esta mesma dificuldade pode ser encontrada nos testemunhos de sondagem, pois o limite que separa uma descontinuidade lisa de uma rugosa é muitas vezes tênue, se tratando mais de um intervalo gradacional.

Outra forma para se quantificar a rugosidade em imagens de televisionamento seria identificar o seu perfil geométrico, enquadrando-o entre as opções apresentadas na Figura 40. Nesta figura, à esquerda se encontram os perfis de rugosidade sugeridos por Barton (1987) e, à direita, uma modificação para as fraturas observadas nas imagens de televisionamento. Nos casos de testemunhos, tanto virtuais como os reais, só é possível observar a rugosidade em uma escala de detalhe, diferente do que ocorre na descrição deste mesmo parâmetro em paredes rochosas (denominada também ondulação). Os perfis de Barton, já apresentados na Figura 16, foram modificados separando os perfis de menor detalhe, inicialmente divididos em recortada, ondulada e plana, juntando com os de maior detalhe, sendo possível a caracterização das descontinuidades apenas em rugosa, lisa ou polida. O termo "polida" só deverá ser utilizado em casos quando houver uma evidência clara de deslocamento em cisalhamento, segundo o definido em ISRM (1978).

Na Figura 41, segue uma sugestão para ser aplicada no televisionamento, com o objetivo de detalhar e buscar maior exatidão no cálculo da rugosidade nos planos de descontinuidade, conforme 
sugerido por Barton (2013). A linha apresentada nesta figura, no canto superior esquerdo, nas imagens de televisionamento de sondagem, deve ser a linha traçada pelo programa, conforme apresentado na Figura 39.

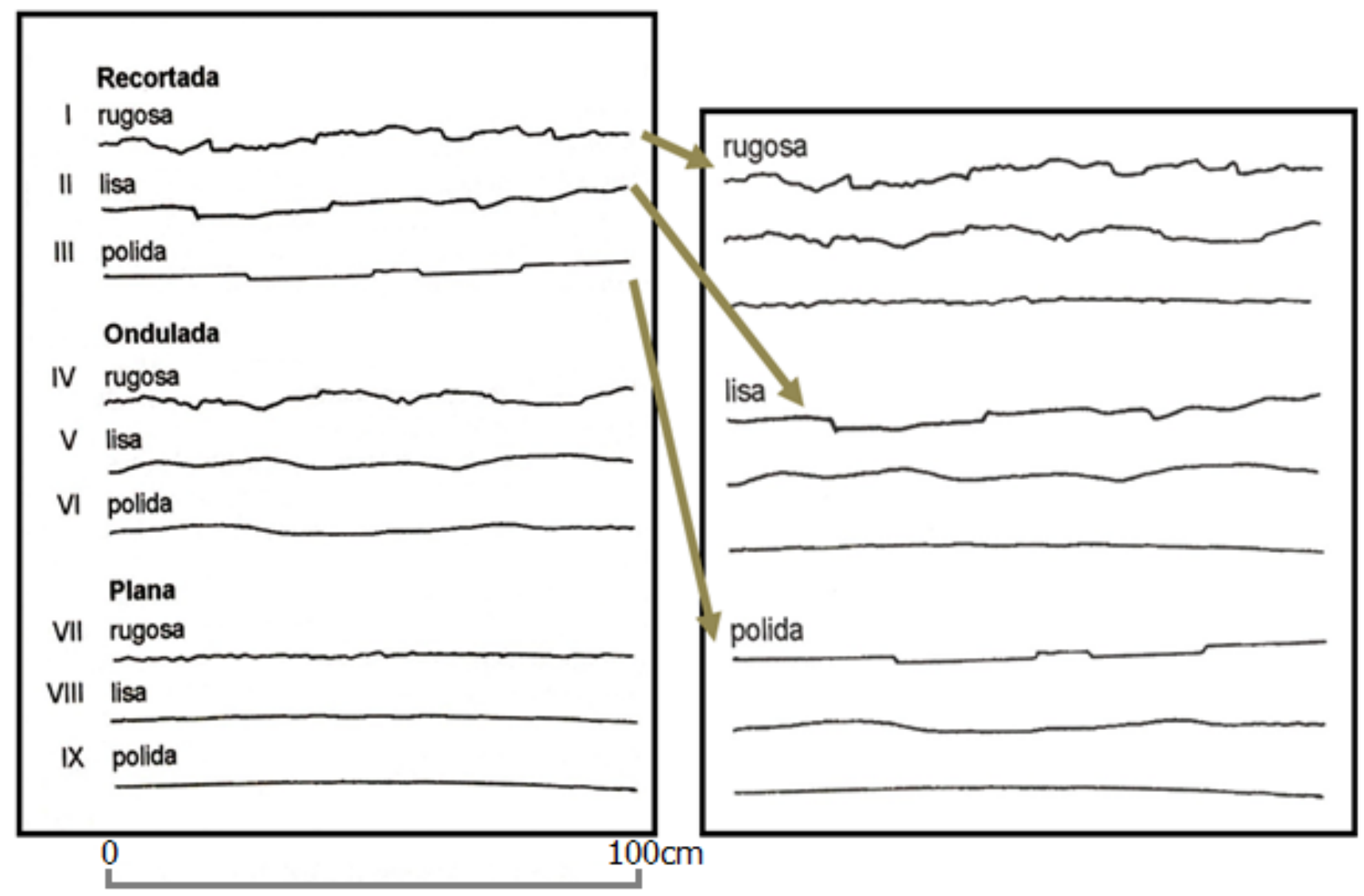

Figura 40 - Perfis de rugosidade de Barton et al. (1987) à esquerda, e adaptação dos perfis de rugosidade para aplicação em imagens de televisionamento. As linhas apresentadas nos perfis possuem aproximadamente $100 \mathrm{~cm}$ em comprimento. 


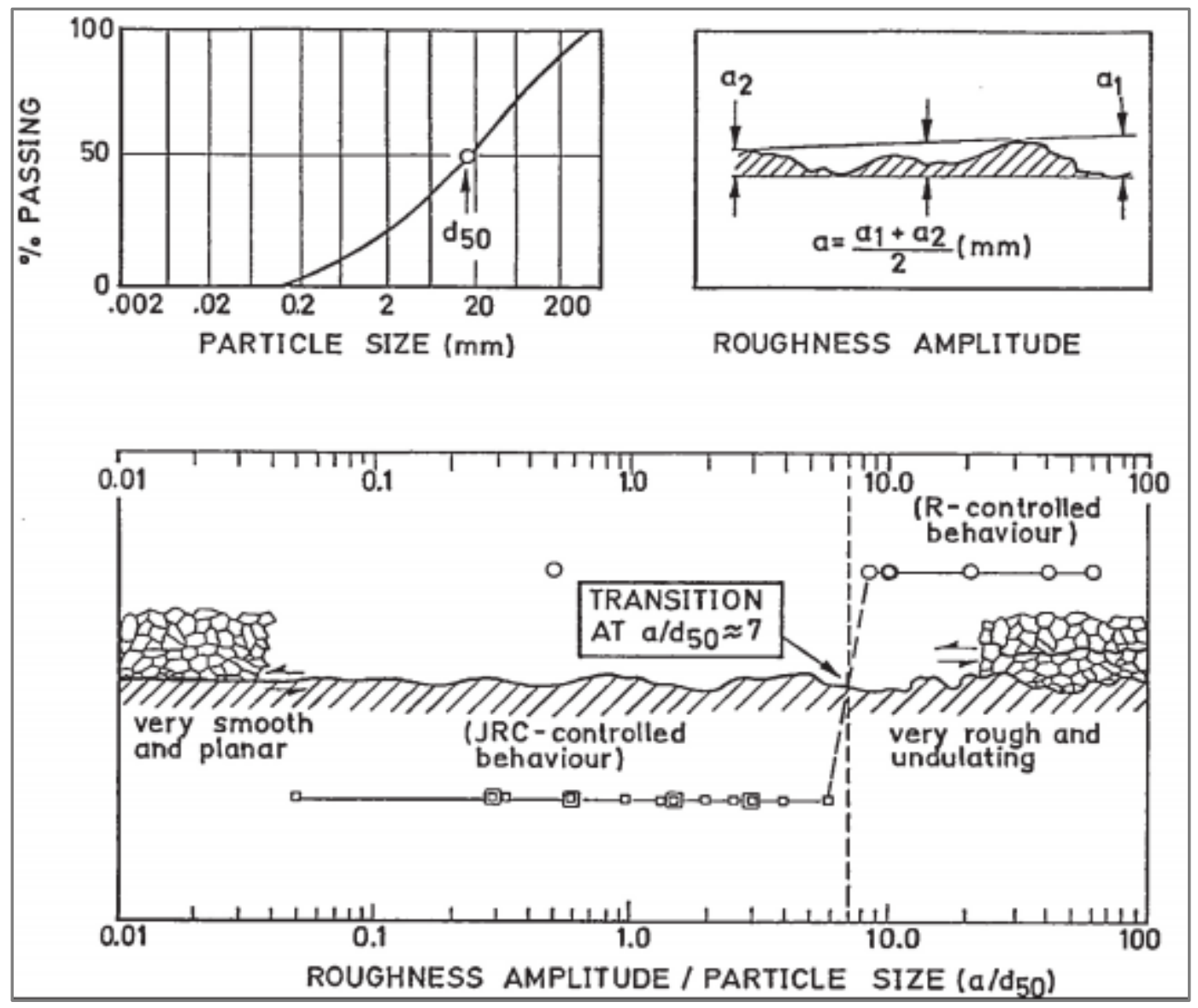

Figura 41 - Cálculo da amplitude de perfis de rugosidade em superfície rochosa, considerando a amplitude da rugosidade (a) e o tamanho dos grãos (Barton, 2013).

\subsubsection{Abertura}

A distância entre as paredes de uma descontinuidade, medida no sentido ortogonal, corresponde à sua abertura, como já especificado em 4.3.2. No caso do testemunho virtual, há a oportunidade de observar com detalhe a abertura da descontinuidade que praticamente se perde na operação de sondagem, quando da recuperação dos testemunhos. Já há recomendações do uso de equipamentos de filmagem na definição deste parâmetro pela ISRM (1978).

Portanto, este parâmetro deverá ser incluído nas observações dos testemunhos virtuais e, sempre que uma fratura não for selada, deverá ser indicada sua abertura. Para indicação da abertura de uma descontinuidade, sugere-se a utilização da tabela de abertura fornecida nos métodos de descrição e caracterização de descontinuidades da ISRM (1978), conforme apresentado na Tabela 3, apresentada no item 4.3.2. Sugere-se a utilização apenas dos termos fechada, semi-aberta e aberta, indicando a respectiva abertura em centímetros na coluna espessura da Tabela 8. Alguns exemplos de descontinuidades abertas são apresentados nas Fotos 20 a 23. Nas Fotos 22 e 23, incluem-se os testemunhos de sondagem ao lado para comparação. Na primeira foto, Foto 22, ocorre uma fratura subvertical bastante evidente no testemunho de sondagem, não tão evidente nas imagens do 
televisionamento nesta resolução; entretanto, na resolução original é possível observar que esta fratura se encontra preenchida por película argilosa. Na Foto 23, ao se observar o testemunho de sondagem, podem-se gerar dúvidas se as fraturas subhorizontais se tratam de quebra mecânica ou fraturas na rocha, o que é solucionado ao se observar a imagem do televisionamento; inclusive foi justamente neste trecho onde foram realizados ensaios de perda d'água sob pressão, que serão detalhados mais adiante.

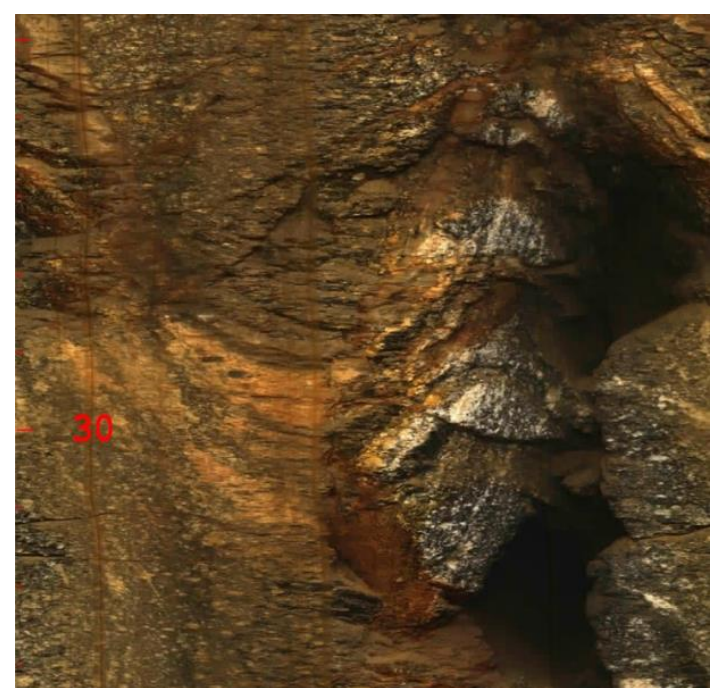

Foto 20 - Fratura aberta e subvertical, paredes colapsadas, não sendo possível determinar o plano exato desta fratura aberta. Fonte: Metrô-SP.

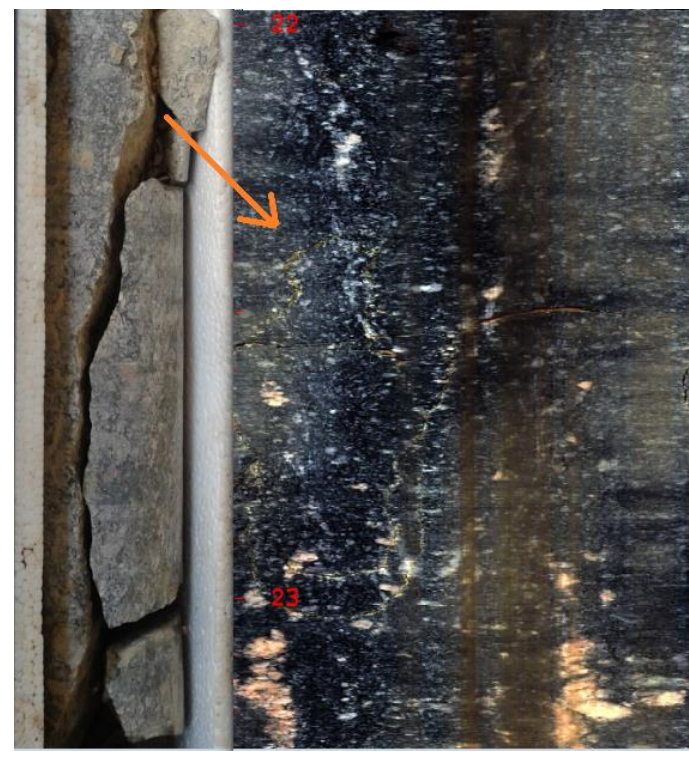

Foto 22 - Fratura vertical aberta no testemunho de sondagem, à esquerda, e sua respectiva imagem à direita (arquivo pessoal).

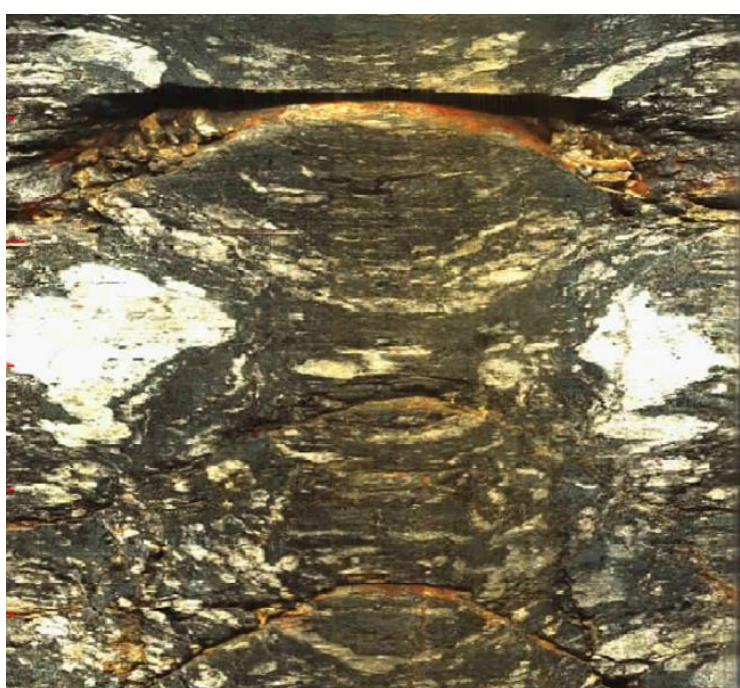

Foto 21 - Plano de fratura aberta bem definido e fraturas semi-abertas, da mesma família, logo abaixo. Fonte: Metrô-SP.

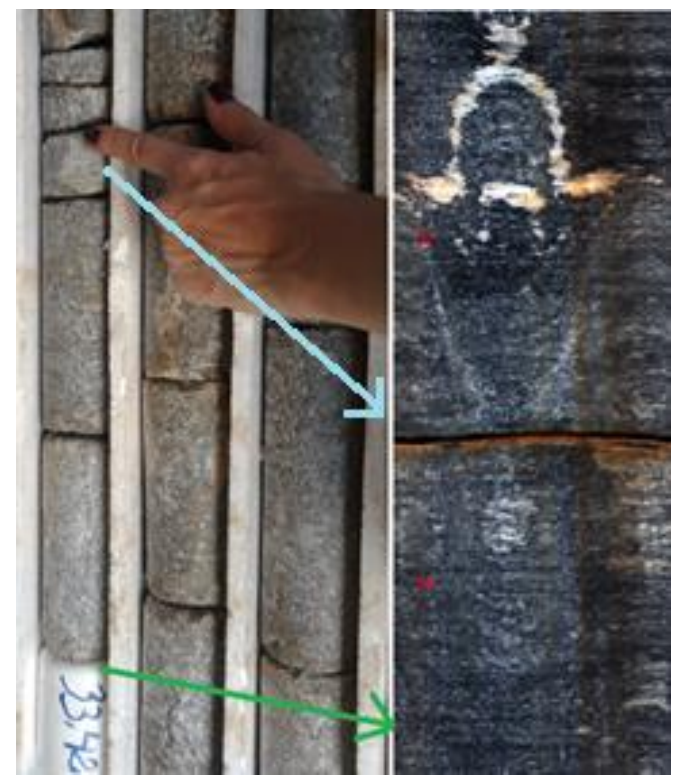

Foto 23 - Fratura horizontal aberta no testemunho de sondagem, à esquerda e imagem no televisionamento de sondagem, à direita (arquivo pessoal). 


\subsubsection{Preenchimento, Percolação D’Água e Condições de Alterações das Paredes}

A descrição das condições de alteração das paredes denota as mesmas limitações e subjetividade que a caracterização do grau de alteração da rocha. Entretanto, é possível inferir estados de alteração das paredes de descontinuidades, levando-se em consideração o brilho dos minerais ao longo das feições. As condições de alteração das paredes e a presença de preenchimento podem ser caracterizadas utilizando-se a Tabela 9, modificada de IPT (1984). Para a elaboração desta tabela, foram levadas em consideração as condições de alteração de paredes, assim como preenchimentos mais frequentes nas rochas do embasamento de São Paulo. Há certamente uma necessidade de verificação e possíveis ajustes para demais litotipos em outros contextos geológicos.

Muitas vezes, o preenchimento original pode ter sido removido pela lavagem durante a perfuração e o que observamos na imagem é uma abertura que inicialmente estava preenchida, restando, algumas vezes, apenas resquícios do preenchimento então existente, como por exemplo, as fraturas abertas nas Fotos 24, 25 e 26, sendo estas classificadas como D4, D5 e D5, respectivamente. Estas figuras poderiam ter sido caracterizadas também como D6, D5/D6 e D5/D6, pois muito provavelmente se encontravam preenchidas por material argilo-arenoso. Já na Foto 27, o material argiloso de coloração esverdeada segue presente, sendo classificada como D6. O preenchimento de material pétreo rijo seria responsável pela classificação da fratura observada na Foto 28 como D2. Sempre se faz imprescindível caracterizar devidamente o preenchimento, caso haja dúvidas indicar em um campo extra na Tabela 8, denominado de "observações".

Também são observáveis evidências de percolação d'água, quando existentes, como paredes oxidadas e a própria surgência de água no interior do furo, fator muito importante para a estabilidade e qualidade geotécnica de um maciço, além dos aspectos hidrogeológicos. A Foto 29 ilustra o exemplo de claras evidências de percolação d'água em uma descontinuidade, sendo possível visualizar também uma película de oxidação.

Certamente, uma das vantagens do televisionamento é justamente esta observação detalhada do material de preenchimento, assim como sua real abertura. Exemplo disso pode ser verificado na Figura 41, de Baillot et al. (2004), onde é possível comparar a imagem com fratura aberta e preenchida com fragmentos de rocha (D5) e o observado nos testemunhos de sondagem, onde estes fragmentos se perdem na lavagem do procedimento da sondagem rotativa mecanizada e a característica de abertura não é devidamente observada. 
Tabela 9 - Caracterização do preenchimento, modificado de IPT (1984).

\begin{tabular}{|c|c|}
\hline SIGLA & $\begin{array}{l}\text { CONDIÇÕES DE ALTERAÇÃO E PREENCHIMENTO DAS PAREDES DE } \\
\text { DESCONTINUIDADES }\end{array}$ \\
\hline D1 & Contato rocha-rocha, paredes sãs, sem preenchimento, brilho intenso. \\
\hline D2 & Contato rocha-rocha, preenchimento de material pétreo rijo (calcita, quartzo, epídoto). \\
\hline D3 & $\begin{array}{c}\text { Paredes com alteração incipiente, brilho mais fraco, sinais de percolação d'água, oxidadas, sem } \\
\text { preenchimento. }\end{array}$ \\
\hline D4 & Paredes alteradas, brilho fraco, preenchimento ausente, fratura aberta. \\
\hline D5 & Paredes alteradas, sem brilho, com preenchimento de fragmentos de rocha. \\
\hline D6 & Paredes alteradas, sem brilho, com preenchimento de argila e/ou areia (detalhar). \\
\hline D7 & Paredes alteradas, sem brilho, com preenchimento distinto ou não identificado (detalhar). \\
\hline
\end{tabular}

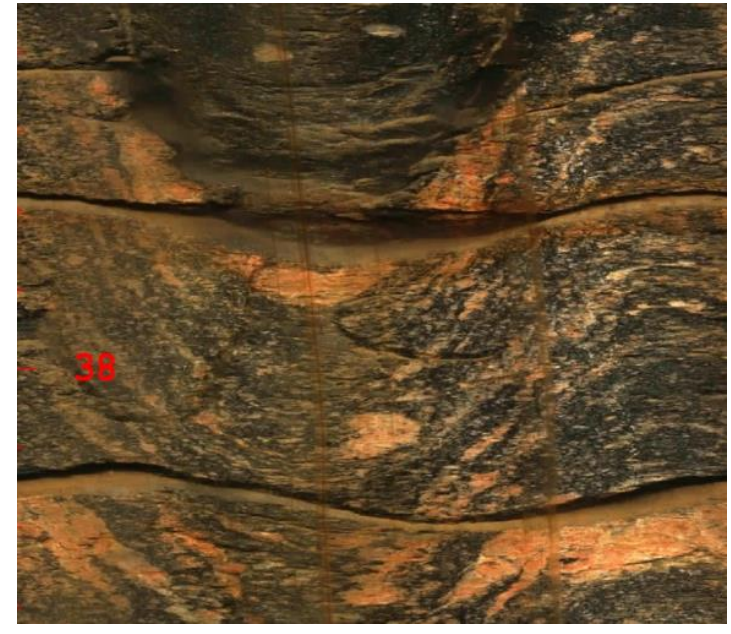

Foto 24 - Fraturas abertas com preenchimento ausente, ocorrendo apenas película de alteração, classificada segundo Tabela 9 como D4. Fonte: Metrô-SP.

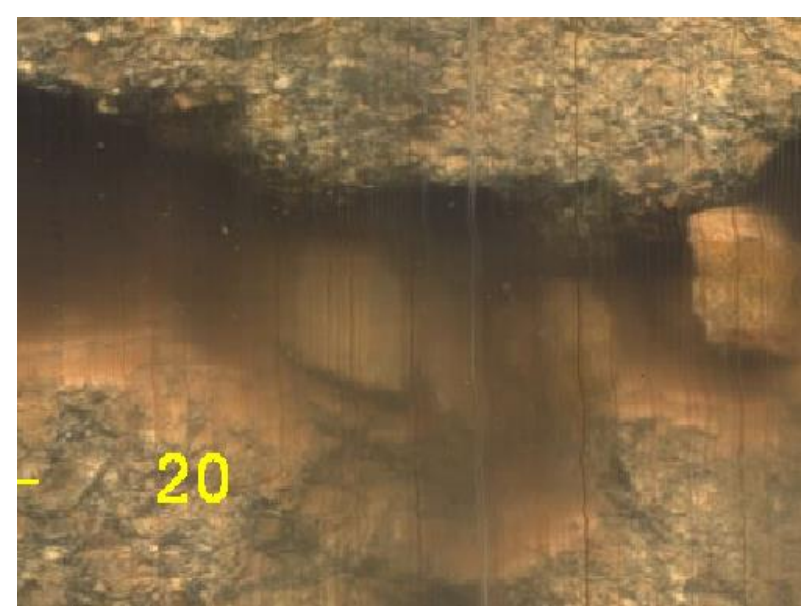

Foto 26 - Fenda (fratura aberta), com preenchimento de fragmentos de rocha (D5), também com preenchimento areno-argiloso tendo sido lavado (D5/D6). Fonte: Metrô-SP.

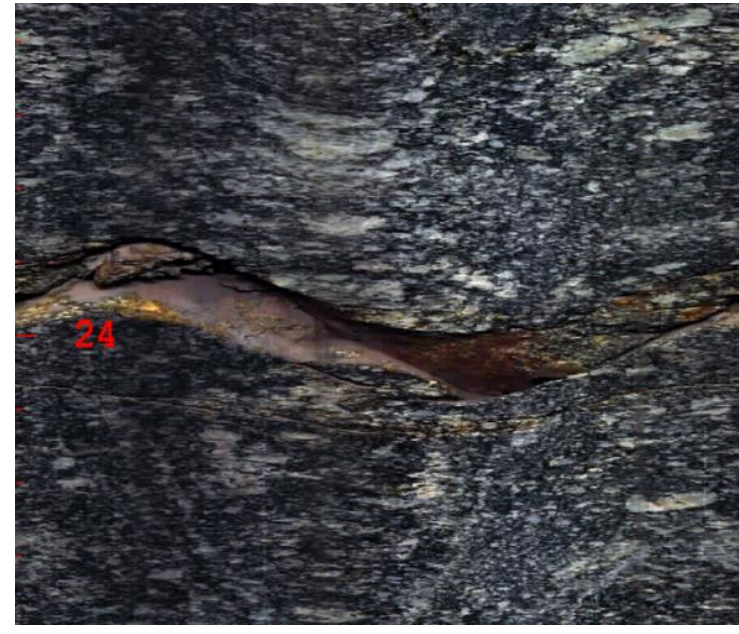

Foto 25 - Fratura aberta, com preenchimento de fragmentos de rocha (D5). Provavelmente restante do preenchimento arenoso foi lavado (D5/D6). Fonte: MetrôSP.

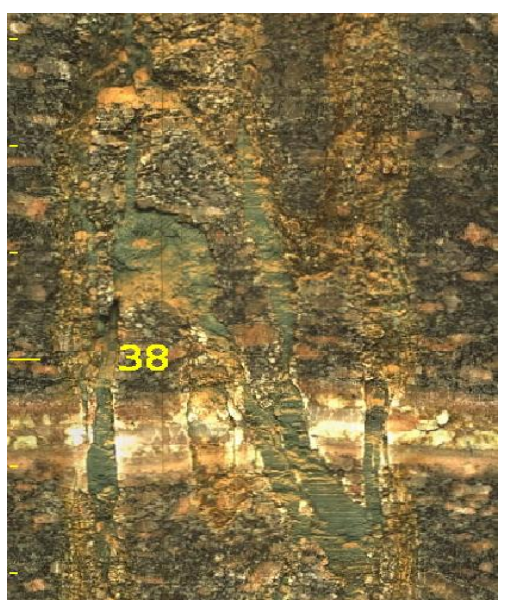

Foto 27 - Fratura com preenchimento argiloso de coloração esverdeada, tipicamente encontrado em algumas descontinuidades do embasamento da BSSP, na região norte da RMSP (extensão da Linha 2 - Verde). Fonte: Metrô-SP. 


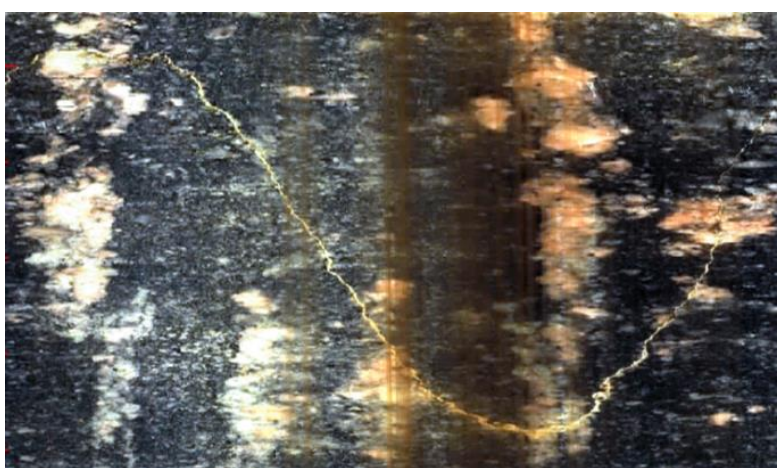

Foto 28 - Fratura com preenchimento de material pétreo rijo (quartzo - D2). Fonte: Metrô-SP.

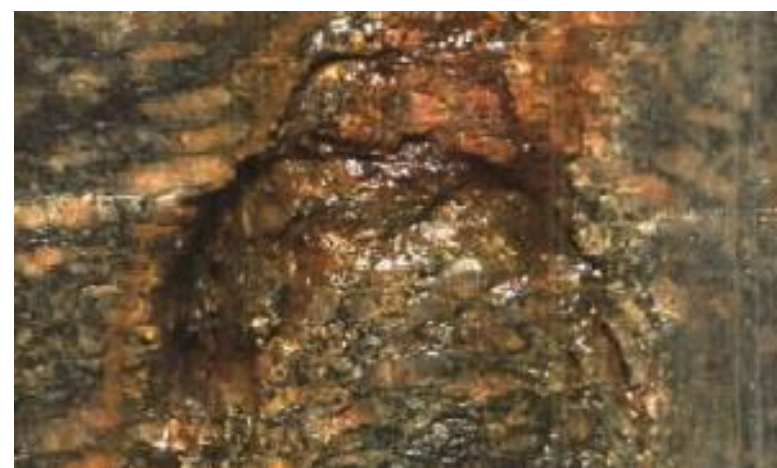

Foto 29 - Fratura apresentando evidências claras de percolação d'água. Fonte: MetrôSP.

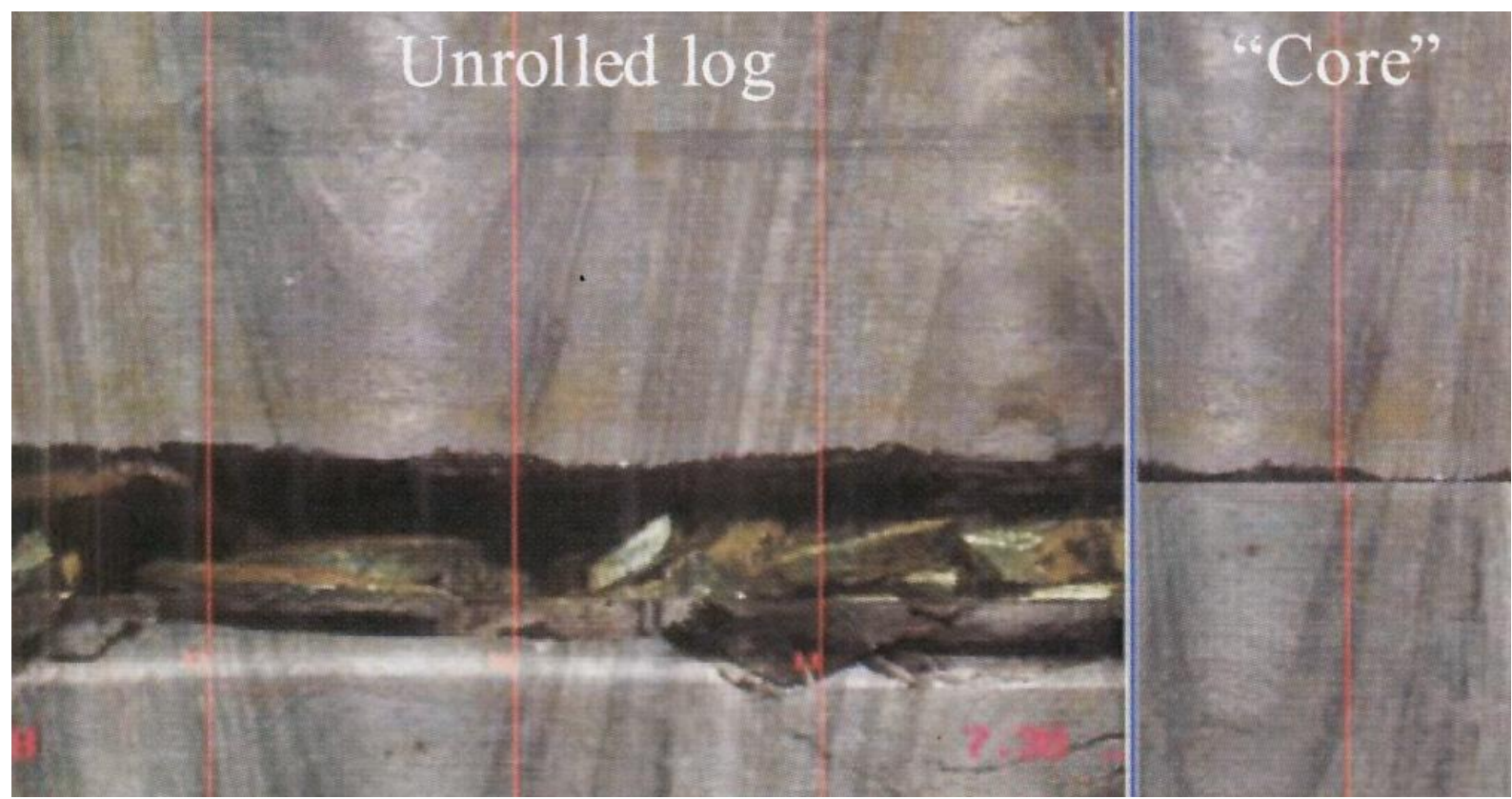

Figura 42 - Comparação de fratura aberta em imagem de televisionamento, apresentando preenchimento de fragmentos de rocha, à direita e imagem de testemunho de sondagem, onde esta mesma descontinuidade aberta é praticamente "perdida" devido ao processo de lavagem da sondagem mecanizada (Baillot et al., 2004).

\subsubsection{Grau de Fraturamento e Espaçamento}

O grau de fraturamento de um maciço rochoso visa caracterizar a distribuição de descontinuidades em testemunhos de sondagem, conforme já especificado no item 4.3.2. O fraturamento é expresso em graus de intensidade e explicita a quantidade de fraturas por metro, definido em trechos com fraturamento homogêneo (isofraturamento), conforme apresentado na Tabela 2.

O mesmo parâmetro pode ser utilizado nos testemunhos virtuais, levando-se em consideração que um testemunho de sondagem poderá apresentar maior incidência de fraturamento devido a 
quebras mecânicas, dependendo das condições na perfuração e posterior descrição, podendo haver modificações significativas que dependem da experiência da equipe técnica envolvida no procedimento.

O grau de fraturamento deverá ser indicado conforme ilustrado na Tabela 8, utilizando os parâmetros da Tabela 2. Deverão ser considerados os trechos em que o espaçamento das descontinuidades é homogêneo, assim como consideradas apenas as fraturas relevantes e que implicarão, muito provavelmente, na quebra do testemunho ao longo deste plano.

O espaçamento poderá ser diretamente calculado em função da distância entre cada fratura, sendo considerado em função do parâmetro $\lambda$, número de descontinuidades por metro, conforme citado em Priest \& Hudson (1976) e detalhado no item 4.3.2.

É importante ressaltar que há uma tendência de serem demarcados todos os planos que são visualizados na imagem de televisionamento, entretanto alguns planos não são contínuos e muito provavelmente não implicarão necessariamente na quebra real do testemunho de sondagem. Sugerese aqui que sempre que ocorrer um plano não contínuo e/ou não tão evidente, que isto seja indicado em uma coluna extra, denominada “observações", inserida na Tabela 8. Posteriormente, no tratamento dos dados, estes planos deverão ser desconsiderados, inclusive para cálculo do RQD teórico.

Também necessário citar que, muitas vezes, ocorrem fraturas verticais a subverticais com relação à inclinação do furo televisionado, onde nem sempre é possível a demarcação destas na fase de interpretação de imagens, devido ao Software não permitir o fechamento de curvas senoidais extremamente abertas. Entretanto, é essencial que estas feições estejam caracterizadas e façam parte dos demais parâmetros a serem descritos, como o espaçamento e o grau de fraturamento. A Foto 30 ilustra um exemplo da ocorrência de um set de fraturas verticais.

Outra sugestão é a programação de sondagens inclinadas e televisadas sempre que possível. Sondagens inclinadas serão de extrema valia na definição do modelo estrutural em 3 dimensões, contribuindo na definição de parâmetros como Jv e RQD, já citados anteriormente. O ideal seria definir a direção de uma sondagem inclinada após definidas as direções dos principais sets de famílias de descontinuidades inclinadas que ocorrem no furo vertical. Isso foi realizado ao longo da Linha 4 - Fase, do Metrô de São Paulo, resultando na caracterização de um sistema de fraturas subverticais que se encontravam abertas, sendo que este fato não pode ser observado nos furos televisionados verticais. Este sistema de fratura pode ser visualizado na Foto 31. 


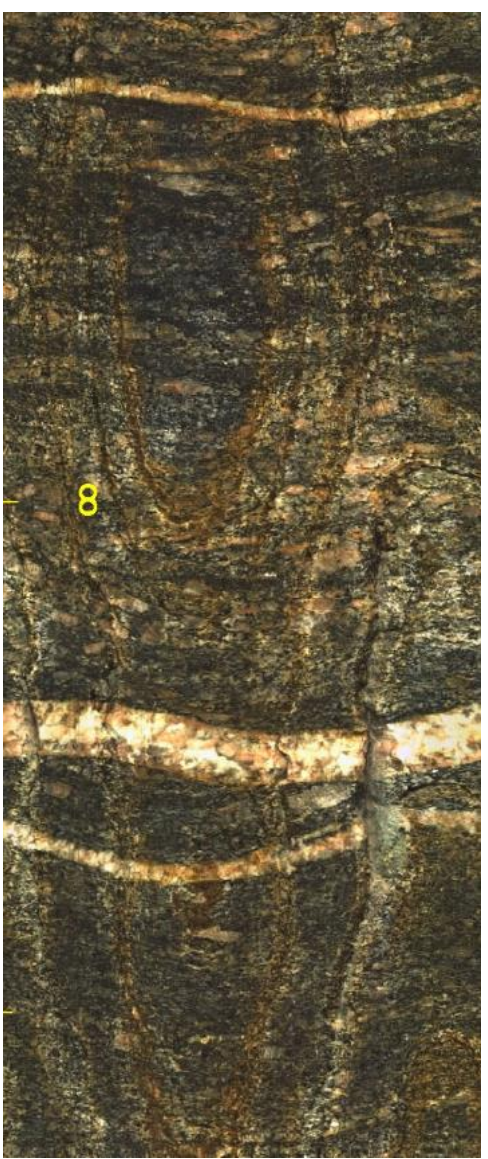

Foto 30 - Exemplo de ocorrência de set de fraturas verticais, com relação à direção do furo televisionado. Fonte: Metrô-SP.

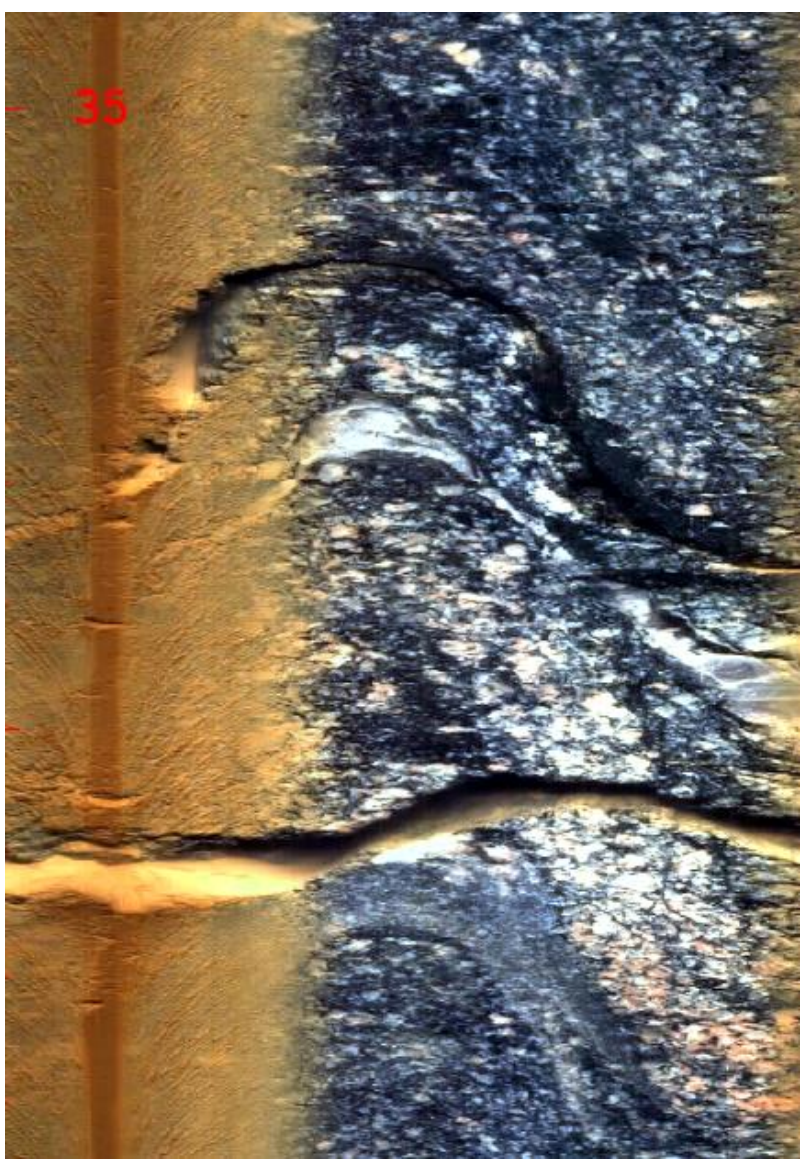

Foto 31 - Fraturas abertas subverticais que foram filmadas em furo inclinado, após observação destas fraturas em furo vertical. Fonte: Metrô-SP.

Outro exemplo de trechos mais fraturados, localizados em uma rocha de boa qualidade e pouco fraturada, pode ser visualizado na Foto 32. O maciço rochoso gnáissico nesta região onde foi filmado o respectivo furo encontra-se pouco fraturado, entretanto há alguns trechos restritos com maior frequência do mesmo set de fraturas, que certamente é essencial na caracterização do maciço rochoso e, especialmente no caso de escavações subterrâneas, deve ser locado, principalmente com relação à posição deste sistema quanto ao túnel e/ou estação, poços, etc. 


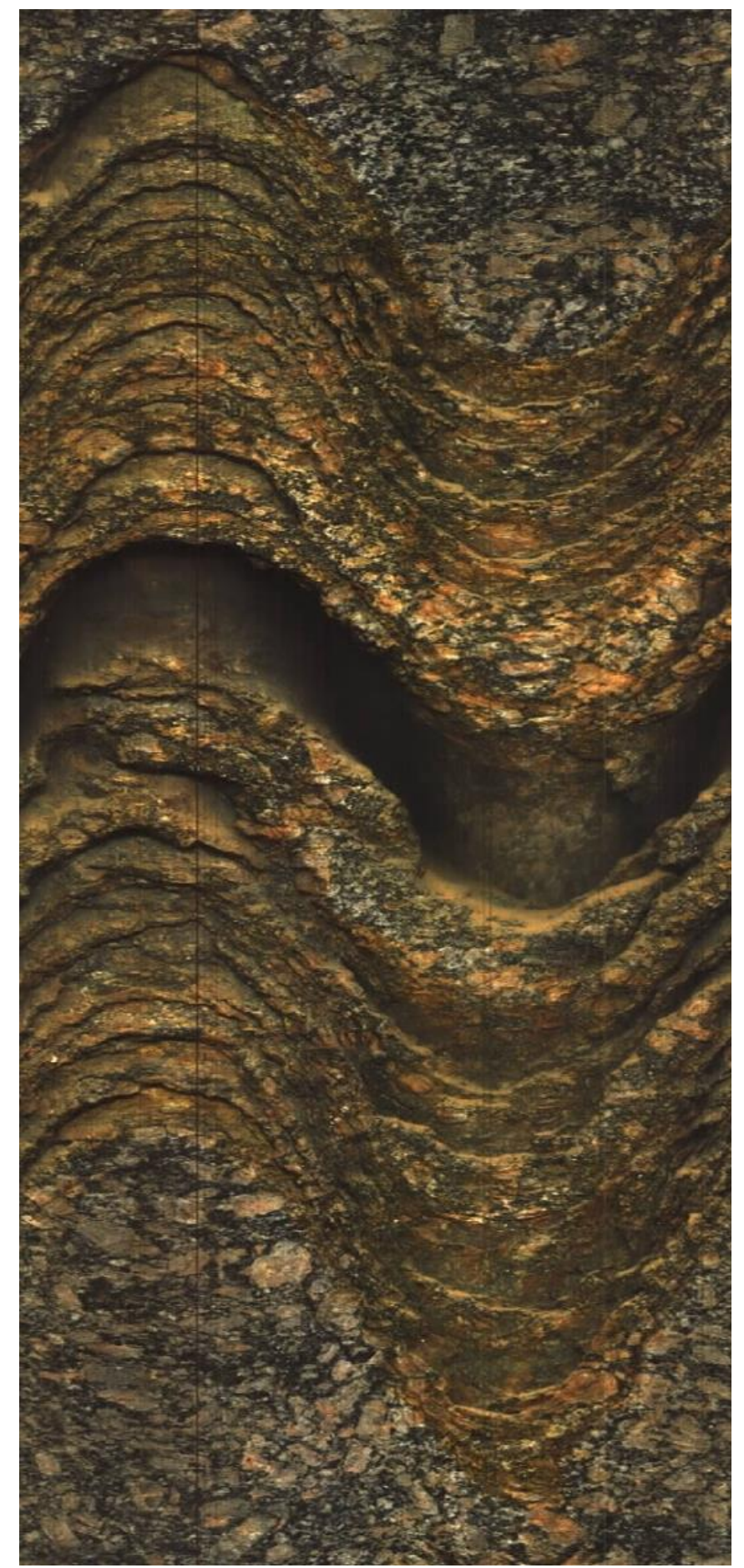

Foto 32 - Sistema de fraturas paralelas, pouco espaçadas, aumentando o grau de fraturamento no trecho de um maciço pouco fraturado. Fonte: Metrô-SP.

\subsubsection{RQD teórico}

Tendo como base o apresentado sobre o RQD teórico no item 4.3.2, considera-se aqui que um testemunho virtual pode ser diretamente análogo a uma scanline, sendo sugerida esta aplicação de RQD teórico para testemunhos virtuais. Recomenda-se a utilização do parâmetro $\lambda$ (espaçamento médio das descontinuidades), tendo como base os trechos isofraturados, e utilizando-se a equação 
definida segundo Priest \& Hudson (1976), equação (1) $\left(\operatorname{RQD}^{*}=100 \mathrm{e}^{-0.1 \lambda(0.1 \lambda+1)}\right)$, para o caso de maciços com distribuição de descontinuidades que se encaixariam melhor com uma função exponencial negativa (granito e gnaisse, por exemplo) ou a equação (3), segundo Sen \& Eissa (1992), $\left(E(R Q D)=100\left\{1-F\left[\frac{\ln (0.1 \lambda)}{\sigma_{\ln x}}-\sigma_{\ln \chi}+1\right]\right\}\right)$, para maciços onde o espaçamento se aproxime de uma distribuição normal, segundo o definido em Oliveira (2000).

Aconselha-se a comparação deste RQD teórico obtido com os RQD's medidos nos testemunhos destas mesmas sondagens, buscando, assim, a determinação da aplicabilidade do método. É importante considerar apenas as descontinuidades relevantes, desconsiderando pequenas fissuras que, provavelmente, não implicariam em uma quebra do testemunho, assim como citado para o caso do grau de fraturamento.

O RQD teórico deverá também ser obtido para trechos isofraturados, assim como sugerido para o RQD medido em testemunhos de sondagem que, ao invés de considerar manobras, considera trechos em que o espaçamento das descontinuidades é homogêneo.

Sugere-se a adição de uma coluna dos valores de RQD teórico como uma coluna extra na Tabela 8, indicando sempre qual foi a equação utilizada para a obtenção destes valores. Vale ressaltar a importância de uma comparação dos valores de RQD obtidos em imagens com os calculados diretamente nos testemunhos de sondagem, como efeito de validação desta proposta e verificação de aplicabilidade.

\subsubsection{Tratamento estrutural}

Juntamente com as imagens do testemunho virtual e as tabelas indicando os parâmetros de caracterização do maciço rochoso observados no televisionamento, sugere-se ser apresentado o tratamento estrutural destes dados em estereograma de Schmidt-Lambert (hemisfério inferior), diagrama de roseta e diagrama de concentração de polos.

Para tais diagramas, os dados deverão ser tratados preferencialmente separadamente com relação ao tipo de estrutura, fraturas, falhas, foliação, etc. Para os diagramas de Schmidt-Lambert, deverão ser lançados apenas os polos dos planos para todos os casos, com exceção das falhas e zonas de cisalhamento, que poderão ser lançados também os planos.

Para todos os diagramas deverão ser apresentados os parâmetros considerados na elaboração destes, como número de dados, intervalos de concentração, dispersão dos dados, etc. Nas Figuras 43, 44 e 45 seguem exemplos dos diagramas Schmidt-Lambert, concentração de polos e roseta, 
respectivamente, para dados obtidos em televisionamento realizado em projeto da Linha 2 - Verde, extensão Vila Prudente - Guarulhos, do Metrô de São Paulo. Estas figuras foram geradas a partir do Software livre OpenStereo (Grohmann \& Campanha, 2010).

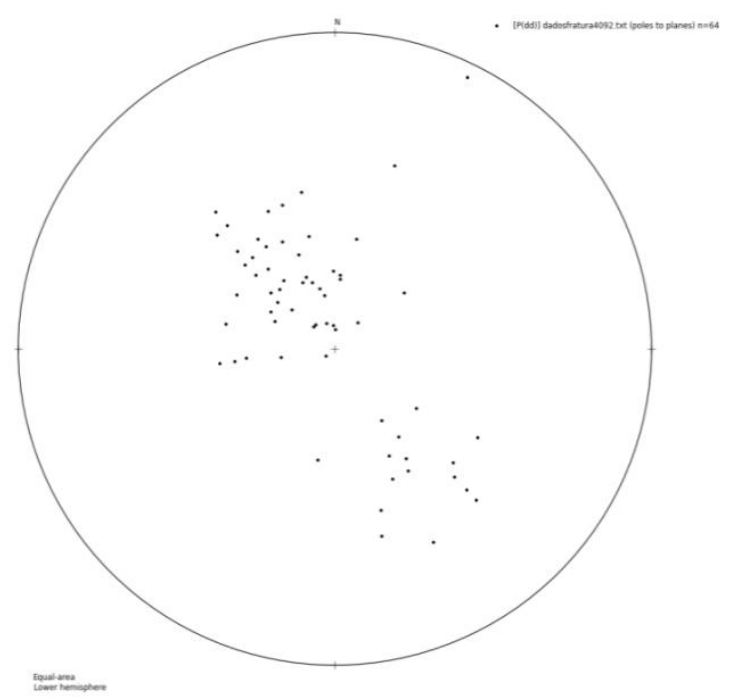

Figura 43- Exemplo de polos de fraturas de medidas no televisionamento plotados em estereograma Schmidt-Lambert, hemisfério inferior (Oliveira et al., 2013).

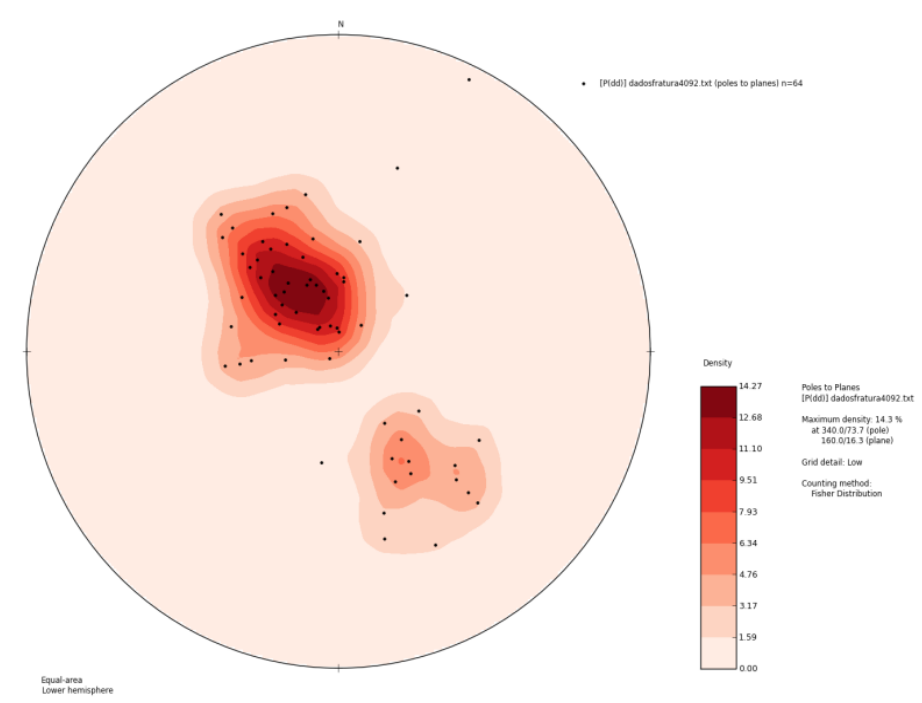

Figura 44- Exemplo de Diagrama Schmidt-Lambert estatístico de concentração de polos, hemisfério inferior (Oliveira et al., 2013).

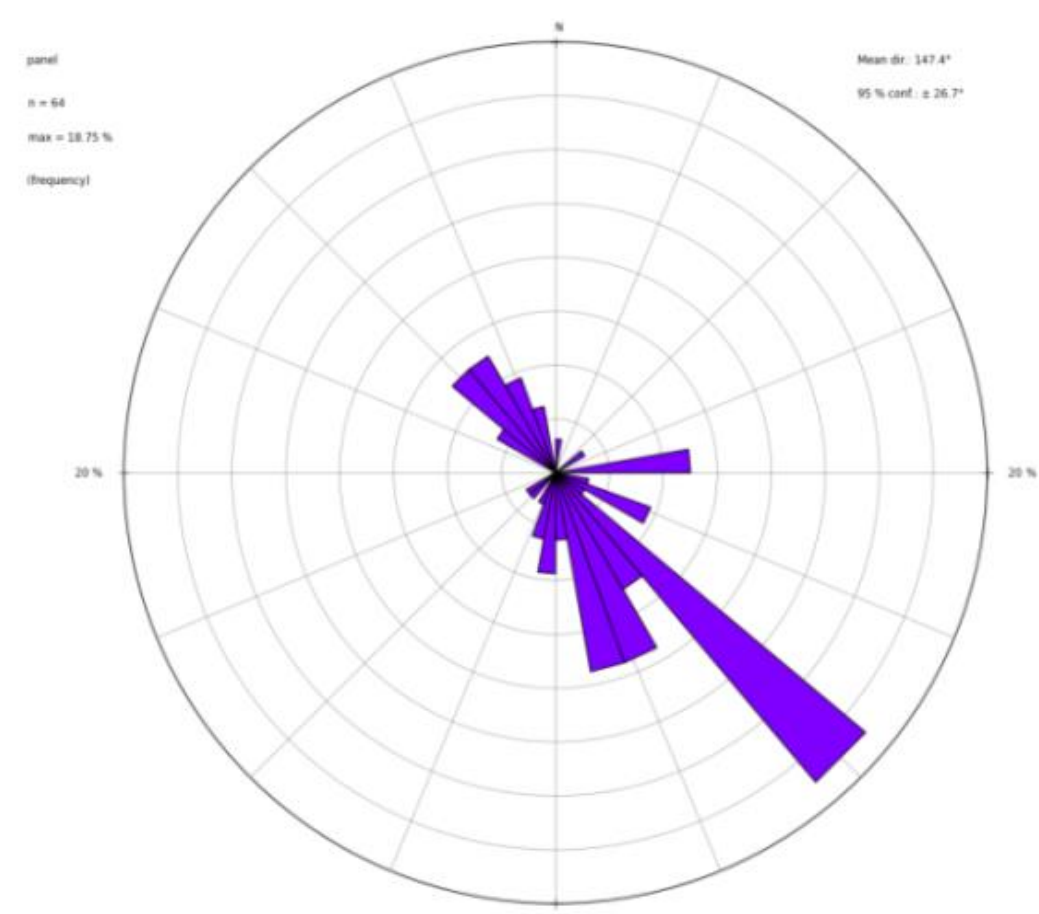

Figura 45 - Exemplo de diagrama estatístico de roseta, hemisfério inferior (Oliveira et al., 2013). 


\section{APLICAÇÃO DO TELEVISIONAMENTO ÓPTICO - ESTUDO DE CASO}

Conforme especificado no item 3, a metodologia proposta para a interpretação dos dados obtidos no televisionamento óptico de paredes de furos de sondagens foi aplicada em sondagens executadas ao longo de projetos de linhas metroviárias, para a Companhia do Metropolitano de São Paulo (CMSP). Nos projetos de extensão da Linha 2 Verde e Linha 4 Amarela foi executada uma quantidade maior de filmagens de furos de sondagens, o que permitiu um volume maior de dados para serem analisados e interpretados.

No caso da Linha 2 Verde não houve continuidade da análise devido à uma alteração no traçado da linha, sendo que a análise foi interrompida já que o trecho onde estas sondagens foram realizadas não será escavado. Já na extensão da Linha 4, para o município de Taboão da Serra, os dados obtidos tiveram grande utilidade na definição de soluções de engenharia, sendo de grande valia na caracterização do maciço rochoso, assim como na adoção de soluções para contenção e estabilização do maciço rochoso, tanto para o túnel de via como para as demais unidades construtivas, conforme será detalhado mais adiante.

\subsection{Estudo de caso 1: Linha 2 Verde - Extensão Vila Prudente - Guarulhos}

A extensão da Linha 2 Verde do Metrô de São Paulo interligará o trecho da Estação Vila Prudente com o município de Guarulhos. Este projeto contribui para uma expansão no sistema atual em aproximadamente $15 \mathrm{~km}$ de linhas, 13 novas estações e um pátio para estacionamento e manutenção de trens. Conforme mencionado acima, houve uma alteração no traçado da linha, sendo que o trecho analisado, indicado com o círculo em verde na Figura 46, não será mais parte desta extensão. 


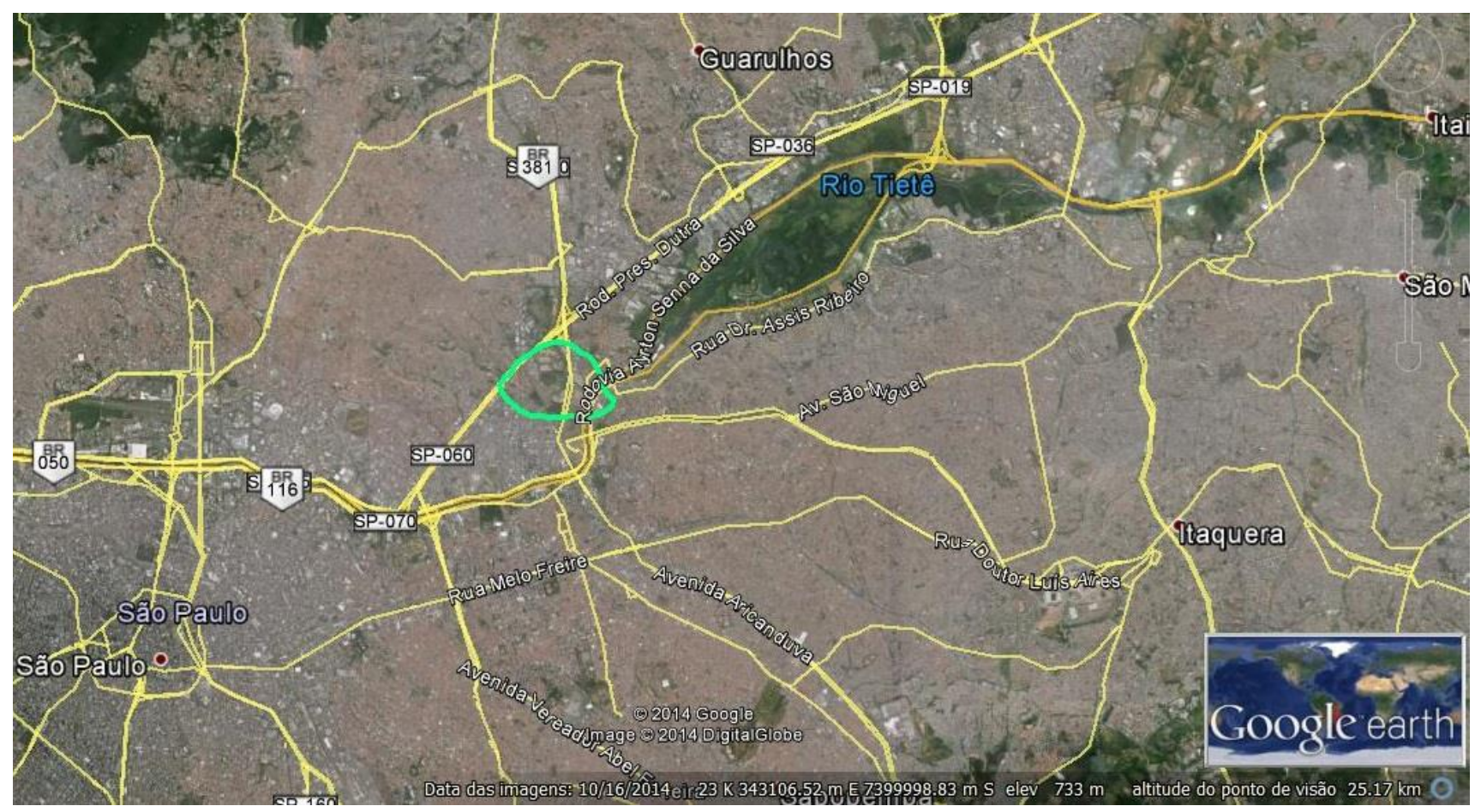

Figura 46 - Localização da área onde foi realizado o televisionamento dos furos de sondagem para projeto básico de extensão da Linha 2 - Verde, Metrô-SP (imagem do Google Earth).

Esta metodologia foi aplicada em um total de 32 furos entre as estações Ticoatira e Paulo Freire. Um dos objetivos foi de caracterizar o maciço rochoso, descrevendo parâmetros como grau de intemperismo e textura para a matriz rochosa e, orientação, espaçamento, rugosidade, condição de alteração das paredes, abertura, preenchimento e grau de faturamento das descontinuidades que cortam o maciço.

Com o objetivo de verificar a aplicabilidade desta metodologia, assim como apresentar possibilidades de seu uso em levantamentos geológico-geotécnicos, como a geração de dados estatísticos dos parâmetros descritos, foi considerado um pequeno trecho de aproximadamente $1 \mathrm{Km}$ de extensão ao longo deste projeto (Figura 47). Um total de 17 dos 32 furos televisionados foi selecionado, suas respectivas imagens foram descritas e as descontinuidades aí observadas foram tratadas estatisticamente, fornecendo informações sobre as características do maciço e contribuindo para conclusões iniciais sobre a aplicabilidade deste método.

Foram gerados diagramas estatísticos para os seguintes parâmetros das descontinuidades: abertura, rugosidade, condições de alteração das paredes, grau de fraturamento e estereogramas de concentração de polos. Foi possível então visualizar a variação destes parâmetros ao longo deste trecho. 


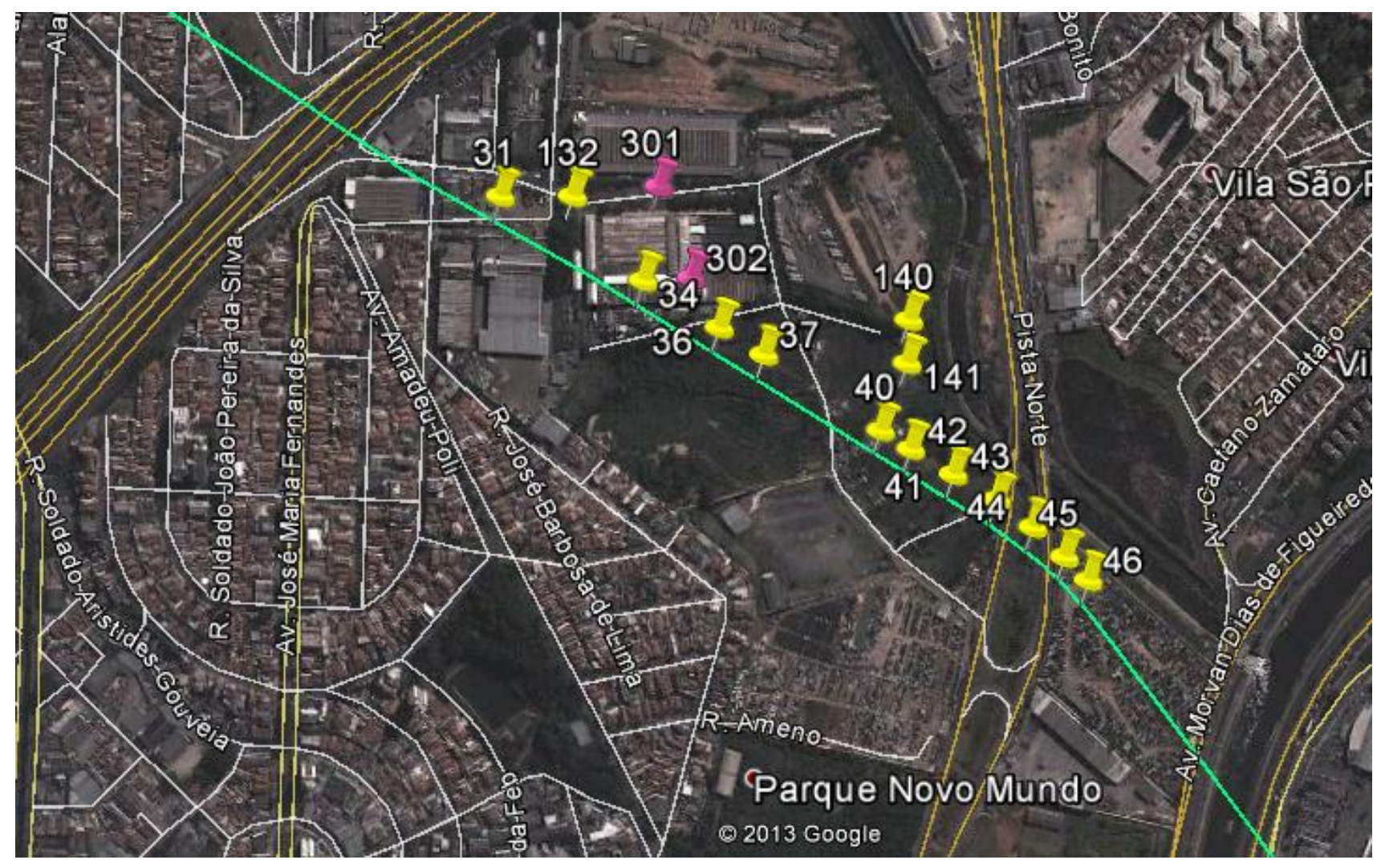

Figura 47 - Furos de sondagem analisados no trecho não adotado da extensão da Linha 2 Verde, MetrôSP (imagem do Google Earth).

Foram desconsideradas as fraturas não contínuas e/ou imperceptíveis, conforme comentado no item 5.2.5. Os parâmetros alteração das paredes, abertura e rugosidade das descontinuidades, assim como grau de fraturamento foram considerados para a elaboração de gráficos do tipo pizza, indicando a porcentagem de cada parâmetro que ocorria ao longo do trecho televisionado. A Figura 48 apresenta um exemplo do procedimento realizado para cada um dos furos considerados, indicando a quantidade de cada parâmetro e respectivos gráficos. Cada gráfico de pizza para cada sondagem foi plotado no mapa da região utilizando o Software ArcGIS e as imagens provenientes do Google Earth, sendo possível concluir como cada um destes parâmetros variava ao longo da linha. 


\begin{tabular}{|c|c|c|}
\hline Rugosidade & Qtd & $\%$ \\
\hline Lisa - 31,1\% & 32 & $31,1 \%$ \\
\hline Rugosa - 68,9\% & 71 & $68,9 \%$ \\
\hline Total & 103 & $100 \%$ \\
\hline
\end{tabular}

\begin{tabular}{|c|c|c|}
\hline Abertura & Qtd & $\%$ \\
\hline Aberta - 2,9\% & 3 & $2,9 \%$ \\
\hline Semi-aberta $-5,8 \%$ & 6 & $5,8 \%$ \\
\hline Fechada - 91,3\% & 94 & $91,3 \%$ \\
\hline Total & 103 & $100 \%$ \\
\hline
\end{tabular}

\begin{tabular}{|c|c|c|}
\hline Alteração & Qtd & $\%$ \\
\hline D1 - 59,2\% & 61 & $59,2 \%$ \\
\hline D2 - 1,0\% & 1 & $1,0 \%$ \\
\hline D3 - 37,9\% & 39 & $37,9 \%$ \\
\hline D4 - 1,0\% & 1 & $1,0 \%$ \\
\hline D5 - 1,0\% & 1 & $1,0 \%$ \\
\hline Total & 103 & $100 \%$ \\
\hline
\end{tabular}

\begin{tabular}{|c|c|c|}
\hline Grau de Frat & Metros & $\%$ \\
\hline F1 $-19,6 \%$ & 5,40 & $19,6 \%$ \\
\hline F2 - 58,1\% & 15,99 & $58,1 \%$ \\
\hline F3 - 22,2\% & 6,12 & $22,2 \%$ \\
\hline & & \\
\hline Total & 27,51 & $100,0 \%$ \\
\hline
\end{tabular}
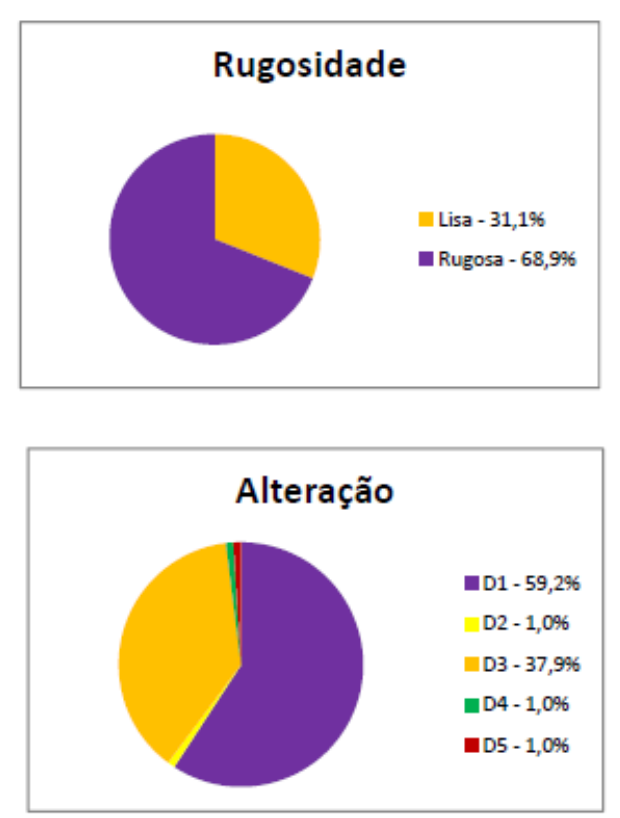
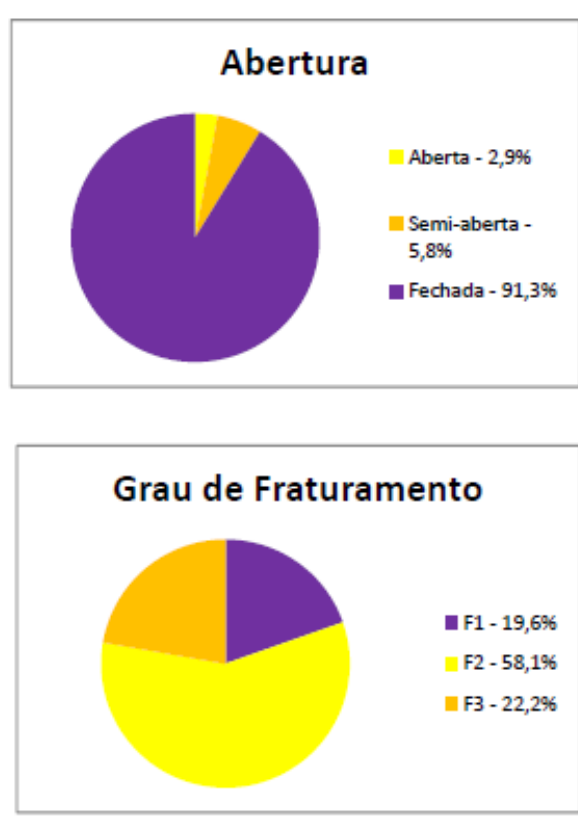

Figura 48 - Exemplo do procedimento realizado para cada um dos furos considerados para tratamento estatístico.

Na Figura 49 são apresentados os resultados estatísticos para o parâmetro alteração das paredes, tendo sido utilizada a Tabela 9 para caracterização desta feição. Já na Figura 50, os gráficos de pizza refletem a variação do parâmetro abertura para estes furos ao longo da linha. As Figuras 51 e 52 apresentam os resultados para os parâmetros rugosidade e grau de fraturamento, respectivamente.

Comparando as três primeiras figuras, conclui-se que, neste trecho, o maciço a sudeste se encontra em piores condições geomecânicas que a área a noroeste, pois ocorrem com mais frequência fraturas abertas e com ocorrência de preenchimento de fragmentos de rocha e sedimento argiloarenoso, principalmente na região próxima aos furos 140 e 141, assim como a maior concentração de fraturas lisas está também nessa região. A exceção seria apenas o furo 300, em que ocorre também uma frequência considerável de fraturas abertas, assim como uma quantidade maior de trechos muito fraturados $(\mathrm{F} 4)$. 


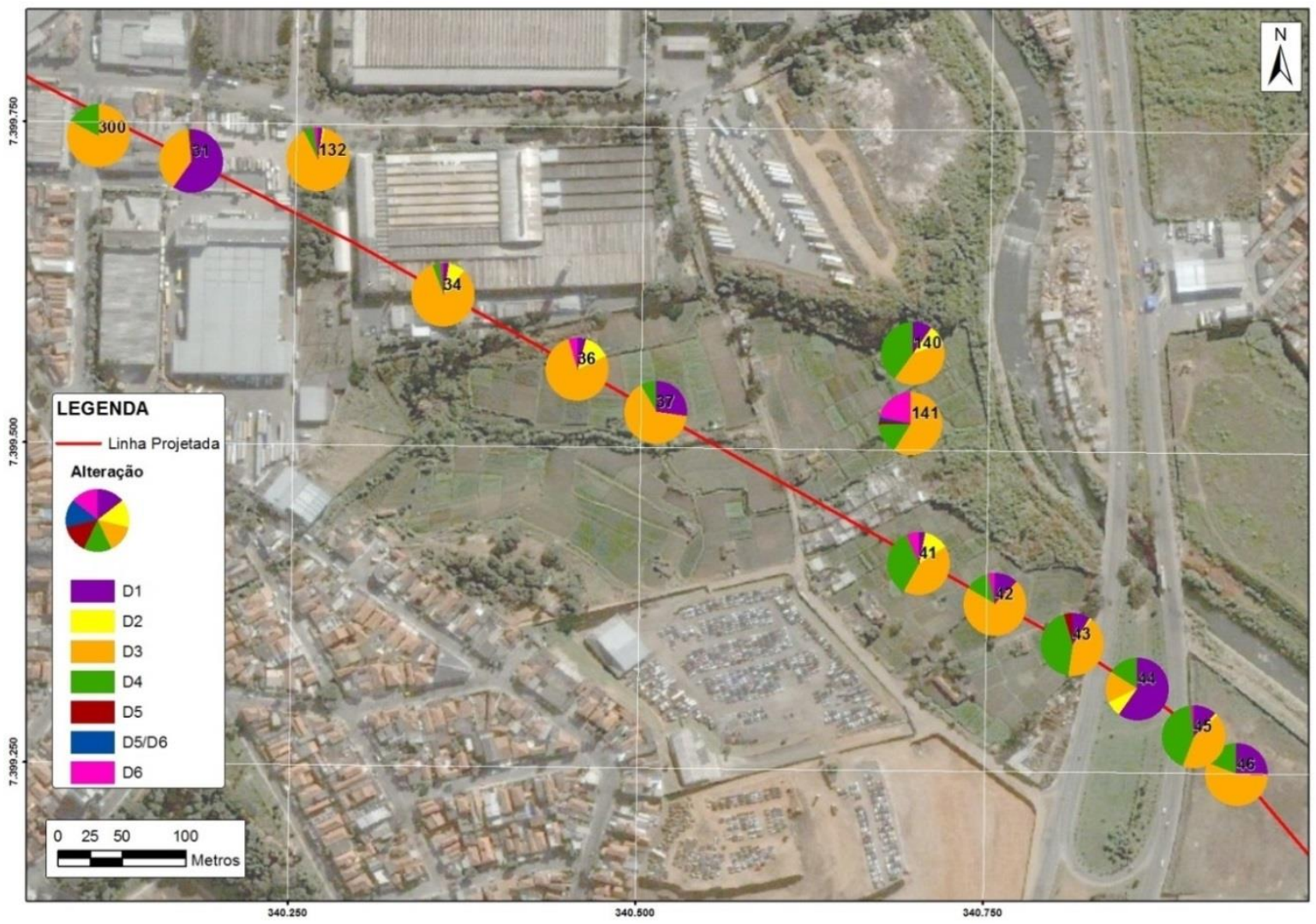

Figura 49 - Variação do parâmetro alteração das paredes das descontinuidades ao longo do trecho Linha 2 Verde Extensão Vila Prudente - Guarulhos.

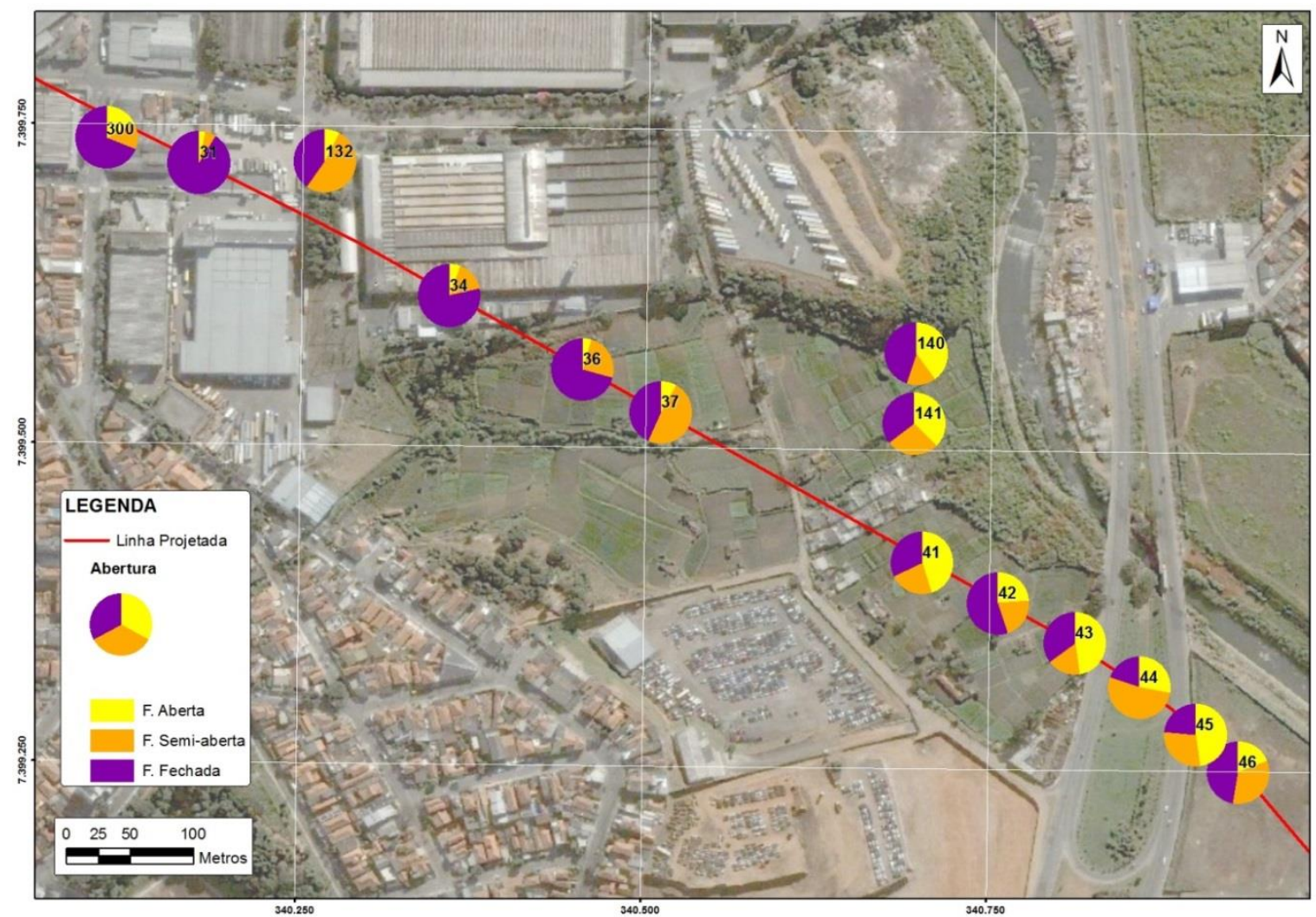

Figura 50 - Variação do parâmetro abertura das descontinuidades ao longo do trecho- Linha 2 Verde Extensão Vila Prudente - Guarulhos. 


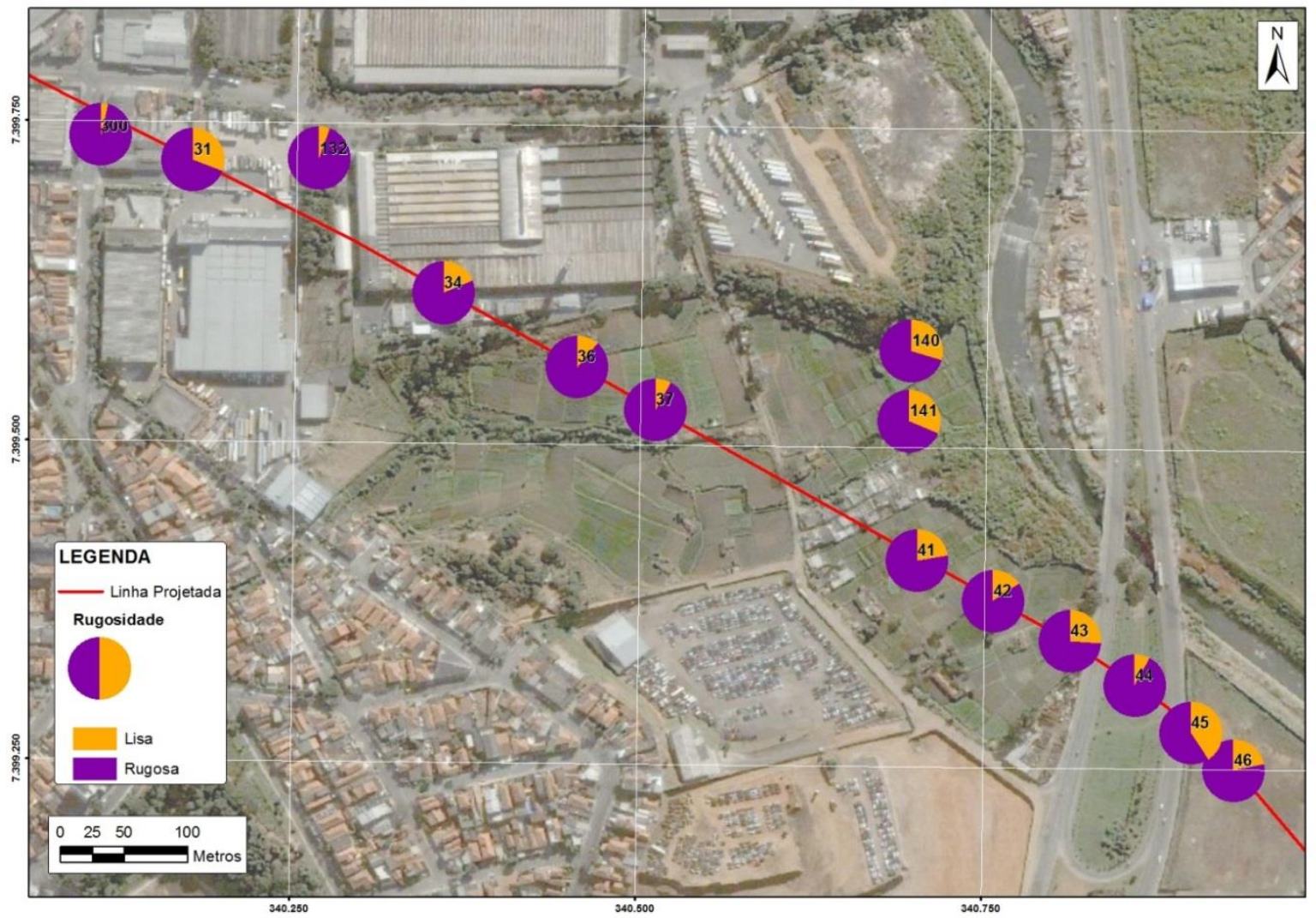

Figura 51 - Variação do parâmetro rugosidade das descontinuidades ao longo do trecho- Linha 2 Verde Extensão Vila Prudente - Guarulhos.

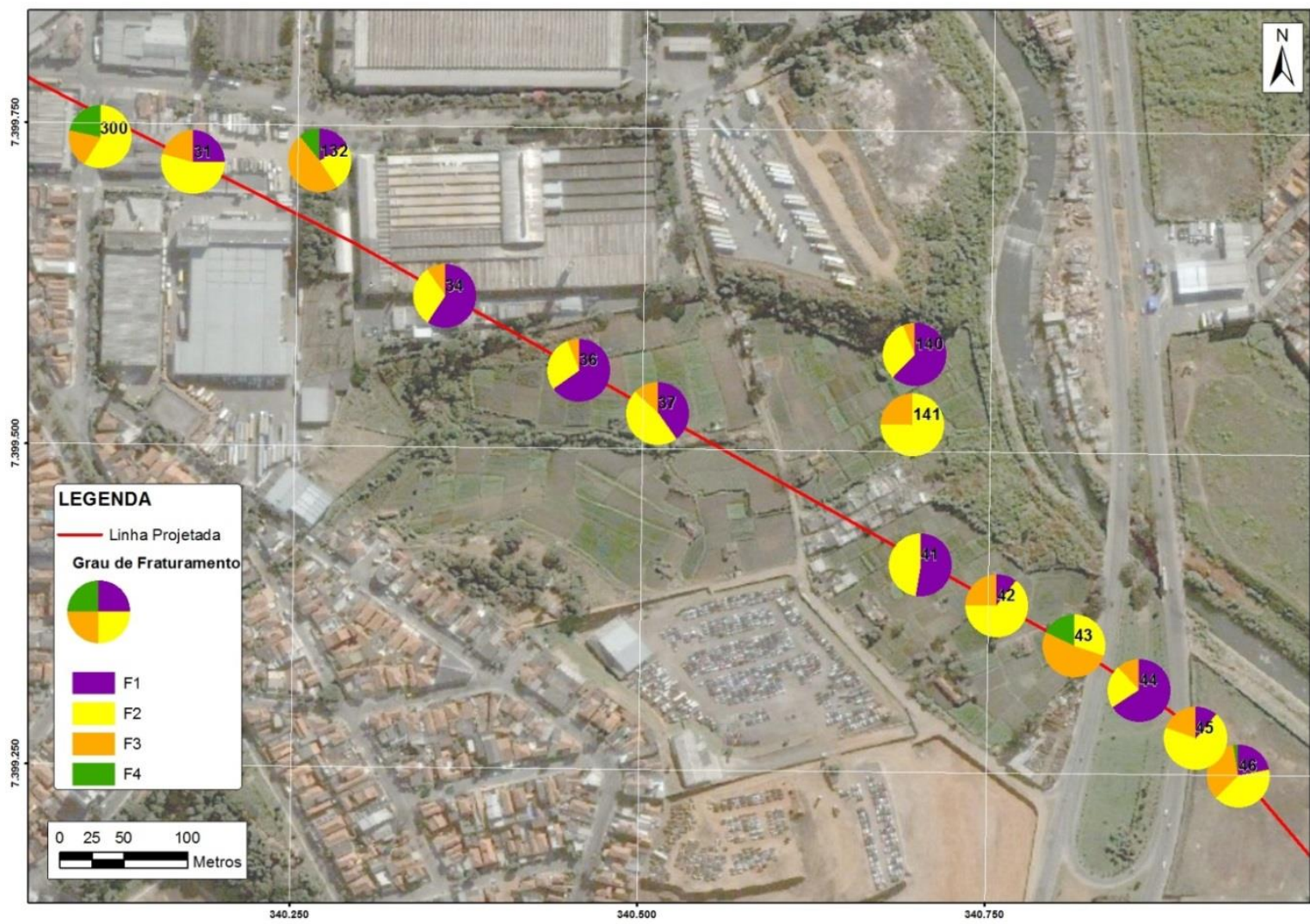

Figura 52 - Variação do parâmetro grau de fraturamento das descontinuidades ao longo do trechoLinha 2 Verde Extensão Vila Prudente - Guarulhos. 
Posteriormente, foram consideradas as atitudes estruturais dos planos de fraturas destes furos, sendo plotados em estereogramas. Para a confecção dos estereogramas foi utilizado diagrama de concentração de polos pela rede Schmidt-Lambert, hemisfério inferior, a partir do Software Dips (Rocscience, 1999). Na Figura 53 apresenta-se diagrama de concentração de polos com as principais famílias definidas, total de 5. Na Figura 54 estão apresentados estes cinco planos, juntamente com o eixo de direção do túnel de via, caso o traçado da linha não tivesse sido alterado.
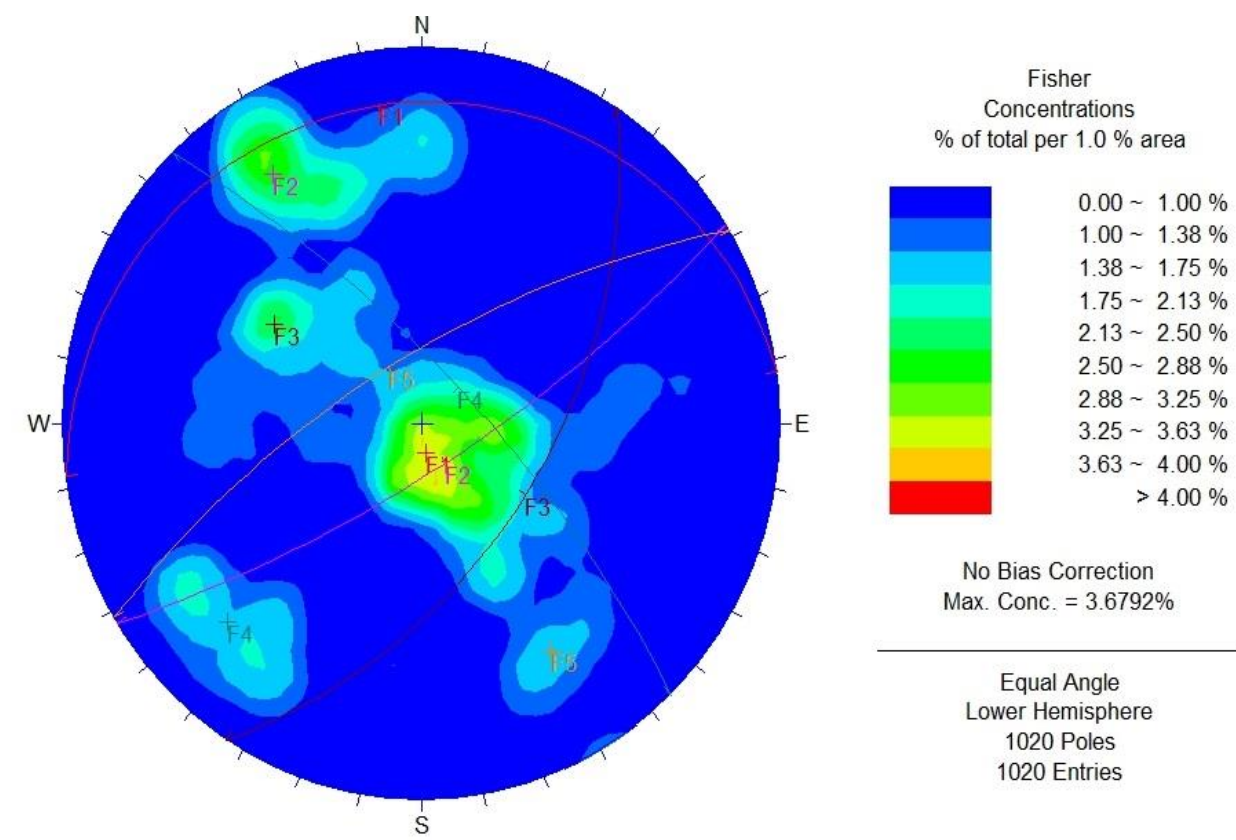

No Bias Correction Max. Conc. $=3.6792 \%$

Equal Angle Lower Hemisphere 1020 Poles 1020 Entries

Figura 53 - Diagrama de concentração de polos para furos selecionados da Linha 2 Verde, Software Dips (Rocscience, 1999).
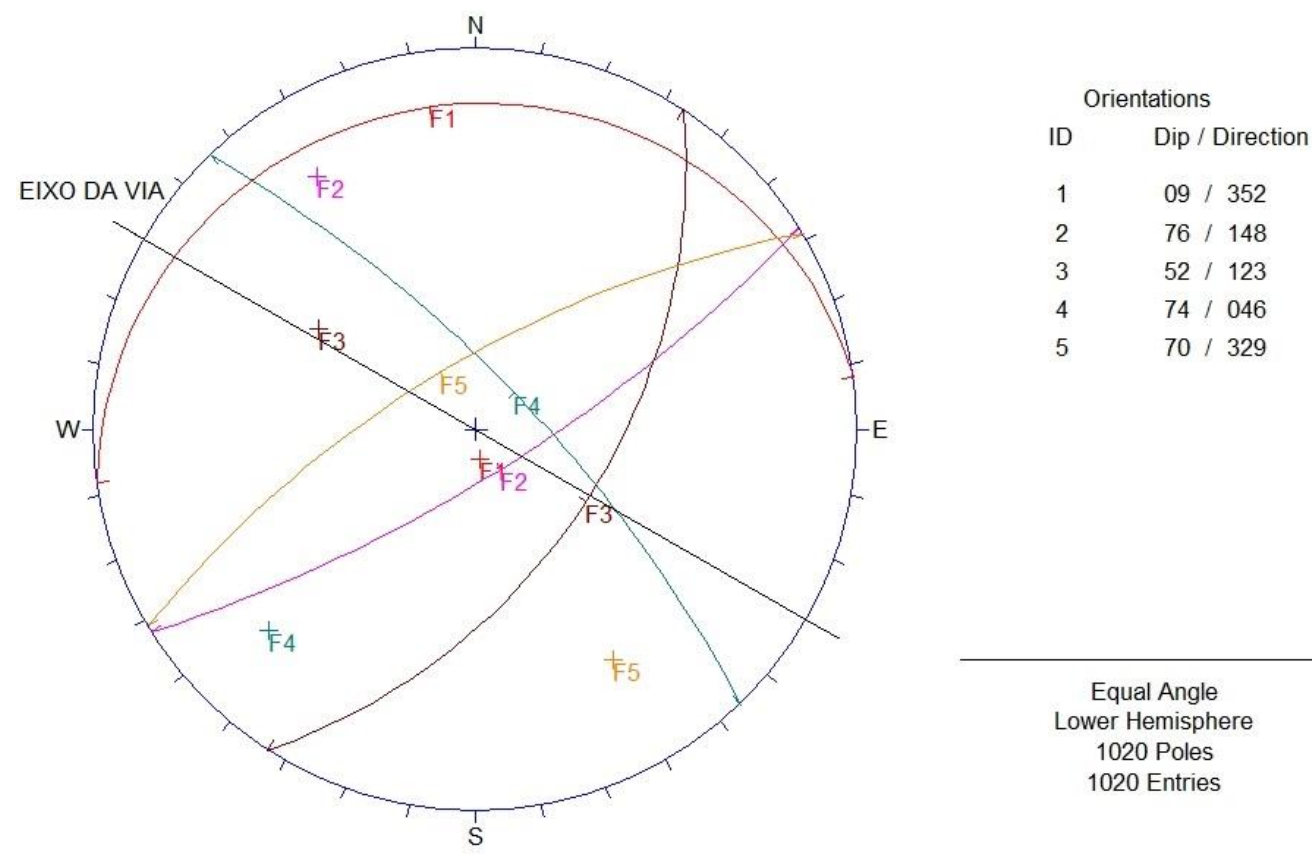

Equal Angle Lower Hemisphere 1020 Poles 1020 Entries

Figura 54 - Planos das principais famílias definidas para furos selecionados da Linha 2 Verde, e eixo do túnel de via para alternativa não adotada, Software Dips (Rocscience, 1999). 
Utilizando o Software Unwedge (Rocscience, 2004), foram simuladas análises cinemáticas bidimensionais, segundo parâmetros definidos por Hoek \& Bray (1981), e tridimensionais, definindo os principais blocos formados, a partir da combinação de todos os principais sets de descontinuidades, segundo o proposto por Goodman \& Shi (1985). As Figuras 55, 56 e 57 são exemplos dos resultados obtidos. Uma mesma análise foi realizada para o estudo de caso seguinte, na Linha 4 Amarela, sendo mais detalhada que a presente, por razões já descritas anteriormente.

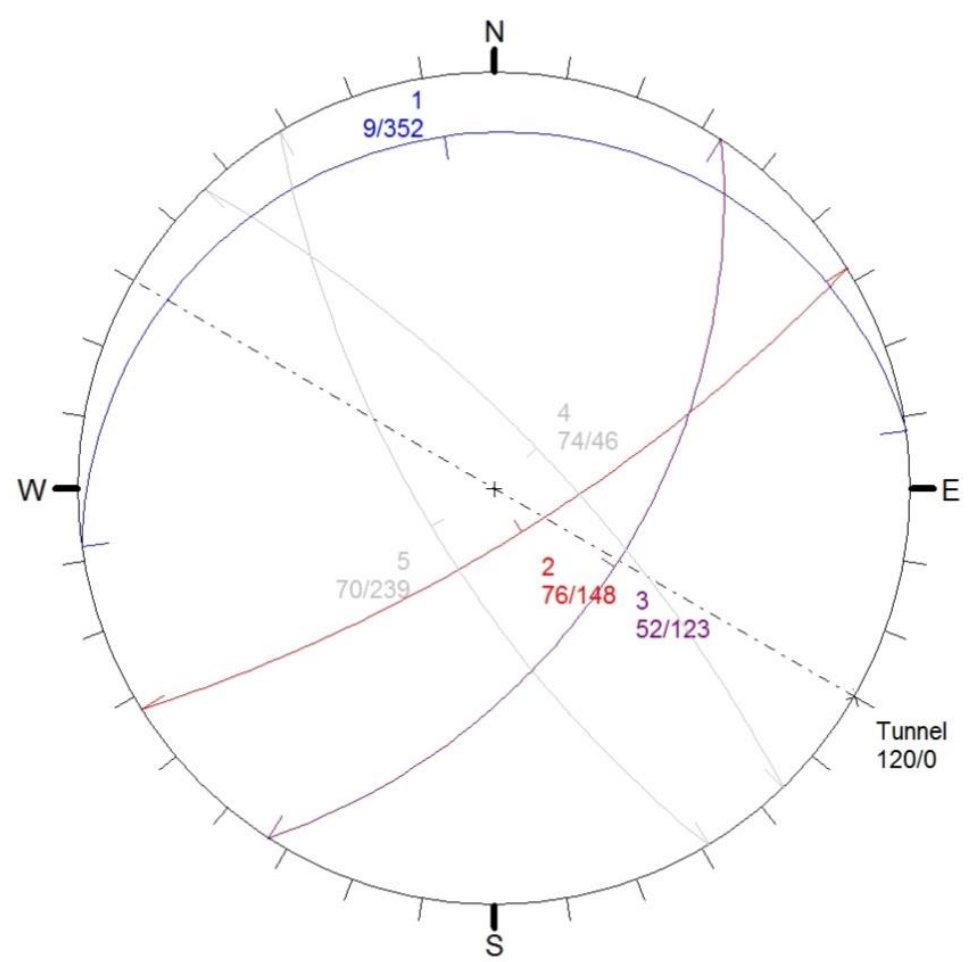

Figura 55 - Análise bidimensional da interação dos planos de fraturas principais e eixo do túnel, utilizando Software Unwedge (Rocscience, 2004).

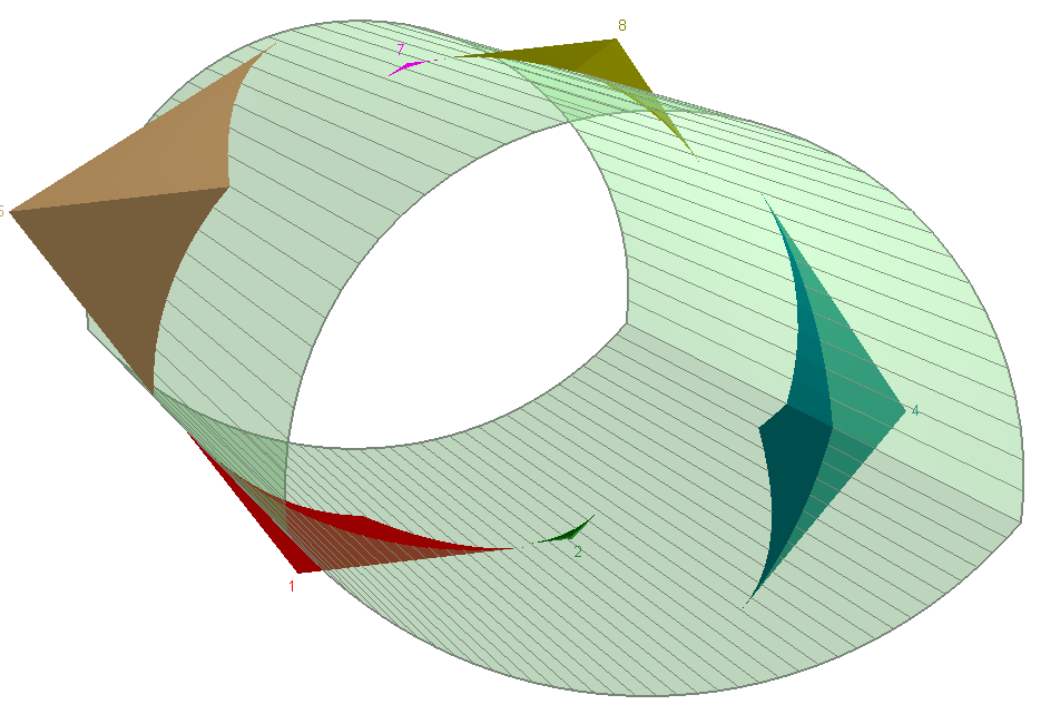

Figura 56 - Análise tridimensional da interação dos planos de fraturas principais e eixo do túnel, apresentando blocos formados, utilizando Software Unwedge (Rocscience, 2004). 


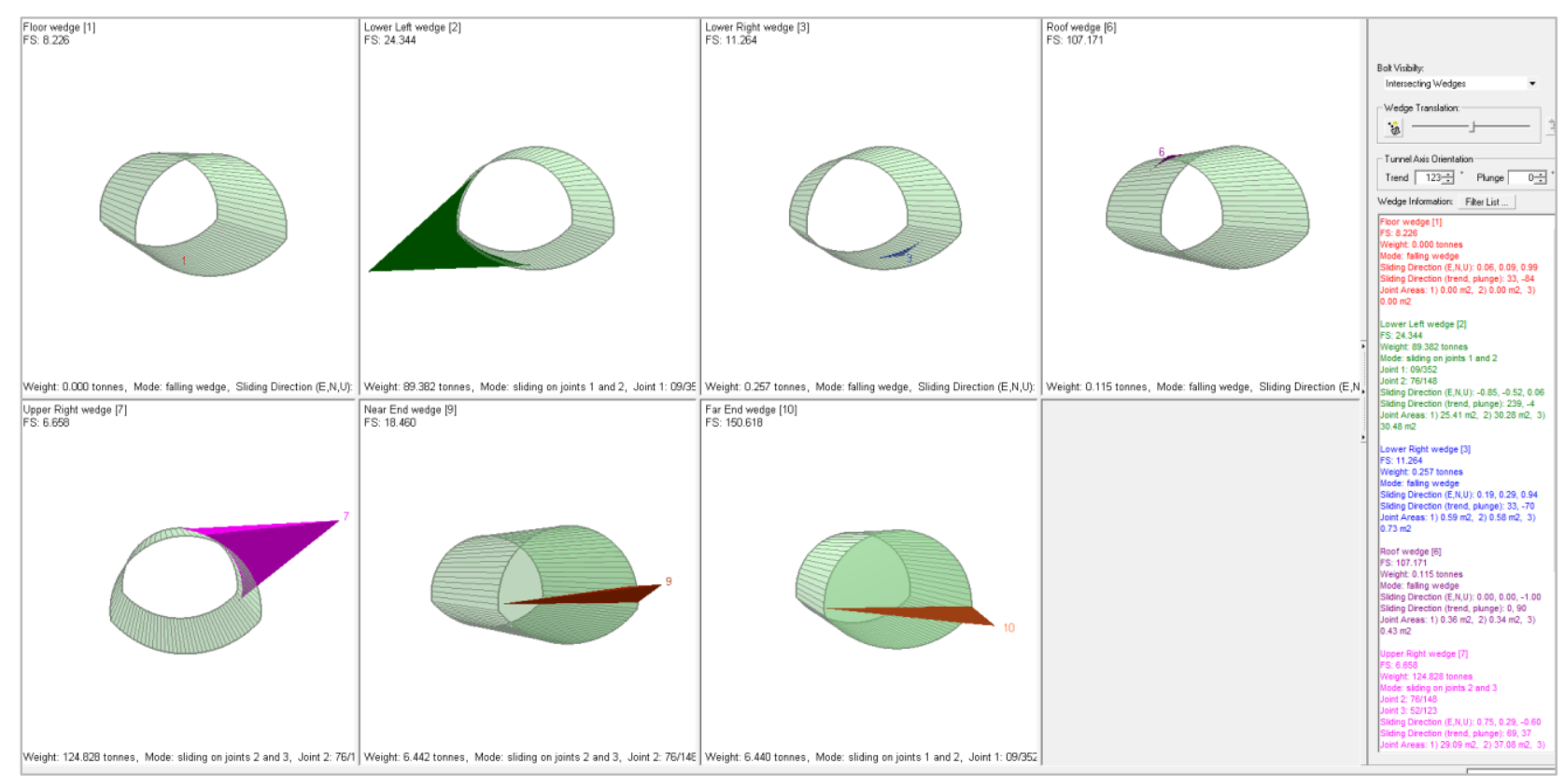

Figura 57 - Análise tridimensional apresentando cada bloco formado, indicando fator de segurança, volume e peso de cada bloco, elaborado com Software Unwedge (Rocscience, 2004).

\subsection{Estudo de caso 2: Linha 4 Amarela - Extensão Vila Sônia - Taboão da Serra}

Atualmente, a Linha 4 Amarela opera com traçado que compreende a Estação Luz até a Estação Butantã (9 km de extensão) e conta com as seguintes estações: Butantã, Pinheiros, Faria Lima, Paulista, República e Luz. Esta configuração promove a interligação com a rede de metrô nas Estações Paulista, República e Luz, com o trem metropolitano (CPTM) através das estações Pinheiros e Luz, e com parte da demanda integrada dos sistemas de ônibus municipal e intermunicipal, originários da região oeste, no Terminal Butantã junto à Estação Butantã.

A Fase 2 da expansão desta linha está atualmente em construção. Nesta fase, serão adicionadas novas estações intermediárias, além do prolongamento do traçado de Butantã até Vila Sônia acrescentando 3,8 Km. Neste trecho, serão construídas as estações São Paulo-Morumbi e Vila Sônia e o trecho restante será complementado com as Estações Fradique Coutinho, Oscar Freire e Higienópolis-Mackenzie. Ainda contará o Metrô com a construção de terminais intermodais em São Paulo-Morumbi e Vila Sônia, para promover a integração com o sistema ônibus.

A Fase 3 da extensão da Linha 4 compreende a continuação do traçado da Linha 4 - Fase 2, a partir do VSE David Matarasso (Fase 2), na altura do nº 4890 da Av. Prof. Francisco Morato, até o VSE Emília Garrido (Fase 3), com um total de $2.334 \mathrm{~km}$ (Figura 58). Estão inclusos no projeto as seguintes unidades construtivas: túnel de via, 2 VSE's, 4 poços de acesso e 2 estações (Chácara do Jóquei e Largo do Taboão). 
Na Figura 59 é possível visualizar todos os furos televisionados para este projeto, totalizando 17 furos, com 503 metros de rocha filmada. A seguir, detalham-se as informações obtidas a partir destes dados do televisionamento. Resumidamente, os dados contribuíram para a caracterização e classificação do maciço rochoso, para a definição de intervalos para ensaios de perda d'água sob pressão (EPA), correlacionando os resultados de permeabilidade com as descontinuidades presentes no maciço e, finalmente, para uma análise estrutural detalhada, provendo não só o modelo estrutural do maciço, mas informações utilizadas para a análise cinemática e de estabilidade do túnel de via, 6 poços e as paredes da Estação Largo do Taboão.

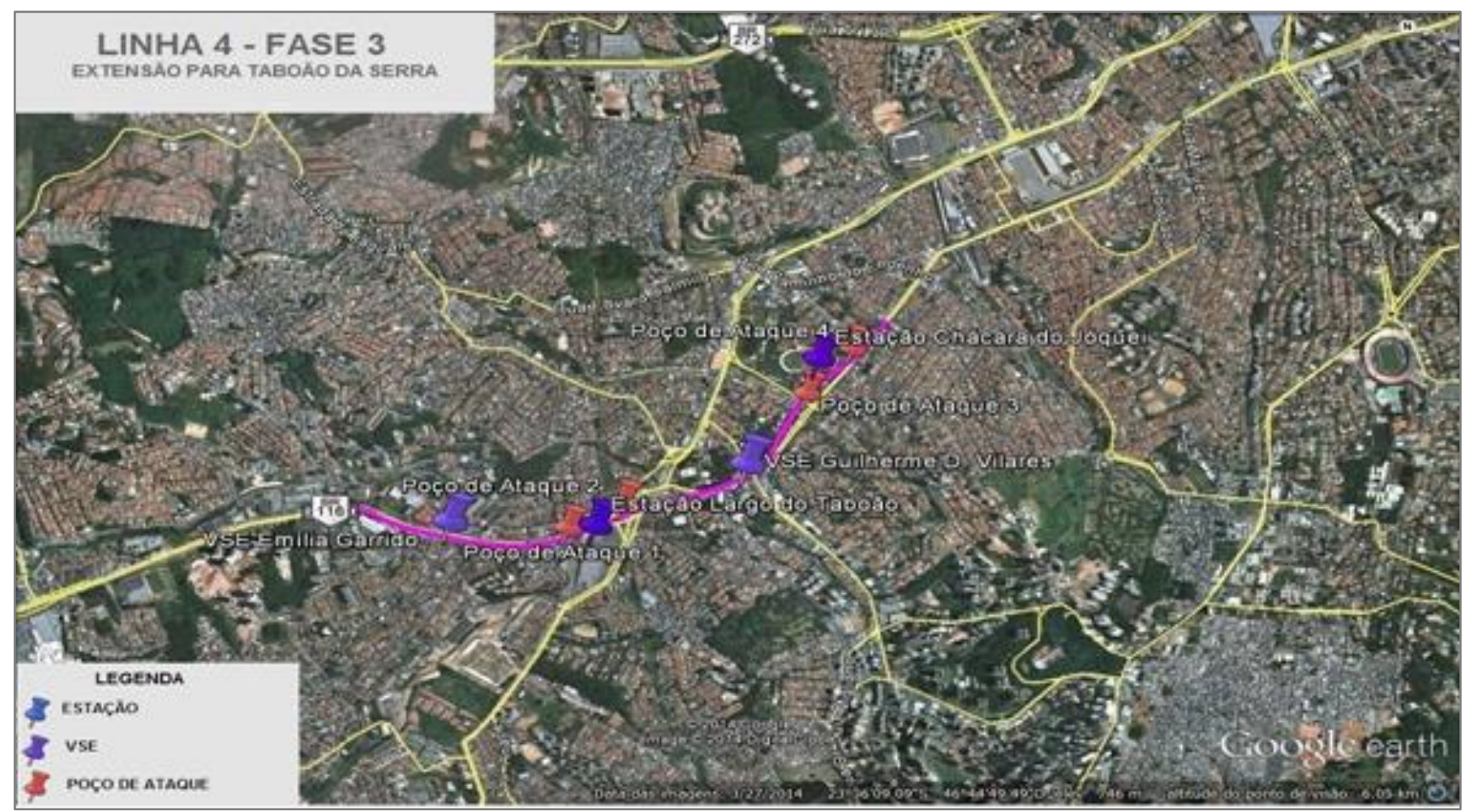

Figura 58 - Traçado esquemático da Linha 4 Amarela Fase 3, indicando as principais unidades construtivas (Google Earth). 


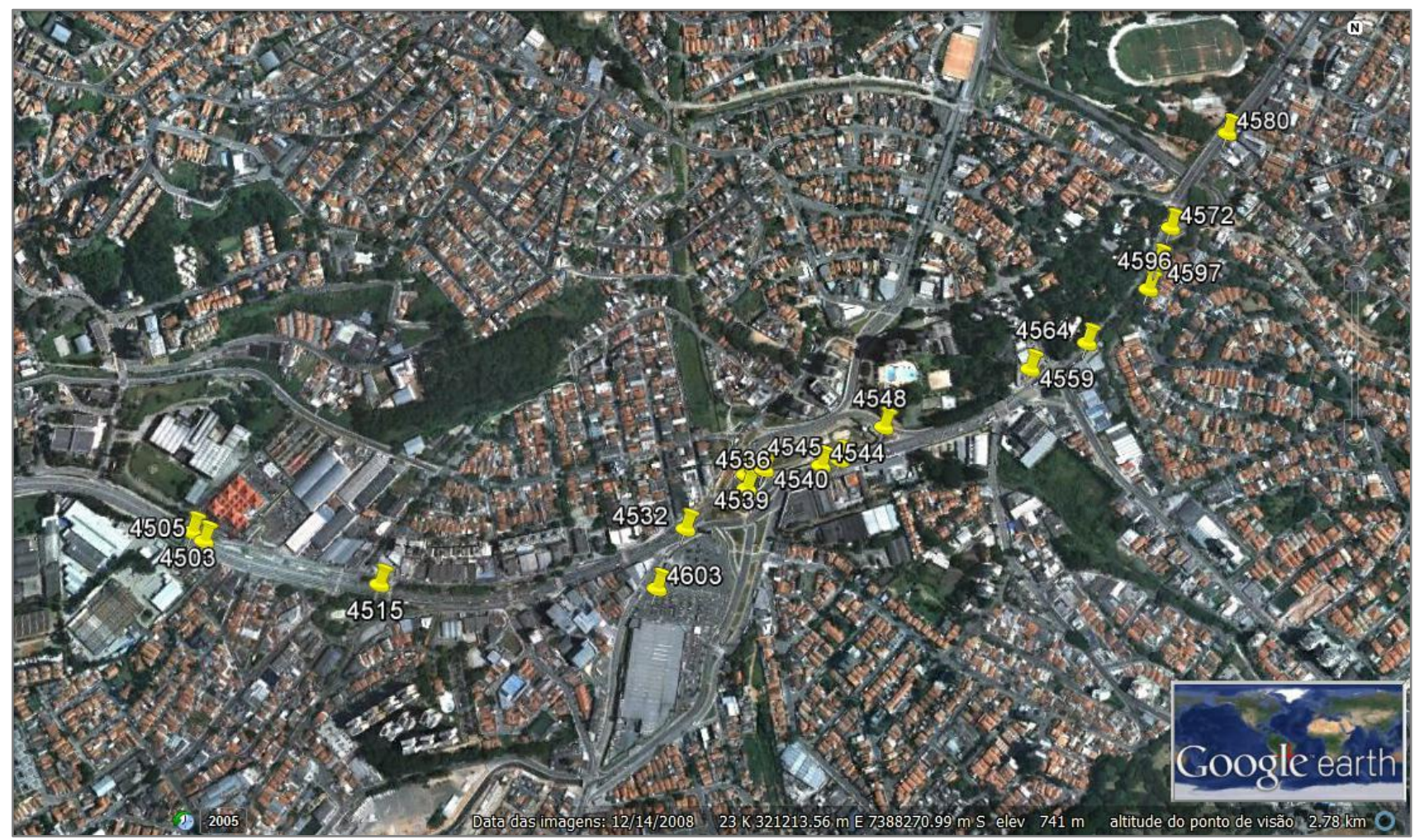

Figura 59 - Furos de sondagens televisionados ao longo da Linha 4 Amarela - Fase 3 (Google Earth).

\subsubsection{Caracterização geológico-geotécnica do maciço rochoso}

O traçado da Fase 3 da Linha 4 do Metrô está situado ao longo da borda sudoeste da Bacia Sedimentar de São Paulo, cruzando quase que exclusivamente rochas do embasamento pertencentes ao Complexo Embu.

No topo da estratigrafia ao longo do eixo ocorrem depósitos tecnogênicos, praticamente em todo o trecho investigado, salvo exceção de algumas regiões onde aflora o diretamente o solo de alteração do embasamento.

Aparecendo de forma restrita em algumas localidades, ocorrem depósitos sedimentares do Quaternário da Bacia de São Paulo, denominados de depósitos aluvionares, formando lentes que não ultrapassam seis metros de espessura em pequenas áreas. Também foram encontradas de forma localizada lentes pertencentes aos depósitos da Formação São Paulo, na região da Estação Chácara do Jóquei.

A grande parte do subsolo investigado ao longo do trecho é composta por gnaisses biotíticos migmatizados e migmatitos pertencentes ao embasamento, assim como seu solo de alteração. Estas rochas do embasamento se encontram geralmente deformadas por influência das zonas de cisalhamento atuantes na região, principalmente por sua proximidade com a Falha de Caucaia, a 
norte do trecho. A principal estrutura observada é um bandamento composicional, sendo esta uma característica essencial na compreensão do condicionamento estrutural da região. Esta estrutura influencia a formação de um topo rochoso irregular, onde as bandas máficas, com concentração de biotita, além de apresentar planos de fraqueza, também implicam em regiões de baixos topográficos, quando comparadas às zonas com maior concentração de minerais félsicos, ricos em quartzo e feldspato, mais resistentes à alteração e, geralmente, relacionados a limites de topos rochosos topograficamente mais rasos.

Todo este substrato rochoso está afetado por um forte condicionante estrutural, o que se assemelharia a uma "caixa de ovos", implicando nesta irregularidade constante de altos e baixos topográficos, heterogeneidade da rocha, com classes de maciço bastante variáveis, tanto verticalmente quanto horizontalmente.

Nas Figuras 60 a 63, é apresentada a seção geológico-geotécnica longitudinal, ao longo do eixo da via e, na Figura 64, apresenta-se a respectiva legenda para estas seções. Nesta seção, é possível observar a ocorrência do topo rochoso bastante irregular, onde em alguns trechos a via cruzará trechos em solo, rocha saprolítica, até mesmo trechos com passagem de blocos de matacões, como é o caso da Estação Chácara do Jóquei. Também foram identificadas algumas zonas de falha e/ou cisalhamento que, mesmo se tratando de zonas muito antigas, formadas durante eventos colisionais do Pré-Cambriano, podem implicar em trechos de piores classes de maciço, mais fraturados, com descida até mesmo do topo rochoso, como o que se observa logo antes da Estação Largo do Taboão ou no trecho após a Estação Chácara do Jóquei.

Com base nas informações das sondagens realizadas, foram levantados alguns quantitativos que são apresentados nas Figuras 65 e 66, indicando a quantidade aproximada de cada unidade e, dentro do maciço rochoso, a quantidade de cada classe de maciço, segundo o proposto por Bieniawski (1989). O que fica evidente ao detalhar a seção geológica é justamente esta heterogeneidade ao longo da linha, ocorrendo intercalações bruscas entre trechos de maciço rochoso de boa classe geomecânica (Classes I/II) e trechos de classe geomecânica muito baixa (Classes IV/V). Estas informações puderam ser observadas com detalhe tanto nos testemunhos de sondagem e principalmente nas imagens de televisionamento. 


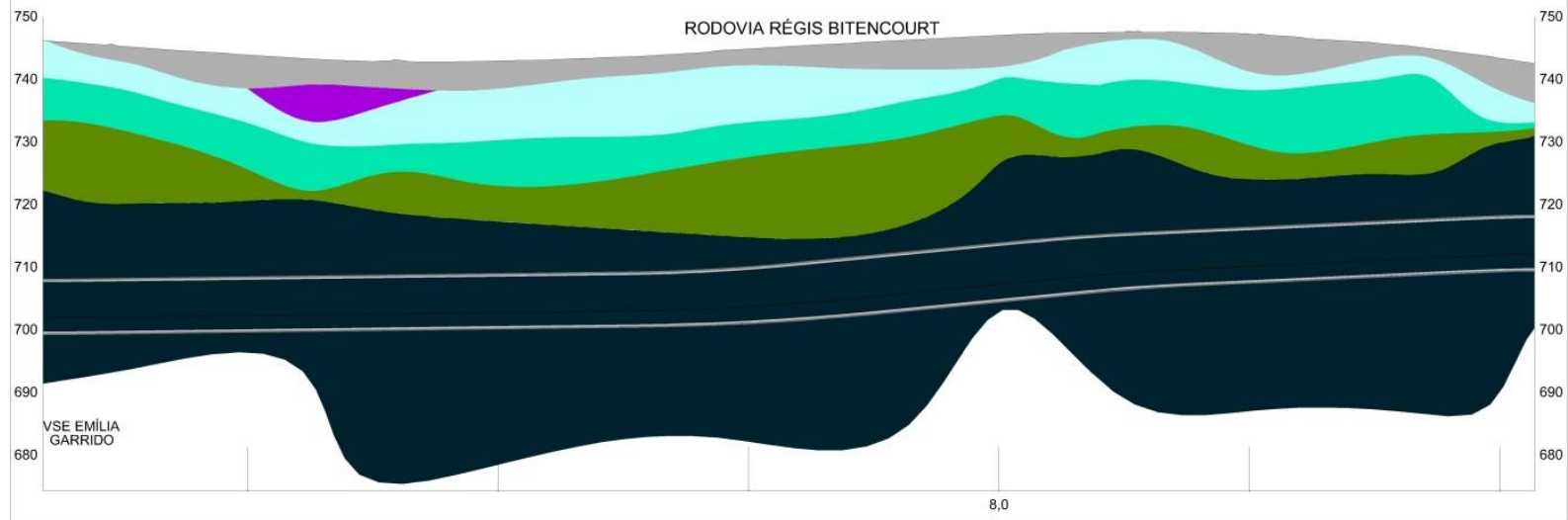

Figura 60 - Seção longitudinal geológico-geotécnica 1 de 4, simplificada, da Linha 4 Amarela - Fase 3 extensão Taboão da Serra. Fonte: Metrô-SP.

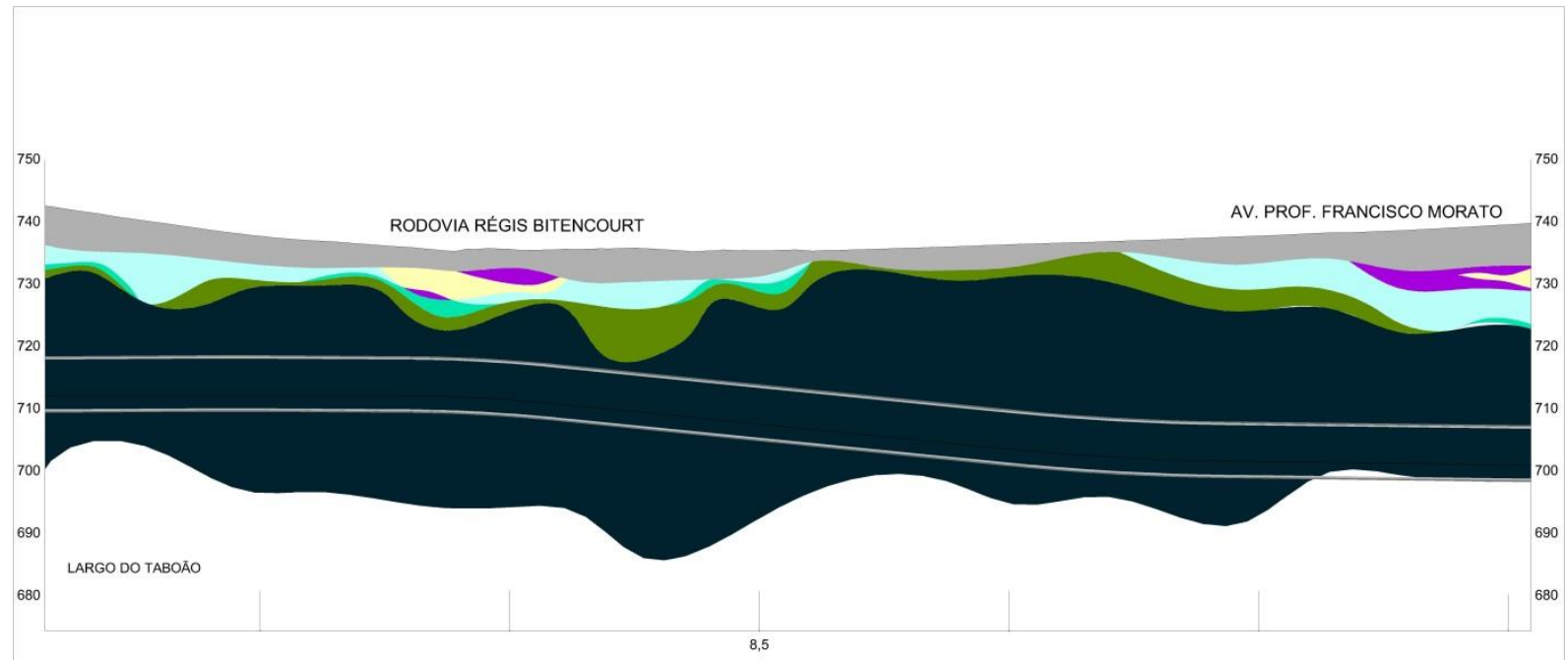

Figura 61 - Seção longitudinal geológico-geotécnica 2 de 4, simplificada, da Linha 4 Amarela - Fase 3 extensão Taboão da Serra. Fonte: Metrô-SP.

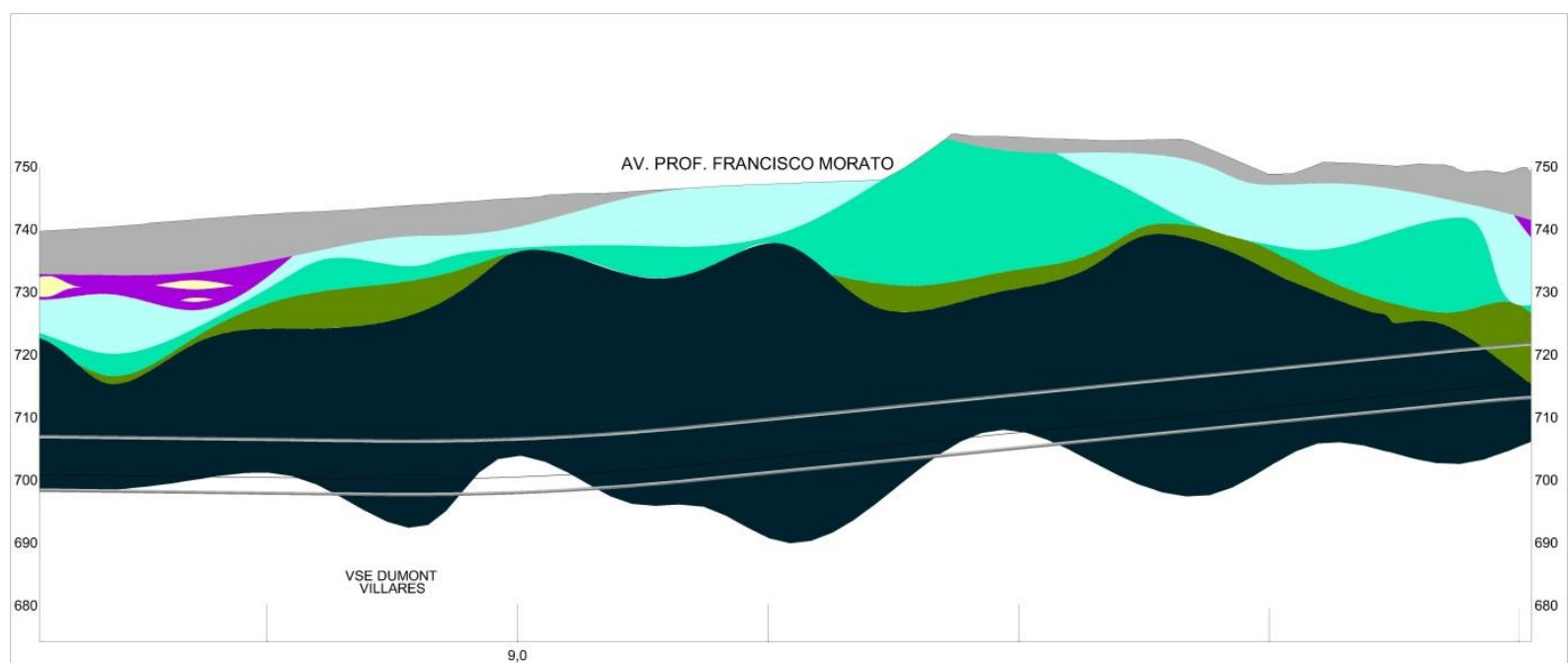

Figura 62 - Seção longitudinal geológico-geotécnica 3 de 4, simplificada, da Linha 4 Amarela - Fase 3 extensão Taboão da Serra. Fonte: Metrô-SP. 


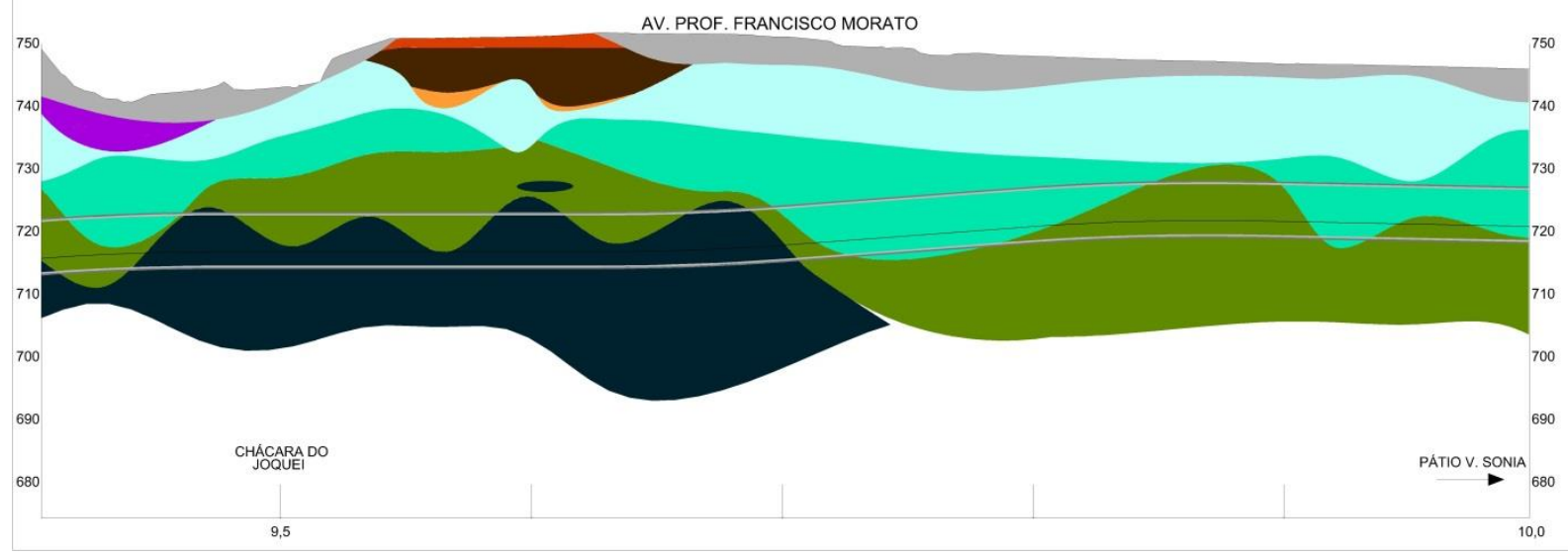

Figura 63 - Seção longitudinal geológico-geotécnica 4 de 4, simplificada, da Linha 4 Amarela - Fase 3 extensão Taboão da Serra. Fonte: Metrô-SP.

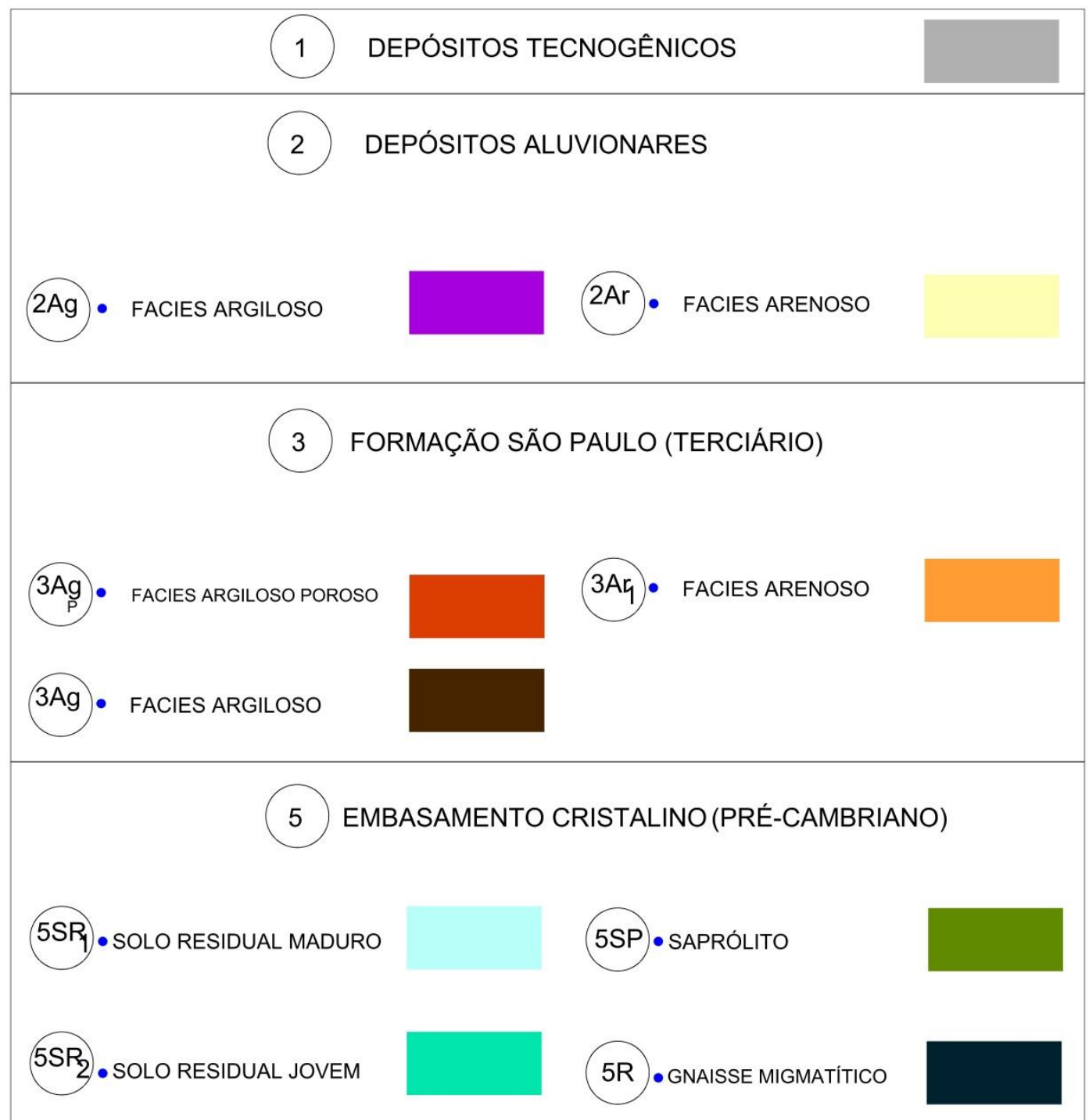

Figura 64 - Legenda das unidades e materiais geológicos referentes às seções das figuras anteriores (modificado de Kutner \& Bjornberg, 1997). 


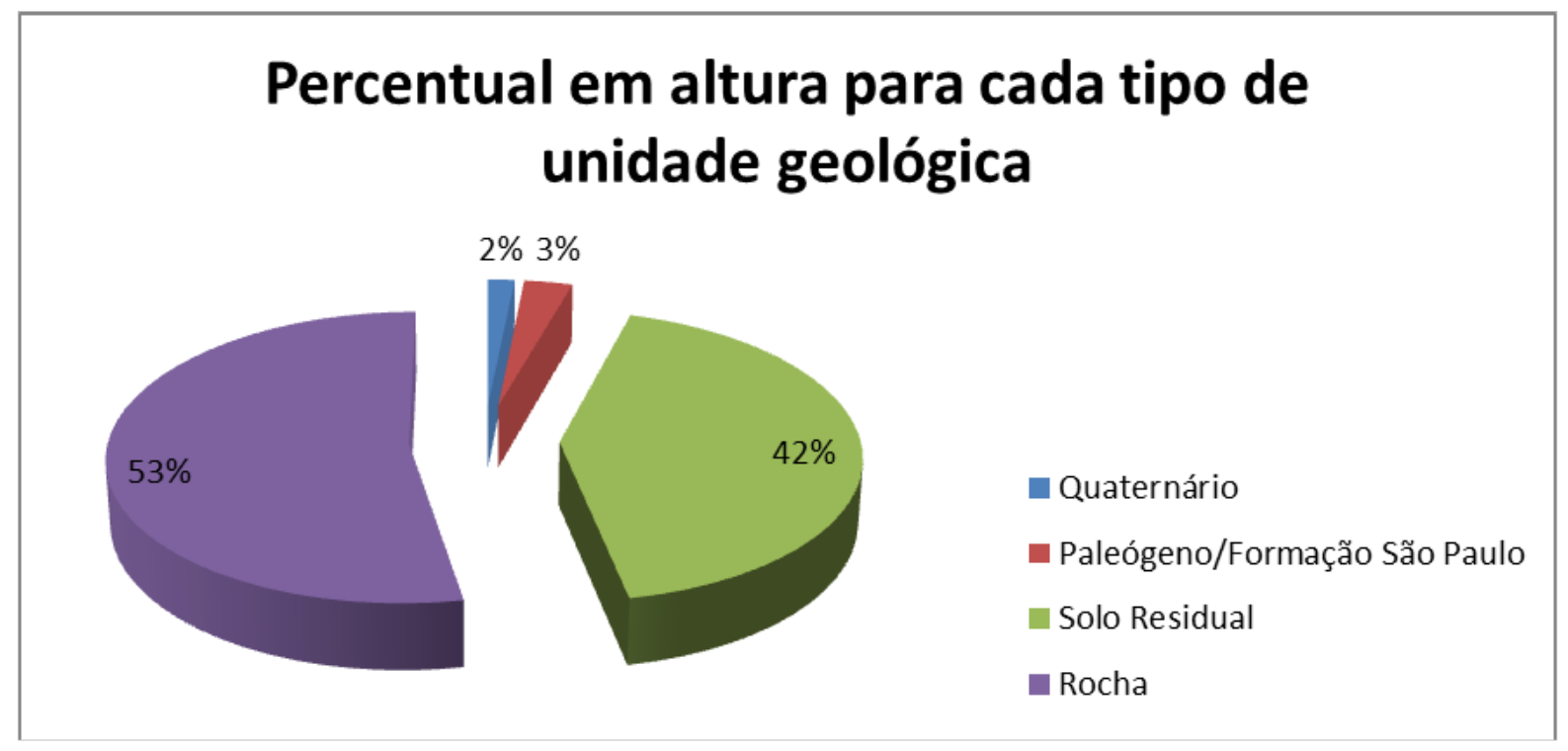

Figura 65 - Quantificação das unidades que ocorrem no trecho, tendo como base as informações das sondagens ao longo da seção geológico-geotécnica.

\section{Percentual em altura para cada classe de maciço rochoso}

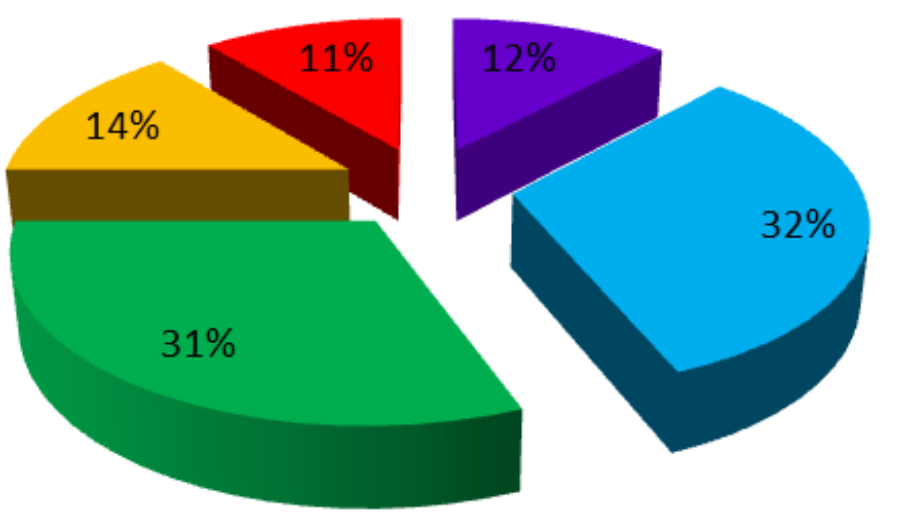

- Classe I

Classe II

Classe III

Classe IV

Classe V

Figura 66 - Quantidade da classe geomecânica do maciço rochoso ao longo do trecho em questão, a partir da classificação de Bieniawski (1989).

O maciço rochoso ocorre praticamente em todo o trajeto do túnel e é representado quase que exclusivamente por uma rocha migmatítica, de granulação média grossa, apresentando bandamento descontínuo e irregular, com lentes claras (leucossoma) alternadas com lentes máficas (melanossoma). Ocorrem trechos também de rocha gnáissica, possivelmente a paleossoma deste migmatito. Este gnaisse também apresenta granulação média a grossa, sendo bandado e com foliação 
gnáissica típica, algumas vezes textura equigranular e outras, mais frequentemente, inequigranular, contendo megacristais de feldspato. Ocorrem também, com certa frequência, rochas milonitizadas, apresentando feições de crenulação e estiramento dos cristais. Alguns trechos estão intensamente fraturados, muito possivelmente estando relacionados a zonas de falha, dando origem a rochas cataclasadas.

A rocha migmatítica (Fotos 33 e 34) possui bandas irregulares, geralmente dobradas e indicando a formação de dobras intrafoliais, conforme pode ser observado nas Fotos 35 e 36, indicando o intenso retrabalhamento metamórfico estrutural a que estas rochas foram submetidas.

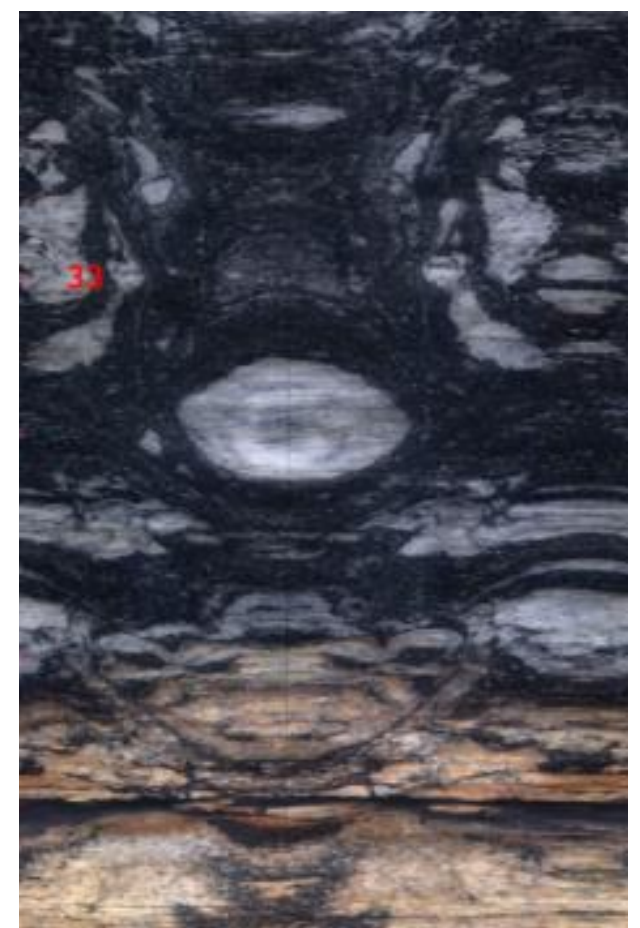

Foto 33 - Televisionamento da sondagem 4503 (Metrô-SP).

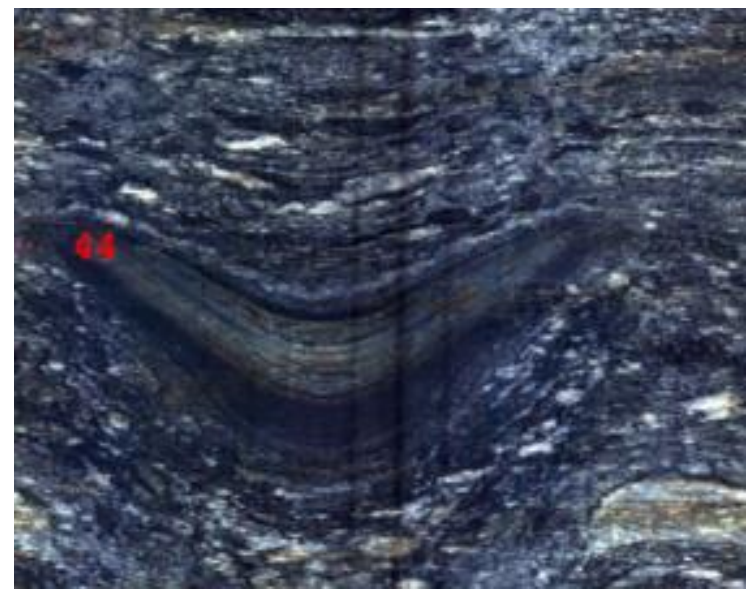

Foto 35 - Televisionamento da sondagem 4515 (Metrô-SP).

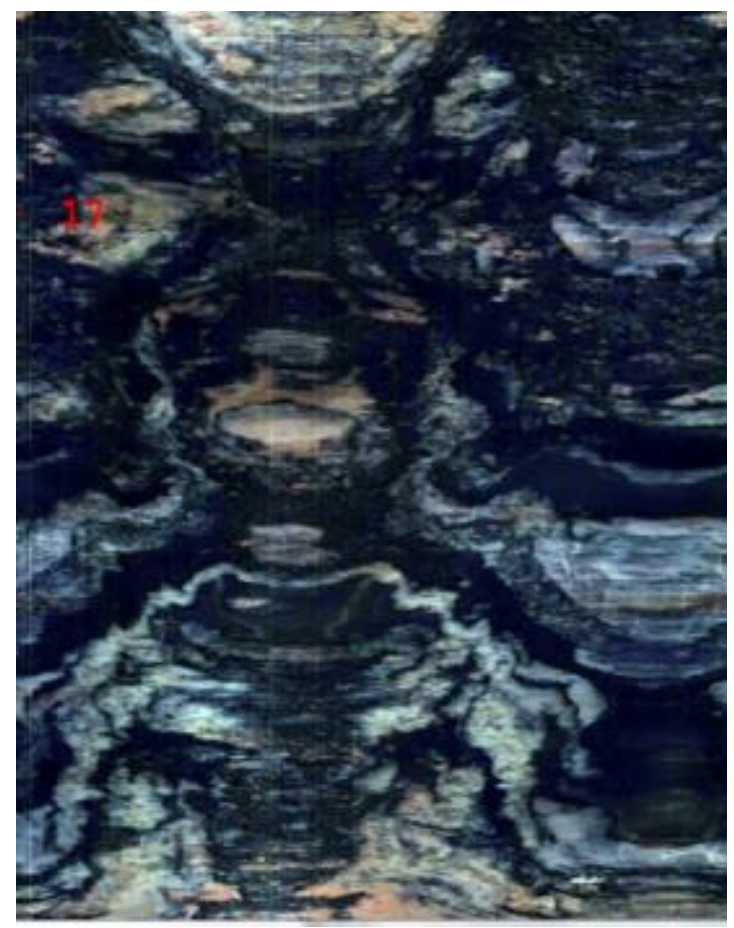

Foto 34 - Televisionamento da sondagem 4540 (Metrô-SP).

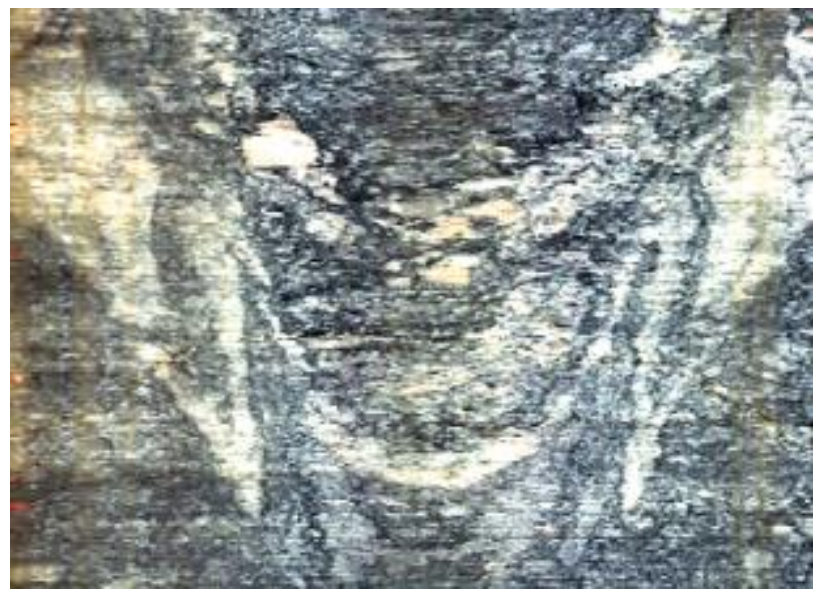

Foto 36 - Televisionamento da sondagem 4559 (presença de veios dobrados) (Metrô-SP). 
Em muitos furos, pode ser observada a presença de feições miloníticas, principalmente quando próximo às falhas citadas. Nestas rochas, os grãos se encontram bastante estirados, quase com aspecto açucarado, foliação bastante evidente e muitas vezes crenulado (Fotos 37 e 38). Também se observou rocha cataclasada em alguns locais, conforme ilustrado nas Fotos 39 e 40. A rocha se encontra bastante foliada, sendo que foi possível estimar a foliação a partir das imagens de televisionamento, considerando os planos de fratura paralelos à foliação. Na maior parte das imagens a foliação média indicada foi 150/50-70 (N60E/50-70SE), sendo que na sondagem 4559 se encontra subvertical $\left(81^{\circ}\right)$ e, em outras, a direção da foliação mudou completamente, como nas sondagens 4536 e 4539 (353/70 e 334/82, respectivamente).

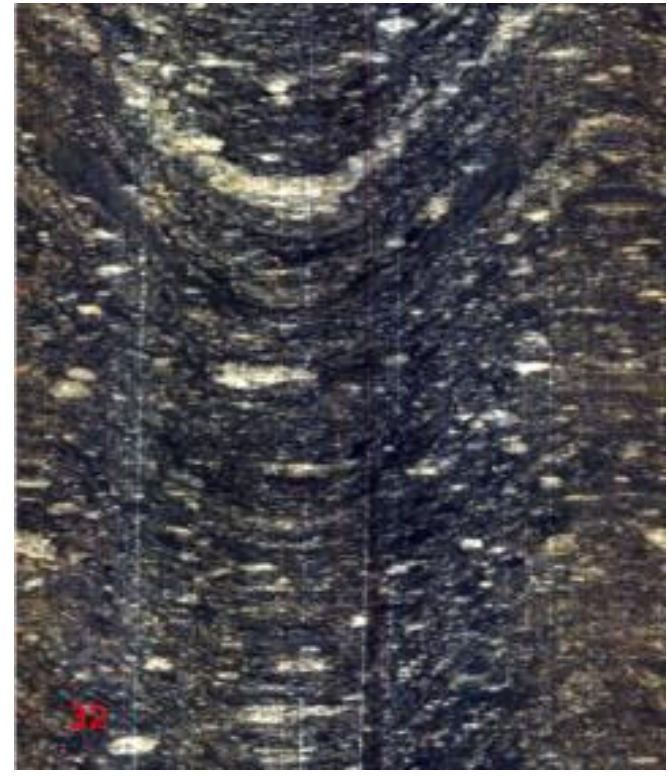

Foto 37 - Televisionamento da sondagem 4515 (Metrô-SP).

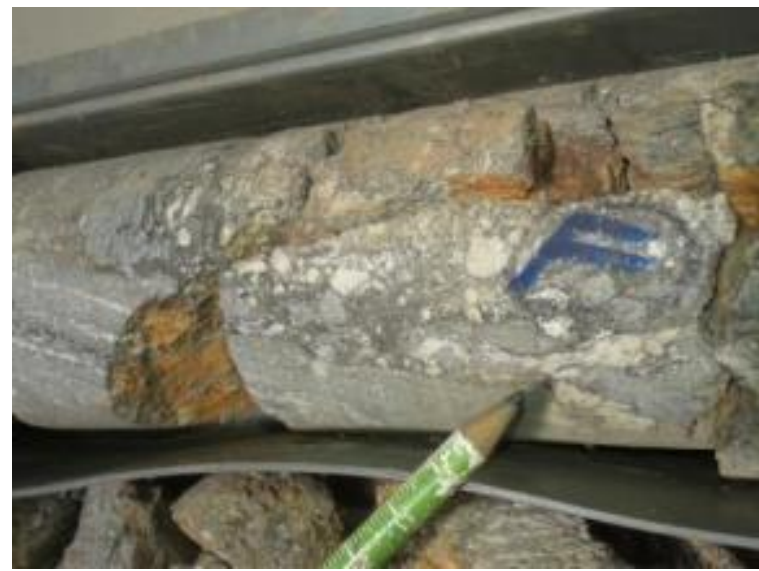

Foto 39 - Testemunho das sondagem 4534 indicando rocha com feições cataclasadas 4515 (Metrô-SP).

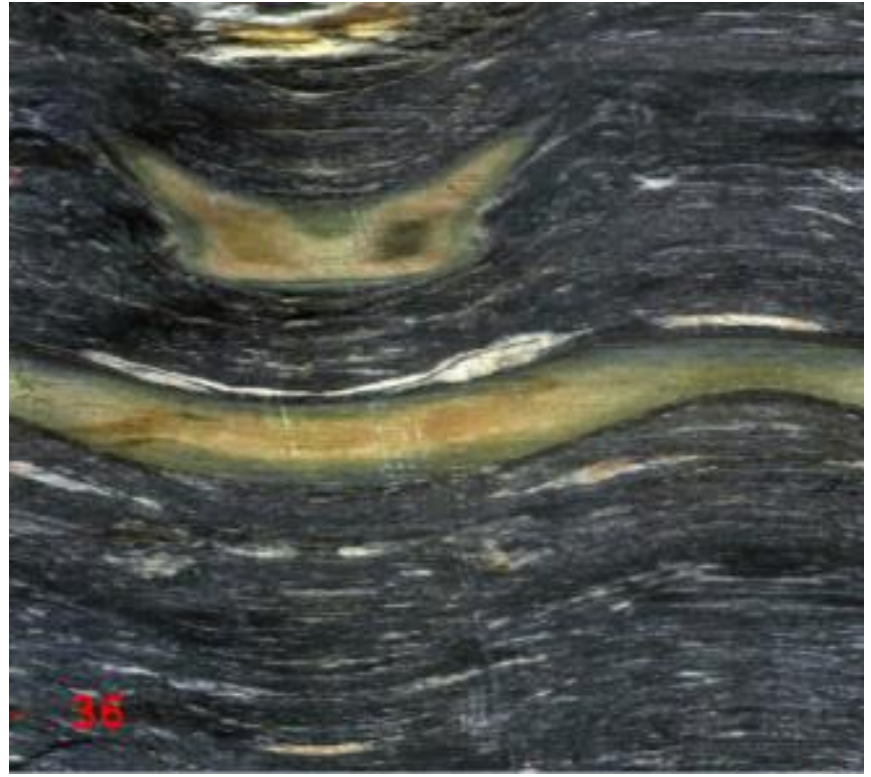

Foto 38 - Televisionamento da sondagem 4548 (aspecto da estrutura milonítica) (Metrô-SP).

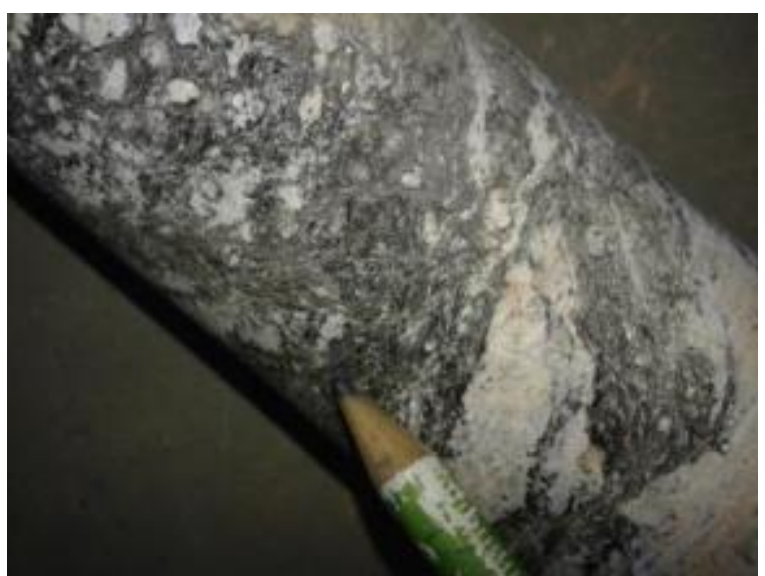

Foto 40 - Testemunho da sondagem inclinada 4539, indicando rocha com feições cataclasadas 4515 (Metrô-SP). 
A rocha em alguns trechos se encontrava sã, muito pouco alterada, coerente, pouco fraturada, valores de RQD próximos a $100 \%$, poucas famílias de fraturas e, por essa razão, foi classificada como classe II, segundo critérios indicados por Bieniaswki (1989). Nos trechos em que se encontrava mais fraturada, mais alterada e com menores valores de RQD, foram classificadas como sendo classe III, sendo, de forma geral, o tipo de maciço que predomina na linha. Nos trechos bem mais fraturados, com rocha mais alterada, maior número de famílias de fraturas e zonas de cisalhamento e falha, foi classificada como classe IV, ou até mesmo classe $\mathrm{V}$, nos casos onde a rocha se encontrava extremamente fraturada e alterada. Vale ressaltar que muitos testemunhos foram verificados para servir como base para esta classificação.

O que se notou, como já comentado anteriormente, foi uma alternância frequente nestas classes de maciço, algumas vezes ocorrendo um trecho inicial classe II/III sobrepondo um trecho de qualidade inferior, como classe IV/V. Provavelmente, isto está relacionado ao fato de ocorrerem lentes com predominância de máficos intercaladas a lentes com predominância de félsicos e, portanto, mais resistentes. Também certamente, estas alternâncias frequentes estão diretamente relacionadas a um controle estrutural, onde ocorrem zonas de falha e zonas de rocha milonitizada.

Também se adiciona a informação que as imagens de televisionamento foram essenciais para esta classificação, pois diversas vezes as informações necessárias para a pontuação segundo os critérios de Bieniawski (1989) estavam ausentes nos perfis de sondagem ou não eram suficientes. Certamente estas imagens contribuíram para uma maior aproximação da realidade da descrição de alguns parâmetros, como abertura, por exemplo. Os dados do televisionamento também foram essenciais na consideração de um dos parâmetros de cálculo de caráter estrutural, referente ao ajuste do RMR com relação à orientação do eixo do túnel versus a orientação das famílias de descontinuidades, após compartimentação da linha em cinco setores, conforme será visto em detalhe mais adiante.

Dois furos de sondagem foram selecionados para ensaio de compressão uniaxial em rocha: um furo na região da Estação Chácara do Jóquei e outro na região da Estação Largo do Taboão. É importante ressaltar que os valores encontrados em alguns trechos foram bastante baixos, condizentes com um maciço classe IV, mesmo o testemunho amostrado aparentar uma rocha de uma classe superior. Talvez isso se deva ao fato de que a rocha está bastante microfissurada, tanto que isso foi observado nas imagens de televisionamento e nos testemunhos. 


\subsubsection{Aspectos geológico-geotécnicos das descontinuidades}

Para a elaboração deste item, foram considerados os dados obtidos no televisionamento das 17 sondagens. Os parâmetros tiveram como base a metodologia proposta exposta, em detalhe, no item 5. Foram desconsideradas todas aquelas descontinuidades classificadas como sendo imperceptíveis, onde não se havia a certeza de que realmente haveria uma quebra no testemunho real de sondagem, conforme já comentado anteriormente. Dentre estes 17 furos, 3 são furos inclinados, o que possibilitou amostrar também as fraturas verticais.

Os dados descritos para os parâmetros alteração das paredes, abertura e rugosidade das descontinuidades, assim como grau de fraturamento foram considerados para a elaboração de gráficos do tipo pizza, indicando a porcentagem de cada parâmetro que ocorria ao longo do trecho televisionado. Cada gráfico de pizza para cada furo considerado foi plotado no mapa utilizando o Software ArcGIS e as imagens provenientes do Google Earth, dessa forma foi possível compreender como cada parâmetro variava ao longo do trecho, como já havia sido feito para o caso anterior, na extensão da Linha 2 Verde.

Na Figura 67, foram plotados os gráficos pizza considerando a variação para o parâmetro alteração das paredes, tendo sido classificados de acordo com a Tabela 9. De uma forma geral, as piores condições de alteração das paredes estão mais concentradas na região do Largo do Taboão (sondagens 4536, 4539, 4540, 4545 e 4603), além da sondagem 4559, que também apresenta quantidade significante de juntas com preenchimento de fragmento de rocha e/ou sedimento argilo arenoso. É importante citar que essas fraturas classificadas tanto como D5 e/ou D6 são juntas abertas, onde este fato, aliado ao tipo de preenchimento, implica numa diminuição significativa da resistência ao cisalhamento. 


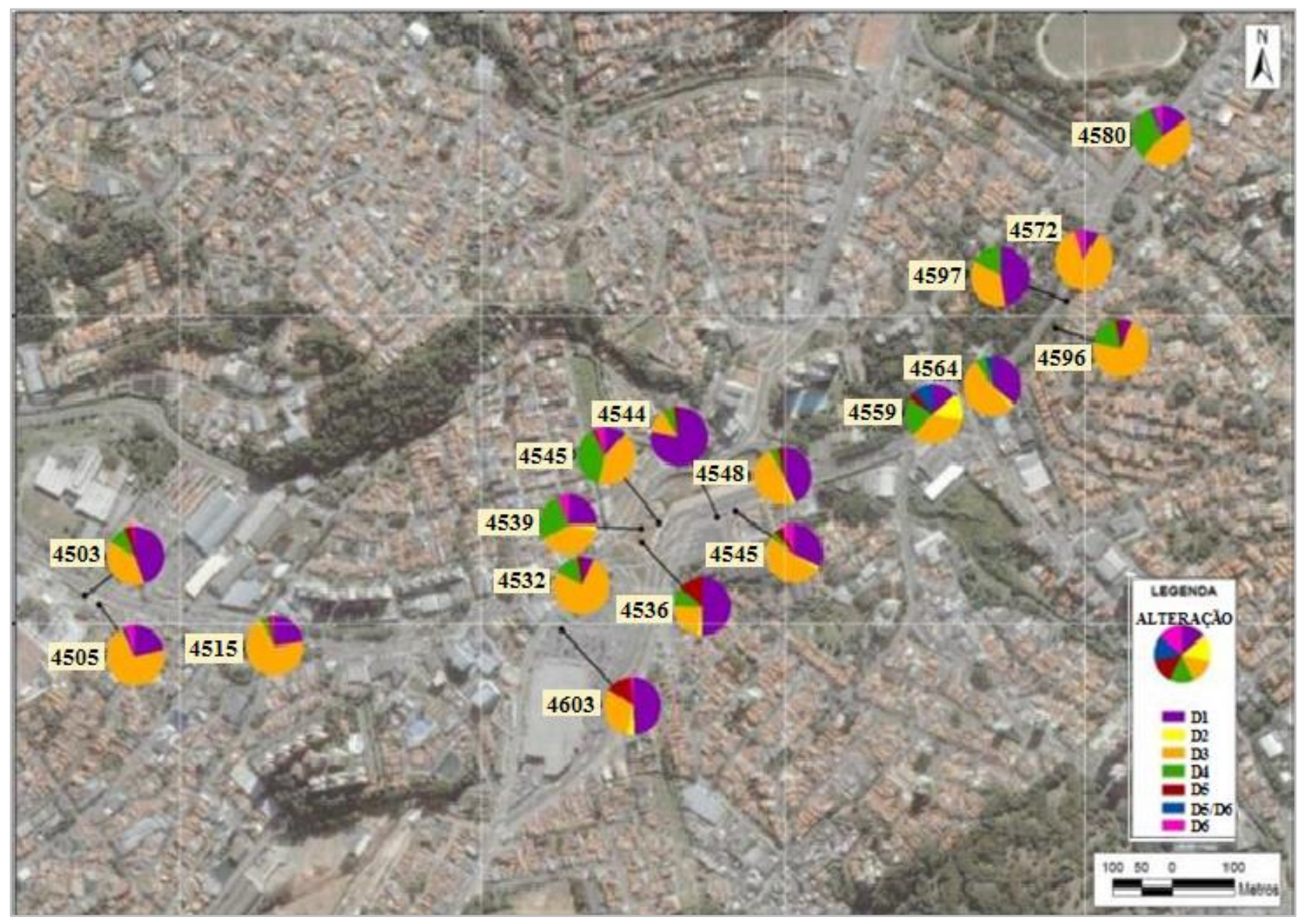

Figura 67 - Variação do parâmetro alteração das paredes das descontinuidades ao longo do trecho.

Para o parâmetro abertura foi considerada a planilha sugerida por ISRM (1978), apresentada na Tabela 3. Os resultados estão apresentados na Figura 68 e apoiam os resultados apresentados na Figura 67, onde as piores fraturas, neste caso as abertas, se encontram também na região do Largo do Taboão (centro-leste da área) e na sondagem 4559. Os furos 4505, 4580 e 4596 também apresentaram uma quantidade relevante de fraturas semi-abertas e abertas. 


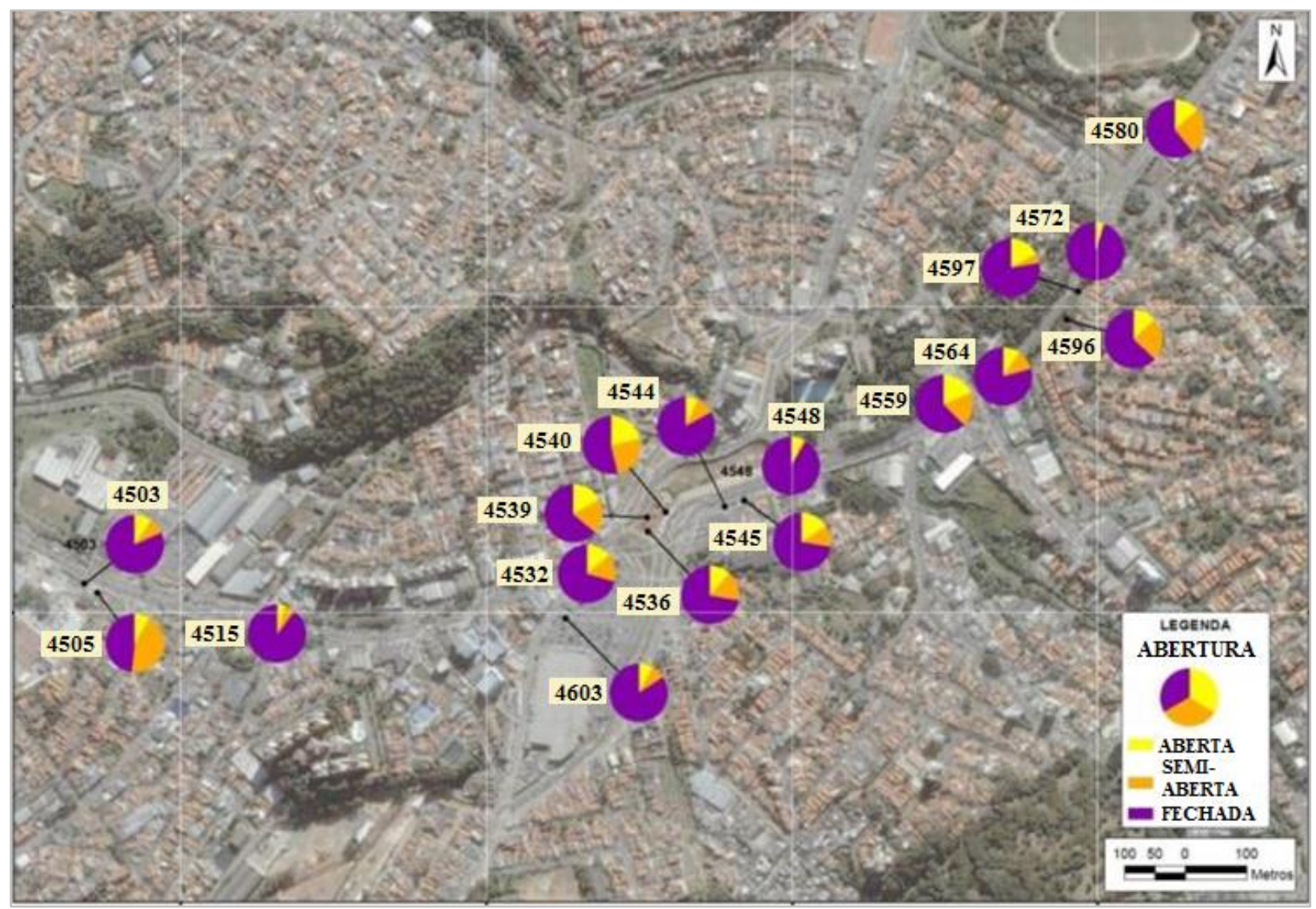

Figura 68 - Variação do parâmetro abertura das descontinuidades ao longo do trecho.

Nas Fotos 41 a 44, é possível verificar algumas descontinuidades abertas nas imagens de televisionamento. $\mathrm{Na}$ foto 42 , a sondagem 4539 foi feita com uma inclinação de $55^{\circ}$, próxima à sondagem 4536. Na sondagem vertical, foi possível verificar a ocorrência de fraturas verticais na lateral da imagem, não sendo possível, entretanto medi-las corretamente, devido a limitações do Software do televisionamento, conforme já relatado. Ao ser executada a filmagem da sondagem 4539, foi possível observar que estas fraturas verticais se encontravam, em sua maioria, abertas, sendo esta uma informação importante para o projeto de escavação do túnel de via. Estas mesmas fraturas abertas de mergulho vertical podem ser observadas na sondagem inclinada 4597 (Foto 44). 


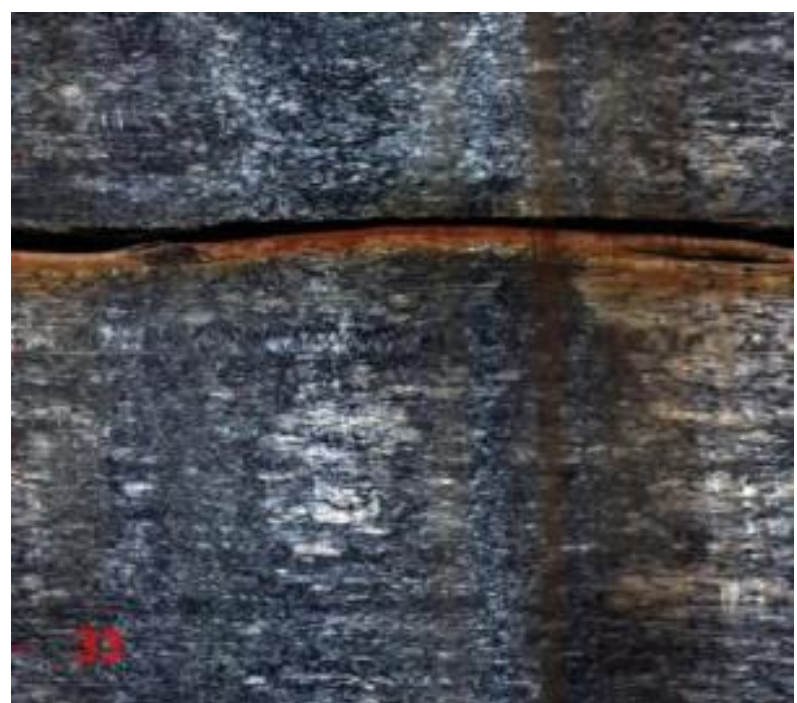

Foto 41- Fratura aberta na sondagem 4559 (Metrô-SP).

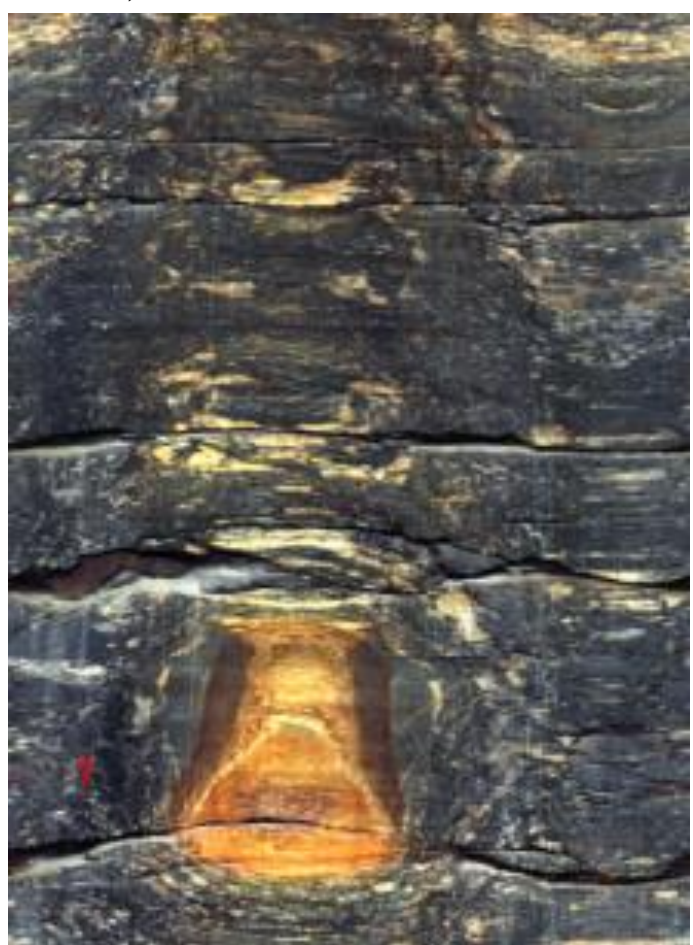

Foto 43 - Fraturas abertas na sondagem 4544 (Metrô-SP).

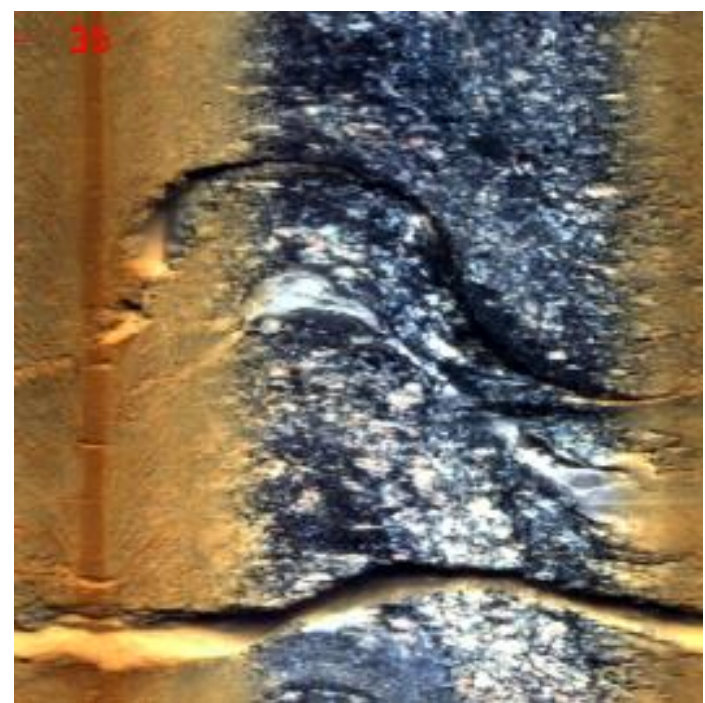

Foto 42- Fraturas abertas na sondagem 4539 (inclinada) (Metrô-SP).

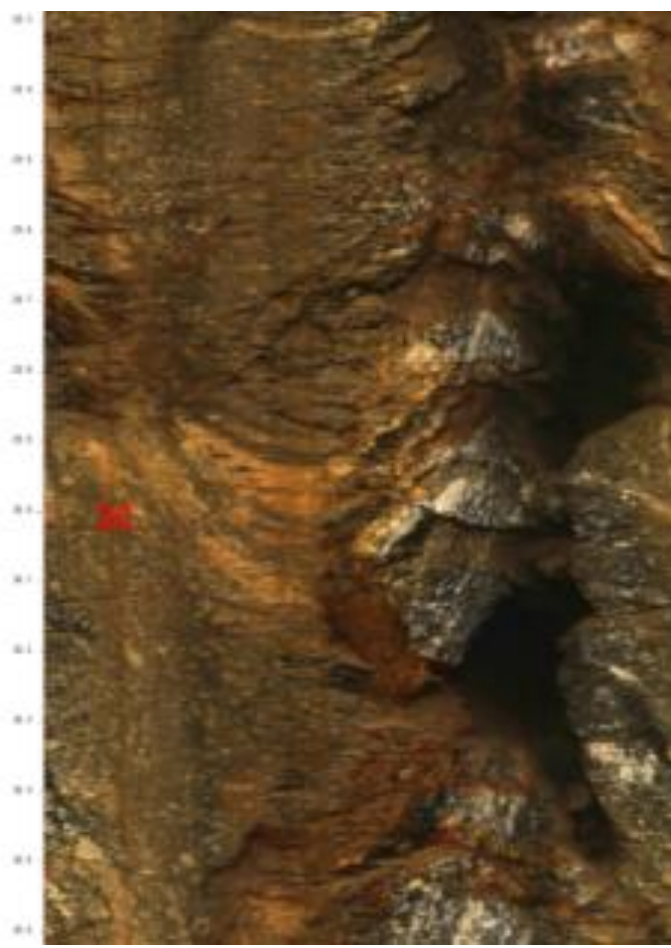

Foto 44 - Conjunto de fraturas abertas, formando fenda, ao longo da sondagem inclinada 4597 (Metrô-SP).

Na Figura 69, está representada a variação do parâmetro rugosidade, segundo o proposto no item 5.2.2. As fraturas foram descritas como rugosas, lisas ou polidas; esta última quando verificada a ocorrência de falha. Conforme se pode observar nesta figura, a frequência maior de fraturas lisas, que seria uma condição geomecânica inferior a uma descontinuidade rugosa, ocorre nas sondagens 4503, 4505, 4539, 4545 e 4559. Também nota-se a ocorrência de uma fratura polida na sondagem 4580 , referente a uma pequena falha observada na imagem. 


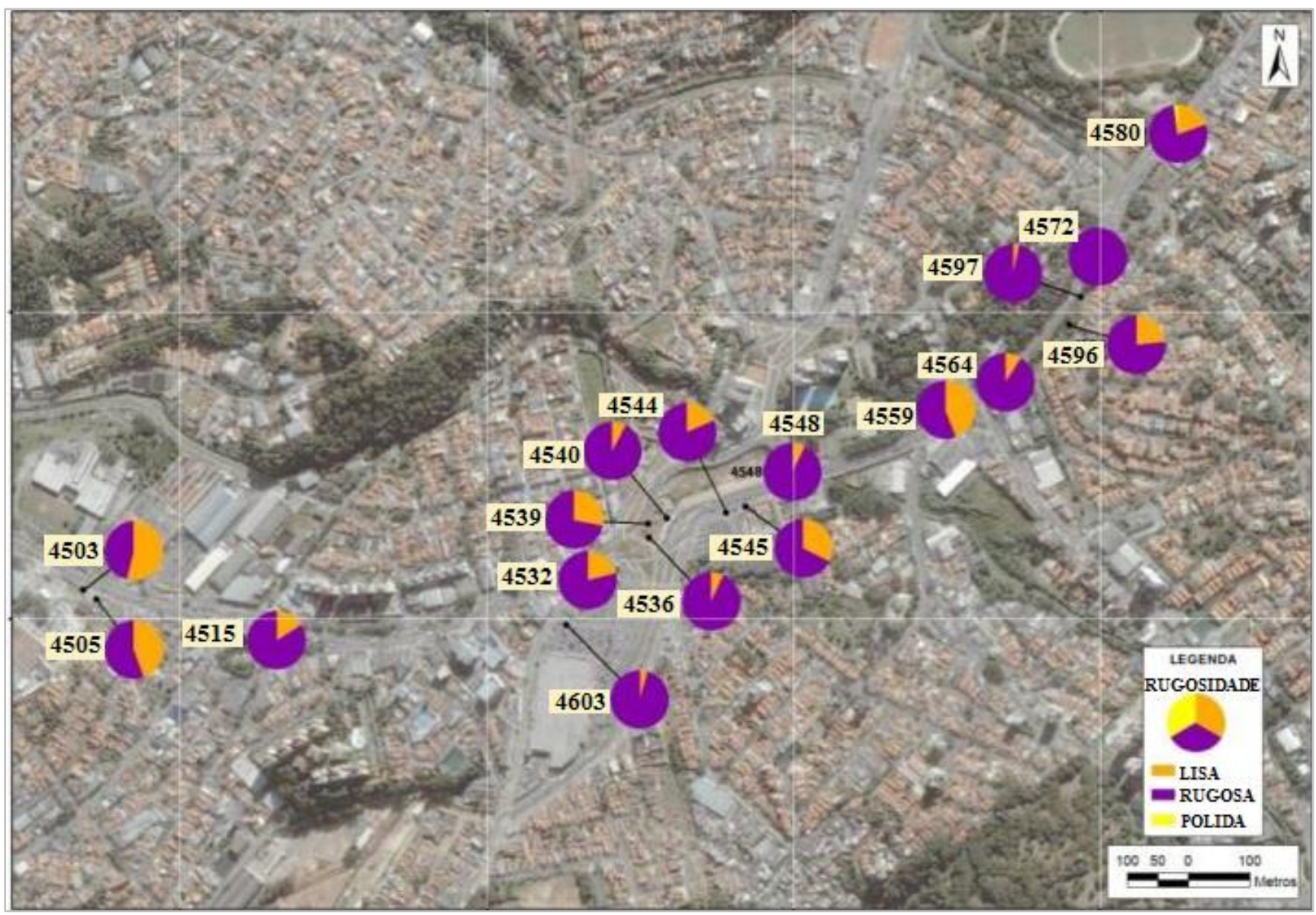

Figura 69 - Variação do parâmetro rugosidade das descontinuidades ao longo do trecho.

E, por último, na Figura 70, foi considerado o parâmetro grau de fraturamento, tendo como base a classificação segundo o IPT, 1984 e apresentado na Tabela 2.

Conforme se observa na Figura 70, as regiões de rocha mais fraturada ao longo do trecho, com maior ocorrência de fraturamento F4, ocorrem próximas aos furos 4503, 4515, 4544, 4545, 4548, 4564 e 4597. As sondagens do Largo do Taboão, apesar de terem qualidades piores para condições de alteração das paredes e abertura das descontinuidades, não se encontram tão fraturados como estes furos citados acima.

Com relação ao furo 4544, foi levantada uma quantidade significativa de F5, ou seja, acima de 20 fraturas por metro, também tendo sido caracterizados no perfil de sondagem trechos de fraturamento F5. Na Foto 43, é possível observar as condições de fraturamento deste furo televisionado. Este furo 4544, juntamente com os furos 4545 e 4548, próximo a este, são os furos com maior incidência de grau de fraturamento F4/F5, além do furo inclinado 4597. O furo 4597, locado proximamente ao furo 4596 , foi perfurado na direção $280^{\circ}$, mergulhando $80^{\circ}$ e interceptou trechos com fraturas extremamente abertas, conforme pode ser visualizado na Foto 44. Todos estes 
furos acima indicam trechos ao longo da linha nos quais deve ser tomada uma precaução maior durante a escavação do maciço, por serem trechos com pior qualidade de rocha.

Também é importante considerar que os furos televisionados não necessariamente implicam sempre nas piores condições do maciço encontradas, sendo que há outros furos, como o furo 4520, por exemplo, no qual o testemunho de sondagem reflete um maciço bastante fraturado e com rocha cisalhada, porém não tendo sido televisionado. De forma geral, as fraturas observadas tanto no televisionamento como nos testemunhos de sondagem, em sua maioria, não apresentaram alterações piores do que uma película argilosa ou paredes oxidadas. Vale ressaltar que a família subvertical observada principalmente nos furos inclinados teve maior incidência de fraturas abertas que o restante das fraturas, podendo ser estas as juntas distensivas mencionadas por Hasui et al. (1993), no item 4.1.7.

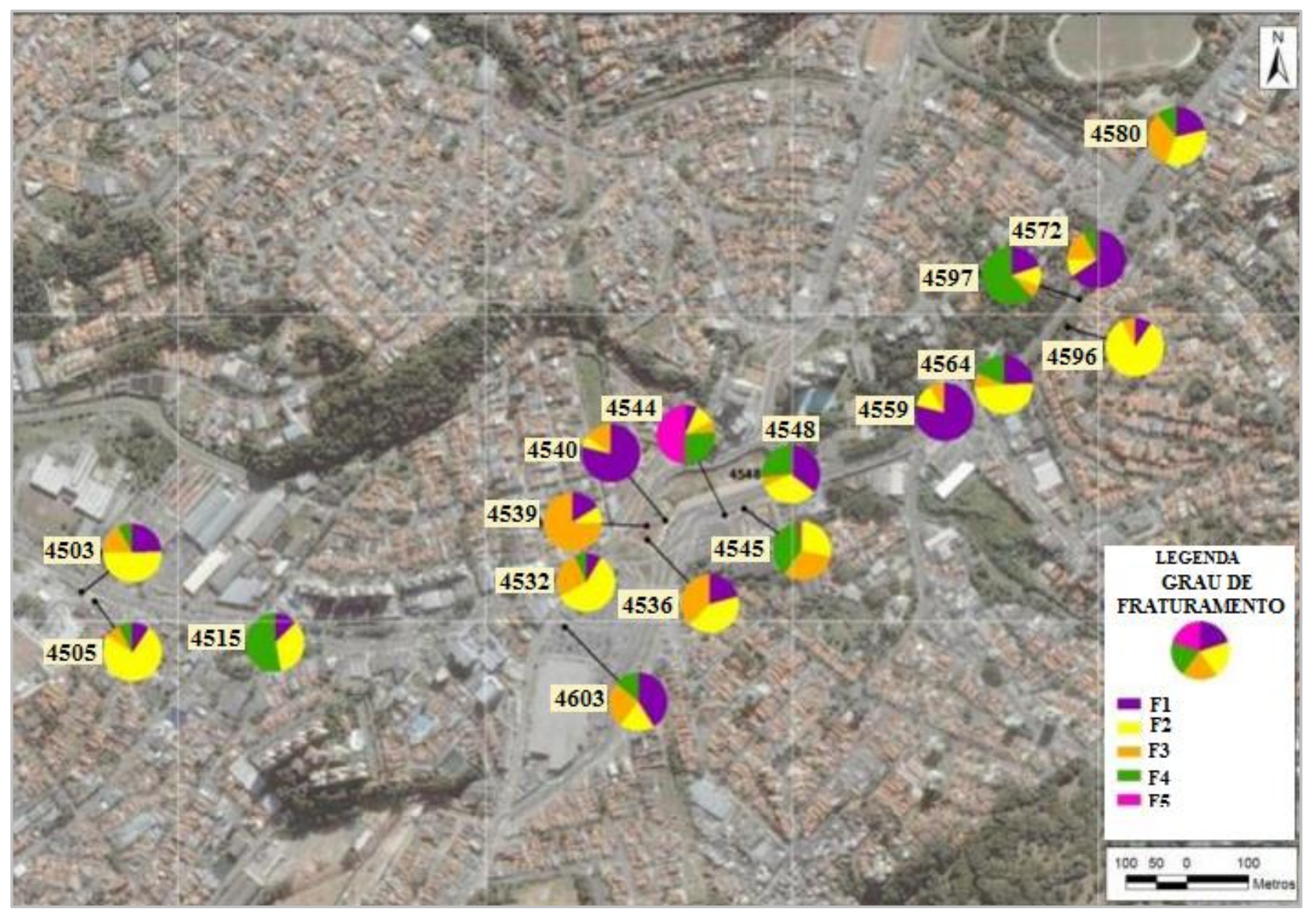

Figura 70 - Variação do parâmetro grau de fraturamento ao longo do trecho.

\subsubsection{Análise estrutural e de estabilidade cinemática}

A análise estrutural utilizou os dados provenientes do televisionamento do total de 17 furos de sondagem, sendo que desses 17 furos, três foram executados com mergulho menor que $90^{\circ}$ (furos 
4539,4597 e 4603 , com $55^{\circ}, 80^{\circ}$ e $70^{\circ}$, respectivamente). Também, como já mencionado, não foram consideradas para esta análise as fraturas classificadas como imperceptíveis. Para a confecção dos estereogramas, foi utilizado diagrama de concentração de polos pela rede Schmidt-Lambert, hemisfério inferior, a partir do Software Dips (Rocscience, 1999).

Posteriormente, as principais famílias foram utilizadas para análises cinemáticas bidimensionais, segundo parâmetros definidos por Hoek \& Bray (1981) e tridimensionais, definindo os principais blocos formados, a partir da combinação de todos os principais sets de descontinuidades, segundo o proposto por Goodman \& Shi (1985). Para esta última análise, utilizouse o Software Unwedge (Rocscience, 2004), utilizando-se a seção do túnel de via deste projeto, conforme detalhado mais adiante.

Inicialmente analisou-se cada furo separadamente (Figuras 71 a 87), e também, analisaram-se em conjunto todos os furos (Figura 88). Neste último caso, foram consideradas apenas as fraturas abertas e semi-abertas, com o objetivo de garantir que as fraturas consideradas abordavam realmente planos relevantes. Tomou-se esta posição, pois se notou uma tendência de inclusão de diversos planos que não se tratavam necessariamente de descontinuidades evidentes e relevantes à análise estrutural que, muito possivelmente, não implicariam na quebra do testemunho de sondagem, evitando assim uma grande dispersão dos dados.

Podem-se observar na maioria dos furos três famílias principais, com exceção do furo 4572. Uma das famílias encontradas também é a mesma dos planos de foliação, tendo sido esta chamada de F1, com orientação aproximada N60E/55SE. A outra família considerada é subhorizontal, tendo sido chamada de F2, com orientação aproximada E-W/10N. E a última família, subvertical, pode ser observada principalmente nos furos inclinados (4539, 4597 e 4603), tendo atitude aproximada N45W/89NE. É claramente visível que a família de maior concentração é a família subhorizontal; contudo, isso muito possivelmente se deve ao enviesamento dos dados, já que a maioria destes furos é vertical, havendo uma tendência de se medir com maior frequência as juntas horizontais. Também reflexo desse viés seria que as juntas verticais só aparecem com maior incidência nas sondagens inclinadas, entretanto tais sets de famílias foram observados ao se verificar os testemunhos de sondagens.

Com relação à foliação, por se tratar de uma rocha migmatítica, muitas vezes esta não se encontrava tão evidente nas imagens e mudando constantemente de direção. Entretanto, como não foi claramente indicada no televisionamento dos furos, muitas vezes tendo sido indicada incorretamente, optou-se por não incluir separadamente os planos de foliação nos estereogramas, tendo sido considerada esta feição simplesmente paralela à família F1. Inclusive esta direção da família F1 
(N60E/55SE) é muito próxima da encontrada em medidas da foliação obtidas em solo residual no Pátio Vila Sônia, segundo relatório técnico do projeto executivo da Fase 2 (RT-4.20.00.00/6C3-002, CMSP, 2012), onde foi definido um plano médio com atitude N70E/70SE, o que é concordante com a medida do trend regional, ENE-WSW, aproximadamente paralela à Falha de Caucaia, apoiando a decisão de incluir a foliação na família F1 para esta análise.

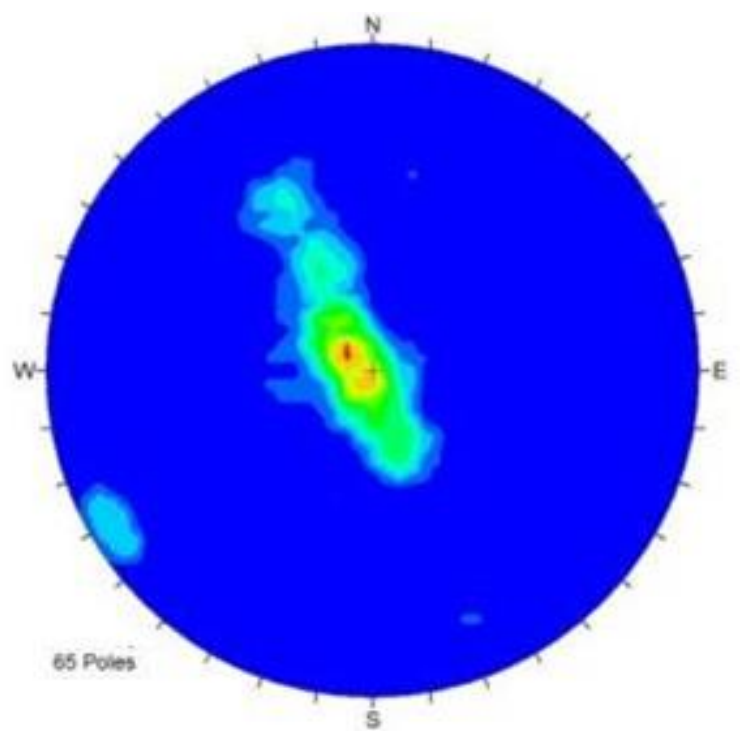

Figura 71 - Estereograma de concentração de polos das fraturas para a sondagem televisada 4503.

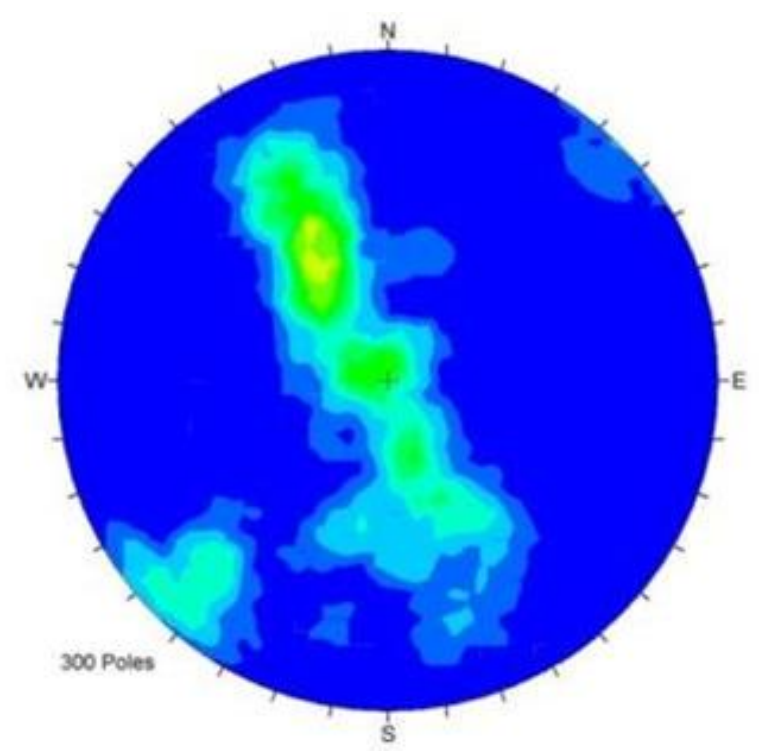

Figura 73 - Estereograma de concentração de polos das fraturas para a sondagem televisada 4515.

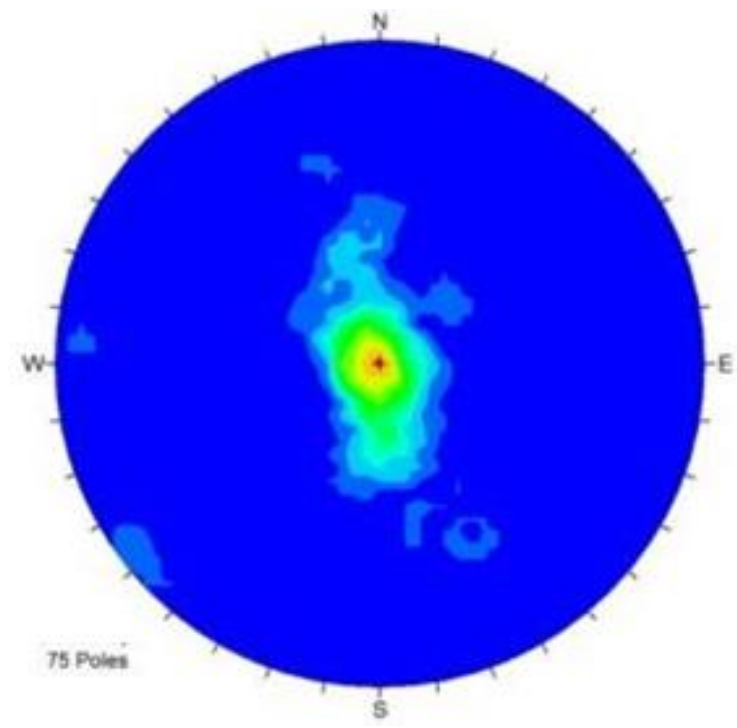

Figura 72 - Estereograma de concentração de polos das fraturas para a sondagem televisada 4505.

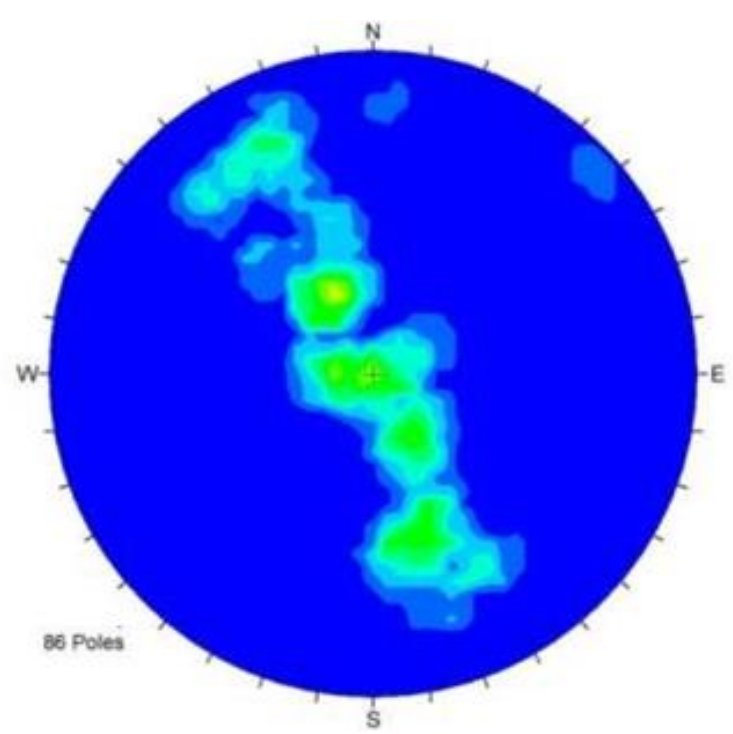

Figura 74 - Estereograma de concentração de polos das fraturas para a sondagem televisada 4532. 


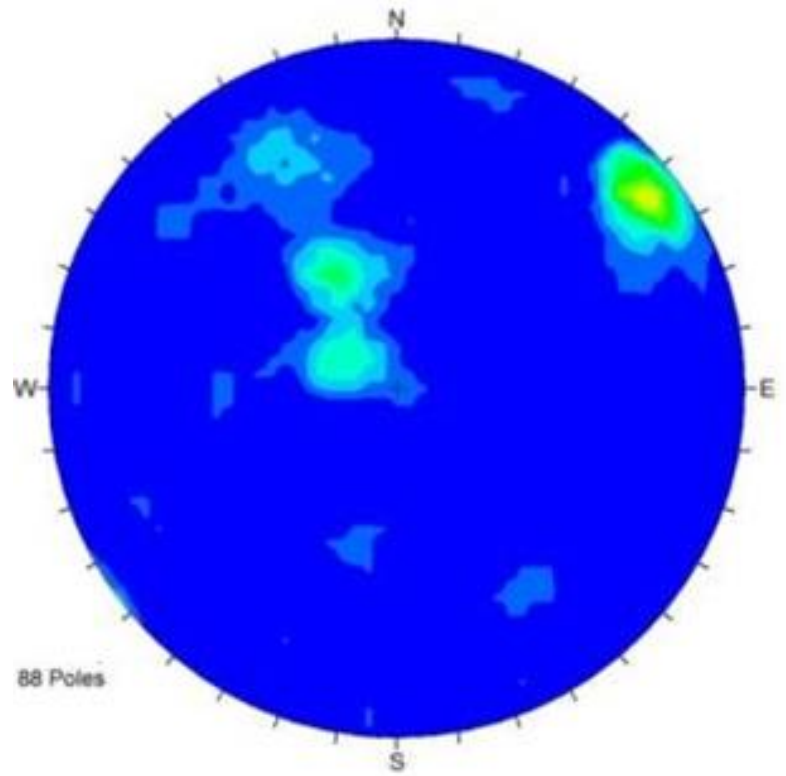

Figura 75 - Estereograma de concentração de polos das fraturas para a sondagem televisada 4536.

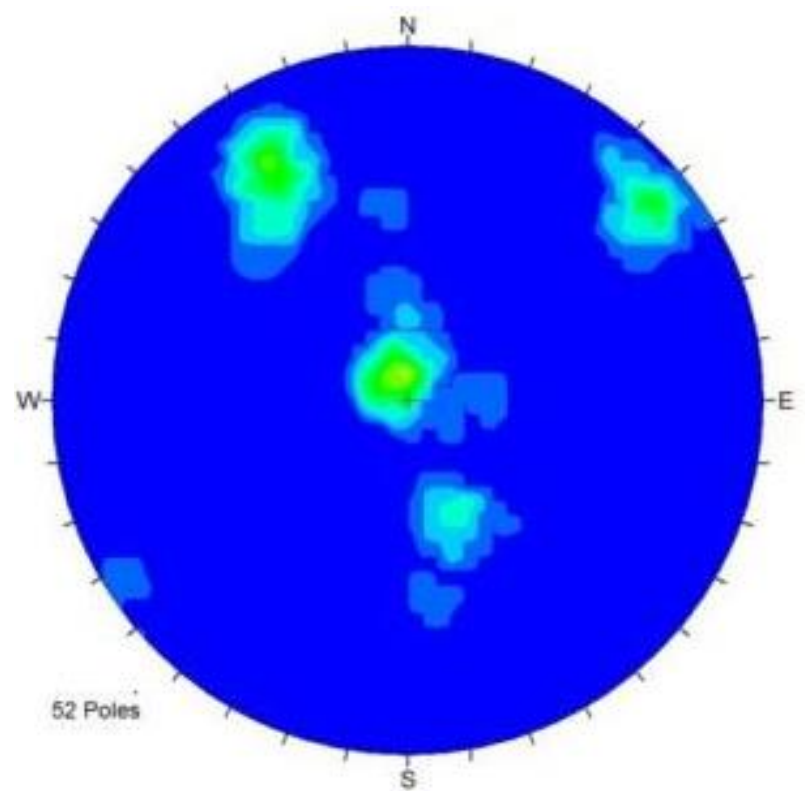

Figura 77 - Estereograma de concentração de polos das fraturas para a sondagem televisada 4540 .

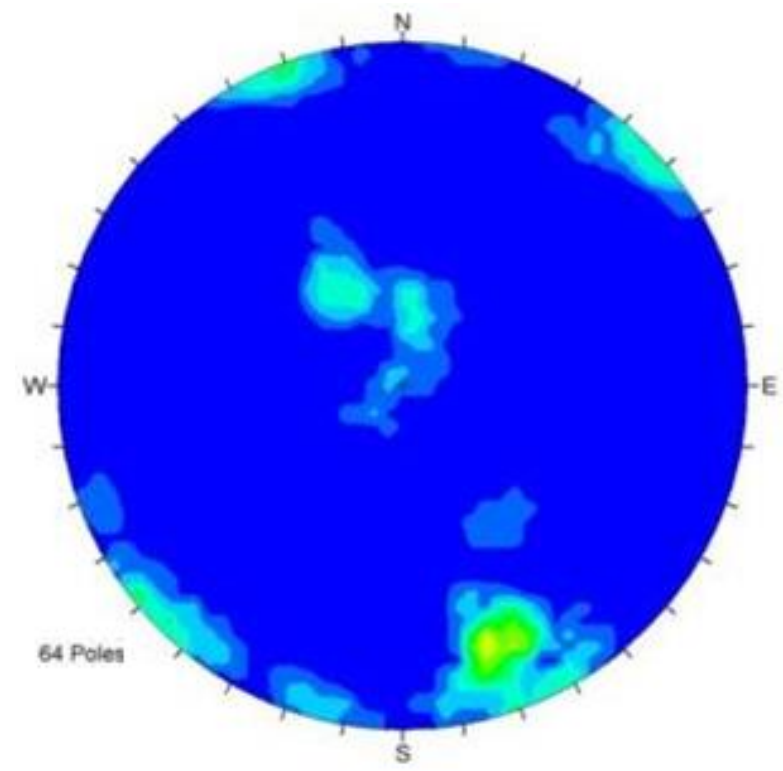

Figura 76 - Estereograma de concentração de polos das fraturas para a sondagem televisada 4539 (inclinada).

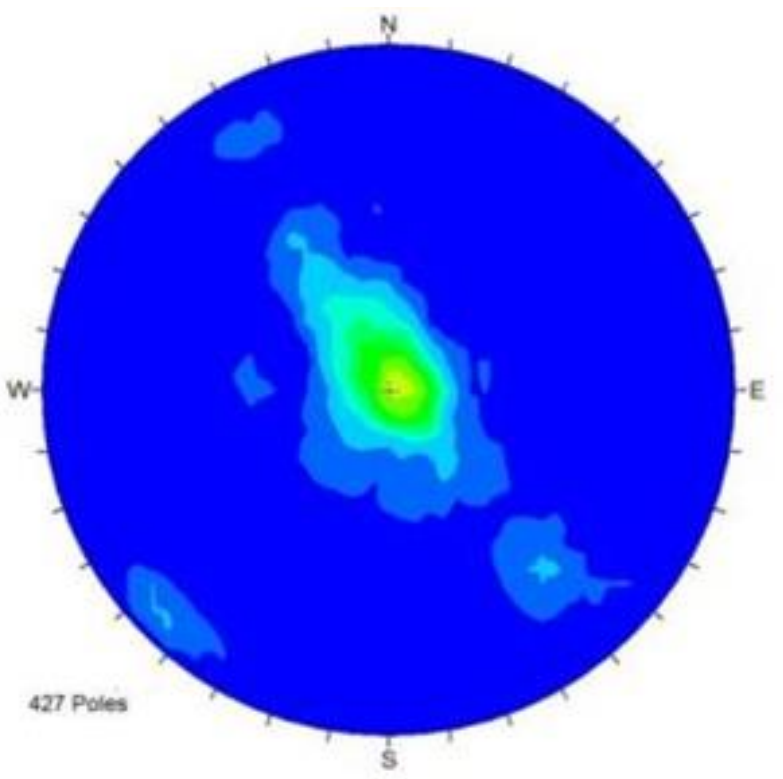

Figura 78 - Estereograma de concentração de polos das fraturas para a sondagem televisada 4544. 


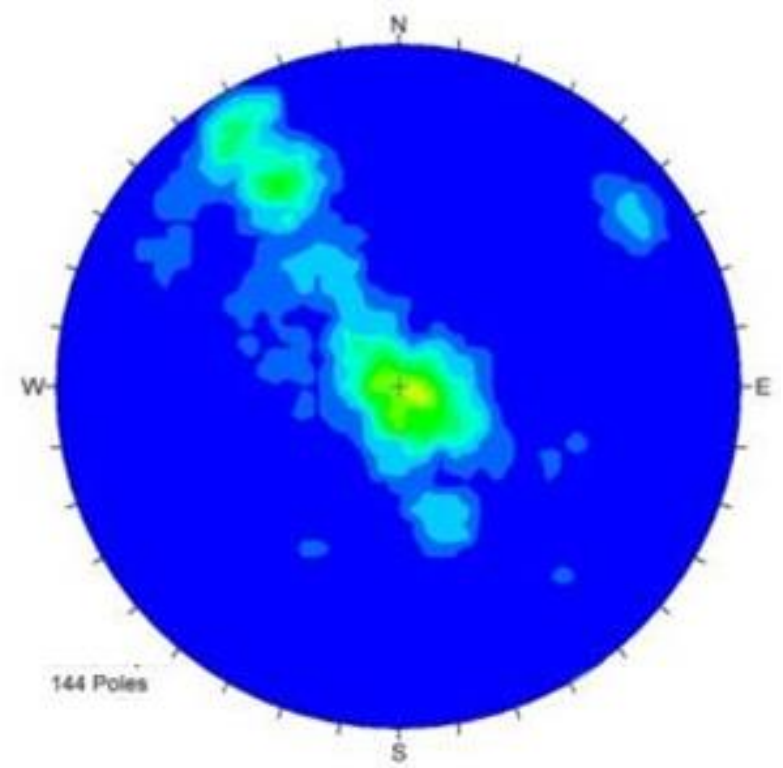

Figura 79 - Estereograma de concentração de polos das fraturas para a sondagem televisada 4545.

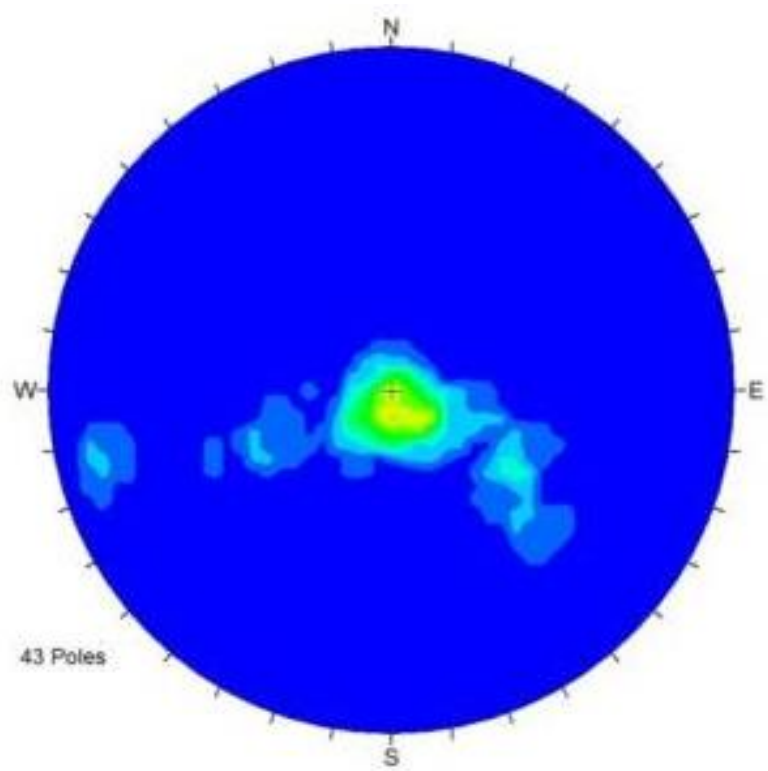

Figura 81 - Estereograma de concentração de polos das fraturas para a sondagem televisada 4559.

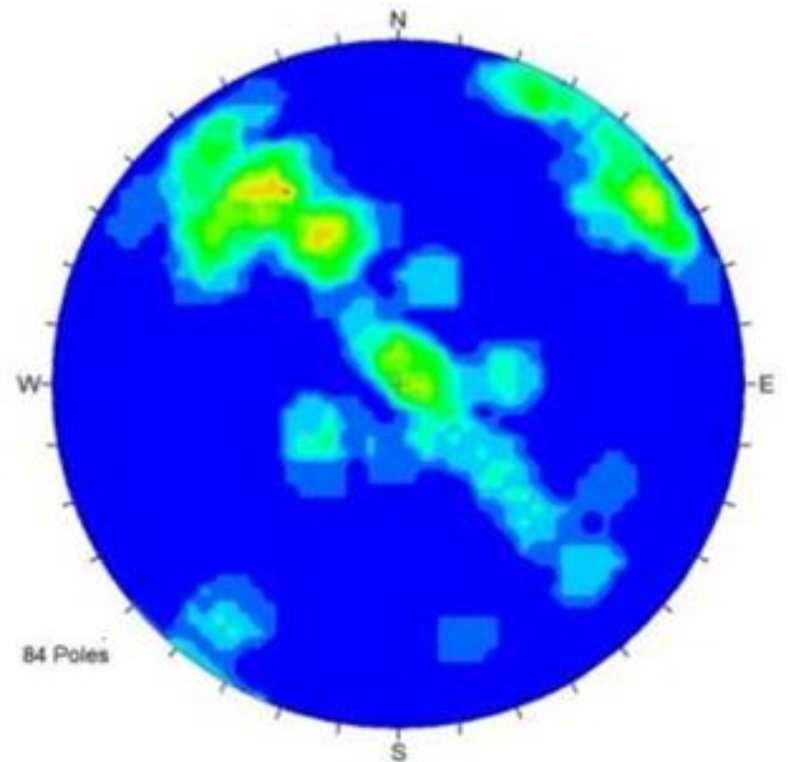

Figura 80 - Estereograma de concentração de polos das fraturas para a sondagem televisada 4548.

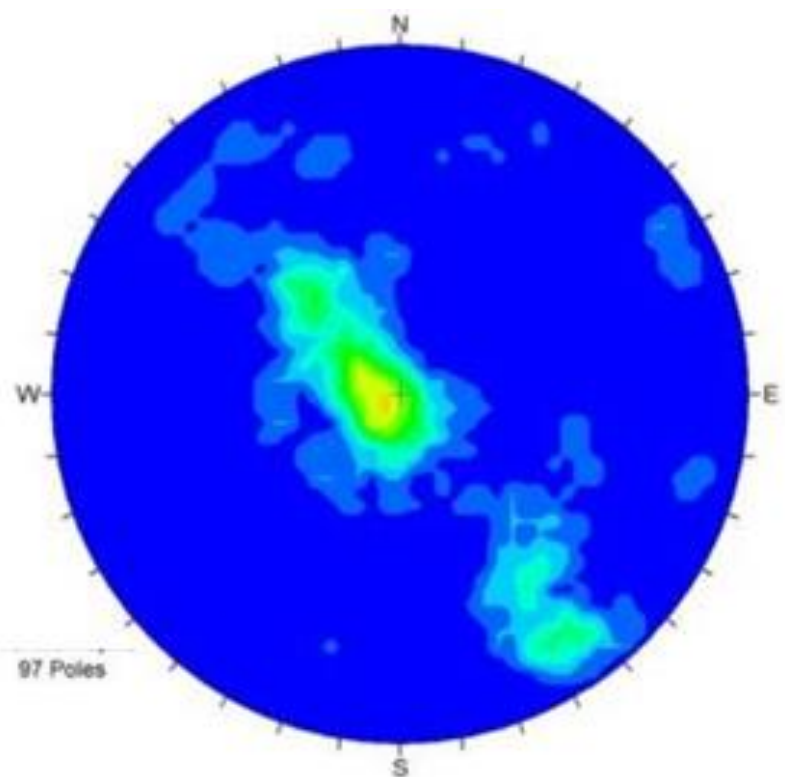

Figura 82 - Estereograma de concentração de polos das fraturas para a sondagem televisada 4564. 


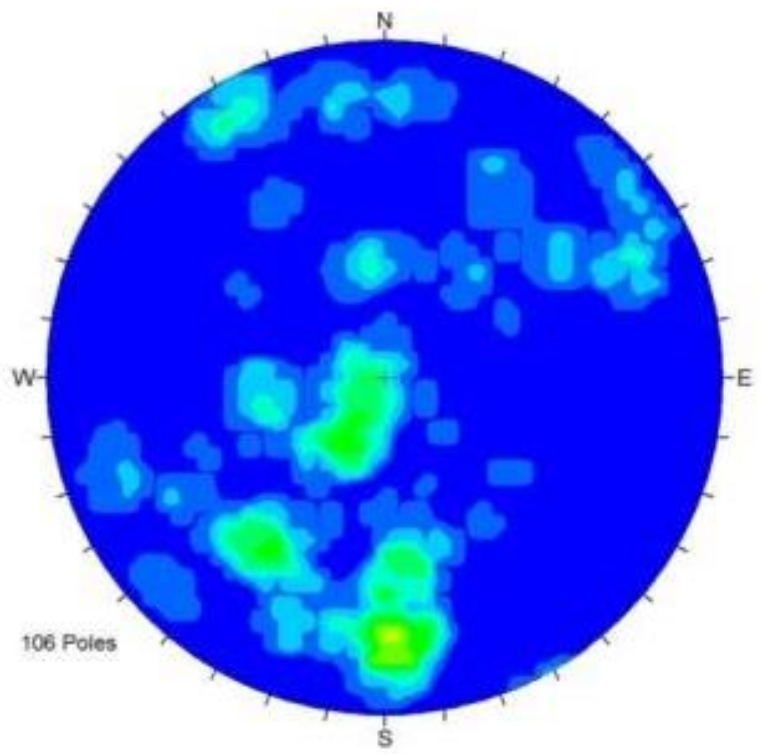

Figura 83 - Estereograma de concentração de polos das fraturas para a sondagem televisada 4572.

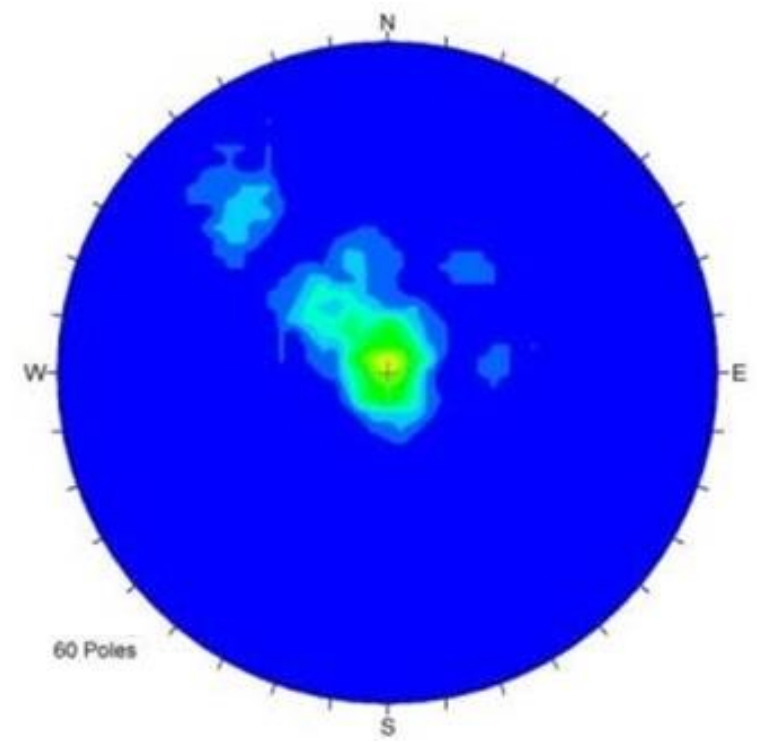

Figura 85 - Estereograma de concentração de polos das fraturas para a sondagem televisada 4596.

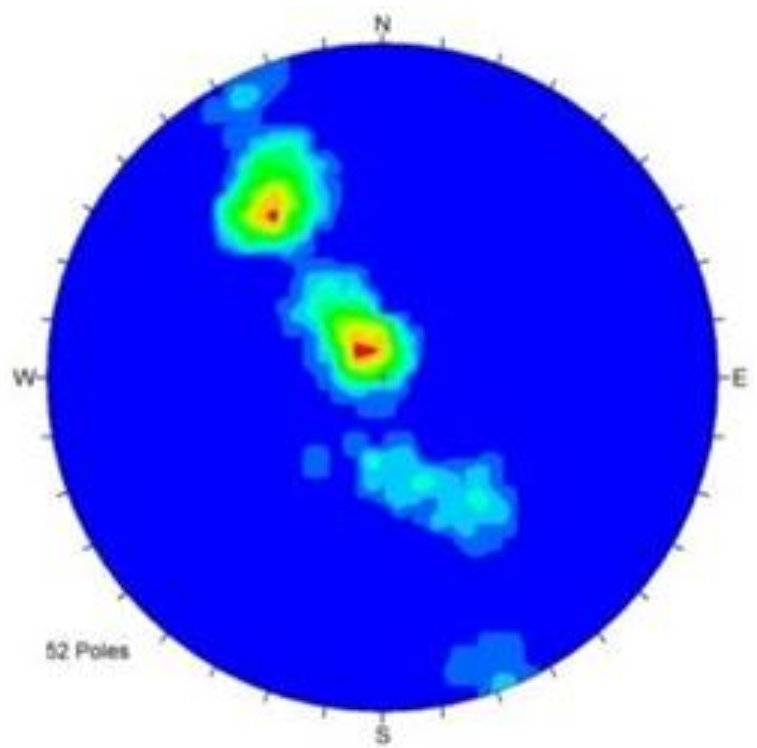

Figura 84- Estereograma de concentração de polos das fraturas para a sondagem televisada 4580.

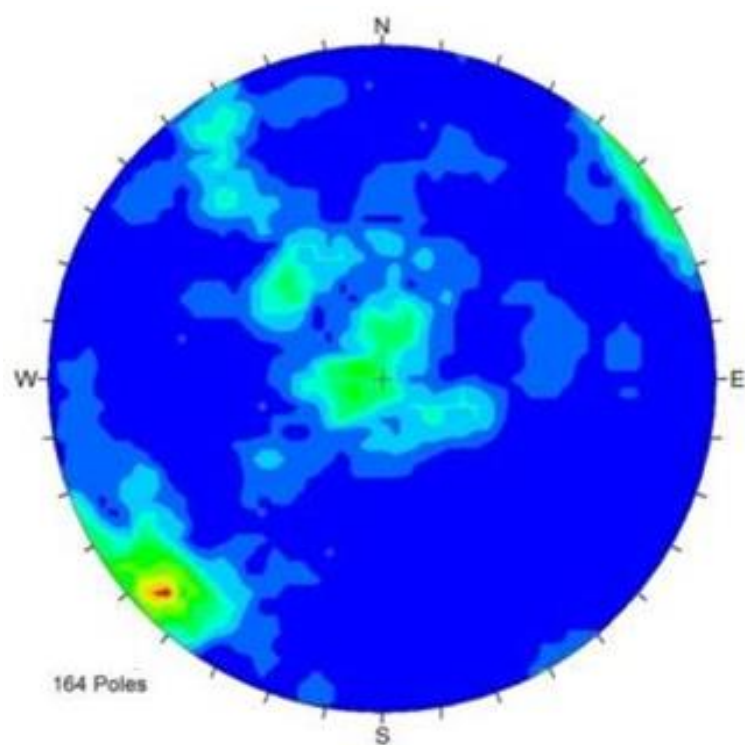

Figura 86 - Estereograma de concentração de polos das fraturas para a sondagem televisada 4597 (inclinada). 

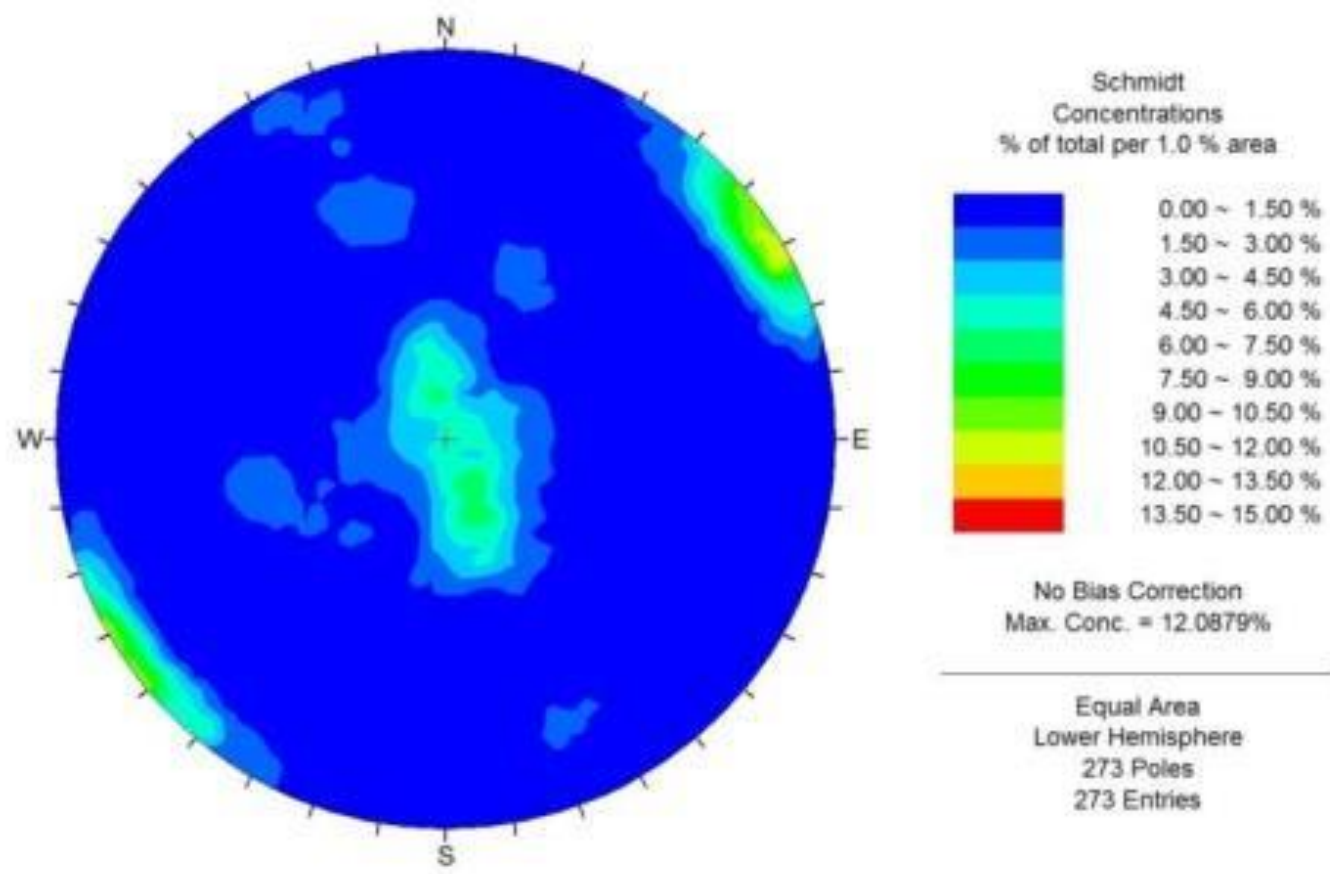

No Bias Correction Max Conc $=12.0879 \%$

Equal Area

Lower Hemisphere

273 Poles

273 Entries

Figura 87 - Estereograma de concentração de polos das fraturas para a sondagem televisada 4603 (inclinada).

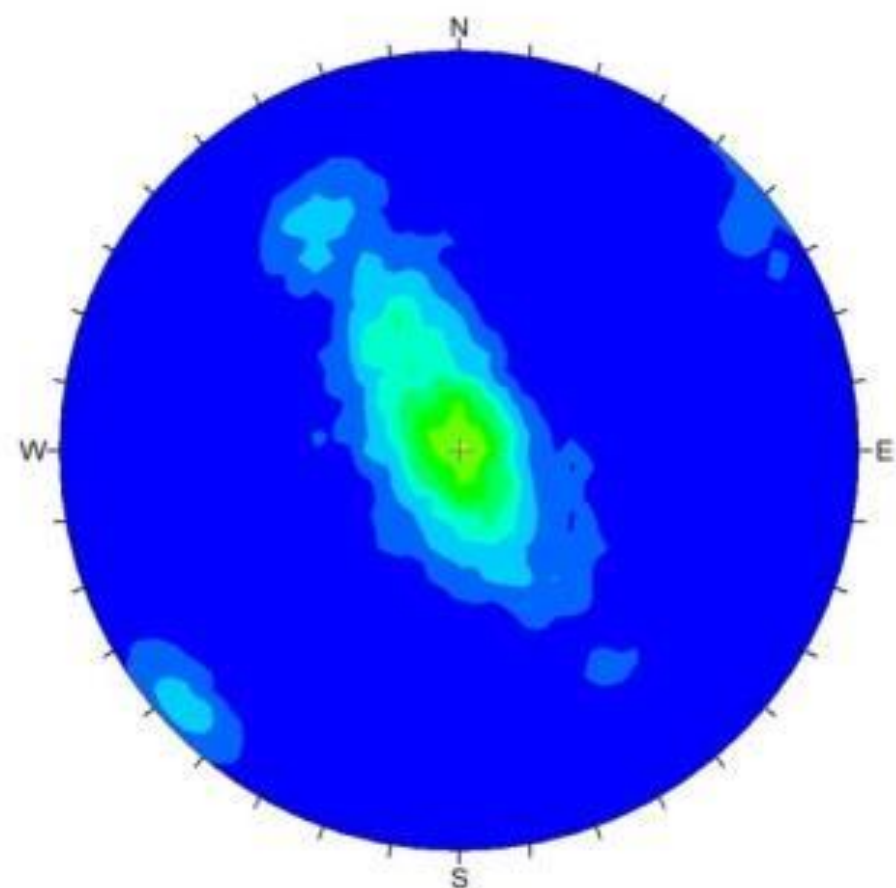

Schmidt

Concentrations

$\%$ of total per $1.0 \%$ area

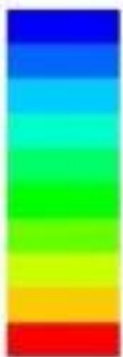

$0.00-1.50 \%$

$1.50-3.00 \%$

$3.00-4.50 \%$

$4.50-6.00 \%$

$6.00-7.50 \%$

$7.50=9.00 \%$

$9.00 \sim 10.50 \%$

$10.50-12.00 \%$

$12.00 \sim 13.50 \%$

$13.50-15.00 \%$

No Bias Correction Max. Conc $=10.7660 \%$

Equal Area

Lower Hemisphere

483 Poles

483 Entries

Figura 88 - Estereograma de concentração de polos das fraturas de todos os furos, considerando-se apenas as fraturas abertas e semi-abertas. 
Na Figura 88, é possível observar o conjunto das concentrações de polos para todos os furos de sondagem. Devido à similaridade dos diagramas, pode-se afirmar que há um padrão estrutural coerente observado a partir dos dados de televisionamento destas sondagens.

É possível fazer uma comparação direta das famílias aqui encontradas com as famílias levantadas por Hasui (1993) em seus estudos para a CMSP nesta mesma Linha 4, conforme já detalhado no item 4.1.7 - Geologia Estrutural. Uma primeira comparação seria com relação à foliação que, segundo Hasui (1993), esta, segundo suas observações, constituiria em subvertical (N79E/subvert) e não inclinada (N60E/55SE), todavia isto poderia ter sido afetado pela obtenção das medidas estruturais em zona mais próxima a uma zona de cisalhamento, com foliação verticalizada. Em algumas das imagens, foi possível observar uma foliação verticalizada, porém, não havendo sido possível delimitar sua atitude exata. Hasui denominou esta família de F1, sendo estas, juntas de relaxamento. Esta família F1 de Hasui pode ser observada principalmente nos furos inclinados, especialmente o furo 4539, onde se torna bastante evidente. Como poderá ser visto mais adiante, este set foi evidenciado apenas na Linha Estrutural 3, como F7.

A família 2 de Hasui, também subvertical, foi a denominada aqui de F3, família subvertical, tendo sido encontrada em praticamente todos os furos analisados, principalmente furo 4559. Estas juntas referentes à família 2 são as juntas de tração e, segundo relatório técnico da Linha 4 - Fase 2, seriam as fraturas mais abertas e mais propensas à percolação de fluídos.

As famílias 3 e 4 de Hasui de direção NW-SE e NNE-SSW correspondem às direções de falhas conjugadas sintéticas e antitéticas ( $R$ e R'), respectivamente. A família 3 de Hasui foi observada apenas no furo 4505 e a família 4 foi observada nos furos 4539 e 4548 . Em alguns casos, as famílias 2 e 4 se juntaram e formaram uma mesma concentração, ou até mesmo foi encontrada uma concentração na média entre estes dois planos de concentração.

A família 5 de Hasui correspondente à família F1 deste estudo, encontrada na maioria dos furos analisados, seria a que foi considerada paralela à foliação aqui neste estudo. A família 6 de Hasui foi encontrada sem concentração significativa nos furos 4548, 4559, 4572 e 4597. E, por último, a família 7 de Hasui corresponde à família aqui denominada de F2, subhorizontal, sendo esta certamente a mais significativa neste levantamento, tanto conforme pode ser observado nos estereogramas, assim como diretamente nas imagens do televisionamento.

Para dar continuidade à análise estrutural, optou-se por dividir a linha em 5 setores, conforme a mudança principal da direção do eixo do túnel de via, setores estes indicados na Figura 89. Para 
cada setor, foram selecionadas apenas as sondagens que ocorrem dentro de cada setor, com exceção da sondagem 4572, que se encontrava no limite entre dois setores.

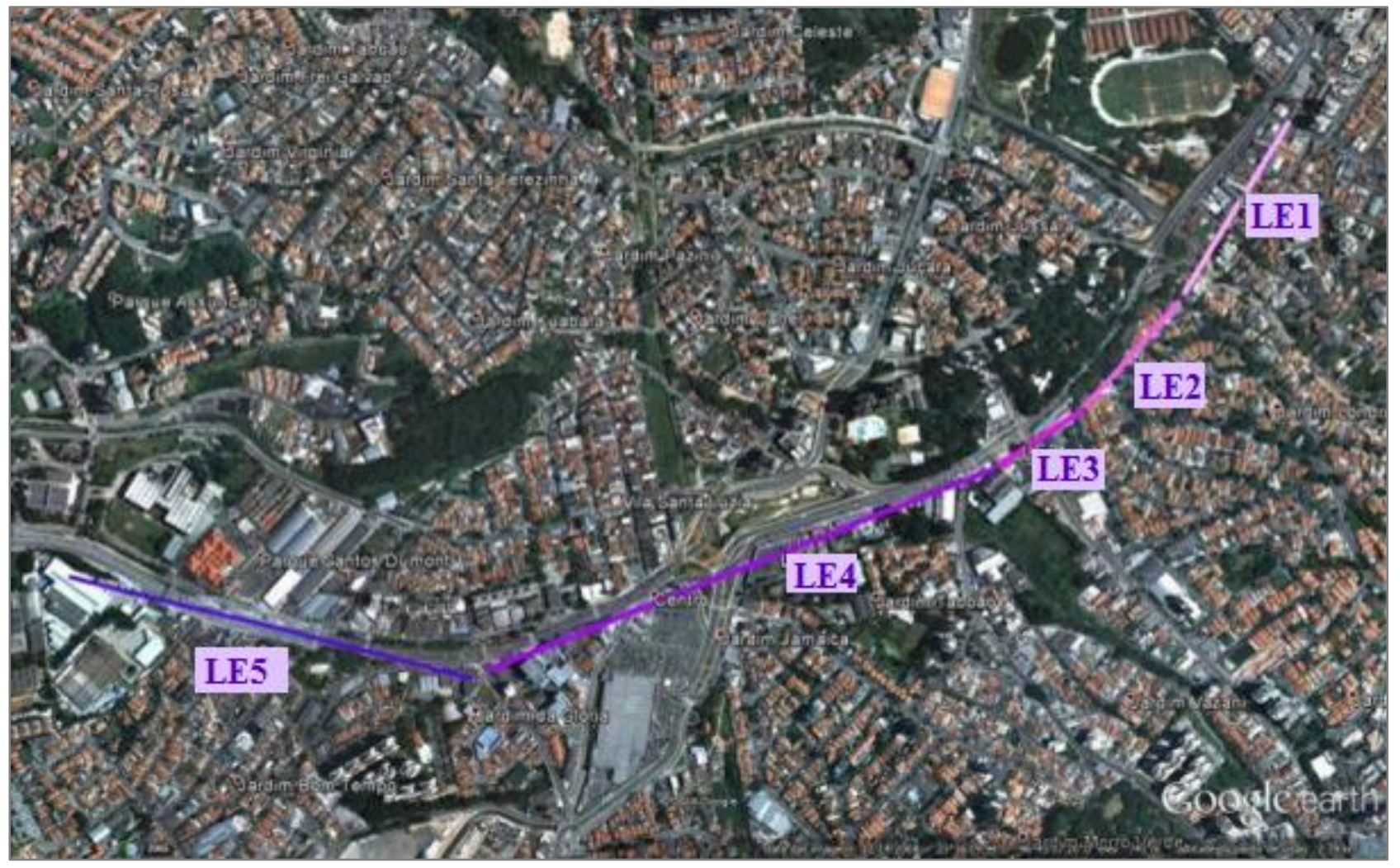

Figura 89 - Localização e direção das cinco linhas estruturais delimitadas ao longo do trecho referente à Linha 4 - Fase 3 (Google Earth).

As Figuras 90 a 94 referem-se à análise estrutural conjunta das sondagens pertencentes a cada respectivo setor. Abaixo segue a direção para cada um dos setores, assim como as sondagens para cada um destes:

$>$ LINHA ESTRUTURAL 1: DIREÇÃO: $3^{\circ}$ - SONDAGENS:4572 e 4580;

$>$ LINHA ESTRUTURAL 2: DIREÇÃO : 25ำ - SONDAGENS: 4572, 4596 e 4597;

$>$ LINHA ESTRUTURAL 3: DIREÇÃO: 52 ${ }^{\circ}$ - SONDAGENS: 4559 e 4564;

$>$ LINHA ESTRUTURAL 4: DIREÇÃO: 70 $^{\circ}$ - SONDAGENS: 4532, 4536, 4539, 4540, 4544, 4545 e 4548;

$>$ LINHA ESTRUTURAL 5: DIREÇÃO 103 ${ }^{\circ}$ - SONDAGENS: 4503, 4505 e 4515. 


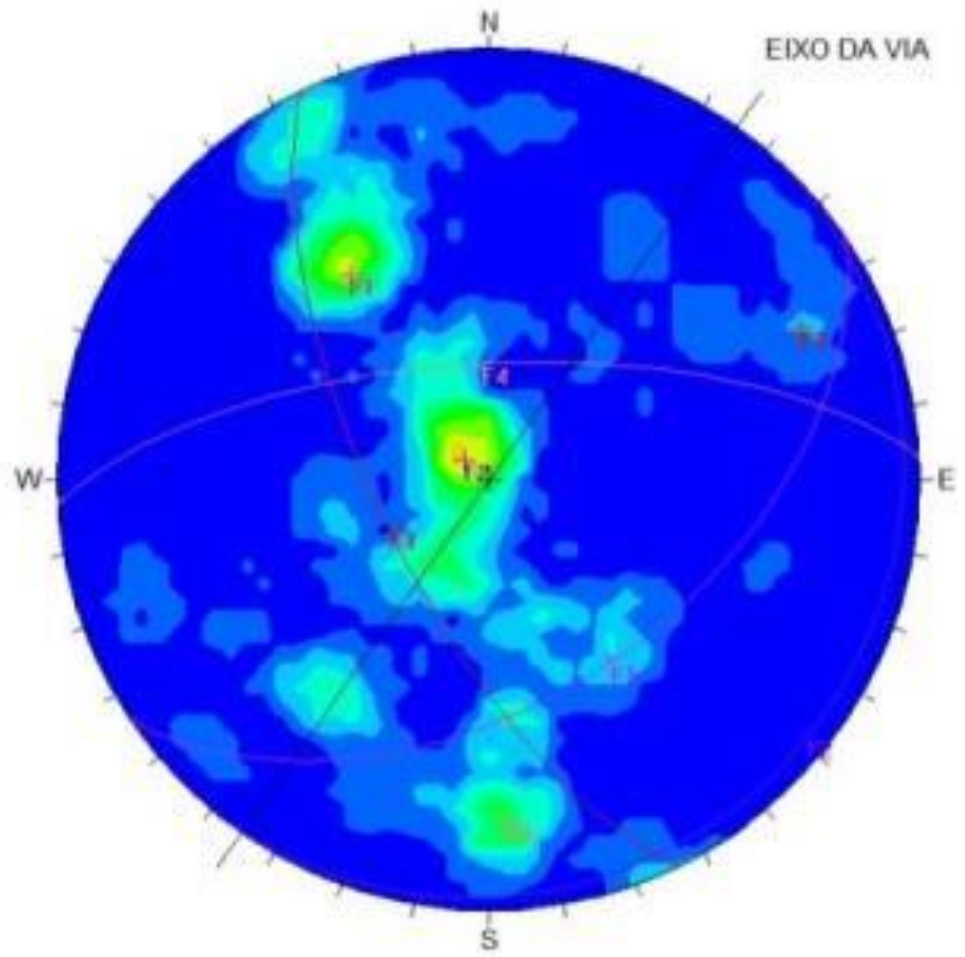

Schmidt

Concentrations

$\%$ of total per $1.0 \%$ area
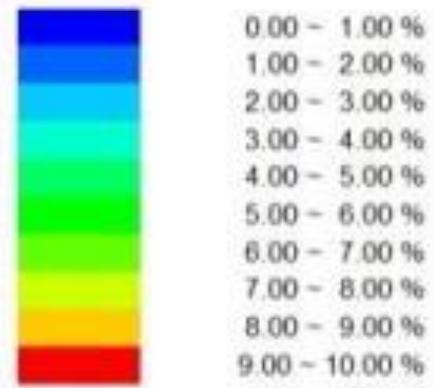

No Bias Correction Max Conc. $=8.8008 \%$

Equal Area

Lower Homisphere

158 Poles

158 Entries

Figura 90 - Estereograma para sondagens pertencentes à Linha Estrutural 1 e respectivas famílias de descontinuidades.

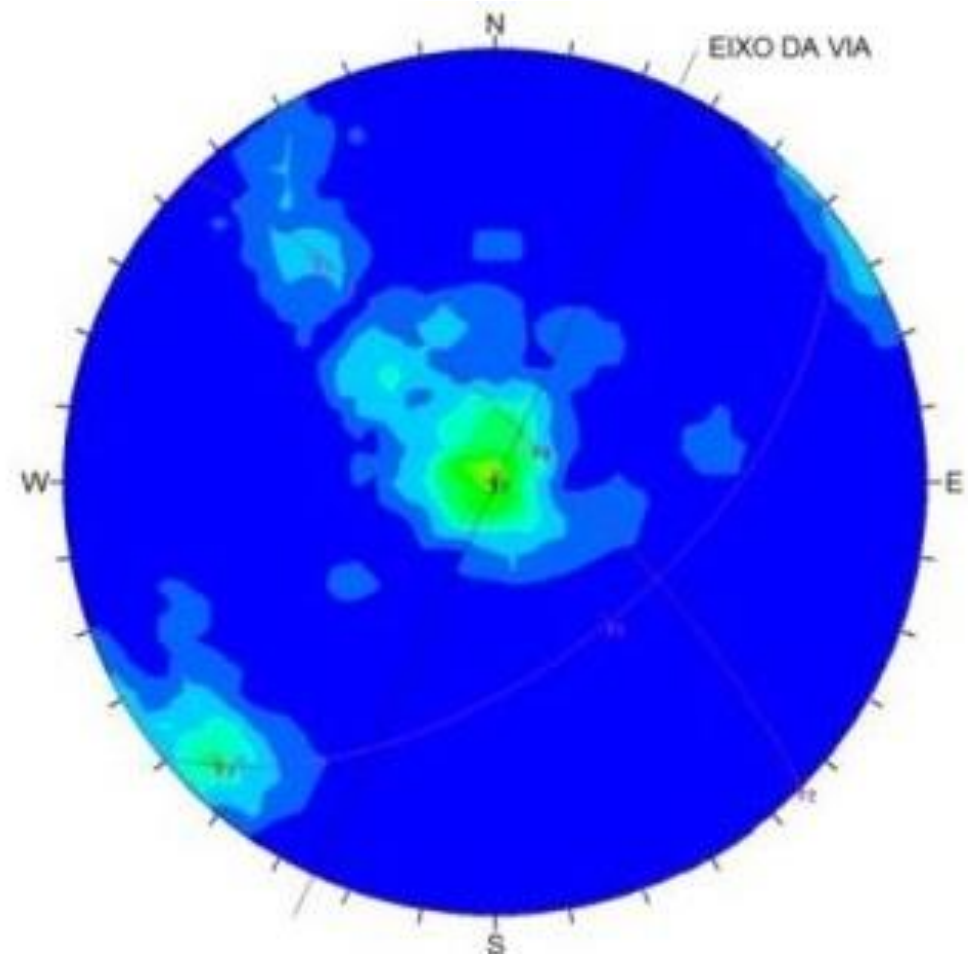

Schmidt

Concentrations

$\$$ of total per $1.0 \%$ area

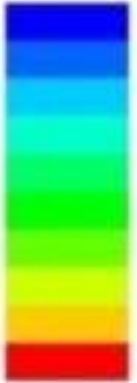

$0.00-1.50 \%$

$1.50-3.00 \%$

$3.00-4.50 \%$

$4.50-6.00 \%$

$6.00-7.50 \%$

$7.50=900 \%$

$9.00-10.50 \%$

$10.50-1200 \%$

$12.00-13.50 \%$

$13.50-15.00 \%$

No Bias Correction Max. Conc, $=10.0000 \%$

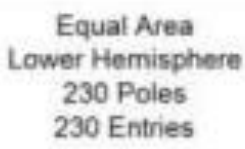

Figura 91 - Estereograma para sondagens pertencentes à Linha Estrutural 2 e respectivas famílias de descontinuidades, tendo sido consideradas apenas as fraturas abertas e semi-abertas da sondagem 4572 . 


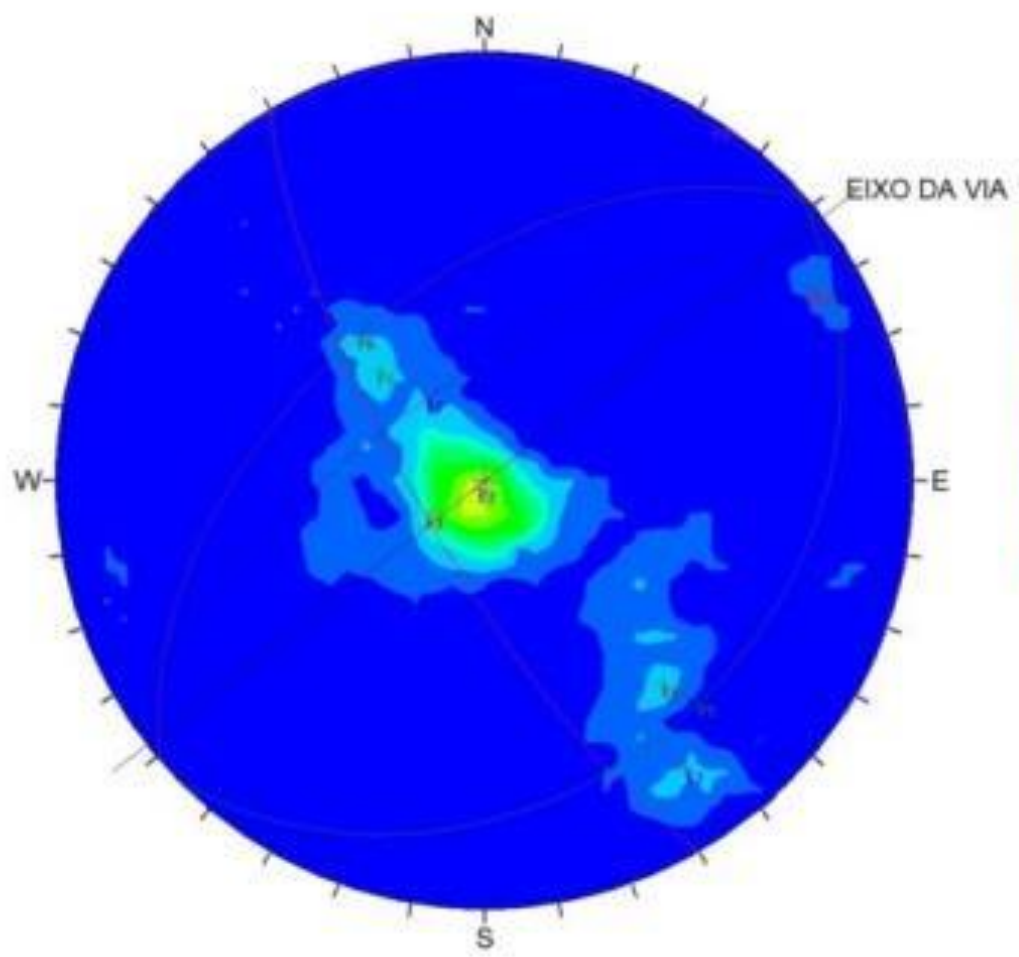

Schmidt

Concentrations

$\%$ of total per $1.0 \%$ area

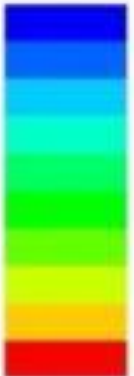

$0.00-2.00 \%$

$2.00-4.00 \%$

$4.00-6.00 \%$

$6.00-8.00 \%$

$8.00 \sim 10.00 \%$

$10.00 \sim 12.00 \%$

$12.00-14.00 \%$

$14.00 \sim 16.00 \%$

$16.00-18.00 \%$

$18.00-20.00 \%$

No Bias Correction Max. Conc, $=15.0000 \%$

\author{
Equal Area \\ Lower Hemisphere \\ 140 Poles \\ 140 Entries
}

Figura 92 - Estereograma para sondagens pertencentes à Linha Estrutural 3 e respectivas famílias de descontinuidades.

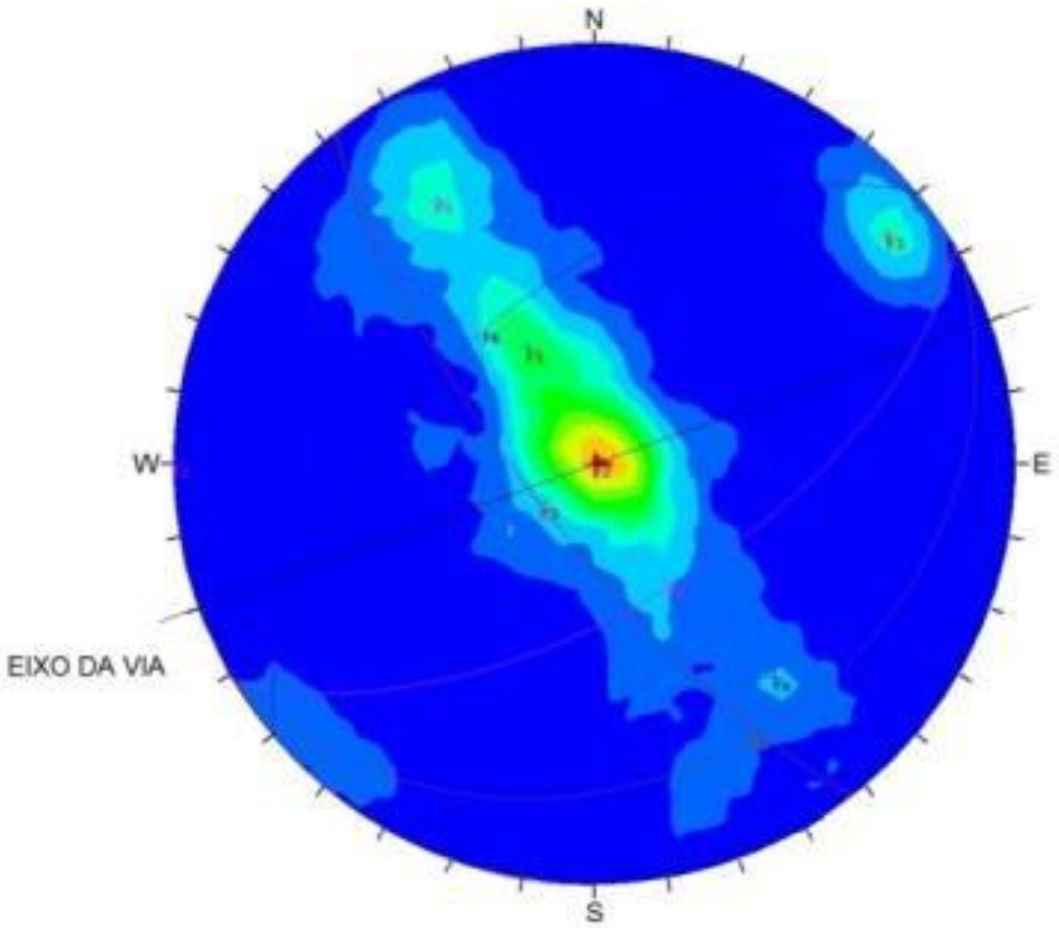

Schmidt

Concentrations

$\%$ of total per $1.0 \%$ area

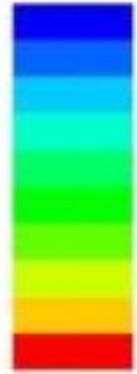

$0.00-1.00 \%$

$1.00-2.00 \%$

$2.00-3.00 \%$

$3.00-4.00 \%$

$4.00 \sim 5.00 \%$

$5.00-6.00 \%$

$6.00-700 \%$

$700-8.00 \%$

$8.00 \sim 9.00 \%$

$9.00 \sim 10.00 \%$

No Bias Correction

Max. Conc $=9.3122 \%$

Equal Area

Lower Hemisphere

945 Poles

945 Entries

Figura 93 - Estereograma para sondagens pertencentes à Linha Estrutural 4 e respectivas famílias de descontinuidades. 

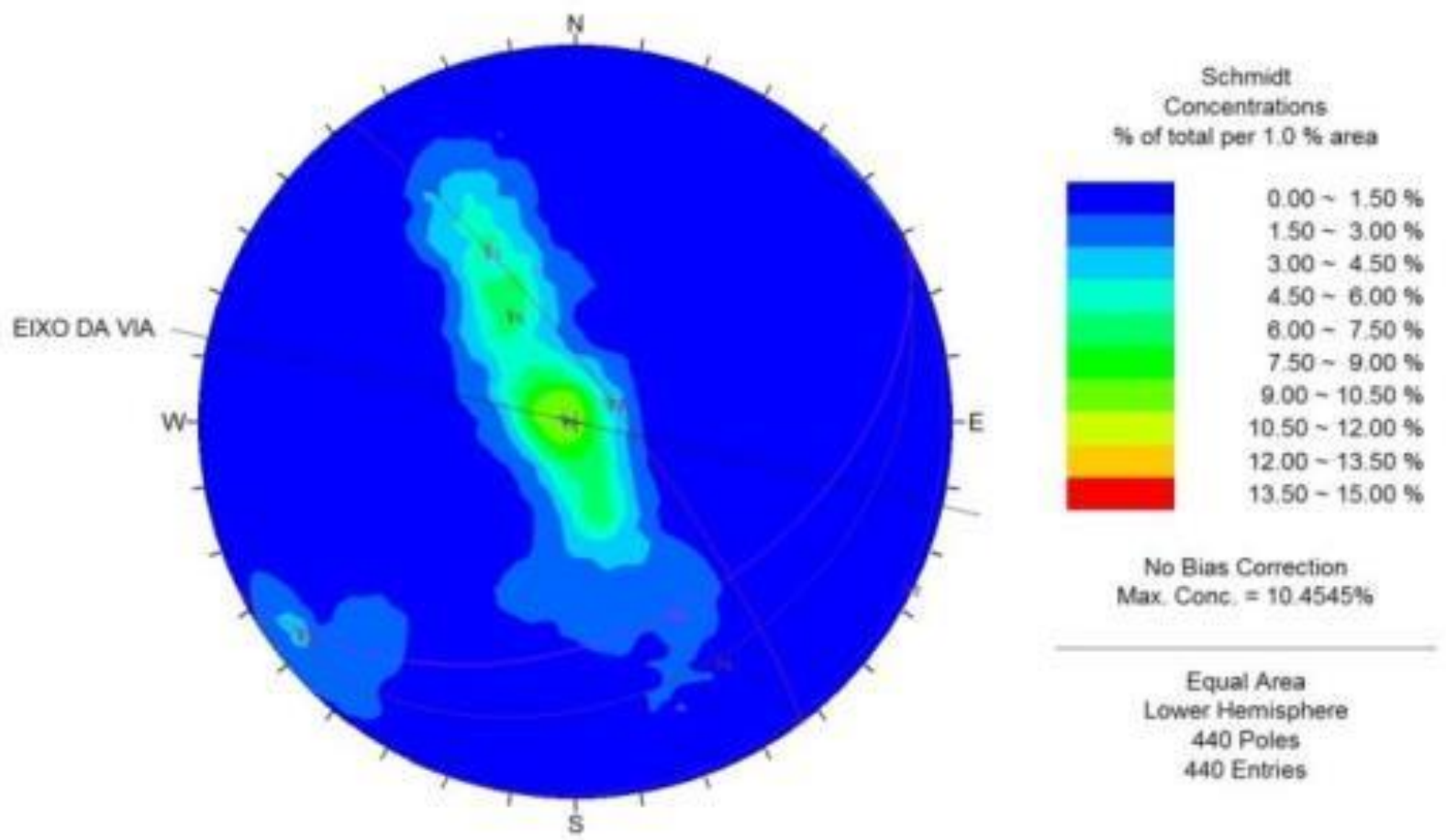

Figura 94 - Estereograma para sondagens pertencentes à Linha Estrutural 5 e respectivas famílias de descontinuidades.

Na Tabela 10, apresenta-se um resumo das famílias encontradas para cada uma das linhas analisadas. A seleção de cada uma das famílias em cada linha foi determinada através da concentração dos polos, considerando a frequência de polos para cada uma dessas direções, ou seja, as principais famílias foram as que implicaram em uma maior frequência de ocorrência de fraturas para o respectivo intervalo desta direção. Não foi possível considerar os parâmetros de persistência, já que não é possível levantar este parâmetro nos dados de televisionamento. Apenas com um levantamento de fraturas em afloramentos seria possível caracterizar o parâmetro persistência, o que não se encontrava disponível no local.

Tabela 10 - Linhas estruturais e respectivas famílias consideradas em cada uma destas.

\begin{tabular}{c|c|c|c|c|c|c|c|c}
\hline $\begin{array}{c}\text { LINHA } \\
\text { ESTRUTURAL }\end{array}$ & DIREÇÃO & F1 & F2 & F3 & F4 & F5 & F6 & F7 \\
\hline 1 & $\mathrm{~N} 35^{\circ}$ & $146 / 48$ & $129 / 6$ & $244 / 69$ & $357 / 68$ & - & - & - \\
\hline 2 & $\mathrm{~N} 25^{\circ}$ & $141 / 46$ & $135 / 1$ & $45 / 80$ & - & - & - & - \\
\hline 3 & $\mathrm{~N} 52^{\circ}$ & - & $33 / 2$ & $240 / 70$ & - & $136 / 29$ & $319 / 53$ & $325 / 71$ \\
\hline 4 & $\mathrm{~N} 70^{\circ}$ & $149 / 62$ & $270 / 0$ & $232 / 77$ & - & $150 / 26$ & $320 / 56$ & - \\
\hline 5 & $\mathrm{~N} 103^{\circ}$ & $153 / 43$ & $116 / 03$ & $53 / 81$ & - & $149 / 28$ & - & - \\
\hline
\end{tabular}


Com relação ao espaçamento de cada uma destas famílias é importante ressaltar que ocorre um viés dos dados, já que a grande maioria dos furos é vertical, amostrando certamente com maior frequência as juntas de mergulho próximo ao plano horizontal. Logo, as famílias com menor espaçamento, são as juntas de mergulho ortogonal ao mergulho da sondagem, as horizontais, assim como as de maior espaçamento, são as verticais. Uma forma de diminuir este viés e, complementar esta análise com maior confiabilidade, seria realizar também furos horizontais, como por exemplo, furos destrutivos televisionados na frente de escavação, sugerido em nota para o projeto executivo. Contrário, haverá um enviesamento destes dados. Outra forma seria a aplicação da correção proposta por Terzaghi (1965), que será utilizada mais adiante em outro item, para estimativa dos valores de espaçamento.

De qualquer forma, todas as concentrações maiores de polos foram consideradas como possíveis famílias para cada linha estrutural determinada, e todas as combinações de blocos formados entre todas estas famílias foram referidas.

Adicionalmente, relata-se que, no caso da Linha Estrutural 2, percebeu-se uma grande influência ao se considerar todas as fraturas da sondagem 4572, causando uma maior dispersão dos dados, o que não aconteceu na Linha Estrutural 1. Optou-se, então, por considerar apenas as fraturas abertas e semi-abertas para a confecção do diagrama de concentração dos polos de fraturas para a Linha Estrutural 2.

Seguramente, as famílias principais são as três primeiras F1, F2 e F3; no entanto, a F1 não foi observada na Linha Estrutural 3, sendo que a família denominada aí de F5 possui direção muito similar, podendo ser considerada equivalente à esta direção.

Efetuando-se uma breve correlação com os dados fornecidos por outros autores em suas análises estruturais do embasamento da Bacia de São Paulo, apresentados no item geologia regional, subitem geologia estrutural (4.1.7), é possível conjecturar que as juntas subverticais classificadas aqui como F3, F4 e F7 sejam as juntas subverticais citadas por Hasui et al. (1993), como sendo as juntas de cisalhamento, de distensão e de cisalhamento, respectivamente. Também um paralelo pode ser feito com os dados obtidos por Fernandes et al. (2005), onde estes autores julgaram como sendo de maior importância as juntas subhorizontais, com direções próximas à família aqui denominada de F2; mas, as direções encontradas foram bastante distintas das encontradas neste levantamento (N5W/10E), porém, sendo esta família também de extrema importância na análise aqui apresentada. Neste mesmo estudo, foram levantadas três famílias subverticais: N85E/75W; N30/65W; N60/75E. Estas famílias poderiam estar correlacionadas com a família F4 (N85E/75W), F6 e F7 (N30/65W), sendo que a última não foi encontrada correlação neste estudo, podendo talvez estar próxima à 
famílias F1 (N60/75E); contudo, com mergulho relativamente maior. E, por último, a família levantada pelos autores com direção N25/35E poderia estar relacionada com as famílias F1 e F5 aqui determinadas.

Novamente fazendo uma comparação com as fraturas encontradas por Hasui (1993), a família F7 deste autor é referente às fraturas mais amostradas nesta análise, as famílias subhorizontais denominadas aqui de F2 e presente em todas as linhas estruturais. A família de Hasui denominada de F5, conforme pode ser visualizado na Figura 8 (item 4.1.7-Geologia Estrutural) seria referente à F1, presente nas linhas estruturais 1, 2, 4 e 5. As fraturas subverticais de Hasui, todas as quatro famílias que ele considerou como sendo principais, foram observadas em todas as linhas estruturais, como famílias F3, F4 e F7. As demais famílias aqui observadas (F5 e F6) não foram citadas por este autor.

É importante ressaltar que a forma de obtenção destas medidas foi completamente distinta, pois em 1993 não havia equipamento de televisionamento óptico no mercado brasileiro, considerando que o primeiro equipamento no país foi obtido apenas em 2001 (Baillot et al., 2004); portanto, o enviesamento dos dados também será distinto. Em uma situação as medidas foram obtidas em linhas verticais, ou subverticais (televisionamento de sondagens) e, na outra, em afloramentos de campo, preferencialmente horizontais, havendo uma maior amostragem de fraturas horizontais no primeiro caso e verticais no segundo. Ainda há uma limitação do equipamento do televisionamento óptico de sondagens em se definir com exatidão as atitudes de planos verticais ou subverticais, principalmente quando medidas são obtidas em furos verticais, o que poderia justificar a falta de precisão no ajuste entre as medidas obtidas aqui neste trabalho e no relatório de Hasui, de 1993.

Finalmente, após definidas as famílias principais em cada linha estrutural, o Software Unwedge (Rocscience, 2004) foi então utilizado para a análise da estabilidade do túnel. Para cada linha, foi feita a análise em combinações de três sets de descontinuidades, sendo que os resultados são apresentados nas Figuras 95 a 108. Para a análise da estabilidade foi desconsiderada a família F6 na Linha Estrutural 4, tendo sido apenas citada na Tabela 10, por não julgar ser essencial à análise.

Em todos os casos, considerou-se o maciço não drenado e sem prever contenções e tratamentos para a rocha (tirantes, concreto projetado, etc.). Vale ressaltar que foram consideradas aqui as piores condições do maciço, ou seja, preferiu-se adotar uma análise a favor da segurança.

Foram elaboradas tanto uma análise bidimensional, em estereogramas, como uma análise tridimensional. Na análise bidimensional, foram consideradas para cada combinação apenas três famílias, como já citado, sendo que na figura as famílias desconsideradas aparecem em cinza claro. As famílias consideradas para a combinação são citadas na legenda de sua respectiva figura. Atentar 
para as notas de rodapé, pois em alguns casos há diferenças nas denominações para cada família, devido a limitações do Software.

Para todas as análises, foram considerados um ângulo de atrito de $30^{\circ}$, densidade da rocha 2,7 $\mathrm{t} / \mathrm{m}^{3}$ e valor zero para ondulação, coesão e tensão confinante. Com relação à coluna d'água, foi verificada sua altura média para linha estrutural. Na Tabela 11, encontram-se os valores utilizados. Para cada combinação entre as famílias em cada linha estrutural são apresentados estereogramas com esta combinação em conjunto com a direção do túnel neste setor, os blocos formados para esta combinação e, por último, cada bloco apresentado separadamente, indicando seu fator de segurança, assim como volume $\left(\mathrm{m}^{3}\right)$ e peso do bloco (toneladas).

É importante lembrar novamente que não foram considerados tirantes, ou qualquer outro tipo de tratamento, tampouco qualquer simulação para maciço drenado. Desta forma, há uma frequência alta de valores de fator de segurança menores do que 1 , ou seja, indicando a queda iminente deste bloco. Esta análise apenas teve inicialmente o intuito de subsidiar as decisões de engenharia tomadas no projeto básico da Linha 4 Fase 3 e, principalmente, apresentar sugestões de aplicações dos dados do televisionamento para projetos de escavações subterrâneas urbanas, a partir de estudo de casos.

Tabela 11 - Parâmetros utilizados para análise no Software Unwedge considerando maciço não drenado.

\begin{tabular}{|c|c|c|c|c|c|c|}
\hline $\begin{array}{c}\text { LINHA } \\
\text { ESTRUTURAL }\end{array}$ & $\begin{array}{c}\text { DENSIDADE } \\
\text { DA ROCHA } \\
\left(\mathbf{T} / \mathbf{M}^{3}\right)\end{array}$ & $\begin{array}{c}\text { ÂNGULO } \\
\text { DE } \\
\text { ATRITO }\end{array}$ & $\begin{array}{c}\text { TENSÃO } \\
\text { CONFINANTE } \\
\left(\mathbf{T}^{2} \mathbf{M}^{2}\right)\end{array}$ & $\begin{array}{c}\text { COESÃO } \\
\left(\mathbf{T} / \mathbf{M}^{2}\right)\end{array}$ & ONDULAÇÃO & $\begin{array}{l}\text { ELEVAÇÃO } \\
\text { DA COLUNA } \\
\text { D'ÁGUA (M) }\end{array}$ \\
\hline 1 & \multirow{5}{*}{2,7} & \multirow{5}{*}{$30^{\circ}$} & 0 & \multirow{5}{*}{0} & \multirow{5}{*}{0} & 18 \\
\hline 2 & & & 0 & & & 20 \\
\hline 3 & & & 0 & & & 16 \\
\hline 4 & & & 0 & & & 25 \\
\hline 5 & & & 0 & & & 24 \\
\hline
\end{tabular}

Para a Linha Estrutural 1 foram feitas 4 combinações entre as famílias F1, F2, F3 e F4, tanto para análise bidimensional (Figuras 95, 98, 101 e 104) como tridimensional (Figuras 96, 99, 102 e 105). Na Figura 95, há uma cunha formada com as famílias F1 e F3, o que poderia ser problemático, principalmente no caso de um avanço da escavação partindo de sudoeste para nordeste, neste trecho de linha. Na Figura 98, a cunha formada pelas famílias F1 e F4 muito provavelmente não seria problemática, já que seu ponto de intersecção está abaixo do ângulo de atrito de $30^{\circ}$, não deslizando. Na Figura 101, há formação de uma cunha no teto do túnel com a combinação das famílias F1, F3 e F4, podendo ocorrer desprendimento deste bloco rochoso, sendo a situação mais crítica encontrada. 
Por último, na Figura 104, ocorre uma cunha formada com as famílias F3 e F4, que deslizaria na parede sudeste do túnel ao longo da Linha Estrutural 1.

Com respeito à análise tridimensional presume-se que os blocos mais problemáticos formados são os seguintes:

Bloco número 4, formado pelas famílias F1, F2 e F3, no canto superior esquerdo, fator de segurança igual a 0,1 , com volume aproximado de $174 \mathrm{~m}^{3}$ e peso em torno de 471 toneladas (Figuras 96 e 97);

$>$ Bloco número 3, formado pelas famílias F1, F2 e F4, no canto superior esquerdo, fator de segurança igual a 1,2, com volume aproximado de $467 \mathrm{~m}^{3}$ e peso em torno de 1261 toneladas (Figuras 99 e 100);

$>$ Bloco número 8, formado pelas famílias F1, F3 e F4, no teto, fator de segurança igual a 0 , com volume aproximado de $5 \mathrm{~m}^{3}$ e peso em torno de 15 toneladas (Figuras $102 \mathrm{e}$ 103);

Bloco número 5, formado pelas famílias F2, F3 e F4, no canto superior direito, fator de segurança igual a 0 , com volume aproximado de $45 \mathrm{~m}^{3}$ e peso em torno de 121 toneladas (Figuras 105 e 106);

Bloco número 8, formado pelas famílias F2, F3 e F4, no canto superior esquerdo, fator de segurança igual a 0 , com volume aproximado de $1 \mathrm{~m}^{3}$ e peso em torno de 4 toneladas, apesar de que o peso e o volume não sejam significativos, provavelmente não implicando em queda para maciço drenado (Figuras 105 e 106). 


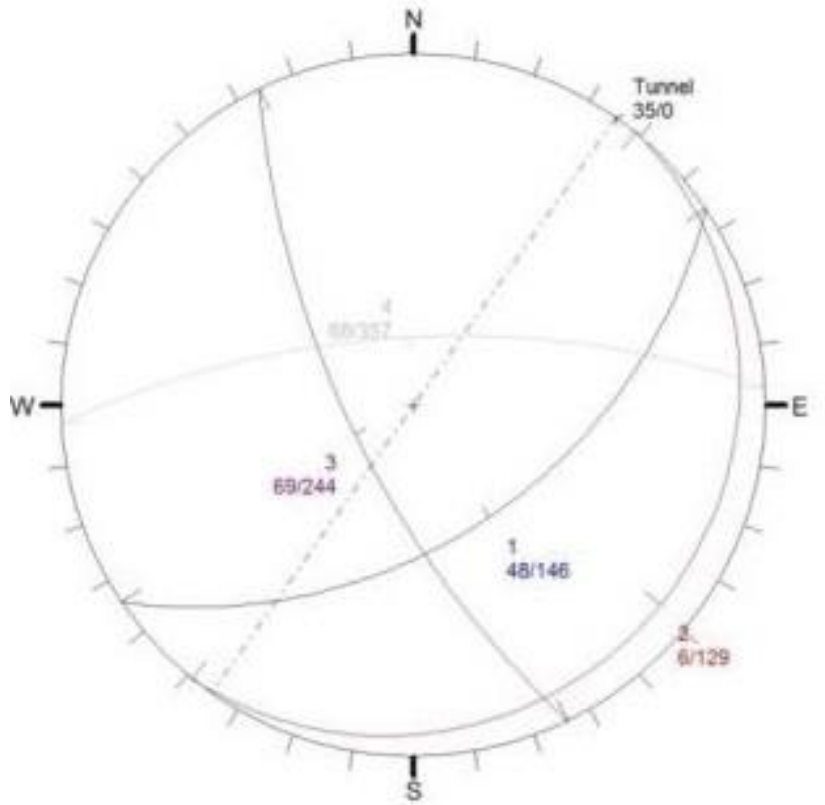

Figura 95 - Análise cinemática bidimensional de cunhas, para Linha Estrutural 1, combinação 1 de 4 famílias de descontinuidades $(\mathrm{F} 1+\mathrm{F} 2+\mathrm{F3})$ (Software Unwedge).

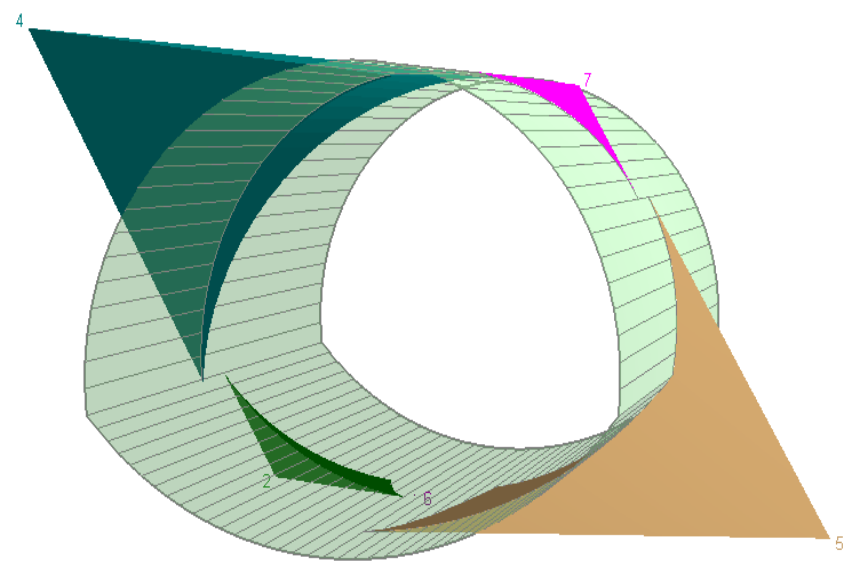

Figura 96 - Seção do túnel ao longo da Linha Estrutural $1 \mathrm{com}$ respectivas cunhas geradas pela combinação 1 de 4 de famílias de descontinuidades $(\mathbf{F 1 + F 2 + F 3 ) ~ ( S o f t w a r e ~ U n w e d g e ) . ~}$

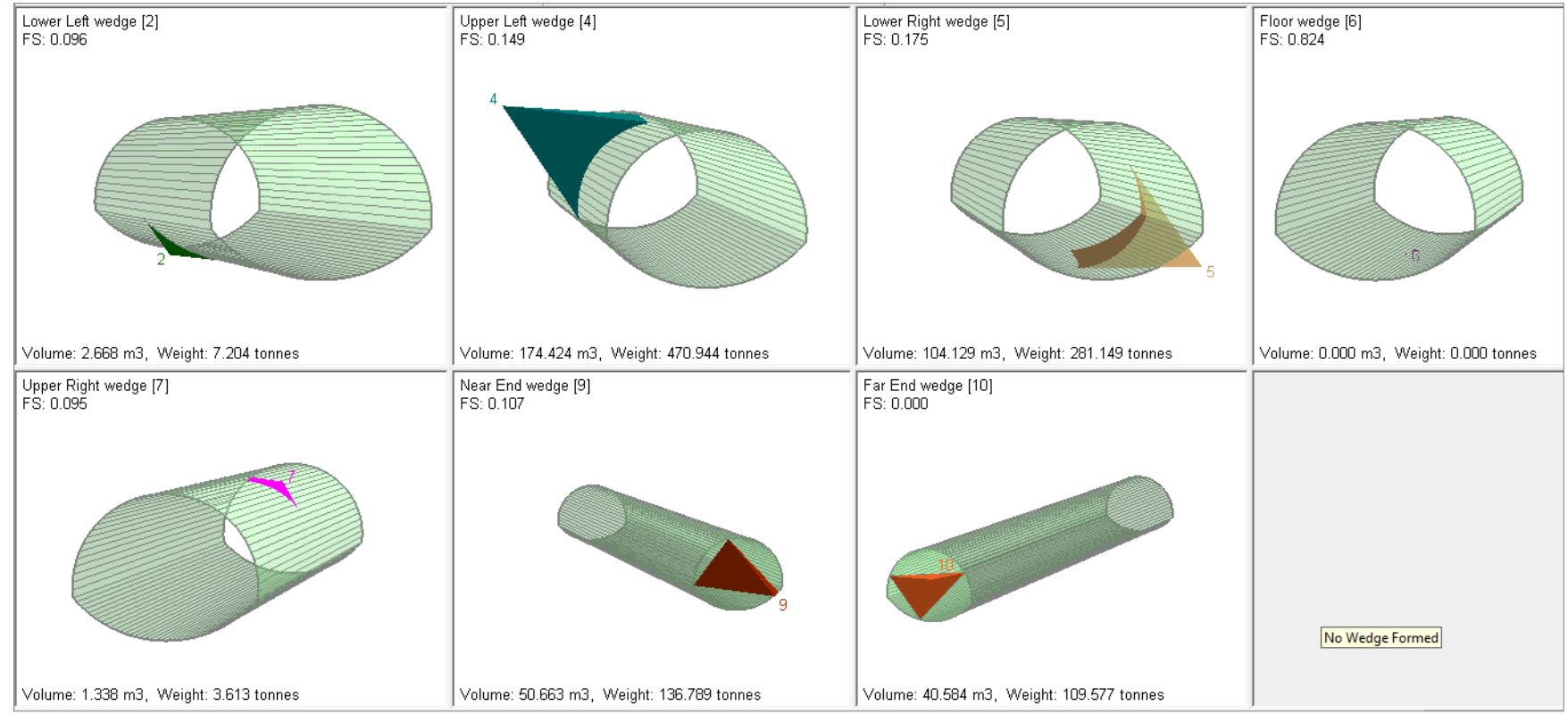

Figura 97 - Seções do túnel ao longo da Linha Estrutural 1 com respectivas cunhas geradas pela combinação 1 de 4 de famílias de descontinuidades $(\mathrm{F} 1+\mathrm{F} 2+\mathrm{F3})$, indicando o fator de segurança (FS), volume e peso de cada bloco (Software Unwedge). 


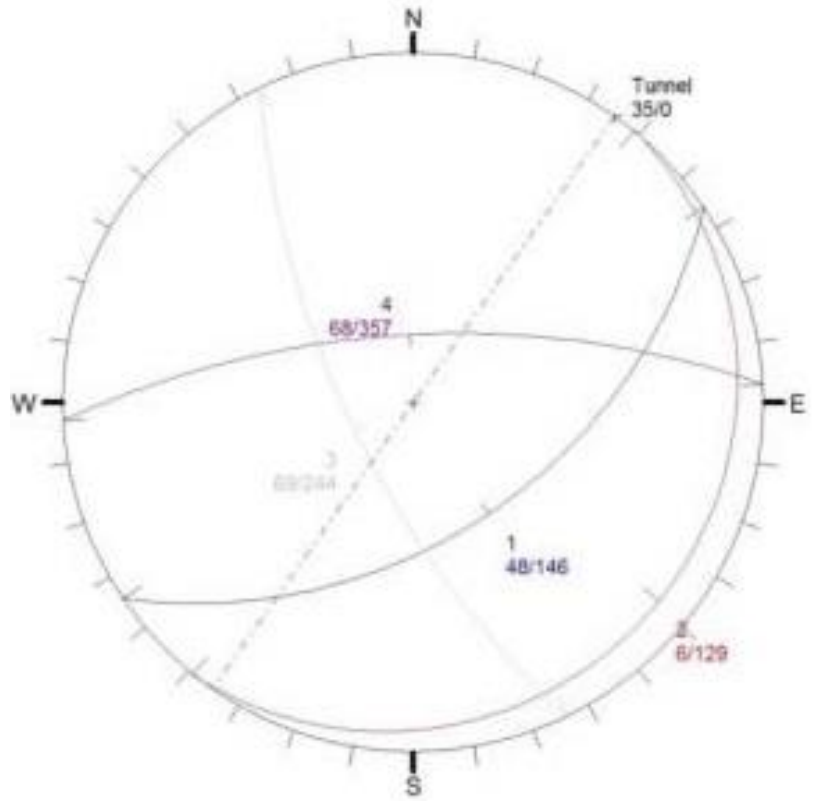

Figura 98 - Análise cinemática bidimensional de cunhas, para Linha Estrutural 1, combinação 2 de 4 famílias de descontinuidades $(\mathrm{F} 1+\mathrm{F} 2+\mathrm{F} 4)$ (Software Unwedge).

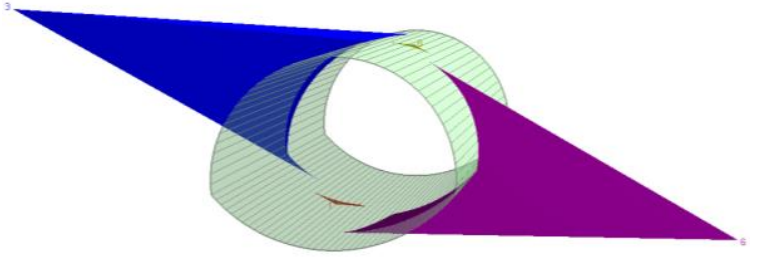

Figura 99 - Seção do túnel ao longo da Linha Estrutural $1 \mathrm{com}$ respectivas cunhas geradas pela combinação2 de 4 famílias de descontinuidades (F1+F2+F4) (Software Unwedge).

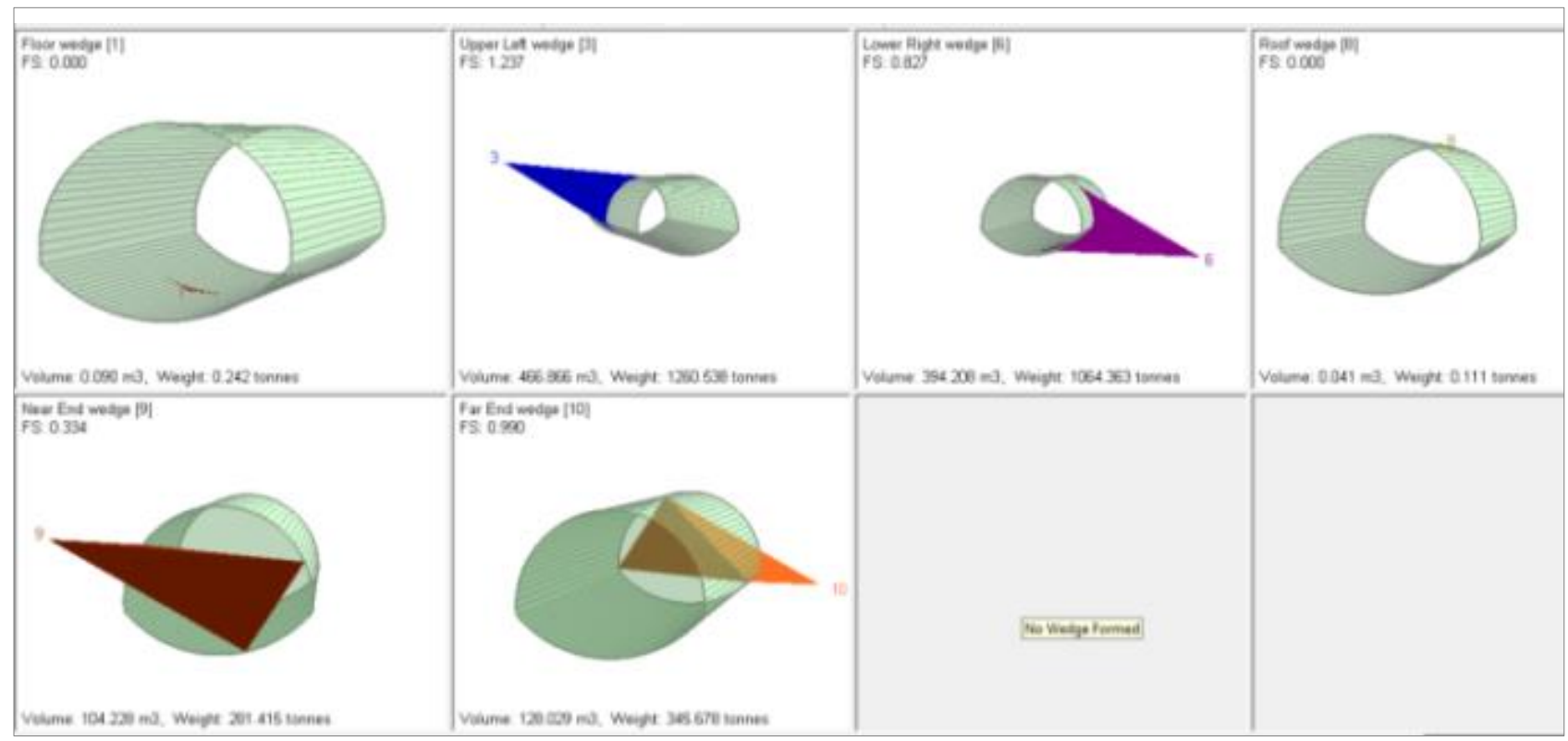

Figura 100 - Seções do túnel ao longo da Linha Estrutural 1 com respectivas cunhas geradas pela combinação 2 de 4 de famílias de descontinuidades (F1+F2+F4), indicando o fator de segurança (FS), volume e peso de cada bloco (Software Unwedge). 


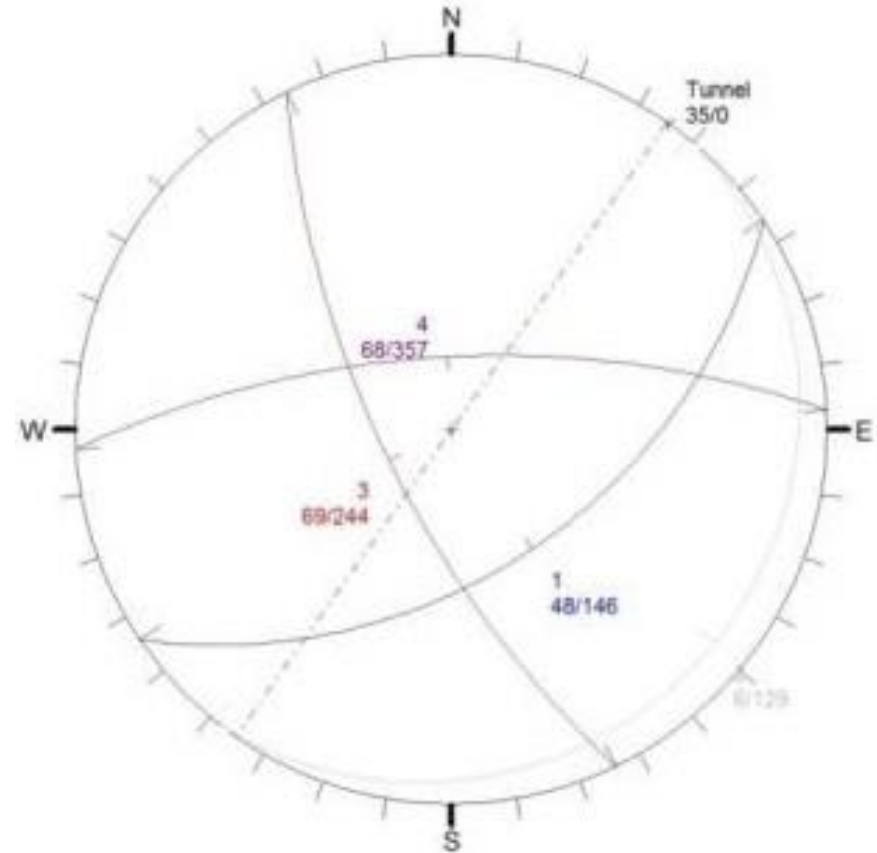

Figura 101 - Análise cinemática bidimensional de cunhas, para Linha Estrutural 1, combinação 3 de 4 famílias de descontinuidades $($ F1+F3+F4) (Software Unwedge).

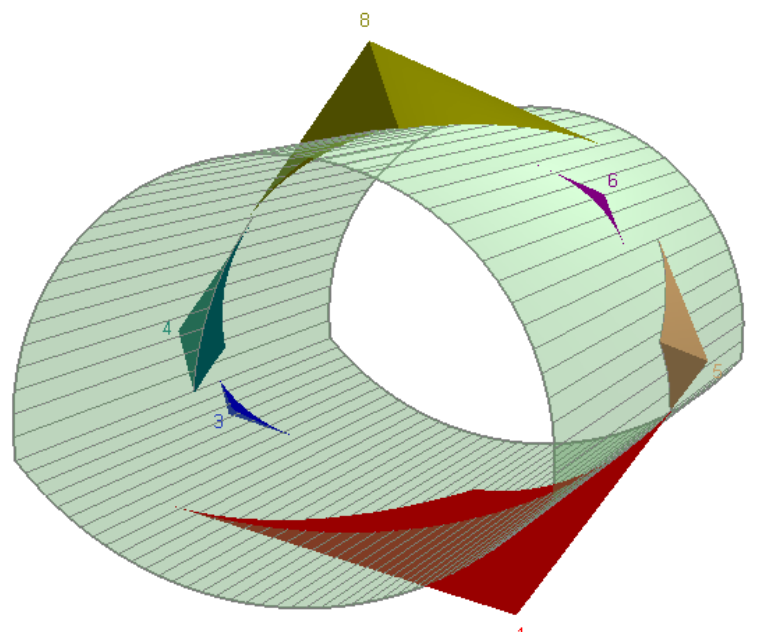

Figura 102 - Seção do túnel ao longo da Linha Estrutural 1 com respectivas cunhas geradas pela combinação 3 de 4 de famílias de descontinuidades (F1+F3+F4) (Software Unwedge).

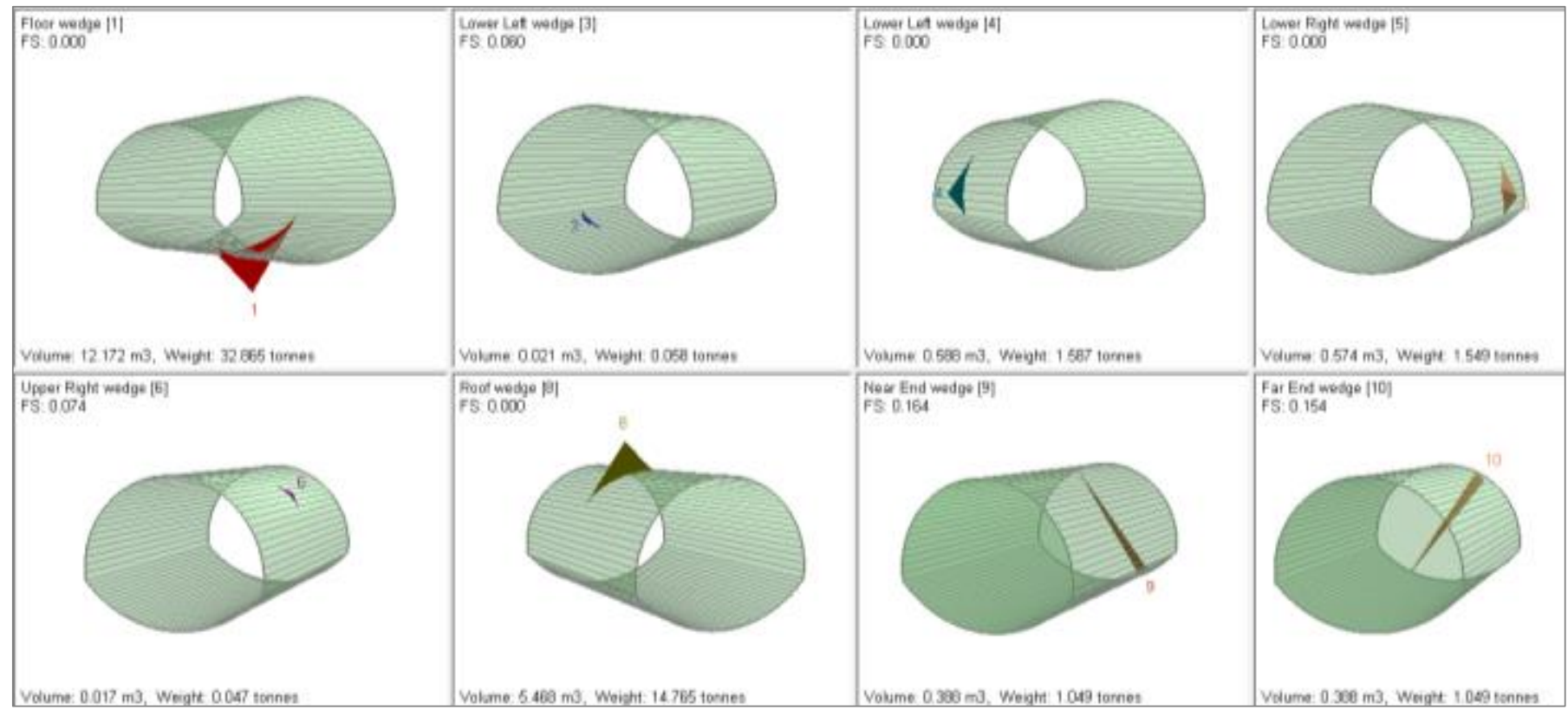

Figura 103 - Seções do túnel ao longo da Linha Estrutural 1 com respectivas cunhas geradas pela combinação 3 de 4 de famílias de descontinuidades $(F 1+F 3+F 4)$, indicando o fator de segurança (FS), volume e peso de cada bloco (Software Unwedge). 


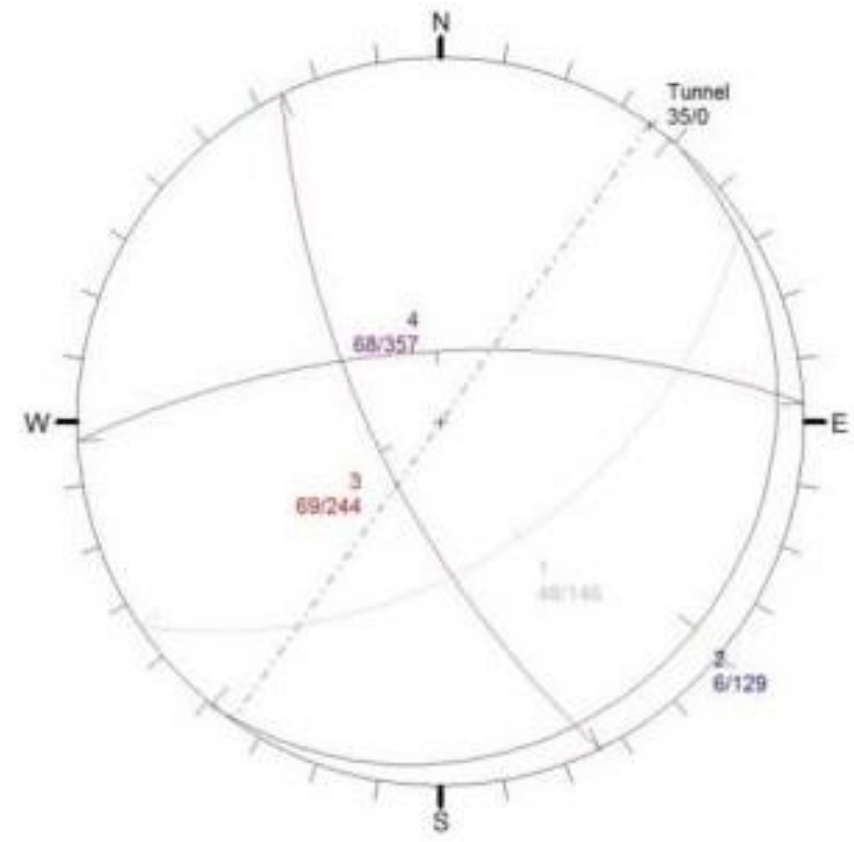

Figura 104 - Análise cinemática bidimensional de cunhas, para Linha Estrutural 1, combinação 4 de 4 famílias de descontinuidades $(\mathbf{F} 2+\mathbf{F 3}+\mathrm{F4})$ (Software Unwedge).

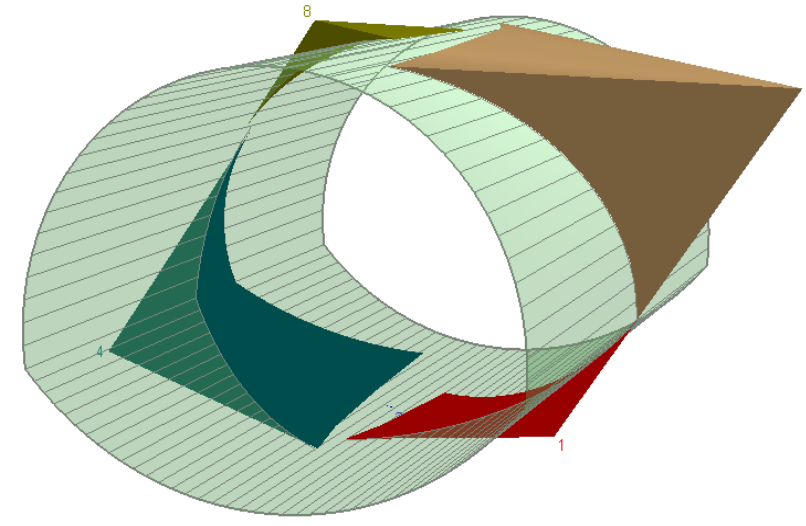

Figura 105 - Seção do túnel ao longo da Linha Estrutural $1 \mathrm{com}$ respectivas cunhas geradas pela combinação 4 de 4 famílias de descontinuidades $(\mathbf{F} 2+\mathrm{F3}+\mathrm{F4})$ (Software Unwedge).

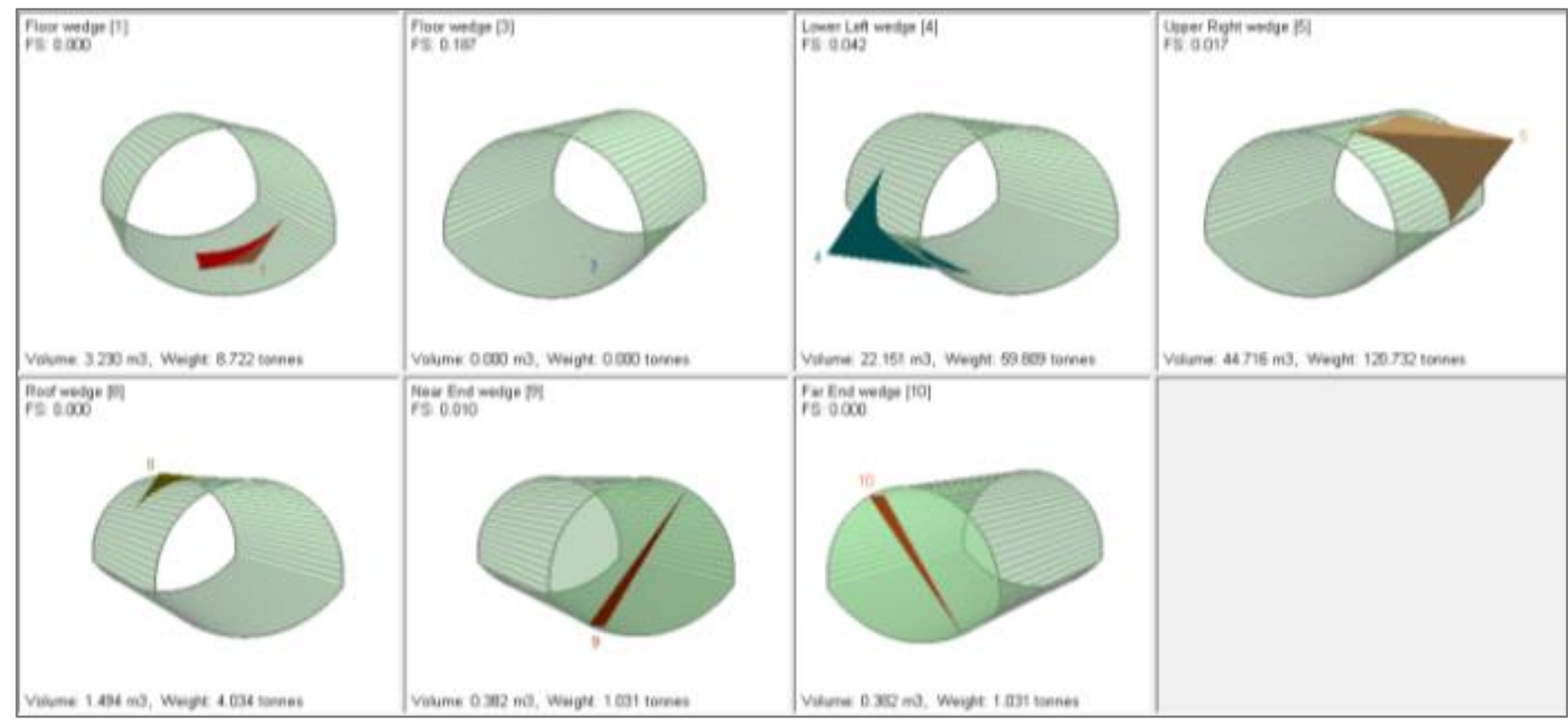

Figura 106 - Seções do túnel ao longo da Linha Estrutural 1 com respectivas cunhas geradas pela combinação 4 de 4 de famílias de descontinuidades $(F 2+F 3+F 4)$, indicando o fator de segurança (FS), volume e peso de cada bloco (Software Unwedge). 
Com relação à Linha Estrutural 2, foi necessária apenas uma combinação, já que foram delimitadas apenas três famílias de descontinuidades, F1, F2 e F3. A análise bidimensional, apresentada na Figura 107, indica apenas uma possível cunha formada pela família F1 e F3, sendo que a família F3, subvertical, seria a mais problemática para a estabilidade do túnel, pois se encontra praticamente ortogonal à direção da via neste trecho. Caso a escavação seja realizada na direção NE para SW será necessário um cuidado maior, pois este plano subvertical está mergulhando para NE, do que se realizada no sentido contrário. Esta família subvertical poderá, por exemplo, formar cunhas menores com outros planos menos significativos na análise estrutural.

Com relação à análise tridimensional de blocos, o mais problemático seria o bloco 3, com fator de segurança 0,048 , no canto superior esquerdo, com volume aproximado de $116 \mathrm{~m}^{3}$ e peso 313 toneladas (Figuras 108 e 109).

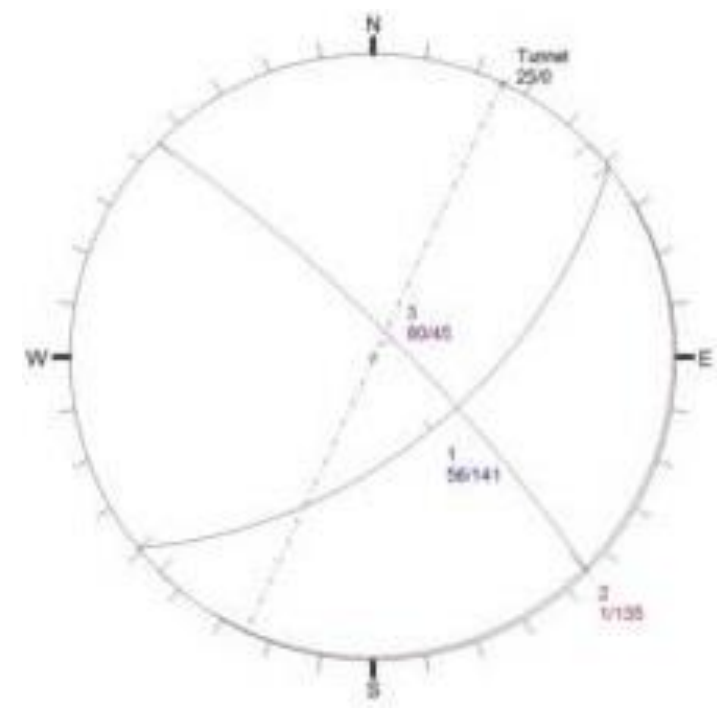

Figura 107 - Análise cinemática bidimensional de cunhas, para Linha Estrutural 2, combinação 1 de 3 famílias de descontinuidades $($ F1+F2+F3) (Software Unwedge).

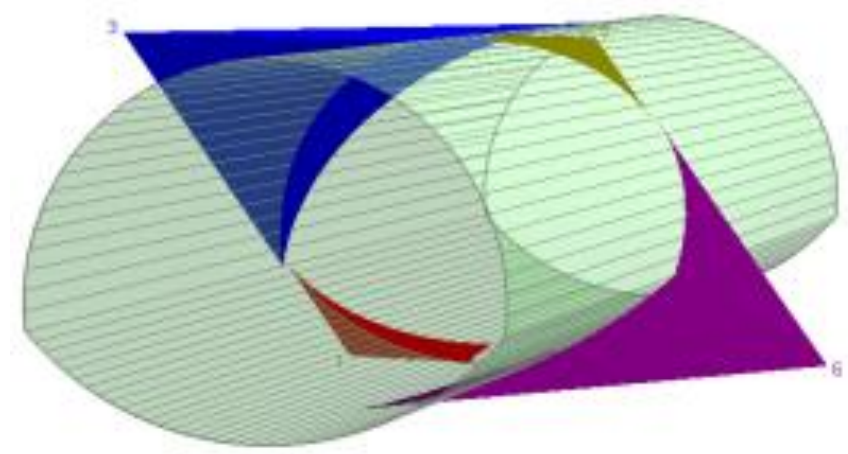

Figura 108- Seção do túnel ao longo da Linha Estrutural $2 \mathrm{com}$ respectivas cunhas geradas pela combinação 1 de 3 famílias de descontinuidades $(\mathrm{F} 1+\mathrm{F} 2+\mathrm{F3})$ (Software Unwedge). 


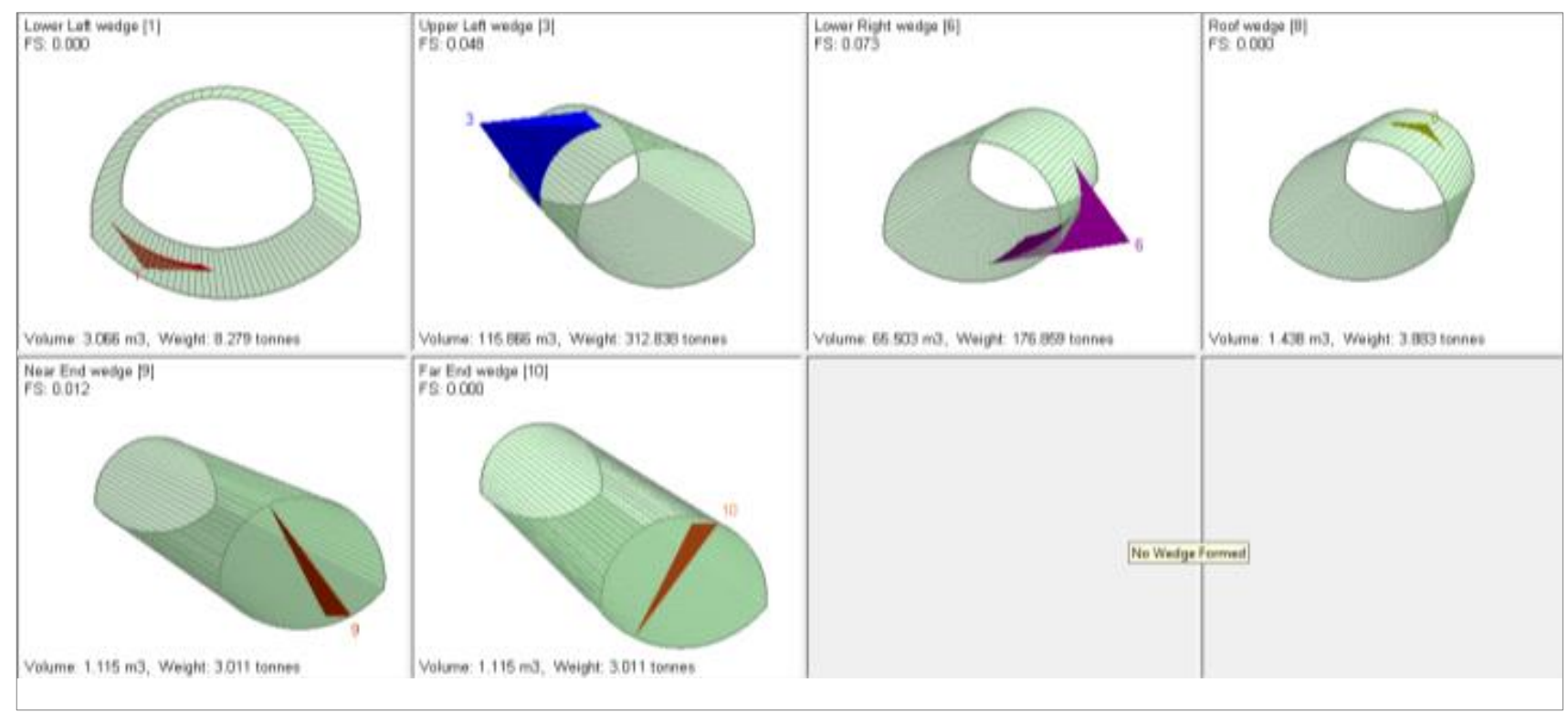

Figura 109- Seções do túnel ao longo da Linha Estrutural 2 com respectivas cunhas geradas pela combinação 1 de 3 de famílias de descontinuidades (F1+F2+F3), indicando o fator de segurança (FS), volume e peso de cada bloco (Software Unwedge).

No caso da Linha Estrutural 3, considerou-se o total de 5 famílias, com dez combinações entre elas, sendo que nesta linha, como já mencionado anteriormente, a família F1 está ausente; porém, ocorrendo um set com direção parecida, mas pouco menos inclinada, denominada de F5. Nas figuras segue a seguinte equivalência de números apresentados nas figuras e seguintes famílias: (1) F2; (2) F3; (3) F5; (4) F6 e (5) F7.

Nas Figuras 110, 113, 116, 119, 122, 125, 128, 131, 134 e 137, podem ser observadas as análises bidimensionais para as combinações das famílias de fraturas, ocorrendo a formação de algumas cunhas com possibilidade de deslizamento por sobre um dos planos ou a intersecção de dois planos, não ocorrendo nenhum desprendimento de cunha no teto (para isso seria necessária a intersecção de pelo menos três sets de descontinuidades).

No caso da Figura 110, o rumo da linha de intersecção ao qual se daria o deslizamento (F3+F5) possui inclinação um pouco maior que o ângulo de atrito, o que somada às condições de rugosidade das juntas, dificilmente implicaria em seu deslizamento. Já nas Figuras 113, 116, 128, 131 e 134 ocorre formação de cunhas com rumo da linha de intersecção muito maior que o ângulo de atrito, ou seja, com possibilidade de deslizamento.

Nas Figuras 119, 122, 125, 134 e 137, é evidente a possibilidade de deslizamento planar de algumas famílias em que a direção do plano é paralela à direção da linha. Deve-se considerar esta possibilidade para esta linha estrutural, pois o enviesamento dos dados devido à orientação da tomada de dados, preferencialmente vertical, pode ter mascarado a existência de uma frequência maior de 
planos verticais, que contribuiriam para que este tipo de deslizamento ocorresse, formando cunhas com estes planos paralelos à direção da via. Um ótimo exemplo desta situação seria o ilustrado na Figura 134, onde duas possibilidades de cunhas podem ser formadas com duas famílias paralelas à direção da via (F6 e F7), sendo cortadas por uma família de alto ângulo de inclinação (F3).

Com relação aos blocos tridimensionais, a maioria dos formados pela combinação de todas as famílias possuem dimensões pequenas, conforme pode ser observado nas Figuras 111, 117, 123, 126 e 129. Julga-se que os blocos mais problemáticos formados são os seguintes:

Bloco número 4, formado pelas famílias F2, F3 e F5, no canto superior direito, fator de segurança igual a 0,35 , com volume aproximado de $87 \mathrm{~m}^{3}$ e peso em torno de 4 toneladas (Figuras 111 e 112);

$>$ Bloco número 7, formado pelas famílias F2, F3 e F6, no canto superior direito, fator de segurança igual a 0 , com volume aproximado de $483 \mathrm{~m}^{3}$ e peso em torno de 1304 toneladas (Figuras 114 e 115);

Bloco número 8, formado pelas famílias F2, F3 e F7, no teto, fator de segurança igual a 0 , com volume aproximado de $19 \mathrm{~m}^{3}$ e peso em torno de 51 toneladas (Figuras $117 \mathrm{e}$ $118)$;

$>$ Bloco número 6, formado pelas famílias F2, F5 e F7, no canto superior esquerdo, fator de segurança igual a 0 , com volume aproximado de $18 \mathrm{~m}^{3}$ e peso em torno de 47 toneladas (Figuras 123 e 124);

$>$ Bloco número 5, formado pelas famílias F2, F6 e F7, no canto superior direito, fator de segurança igual a 0 , com volume aproximado de $37 \mathrm{~m}^{3}$ e peso em torno de 99 toneladas (Figuras 126 e 127);

Bloco número 7, formado pelas famílias F2, F6 e F7, no teto, fator de segurança igual a 0,14 , com volume aproximado de $16 \mathrm{~m}^{3}$ e peso em torno de 43 toneladas (Figuras 126 e 127);

Bloco número 7, formado pelas famílias F3, F5 e F6, no canto superior direito, fator de segurança igual a 0 , com volume aproximado de $61 \mathrm{~m}^{3}$ e peso em torno de 165 toneladas (Figuras 129 e 130);

$>$ Bloco número 8, formado pelas famílias F3, F5 e F7, no teto, fator de segurança igual a 0 , com volume aproximado de $104 \mathrm{~m}^{3}$ e peso em torno de 282 toneladas (Figuras 132 e 133); 
Bloco número 3, formado pelas famílias F3, F6 e F7, no teto, fator de segurança igual a 0,2 , com volume aproximado de $5169 \mathrm{~m}^{3}$ e peso em torno de 13956 toneladas (Figuras 135 e 136). Vale ressaltar que este é o bloco mais problemático em todo o trecho, com maior volume;

Bloco número 7, formado pelas famílias F5, F6 e F7, no canto superior direito, fator de segurança igual a 0 , com volume aproximado de $104 \mathrm{~m}^{3}$ e peso em torno de 282 toneladas (Figuras 138 e 139).

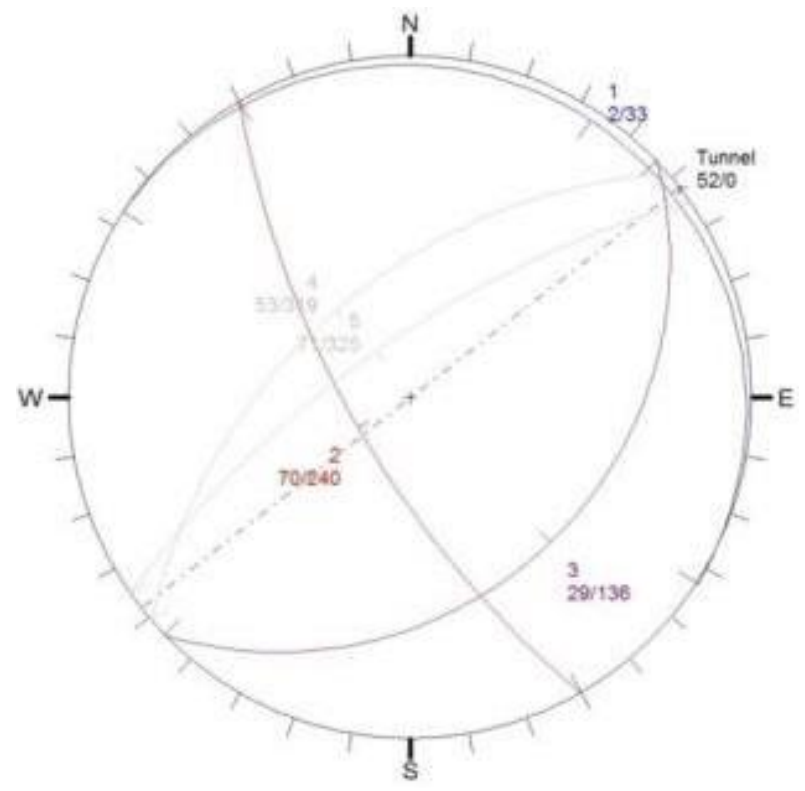

Figura 110- Análise cinemática bidimensional Figura 111- Seção do túnel ao longo da Linha de cunhas, para Linha Estrutural 3, Estrutural 3 com respectivas cunhas geradas pela combinação 1 de 5 famílias de descontinuidades combinação 1 de 5 famílias de descontinuidades (F2+F3+F5)3 (Software Unwedge).

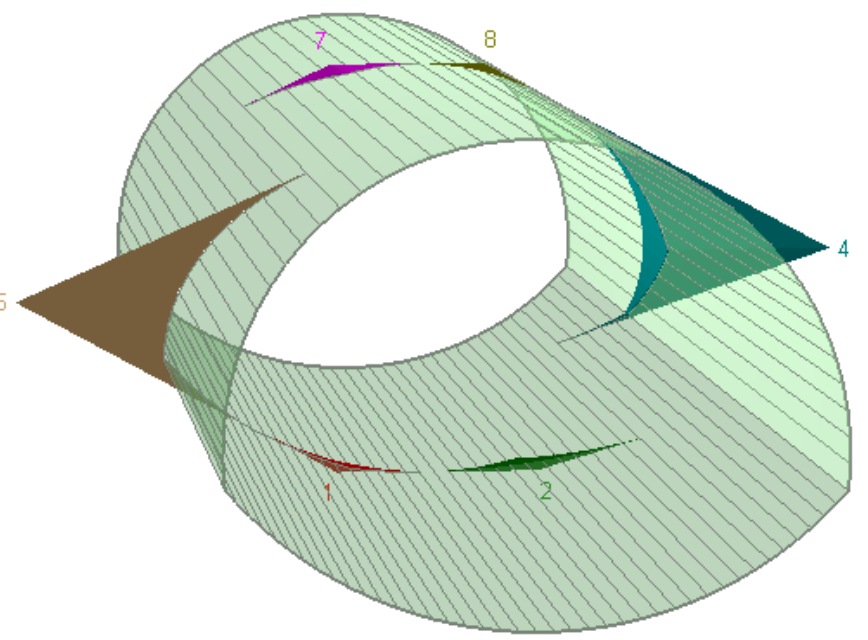

(F2+F3+F5) (Software Unwedge).

\footnotetext{
${ }^{3}$ Para linha estrutural 3, os números apresentados nas imagens são referentes às seguintes famílias: (1) F2; (2) F3; (3) F5; (4) F6 e (5) F7.
} 


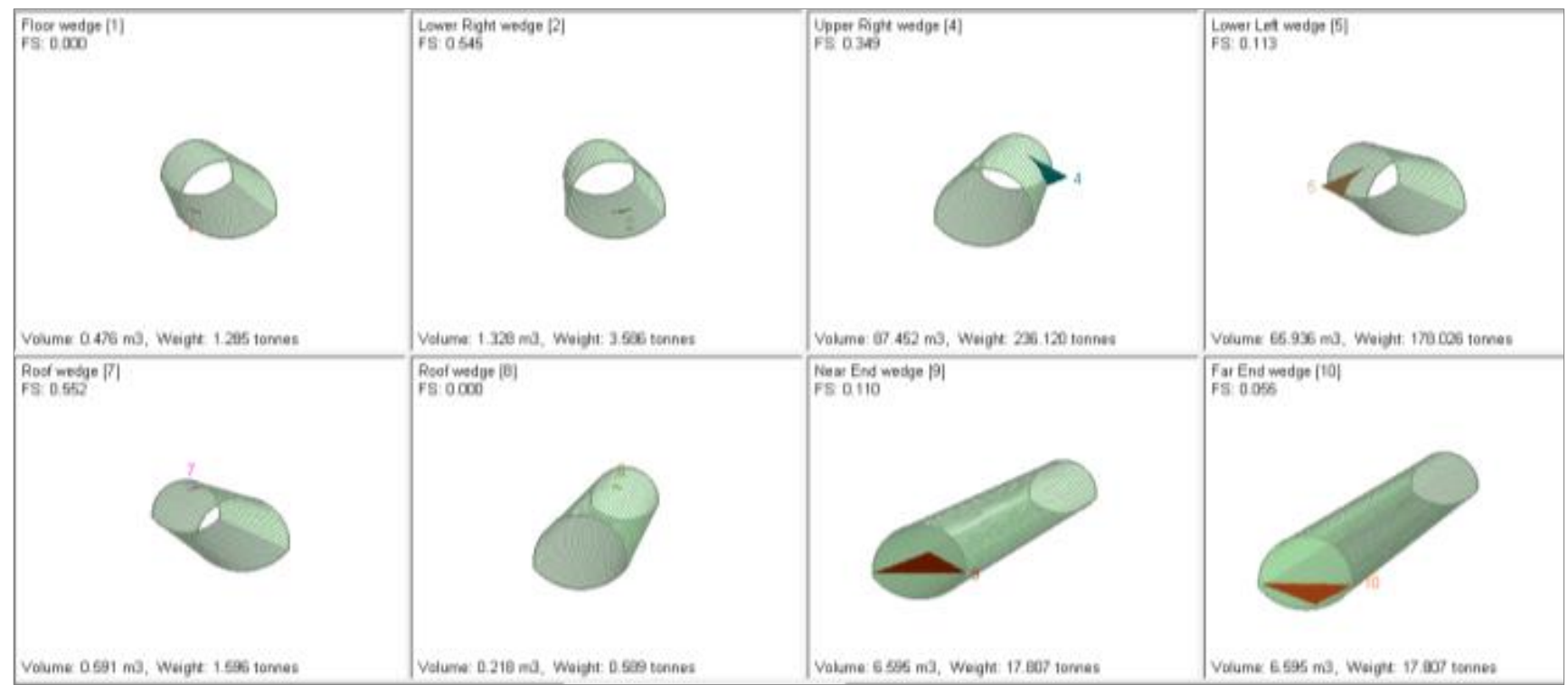

Figura 112 - Seções do túnel ao longo da Linha Estrutural 3 com respectivas cunhas geradas pela combinação 1 de 5 de famílias de descontinuidades $(\mathrm{F} 2+\mathrm{F3}+\mathrm{F5})$, indicando o fator de segurança (FS), volume e peso de cada bloco (Software Unwedge).
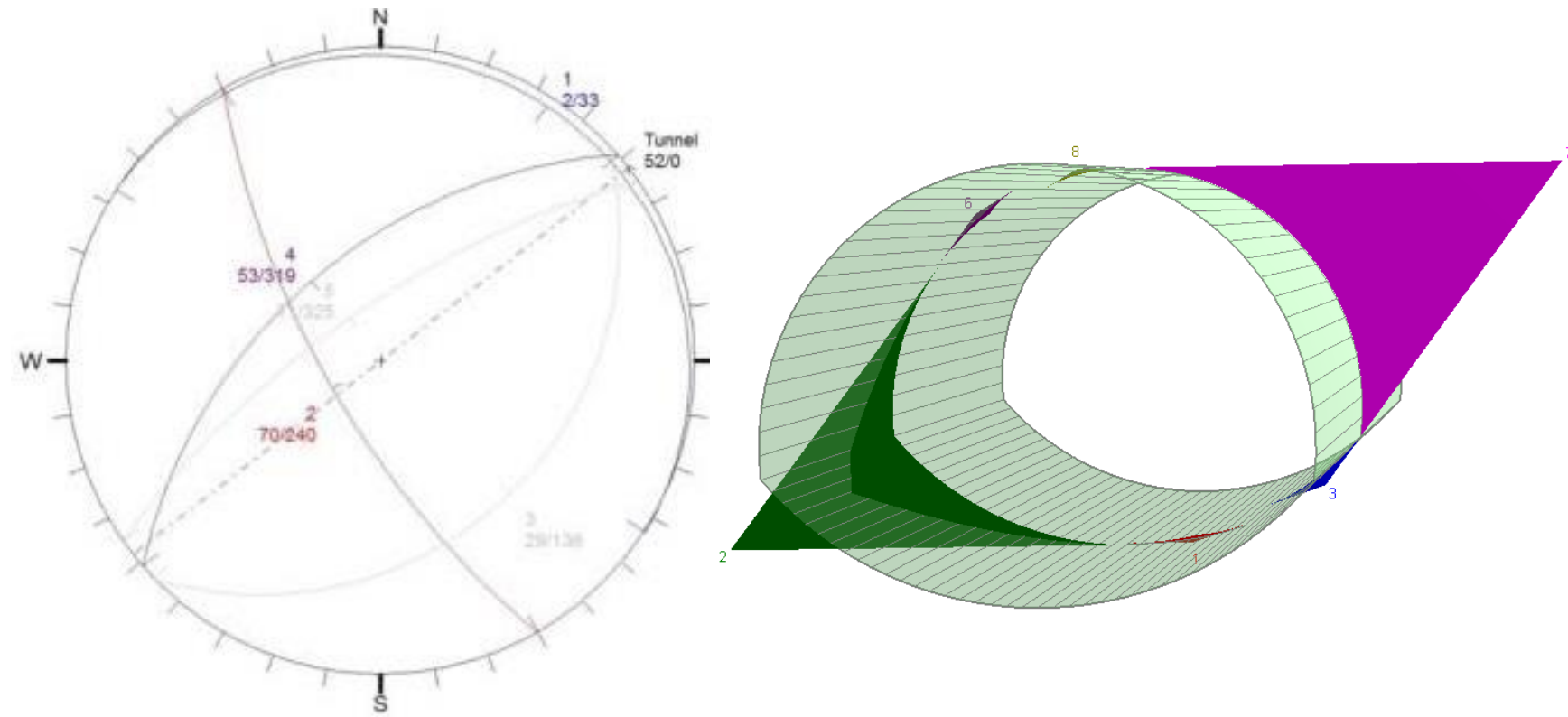

Figura 113- Análise cinemática Figura 114 - Seção do túnel ao longo da Linha bidimensional de cunhas, para Linha Estrutural 3 com respectivas cunhas geradas pela Estrutural 3, combinação 2 de 5 famílias de combinação2 de 5 famílias de descontinuidades descontinuidades (F2+F3+F6) (Software (F2+F3+F6) (Software Unwedge).

Unwedge). 


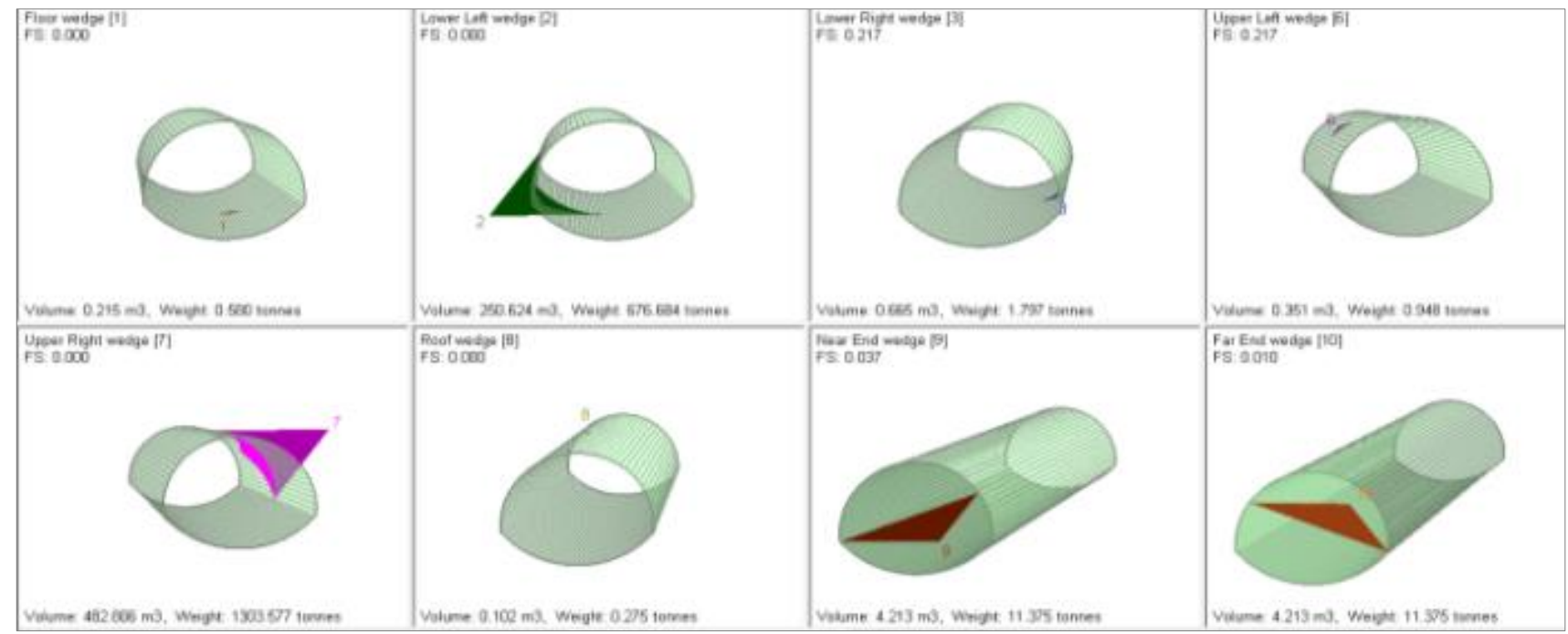

Figura 115 - Seções do túnel ao longo da Linha Estrutural 3 com respectivas cunhas geradas pela combinação 2 de 5 de famílias de descontinuidades (F2+F3+F6), indicando o fator de segurança (FS), volume e peso de cada bloco (Software Unwedge).

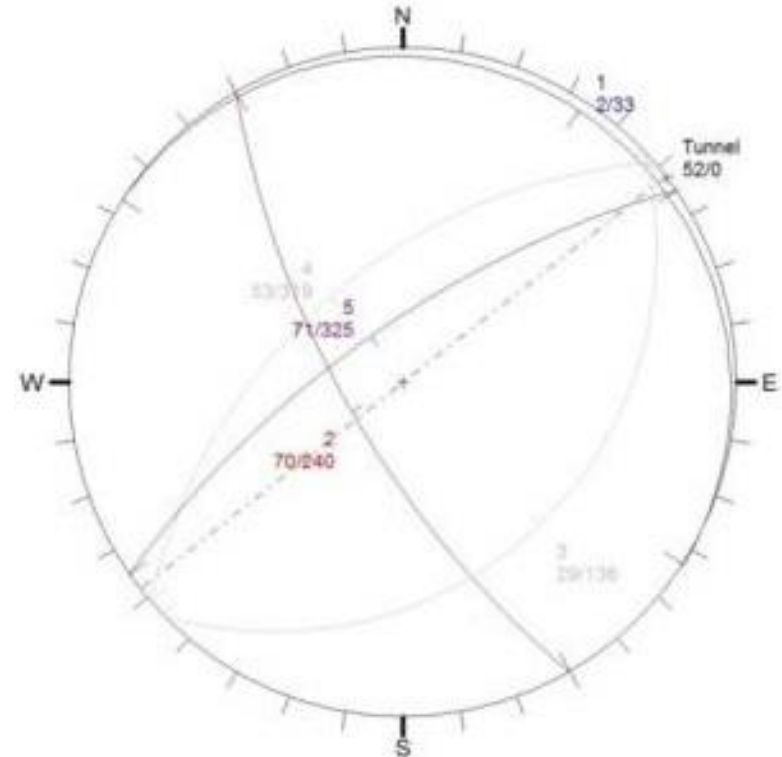

Figura 116 - Análise cinemática bidimensional Figura 117 - Seção do túnel ao longo da Linha de cunhas, para Linha Estrutural 3, Estrutural 3 com respectivas cunhas geradas pela combinação 3 de 5 famílias de combinação 3 de 5 famílias de descontinuidades descontinuidades (F2+F3+F7) (Software (F2+F3+F7) (Software Unwedge).

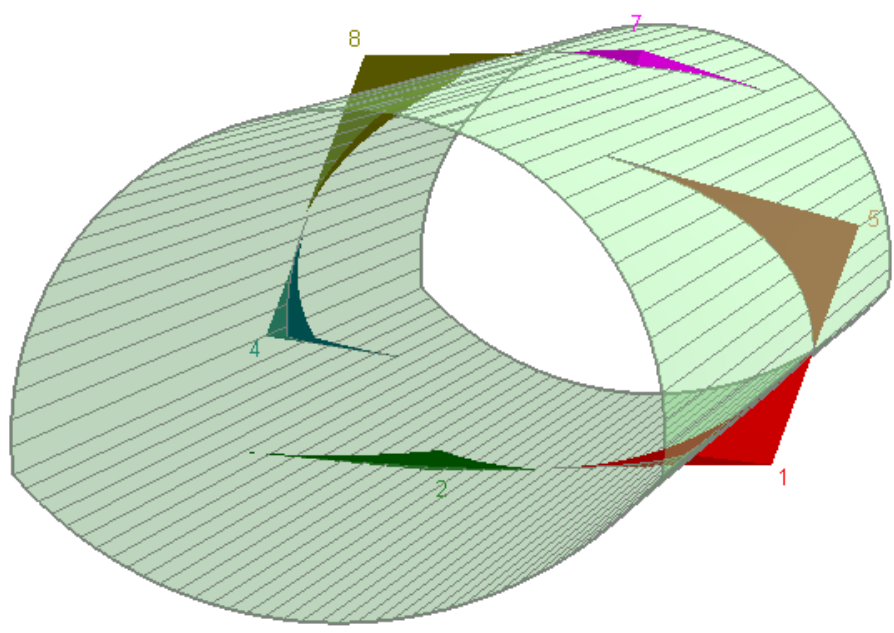

Unwedge). 


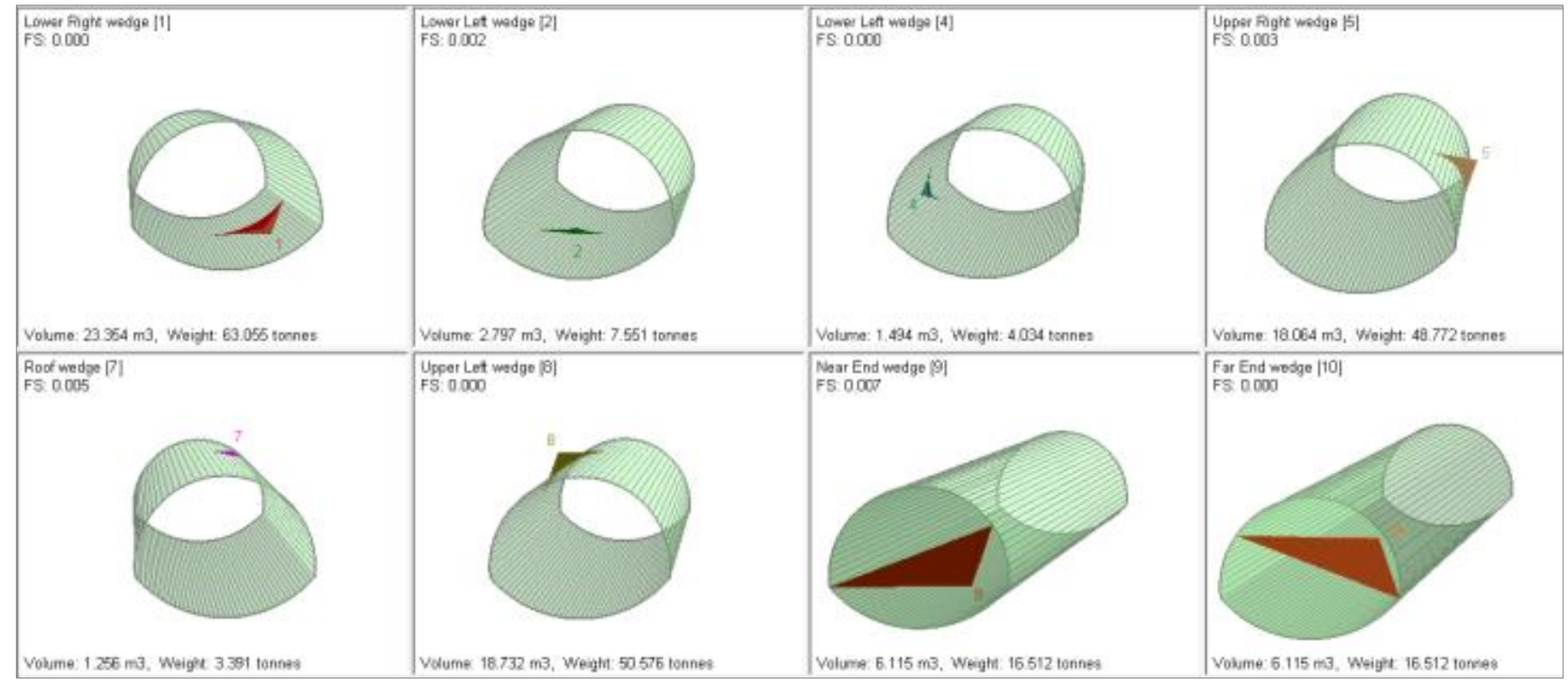

Figura 118 - Seções do túnel ao longo da Linha Estrutural 3 com respectivas cunhas geradas pela combinação 3 de 5 de famílias de descontinuidades (F2+F3+F7), indicando o fator de segurança (FS), volume e peso de cada bloco (Software Unwedge).

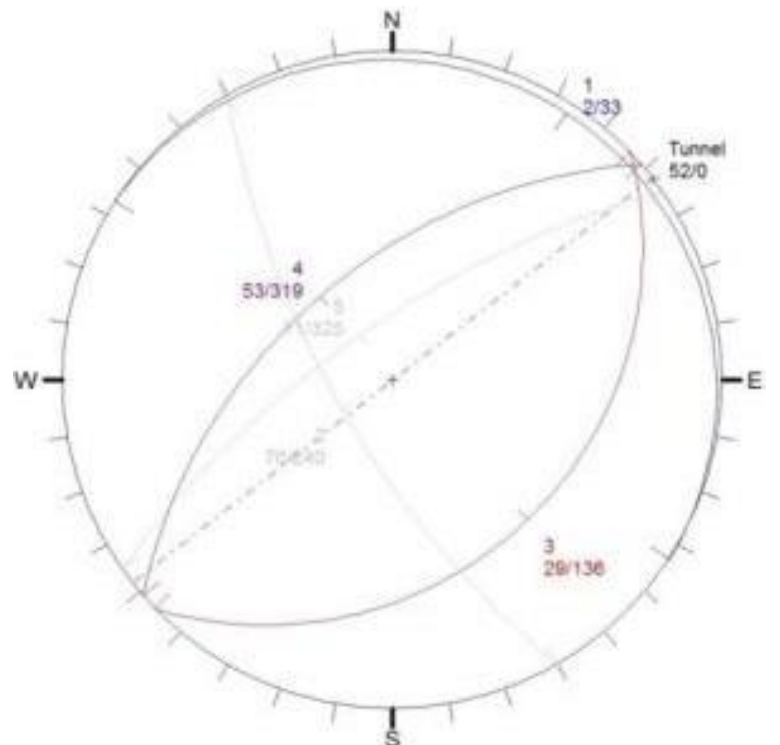

Figura 119 - Análise cinemática bidimensional de cunhas, para Linha Estrutural 3, combinação 4 de 5 famílias de descontinuidades (F2+F5+F6) (Software Unwedge).

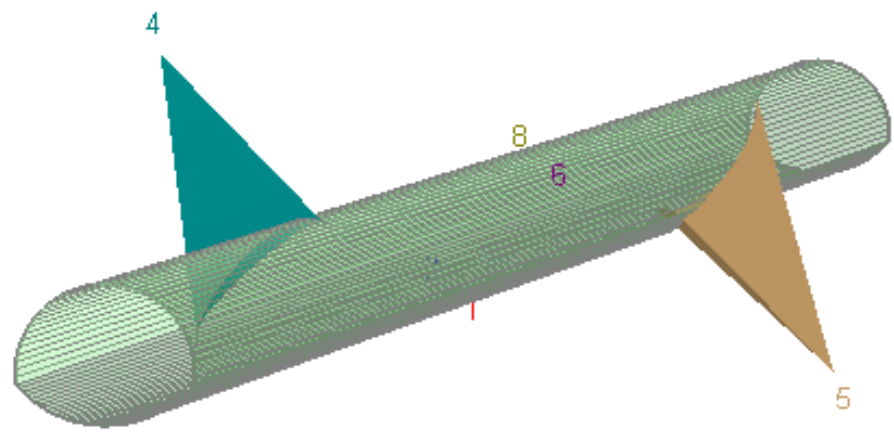

Figura 120 - Seção do túnel ao longo da Linha Estrutural $3 \mathrm{com}$ respectivas cunhas geradas pela combinação 4 de 5 famílias de descontinuidades (F2+F5+F6) (Software Unwedge). 


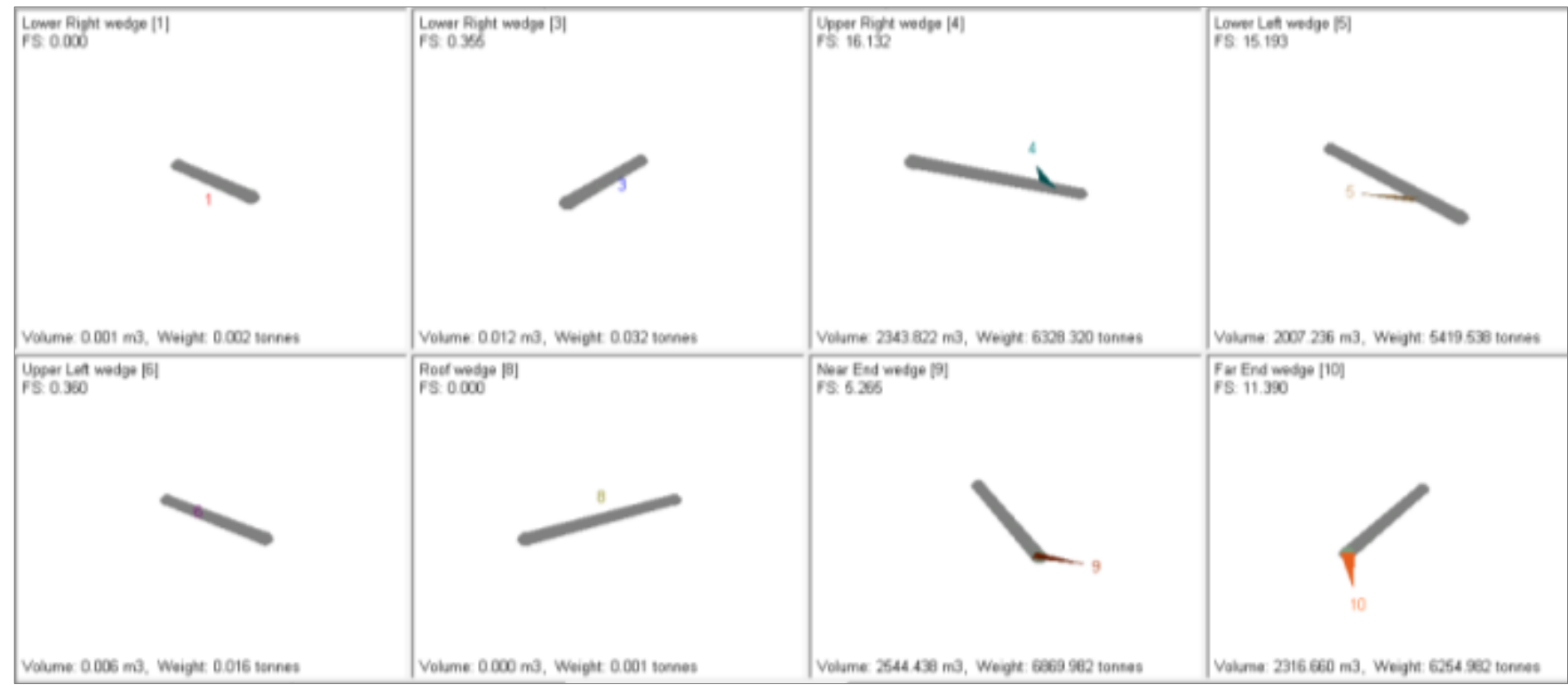

Figura 121- Seções do túnel ao longo da Linha Estrutural 3 com respectivas cunhas geradas pela combinação 4 de 5 de famílias de descontinuidades (F2+F5+F6), indicando o fator de segurança (FS), volume e peso de cada bloco (Software Unwedge).

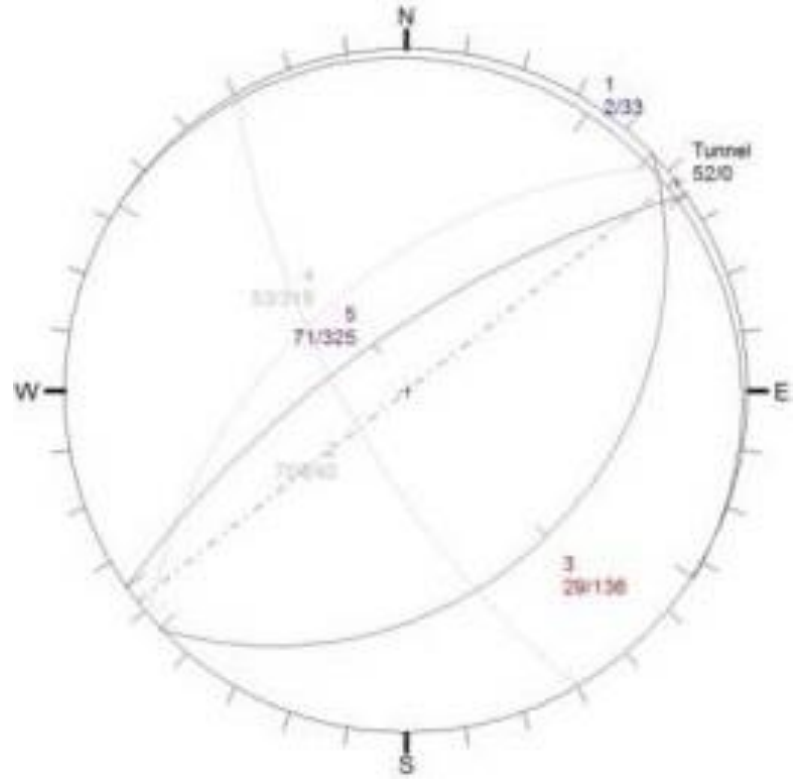

Figura 122 - Análise cinemática bidimensional de cunhas, para Linha Estrutural 3, combinação 5 de 5 famílias de descontinuidades (F2+F5+F7) (Software Unwedge).

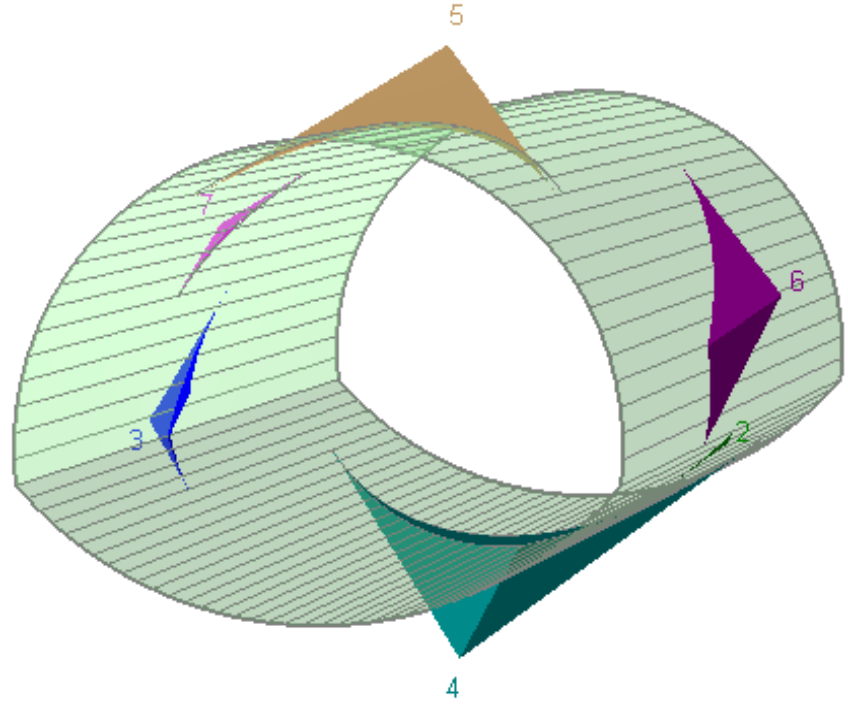

Figura 123 - Seção do túnel ao longo da Linha Estrutural 3 com respectivas cunhas geradas pela combinação 5 de 5 famílias de descontinuidades (F2+F5+F7) (Software Unwedge). 


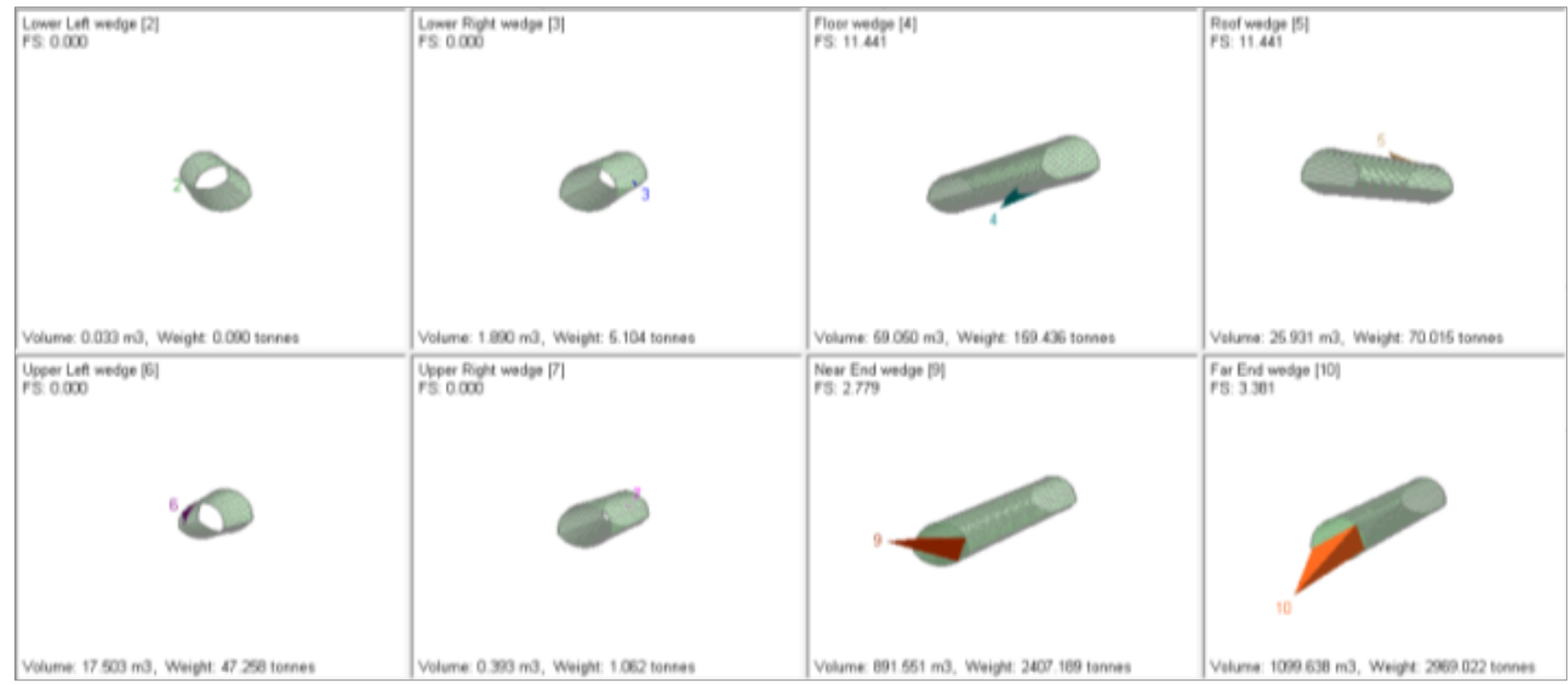

Figura 124 - Seções do túnel ao longo da Linha Estrutural 3 com respectivas cunhas geradas pela combinação 5 de 5 de famílias de descontinuidades (F2+F5+F7), indicando o fator de segurança (FS), volume e peso de cada bloco (Software Unwedge).

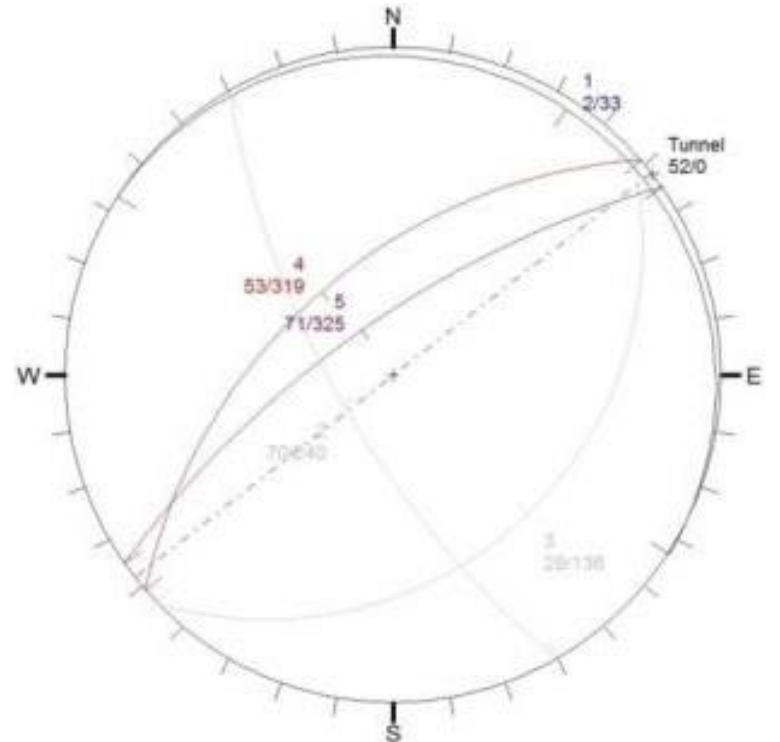

Figura 125 - Análise cinemática bidimensional de cunhas, para Linha Estrutural 3, combinação 6 de 5 famílias de descontinuidades (F2+F6+F7) (Software Unwedge).

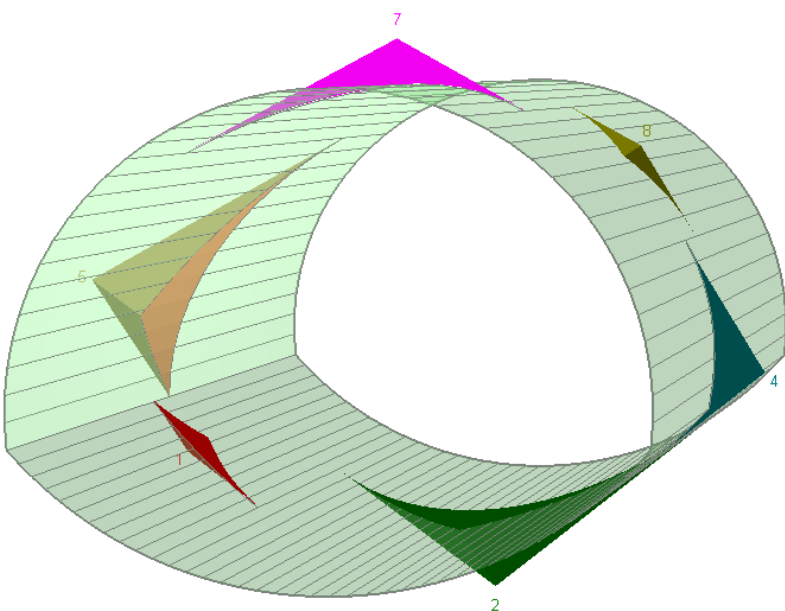

Figura 126 - Seção do túnel ao longo da Linha Estrutural 3 com respectivas cunhas geradas pela combinação 6 de 5 famílias de descontinuidades $($ F2+F6+F7) (Software Unwedge). 


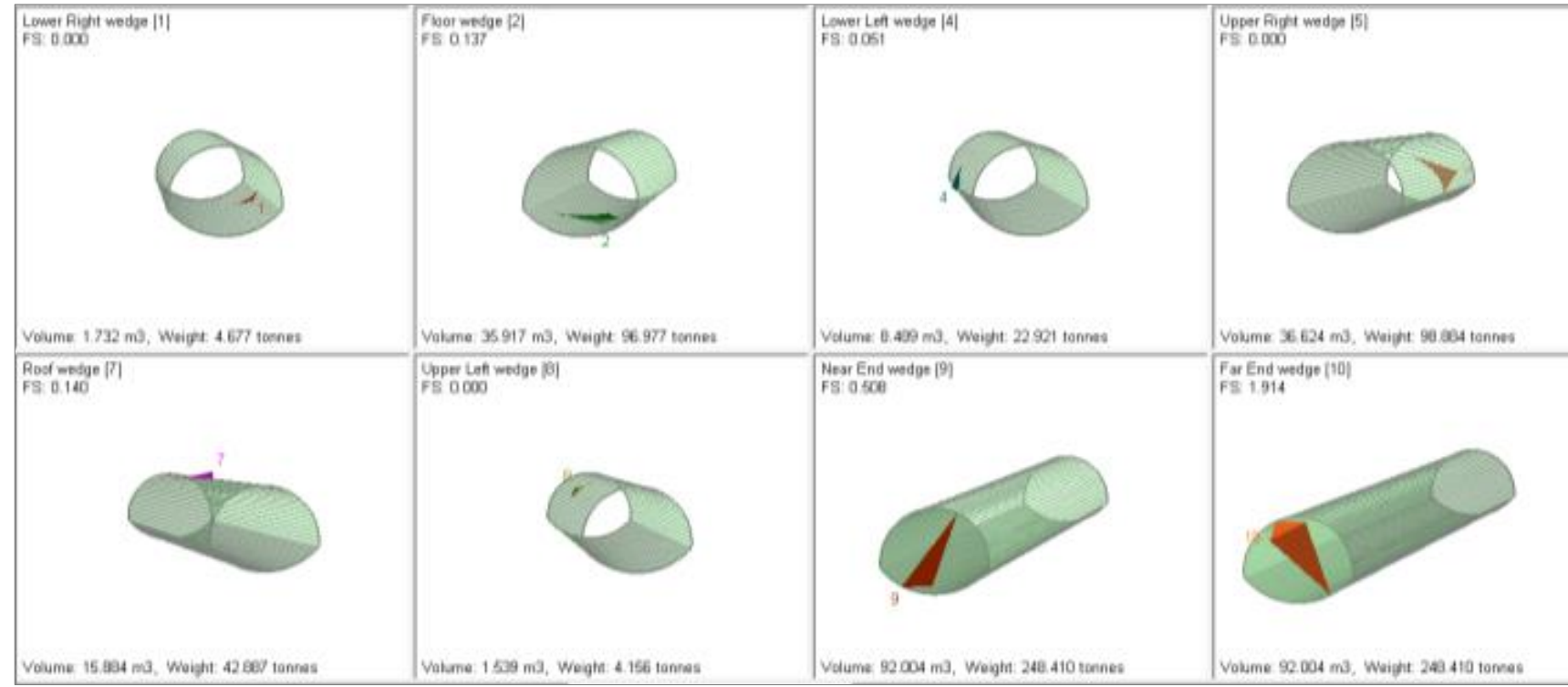

Figura 127 - Seções do túnel ao longo da Linha Estrutural 3 com respectivas cunhas geradas pela combinação 6 de 5 de famílias de descontinuidades (F2+F6+F7), indicando o fator de segurança (FS), volume e peso de cada bloco (Software Unwedge).

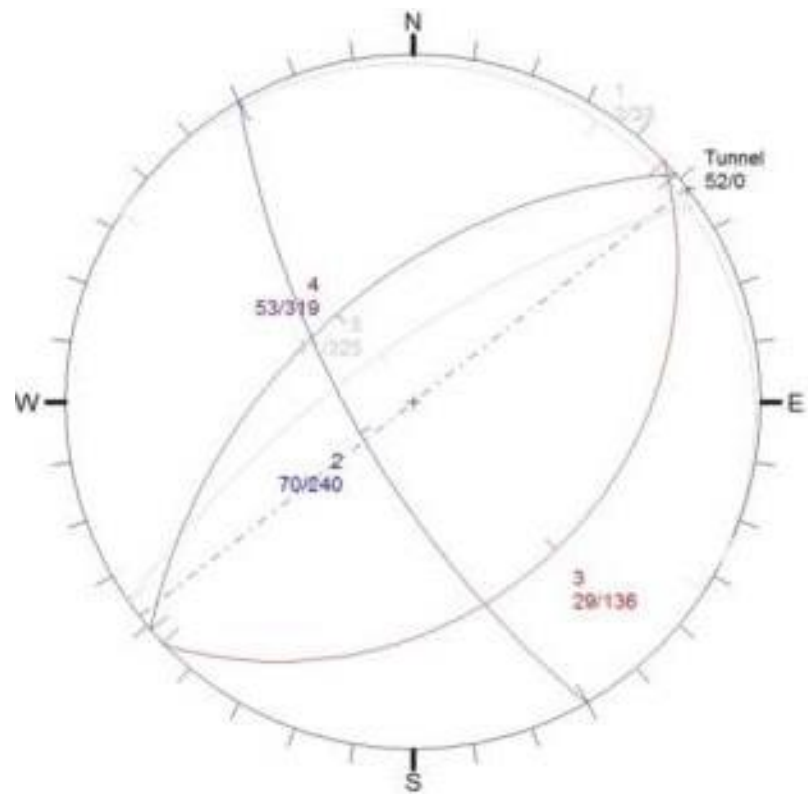

Figura 128 - Análise cinemática bidimensional de cunhas, para Linha Estrutural 3, combinação 7 de 5 famílias de descontinuidades (F3+F5+F6) (Software Unwedge).

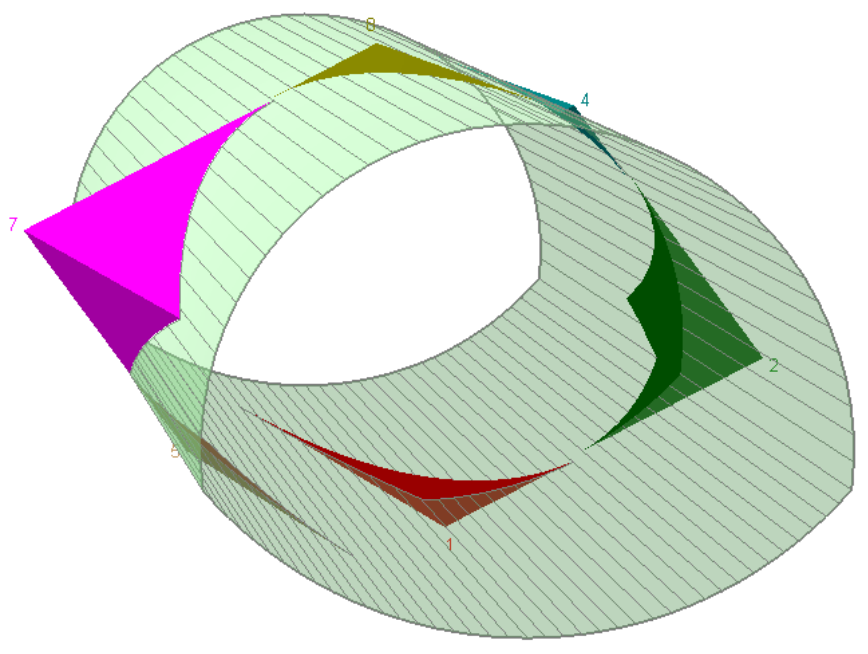

Figura 129 - Seção do túnel ao longo da Linha Estrutural $3 \mathrm{com}$ respectivas cunhas geradas pela combinação 7 de 5 famílias de descontinuidades (F3+F5+F6) (Software Unwedge). 


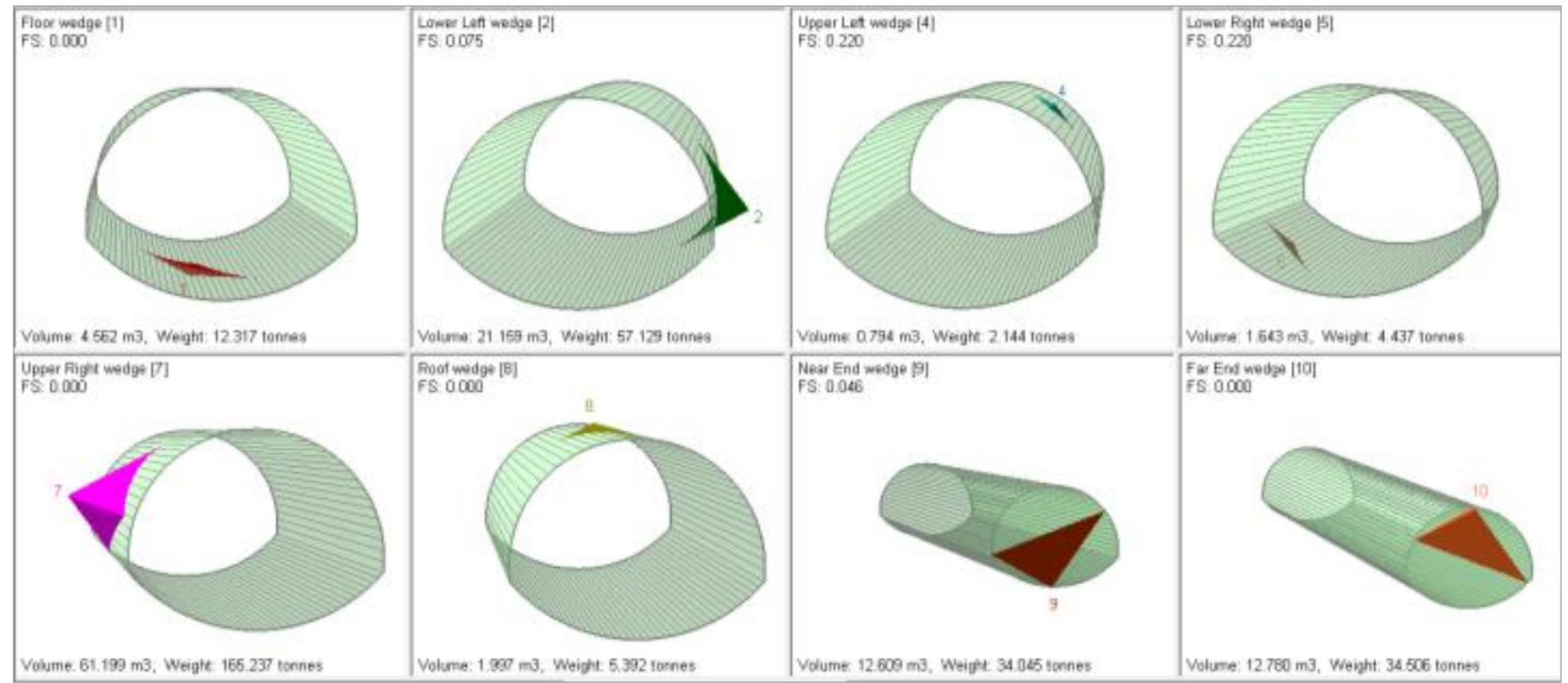

Figura 130 - Seções do túnel ao longo da Linha Estrutural 3 com respectivas cunhas geradas pela combinação 7 de 5 de famílias de descontinuidades (F3+F5+F6), indicando o fator de segurança (FS), volume e peso de cada bloco (Software Unwedge).

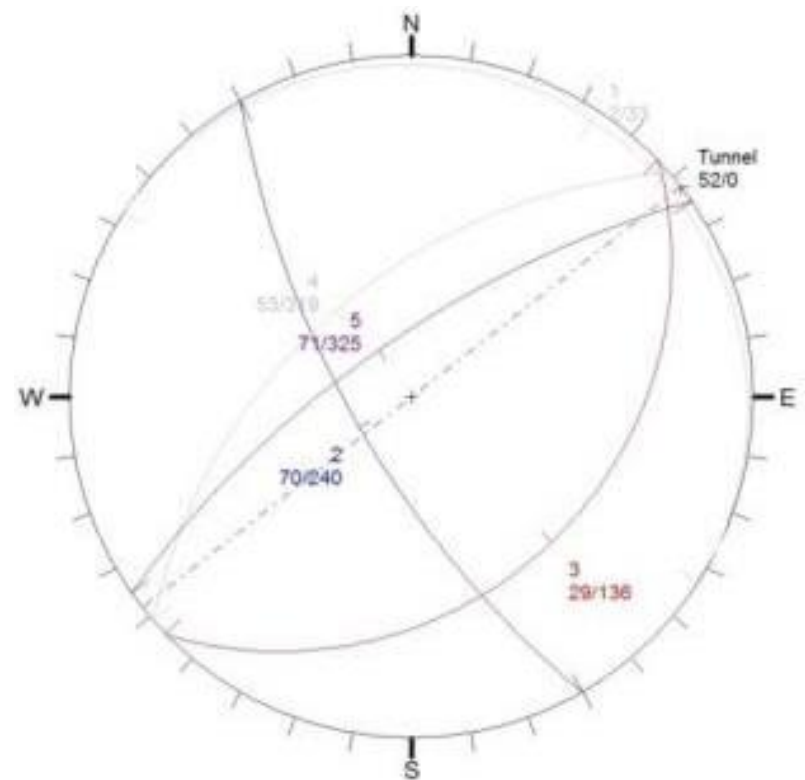

Figura 131 - Análise cinemática bidimensional de cunhas, para Linha Estrutural 3, combinação 8 de 5 famílias de descontinuidades (F3+F5+F7) (Software Unwedge).

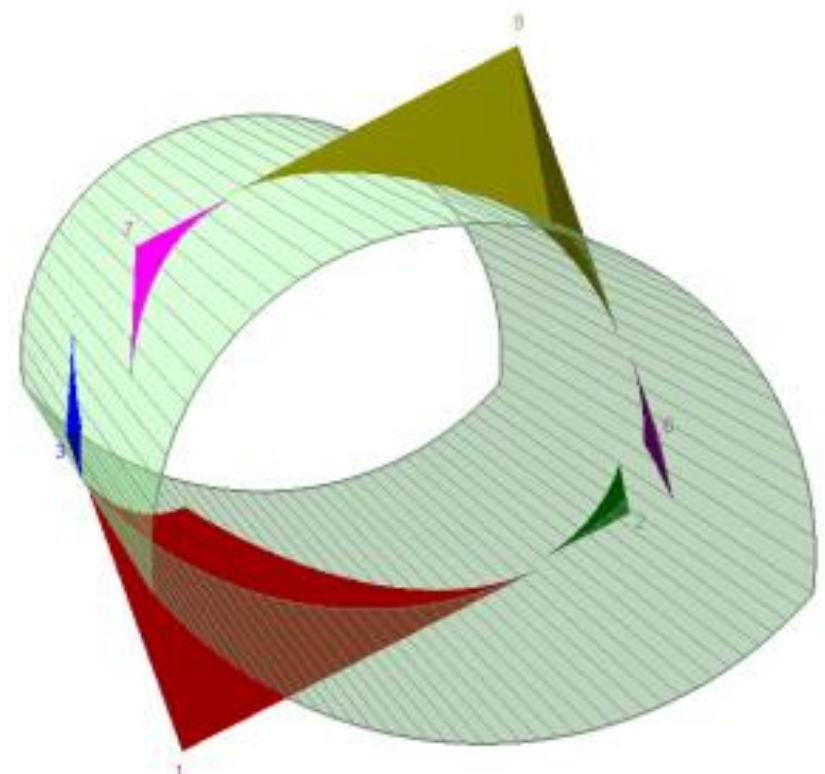

Figura 132 - Seção do túnel ao longo da Linha Estrutural $3 \mathrm{com}$ respectivas cunhas geradas pela combinação 8 de 5 famílias de descontinuidades (F3+F5+F7) (Software Unwedge). 


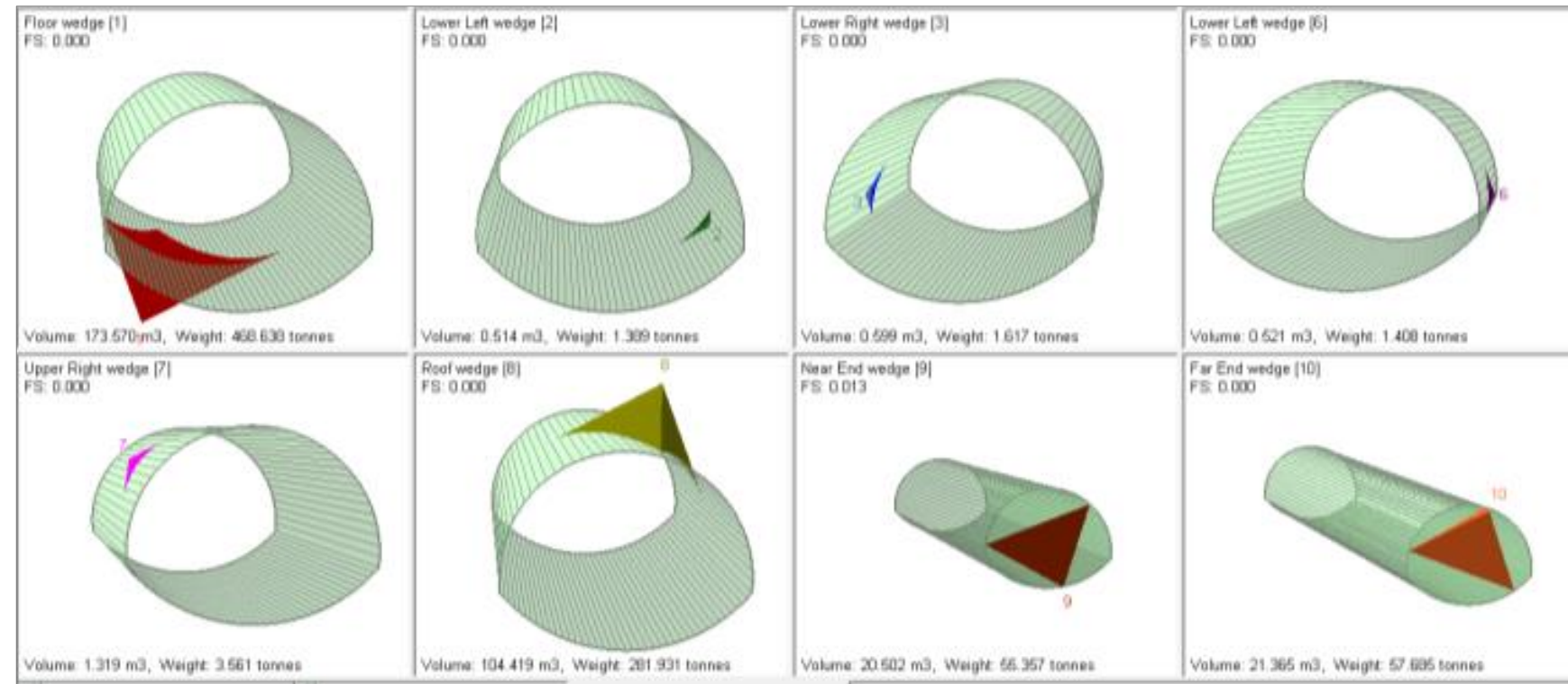

Figura 133 - Seções do túnel ao longo da Linha Estrutural 3 com respectivas cunhas geradas pela combinação 8 de 5 de famílias de descontinuidades (F3+F5+F7), indicando o fator de segurança (FS), volume e peso de cada bloco (Software Unwedge).

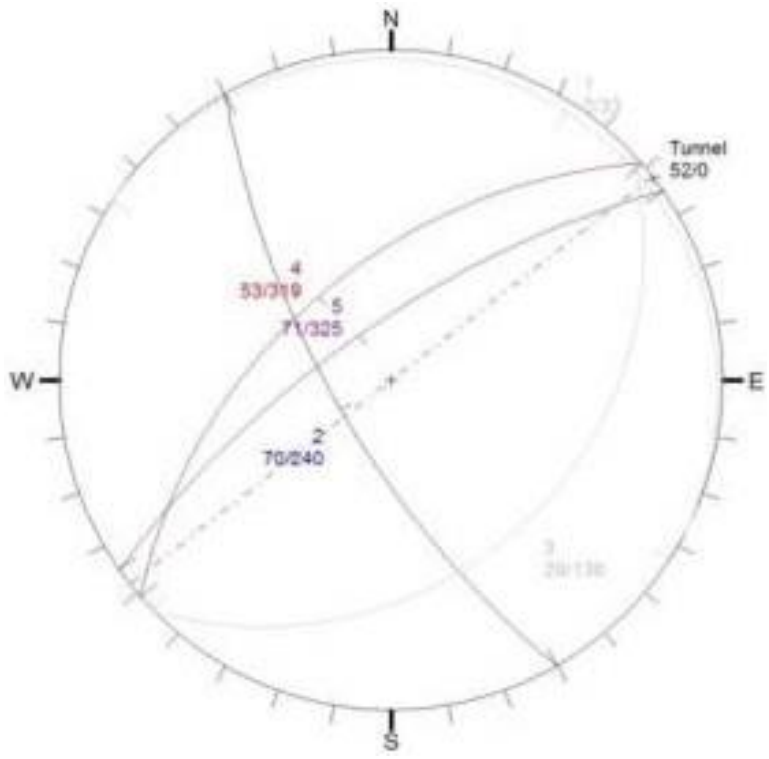

Figura 134 - Análise cinemática bidimensional de cunhas, para Linha Estrutural 3, combinação 9 de 5 famílias de descontinuidades (F3+F6+F7) (Software Unwedge).

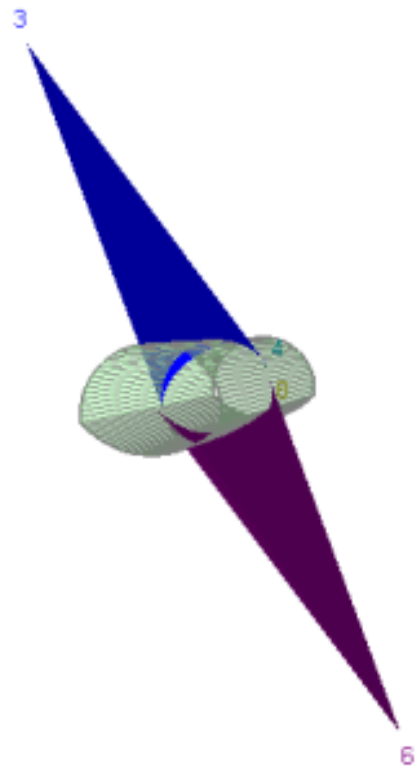

Figura 135 - Seção do túnel ao longo da Linha Estrutural $3 \mathrm{com}$ respectivas cunhas geradas pela combinação 9 de 5 famílias de descontinuidades (F3+F6+F7) (Software Unwedge). 


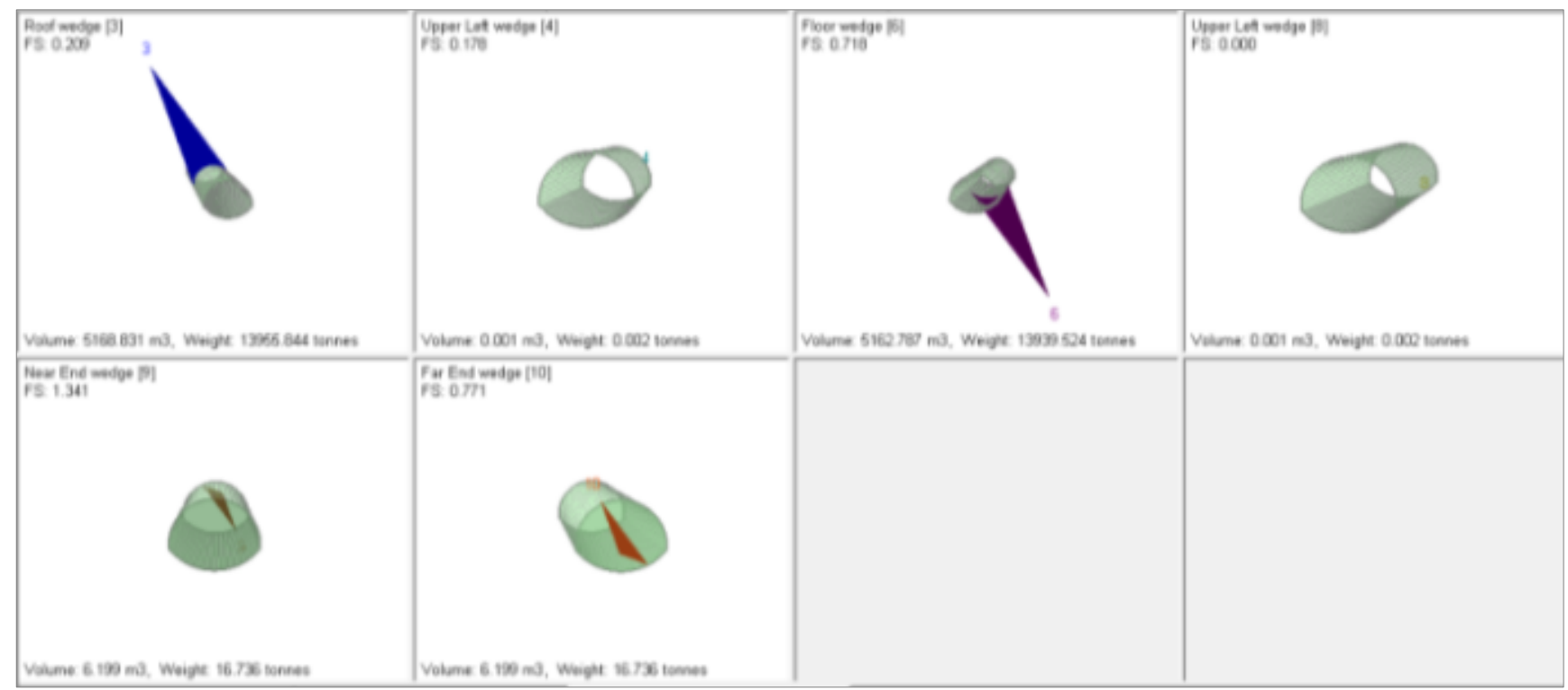

Figura 136 - Seções do túnel ao longo da Linha Estrutural 3 com respectivas cunhas geradas pela combinação 9 de 5 de famílias de descontinuidades (F3+F6+F7), indicando o fator de segurança (FS), volume e peso de cada bloco (Software Unwedge).

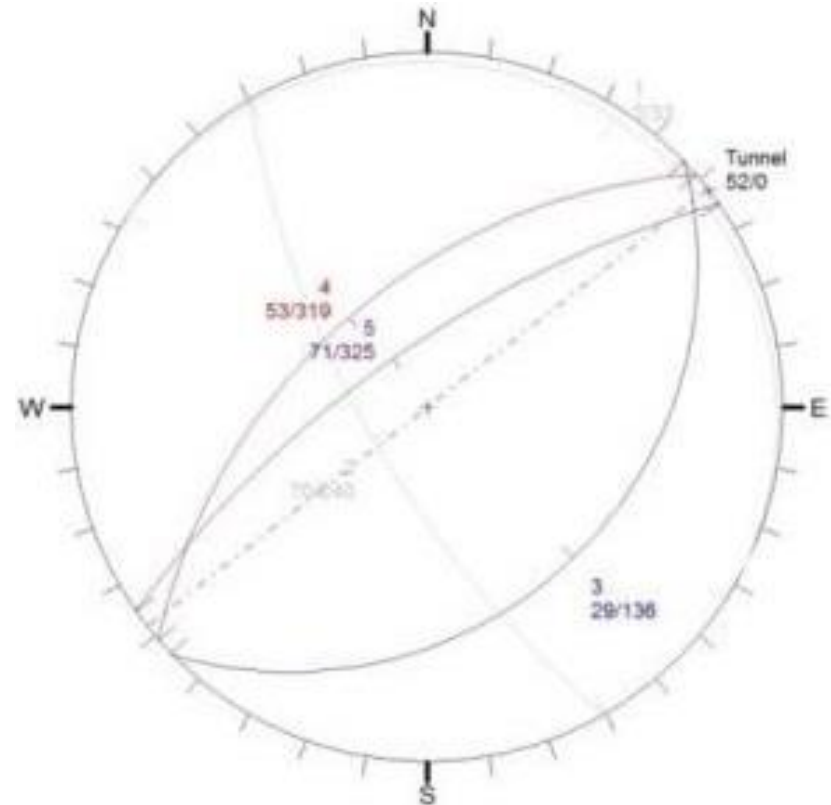

Figura 137 - Análise cinemática bidimensional de cunhas, para Linha Estrutural 3, combinação 10 de 5 famílias de descontinuidades (F5+F6+F7) (Software Unwedge).

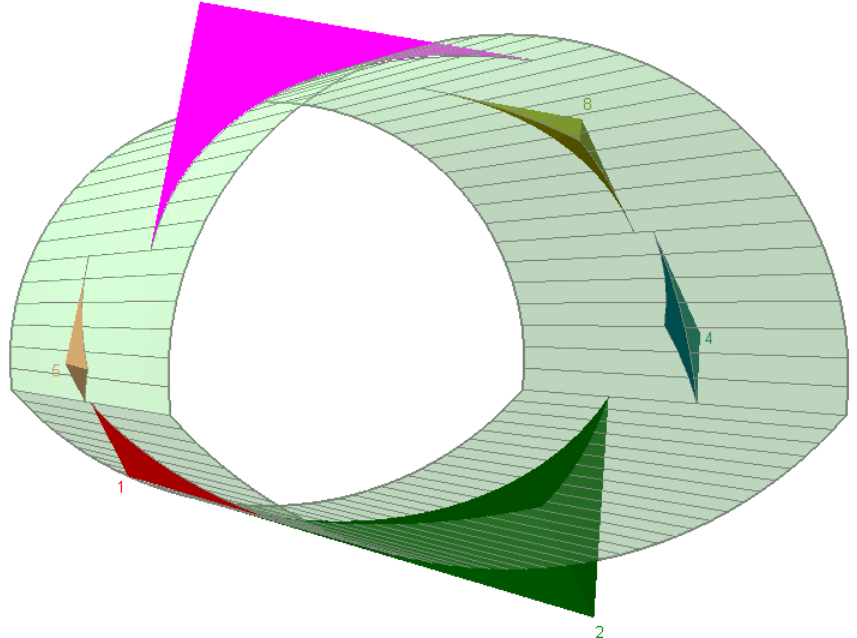

Figura 138 - Seção do túnel ao longo da Linha Estrutural $3 \mathrm{com}$ respectivas cunhas geradas pela combinação de $\mathbf{1 0}$ de $\mathbf{5}$ famílias de descontinuidades (F5+F6+F7) (Software Unwedge). 


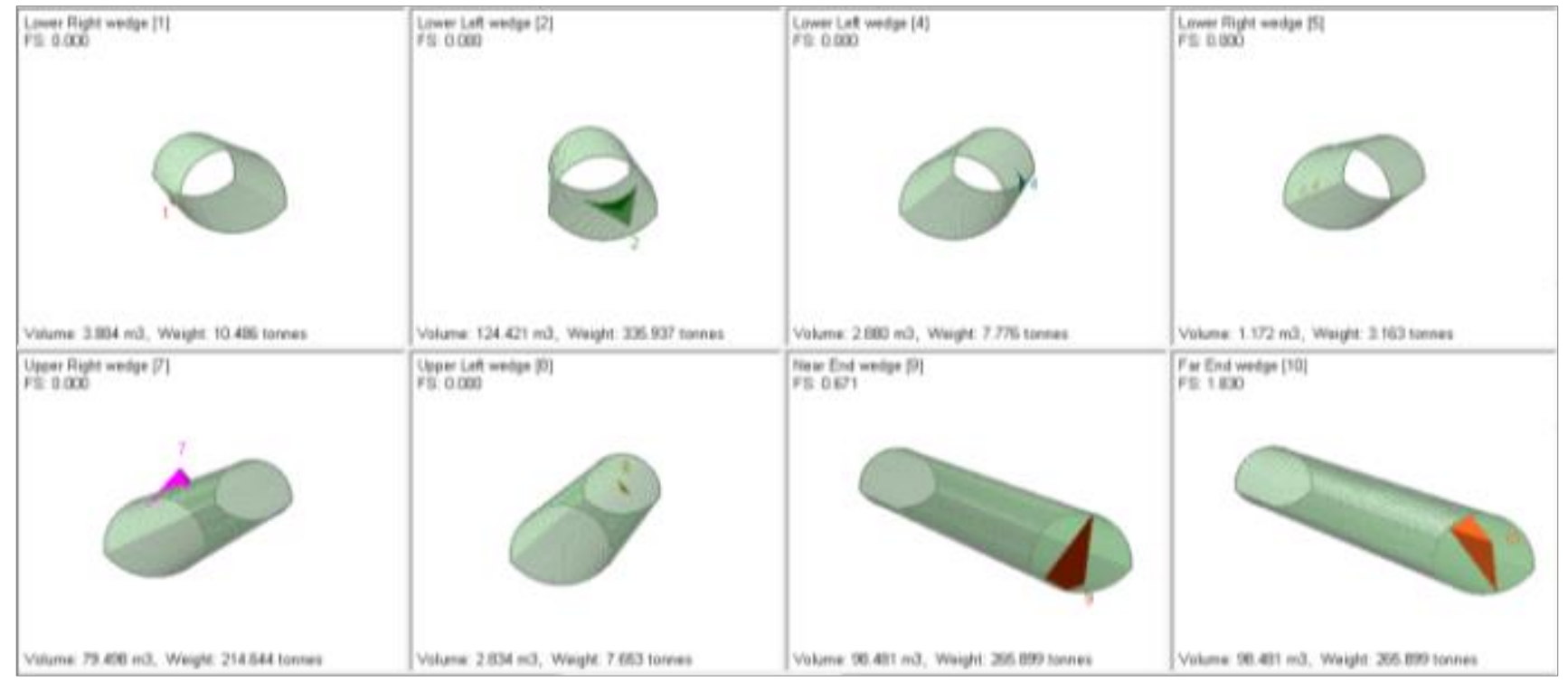

Figura 139 - Seções do túnel ao longo da Linha Estrutural 3 com respectivas cunhas geradas pela combinação 10 de 5 de famílias de descontinuidades (F5+F6+F7), indicando o fator de segurança (FS), volume e peso de cada bloco (Software Unwedge).

Com respeito à Linha Estrutural 4, foram consideradas 4 famílias no total, contando no total com quatro combinações entre as famílias. Com relação à análise por estereogramas, podemos observar que há formação de cunhas com deslizamento principalmente pela família 1, sendo cortada pela família 3 subvertical (Figuras 140 e 146). Também ocorre uma cunha formada pela família F5, denominada nos desenhos de número 4, porém devido ao baixo ângulo de mergulho, não são cunhas preocupantes. Também é importante trazer atenção ao fato de que a principal família F1, de direção 149/62, está praticamente paralela à direção do túnel, com uma diferença de apenas $10^{\circ}$, o que pode implicar em deslizamentos por sobre este plano, cortado por planos subverticais como os da família F3.

Com respeito à análise tridimensional para este trecho, conclui-se que os blocos mais problemáticos formados são os seguintes:

Bloco número 3, formado pelas famílias F1, F2 e F3, no canto superior esquerdo, fator de segurança igual a 0, com volume aproximado de $199 \mathrm{~m}^{3}$ e peso em torno de 538 toneladas (Figuras 141 e 142);

$>$ Bloco número 8, formado pelas famílias F1, F2 e F3, no teto, fator de segurança igual a 0 , com volume aproximado de $6 \mathrm{~m}^{3}$ e peso em torno de 17 toneladas (Figuras $144 \mathrm{e}$ $145)$; 
Bloco número 2, formado pelas famílias F1, F3 e F5, no canto superior esquerdo, fator de segurança igual a 0 , com volume aproximado de $118 \mathrm{~m}^{3}$ e peso em torno de 319 toneladas (Figuras 147 e 148);

Bloco número 5, formado pelas famílias F2, F3 e F5, no canto superior esquerdo, fator de segurança igual a 0,5 , com volume aproximado de $1694 \mathrm{~m}^{3}$ e peso em torno de 4574 toneladas (Figuras 150 e 151). Certamente este é o bloco mais problemático no trecho.

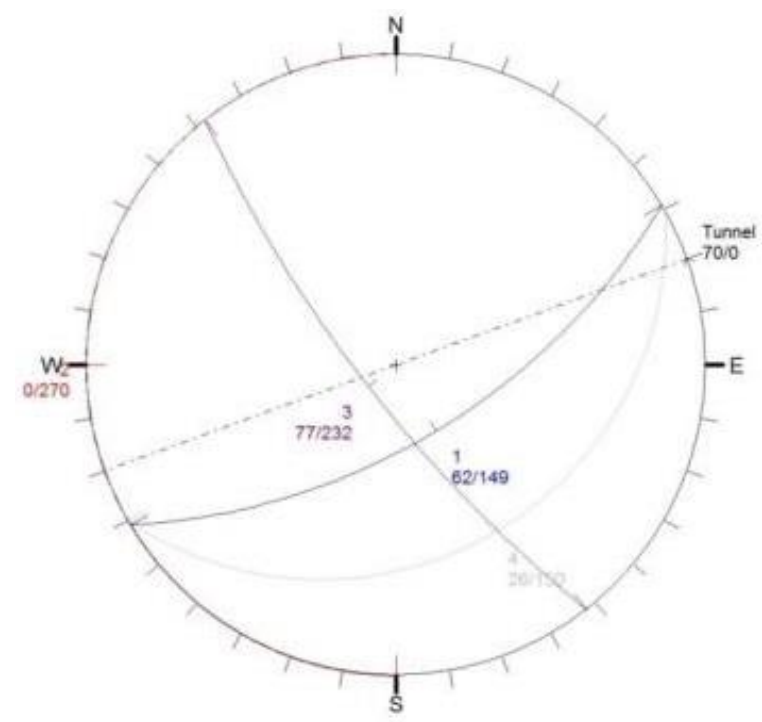

Figura 140 - Análise cinemática bidimensional de cunhas, para Linha Estrutural 4, combinação 1 de 4 famílias de descontinuidades $\quad(\mathbf{F 1}+\mathbf{F} 2+\mathbf{F 3})($ Software Unwedge).

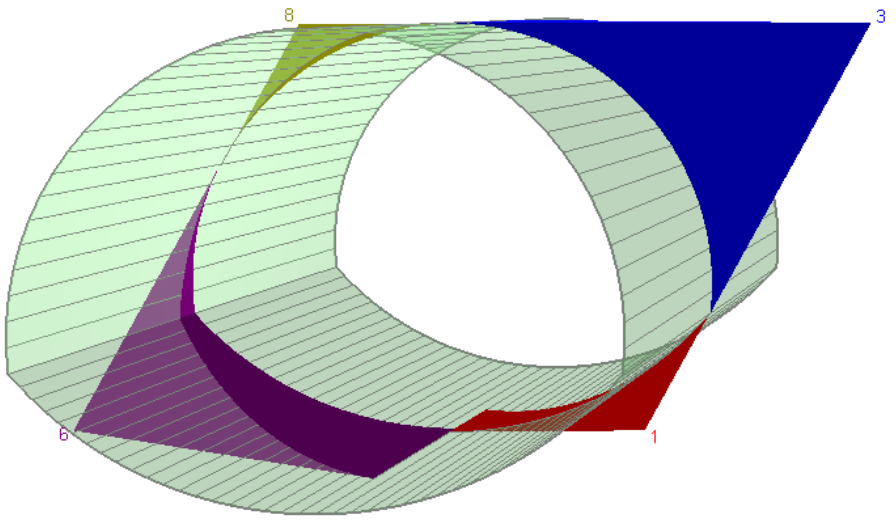

Figura 141 - Seção do túnel ao longo da Linha Estrutural $4 \mathrm{com}$ respectivas cunhas geradas pela combinação 1 de 4 famílias de descontinuidades (F1+F2+F3) (Software Unwedge).

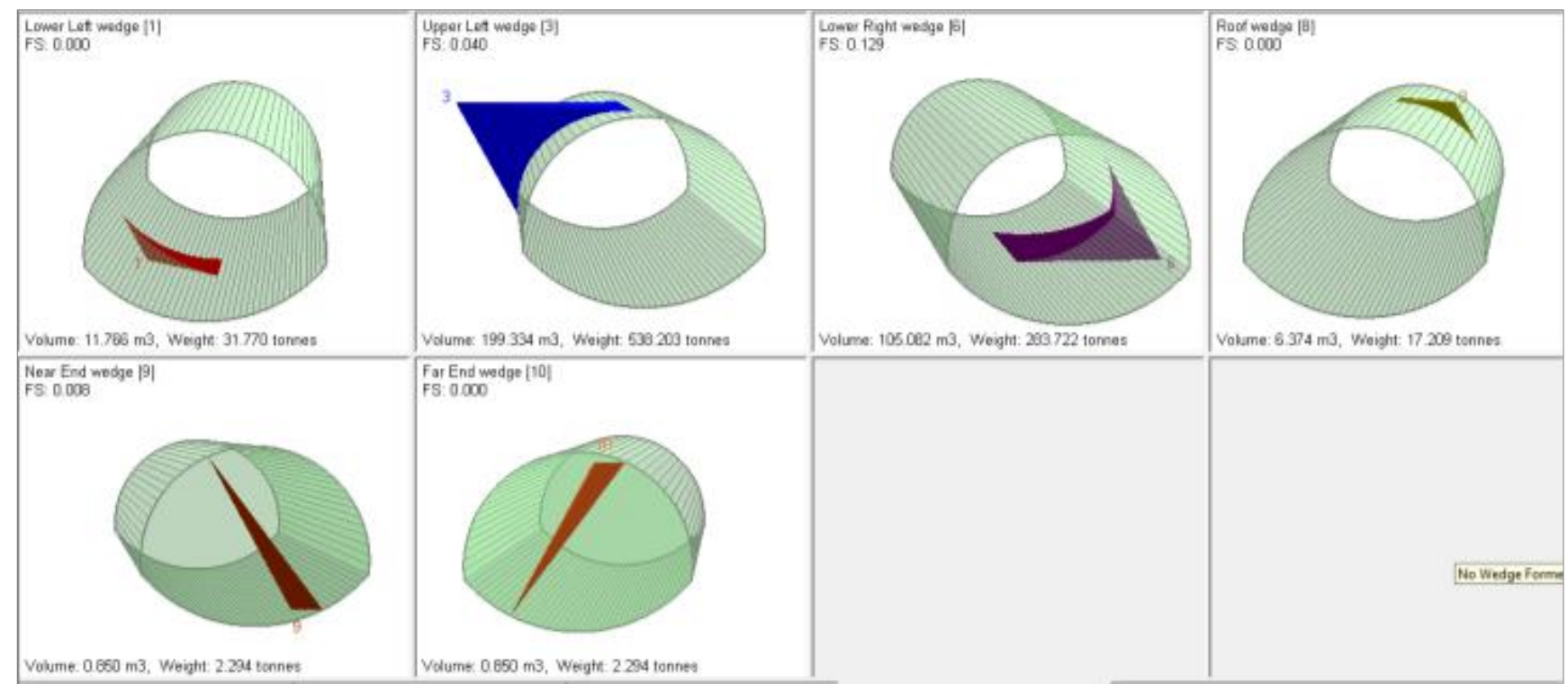

Figura 142-Seções do túnel ao longo da Linha Estrutural $4 \mathrm{com}$ respectivas cunhas geradas pela combinação 1 de 4 de famílias de descontinuidades (F1+F2+F3), indicando o fator de segurança (FS), volume e peso de cada bloco (Software Unwedge). 


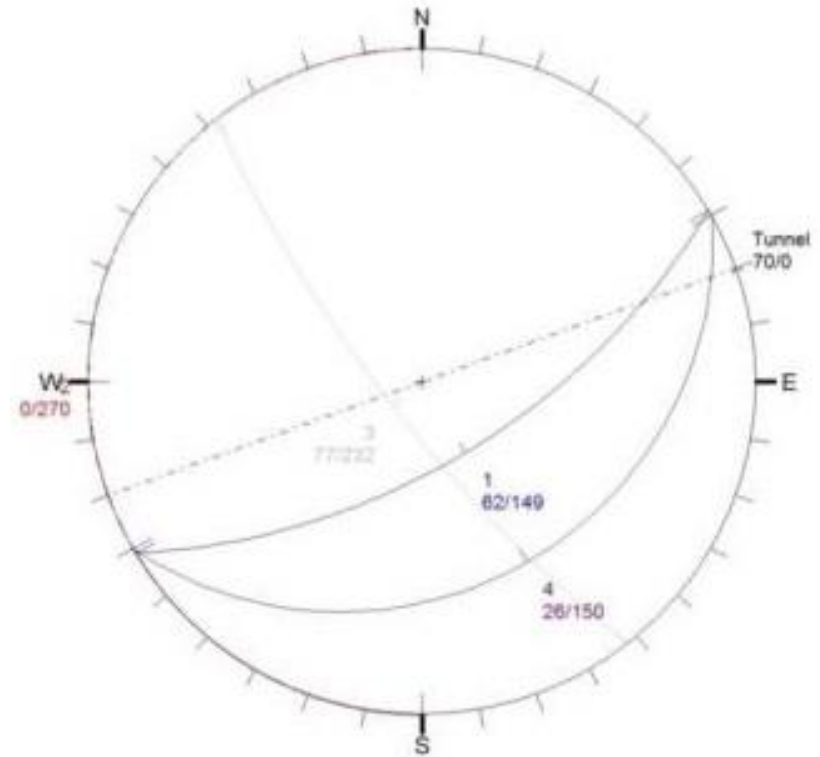

Figura 143 - Análise cinemática bidimensional de cunhas, para Linha Estrutural 4, combinação 2 de 4 famílias de descontinuidades (F1+F2+F5)4 (Software Unwedge).
Figura 144 - Seção do túnel ao longo da Linha Estrutural $4 \mathrm{com}$ respectivas cunhas geradas pela combinação 2 de 4 famílias de descontinuidades (F1+F2+F5) (Software Unwedge).

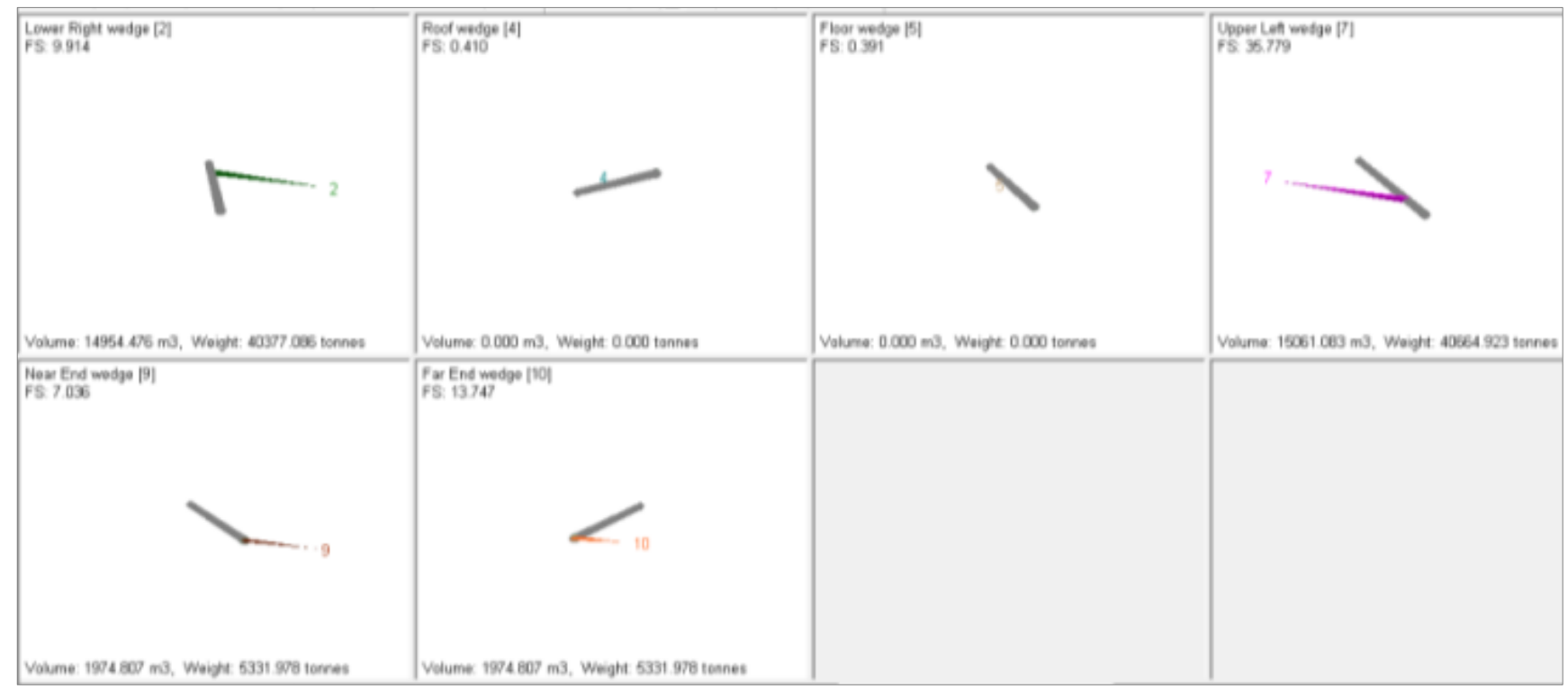

Figura 145 - Seções do túnel ao longo da Linha Estrutural 4 com respectivas cunhas geradas pela combinação 2 de 4 de famílias de descontinuidades (F1+F2+F5), indicando o fator de segurança (FS), volume e peso de cada bloco (Software Unwedge).

\footnotetext{
${ }^{4}$ Para esta Linha Estrutural 4 considerar a numeração (4) nas imagens referente à família F5. A família F6 foi desconsiderada para as análises, pois apresenta menor representatividade.
} 


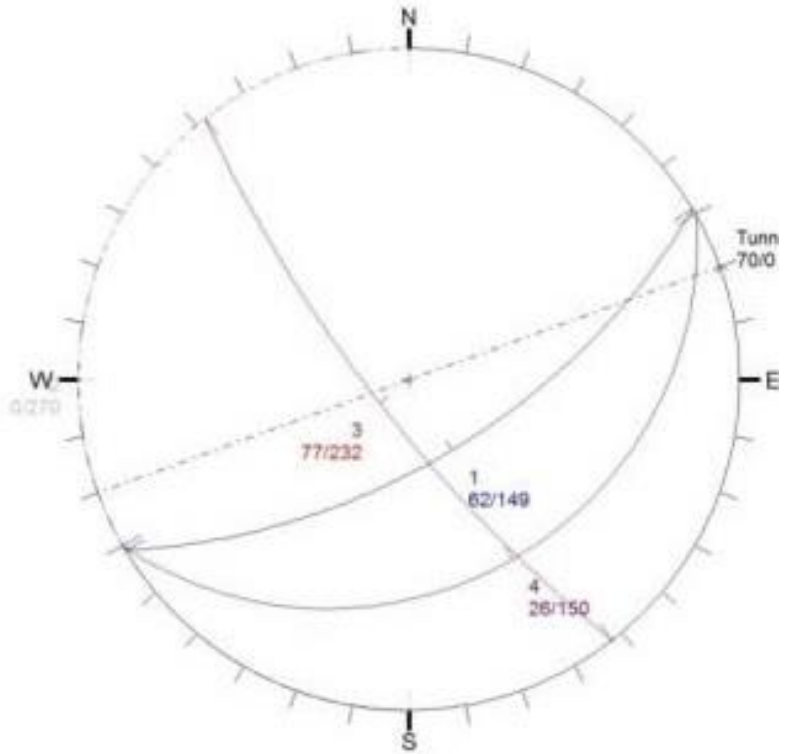

Figura 146 - Análise cinemática bidimensional de cunhas, para Linha Estrutural 4, combinação 3 de 4 famílias de descontinuidades (F1+F3+F5) (Software Unwedge).

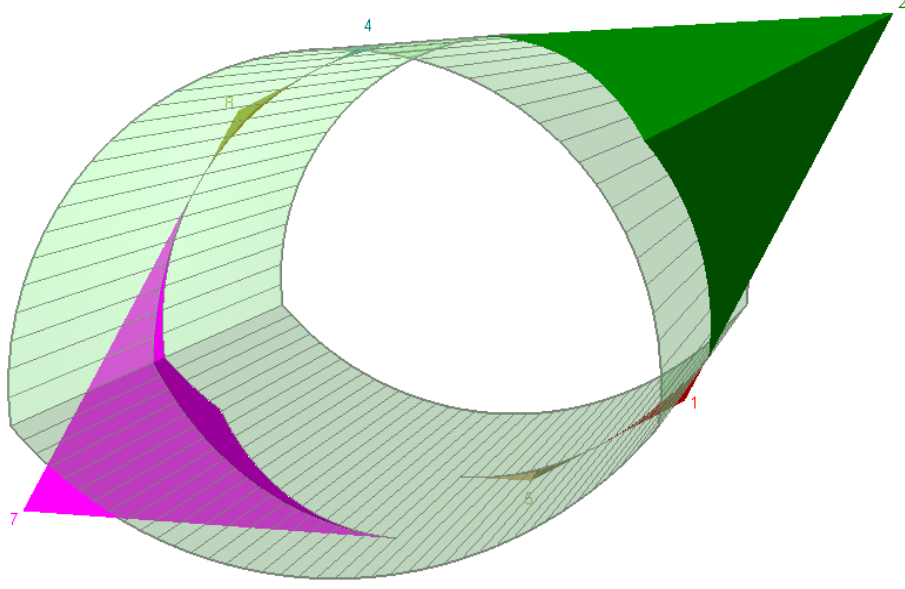

Figura 147 - Seção do túnel ao longo da Linha Estrutural $4 \mathrm{com}$ respectivas cunhas geradas pela combinação 3 de 4 famílias de descontinuidades $(\mathrm{F} 1+\mathrm{F} 3+\mathrm{F5})$ (Software Unwedge).

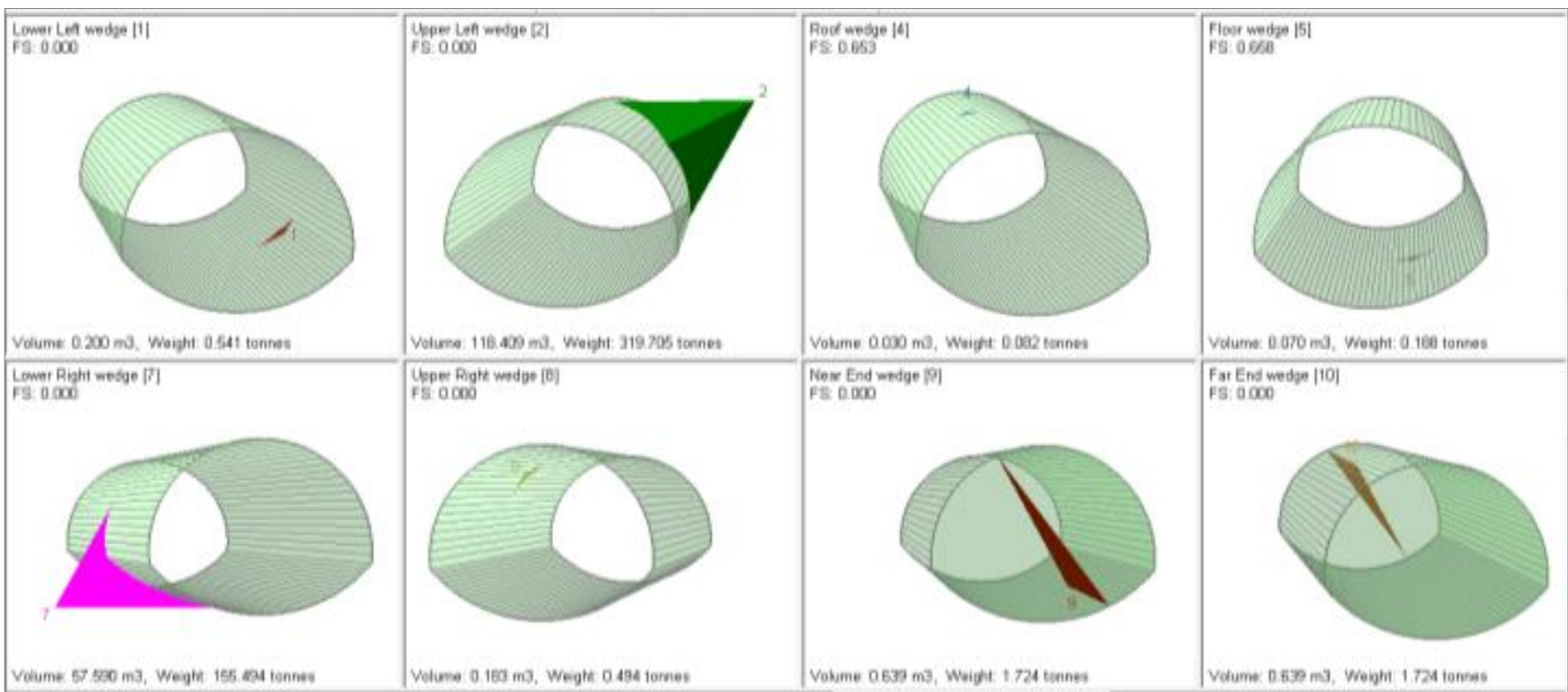

Figura 148 - Seções do túnel ao longo da Linha Estrutural 4 com respectivas cunhas geradas pela combinação 3 de 4 de famílias de descontinuidades (F1+F3+F5), indicando o fator de segurança (FS), volume e peso de cada bloco (Software Unwedge). 


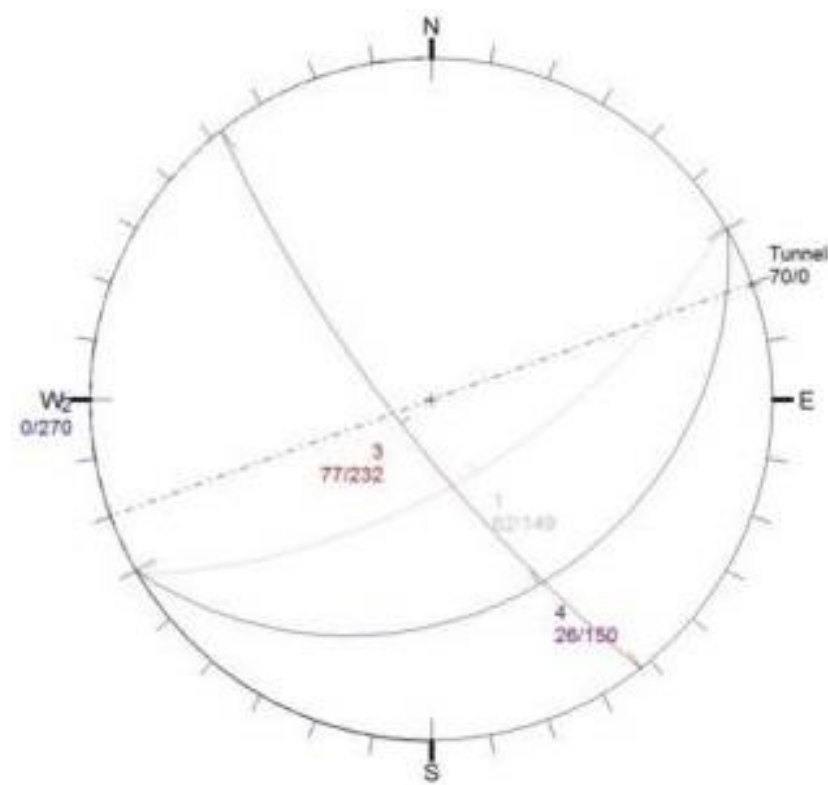

Figura 149 - Análise cinemática bidimensional de cunhas, para Linha Estrutural 4, combinação 4 de 4 famílias de descontinuidades (F2+F3+F5) (Software Unwedge).

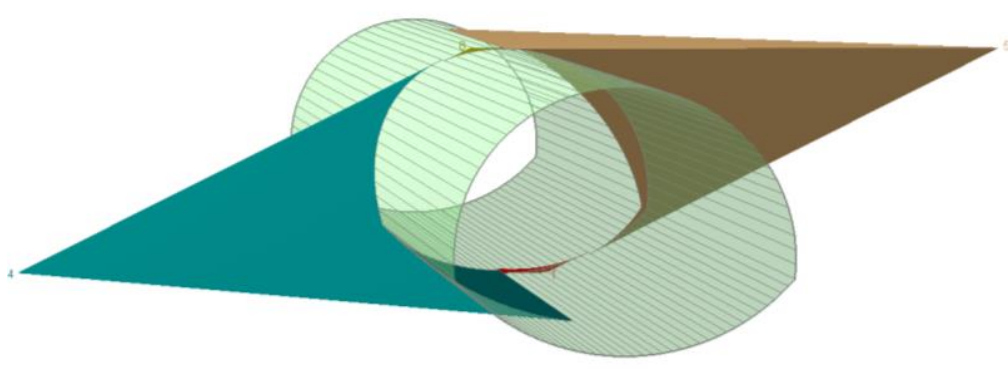

Figura 150 - Seção do túnel ao longo da Linha Estrutural 4 com respectivas cunhas geradas pela combinação 4 de 4 famílias de descontinuidades (F2+F3+F5) (Software Unwedge).

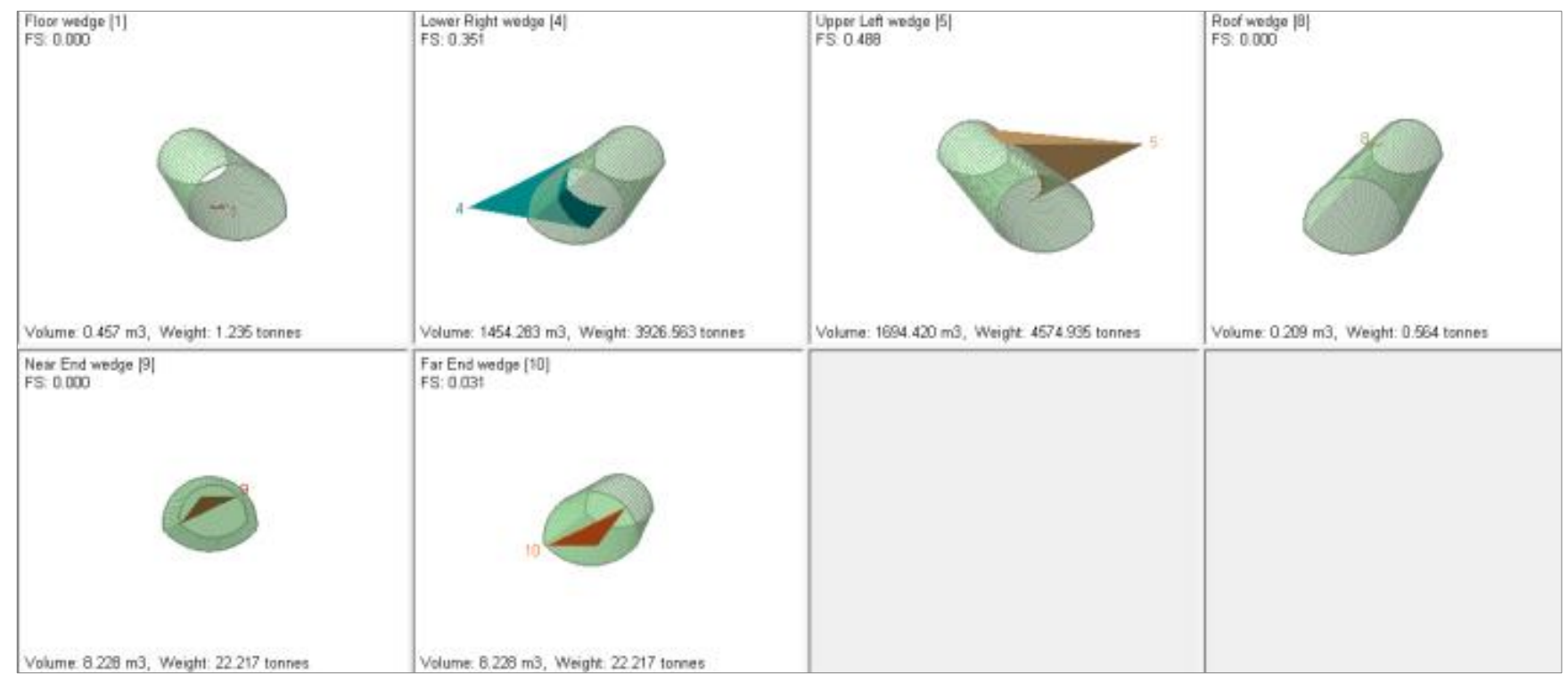

Figura 151 - Seções do túnel ao longo da Linha Estrutural 4 com respectivas cunhas geradas pela combinação 4 de 4 de famílias de descontinuidades (F2+F3+F5), indicando o fator de segurança (FS), volume e peso de cada bloco (Software Unwedge).

E, por último, foi analisada a Linha Estrutural 5, considerando-se quatro famílias principais e também quatro combinações. Na Figura 152, pode ser observada a possibilidade de uma cunha entre as famílias F1 e F3, que seria problemática principalmente se a escavação da via se desse no sentido de direção de sudeste para noroeste. O mesmo pode ser observado nas Figuras 158 e 161, com cunhas formadas lateralmente, que seriam mais problemáticas no avanço de sudeste para noroeste deste 
trecho. Além disso, não há outras cunhas ou planos instáveis. A família subvertical F3 está com ângulo bem acima de $20^{\circ}$ de direção com a direção da linha, o que ajudaria em favor da estabilidade.

Em relação à análise tridimensional neste segmento, conclui-se que os blocos mais problemáticos formados são os seguintes:

$>$ Bloco número 4, formado pelas famílias F1, F2 e F3, no canto superior esquerdo, fator de segurança igual a 0,1, com volume aproximado de $61 \mathrm{~m}^{3}$ e peso em torno de 166 toneladas (Figuras 153 e 154);

$>$ Bloco número 4, formado pelas famílias F1, F3 e F5, no canto superior esquerdo, fator de segurança igual a 0 , com volume aproximado de $12 \mathrm{~m}^{3}$ e peso em torno de 34 toneladas (Figuras 159 e 160);

Bloco número 7, formado pelas famílias F2, F3 e F5, no canto superior esquerdo, fator de segurança igual a 0,26, com volume aproximado de $128 \mathrm{~m}^{3}$ e peso em torno de 346 toneladas (Figuras 162 e 163).

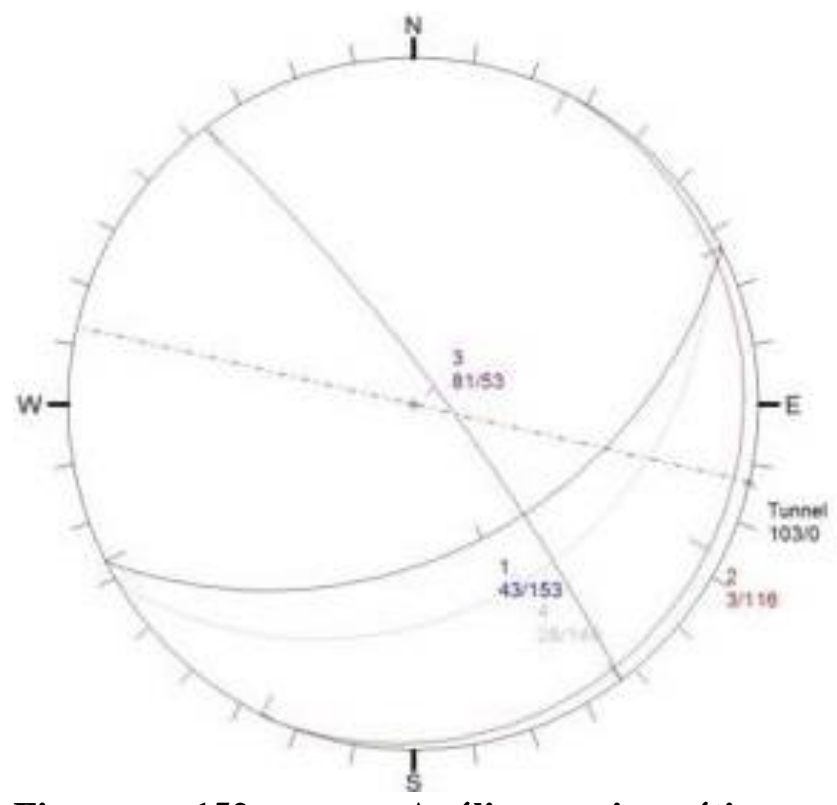

Figura 152 - Análise cinemática bidimensional de cunhas, para Linha Estrutural 5, combinação 1 de 4 famílias de descontinuidades $\quad(\mathbf{F 1}+\mathbf{F} 2+\mathbf{F 3}) \quad$ (Software Unwedge).

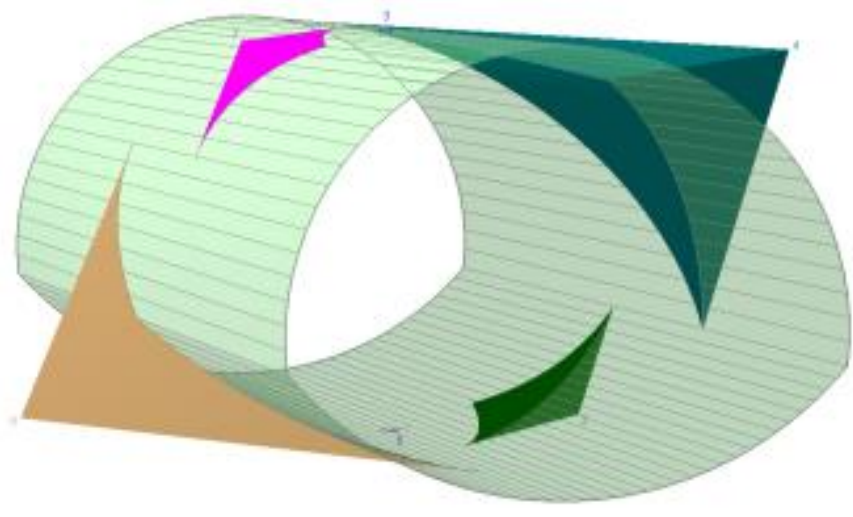

Figura 153 - Seção do túnel ao longo da Linha Estrutural 5 com respectivas cunhas geradas pela combinação 1 de 4 famílias de descontinuidades (F1+F2+F3) (Software Unwedge). 


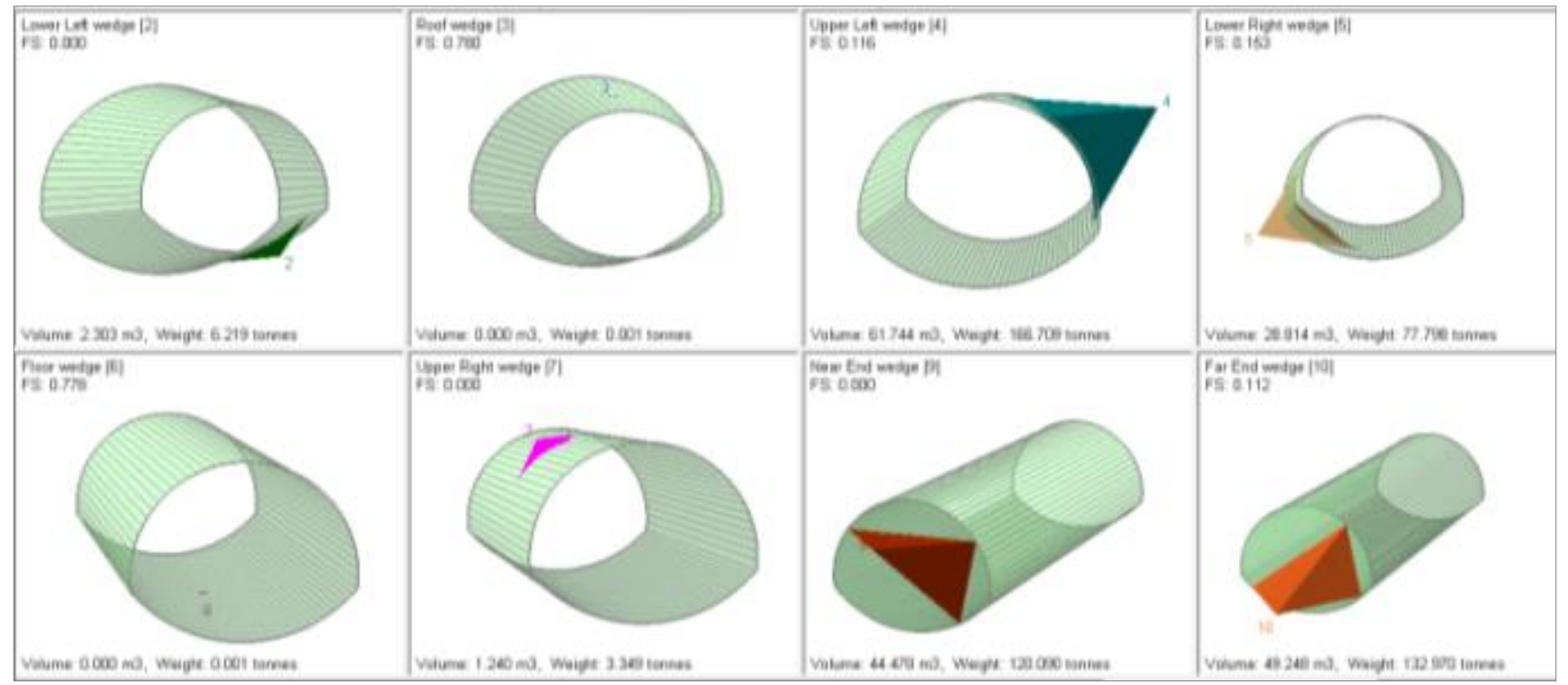

Figura 154 - Seções do túnel ao longo da Linha Estrutural 5 com respectivas cunhas geradas pela combinação 1 de 4 de famílias de descontinuidades (F1+F2+F3), indicando o fator de segurança (FS), volume e peso de cada bloco (Software Unwedge).

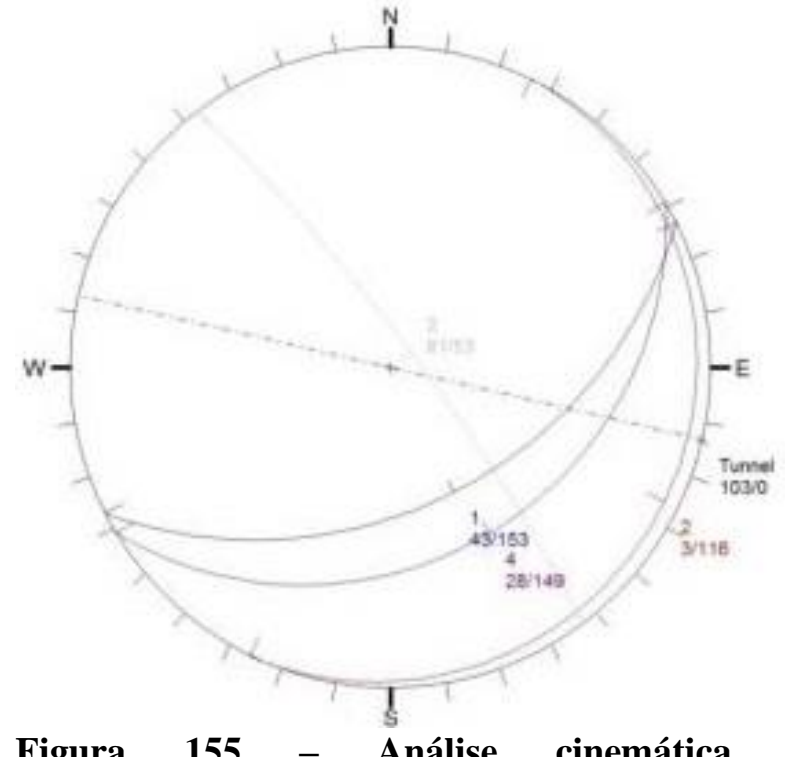

Figura 155 - Análise cinemática bidimensional de cunhas, para Linha Estrutural 5, combinação 2 de 4 famílias de descontinuidades $(\mathrm{F} 1+\mathrm{F} 2+\mathrm{F5})^{5} \quad$ (Software Unwedge).

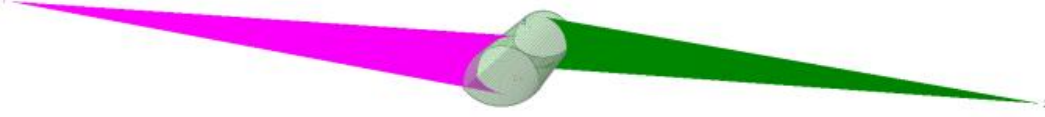

Figura 156 - Seção do túnel ao longo da Linha Estrutural 5 com respectivas cunhas geradas pela combinação 2 de 4 famílias de descontinuidades (F1+F2+F5) (Software Unwedge).

\footnotetext{
${ }^{5}$ Para esta linha estrutural 5 considerar a numeração (4) nas imagens referente à família F5.
} 


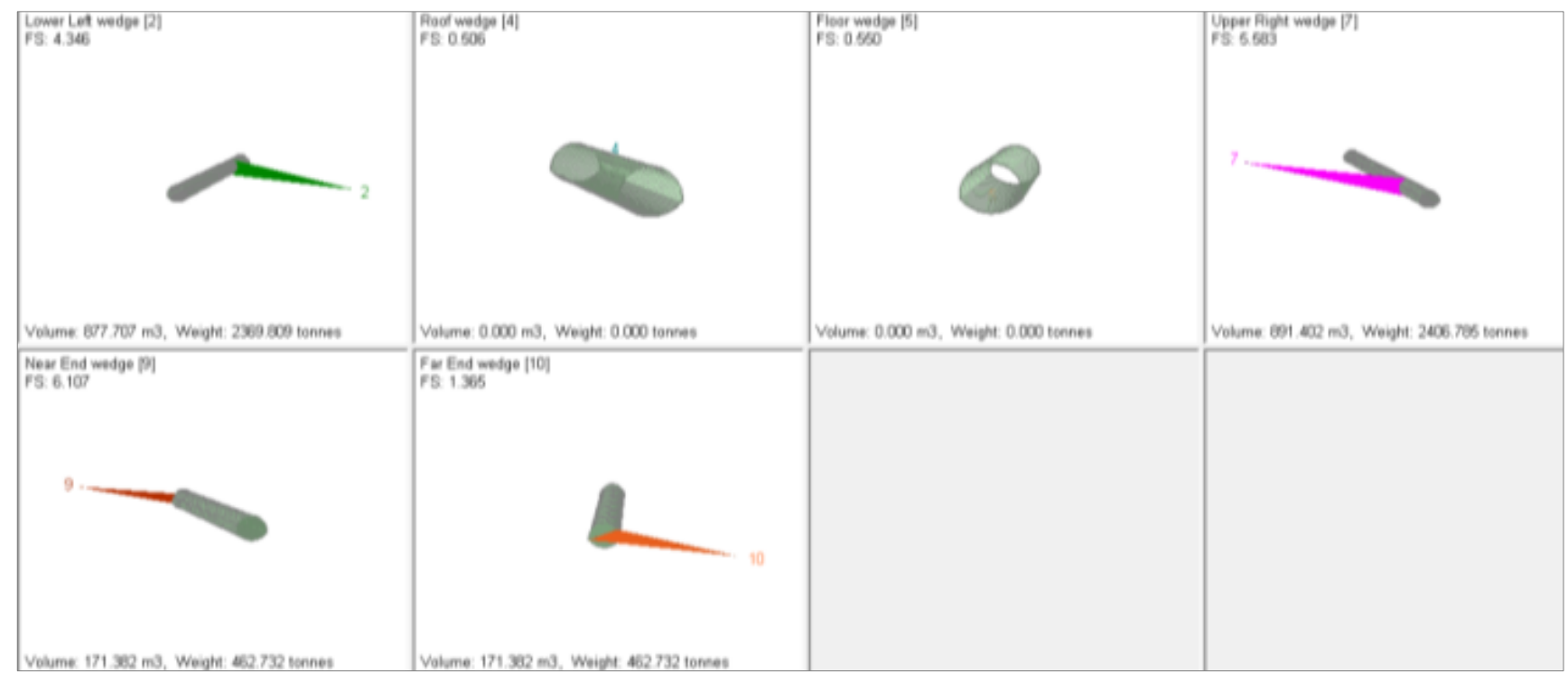

Figura 157 - Seções do túnel ao longo da Linha Estrutural 5 com respectivas cunhas geradas pela combinação 2 de 4 de famílias de descontinuidades (F1+F2+F5), indicando o fator de segurança (FS), volume e peso de cada bloco (Software Unwedge).

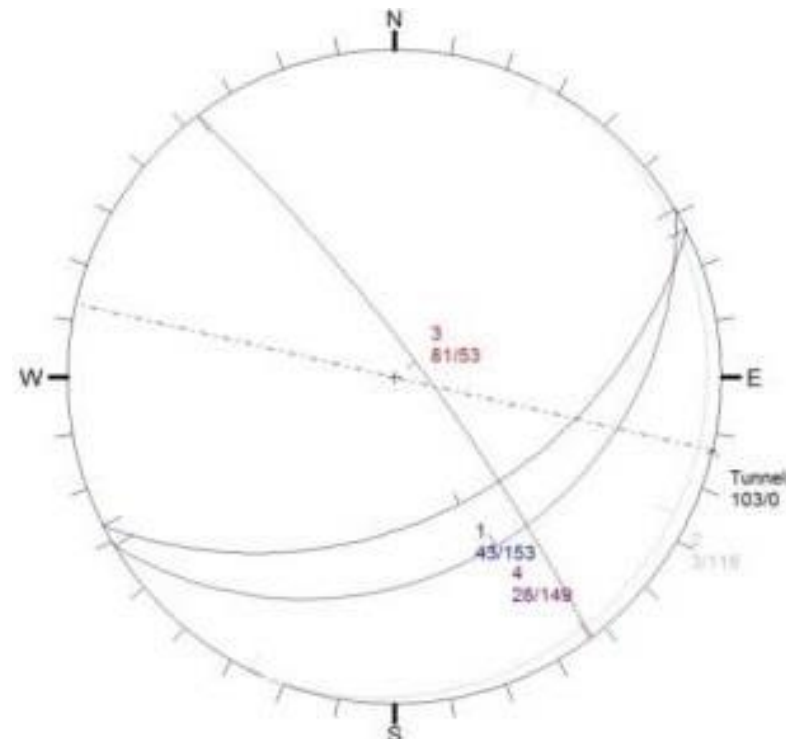

Figura 158 - Análise cinemática bidimensional de cunhas, para Linha Estrutural 5, combinação 3 de 4 famílias de descontinuidades (F1+F3+F5) (Software Unwedge).

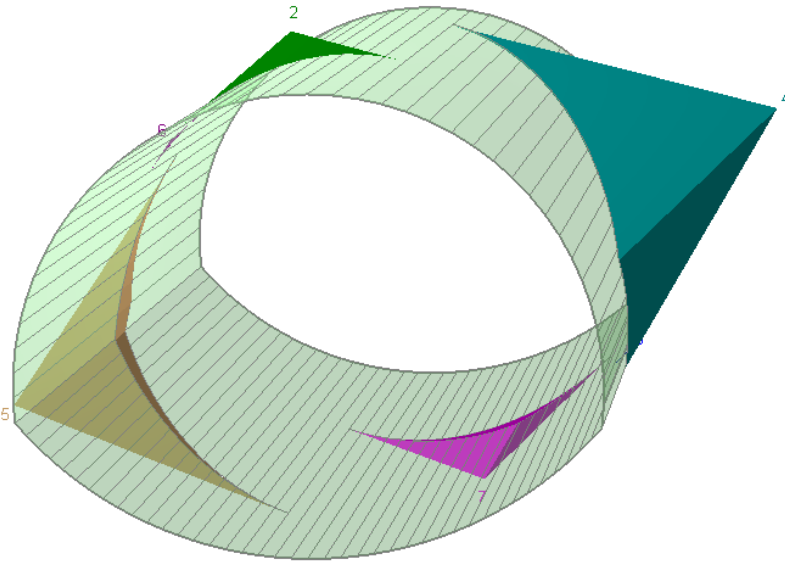

Figura 159 - Seção do túnel ao longo da Linha Estrutural 5 com respectivas cunhas geradas pela combinação 3 de 4 famílias de descontinuidades (F1+F3+F5) (Software Unwedge). 


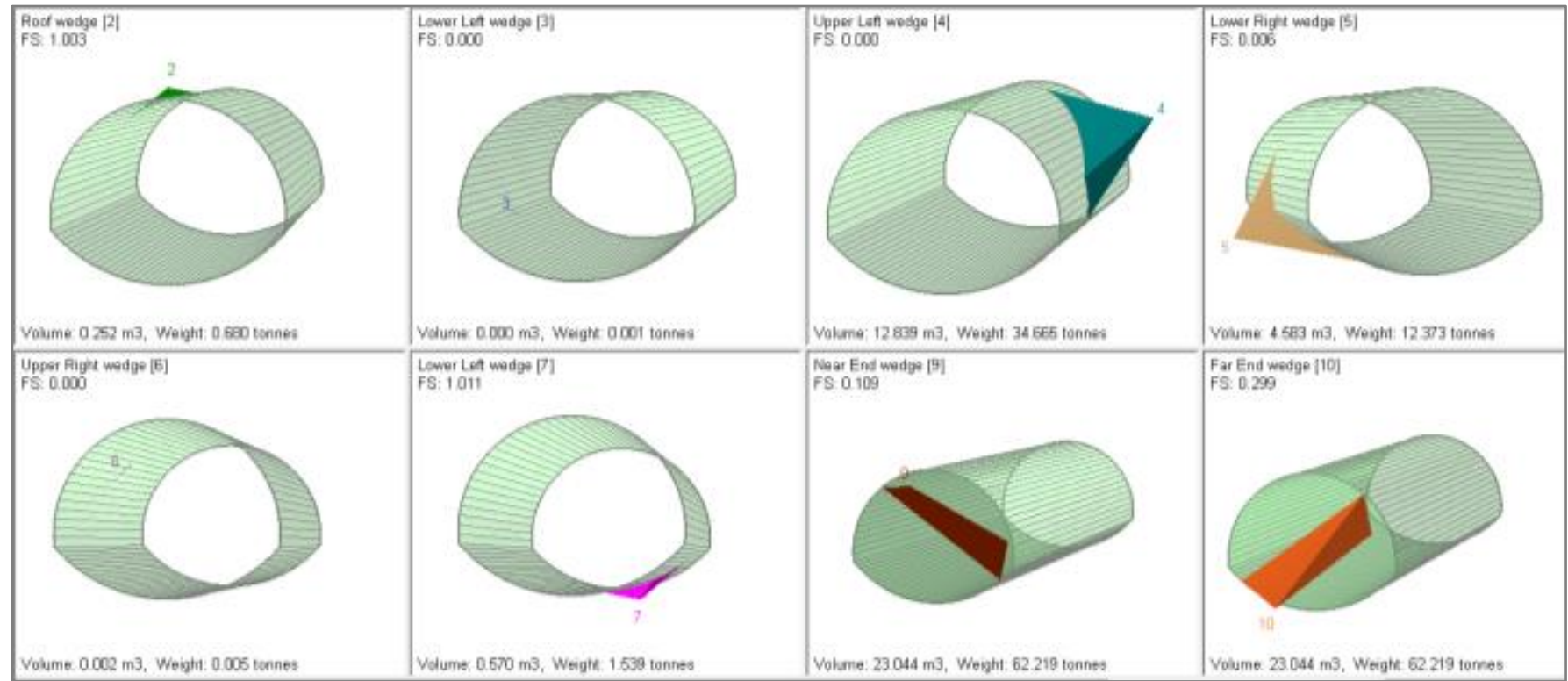

Figura 160 - Seções do túnel ao longo da Linha Estrutural 5 com respectivas cunhas geradas pela combinação 3 de 4 de famílias de descontinuidades (F1+F3+F5), indicando o fator de segurança (FS), volume e peso de cada bloco (Software Unwedge).

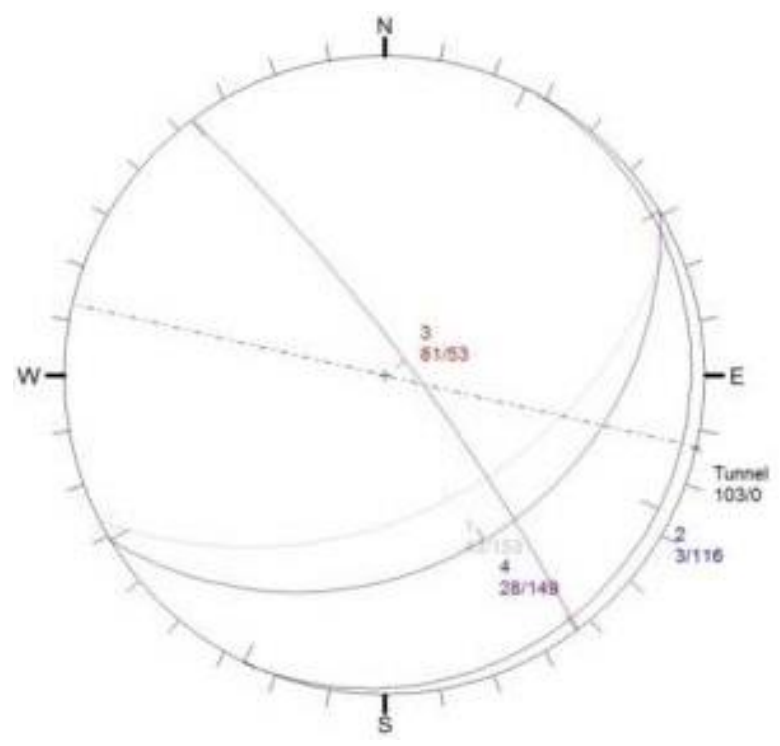

Figura 161 - Análise cinemática bidimensional de cunhas, para Linha Estrutural 5, combinação 4 de 4 famílias de descontinuidades (F2+F4+F5) (Software Unwedge).

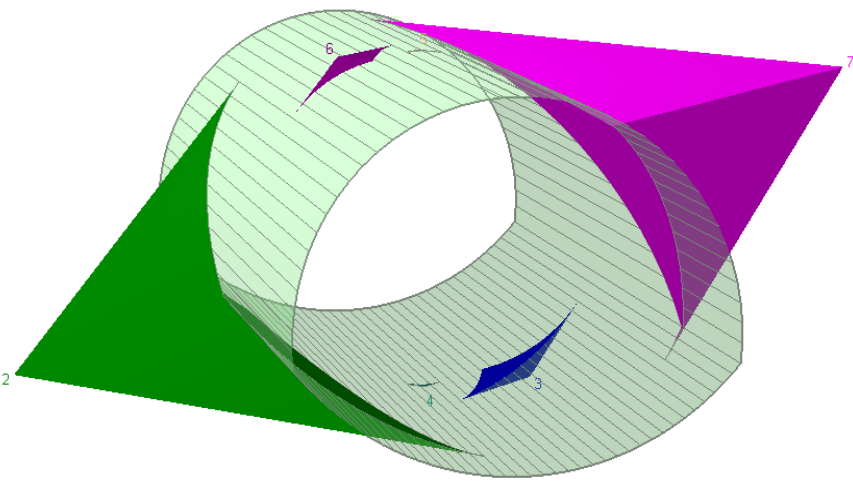

Figura 162 - Seção do túnel ao longo da Linha Estrutural $5 \mathrm{com}$ respectivas cunhas geradas pela combinação 4 de 4 famílias de descontinuidades (F2+F4+F5) (Software Unwedge). 


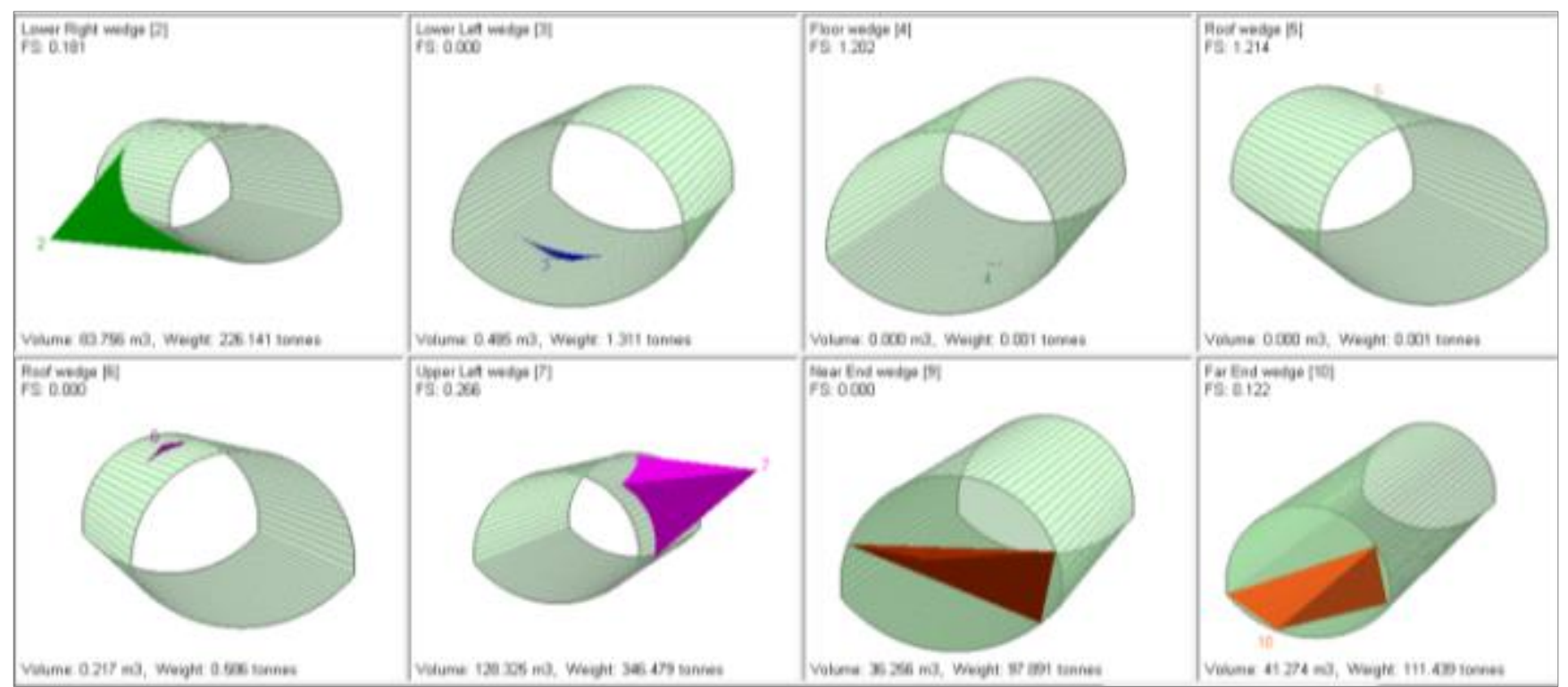

Figura 163 - Seções do túnel ao longo da Linha Estrutural 5 com respectivas cunhas geradas pela combinação 4 de 4 de famílias de descontinuidades (F2+F4+F5), indicando o fator de segurança (FS), volume e peso de cada bloco (Software Unwedge).

Vale ressaltar novamente que esta análise é ilustrativa das possibilidades de combinação de blocos e planos formados que venham a ser instáveis, dependendo da direção de avanço e do projeto construtivo definido, para um maciço não drenado, com parâmetros utilizados a favor da segurança. Estas análises têm como intuito servir de base para o desenho e soluções adotadas para promover a estabilidade das paredes e teto da via, sendo que seguramente em fase posterior da obra este mesmo tipo de análise poderá dar prosseguimento, levando em consideração parâmetros adicionais obtidos através das investigações geológico-geotécnicas de um projeto executivo.

6.2.4 Aplicação dos dados para análise estrutural e de estabilidade dos poços

O mesmo procedimento realizado para o túnel de via, de análise estrutural e cinemática, utilizando tanto o Software Dips como o Software Unwedge foi realizado para todos os seis poços que serão escavados neste projeto da Linha 4 Amarela Fase 3. Dentre estes seis, dois serão poços definitivos, VSE's e quatro poços de ataque (acesso), tendo como objetivo aumentar as possibilidades de frentes de escavação e reduzir o tempo necessário de execução da obra. Alguns dos poços, aqueles que não se encontram locados logo acima do eixo da via, possuirão túneis de acesso, sendo que o mesmo procedimento também foi realizado para estas unidades construtivas. Nas Figuras 164 e 165, é possível visualizar um exemplo desta análise, já com o tratamento proposto com tirantes.

Uma informação importante é que após ser realizada esta análise, tendo como base os dados fornecidos pelas sondagens televisionadas nas proximidades de cada unidade construtiva, houve, em 
alguns casos, a mudança no tamanho da tela metálica e no espaçamento dos tirantes, ou até mesmo a quantidade de contenção a ser adotada, devido ao tamanho e forma dos blocos formados e as possibilidades de deslizamentos. Sempre se sugerindo em nota que o mapeamento destes blocos deve ser feito ao longo da execução da obra, pela equipe de acompanhamento técnico de obra (A.T.O.).

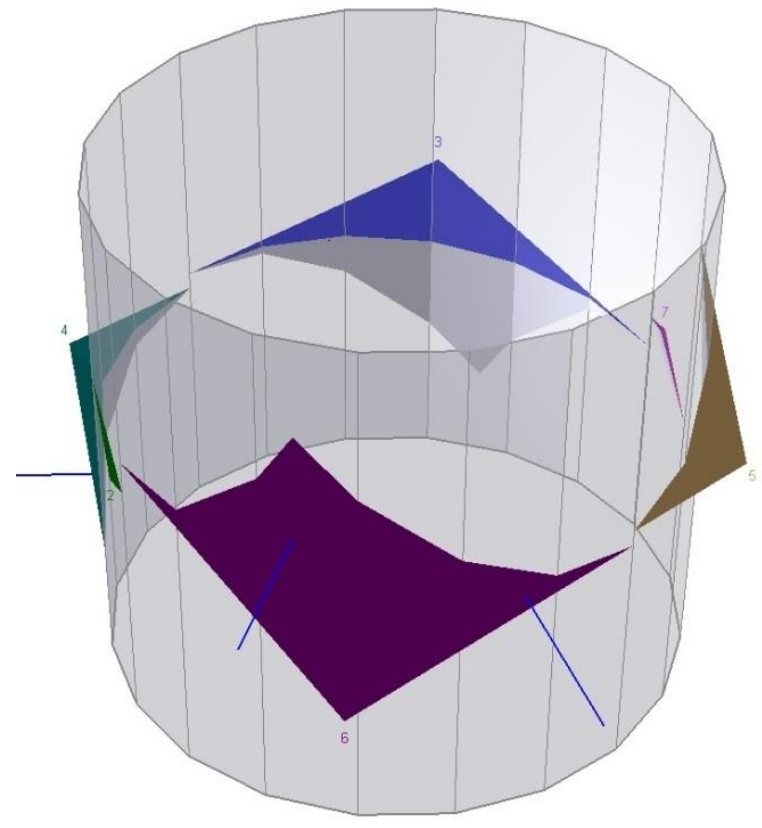

Figura 164 - Exemplo de análise cinemática tridimensional para escavação de um poço (Software Unwedge).

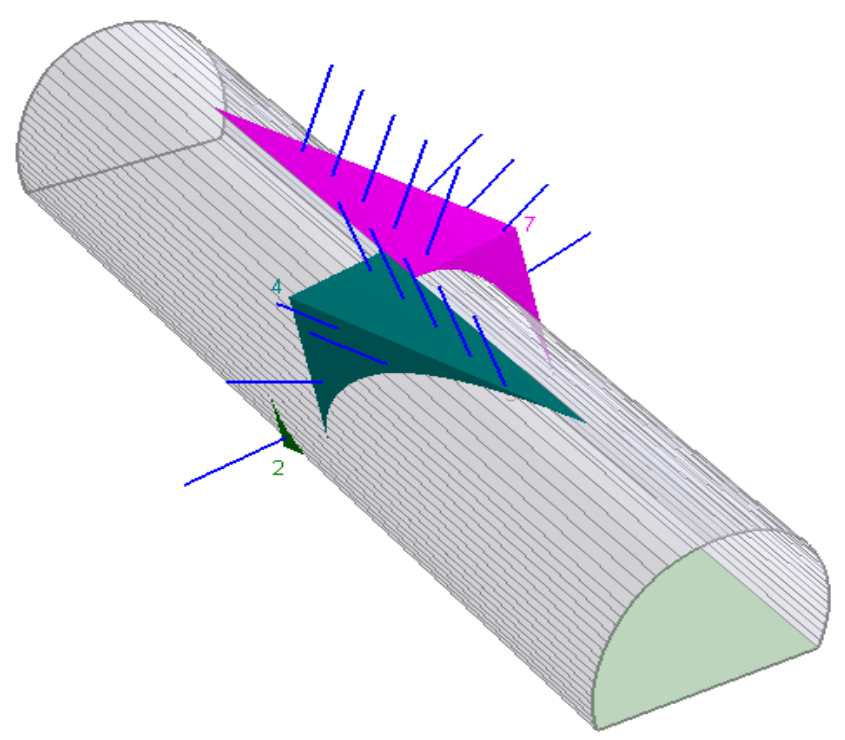

Figura 165 - Exemplo de análise cinemática tridimensional para túnel de acesso de um dos poços (Software Unwedge).

6.2.5 Aplicação dos dados para análise estrutural e de estabilidade das paredes da Estação Largo do Taboão

A Estação Largo do Taboão terá duas áreas escavadas em vala, que estarão conectadas entre si: a primeira, que corresponde ao corpo da estação, atualmente sob a rodovia Regis Bittencourt, e a segunda, correspondente ao Terminal Sul, atualmente na região do estacionamento do hipermercado Extra. A Figura 166 ilustra as dimensões desta estação, assim como a indicação das paredes que foram foco da análise de estabilidade utilizando diretamente os dados do televisionamento. 


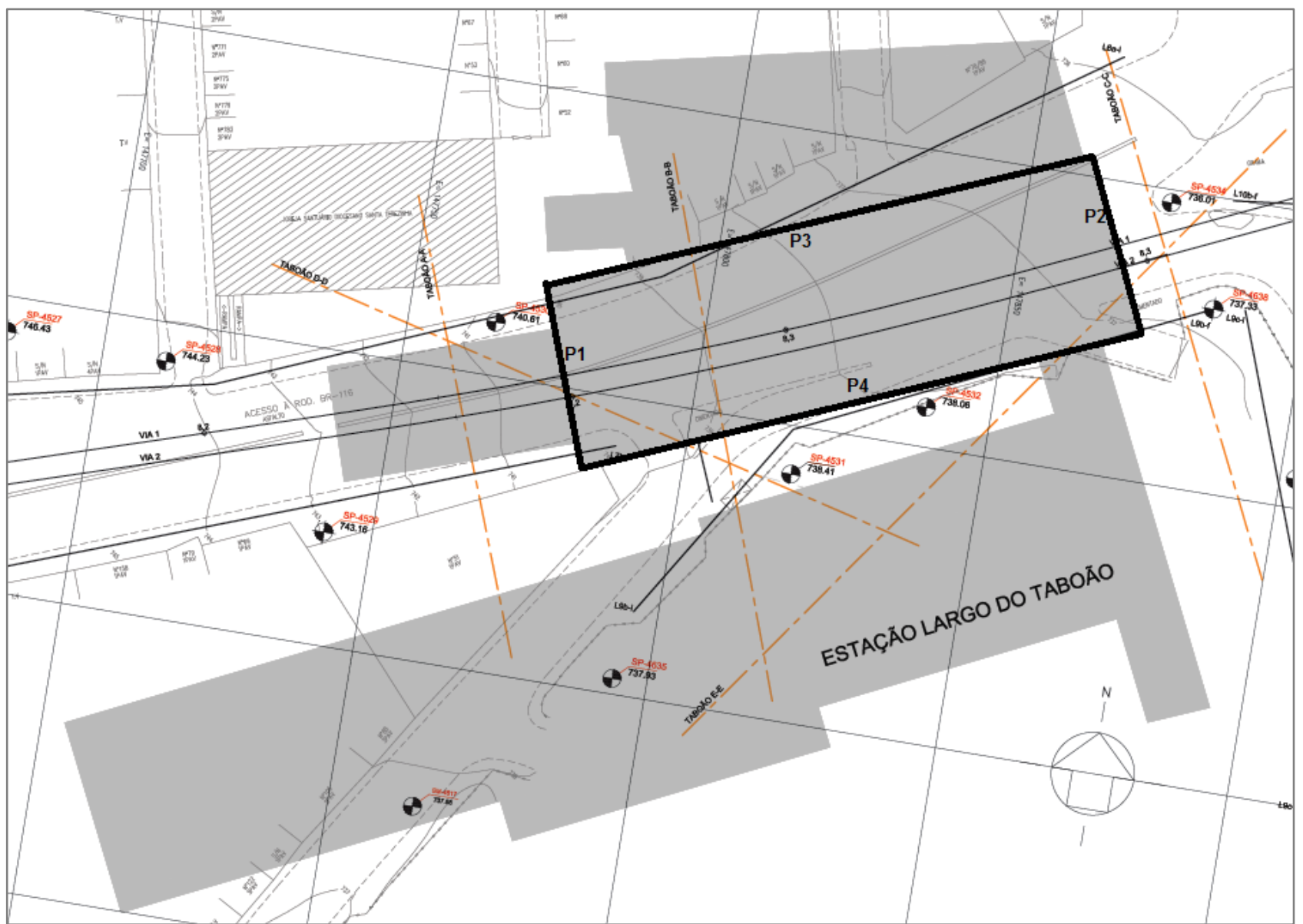

Figura 166 - Paredes consideradas para as análises na Estação do Largo do Taboão (P1, P2, P3 e P4) (Metrô-SP).

O maciço a ser escavado no local onde está prevista a estação apresenta pequena cobertura em solo de aproximadamente 7 metros de espessura. Dentre estes materiais é identificada a presença de aterros de espessuras variando entre 3 e 8 metros, com material bastante heterogêneo. O projeto de escavação da estação será iniciado a partir da remoção desta camada de aterro, seguida da remoção de pequena espessura de camada de solo de alteração de rocha, na maior parte do trecho.

O topo rochoso indicado nas sondagens no local será escavado a partir da cota 730 , em rocha alterada a muito alterada, classes IV e V. Observa-se que a qualidade do maciço não apresenta melhora significativa com a profundidade, uma vez que, na base da escavação próxima do eixo da via o maciço apresenta baixa qualidade, classes IV e V, o que se repete no lado oposto onde se observa intercalação de maciço de classe III e IV.

Foram observadas feições cataclásticas nos testemunhos de rocha, sendo que é possível encontrar camadas de maciço rochoso cataclasado, fraturado e de baixa qualidade geomecânica em 
contato lateral com trechos de rocha com qualidade geomecânica superior, rocha intacta, pouco fraturada.

Para a execução de um dos pilares da estação, que terá sua fundação diretamente na rocha, levaram-se em consideração os resultados obtidos do televisionamento da sondagem 4532, assim como o perfil de sondagem e fotos do testemunho desta mesma sondagem. Ao ser feita uma análise destes dados, observou-se a ocorrência de planos de descontinuidades sub-horizontais abertos e com preenchimento, no intervalo de profundidade de 8,5 a 9,5 metros.

Na Figura 167, podemos observar o aspecto destes planos de descontinuidade na imagem do televisionamento. São planos horizontais com abertura aparente considerável, ocorrendo também fraturas sub-verticais que, em conjunto com os planos horizontais, implicam em um trecho localmente bastante fraturado. Conforme pode ser observado também no perfil individual desta sondagem, este trecho obteve recuperação de apenas 70\%, sendo que seu RQD também é bastante mais baixo, 40\% (Figura 168). Estas fraturas abertas são referentes às juntas "cascas de cebola", citadas por Hasui (1993) ao se referir às juntas de alívio do maciço, subhorizontais.

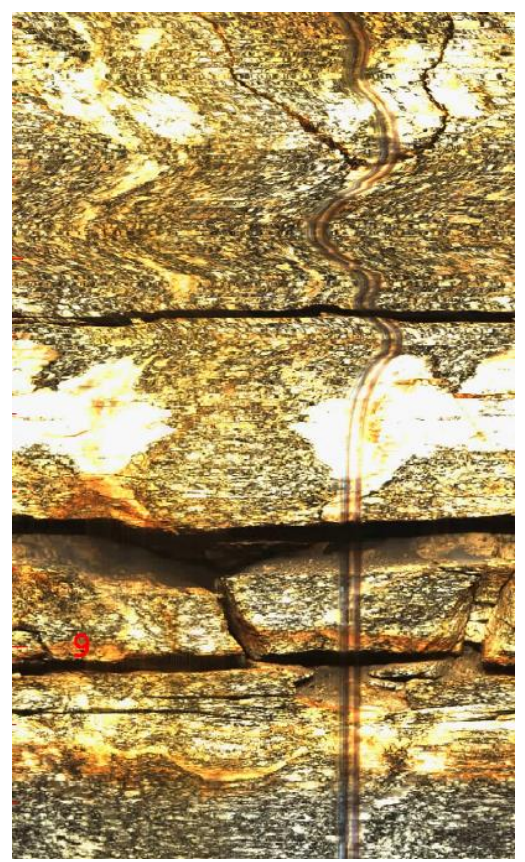

Figura $167 \quad$ - Fraturas filmadas no televisionamento do furo de sondagem 4532, na região do Largo do Taboão.
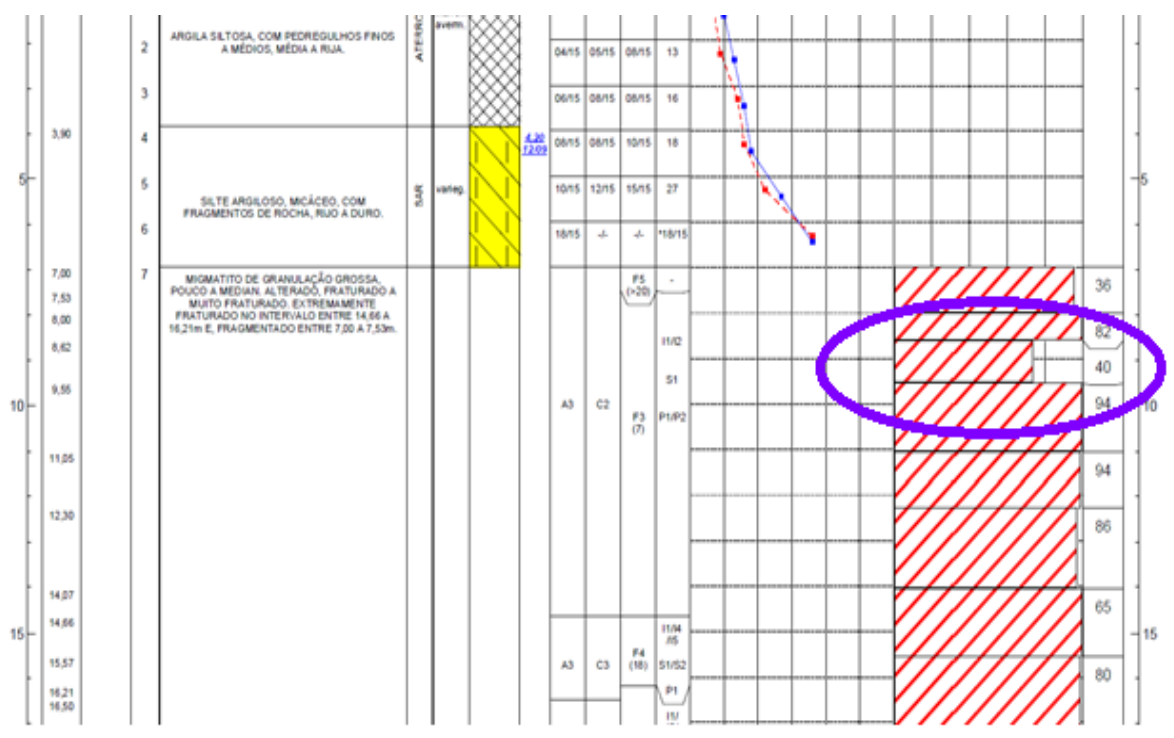

Figura 168 - Perfil individual da sondagem 4532, com trecho de baixa recuperação em rocha indicado com círculo.

Devido a essas condições presentes no maciço rochoso desta região, verificada principalmente a partir da imagem de televisionamento óptico, adotou-se como solução a escavação até a cota 727. 
Com relação à estabilidade das principais paredes de escavação da Estação Largo do Taboão, primeiramente foram levantadas as direções de todas as paredes e nomeadas, conforme apresentado na Figura 166 (P1, P2, P3 e P4). Optou-se por restringir a análise estrutural considerando as paredes que implicarão em paredes rochosas mais amplas, onde seria possível a ocorrência de delizamentos planares, em cunha e/ou tombamento. Em seguida, foi feita a análise cinemática dos blocos rochosos, tanto para análise bidimensional, como tridimensional. A ideia principal desta análise foi qualificar os possíveis planos de deslizamento (planar e cunha) e/ou tombamento. O objetivo principal é prover à equipe de A.T.O. subsídios para estabilização de tais blocos formados quando na escavação de tais paredes.

É importante ressaltar que durante o projeto executivo deverá ser realizado levantamento sistemático dos planos de descontinuidades nesta região, principalmente mapeamento destes planos nas paredes da estação, assim que estas forem sendo escavadas. Deverá ser realizado um refinamento dos valores de espaçamento entre as famílias de descontinuidades, assim como observação da persistência de cada um destes planos, já que ambos parâmetros são condicionantes do tamanho de cada bloco formado. Ressalta-se que, devido à ausência de afloramentos rochosos, onde se faz possível estimar a persistência de tais planos de descontinuidade, adotou-se postura conservadora, a favor da segurança, considerando uma persistência alta para tais planos, de pelo menos 10 metros de extensão, possivelmente sendo mais extensos em realidade, devido ao caráter regional de tais famílias de descontinuidades principais.

Todos os dados foram obtidos das sondagens televisionadas na região ou nas proximidades da Estação Largo do Taboão. As sondagens consideradas foram 4532, 4536, 4539 e 4540. Todas as descontinuidades que foram consideradas relevantes, denifidas na análise do televisionamento, foram lançadas em diagrama Schimidt-Lambert, hemisfério inferior, através do Software Dips (Rocscience, 1999). Foi elaborado diagrama de contagem de polos e dessa forma definidas as principais famílias nesta região, assim como realizado para as demais unidades construtivas. Para tal definição, também foram levados em conta os resultados obtidos tanto por Hasui (1993) e IPT (1997), sendo que foi realizada uma comparação entre as atitudes obtidas nesta análise com as atitudes obtidas por estes autores.

Assim, conforme observado nas Figuras 169 e 170, foram consideradas sete famílias, sendo estas (direção de mergulho/mergulho): F1 - 143/57, F2 - 090/06, F3 - 229/82, F4 - 154/26, F5 325/57, F6 - 081/77 e F7 - 013/88. Todos os dados das descontinuidades foram separados segundo estas famílias, considerando os intervalos da Tabela 12, sendo que foi obtido o espaçamento médio para cada família, após ser feita a correção proposta por Terzarghi (1965), para corrigir o efeito do 
mergulho de cada família X direção da linha de medida, sendo esta última o mergulho de cada furo. Todos os furos foram realizados na vertical, exceção do furo 4539. Os espaçamentos obtidos foram comparados aos valores obtidos tanto por Hasui (1993) como por IPT (1997), sendo que foi feita uma correlação entre todos estes valores, estimando valores para a análise a ser realizada, principalmente com relação à estimativa do tamanho de blocos formados.

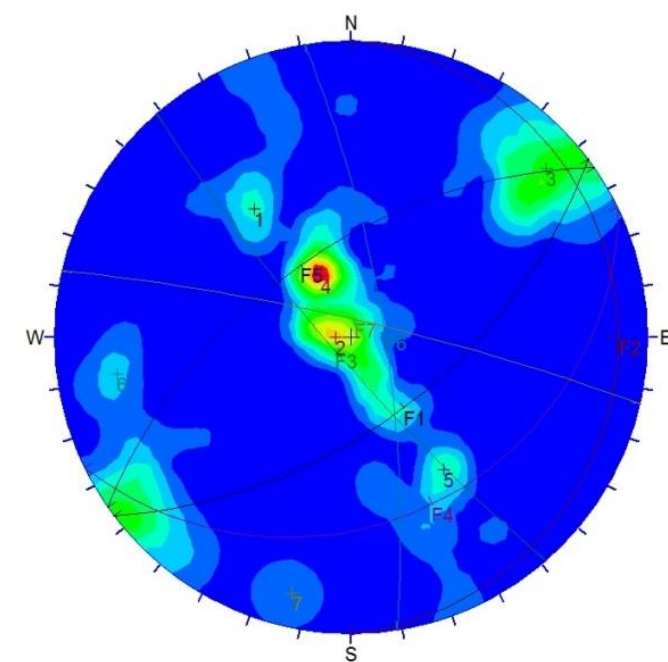

Figura 169 - Diagrama de contagem de polos com os dados obtidos do televisionamento das sondagens da região da Estação Largo do Taboão (Software Dips).
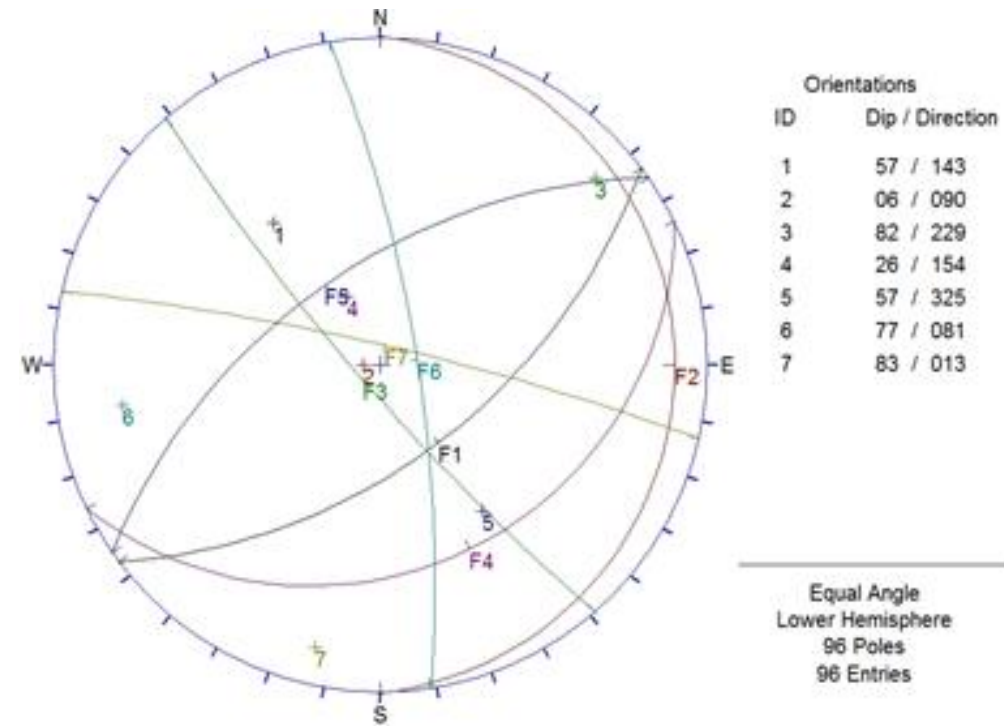

$57 / 143$

$06 / 090$

$82 / 229$

$26 / 154$

$57 / 325$

77,081

$83 / 013$

Figura 170 - Resumo das famílias definidas como essenciais para a análise estrutural das paredes da vala da estação (Software Dips).

Tabela 12 - Principais famílias definidas para análise das paredes da vala da Estação Largo do Taboão.

\begin{tabular}{|c|c|c|c|c|c|c|c|c|c|c|c|c|c|}
\hline \multicolumn{4}{|c|}{ VALORES OBTIDOS NO TELEVISAMENTO } & \multicolumn{2}{|c|}{$\begin{array}{l}\text { EQUIVALÊNCIA } \\
\text { LITERATURA }\end{array}$} & \multicolumn{5}{|c|}{$\begin{array}{l}\text { VALORES MÉDIOS DE ESPAÇAMENTO POR } \\
\text { FAMÍLIA }(\mathrm{m})^{* 2}\end{array}$} & \multicolumn{2}{|c|}{ VALORES ESPAÇAMENTO LITERATURA } & \multirow{2}{*}{$\begin{array}{c}\text { VALORES DE } \\
\text { ESPAÇAMENTO } \\
\text { ESTIMADOS (m) }\end{array}$} \\
\hline FAMÍLIA & $\begin{array}{c}\text { INTERVALO DIREÇÃO } \\
\text { DE MERGULHO }\end{array}$ & $\begin{array}{l}\text { INTERVALO } \\
\text { MERGULHO }\end{array}$ & $\begin{array}{c}\text { ATITUDE MÉDIA } \\
\text { OBTIDA }^{* 1}\end{array}$ & IPT & HASUI & $\begin{array}{r}\text { FURO } \\
4532\end{array}$ & $\begin{array}{c}\text { FURO } \\
4536\end{array}$ & $\begin{array}{r}\text { FURO } \\
4539\end{array}$ & $\begin{array}{l}\text { FURO } \\
4540\end{array}$ & MÉDIA & IPT & HASUI & \\
\hline $\mathrm{F} 1$ & $125-165$ & $40^{\circ}-70^{\circ}$ & $143 / 57$ & - & F5 & 0,65 & 0,70 & 0,16 & 0,60 & 0,53 & - & MÉTRICO & 0,6 \\
\hline $\mathrm{F} 2$ & TODOS & $0-15^{\circ}$ & $090 / 06$ & $\mathrm{~F} 4$ & F7 & 0,70 & 1,20 & 1,16 & 2,65 & 1,43 & 0,27 & MÉTRICO & 1,2 \\
\hline $\mathrm{F3}$ & $200-250$ OU $30-70$ & $>65^{\circ}$ & $229 / 82$ & $\mathrm{~F} 2$ & $\mathrm{~F} 2$ & 2,38 & 0,32 & 1,35 & 0,78 & 1,21 & 0,14 & VÁRIOS DECÍMETROS & 0,5 \\
\hline $\mathrm{F} 4$ & $130-160$ & $15^{\circ}-36^{\circ}$ & $154 / 26$ & - & - & 1,44 & 1,38 & 1,30 & 8,28 & 3,10 & - & - & 2,5 \\
\hline F6 & $55-105$ OU $245-290$ & $>65^{\circ}$ & $081 / 77$ & - & F3 & 1,02 & 0,09 & 0,90 & 0,88 & 0,72 & - & VÁRIOS DECÍMETROS A METROS & 0,7 \\
\hline F7 & $345-025$ OU $160-200$ & $>65^{\circ}$ & $013 / 83$ & $\mathrm{~F} 1$ & $\mathrm{~F} 4$ & 1,36 & 2,03 & 0,51 & - & 1,30 & 0,33 & MÉTRICO & 1,3 \\
\hline
\end{tabular}

*1 Obtido por interpretação de polos de concentração em diagrama de contagem Schimidt-Lambert, hemisfério inferio, Software DIPS.

*2 Corrigidos utilizando correção proposta por Tezarghi (1965).

Em mão desses dados, foi feita uma análise cinemática dos blocos formados, tendo como base as seguintes considerações:

A análise cinemática de blocos rochosos em taludes é necessária para se estimar a estabilidade das paredes. Segundo Hoek (1966), em projetos realizados em estruturas rochosas, a consideração mais importante é a estabilidade de toda a estrutura; 
A cinemática refere-se à movimentação de corpos, sem fazer, entretanto, referência às forças que causam o movimento. Para que um bloco de rocha fique livre para cair do teto ou escorregar das paredes de uma escavação é necessário que seja separado do restante da massa rochosa por pelo menos três descontinuidades (Fiori \& Carmignani, 2009).

Para a análise bidimensional, foram considerados os preceitos propostos por Hoek \& Bray (1981), conforme o resumo apresentado na Figura 171, que exemplifica os três tipos de ruptura que podem ocorrer em taludes rochosos, assim como sua representação nos estereogramas: ruptura planar, ruptura em cunha e tombamento.

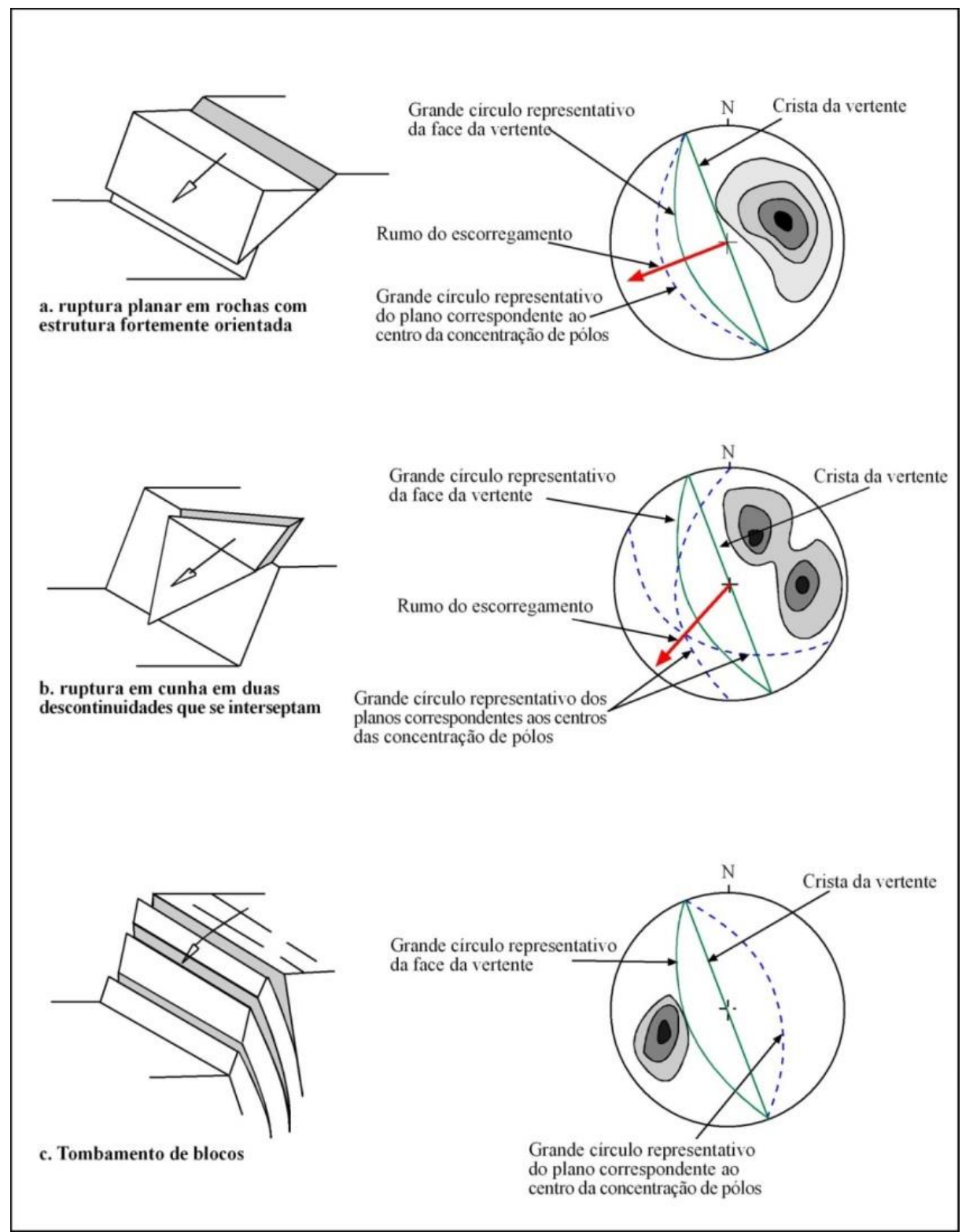

Figura 171 - Resumo das possibilidades de escorregamento e ruptura em maciços rochosos, traduzido de Hoek \& Bray (1981). 
Nas Figuras 172 a 175, foi feita esta análise bidimensional para cada parede (P1, P2, P3 e P4), sendo indicada qual a possibilidade de cada tipo de ruptura para cada parede e um resumo é apresentado na Tabela 13. Parte desta análise foi elaborada com o Software Dips (Rocscience, 1999) e parte foi feita manualmente, para indicar as possibilidades de ruptura. Cada parede está indicada com o traço na cor roxa e a abertura da vala está indicada pelo círculo em amarelo, que indica também o ângulo de atrito considerado, neste caso de $30^{\circ}$.
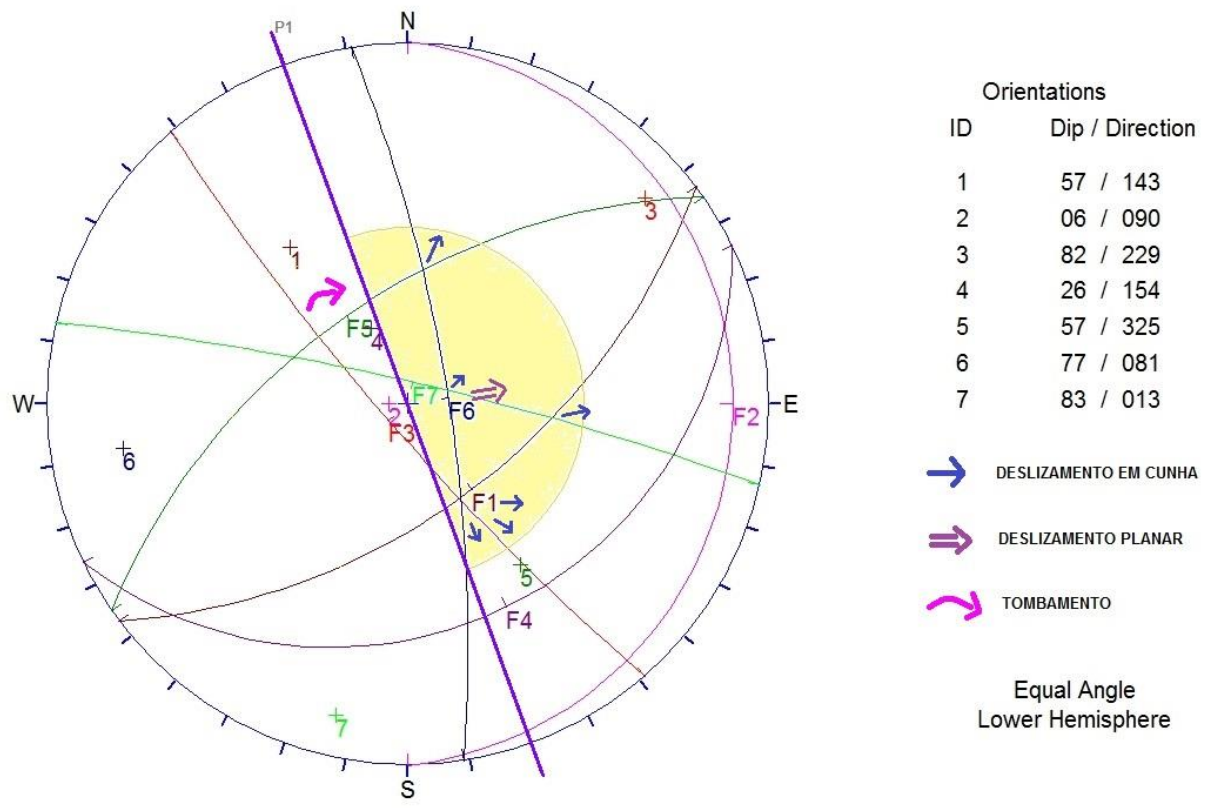

Figura 172 - Análise bidimensional da Parede 1 considerando principais famílias e principais possibilidades de escorregamento.
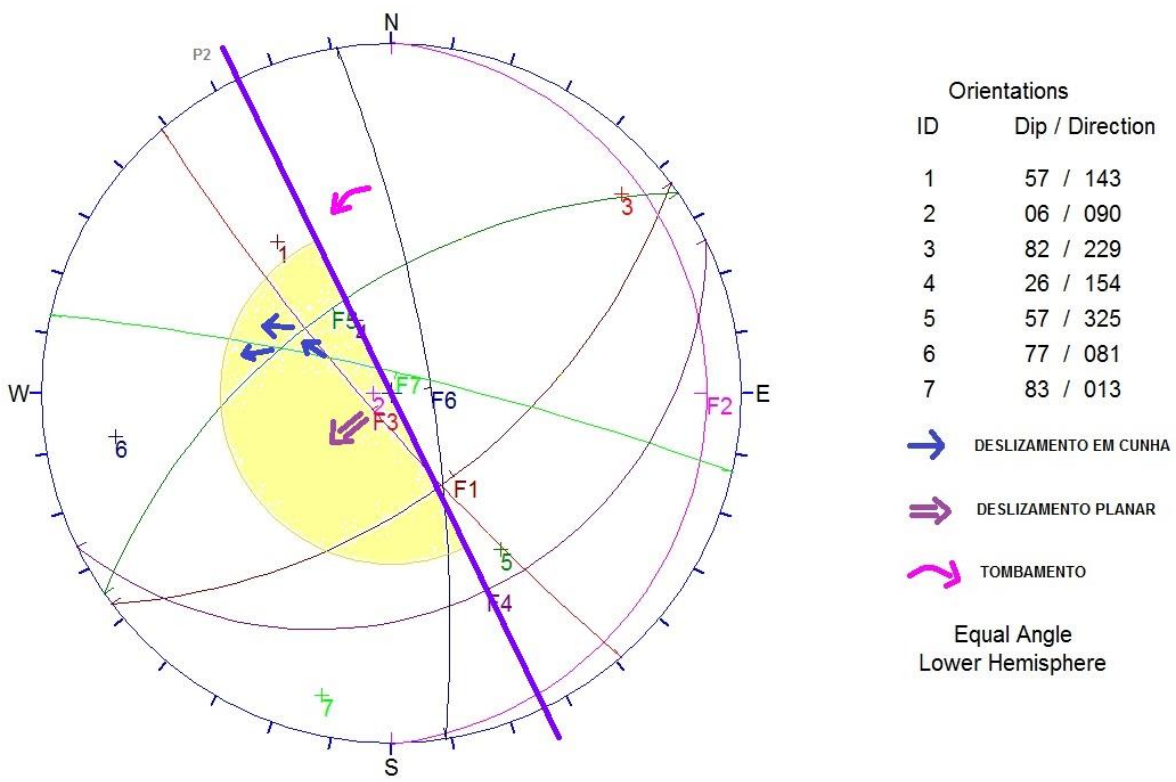

Figura 173 - Análise bidimensional da Parede 2 considerando principais famílias e principais possibilidades de escorregamento. 

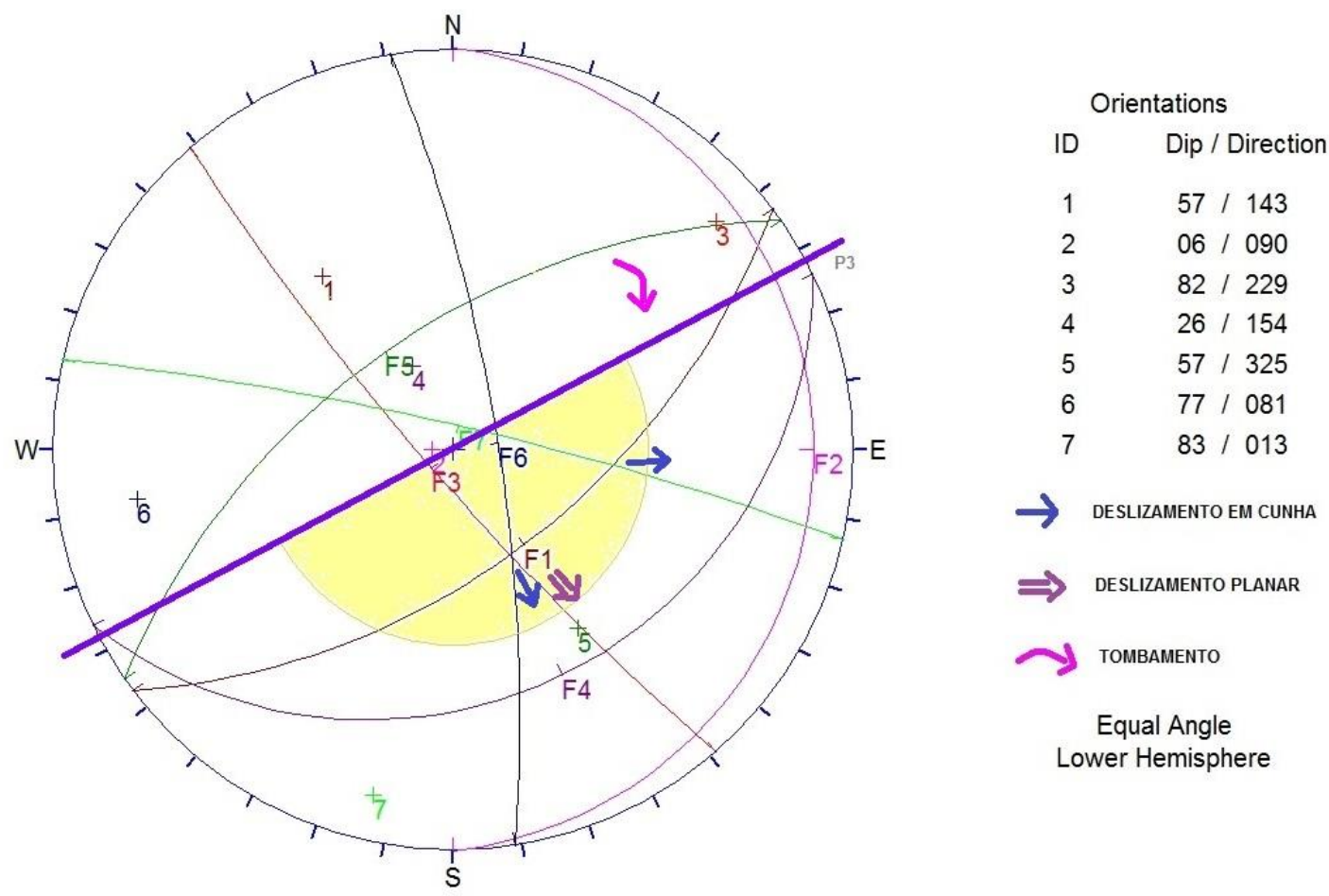

Figura 174 - Análise bidimensional da Parede 3 considerando principais famílias e principais possibilidades de escorregamento.
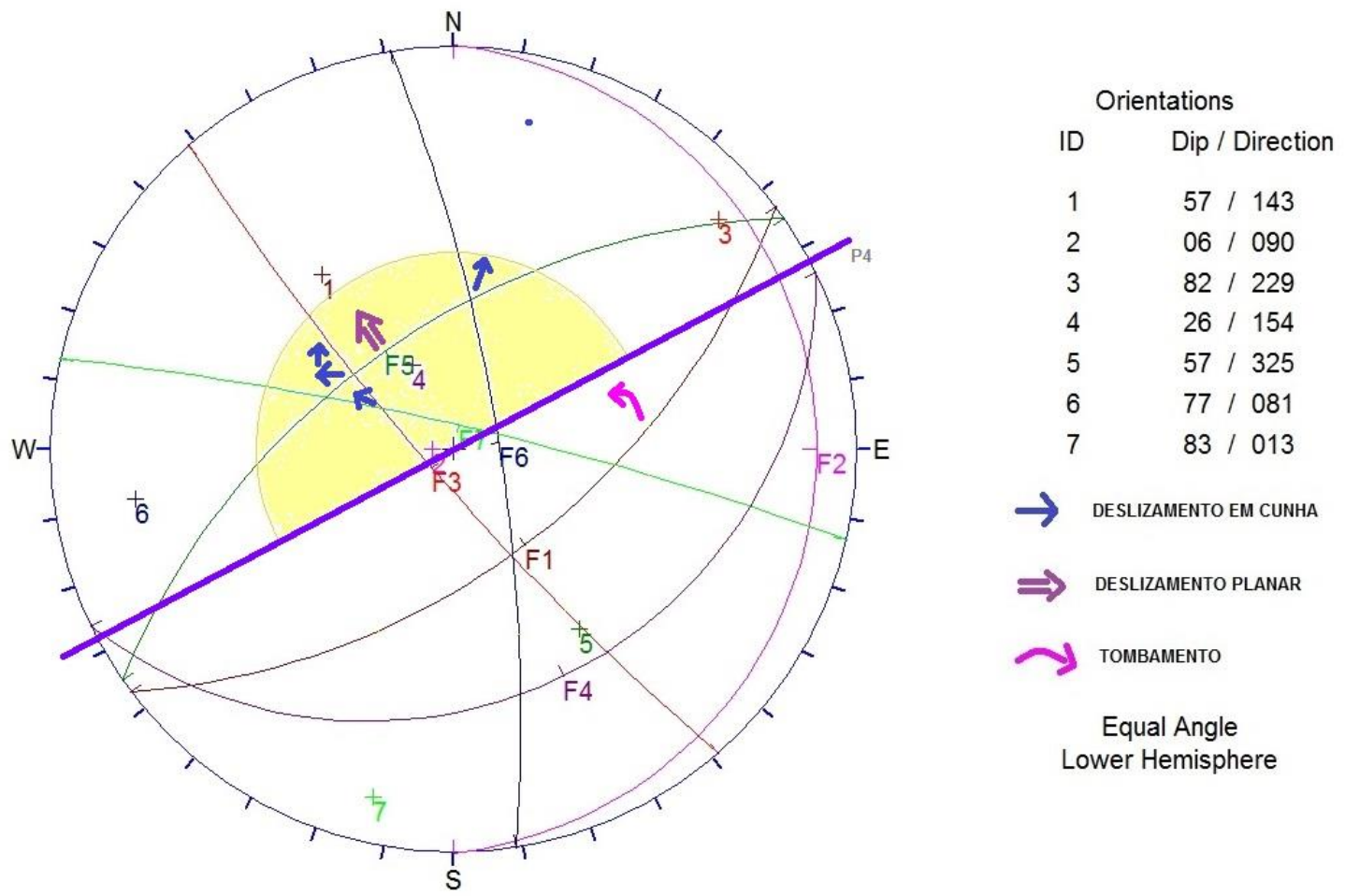

Figura 175 - Análise bidimensional da Parede 4 considerando principais famílias e principais possibilidades de escorregamento. 
Tabela 13 - Resumo da análise cinemática bidimensional das paredes da vala da Estação Largo do Taboão.

\begin{tabular}{|c|c|c|c|c|}
\hline PAREDE & FAMÍLIA & CUNHA & PLANAR & TOMBAMENTO \\
\hline \multirow{7}{*}{ P1 } & $\mathrm{F} 1$ & $+\mathrm{F} 3+\mathrm{F} 6+\mathrm{F} 7$ & - & - \\
\hline & $\mathrm{F} 2$ & - & - & - \\
\hline & F3 & $+F 1+F 6$ & - & SIM \\
\hline & $\mathrm{F} 4$ & NÃO OCORRE & - & - \\
\hline & F5 & - & SIM & - \\
\hline & $\mathrm{F} 6$ & $+\mathrm{F} 1+\mathrm{F} 3+\mathrm{F} 5+\mathrm{F} 7$ & - & - \\
\hline & F7 & $+\mathrm{F} 1+\mathrm{F} 6$ & - & - \\
\hline \multirow{7}{*}{ P2 } & $\mathrm{F} 1$ & - & - & - \\
\hline & $\mathrm{F} 2$ & - & - & - \\
\hline & F3 & $+\mathrm{F} 5+\mathrm{F} 7$ & SIM & - \\
\hline & $\mathrm{F} 4$ & - & - & - \\
\hline & F5 & $+\mathrm{F} 3+\mathrm{F} 7$ & - & - \\
\hline & F6 & - & - & SIM \\
\hline & F7 & $+\mathrm{F} 3+\mathrm{F} 6$ & - & - \\
\hline \multirow{7}{*}{ P3 } & F1 & $+\mathrm{F} 3+\mathrm{F} 6+\mathrm{F} 7$ & SIM & \\
\hline & $\mathrm{F} 2$ & - & - & - \\
\hline & F3 & $+\mathrm{F} 1+\mathrm{F} 6$ & - & - \\
\hline & $\mathrm{F} 4$ & - & $-*$ & - \\
\hline & F5 & - & - & SIM \\
\hline & $\mathrm{F} 6$ & $+\mathrm{F} 1+\mathrm{F} 3+\mathrm{F} 7^{* *}$ & - & - \\
\hline & F7 & $+\mathrm{F} 1+\mathrm{F} 6^{* *}$ & - & - \\
\hline \multirow{7}{*}{ P4 } & $\mathrm{F} 1$ & - & - & SIM \\
\hline & $\mathrm{F} 2$ & - & - & - \\
\hline & F3 & $+\mathrm{F} 5+\mathrm{F} 7$ & - & - \\
\hline & $\mathrm{F} 4$ & - & - & - \\
\hline & F5 & $+\mathrm{F} 3+\mathrm{F} 6+\mathrm{F} 7$ & SIM & - \\
\hline & $\mathrm{F} 6$ & +F5 & - & - \\
\hline & F7 & $+\mathrm{F} 3+\mathrm{F} 5$ & - & - \\
\hline
\end{tabular}

* poderá ocorRer deslizamento planar caso ÂNGULO de ATRITo diminua, ou PRESSÕ̃es ELEVAdAS DE COLUNA D'ÁGUA, POR EXEMPLO, FRATURAS COM PREENCHIMENTO ARGILOSO, OU PLANOS PREFERENCIAIS DE FLUXO D'ÁGUA

\section{** MUITO POUCO PROVÁVEL DEVIDO À ORIENTAÇÃO DA LINHA DE INTERSECÇÃO}

Em seguida, se empregou a Teoria dos Blocos Chaves, de Goodman \& Shi (1985), conforme o exposto no item 4.4, para identificar os possíveis blocos críticos em cada uma das paredes. O que foi feito então para cada um dos taludes foi projetar as sete famílias de juntas consideradas e a orientação de cada parede, delimitando a PS e PE para cada caso. Todas as PJ's que caíram inteiramente dentro da PS foram consideradas como blocos críticos e removíveis. 
Nas Figuras 176 a 179, apresenta-se esta análise feita manualmente, considerando-se todas as sete famílias, exibindo tais blocos removíveis em amarelo, para cada parede principal (P1, P2, P3 e P4). Na Tabela 14, foi feito um resumo de todos estes blocos removíveis (blocos-chave), separandoos em dimensões distintas. Notar que há desde blocos de dimensões pequenas até "super blocos", que deverão ser considerados na definição das premissas para contenção destes taludes.

Basicamente, o intuito é apresentar que podem ocorrer blocos de diversas dimensões nas paredes, sendo que com um acompanhamento técnico será possível identificar a ocorrência ou não dos principais blocos e promover sua estabilização. Ressalta-se que foram consideradas todas as combinações de famílias identificadas. No entanto, não necessariamente todas estas combinações ocorrerão nas superfícies escavadas.

Observando as figuras seguintes, é possível assumir que a parede com maior possibilidade de ocorrência de blocos de maiores dimensões é a parede P2. A parede P4 também apresenta blocos de dimensões maiores. Devido ao fato de terem sido utilizadas 7 famílias de juntas no total, há um grande número de combinações possíveis de blocos formados, contudo a equipe de A.T.O. deverá, através de mapeamento das paredes das escavações destes taludes da estação, fazer um levantamento sistemático contínuo, observando, assim que surgirem, os planos de descontinuidades em cada parede. Assim, com o auxílio das 4 figuras seguintes, será possível identificar quais as possíveis combinações de blocos considerados blocos-chave, sendo que a estabilização imediata de tais blocos críticos implicará na estabilização dos demais blocos, conforme o exposto no item 4.4.

Ressalta-se que, ao fazer a consideração de cada bloco formado, há que se lembrar da possibilidade de inexistência de algum dos planos que formam tais blocos, portanto resultando em outras combinações. Por exemplo, na Figura 176, da parede P1, a inexistência dos planos F4 e F7 ocasionará um bloco todavia maior, formado pelas famílias F2, F3 e F5. Ou, então, no caso da Figura 177, a não ocorrência dos planos F1, F2, F3, F4, F5 e F7 implicaria na provável formação de um super bloco formado pelos planos F3 e F6 e assim em diante. 


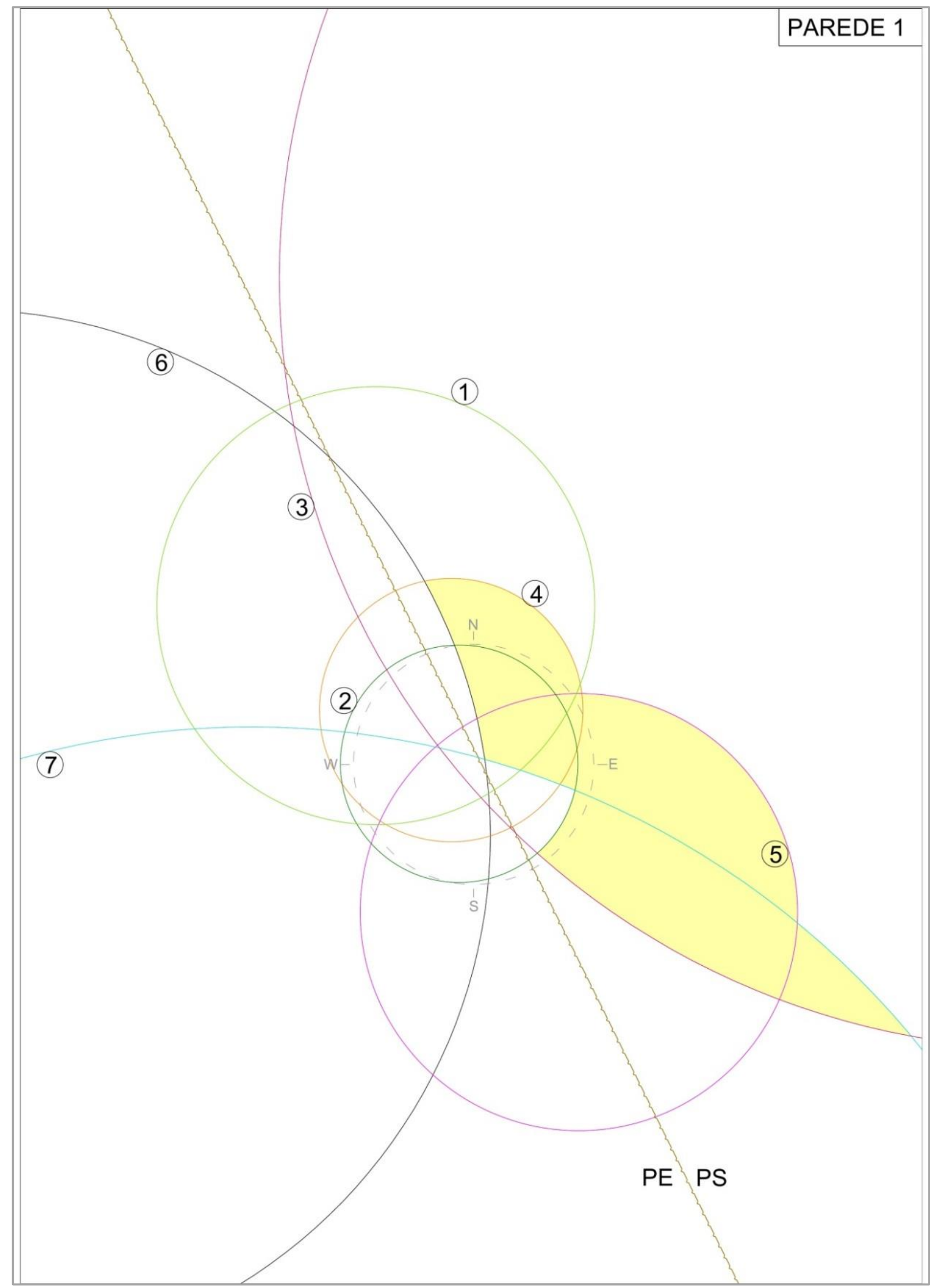

Figura 176 - Blocos removíveis (em amarelo) para parede P1, sendo PE a parede de escavação (a rocha) e PS o espaço escavado. 


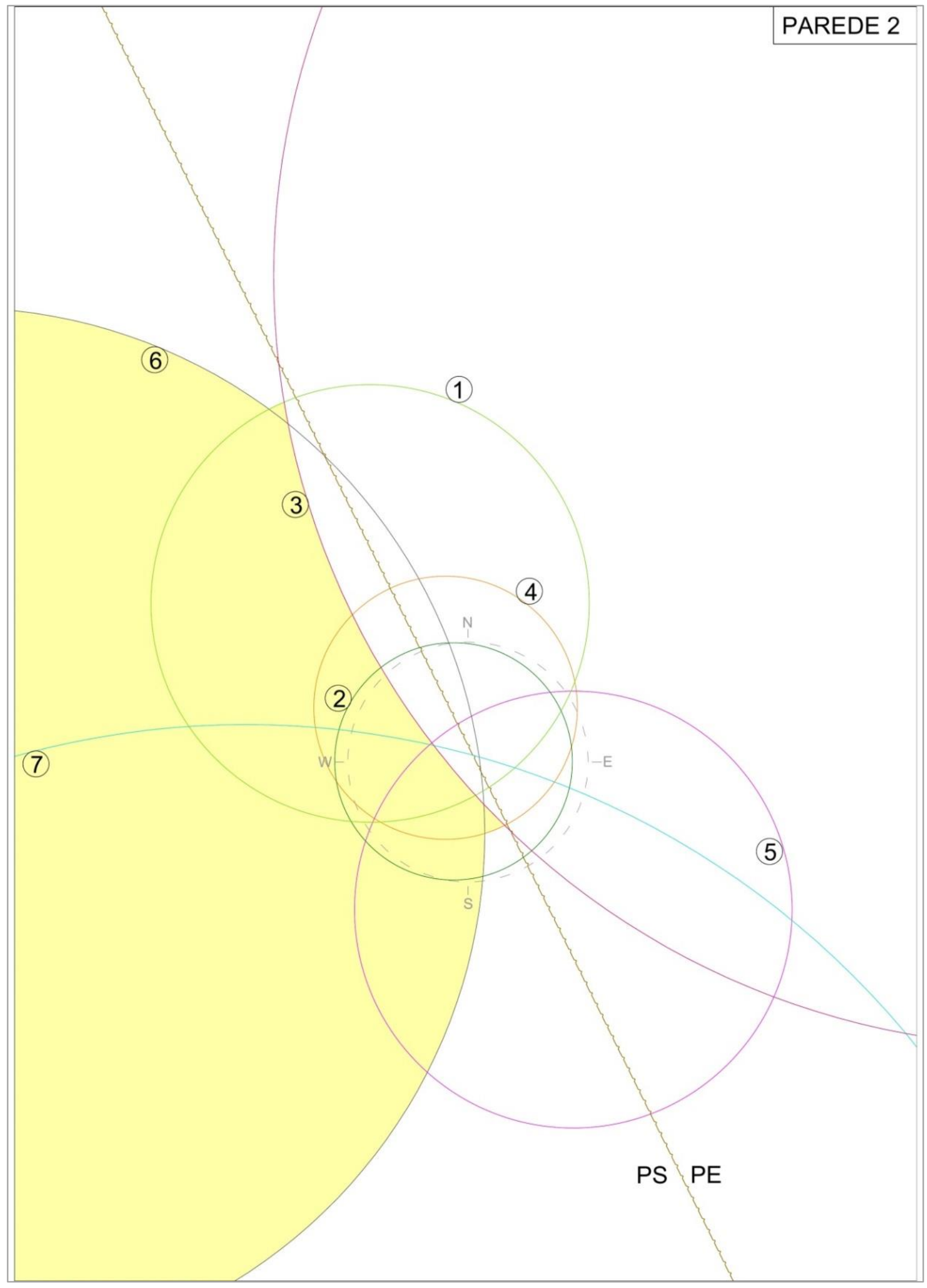

Figura 177 - Blocos removíveis (em amarelo) para parede P2, sendo PE a parede de escavação (a rocha) e PS o espaço escavado. 


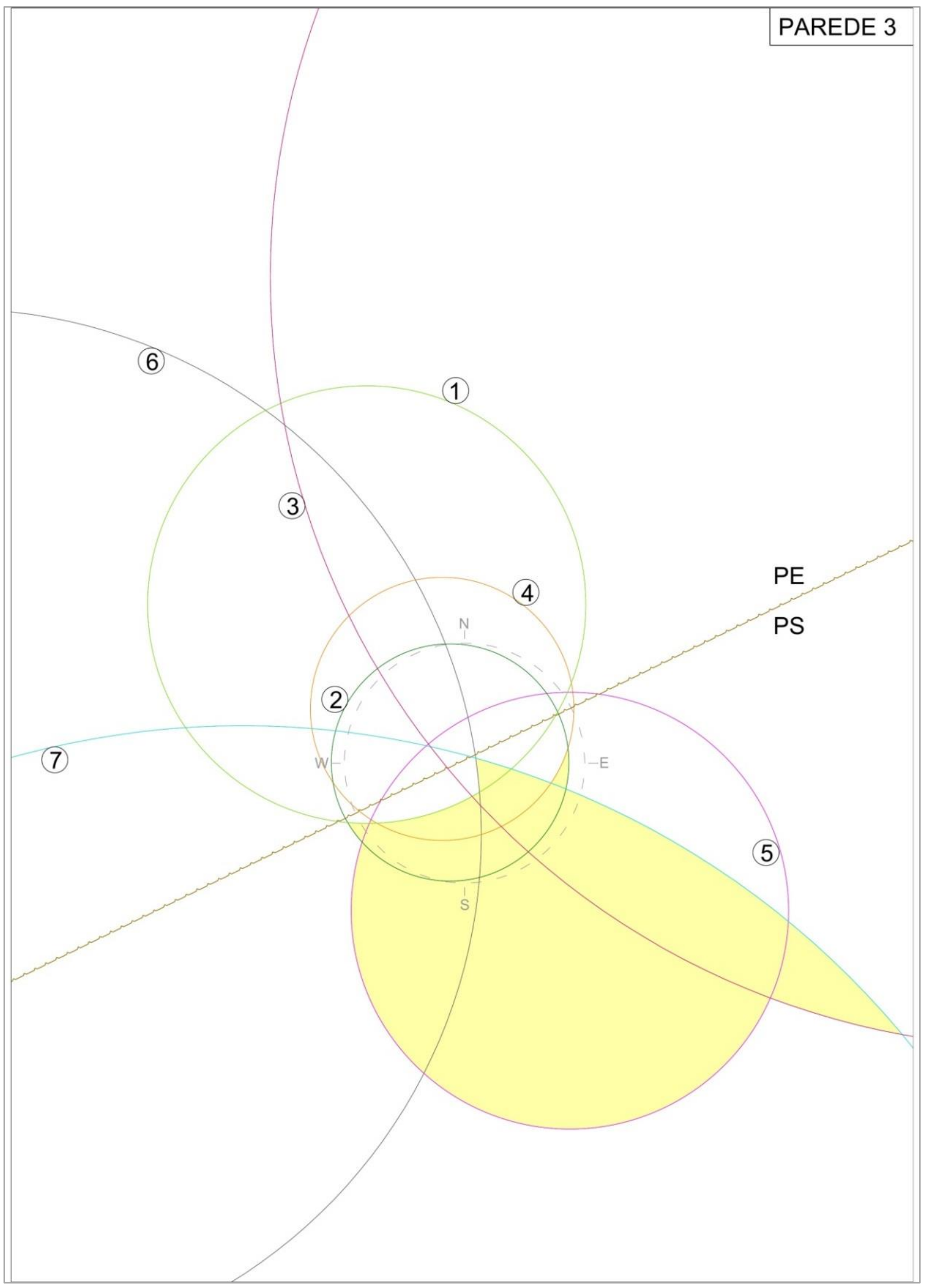

Figura 178 - Blocos removíveis (em amarelo) para parede P3, sendo PE a parede de escavação (a rocha) e PS o espaço escavado. 


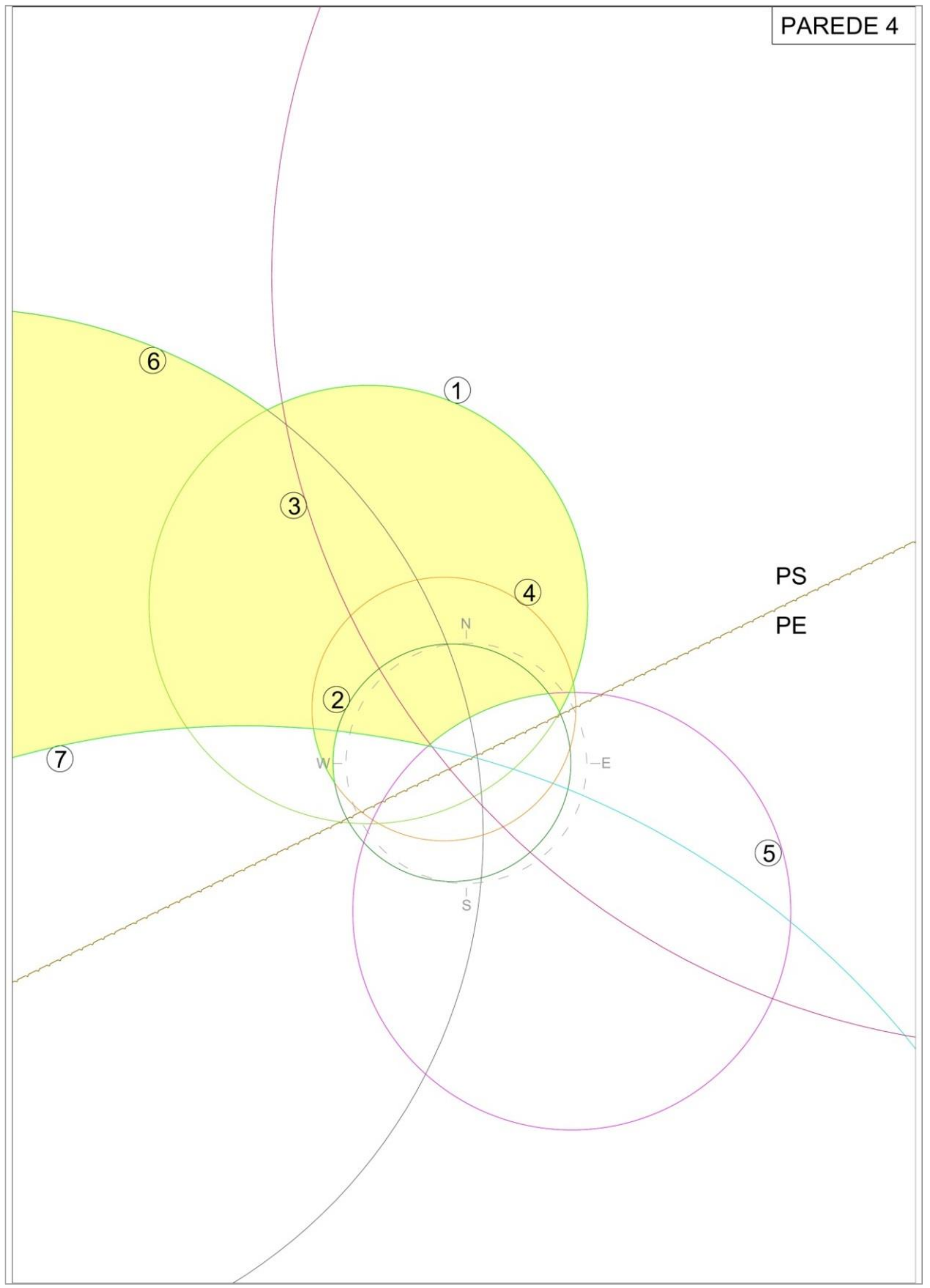

Figura 179 - Blocos removíveis (em amarelo) para parede P4, sendo PE a parede de escavação (a rocha) e PS o espaço escavado. 
Tabela 14 - Resumo dos blocos chaves (removíveis) nas 4 paredes da Estação largo do Taboão.

\begin{tabular}{|c|c|c|c|c|}
\hline \multirow{3}{*}{ PAREDE } & \multicolumn{4}{|c|}{ BLOCOS CHAVES - DIMENSÕES } \\
\hline & MENORES & MEDIANOS & GRANDES & SUPER BLOCOS \\
\hline & $<2(\mathrm{~m})$ & $1-10(\mathrm{~m})$ & $10-40(\mathrm{~m})$ & $>40(\mathrm{~m})$ \\
\hline \multirow{10}{*}{ P1 } & $\mathrm{F} 11+\mathrm{F} 51+\mathrm{F} 2 \mathrm{~S}$ & $\mathrm{~F} 11+\mathrm{F} 21+\mathrm{F} 51+\mathrm{F} 6 \mathrm{~S}+\mathrm{F} 7 \mathrm{~S}$ & $\mathrm{~F} 5 \mathrm{I}+\mathrm{F} 6 \mathrm{~S}+\mathrm{F} 7 \mathrm{~S}$ & - \\
\hline & $\mathrm{F} 1 \mathrm{~S}+\mathrm{F} 2 \mathrm{~S}+\mathrm{F} 5 \mathrm{I}+\mathrm{F} 4 \mathrm{I}$ & $\mathrm{F} 2 \mathrm{I}+\mathrm{F} 5 \mathrm{~S}+\mathrm{F} 6 \mathrm{~S}$ & $\mathrm{~F} 2 \mathrm{~S}+\mathrm{F} 3 \mathrm{I}+\mathrm{F} 5 \mathrm{I}$ & - \\
\hline & $\mathrm{F} 1 \mathrm{~S}+\mathrm{F} 5 \mathrm{~S}+\mathrm{F} 4 \mathrm{I}$ & $\mathrm{F} 1 \mathrm{I}+\mathrm{F} 2 \mathrm{~S}+\mathrm{F} 4 \mathrm{I}+\mathrm{F} 5 \mathrm{~S}+\mathrm{F} 6 \mathrm{~S}$ & $\mathrm{~F} 2 \mathrm{~S}+\mathrm{F} 3 \mathrm{I}+\mathrm{F} 7 \mathrm{I}$ & - \\
\hline & $\mathrm{F} 1 \mathrm{~S}+\mathrm{F} 2 \mathrm{I}+\mathrm{F} 4 \mathrm{I}+\mathrm{F} 7 \mathrm{~S}$ & $\mathrm{~F} 3 \mathrm{I}+\mathrm{F} 5 \mathrm{~S}+\mathrm{F} 7 \mathrm{I}$ & $\mathrm{F} 5 \mathrm{I}+\mathrm{F} 3 \mathrm{I}+\mathrm{F} 7 \mathrm{I}+\mathrm{F} 2 \mathrm{~S}$ & - \\
\hline & $\mathrm{F} 2 \mathrm{I}+\mathrm{F} 4 \mathrm{~S}+\mathrm{F} 7 \mathrm{~S}$ & $\mathrm{~F} 2 \mathrm{~S}+\mathrm{F} 4 \mathrm{~S}+\mathrm{F} 5 \mathrm{I}+\mathrm{F} 7 \mathrm{~S}$ & $\mathrm{~F} 5 \mathrm{I}+\mathrm{F} 2 \mathrm{~S}+\mathrm{F} 7 \mathrm{~S}$ & - \\
\hline & - & $\mathrm{F} 2 \mathrm{~S}+\mathrm{F} 3 \mathrm{I}+\mathrm{F} 5 \mathrm{I}+\mathrm{F} 7 \mathrm{I}$ & - & - \\
\hline & - & $\mathrm{F} 41+\mathrm{F} 6 \mathrm{~S}+\mathrm{F} 7 \mathrm{~S}$ & - & - \\
\hline & - & $\mathrm{F} 4 \mathrm{I}+\mathrm{F} 6 \mathrm{~S}+\mathrm{F} 5 \mathrm{~S}$ & - & - \\
\hline & - & $\mathrm{F} 2 \mathrm{I}+\mathrm{F} 5 \mathrm{I}+\mathrm{F} 6 \mathrm{~S}+\mathrm{F} 7 \mathrm{~S}$ & - & - \\
\hline & - & $\mathrm{F} 2 \mathrm{I}+\mathrm{F} 6 \mathrm{~S}+\mathrm{F} 7 \mathrm{~S}$ & - & - \\
\hline \multirow{12}{*}{$\mathrm{P} 2$} & $\mathrm{~F} 11+\mathrm{F} 21+\mathrm{F} 4 \mathrm{~S}$ & $\mathrm{~F} 11+\mathrm{F} 2 \mathrm{~S}+\mathrm{F} 4 \mathrm{~S}+\mathrm{F} 7 \mathrm{I}$ & $\mathrm{F} 11+\mathrm{F} 3 \mathrm{~S}+\mathrm{F} 4 \mathrm{~S}+\mathrm{F} 7 \mathrm{~S}$ & $\mathrm{~F} 3 \mathrm{~S}+\mathrm{F} 6 \mathrm{I}+\mathrm{F} 7 \mathrm{~S}$ \\
\hline & $\mathrm{F} 2 \mathrm{~S}+\mathrm{F} 4 \mathrm{I}+\mathrm{F} 7 \mathrm{I}$ & $\mathrm{F} 2 \mathrm{~S}+\mathrm{F} 5 \mathrm{I}+\mathrm{F} 6 \mathrm{I}$ & $\mathrm{F} 11+\mathrm{F} 3 \mathrm{~S}+\mathrm{F} 7 \mathrm{~S}$ & $\mathrm{~F} 3 \mathrm{~S}+\mathrm{F} 6 \mathrm{I}+\mathrm{F} 7 \mathrm{I}$ \\
\hline & $\mathrm{F} 2 \mathrm{I}+\mathrm{F} 3 \mathrm{~S}+\mathrm{F} 7 \mathrm{~S}$ & $\mathrm{~F} 3 \mathrm{~S}+\mathrm{F} 5 \mathrm{I}+\mathrm{F} 6 \mathrm{I}$ & - & $\mathrm{F} 3 \mathrm{~S}+\mathrm{F} 6 \mathrm{I}$ \\
\hline & $\mathrm{F} 3 \mathrm{~S}+\mathrm{F} 4 \mathrm{I}+\mathrm{F} 6 \mathrm{~S}$ & $\mathrm{~F} 11+\mathrm{F} 3 \mathrm{~S}+\mathrm{F} 7 \mathrm{I}$ & - & - \\
\hline & $\mathrm{F} 11+\mathrm{F} 3 \mathrm{~S}+\mathrm{F} 6 \mathrm{~S}$ & $\mathrm{~F} 2 \mathrm{I}+\mathrm{F} 3 \mathrm{~S}+\mathrm{F} 6 \mathrm{I}+\mathrm{F} 7 \mathrm{I}$ & - & - \\
\hline & $\mathrm{F} 1 \mathrm{I}+\mathrm{F} 3 \mathrm{~S}+\mathrm{F} 5 \mathrm{I}$ & $\mathrm{F} 4 \mathrm{I}+\mathrm{F} 3 \mathrm{~S}+\mathrm{F} 7 \mathrm{~S}$ & - & - \\
\hline & $\mathrm{F} 1 \mathrm{I}+\mathrm{F} 4 \mathrm{~S}+\mathrm{F} 5 \mathrm{I}$ & $\mathrm{F} 4 \mathrm{I}+\mathrm{F} 3 \mathrm{~S}+\mathrm{F} 6 \mathrm{I}+\mathrm{F} 7 \mathrm{I}$ & - & - \\
\hline & $\mathrm{F} 2 \mathrm{I}+\mathrm{F} 6 \mathrm{I}+\mathrm{F} 4 \mathrm{~S}+\mathrm{F} 5 \mathrm{I}$ & - & - & - \\
\hline & $\mathrm{F} 1 \mathrm{~S}+\mathrm{F} 3 \mathrm{~S}+\mathrm{F} 4 \mathrm{I}+\mathrm{F} 6 \mathrm{I}$ & - & - & - \\
\hline & $\mathrm{F} 2 \mathrm{I}+\mathrm{F} 4 \mathrm{I}+\mathrm{F} 5 \mathrm{~S}+\mathrm{F} 7 \mathrm{I}$ & - & - & - \\
\hline & $\mathrm{F} 2 \mathrm{~S}+\mathrm{F} 3 \mathrm{~S}+\mathrm{F} 4 \mathrm{I}+\mathrm{F} 7 \mathrm{~S}$ & - & - & - \\
\hline & $\mathrm{F} 1 \mathrm{~S}+\mathrm{F} 2 \mathrm{I}+\mathrm{F} 5 \mathrm{~S}$ & - & - & - \\
\hline \multirow{7}{*}{ P3 } & $\mathrm{F} 11+\mathrm{F} 6 \mathrm{~S}+\mathrm{F} 7 \mathrm{I}$ & $\mathrm{F} 1 \mathrm{~S}+\mathrm{F} 3 \mathrm{I}+\mathrm{F} 4 \mid+\mathrm{F} 7 \mathrm{I}$ & $\mathrm{F} 3 \mathrm{I}+\mathrm{F} 2 \mathrm{~S}+\mathrm{F} 5 \mathrm{I}+\mathrm{F} 7 \mathrm{I}$ & $\mathrm{F} 1+\mathrm{F} 5 \mathrm{I}+\mathrm{F} 7 \mathrm{I}$ \\
\hline & $\mathrm{F} 2 \mathrm{l}+\mathrm{F} 4 \mathrm{~S}+\mathrm{F} 7 \mathrm{~S}$ & $\mathrm{~F} 2 \mathrm{I}+\mathrm{F} 3 \mathrm{I}+\mathrm{F} 4 \mathrm{~S}+\mathrm{F} 7 \mathrm{I}$ & $\mathrm{F} 2 \mathrm{~S}+\mathrm{F} 5 \mathrm{I}+\mathrm{F} 6 \mathrm{I}$ & - \\
\hline & $\mathrm{F} 1 \mathrm{~S}+\mathrm{F} 2 \mathrm{I}+\mathrm{F} 5 \mathrm{~S}$ & $\mathrm{~F} 1 \mathrm{~S}+\mathrm{F} 4 \mathrm{I}+\mathrm{F} 3 \mathrm{~S}+\mathrm{F} 6 \mathrm{I}$ & $\mathrm{F} 2 \mathrm{~S}+\mathrm{F} 5 \mathrm{I}+\mathrm{F} 3 \mathrm{~S}+\mathrm{F} 6 \mathrm{~S}$ & - \\
\hline & $\mathrm{F} 1 \mathrm{I}+\mathrm{F} 4 \mathrm{~S}+\mathrm{F} 5 \mathrm{I}$ & $\mathrm{F} 1 \mathrm{~S}+\mathrm{F} 4 \mathrm{~S}+\mathrm{F} 6 \mathrm{I}+\mathrm{F} 2 \mathrm{I}+\mathrm{F} 5 \mathrm{I}$ & $\mathrm{F} 2 \mathrm{~S}+\mathrm{F} 5 \mathrm{I}+\mathrm{F} 7 \mathrm{I}$ & - \\
\hline & $\mathrm{F} 4 \mathrm{I}+\mathrm{F} 6 \mathrm{~S}+\mathrm{F} 3 \mathrm{~S}$ & $\mathrm{~F} 5 \mathrm{~S}+\mathrm{F} 3 \mathrm{I}+\mathrm{F} 7 \mathrm{I}$ & $\mathrm{F} 1 \mathrm{~S}+\mathrm{F} 3 \mathrm{I}+\mathrm{F} 7 \mathrm{I}$ & - \\
\hline & $\mathrm{F} 1 \mathrm{~S}+\mathrm{F} 3 \mathrm{I}+\mathrm{F} 6 \mathrm{I}$ & - & $\mathrm{F} 1 \mathrm{~S}+\mathrm{F} 5 \mathrm{I}+\mathrm{F} 2 \mathrm{I}+\mathrm{F} 7 \mathrm{I}$ & - \\
\hline & $\mathrm{F} 3 \mathrm{~S}+\mathrm{F} 2 \mathrm{I}+\mathrm{F} 6 \mathrm{~S}+\mathrm{F} 4 \mathrm{~S}$ & - & - & - \\
\hline \multirow{7}{*}{ P4 } & $\mathrm{F} 2 \mathrm{~S}+\mathrm{F} 4 \mathrm{I}+\mathrm{F} 7 \mathrm{I}$ & $\mathrm{F} 2 \mathrm{I}+\mathrm{F} 3 \mathrm{~S}+\mathrm{F} 7 \mathrm{~S}$ & $\mathrm{~F} 1 \mathrm{I}+\mathrm{F} 4 \mathrm{~S}+\mathrm{F} 6 \mathrm{~S}$ & $\mathrm{~F} 1 \mathrm{~S}+\mathrm{F} 6 \mathrm{I}+\mathrm{F} 7 \mathrm{~S}$ \\
\hline & $\mathrm{F} 1 \mathrm{I}+\mathrm{F} 2 \mathrm{~S}+\mathrm{F} 5 \mathrm{I}$ & $\mathrm{F} 3 \mathrm{I}+\mathrm{F} 5 \mathrm{I}+\mathrm{F} 6 \mathrm{I}+\mathrm{F} 2 \mathrm{I}$ & $\mathrm{F} 11+\mathrm{F} 3 \mathrm{~S}+\mathrm{F} 7 \mathrm{~S}+\mathrm{F} 4 \mathrm{~S}$ & $\mathrm{~F} 1 \mathrm{I}+\mathrm{F} 3 \mathrm{I}+\mathrm{F} 5 \mathrm{~S}$ \\
\hline & - & $\mathrm{F} 2 \mathrm{I}+\mathrm{F} 5 \mathrm{~S}+\mathrm{F} 6 \mathrm{~S}$ & $\mathrm{~F} 5 \mathrm{~S}+\mathrm{F} 1 \mathrm{I}+\mathrm{F} 41+\mathrm{F} 7 \mathrm{~S}$ & $\mathrm{~F} 11+\mathrm{F} 2 \mathrm{~S}+\mathrm{F} 7 \mathrm{~S}$ \\
\hline & - & $\mathrm{F} 2 \mathrm{~S}+\mathrm{F} 3 \mathrm{~S}+\mathrm{F} 4 \mathrm{I}+\mathrm{F} 7 \mathrm{~S}$ & - & $\mathrm{F} 5 \mathrm{~S}+\mathrm{F} 6 \mathrm{I}+\mathrm{F} 7 \mathrm{~S}$ \\
\hline & - & $\mathrm{F} 2 \mathrm{~S}+\mathrm{F} 3 \mathrm{I}+\mathrm{F} 6 \mathrm{I}+\mathrm{F} 4 \mathrm{I}$ & - & - \\
\hline & - & $\mathrm{F} 2 \mathrm{~S}+\mathrm{F} 1 \mathrm{I}+\mathrm{F} 4 \mathrm{I}+\mathrm{F} 6 \mathrm{~S}$ & - & - \\
\hline & - & $\mathrm{F} 4 \mathrm{~S}+\mathrm{F} 3 \mathrm{I}+\mathrm{F} 6 \mathrm{I}$ & - & - \\
\hline
\end{tabular}


6.2.6 Correlação dos dados do televisionamento com ensaios de perda d'água sob pressão

O ensaio de perda d'água sob pressão, também denominado de ensaio Lugeon, em homenagem ao geólogo suíço que o desenvolveu, Maurice Lugeon, consiste na injeção (radial) de água sob pressão num certo trecho de um furo de sondagem e na medição da quantidade de água que entra no maciço rochoso durante certo tempo, a uma dada pressão de injeção, depois de estabelecido um regime de escoamento permanente. A realização do ensaio em vários degraus de pressão, crescentes e decrescentes, permite traçar curvas caudal versus pressão (Q-P), que dão informação quanto ao regime de percolação do maciço e quanto ao estado e tipo de fraturamento nas vizinhanças do trecho ensaiado. Estes ensaios são realizados com o intuito de se avaliar as características hidráulicas do maciço rochoso (condutividade e permeabilidade).

Na Linha 4 Fase 3, foram realizados ensaios de perda d'água sob pressão (EPA) em diversos intervalos, num total de seis sondagens, sendo que em duas destas foram realizados televisionamento das paredes da sondagem (4505 e 4545).

O fluxo d'água nos trechos em rocha é condicionado diretamente pelas descontinuidades no maciço, denominada de porosidade secundária por fraturação. Estes ensaios foram todos realizados nos trechos em rocha, sendo que a definição dos trechos se baseou nas imagens obtidas do televisionamento, tendo o devido cuidado de selecionar alguns trechos mais fraturados ou com presença de fraturas abertas. Em alguns dos casos, estas fraturas, por estarem tanto abertas como interconectadas, resultaram num valor de condutividade hidráulica maior.

$\mathrm{Na}$ sondagem 4505, por exemplo, as imagens de televisionamento revelam um sistema de juntas subhorizontais justamente no trecho ensaiado, onde a condutividade hidráulica foi maior (H3 média), nas profundidades de 29,6 e 35,16 metros, segundo imagem televisada, sendo que a última fratura apresenta clara evidência de percolação, estando com paredes oxidadas (Fotos 45 e 46, respectivamente). Interessante notar que não há uma estreita correlação entre o grau de fraturamento e a condutividade hidráulica, já que estes mesmos trechos são F1 e F2. Só foi possível perceber essa relação de um acréscimo da condutividade hidráulica com as imagens do televisionamento ou ao observar atentamente os testemunhos de sondagem. Entretanto, no caso dos testemunhos de sondagem, a abertura da descontinuidade não estaria claramente visível como nas imagens do televisionamento. 


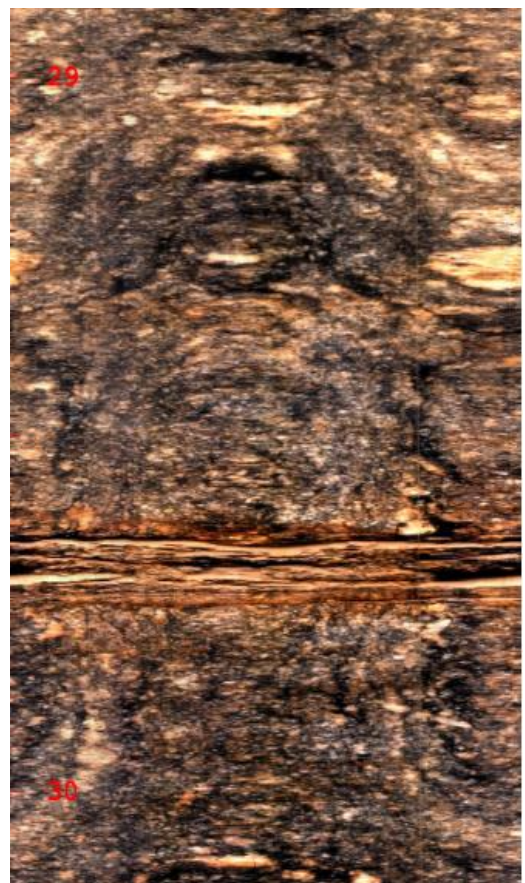

Foto 45 - Trecho fraturado a 29,6 metros na sondagem 4505, onde a permeabilidade foi superior aos demais intervalos (Metrô-SP).

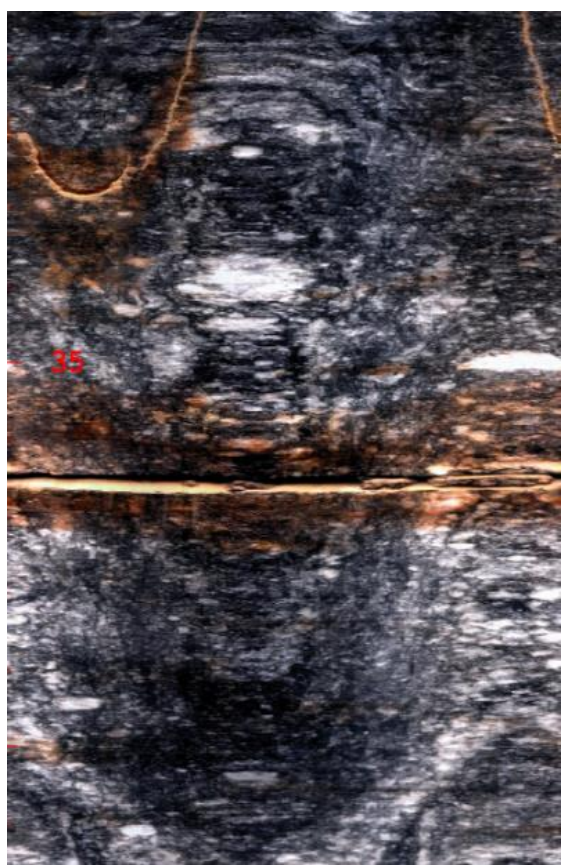

Foto 46 - Trecho fraturado a 35,16 metros na sondagem 4505 , onde a permeabilidade foi superior aos demais intervalos (Metrô-SP).

Com relação à sondagem 4545, no trecho referente ao grau de condutividade muito alto (H5), conforme apresentado na Tabela 15 , os valores de condutividade estão na ordem de $10^{-2} \mathrm{~cm} / \mathrm{s}$, no intervalo de profundidade entre 21 e 22 metros, ocorrendo fraturas subhorizontais abertas, conforme pode ser observado na Foto 47, o que explica a obtenção de valores altos de permeabilidade. Este valor está bem acima do esperado para este maciço, ficando claro que as juntas subhorizontais são responsáveis pelo aumento no grau de condutividade hidráulica.

Tabela 15 - Valores obtidos de permeabilidade para trecho fraturado na sondagem 4545 (Metrô-SP).

\begin{tabular}{|c|c|c|c|c|c|c|c|}
\hline \multirow{3}{*}{4545} & 20,5 & 22,5 & $\mathrm{~F} 3 / \mathrm{F} 4$ & $\mathrm{H} 5$ & $3,27 \times 10^{-4}$ & $2,71 \times 10^{-3}$ & $1,47 \times 10^{-3(6)}$ \\
\hline & 21 & 22 & $\mathrm{~F} 3 / \mathrm{F} 4$ & H5 & $8,98 \times 10^{-3}$ & $1,51 \times 10^{-2}$ & $1,18 \times 10^{-2(\sigma)}$ \\
\hline & 28 & 29 & F2 & H3 & $4,15 \times 10^{-5}$ & $1,32 \times 10^{-4}$ & $6,97 \times 10^{-5}$ \\
\hline
\end{tabular}




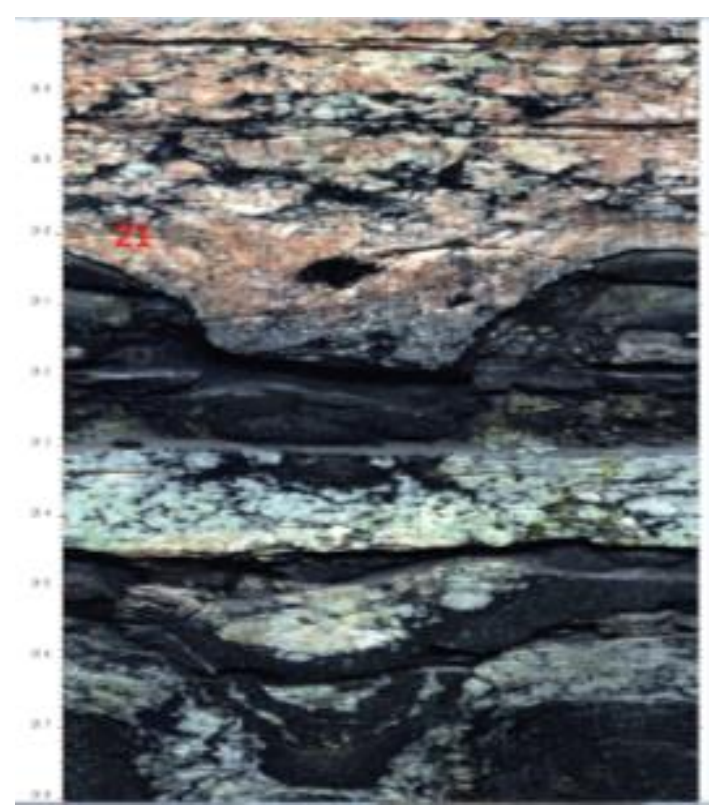

Foto 47 - Fraturas abertas no furo 4545, trecho onde foi realizado ensaio de perda d'água com grau de condutividade $\mathrm{H5}$ (muito alto).

\section{CONSIDERAÇÕES FINAIS}

Neste estudo, foi apresentada uma proposta metodológica para a caracterização geológicogeotécnica dos testemunhos virtuais obtidos a partir do televisionamento óptico de furos de sondagens. Esta proposta teve como base principalmente as premissas já existentes para caracterização geológico-geotécnica de testemunhos de sondagens utilizadas no Brasil, adaptadas das sugestões apresentadas em ISRM (1978).

O objetivo foi buscar uma quantificação e uma padronização das informações obtidas em tais produtos, caracterizando o maciço rochoso e fornecendo subsídios para as soluções de engenharia a serem projetadas. Durante um período aproximado de três anos, esta metodologia foi aplicada nas investigações geológico-geotécnicas de obras metroviárias da Companhia do Metropolitano de São Paulo. Ao longo desses anos, ajustes e modificações foram feitos, sendo que atualmente esta metodologia aqui proposta já faz parte das especificações técnicas deste serviço nesta mesma companhia.

Um dos fatores limitantes é, sem dúvida, a limitação de amostragem, pois todos os dados foram obtidos exclusivamente em rochas do embasamento da Bacia de São Paulo. Certamente, seria necessária a aplicação desta mesma metodologia em distintos litotipos, assim como testada para diversas obras de infraestrutura, ou até mesmo, ampliando o seu uso para outras áreas, como a hidrogeologia, geologia ambiental, prospecção mineral e desenvolvimento de minas subterrâneas, por exemplo. 
É de suma importância a continuidade de avaliações dos parâmetros aqui definidos e indicados, principalmente com relação ao RQD teórico, buscando conclusões sobre sua aplicabilidade da metodologia proposta. Ainda sobre o RQD teórico, indiscutivelmente se faz necessário um levantamento sistemático com uma amostragem considerável, comparando os valores teóricos obtidos com aqueles diretamente levantados nos testemunhos de sondagem, assim como foi realizado por Priest \& Hudson (1976).

Independentemente, este trabalho poderá servir como base para os serviços de televisionamento a serem realizados, tanto por parte da executora de serviços, como por parte da empresa contratante, com respeito à fiscalização destes serviços e padronização dos resultados. As aplicações aqui apresentadas também poderão vir a ser utilizadas como possíveis alternativas às projetistas para análise estrutural, de estabilidade do túnel, poços e estações, assim como caracterização geológico-geotécnica dos maciços rochosos em obras de infraestrutura, servindo como complemento das informações obtidas em testemunhos de sondagens, levantamentos em afloramentos rochosos e demais investigações geológico-geotécnicas.

Novamente, cita-se que um subsolo mais bem conhecido e compreendido implicará em uma diminuição das incertezas do comportamento do meio físico frente às obras a serem realizadas, diminuindo riscos e otimizando as soluções de engenharia. A Figura 180 ilustra essa situação, que foi certamente sentida durante o desenvolvimento do projeto básico da Linha 4 - Fase 3, onde uma maior quantidade de dados, mais precisos, possibilitaram escolhas de projeto possivelmente mais acertadas no que se diz respeito à interação maciço/obra. Possivelmente, a continuidade de aplicação desta ferramenta aumentará suas possibilidades de uso, não só ampliando as opções de investigações geológico-geotécnicas, mas fornecendo novas ferramentas de projeto.
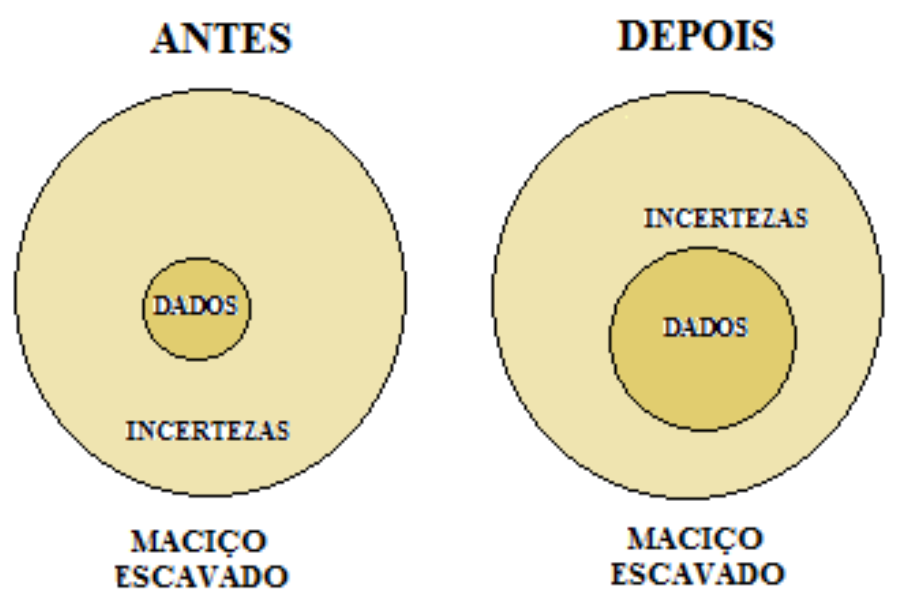

Figura 180 - Ilustração da possível situação a ser encontrada após o uso extensivo do televisionamento óptico e suas inúmeras aplicações. 


\section{BIBLIOGRAFIA}

Associação Brasileira de Geologia de Engenharia e Ambiental, ABGE, 2013. Manual de Sondagens. Boletim n ${ }^{\circ} 3,5^{\mathrm{a}}$ edição, São Paulo, 75p.

Almeida, F.F.M., Hasui, Y., Brito Neves, B.B. \& Fuck, R.A., 1977. Províncias Estruturais Brasileiras. Atas do VIII Simpósio de Geologia do Nordeste, Campina Grande, p. 363-391.

Baillot, R.T., Colas, R., Barton, N., Abrahão, R. \& Ribeiro Júnior, A., 2004. Comparing 360 Televising of Drill Hole Walls with Core Logging. Proc. International Site Investigation Conf. Portugal.

Barton, N., Lien, R. \& Lunde, J., 1974. Engineering Classification of Rock Masses for the Design of Tunnel Support. Rock Mechanical, v.6, n.4, p. 189-236.

Barton, N. 1987. Predicting the Behavior of Underground Openings in Rock. Manuel Rocha Memorial Lecture, Lisbon. NGI Publication 172, 1988. Also Geotecnia 53, July 1988.

Barton, N., 2013. Shear Strength Criteria for Rock, Rock Joints, Rockfill and Rock Masses: Problems and Some Solutions. Journal of Rock Mechanics and Geotechnical Engineering, Vol. 5, p. 249261.

Bieniawski, Z. T., 1973. Engineering Classification of Jointed Rock Masses, Trans. S. Afr. Inst. Civil Eng., 15.

Bieniawski, Z. T., 1989. Engineering Rock Mass Classifications: a Complete Manual. New York: John Wiley and Sons, 251p.

Boadu, F.K. \& Long, L.T., 1994. The Fractal Character of Fracture Spacing and RQD. International Journal of Rock Mechanics and Mining Sciences and Geomechanics Abstracts, V.31, N.2, p. 127-134.

Bruland, A., 2000. Hard Rock Tunnel Boring. The Boring Process. Volume 7. Norwegian University of Science and Technology, Trondheim, 86p.

Campanha, G.A. da C., Gimenez Filho, A., Caetano, S.L.V. Pires, F.A., Dantas, A.S.L., Teixeira, A.L. \& Dehira, L.K., 1985. Geologia das Folhas Iporanga (SG.X-B-V-2) e Gruta do Diabo (SG.22-X-B-VI-1)(SP). São Paulo: IPT/Prominério (Relatório 22.352).

Castro, A.O., 2013. Métodos para Seleção de Tuneladoras e Análise Numérica de Diferentes Alinhamentos de Túneis Sujeitos a Altas Pressões Hidráulicas. Dissertação de Mestrado. UnB, Brasília, 363p.

Chmelina, K., Benko, S., Maierhofer, A., Golser, J., Rabensteiner, K. \& Goliasch, R., 2014. Application of a New Guidance System for Double Shield TBMs at the Koralm Tunnel Project in Austria. Proceedings of the World Tunnel Congress 2014 - Tunnels for a better life. Foz do Iguaçu, Brasil, p.1-8. 
Choi, S.Y. \& Park, H.D., 2004. Variation of Rock Quality (RQD) with Scanline Orientation and Length: a Case Study in Korea. International Journal of Rock Mechanics and Mining Sciences and Geomechanics Abstracts, V.41, p.207-221.

CMSP, Companhia do Metropolitano de São Paulo, 2012. Relatório de Parâmetros Geotécnicos Lote 2 - Extensão Vila Sônia - RT-4.20.00.00/6C3-002. [não publicado].

CPRM - Serviço Geológico do Brasil, 2006. Mapa Geológico do Estado de São Paulo. Ministério de Minas e Energia - Secretaria de Geologia, Mineração e Transformação Mineral. Brasília. Escala 1:750.000.

Deere, D.U., 1964. Technical Description of Rock Cores for Engineering Purposes. Rock Mechanical Engineering Geology, vol. 1, p. 17-22.

Deere, D.U., Hendron, A.J., Patton, F.D. \& Cording, E.J., 1967. Design of Surface and Near-Surface Construction in Rock. In: Symp. Rock Mech., Am. Inst. Min. Metall. \& Pet. Eng., 8, Minneapolis, Minn. Proceedings, p. 237-302.

Deere, D.U., 1989. Rock Quality Designation (RQD) After Twenty Years. U.S. Department of commerce - NTIS - National Technical Information Service, Springfield, 67p.

Devkota, K.C., Ham, J. \& Kim, G., 2009. Characteristics of Discontinuity Spacing of Yeongdeok Granite. Geosciences Journal, V. 13. N.2, p. 161-165.

Fernandes, A.J., 1991. O Complexo Embu no Leste do Estado de São Paulo: Contribuição ao Conhecimento da Litoestratigrafia e da Evolução Estrutural e Metamórfica. Dissertação de Mestrado. IGC-USP, São Paulo, 120p.

Fernandes, A.J., Perrota, M.M, Salvador, E.D., Azevedo, S.G., Gimenez Filho, A., Stefani, F.L., Paulon, N., 2005. Aquíferos Fraturados. In: Mapa de Águas Subterrâneas do Estado de São Paulo, Escala 1:1.000.000 - Nota Explicativa. DAEE/IG/IPT/CPRM, p. 66-84.

Fiori, A.P. \& Carmignani, L., 2009. Fundamentos de Mecânica dos Solos e das Rochas - Aplicações na Estabilidade de Taludes. Editora UFPR, 2 ed., Curitiba, 604p.

Franklin, J.A., 1970. Observations and Tests for Engineering Description and Mapping of Rocks. Proc. $4^{\text {th }}$ Congress ISRM, Beograd, $6 \mathrm{p}$.

Glover, P.W.J. \& Bormann, P., 2007. The Characterization of Trough and Planar Cross-Bedding from Borehole Image Logs. Journal of Applied Geophysics, V. 62, p. 178-191.

Goodman, R.E. \& Shi, G.H., 1985. Block Theory and its Application to Rock Engineering. New Jersey: Prentice-Hall, Inc., Englewood Cliffs, 338p.

Goodman, R.E., 1989. Introduction to Rock Mechanics. New York: John Wiley \& Sons, 562p.

Grohmann, C.H. \& Campanha, G.A. da C., 2010. OpenStereo: Open Source, Cross-Platform Software for Structural Geology Analysis. Presented at the AGU 2010 Fall Meeting, American Geophysical Union (AGU), San Francisco, CA.

Gurgueira, M.D., 2013. Correlação de Dados Geológicos e Geotécnicos na Bacia de São Paulo. Dissertação de Mestrado. IGC-USP, São Paulo, 80p. 
Hansen, T.H., 1988. Rock properties. Norwegian Rock and Soil Assoc., Publ. nº5, 3p.

Harrison, J.P., 1999. Selection of the Threshold Value in RQD Assessments. International Journal of Rock Mechanics and Mining Sciences and Geomechanics Abstracts, V. 36, p. 673-685.

Hasui, Y., Carneiro, C.D.R. \& Coimbra, A.M., 1975. The Ribeira Fold Belt. Revista Brasileira de Geociências, 5(4), p. 257-266.

Hasui Y., Carneiro, C.D.R. \& Bistrich, C.A., 1978. Os Granitos e Granitoides da Região de Dobramentos Sudeste no Estado de São Paulo. In: Congresso Brasileiro de Geologia, 30, Anais. Recife, 2594-2608.

Hasui, Y., Carneiro, C.D.R. 1980. Origem e Evolução da Bacia de São Paulo. In: Mesa Redonda: Aspectos Geológicos e Geotécnicos da Bacia Sedimentar de São Paulo. São Paulo, 1980. Publicação Especial. São Paulo, ABGE/SBG, p. 47-52.

Hasui, Y, 1993. Geologia Estrutural das Rochas na Linha 4 do Metrô - Avaliação e Síntese dos Conhecimentos. Departamento de Projeto Civil - PCI. RT-4.00.00.00/3C3-001. Relatório Interno da Companhia do Metropolitano de São Paulo - Metrô-SP. São Paulo, 27p.

Hasui, Y., Haralyi, N.L.E. \& Costa, J.B.S., 1993. Megaestruturação Pré-Cambriana do Território Brasileiro baseada em Dados Geofísicos e Geológicos. Geociências, v.12, p.7-31.

Hasui, Y., 2010. A Grande Colisão Pré-Cambriana do Sudeste Brasileiro e a Estruturação Regional. In: Geociências, 29, p. 141-169.

Hoek, E., 1966. Rock Mechanics: an Introduction for the Practical Engineer, Parts I, II and III. Mining Magazine, April, June, July.

Hoek, E. \& Brown, E.T., 1980. Underground Excavations in Rock. Institute of Mining and Metallurgy, Londres, 527 p.

Hoek, E. \& Bray, J.W., 1981. Rock Slope engineering. 3. Ed. Rev. London: Institute of Mining and Mettalurgy. $358 \mathrm{p}$.

Hoek, E., 1983. $23^{\text {rd }}$ Rankine Lecture, Strenght of Jointed Rock Masses. Géotechnique, 33, N ${ }^{\mathrm{o}} .3$, p. 1987-223.

IPT, Instituto de Pesquisas Tecnológicas do Estado de São Paulo, 1981. Mapa Geológico do Estado de São Paulo, Escala 1:500.000. Elaborado por Bistrichi, C.A., Campanha, G.A.C. (et al); assessoria: Hasui, Y., Almeida, F.F.M., colaboração: Mioto, J.A., Yamamoto, J.K., Coutinho, J.M.V. (et al); cartografia: Rodrigues dos Santos, M.C.S., desenho: Ferracini, M.M..

IPT, Instituto de Pesquisas Tecnológicas do Estado de São Paulo, 1984. Estudos GeológicoGeotécnicos para Caracterização e Classificação de Maciços Rochosos para Projetos de Engenharia (Túneis, Lavra a Céu Aberto e Barragens). São Paulo. (IPT - Relatório, 10342).

IPT, Instituto de Pesquisas Tecnológicas do Estado de São Paulo, 1997. Caracterização Geomecânica do Maciço Rochoso do Trecho Faria Lima-Ferreira, Linha 4-Amarela. RT-4.00.00.00/3C3-117. Relatório Interno da Companhia do Metropolitano de São Paulo - Metrô-SP. São Paulo, 146p. 
International Society for Rock Mechanics - ISRM, 1978. Suggested Methods for the Quantitative Description of Rock Masses. International Journal of Rock Mechanics and Mining Sciences and Geomechanics Abstracts, vol. 15, n. 6, p. 319-368.

Juliani, C. 1992. O embasamento Pré-Cambriano da Bacia de São Paulo. In: ABAS/ABGE/SBG-SP, c. São Paulo, p. 3-20.

Juliani, C. \& Beljavskis, P. 1995. Revisão da litoestratigrafia da Faixa São Roque/Serra do Itaberaba (SP). Revista do Instituto Geológico, 16 (1/2): p.33-58.

Juliani, C. 1993. Geologia, Petrogênese e Aspectos Metalogenéticos dos Grupos Serra do Itaberaba e São Roque nas Regiões das Serras de Itaberaba e Pedra Branca, NE da Cidade de São Paulo (SP). Tese de Doutorado, Universidade de São Paulo, São Paulo, 803p.

Kalenchuk, K.S., Diederichs, M.S. \& McKinnon, S., 2006. Characterizing Block Geometry in Jointed Rock Masses. International Journal of Rock Mechanics and Mining Sciences and Geomechanics Abstracts, V. 43, p. 1212-1225.

Kutner, A.S. \& Bjornberg, A.J.S., 1997. Contribuição para o Conhecimento Geológico - Geotécnico da Bacia de São Paulo: Litotipos, Notação Estratigráfica e Feições Estruturais Relevantes. Revista Engenharia, v.97, p. 65-73.

Li, L., Ouellet, S. \& Aubertin, M., 2009. An Improved Definition of Rock Quality Designation, RQDc. Proceedings of the $3^{\text {rd }}$ CANUS Rock Mechanics Symposium, Toronto, p. 3934, p.1-10.

Mackiewicz, S. \& Rippe, A., 2010. Prediction of Side Resistance in Poor Quality Rock: RQD vs. GSI. Geoflorida 2010: Advances in Analysis, Modeling \& Design, Florida, p.264-272.

Magalhães, F.S. \& Cella, P.R.C., 1998. Estruturas dos Maciços Rochosos. In: Oliveira, A.M.S. \& Brito, S.N.A.. Geologia de Engenharia, cap. 03, São Paulo, p. 39-55.

Malone, T., Hubbard, B., Merton-Lyn, D., Worthington, P. \& Zwiggelaar, R., 2013. Borehole and Ice Feature Annotation Tool (BIFAT): a Program for the Automatic and Manual Annotation of Glacier Borehole Images. Computers \& Geosciences, 51, p.381-389.

Massad, F., 2012. Resistência ao Cisalhamento e Deformabilidade dos Solos Sedimentares de São Paulo. In: Twin Cities - Solos das Cidades de São Paulo e Curitiba. ABMS, São Paulo, p.107133.

Melo, M.S., Ponçano, W.L., Mook, W.G. \& Azevedo, A.E.G., 1987. Datações C14 em Sedimentos da Grande São Paulo. In: Congresso da Associação Brasileira de Estudos do Quaternário, 1, Porto Alegre, Trabalho Publicado em Anais de Evento, p. 427-436.

Monteiro, M.D., Gurgueira, M.D \& Rocha, H.C., 2012. Geologia da Região Metropolitana de São Paulo. In: Twin Cities - Solos das Cidades de São Paulo e Curitiba. ABMS, São Paulo, p.1544.

Murfitt, J.K., Tattersall, J.W. \& Siu, B., 2006. A Review of the Parameters Governing Predicted and Actual RQD Evaluation in Shatin Heights Tunnels. Proceedings of the HKIE Geotechnical Division $26^{\text {th }}$ Annual Seminar, Hong Kong, p. 261-274. 
Oliveira, D.G.G., 2000. Estudo Geológico-Geotécnico de Maciços Rochosos: Levantamento Sistemático e Caracterização da Distribuição de Descontinuidades em Taludes. Monografia de Trabalho de Formatura, Universidade de São Paulo, São Paulo, 49p.

Oliveira, D.G.G., Monteiro, M.D., Massoni, F. \& Rocha, H.C., 2012.Televisionamento de Furos de Sondagens nos Estudos do Metrô de São Paulo - Proposta Metodológica para Execução e Análise. Revista Brasileira de Geologia de Engenharia e Ambiental, vol. 2, n.1, p. 95-114.

Oliveira, D.G.G., França, D.D., Monteiro, M.D., Massoni, F., Taioli, F., Lemos Filho, M.X. \& Rocha, H.C., 2013. Evolução da Proposta Metodológica para Execução e Análise de Televisionamento de Sondagens: A especificação Técnica do Metrô de São Paulo. Anais do $14^{\circ}$ Congresso Brasileiro de Geologia de Engenharia e Ambiental, Rio de Janeiro.

Palmstrom, A., 1995. RMi - a Rock Mass Characterization System for Rock Engineering Purposes. Tese de Doutorado, Universidade de Oslo, Noruega, 400p.

Palmstrom, A., 2005. Measurements of and Correlations Between Block Size and Rock Quality Designation (RQD). Tunneling and Underground Space Technology, V. 20, p. 362-377.

Piteau, D.R., 1970. Geological Factors Significant to the Stability of Slopes Cut in Rock. Symposium of Planning Open Pit Mines, South African Institute of Mining and Metallurgy, Johannesburg, p.33-53.

Priest, S.D., 1993. Discontinuity Analysis for Rock Engineering, Editora Chapman \& Hall, Londres, $473 \mathrm{p}$.

Priest, S.D. \& Hudson, J.A., 1976. Discontinuity Spacings in Rock. International Journal of Rock Mechanics and Mining Sciences and Geomechanics Abstracts, 13, p. 135-148.

Quigley, P. \& McSwiney, S., 1996. Measurement and Analysis of Rock Mass Fractures and their Applications in Civil Engineering. Geotechnical Society of the Institute of Engineers of Ireland, V. 13, p. 1-24.

Riccomini, C., 1989. O Rifte Continental do Sudeste do Brasil. Instituto de Geociências, Tese de Doutorado, Universidade de São Paulo, São Paulo, 256p.

Riccomini, C. \& Coimbra, A.M., 1992. Geologia da Bacia Sedimentar. Solos da Cidade de São Paulo. ABMS, ABEF, p.37-94

Riccomini, C., Sant'anna, L.C. \& Ferrari, A.L. 2004. Evolução Continental do Rifte Continental do Sudeste do Brasil. In: Geologia do Continente Sul-Americano: Evolução da Obra de Fernando Flávio Marques de Almeida. Neto, V.M., Bartorelli, A., Carneiro, C.D.R. \& Neves, B.B.B. (orgs). Beca, São Paulo, p. 385-405.

Rocscience Inc., 1999. Dips Software. RocScience Inc. Toronto, Canada.

Rocscience Inc., 2004. Unwedge Software. RocScience Inc. Toronto, Canada. 
Rodriguez, S.K., 1998. Geologia Urbana da Região Metropolitana de São Paulo. Tese de Doutoramento, Instituto de Geociências, Universidade de São Paulo, São Paulo, 171p.

Sadowski, G.R. \& Motidome, M.J., 1987. Brazilian Megafaults. Revista Geologica de Chile, Santiago, 31, p. 61-75.

Sen, Z. \& Eissa, E.A., 1992. Rock Quality Charts for Log-Normally Distributed Block Sizes. International Journal of Rock Mechanics and Mining Sciences and Geomechanics Abstracts, vol. 29, p. 1-12.

Sen, Z., 2000. Rock Quality Designation Model Formulation and Simulation for Correlated Fracture Intact Lengths. International Association for Mathematical Geology, V. 32, N.8, p. 985-999.

Serra Junior, E. \& Ojima, L. M., 1998. Caracterização e Classificação de Maciços Rochosos. In: Oliveira, A.M.S. \& Brito, S.N.A.. Geologia de Engenharia, cap. 13. São Paulo. Págs. 211-226.

Schunnesson, H. 1996. RQD Predictions Based on Drill Performance Parameters. Tunnelling and Underground Space Technology, V. 11, N. 3, p. 345-351.

Terzaghi, R.D., 1965. Sources of Error in Joint Surveys. Geotechnique, n¹5, p.287-304.

Trouw, R.A.J., Heilbron, M., Ribeiro, A., Paciullo, F.V.P., Valeriano, C.M., Almeida, J.C.H., Tupinambá, M. \& Andreis, R.R. 2000. The Central Segment of the Ribeira Belt. In: Cordani, U.G., Milani, E.J., Thomaz Filho, A. (eds.). Tectonic Evolution of South America. São Paulo, p.287-310.

Vaz, L. F., Gurgueira, M.D. \& Muzzi, T.O., 2011. Geologia Aplicada a Barragens: uma Revisão de Procedimentos. RBGEA - Revista Brasileira de Geologia de Engenharia e Ambiental, São Paulo, v. 1, p. 73-92.

Warburton, P.M., 1981. Vector Stability Analysis of an Arbitrary Polyhedral Rock Block with Any Number of Free Faces. International Journal of Rock Mechanics and Mining Sciences and Geomechanics Abstracts, vol. 18, p. 415-427.

Williams, J.H. \& Johnson, C.D., 2004. Acoustic and Optical Borehole-Wall Imaging for FracturedRock Aquifer Studies. Journal of Applied Geophysics, 55, p. 151-159.

Winiawer, J.E.B., 2012. Análise de Estabilidade de Túneis Escavados em Meio Rochosos: Aplicação ao Caso do Colapso do Túnel Estação Pinheiros. Dissertação de Mestrado, Escola de Engenharia da Universidade Federal do Rio Grande do Sul, Porto Alegre, 153p.

Zhang, L., 2010. Estimating the Strength of Jointed Rock Masses. Rock Mech. Rock Eng., V. 43, p. 391-402.

Zhao, J., 2007. Tunneling in Rocks - Present Technology and Future Challenges. ITA - AITES WTC 2007. Prague, p. 22-32. 